\title{
Evaluation of Historical and Analytical Data on the TAN TSF-07 Disposal Pond
}

\author{
S. M. Medina
}

Published July 1993

Idaho National Engineering Laboratory

EG\&G Idaho, Inc. Idaho Falls, Idaho 83415

\section{Prepared for the}

\section{U.S. Department of Energy}

Assistant Secretary for Environmental Restoration and Waste Management

Under DOE Idaho Operations Office

Contract DE-AC07-76ID01570 


\section{Evaluation of Historical and Analytical Data on the TAN TSF-07 Disposal Pond}

Approved by:

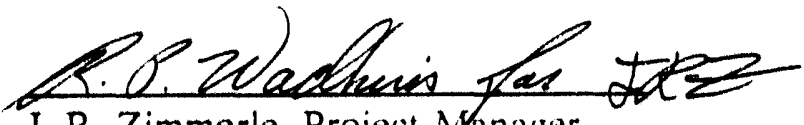

J. R. Zimmerle, Project Mranager

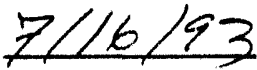

Waste Area Groups 1, 5, 6, \& 10

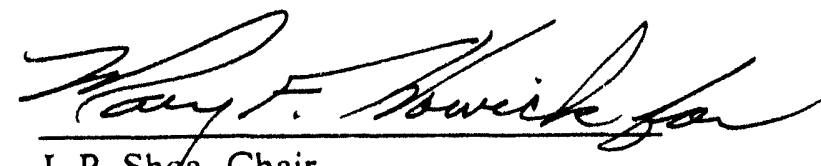

J. P. Shea, Chair

Environmental Restoration

Independent Review Committee

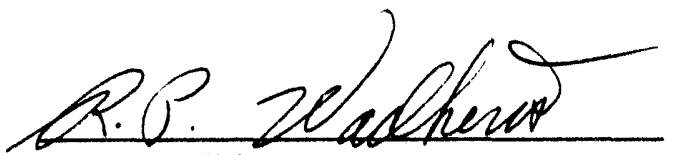

R. P. Wadkins, Manager

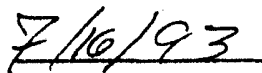

Waste Area Groups 1, 5, 6, \& 10

\section{DISCLAIMER}

This report was prepared as an account of work sponsored by an agency of the United States Government. Neither the United States Government nor any agency thereof, nor any of their employees, makes any warranty, express or implied, or assumes any legal liability or responsibility for the accuracy, completeness, or usefulness of any information, apparatus, product, or process disclosed, or represents that its use would not infringe privately owned rights. Reference herein to any specific commercial product, process, or service by trade name, trademark, manufacturer, or otherwise does not necessarily constitute or imply its endorsement, recommendation, or favoring by the United States Government or any agency thereof. The views and opinions of authors expressed herein do not necessarily state or reflect those of the United States Government or any agency thereof. 


\begin{abstract}
The Technical Support Facility (TSF)-07 Disposal Pond, located at Test Area North at the Idaho National Engineering Laboratory, has been identified as part of Operable Unit 1-06 under the Comprehensive Environmental Response, Compensation, and Liability Act. The Environmental Restoration and Waste Management Department is conducting an evaluation of existing site characterization data for the TSF-07 Disposal Pond Track 1 investigation. The results from the site characterization data will be used to determine whether the operable unit will undergo a Track 2 investigation, an interim action, a remedial investigation/feasibility study, or result in a no-action decision. This report summarizes activities relevant to wastewaters discharged to the pond and characterization efforts conducted from 1982 through 1991. Plan view and vertical distribution maps of the significant contaminants contained in the pond are included. From this evaluation it was determined that cobalt-60, cesium-137, americium-241, mercury, chromium, and thallium are significant contaminants for soils. This report also evaluates the migration tendencies of the significant contaminants into the perched water zone under the pond and the surrounding terrain to support the investigation.
\end{abstract}




\section{ACKNOWLEDGMENTS}

The author wishes to thank the following individuals and organizations for their valuable contribution to this report: J. R. Zimmerle, Environmental Restoration; G. J. Stormberg and C. F. Hersley, Geosciences; D. Jones, Statistics, Reliability, and Analysis Unit; INEL Sample Management Office; and Engineering Graphics Unit. 


\section{CONTENTS}

1. INTRODUCTION $\ldots \ldots \ldots \ldots \ldots \ldots \ldots \ldots \ldots \ldots \ldots \ldots \ldots \ldots \ldots \ldots$

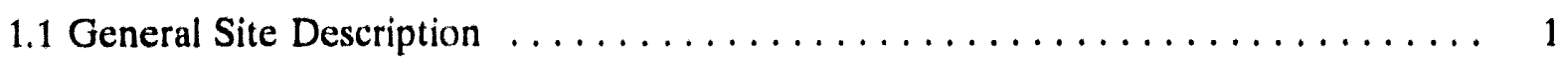

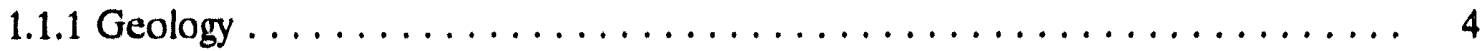

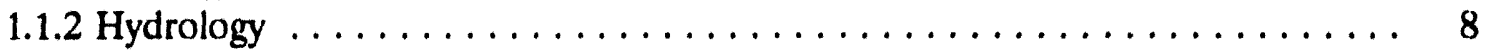

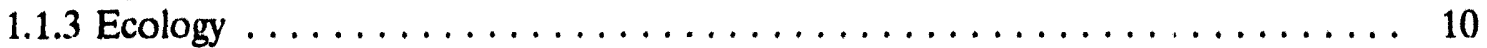

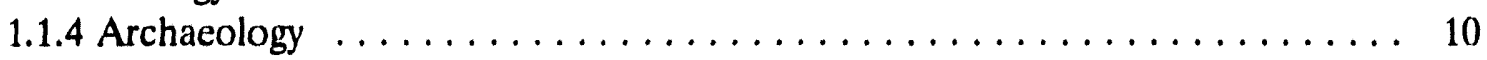

2. EFFLUENT RECEIPT AT TAN/TSF $\ldots \ldots \ldots \ldots \ldots \ldots \ldots \ldots \ldots \ldots$

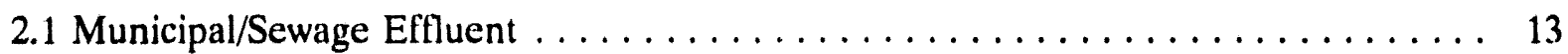

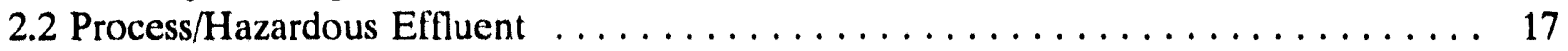

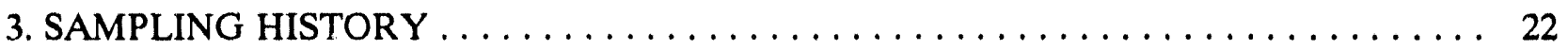

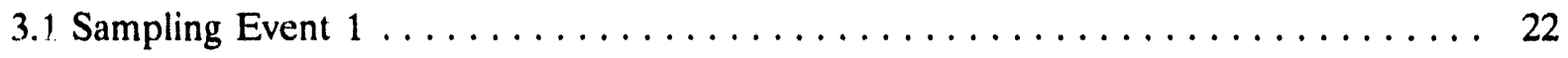

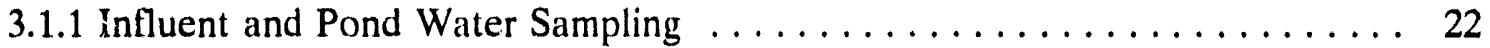

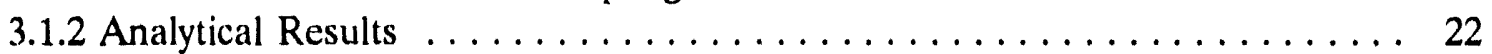

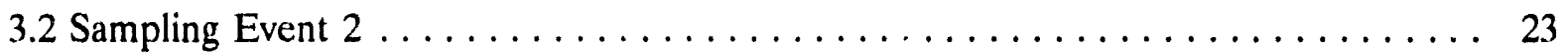

3.2.1 Preliminary Soil/Sediment Assessment $\ldots \ldots \ldots \ldots \ldots \ldots \ldots \ldots \ldots \ldots$

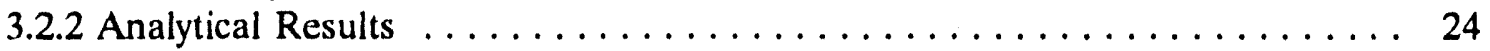

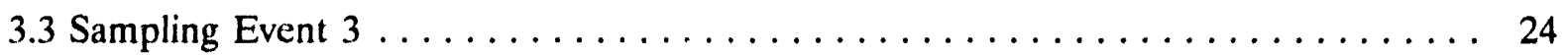

3.3.1 DOE Headquarters Environmental Survey . . . . . . . . . . . . . 24

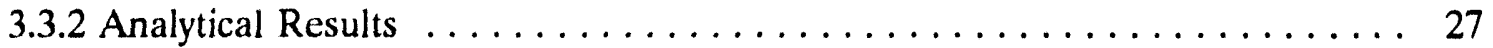

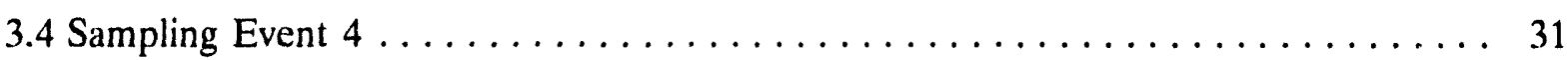

3.4.1 Subsurface Investigation for the TAN RCRA Facility Investigation $\ldots \ldots \ldots 31$

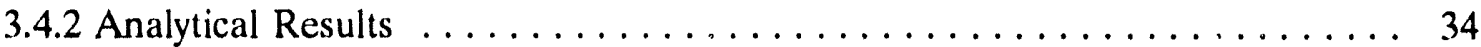

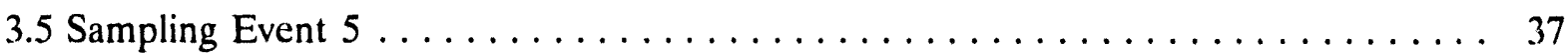

3.5.1 Site Characterization of the TSF-07 Disposal Pond ........... 37

3.5.2 Analytical Results .......................... 37

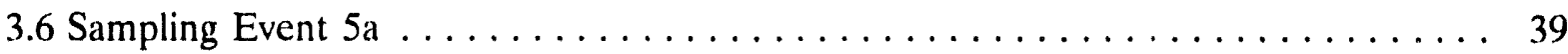

3.6.1 Perched Water Sampling Activities $\ldots \ldots \ldots \ldots \ldots \ldots \ldots \ldots \ldots \ldots$

3.6.2 Analytical Results $\ldots \ldots \ldots \ldots \ldots \ldots \ldots \ldots \ldots \ldots \ldots \ldots \ldots \ldots \ldots \ldots$ 
4.1 Screening Levels for Soils $\ldots \ldots \ldots \ldots \ldots \ldots \ldots \ldots \ldots \ldots \ldots \ldots, 45$

4.2 Screening Values for Water Samples $\ldots \ldots \ldots \ldots \ldots \ldots \ldots \ldots \ldots \ldots \ldots, 45$

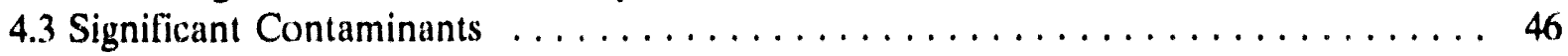

4.4 Screening Results for Sample Data $\ldots \ldots \ldots \ldots \ldots \ldots \ldots \ldots \ldots \ldots . \ldots \ldots$

5. MAJOR CONTAMINANT MIGRATION EVALUATION $\ldots \ldots \ldots \ldots \ldots \ldots \ldots .67$

5.1 Evaluation of Significant Contaminants $\ldots \ldots \ldots \ldots \ldots \ldots \ldots \ldots \ldots \ldots$

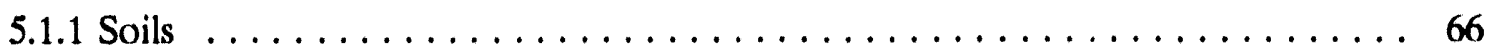

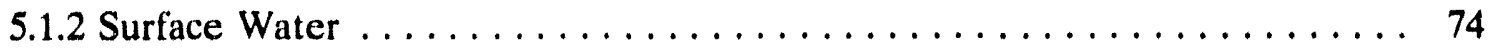

5.1.3 Perched Water .................................. 74

5.2 Contaminant Migration to the Perched Water Zone $\ldots \ldots \ldots \ldots \ldots \ldots \ldots .74$

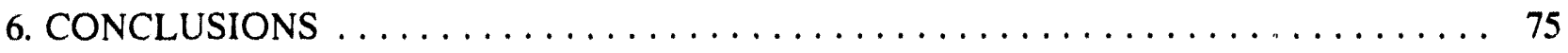

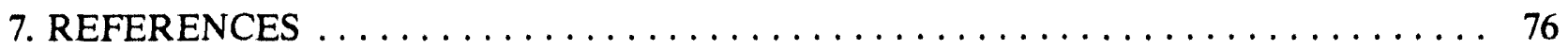

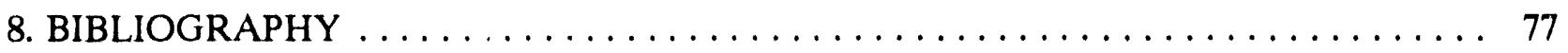

Appendix A-Nonradiological Liquid Effluent Monitoring Program Results $\ldots . \ldots \ldots \ldots$ A-1

Appendix B-Analytical Results for Sump (TAN 655) $\ldots \ldots \ldots \ldots \ldots \ldots \ldots \ldots$ B-1

Appendix C-Analytical Results for Sampling Event 1-Initial Sampling Effort $\ldots \ldots \ldots \ldots$ C-1

Appendix D--Analytical Results for Sampling Event 2-Preliminary Assessment ......... D-1

Appendix E-Analytical Results for Sampling Event 3-DOE-HQ Investigation $\ldots \ldots \ldots \ldots$ E-1

Appendix F-Analytical Results for Sampling Event 4-Subsurface Investigation ......... F-1

Appendix G-Analytical Results for Sampling Event $5 \ldots \ldots \ldots \ldots \ldots \ldots \ldots$ G-1

Appendix H-Analytical Results for Sampling Event $5 a \ldots \ldots \ldots \ldots \ldots \ldots \ldots \ldots$ H-1 


\section{FIGURES}

Figure 1. Location of the INEL site in relation to surrounding areas. . . . . . . . . 2

Figure 2. Map of TAN showing the location of the TSF. 07 disposal pond. . . . . . . 3

Figure 3. Isopatch map of sediment thickness at TAN. $\ldots \ldots \ldots \ldots \ldots \ldots \ldots \ldots \ldots$

Figure 4. Locations of wells and perched water zone at TSF. . . . . . . . . 11

Figure 5. Aerial view of the TSF-07 disposal pond relative to TSF. . . . . . . . . . 14

Figure 6. Process drain and sanitary sewage sources feeding to the TSF-07 pond. . . . . 15

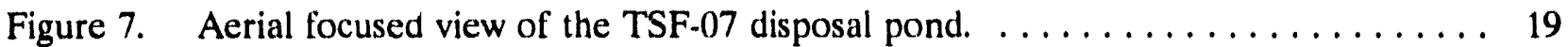

Figure 8. Locations of sediment samples collected in May 1988 and locations of the four

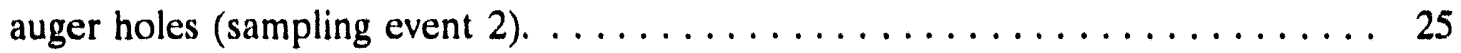

Figure 9. Sample locations for sampling event $3 . \ldots \ldots \ldots \ldots \ldots \ldots \ldots \ldots \ldots \ldots$

Figure 10. Sample locations for sampling event $4 . \ldots \ldots \ldots \ldots \ldots \ldots \ldots \ldots \ldots$

Figure 11. Sample locations for sampling event 5 and 5 a. $\ldots \ldots \ldots \ldots \ldots \ldots$

Figure 12. Vertical distribution of mercury in the TSF-07 disposal pond. $\ldots \ldots \ldots \ldots$

Figure 13. TAN TSF-07 pond mercury contaminant in surface soils $(\mathrm{mg} / \mathrm{kg}) . \ldots \ldots$

Figure 14. Vertical distribution of thallium in the TSF-07 disposal pond. . . . . . . . 62

Figure 15. TAN TSF-07 pond thallium contaminant in surface soils $(\mathrm{mg} / \mathrm{kg}) . \ldots \ldots \ldots$

Figure 16. Vertical distribution of chromium in the TSF.07 disposal pond. . . . . . . 67

Figure 17. TAN TSF-07 pond chromium contaminant in surface soils $(\mathrm{mg} / \mathrm{kg}) \ldots \ldots \ldots 8$

Figure 18. TAN TSF-07 pond cobalt -60 contaminant in surface soils $(\mathrm{pCi} / \mathrm{g}) \ldots \ldots \ldots \ldots$

Figure 19. TAN TSF-07 pond cesium contaminant in surface soils $(\mathrm{pCi} / \mathrm{g}) \ldots \ldots \ldots \ldots$ 


\section{TABLES}

Table 1. Thickness of the surficial sediments near the TSF-07 disposal pond. . . . . . . 5

Table 2. Total percentage of clay and silt composition of representative samples collected from the Terreton Lake heds and the associated area. . . . . . . . . . . . 7

Table 3. Average mineral composition of the silt and clay size fractions from samples collected at the northern part of the INEL. . . . . . . . . . . . . 8

Table 4. Summary of cation exchange capacity of sediments and basalt. . . . . . . . 9

Table 5. Hydraulic conductivity values. $\ldots \ldots \ldots \ldots \ldots \ldots \ldots \ldots \ldots \ldots \ldots \ldots$

Table 6. Summary of wastewater parameters analyzed for from FY 1987-FY 1992 for the TSF-07 disposal pond. . . . . . . . . . . . . . . . . . . . . . . 16

Table 7. Sump data results. $\ldots \ldots \ldots \ldots \ldots \ldots \ldots \ldots \ldots \ldots \ldots \ldots \ldots \ldots \ldots$

Table 8. Sump radiological data results. $\ldots \ldots \ldots \ldots \ldots \ldots \ldots \ldots \ldots \ldots \ldots \ldots$

Table 9. Sump data evaluation. $\ldots \ldots \ldots \ldots \ldots \ldots \ldots \ldots \ldots \ldots \ldots \ldots \ldots \ldots \ldots$

Table 10. Sampling events performed at the TSF-07 disposal pond. $\ldots \ldots \ldots \ldots \ldots$

Table 11. Summary table for soil samples collected during sampling event $2 \ldots \ldots \ldots$

Table 12. Summary data table for the water samples collected during sampling event $3 . \ldots 28$

Table 13. Summary data table for the water samples collected during sampling event $3 . \quad \ldots \quad 29$

Table 14. Summary data table for the soil/sediment samples collected during sampling

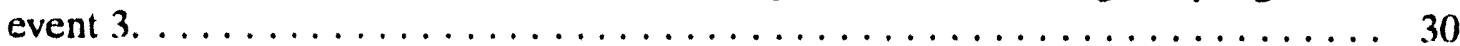

Table 15. Summary data table for the soil sediment samples collected during sampling

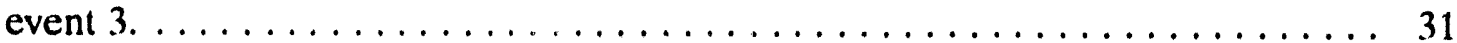

Table 16. Summary data table for the soil sediment samples collected during sampling

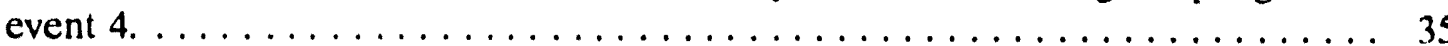

Table 17. Summary data table for sampling event 4 (CLP and TCLP results). . . . . 36

Table 18. Summary data table for the soil samples collected during sampling event $5 \ldots \ldots 39$

Table 19. Summary data table for the soil samples collected during sampling event 5 (for CLP analytes). ............................. 40 
Table 20. Summary data table for the soil samples collected and analyzed for Appendix IX analytes during sampling event $5 . \ldots \ldots \ldots \ldots \ldots \ldots \ldots \ldots \ldots \ldots, 41$

Table 21. Summary data table for the perched water samples collected during sampling event 5 a. .................................... 44

Table 22. Summary data table for the perched water samples collected during sampling event 5 a. ...................................... 43

Table 23. Screening application for soil inorganic analysis (sampling event 2-5) $\ldots \ldots \ldots 46$

Table 24. Screening application for surface water inorganic analysis (sampling event 3) ... . 47

Table 25. Screening application for perched water inorganic analysis (sampling event 5a) $\ldots 48$

Table 26. Screening application for soil organic analysis (sampling event $2-5) \ldots \ldots \ldots \ldots 49$

Table 27. Screening application for surface water organic analysis (sampling event 3 ) $\ldots \ldots 50$

Table 28. Screening application for soil radiological analysis (sampling event 3,5$) \ldots \ldots . \ldots 51$

Table 29. Screening application for surface water radiological analysis (sampling event 3) $\ldots 52$

Table 30. Screening application for perched water radiological analysis (sampling event 5a) .53 


\section{ACRONYMS}

\begin{tabular}{|c|c|}
\hline AA & atomic absorption \\
\hline CEC & cation exchange capacity \\
\hline CERCLA & $\begin{array}{l}\text { Comprehensive Environmental Response, Compensation, and } \\
\text { Liability Act }\end{array}$ \\
\hline CFR & Code of Federal Regulations \\
\hline $\mathrm{CH}$ & core hole \\
\hline CLP & contract laboratory program \\
\hline COCA & Consent Order and Compliance Agreement \\
\hline CRQL & contract-required quantitation limit \\
\hline CTF & Contained Test Facility \\
\hline DOE & Department of Energy \\
\hline DOE-HQ & Department of Energy Headquarters \\
\hline DOE-ID & Department of Energy Idaho Operations Office \\
\hline EPA & Environmental Protection Agency \\
\hline EP TOX & extraction procedure for toxicity \\
\hline $\mathrm{FFA} / \mathrm{CO}$ & Federal Facility Agreement/Consent Order \\
\hline FY & fiscal year \\
\hline GC & gas chromatography \\
\hline $\mathrm{HI}$ & hazard index \\
\hline ICP & inductively coupled plasma \\
\hline INEL & Idaho National Engineering Laboratory \\
\hline IWMIS & Industrial Waste Management Information System \\
\hline LOFT & Loss-of-Fluid Test (Facility) \\
\hline $\mathrm{MCL}$ & maximum contaminant level \\
\hline MS & mass spectrometry \\
\hline NA & not applicable \\
\hline ND & no data \\
\hline PCB & polychlorinated biphenyl \\
\hline RCRA & Resource Conservation and Recovery Act \\
\hline RFI & RCRA facility investigation \\
\hline $\mathrm{RI} / \mathrm{FS}$ & remedial investigation/feasibility study \\
\hline SE & sampling event \\
\hline TAN & Test Area North \\
\hline TCLP & toxicity characteristic leaching procedure \\
\hline TRA & Test Reactor Area \\
\hline TSF & Technical Support Facility \\
\hline VOA & volatile organic analysis \\
\hline VOC & volatile organic compound \\
\hline
\end{tabular}




\section{Evaluation of Historical and Analytical Data on the TAN TSF-07 Disposal Pond}

\section{INTRODUCTION}

This report was prepared by the EG\&G Idaho, Inc., Environmental Restoration and Waste Management Department for the Test Area North groundwater Administrative Record. The Technical Support Facility (TSF)-07 disposal pond, also referred to as the TSF evaporation pond, is located on the southwest side of Test Area North (TAN) at the Idaho National Engineering Laboratory (INEL).

The TSF.07 disposal pond was constructed to replace the TSF-05 injection well and began to receive wastewater in September 1972. The TSF-07 disposal pond is in an unlined area encompassing approximately 35 acres, surrounded by a $1.5-\mathrm{m}(5-\mathrm{ft})$ berm. The pond received wastewater from a variety of sources. The contaminants included sanitary waste discharges, and hazardous and radiological contaminants that originated from TAN service buildings and processes. Because contaminants were detected in the pond, it was classified as a land disposal unit under the Consent Order Compliance Agreement (COCA) and identified as COCA Unit TSF-07.

On December 9, 1991, a Federal Facility Agreement and Consent Order (FFA/CO) was signed between the Department of Energy (DOE) Idaho Operations Office, the Environmental Protection Agency (EPA), and the State of Idaho Department of Health and Welfare. This superseded the COCA agreement. The FFA/CO dictated that existing COCA units, including the TSF-07 disposal pond, be moved from a Resource Conservation and Recovery Act (RCRA) process to a Comprehensive Environmental Response, Compensation, and Liability Act (CERCLA) process. The pond is part of Operable Unit 1-06 and will be undergoing a Track 1 investigation in fiscal year (FY) 1993. The Track 1 investigation will determine whether the disposal pond is required to undergo a Track 2 investigation, an interim action, a remedial investigation/feasibility study (RI/FS), or result in a no-action decision.

This report summarizes activities relevant to wastewaters discharged to the pond and characterization efforts conducted trom 1982 through 1991. The results of sampling and characterization investigations (see Section 3) are evaluated to determine potential migration of significant contaminants into the perched water body under the pond and the surrounding terrain. Plan view and vertical profile maps showing the distribution of major contaminants have been prepared for major sampling events and are included in this report.

\subsection{General Site Description}

The INEL is a $2,315 \mathrm{~km}^{2}\left(894 \mathrm{mi}^{2}\right)$ government-owned, contractor-operated facility in southeast Idaho that is managed under a Department of Energy Idaho Operations Office (DOE-ID) contract. TAN, located at the northern end of INEL, is managed and operated under the DOE-ID contract by EG\&G Idaho, with the exception of the Specific Manufacturing Capability, which is operated by Babcock \& Wilcox Idaho, Inc. (Figure 1). TAN was initially built between 1954 and 1961 to support the Aircraft Nuclear Propulsion Program sponsored by the U.S. Air Force and the Atomic Energy Commission. The TAN facilities and the location of the TSF-07 disposal pond are shown in Figure 2. 


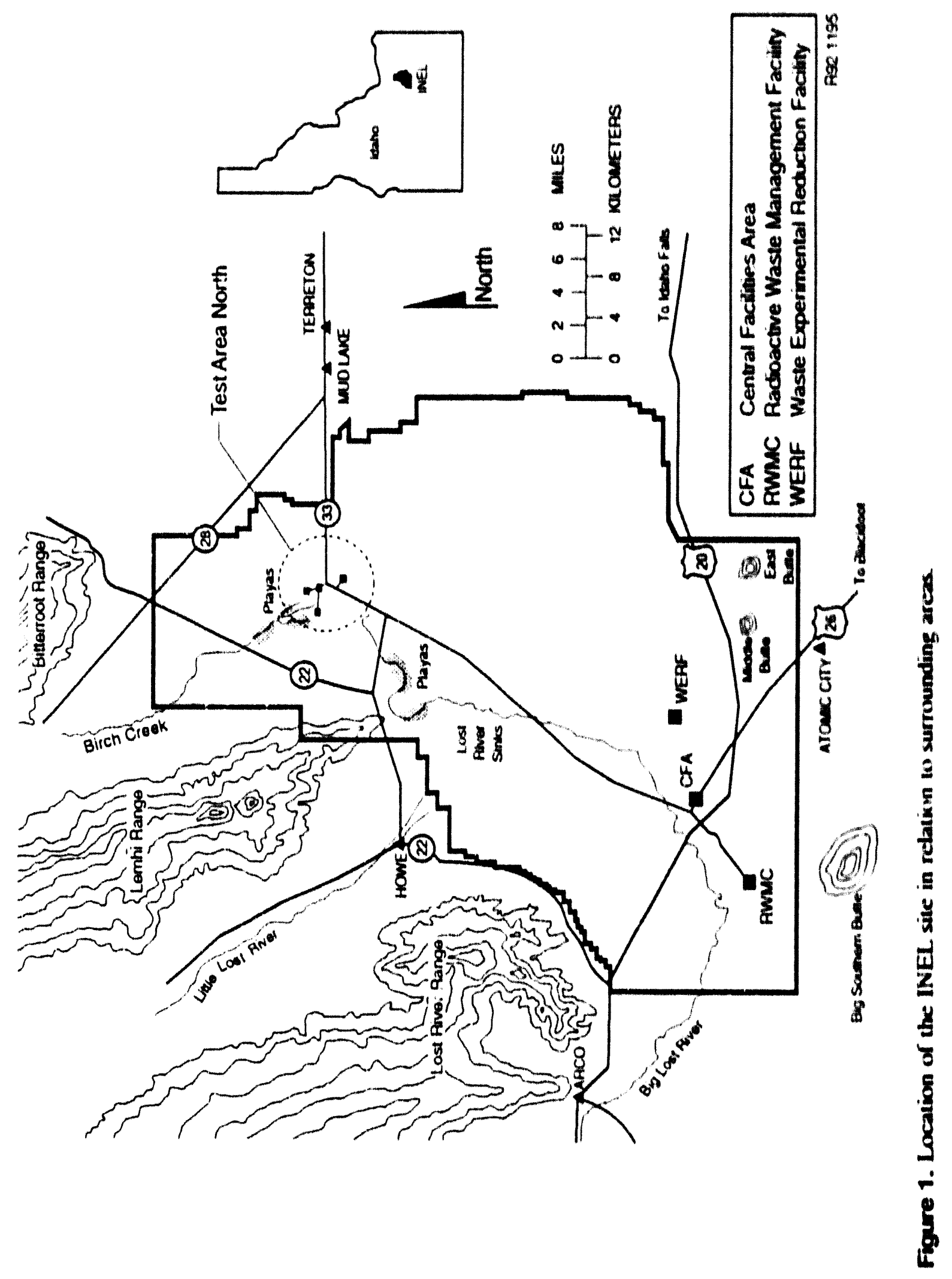




\subsubsection{Geology}

The geology at Test Area North is similar to that of other locations on the INEL, and generally consists of basalt flows intercalated with sedimentary interbeds. The surficial deposits at TAN are composed of playa and lacustrine sediments derived from Birch Creek and the ancient Lake Terreton. Loess, a wind blow sediment, is also prevalent. This report is constrained to the TSF-07 disposal pond; therefore, only the surficial sediments are pertinent to the discussion. A detailed discussion of the geology of the INEL and TAN can be found in the 1992 RI/FS work plan (EG\&G Idaho 1992) and the draft 1993 remedial investigation final report. ${ }^{\text {a }}$

Based on auger holes drilled in the TSF-07 disposal pond during the TAN subsurface investigation (sampling event 4 as described in Section 3), the surficial sediments underlying the pond

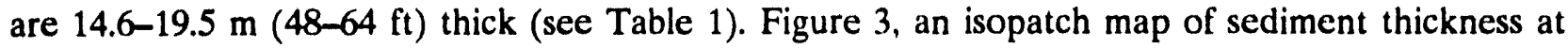
TAN, illustrates the depth to basalt.

Mineralogy of Soils at Depth. The Birch Creek playa deposits that cover approximately $13 \mathrm{~km}^{2}$ $\left(5 \mathrm{mi}^{2}\right)$ to the west and northwest of TAN (Nace et al. 1956) are representative of surficial deposits near the TSF-07 disposal pond. These playa deposits consist of poorly sorted, fine-grained, light gray to light tan sand, silt, and clay that are typically reworked Terreton Lake sediments. The playa deposits are classified generally as clayey, sandy silt with $14 \%$ clay, 5-20\% sand, and 50-70\% silt (Nace et al. 1956.)

The Terreton Lake bed sediments generally underlie the playa deposits and are exposed at the surface in the southern and eastern portions of TAN. These deposits are typically sandy and clayey silt, with lesser amounts of relatively pure clay, silt, and fine gravel (Nace et al. 1956). Table 2 summarizes the percentage of clay, silt, sand, and gravel from the samples collected. Sample numbers 1-5 were collected from the Terreton Lake bed sediments, and sample numbers $6-9$ were collected from the beach and bar deposits associated with the Terreton Lake beds. Sample numbers 1-3 are similar in clay and silt composition, and samples $3,4,8$, and 9 are less abundant in terms of the pure clay and silt fraction. Sample 5 contains a high percentage of silt compared to the other samples. Samples 1, 5, 6, 7, and 8 exhibited a minimum amount of $50 \%$ of silts, with sample 4 and 9 exhibiting a much smaller percentage of this size fraction. The distribution of sample six is closest to the mean distribution of the materials.

Properties of Surface Materials. The geology of the INEL Site has been studied extensively since the early $1950 \mathrm{~s}$. The geological properties that have been measured include mineralogy, cation exchange capacity, and sorption coefficients. Information presented below provides an idea of the normal values expected at the INEL, and where available, for Test Area North.

Mineralogy. The mineralogy of the silt and clay size fractions has been determined for the surficial sediments at 29 locations in the northern part of the INEL. The clay size fraction is relatively impure mineralogically, containing an average of only $68 \%$ clay minerals (presented in Table 3 ). The common clay minerals are montmorillonite, hydrous mica (illite), and kaolinite. The silt and sand size

a. EG\&G Idaho, Inc., TAN Groundwater Remedial Investigation Report (Draft), EGG-ER-10643, February 1993. 
Table 1. Thickness of the surficial sediments near the TSF-07 disposal pond.

\begin{tabular}{llc}
\hline Well number & Location & $\begin{array}{c}\text { Thickness of surficial } \\
\text { sediments (ft) }\end{array}$ \\
\hline TSF Inj & TSF & 37.5 \\
TSFAG-03 & TSF & 53.0 \\
TSFAG-04 & TSF & 48.0 \\
TSFAG-05 & TSF & 53.5 \\
TSFAG-07 & TSF & 64.0 \\
TAN 9 & & \\
TAN 10 & TSF & 24.5 \\
TAN 10A & TSF & 58.0 \\
TAN 11 & TSF & 38.0 \\
TAN 12 & TSF & 48.0 \\
TAN 13 & TSF & 56.4 \\
TAN 13A & TSF & 41.4 \\
TAN 14 & TSF & 39.0 \\
TAN 20 & TSF & 40.5 \\
FET-1 & TSF & 45.0 \\
FET-2 & & 38.0 \\
TAN Disp2 & East of CTF & 39.0 \\
TAN Disp3 & East of CTF & \\
TAN-CH1 & & 37.0 \\
\hline a. Borehole locations. & TSF & 48.0 \\
\hline
\end{tabular}

particles are composed of quartz, calcite, feldspar, and dolomite. This mineralogic difference between the two size fractions suggests that little of the clay has formed in situ by the devitrification of feldspars but has been transported to the area by wind and water (Nace et al. 1956). One sample taken nearest the TSF-07 disposal pond had a clav fraction dominated by hydrous mica and kaolinite, with montmorillonite and quartz as subordinate minerals.

Cation Exchange Capacity and Sorption Coefficients. Cation exchange capacity (CEC) is a measure of the ability of a material to remove cations from solution by exchanging them for cations held loosely within the structure of the material (Rightmire 1984). CEC is an important parameter in controlling the migration of contaminants. CECs have been determined for a large number of surface materials throughout the INEL and are presented in Table 4. The CECs are generally low, reflecting the coarse-grained nature of most alluvial material at the INEL. CECs for surficial materials near the TSF-07 disposal pond are probably in the range of 10 to $40 \mathrm{meq} / 100 \mathrm{~g}$, assuming those materials have the particle size distribution typical of the lacustrine deposits previously described. 


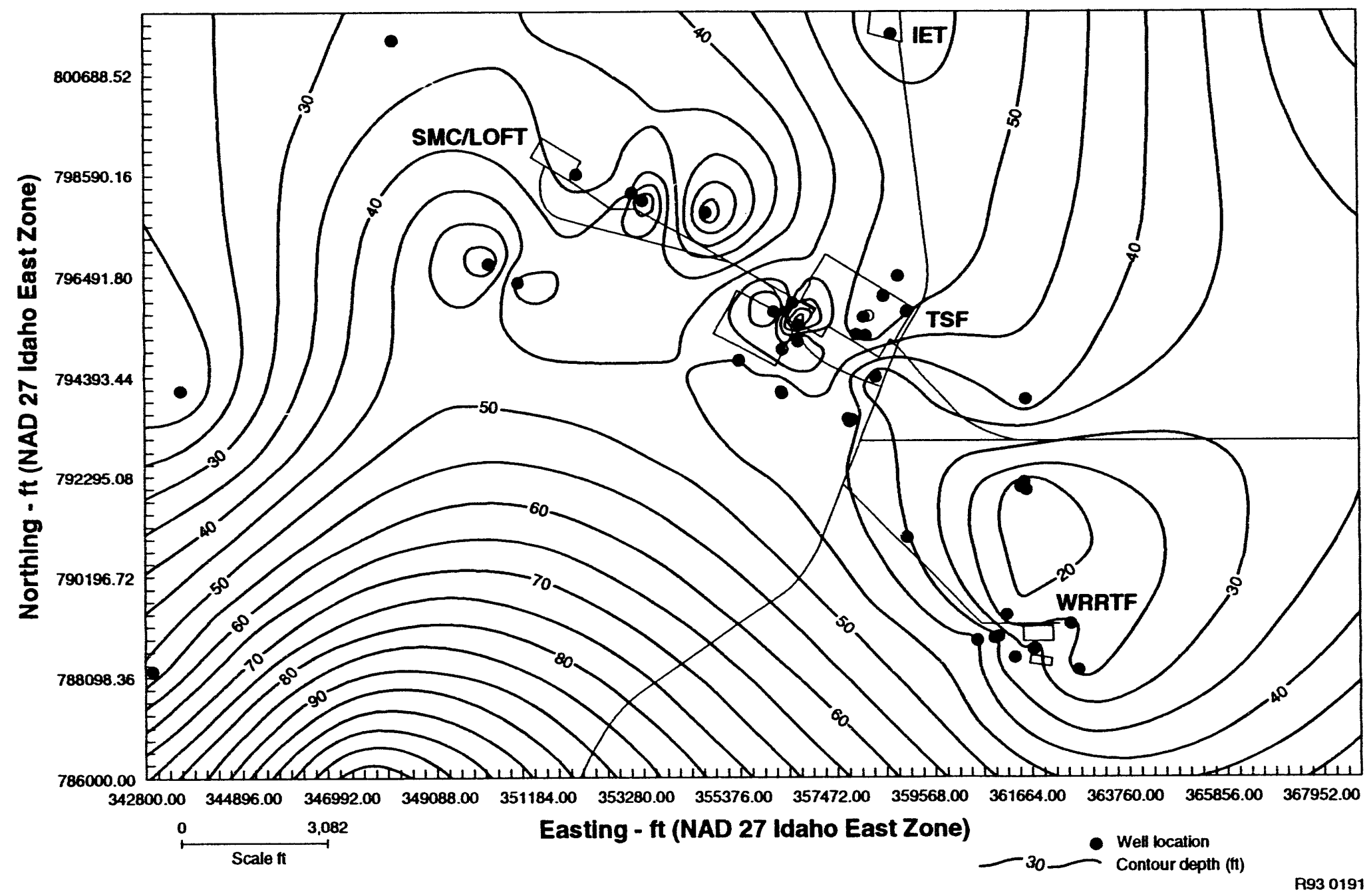

Figure 3. Isopatch map of sediment thickness at TAN. 
Table 2. Total percentage of clay and silt composition of representative samples collected from the Terreton Lake beds and the associated area. ${ }^{a}$

\begin{tabular}{cccccc}
\hline Sample number & $\begin{array}{c}\text { Clay } \\
(\%)\end{array}$ & $\begin{array}{c}\text { Silt } \\
(\%)\end{array}$ & $\begin{array}{c}\text { Sand } \\
(\%)\end{array}$ & $\begin{array}{c}\text { Gravel } \\
(\%)\end{array}$ & $\begin{array}{c}\text { Depth below } \\
\text { land surface } \\
(\mathrm{ft})\end{array}$ \\
\hline 1 & 27 & 50 & 23 & 0 & $3.8-4.3$ \\
2 & 45 & 48 & 7 & 0 & $5.4-5.8$ \\
3 & 21 & 27 & 52 & 0 & $0.0-0.5$ \\
4 & 12 & 19 & 69 & 0 & $0.4-0.8$ \\
5 & 0 & 94 & 6 & 0 & $6.5-6.9$ \\
6 & 12 & 58 & 30 & 0 & 1.0 \\
7 & 8 & 72 & 20 & 0 & 10.0 \\
8 & 0 & 58 & 42 & 0 & 15.0 \\
9 & 6 & 14 & 92 & 0 & $2.4-2.9$
\end{tabular}

a. Reference Nace et al. (1956) for exact sample coordinate location.

Because no studies have been performed on the ability of soils near TAN to retain radionuclides, the results from a study by Schmalz (1977) at the Test Reactor Area (TRA) of the INEL are presented. Sorption coefficients are determined as

$\mathrm{K}_{\mathrm{d}}=\mathrm{Cs} / \mathrm{Cw}$

where

$$
\begin{aligned}
& \mathrm{K}_{\mathrm{d}}=\text { sorption coefficient, } \mathrm{mL} / \mathrm{g} \\
& \mathrm{C}_{\mathrm{s}}=\text { concentration of radionuclide on soil, } \mathrm{mCi} / \mathrm{g} \\
& \mathrm{C}_{\mathrm{w}}=\text { concentration of radionuclide in water, } \mathrm{mCi} / \mathrm{mL} .
\end{aligned}
$$

The sorption coefficients were measured in batch experiments, measured in laboratory column experiments, and calculated from soil and water samples collected in the field. Values $\left(\mathrm{K}_{\mathrm{d}}\right)$ for cesium ranged from a low of $285 \mathrm{~mL} / \mathrm{g}$ for batch experiments to a range of 450 to $900 \mathrm{~mL} / \mathrm{g}$ calculated from field data. Values $\left(\mathrm{K}_{\mathrm{d}}\right)$ for strontium ranged from a low of $7.2 \mathrm{~mL} / \mathrm{g}$ for batch experiments to $40 \mathrm{~mL} / \mathrm{g}$ calculated from field data. Because the field data reflect the most realistic conditions for sorption, these values would be most indicative of the sorptive properties of the Big Lost River alluvium (although the soil properties discussed here are not part of the TAN area, it is the only sorption data currently available at the INEL). 
Table 3. Average mineral composition of the silt and clay size fractions from samples collected at the northern part of the INEL.

$\begin{array}{ll}\text { Clay } & \text { Silt } \\ (\%) & (\%)\end{array}$

Clay minerals

Montmorillonite

34

8

Hydrous mica

21

7

Kaolinite

13

Quartz

14

48

Calcite

13

20

Feldspar

$<5$

8

Dolomite

$=$

$\underline{9}$

Total

100

100

Note: Twenty-nine samples were used in this analysis.

(Reference: Nace, et al. 1956)

In a study of sorption of plutonium on INEL soils (Hardy 1991$)$, values $\left(K_{d}\right)$ were measured for plutonium by using batch experiments and a range of initial plutonium concentrations from $10^{-8}$ to $10^{-6} \mathrm{~mole} / \mathrm{L}$. The sorption coefficients ranged from 140 to $5,000 \mathrm{~mL} / \mathrm{g}$, with a geometric mean of $1,160 \mathrm{~mL} / \mathrm{g}$. The ability to reverse the sorption process was also evaluated by running elution experiments on soil columns. In no case was more than $2 \%$ of the total sorbed plutonium removed from the soil by leaching of the column.

\subsubsection{Hydrology}

Surface water at the INEL comes from streams draining through intermountain valieys to the west and north, localized snowmelt, and rain. Streams entering the INEL include the Big Lost River, Little Lost River, and Birch Creek. Water from these streams does not reach the TSF-0"' disposal pond. The RI/FS work plan (EG\&G Idaho 1992) describes the surface and groundwater hydrology of the TAN area in detail, so it is not discussed here.

Perched Water Zone. Perched water was encountered beneath the TSF-07 disposal pond during the 1989 TAN RCRA Facility Investigation (RFI) characterization effort (EG\&G Idaho 1988). The primary layer responsible for creating the perched water beneath the pond is a clay layer at the basalt/surficial sediment interface. The perching results from fractures in the basalt being filled by the 
Table 4. Summary of cation exchange capacity of sediments and basalt.

\begin{tabular}{|c|c|c|c|}
\hline Type of sample & $\begin{array}{c}\text { Number of } \\
\text { samples }\end{array}$ & Average range & $\begin{array}{c}\text { CEC } \\
(\mathrm{meq} / 100 \mathrm{~g})\end{array}$ \\
\hline \multicolumn{4}{|l|}{ Surface sediments } \\
\hline \multicolumn{4}{|l|}{ Gravel } \\
\hline Coarse, clean & 2 & $1.0-2.9$ & 2.0 \\
\hline Sandy & 52 & $1.4-15.6$ & 4.1 \\
\hline \multicolumn{4}{|l|}{ Sand } \\
\hline Clean & 19 & $1.6-18.0$ & 7.6 \\
\hline Silty & 24 & $1.8-23.6$ & 8.5 \\
\hline Silty and clayey & 21 & $3.3-20.0$ & 10.3 \\
\hline Silty, windblown & 5 & $3.0-7.5$ & 5.2 \\
\hline \multicolumn{4}{|l|}{ Silt } \\
\hline Clean & 4 & $6.2-34.8$ & 20.4 \\
\hline Sandy & 9 & $5.3-38.0$ & 21.9 \\
\hline Sandy and clayey & 17 & $7.1-30.4$ & 13.5 \\
\hline Clayey & 3 & $7.5-42.0$ & 20.3 \\
\hline Clay, silty & 1 & - & 13.7 \\
\hline Soil over silicic rock & 1 & - & 4.4 \\
\hline \multicolumn{4}{|l|}{ Basalt } \\
\hline \multicolumn{4}{|l|}{ Sieve fraction } \\
\hline $0.5 \mathrm{~mm}$ & 6 & $0.4-1.4$ & 0.8 \\
\hline $0.5-0.62 \mathrm{~mm}$ & 8 & $0.6-12.2$ & 3.9 \\
\hline $0.62 \mathrm{~mm}$ & 1 & - & 2.3 \\
\hline
\end{tabular}

clay, thereby decreasing the permeability of the area.

The lateral extent of the perched water is not precisely known. However, nine groundwater monitoring wells and one core hole $(\mathrm{CH})$ were installed during this investigation. These are TAN-9, TAN-10, TAN-10A, TAN-11, TAN-12, TAN-13, TAN-13A, TAN-14, TAN-20, and CH-1 (see Figure 4). These wells were drilled outside the pond berm without encountering perched water (see Figure 3 for well locations relative to the pond).

Five auger holes were also drilled. Three of the five holes, TSFAG-03, TSFAG-04, and TSFAG06, were drilled inside the berm without encountering perched water. The two auger holes where 
perched water was encountered were converted to perched water wells (TSFAG-05 and TSFAG-07) (Figure 4). These wells were installed during the RFI characterization activities. Slug tests were conducted on the wells on June 14,1990 , by EG\&G Idaho. During this testing, it was determined that the depth to basalt is $15.5 \mathrm{~m}(51 \mathrm{ft})$ and the depth to water for TSFAG-05 was $12.7 \mathrm{~m}(41.75 \mathrm{ft})$ with a saturated thickness of $2.8 \mathrm{~m}(9.25 \mathrm{ft}$.). The depth to water in TSFAG-07 was $5.5 \mathrm{~m}$ (18.08 ft) and the saturated thickness was $12.1 \mathrm{~m}(39.92 \mathrm{ft})$. Hydraulic conductivity values were calculated from these tests and are presented in Table 5.

The hydraulic conductivity values are quite low, near the range of values for clay liners used in landfills. The low values of hydraulic conductivity suggest the infiltration from the ponds is at a lower rate than previously thought. This implies more evaporation time and possibly more sorption of contaminants.

\subsubsection{Ecology}

The INEL has been designated as a sagebrush ecosystem (EG\&G Idaho 1984). The ecosystem is composed of shrubs primarily belonging to the genus Artemisia and an understory of perennial grasses and forbs. The RI/FS work plan (EG\&G Idaho 1992) contains specific information concerning the ecology as it pertains to TAN.

\subsubsection{Archaeology}

An archaeological survey has been conducted in and around the TAN area. The final report was completed in December 5,1986 (Reed et al. 1986). Although no significant resources were discovered in the immediate vicinity, minor resources were discovered outside the TSF-07 disposal pond.

Table 5. Hydraulic conductivity values.

\begin{tabular}{ccc}
\hline Well & $\begin{array}{c}\text { Horslev method } \\
(\mathrm{fi} / \text { day })\end{array}$ & $\begin{array}{c}\text { Bouwer \& Rice method } \\
(\mathrm{ft} / \text { day })\end{array}$ \\
\hline TSFAG-(0) & $6.85 \times 10^{-3}$ & $5.80 \times 10^{-3}$ \\
TSFAG-(05 & $4.24 \times 10^{-2}$ & $3.36 \times 10^{-2}$ \\
\hline
\end{tabular}




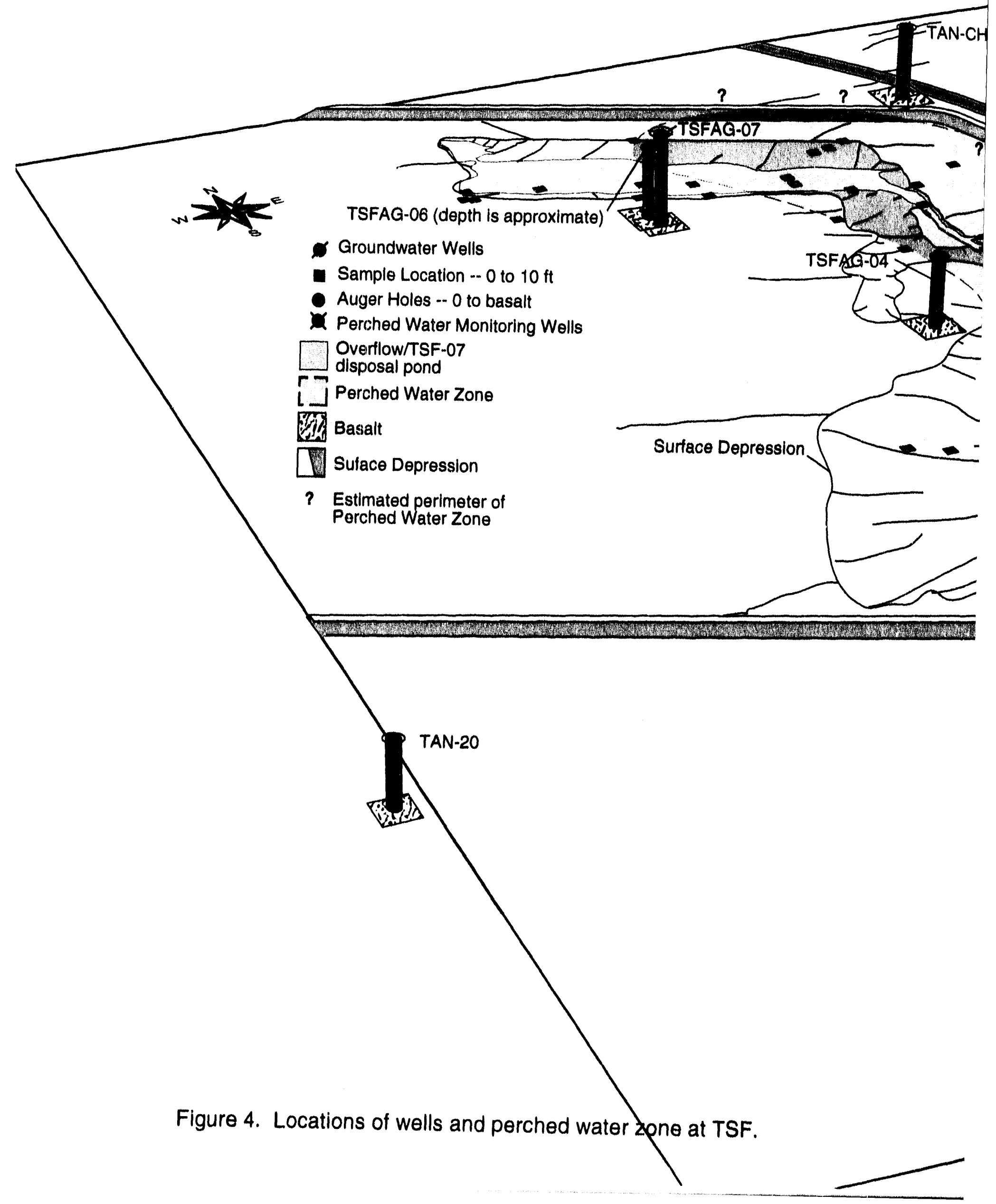




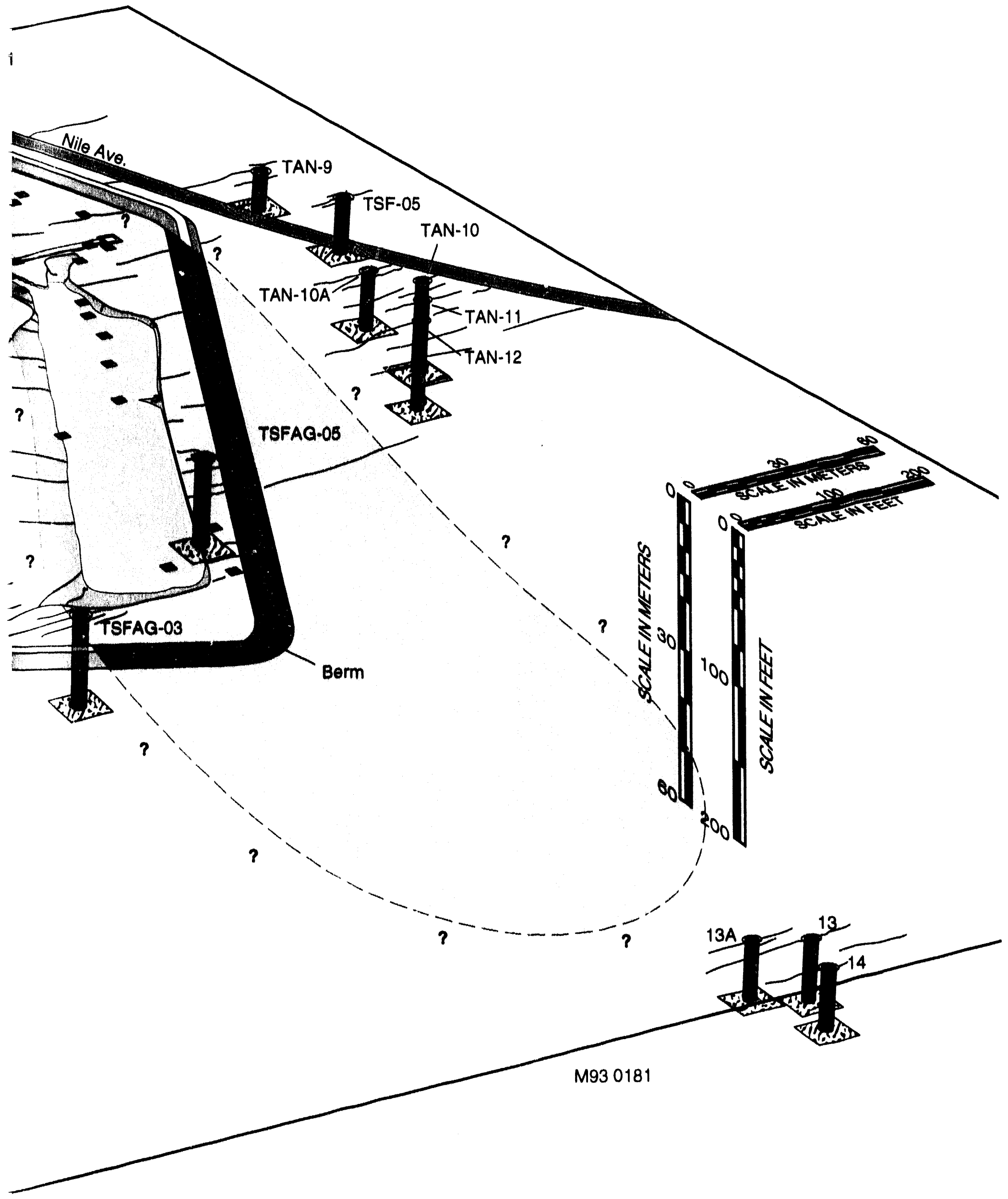




\section{EFFLUENT RECEIPT AT TAN/TSF}

Construction of the TSF-07 disposal pond and common sump (TAN-655) began in 1971 and was completed in late 1972. The pond was constructed to replace the TSF-05 injection well, which was used until September 1972. Refer to Figure 5 for an aerial view of the pond and its relation to TSF. The TSF-07 disposal pond receives effluent from a variety of sources, which include low-level radioactive waste, cold process water, and treated sewage effluent. This waste is mixed in the common sump at TAN-655 and lifted to the TSF-07 disposal pond. Figure 6 is a diagram illustrating the processes that contributed to the effluent entering the pond.

To track the amount of effluent entering the TSF-07 pond, the Industrial Waste Management Information System (IWMIS), a computerized database in effect since 1971, compiles the volume of waste and the sampling results from the measured pollutants. The IWMIS produces an annual report of the INEL solid and liquid industrial waste summary and record-to-date. According to this database, a total of $14,838 \mathrm{~m}^{3}\left(523,940 \mathrm{ft}^{3}\right)$ of sanitary waste has been discharged between 1971 and 1980 into the pond. Section 2.2 describes the volume and types of process wastes discharged into the pond.

This section discusses the current effluent monitoring activities and past disposal practices that may have contributed significant contaminants to the pond.

\subsection{Municlpal/Sewage Effluent}

Restroom sewage from TSF flows to the trickling filter sewage treatment plant. The TSF sewage treatment plant provides primary and secondary treatment for all TSF sanitary waste. Aerobic and anaerobic bacteria work on the waste to digest the solids. The plant influent and effluent are routinely monitored for biochemical oxygen demand, dissolved oxygen, and solids that settle in the tank. The EG\&G Idaho Environmental Monitoring Unit samples for additional parameters. This monitoring program is commonly referred to as the INEL Nonradiological Liquid-Effluent Monitoring Program, which was instituted by EG\&G Idaho in FY 1986. Its purpose is to provide environmental monitoring data results for nonradioactive parameters and pollutants in liquid effluent generated within facilities operated by EG\&G Idaho, including waste entering the TSF-07 disposal pond. The effort includes sampling, analysis, and data interpretation carried out under a rigorous quality assurance program. The data validation efforts are in accordance with EG\&G Idaho Environmental Monitoring Standard Operating Procedures EM-SR-2.1, "Analytical Data Validation in Support of Special Requests."

Analytical parameters include $\mathrm{pH}$, temperalure, conductivity, anions, chloride, lluoride, nitrate, phosphate, metals to contract laboratory program (CLP) detection limits, and total organic carbon using EPA method 415.1. An elevated total organic carbon analysis automatically calls for volatile organic compound (VOC) analysis to be performed. These parameters have been within EPA drinking water standards since the sampling program was initiated. Sampling results from these analyses are kept in a database maintained by the EG\&G Idaho Environmental Monitoring Unit and are documented in an annual report. Table 6 provides an average compilation of the analytical data of the parameters measured from 1987 to 1992 for the TSF-07 disposal pond. 


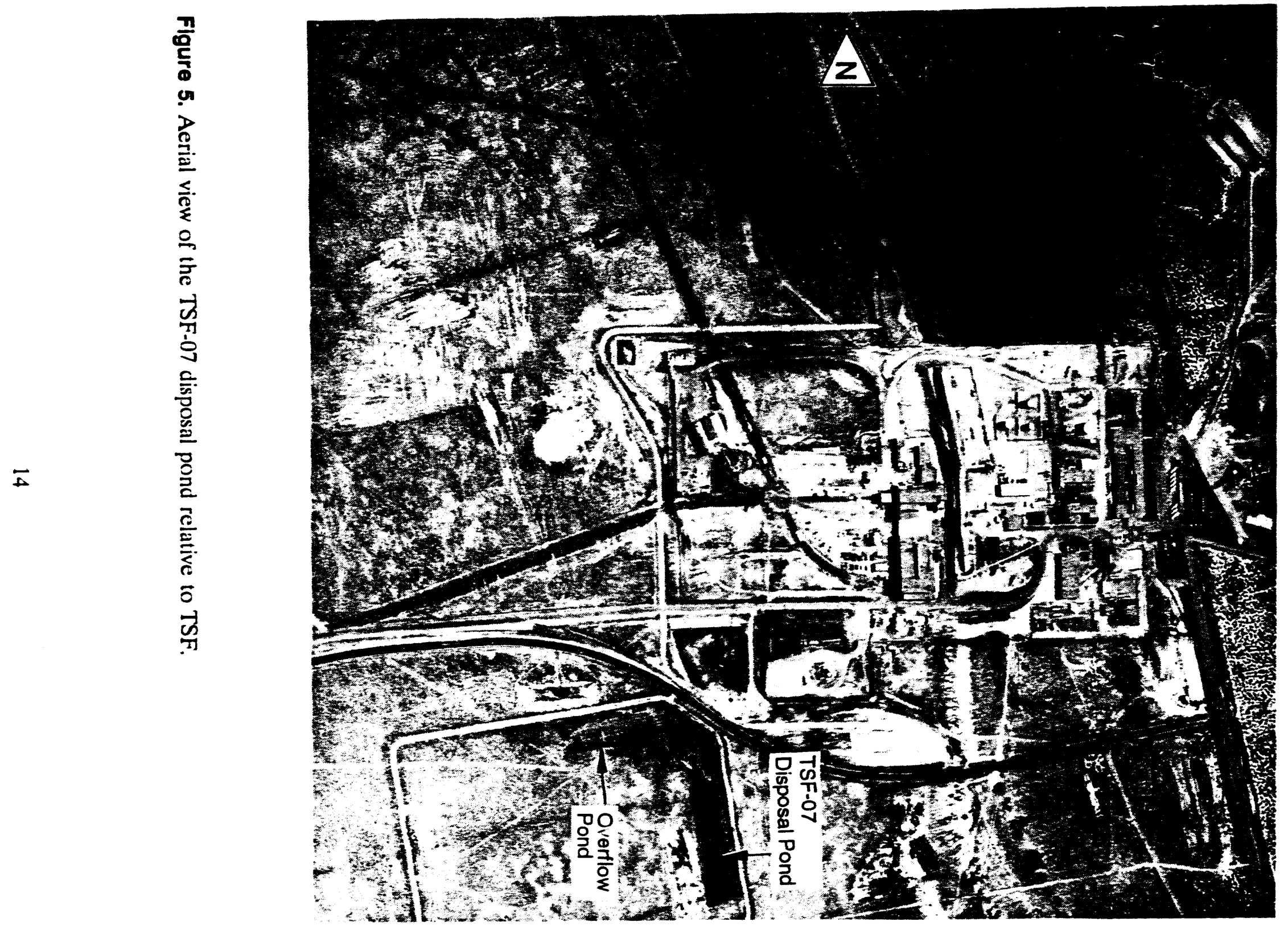




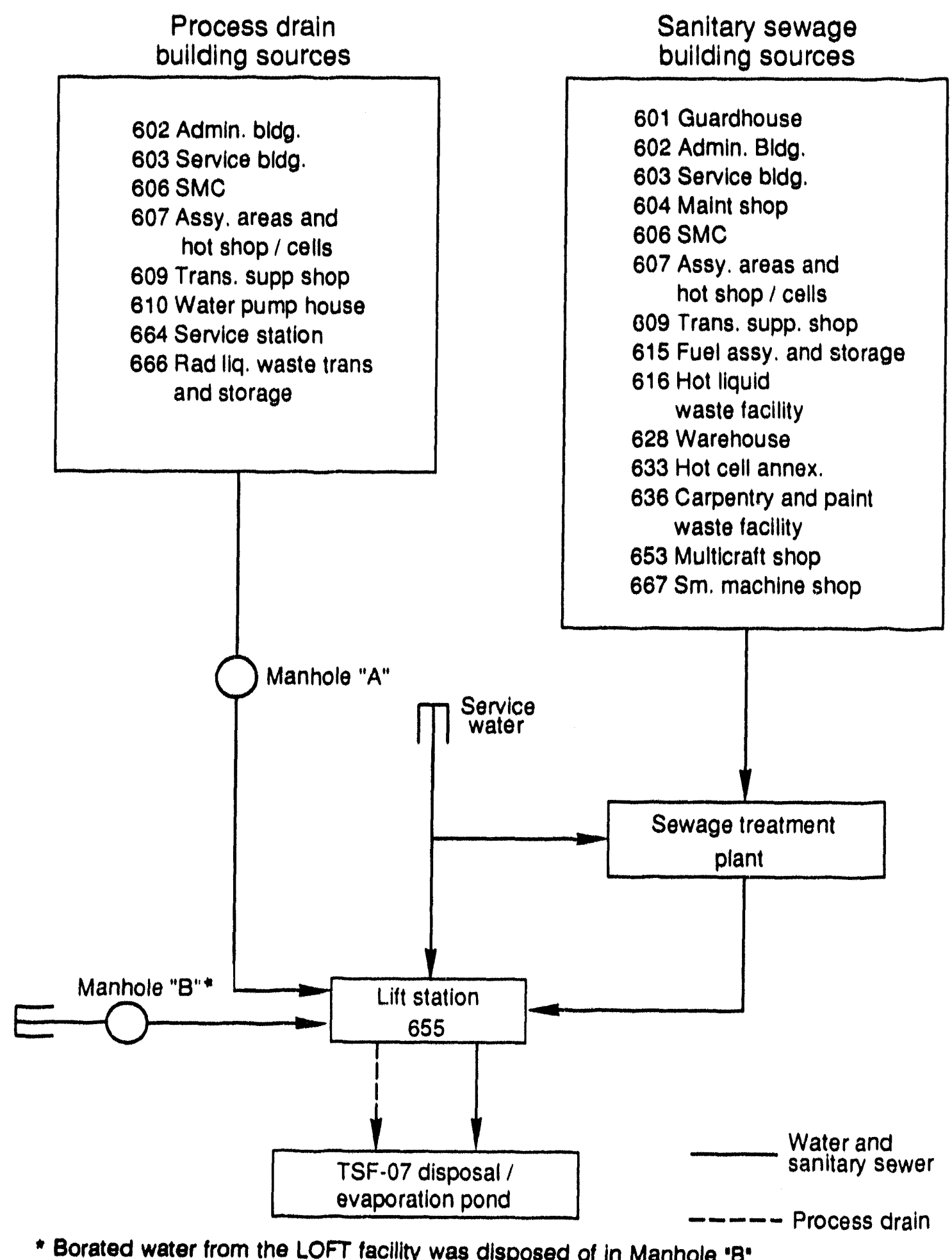

0930004

Figure 6. Process drain and sanitary sewage sources feeding to the TSF-07 pond. 
Table 6. Summary of wastewater parameters analyzed for from FY 1987-FY 1992 for the TSF-07 disposal pond.

\begin{tabular}{|c|c|c|c|c|}
\hline \multirow[b]{2}{*}{ Analyte } & \multirow[b]{2}{*}{ Mean } & \multicolumn{2}{|c|}{ Upper $95 \%$ confidence level } & \multirow{2}{*}{$\begin{array}{l}\text { Regulalory } \\
\text { limil }\end{array}$} \\
\hline & & Level 1 & Level 2 & \\
\hline \multirow{3}{*}{$\begin{array}{l}\text { Cond }(\mu S) \\
\mathrm{pH}\end{array}$} & 513.1 & 862.5 & 1,010 & NA \\
\hline & 7.67 & (1) 6.38 & 5.97 & NA \\
\hline & & (u) 8.95 & 9.36 & NA \\
\hline \multirow{2}{*}{$\begin{array}{l}\text { TOC }(m g / L) \\
\mathrm{Cl}(\mathrm{mg} / \mathrm{L})\end{array}$} & 7.12 & 12.66 & 15.02 & NA \\
\hline & 44.92 & 86.77 & 104.5 & NA \\
\hline \multirow{2}{*}{$\begin{array}{l}F(m g / L) \\
\mathrm{NO}^{3}(\mathrm{mg} / \mathrm{L})\end{array}$} & 0.24 & 0.39 & 0.46 & NA \\
\hline & 14.85 & 25.51 & 30.01 & NA \\
\hline $\mathrm{PO}^{4}(\mathrm{mg} / \mathrm{l})$ & 3.13 & 6.27 & 7.59 & NA \\
\hline $\mathrm{SO}^{4}(\mathrm{mg} / \mathrm{L})$ & 37.59 & 49.11 & 53.98 & NA \\
\hline $\mathrm{Ag}(\mu \mathrm{g} / \mathrm{L})$ & 13.74 & 36.42 & 47.5 .3 & $S,(x \times)$ \\
\hline As $(\mu g / L)$ & $3.60)$ & 8.55 & 10.75 & $5,(x \times)$ \\
\hline $\mathrm{Ba}(\mu \mathrm{g} / \mathrm{L})$ & 107.3 & 212.7 & 257.5 & $1(x),(x \times)$ \\
\hline $\mathrm{Ca}(\mu \mathrm{g} / \mathrm{L})$ & 81,740 & $205,(0 \times 0)$ & $267,0 \times(x)$ & NA \\
\hline$C d(\mu g / L)$ & 6.19 & 10.42 & 12.33 & $1,(x \times)$ \\
\hline & 11.73 & 24.74 & 30.39 & $5,(X X)$ \\
\hline $\mathrm{Cu}(\mu \mathrm{g} / \mathrm{L})$ & 32.90 & 123.0 & 161.3 & NA \\
\hline $\mathrm{Fe}(\mu \mathrm{g} / \mathrm{L})$ & 206.3 & 362.7 & 508.1 & NA \\
\hline $\mathrm{Hg}(\mu \mathrm{g} / \mathrm{L})$ & 1.35 & 9.08 & 12.45 & $2(x)$ \\
\hline $\mathrm{Mg}(\mu \mathrm{g} / \mathrm{L})$ & 14,860 & 19,840 & 22,310 & NA \\
\hline $\mathrm{Mn}(\mu \mathrm{g} / \mathrm{L})$ & 82.80 & 332.9 & 457.1 & NA \\
\hline $\mathrm{Na}(\mu \mathrm{g} / \mathrm{L})$ & 37.240 & 84,200 & $108,(x \times)$ & NA \\
\hline $\mathrm{Ni}(\mu \mathrm{g} / \mathrm{L})$ & 17.47 & 29.67 & 35.43 & NA \\
\hline $\mathrm{Pb}(\mu \mathrm{g} / \mathrm{L})$ & 15.08 & 54.70 & 71.87 & $S,(x \times)$ \\
\hline $\mathrm{Se}(\mu \mathrm{g} / \mathrm{L})$ & 67.46 & 295.7 & 407.5 & $1,(X X X)$ \\
\hline$T 7(\mu \mathrm{g} / \mathrm{L})$ & 75.80 & 185.7 & 259.2 & NA \\
\hline $\mathrm{Zn}(\mu \mathrm{g} / \mathrm{L})$ & 93.21 & 268.3 & 342.3 & NA \\
\hline \multicolumn{5}{|c|}{$\begin{array}{l}=\text { lower concentration level } \\
\mathrm{u}=\text { upper concentration level } \\
\mathrm{NA}=\text { not applicable } \\
\text { Regulatory guideline-RCRA characteristic level }\end{array}$} \\
\hline \multicolumn{5}{|c|}{$\begin{array}{l}\text { Note: Level } 1 \text { is set at the upper } 95 \% \text { contidence level on the individual measurement; thus, a } \\
\text { measurement exceeding Level } 1 \text { has a one in } 20(5 \%) \text { chance of being attributed to random } \\
\text { fluctuations in actual concentrations. Level } 2 \text { is set at the upper } 99 \% \text { confidence limit on the } \\
\text { individual measurements and thus has only a one in } 1(x)(1 \%) \text { chance of being exceeded due to } \\
\text { random fluctuations in actual concentrations. }\end{array}$} \\
\hline
\end{tabular}


Datu Results. Because the TSF-07 disposal pond receives intermittent discharges from a variety of contributing sources, the discharge is nonhomogeneous in nature. This is apparent in the waterquality results for $\mathrm{pH}$ and conductivity. The high conductivity level can be attributed to the soluble salts introduced from the boiler blowdown and demineralizer regeneration discharges. The demineralizer wastewater may also contribute to the observed variances in $\mathrm{pH}$.

\subsection{Process/Hazardous Effluent}

Wastewater has been discharged to the TSF-07 disposal pond since 1972. Some of the processes feeding into the effluent may have contributed contamination to the pond. For example, the TAN-603 facility is the boiler plant that provides steam to the TSF. Phosphate- and sulfate-based chemicals are often added to the boiler makeup water to prevent pipe scaling and corrosion. Approximately $45,700 \mathrm{~L}$ per year $(12,000 \mathrm{gal})$ of this blowdown water is currently being discharged into the sanitary sewage system.

The TSF-07 disposal pond also received condensate from the evaporator process in the intermediate-level waste disposal system. There is no specific information on the chemical characteristics of the evaporator condensate, but if it was similar to the condensate produced at the existing evaporator at the Idaho Chemical Processing Plant, then it can be assumed that it was corrosive (low pH). About 24,004 L (6,342 gal) per year of corrosive condensate waste from the evaporator and about 17,002 L (4,492 gal) per year of corrosive waste from the TAN-607 pipe laundry entered the TSF-07 disposal pond.

The specific hazardous waste suspected to have entered the TSF sewer plant also includes corrosive liquids (acidic and basic solutions) from the TAN-607 pipe laundry and photo laboratory and small amounts of ignitable waste from the TAN-607 maintenance shop. The volume and concentrations of these chemicals that were discharged into the sewer plant and ultimately to the TSF.07 disposal mnd are unknown. However, sampling of the pond influent has shown the wastewater to be rioncorrosive according to the EPA hazardous waste definitions in 40 CFR 261 . Other wastewater areas include the actuator building, the Hot Cell Annex, and all the assembly and maintenance shops located in the TAN-607 building. In addition to these areas, lightly radioactive borated wastewater was transported from the Loss-of-Fluid Test (LOFT) Facility to manhole B in the process waste line just upstream of the TAN-655 sump.

Discussions involving various EG\&G Idaho personnel who were knowledgeable of the TAN/TSF area are documented in a correspondence letter from W. A. Baxter. ${ }^{c}$ In this correspondence, processes that may have contributed to the contamination at the TSF-07 disposal pond were identified. The areas include:

- The hot waste lines that are interconnected through a common vent line located below floor grade in the TAN-607 Hot Shop.

- Two floor drains that are located in the TAN-633 (hot cell area) drain to the sewer system.

c. Private communication between W. A. Baxter and H. J. Zeile, EG\&G Idaho, Inc., May 10, 1988. 
- The floor drain located in the passageway between TAN-607 and TAN-633, which drains to the process water system. Samples collected from the manhole in this line read 8,000 counts per minute and show 800 counts per minute of smearable radioactivity.

- The showers and wash basins, which are used for decontamination of hot shop personnel, drain to the sewer system.

Another area that presumably contributed significant contaminants to the TSF-07 disposal pond includes the TAN-655 area, commonly referred to as the common sump. The sump pump has a capacity of about $3,028 \mathrm{~L} / \mathrm{min}(800 \mathrm{gal} / \mathrm{min})$ and is activated when the sump fills to the float level (refer to Figure 7 for a focused view of the pond). The effluent is then pumped to the pond.

Samples from the sump and the sump margin were collected during a sampling effort in 1989 . Tables 7 and 8 summarize the data resulting from this effort. Only two samples were analyzed for inorganic contaminants. An average value of both samples is included in the table. When compared to background levels for TAN, it was found that at least one of the two samples for each contaminant exceeded the level for inorganic contaminants, as presented in Table 9. (Background levels are baseline concentrations derived from the sampling data originating from EGG-ESQ-9225, EG\&G Idaho 1990.) Complete sump data analytical results are presented in Appendix B.

Two samples were collected and analyzed for gamma contaminants. Cobalt- 60 was found at a maximum concentration of $62.0 \mathrm{pCi} / \mathrm{g}$, compared to the background level of $0.0 \mathrm{pCi} / \mathrm{g}$ for Co- 60 . Cesium-137 was detected at a maximum value of $135.0 \mathrm{pCi} / \mathrm{g}$. The TAN background level for Cs-137 is $1.3 \mathrm{pCi} / \mathrm{g}$.

Only one sample in the sump location was analyzed for inorganic Appendix IX analytes (found in 40 CFR 264, "Standards for Owners and Operators of Hazardous Waste Treatment, Storage, and Disposal Facilities"). The data results are presented in Table 9. The background levels for each of these contaminants are presented in the column next to the concentration level determined from the analytical results. As can be noted, all the contaminants listed in this table exceed the background level. 


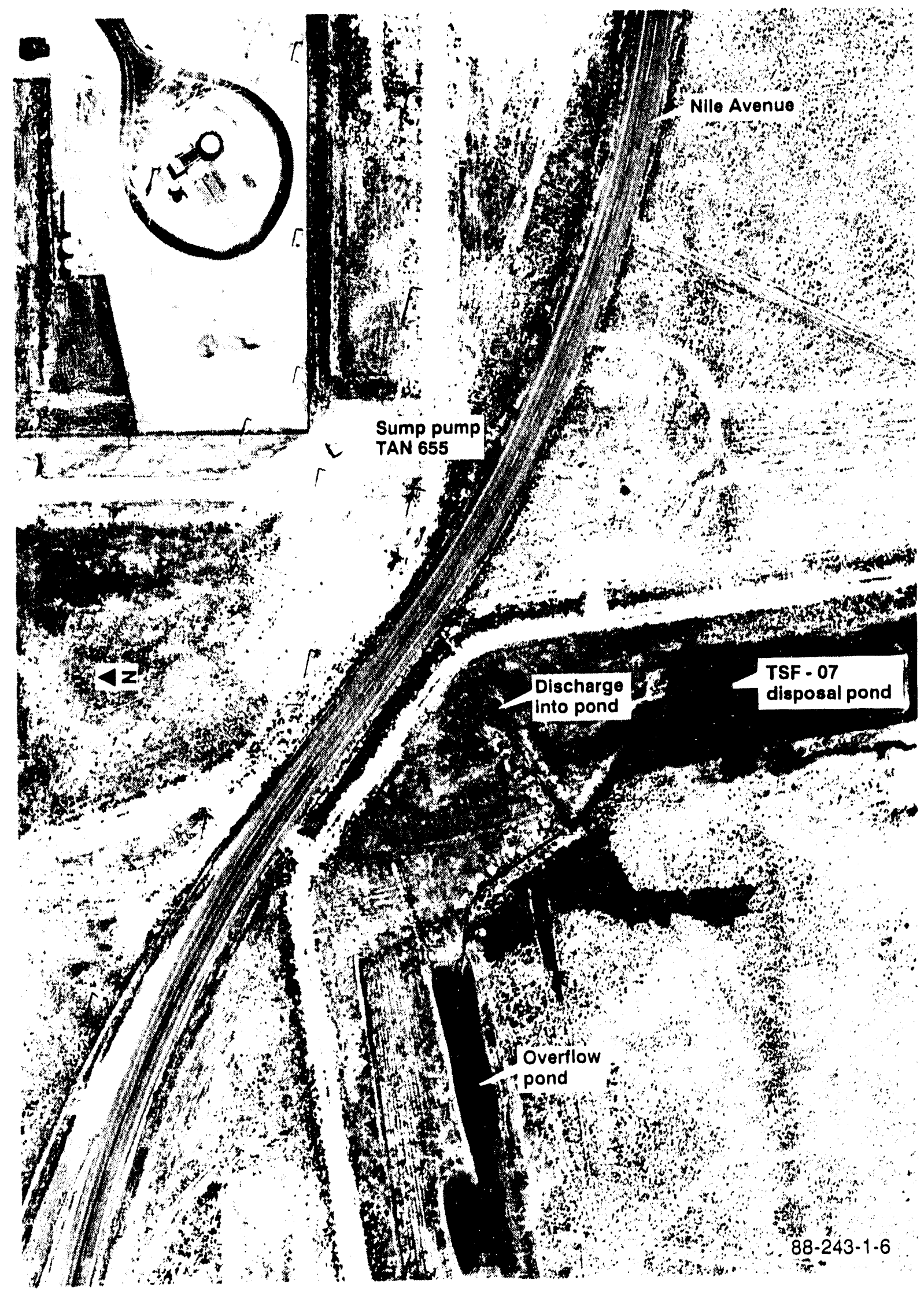

Figure 7. Aerial focused view of the TSF-07 disposal pond. 
Table 7. Sump data results.

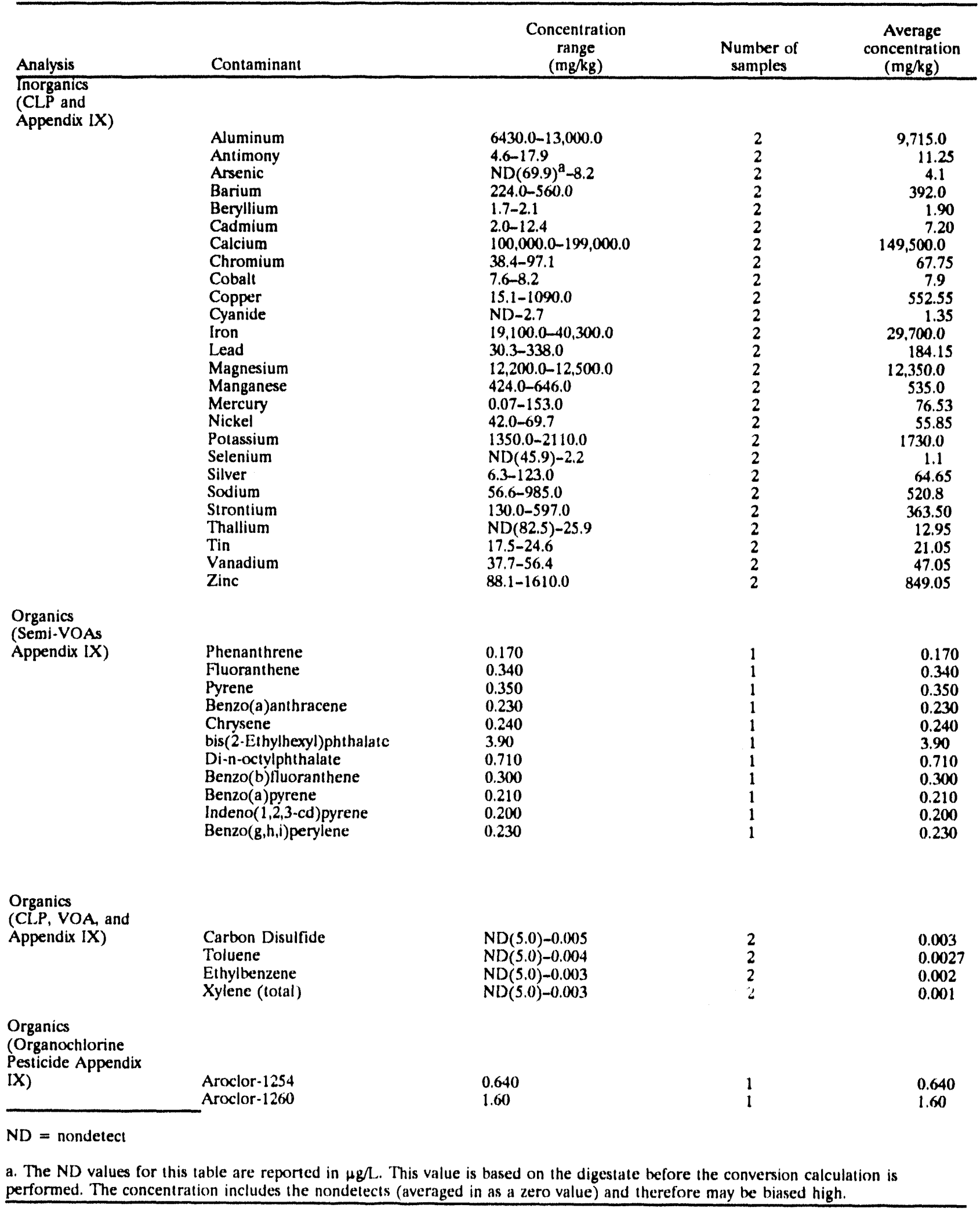


Table 8. Sump radiological data results.

\begin{tabular}{lcccc}
\hline Analysis & Contaminant & $\begin{array}{c}\text { Concentration } \\
\text { range } \\
(\mathrm{pCi} / \mathrm{g})\end{array}$ & $\begin{array}{c}\text { Number } \\
\text { of samples }\end{array}$ & $\begin{array}{c}\text { Average } \\
\text { concentration } \\
(\mathrm{pCi} / \mathrm{g})\end{array}$ \\
\hline Radiological & Co-60 & ND-62.00 & 2 & 31.0 \\
& Cs-137 & ND-135.0 & 2 & 67.5
\end{tabular}

Note: The concentration includes the nondetects (averaged in as a zero value) and therefore may be biased high.

Table 9. Sump data evaluation.

$\begin{array}{lcc}\text { Contaminant } & \begin{array}{c}\text { Background level } \\ \left(\mathrm{mg} / \mathrm{kg}^{\mathrm{a}}\right.\end{array} & \begin{array}{c}\text { Concentration } \\ \text { Barium }\end{array} \\ \begin{array}{l}254.0 \\ \text { Beryllium }\end{array} & 1.5 & 560.0 \\ \text { Cadmium } & 4.6 & 2.1 \\ \text { Chromium } & 38.9 & 12.4 \\ \text { Lead } & 55.6 & 97.1 \\ & & 338.0 \\ \text { Mercury } & 0.06 & \\ \text { Nickel } & 42.5 & 153.0 \\ \text { Silver } & 3.5 & 69.7 \\ \text { Strontium } & 200.0 & 123.0 \\ \text { Thallium } & 18.4 & 597.0 \\ & & 25.9 \\ \text { Vanadium } & 53.7 & \\ \text { Zinc } & 182.0 & 56.4\end{array}$

a. The background levels are specified in DOE/ID-10340 (DOE 1992). The background level for strontium was obtained from Table 4.0.7 of EGG-ES-8204 (DOE 1989c). This level is from Los Alamos National Laboratory soils. 


\section{SAMPLING HISTORY}

This section of the report summarizes the sampling events that were performed at the TSF-07 disposal pond between 1982 and 1992. Table 10 identilies the sampling events hy number, year, media type, and performing organization. The following sections address each sampling event, dates, activities, and a summary of final sample results from each investigation. This document does not discuss any deviations specific to sample collection and analysis as specified in the original sampling and analysis plans.

Screening criteria described in Section 4 are applied to sumpling events 2 through 5 a to determine significant contaminants. Vertical and plan view maps exhibiting the migration tendencies of the significant contaminants are plotted and the data are discussed in Sections 4.4 and Section 5. The screening criteria could not be applied to data obtained from sampling event 1 because the data could not be validated because information was not available (refer to the memorandum in Appendix C).

\subsection{Sampling Event 1}

\subsubsection{Influent and Pond Water Sampling}

Sampling of TSF influent and pond water began in 1982. Two sets of water samples were submitted to California Analytical Laboratories, Inc., for analysis hy priority pollutant methods 6 ()8. 613, 624, and 625, which were originally published in the December 1979 Federal Register. The methods measured for VOCs, base neutral acid extractable compounds, metals by inductively coupled plasma (ICP) and atomic absorption (AA) techniques, and pesticides/polychlorinated biphenyls (PCBs). The EPA and the analytical laboratory had agreements that these methods could be substituted for corresponding CLP procedures. A summary of the data results (derived from Hardy and Stanisich 1991) is presented in the following section.

\subsubsection{Analytical Results}

Organics detected in the influent and pond water include toluene and the pesticide alpha.BHC. which is a phthalate. Phthalates are commonly found in low concentrations in industrial waste streams and in environmental samples. Used as plasticizers and extenders in many forms of plastics, phthalates are considered only slightly toxic and do not present a hazard in the concentrations detected (less than $1 \mathrm{ppm}$ ). Toluene was detected in one of nine samples at $20 \mathrm{pph}$, and alpha-BHC was detected in four samples at a maximum of $7 \mathrm{pph}$. The detection of an alpha-BHC is not surprising because pesticide applications have occurred periodically at TAN/TSF.

Boron was the only metal detected in the pond water above typical concentrations in INEL. surface waters and the only metal detected in excess of surface water criteria for public water supplies. Boron concentrations were detected at or near a maximum of $30 \mathrm{ppm}$ in three samples. In comparison, background concentiations are typically less than $1 \mathrm{ppm}$. Boron was used as a moderator at the LOFT Facility. The water was trucked to a manhole leading to the TSF.(1) disposal pond and is probably the source of the boron detected in the pond water. 
Table 10. Sampling events performed at the TSF-07 disposal pond.

\begin{tabular}{|c|c|c|c|c|}
\hline $\begin{array}{l}\text { Sampling } \\
\text { event }\end{array}$ & Sampling effort & Dates & $\begin{array}{l}\text { Performing } \\
\text { organization }\end{array}$ & $\begin{array}{l}\text { Media } \\
\text { sampled }\end{array}$ \\
\hline 1 & Initial sampling effort & 1982 & EG\&O Idaho & Surface water \\
\hline 2 & $\begin{array}{l}\text { Preliminary } \\
\text { assessment of the } \\
\text { TSF.07 disposal pond }\end{array}$ & 1988 & EG\&G Idaho & Soil, sediment \\
\hline 3 & $\begin{array}{l}\text { DOE environmental } \\
\text { survey of surface } \\
\text { water and soil samples } \\
\text { from the TSF.07 } \\
\text { disposal pond }\end{array}$ & Summer 1988 & $\begin{array}{l}\text { DOE-HQ } \\
\text { Environmental Survey } \\
\text { Team from Oak Ridge } \\
\text { National Laboratory }\end{array}$ & $\begin{array}{l}\text { Soil, sediment, } \\
\text { water }\end{array}$ \\
\hline 4 & $\begin{array}{l}\text { Subsurface } \\
\text { investigation for the } \\
\text { TAN RFI }\end{array}$ & $\begin{array}{l}\text { June and July } \\
1989\end{array}$ & EG\&G Idaho & Soil \\
\hline 5 & $\begin{array}{l}\text { Site characterization } \\
\text { of the TSF.07 } \\
\text { disposal pond (Hardy } \\
\text { and Stanisich, 1991) }\end{array}$ & July 6, 1989 & EG\&G Idaho & $\begin{array}{l}\text { Soil, sediment, } \\
\text { water }\end{array}$ \\
\hline $5 a$ & $\begin{array}{l}\text { Subsurface } \\
\text { investigation of the } \\
\text { TSF-07 disposal pond } \\
\text { (perched water } \\
\text { sampling activities } \\
\text { from TSFAG.05 and } \\
\text { TSFAG.(1) }\end{array}$ & $\begin{array}{l}\text { July } 1990) \\
\text { through May } \\
\text { (99)1 }\end{array}$ & $\begin{array}{l}\text { EG\&G ldaho } \\
\text { Environmentul } \\
\text { Technology Unit }\end{array}$ & Perched water \\
\hline
\end{tabular}

Analytical results for the set of data obtained from this sampling effort did not indicate quality control sample results. Therefore, the data in the reports are of unknown quality and eould not be validated as detined in EG\&G Idaho's Environmental Restoration Standard Operating Procedure 12.1.1. Refer to Appendix $C$ for the leller report and analytical results submilled by California Analytical Luboratorics to EG\&G Idaho.

\subsection{Sampling Event 2}

\subsubsection{Prellminary Soll/8ediment Asesesement}

Surface soil/sediment samples were collected in 1988 as part of the preliminary assessment of the TSF-07 disposal pond. This section summarizes the sampling effort and validation efforts, derived from Hardy and Stanisich (|9|)|). 
In accordance with the sampling and analysis plan, samples were collected by EG\&G Idaho personnel and analyzed by Roy Weston Laboratories using EPA SW.846 methods, and a data package of equivalent detail to a CLP data package was provided with the results. Three surface soil/sediment samples were collected as grab samples near the outfall of the TSF sump (the wastewater inlet). The entire pond was dry during sampling, but the soil/sediment collected from the outfall of the sump was saturated. The samples were analyzed for Appendix IX compounds using SW. 846 methods and producing a data package with the detail of a CLP package. Samples included one duplicate, one tield standard, one rinsate, and one trip blank. Sample locations 1, 2, and 3 were primary locations, while sample 4 was a duplicate of sample 3. Sample locations are shown in Figure 8.

Chain-of-custody procedures were followed, and water samples collected (water samples were the quality assurance samples) for metals analysis were preserved with nitric acid to a pH of less than 2. The samples were shipped in coolers at $4^{\circ} \mathrm{C}$ to the laboratory via overnight delivery service.

\subsubsection{Analytical Reaults}

Appendix D contains the actual data results and data validation elforts for this sampling event. A summary of the data results is presented in Table 11 . The table includes contaminants that were detected, concentration range in mg/kg. the number of samples collected, and the average concentration. (This method of summurizing data will be used for the remaining summary data tables for the other sampling events discussed in this section.) In determining the average eoncen!ration, all values other than R. NR, and nondetect llags (delined as $U$ llags) were taken into account (Environmental Restoration Program, Sumple Management Oflice Standard Operating Procedures 12.1.3 and 12.1.5) If a contaminant is not detected, then the minimum value was presented as ND when presenting the data range.

Metals detected above hackground (as referenced in the previous section) are cadmium and mercury. The TAN hackground level for codmium is $4.6 \mathrm{mg} / \mathrm{kg}$. As noled in the Table 11 , all four of the sumples collected were ahove this range. The hackground level for mercury is $0.06 \mathrm{mg} / \mathrm{kg}$. The four samples collected were all above this level. One of the samples analyaed for mereury was detected at an elevated concentrution of $4(24) .()$ me/kg at sampling location 2.

Organics detected included dichloroditluoromethane, methylene chloride, and tetrahydrofuran. The concentration of dichlorodifluoromethune was $12.0 \mathrm{mg} / \mathrm{kg}$. Methylene chloride was detected at concentrations less than the contract-required quantitation limit (CRQL) of $10 \mathrm{pph}$ and was also detected in methed hlanks at similar concentrations. Tetruliydroliuran was detected in concentrations less than the CROL and in the melhesd blanks. Both methylene chloride and tetrahydrofiuran most likely result from contuminution of the sample by the same souree of contuminution that caused the results observed in the blunks.

\subsection{Sampling Event 3}

\subsubsection{DOE Hoadquartere Environmental Burvey}

The Deparıment of Energy Headquarters (DOE-HQ) environmental survey leam from Oak Ridge National Laboratory collected surface water and soil samples from the TSF.107 disposal pond 


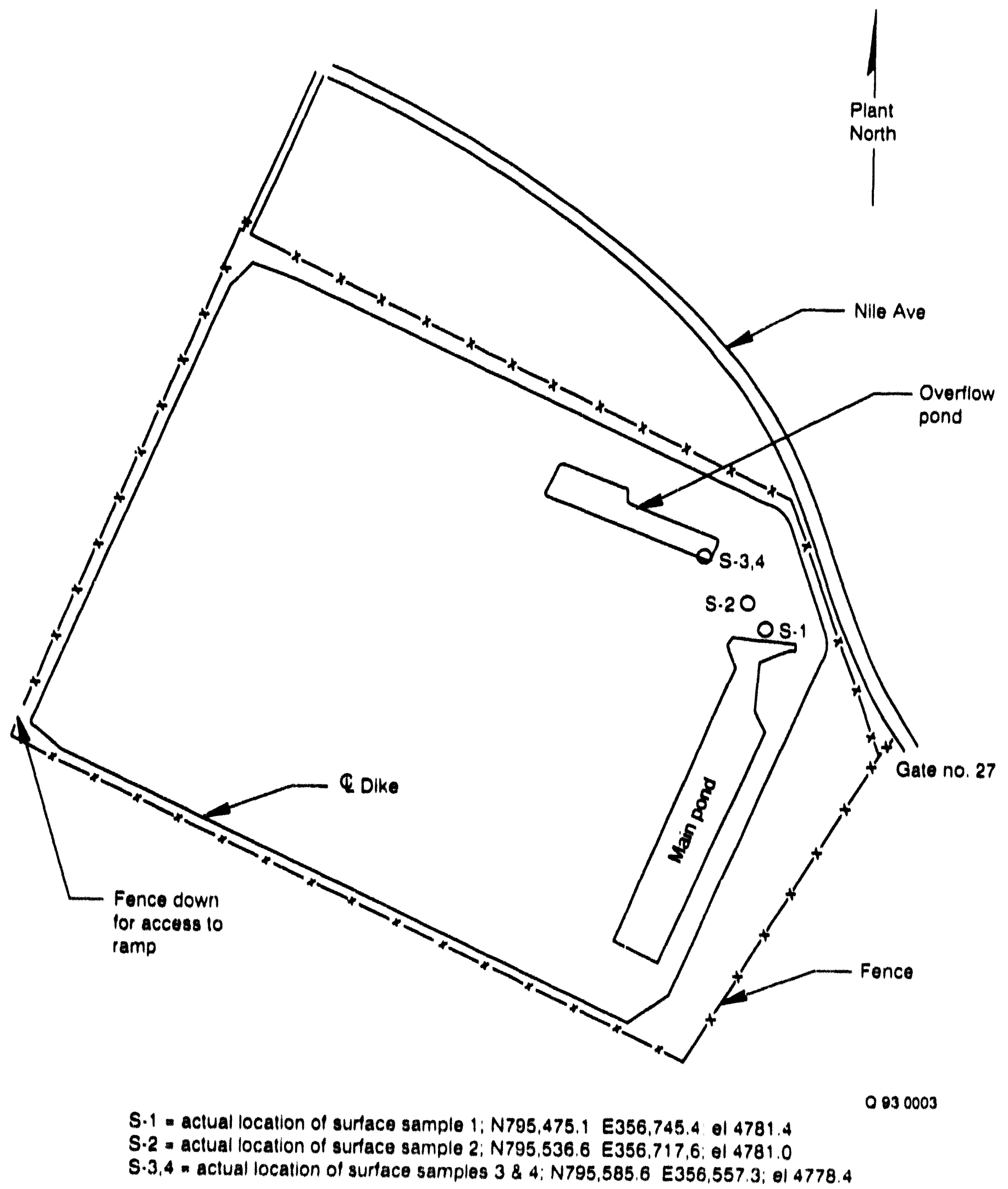

Flgure 8. Locations of sediment samples collected in May 1988 and locations of the four auger holes (sampling event 2). 
Table 11. Summary table for soil samples collected during sampling event 2.

\begin{tabular}{|c|c|c|c|c|}
\hline Analysis & Contaminant & $\begin{array}{l}\text { Concentration } \\
\text { range } \\
(\mathrm{mg} / \mathrm{kg})\end{array}$ & $\begin{array}{c}\text { Number of } \\
\text { samples }\end{array}$ & $\begin{array}{c}\text { Average } \\
\text { concentration } \\
(\mathrm{mg} / \mathrm{kg})\end{array}$ \\
\hline \multirow[t]{17}{*}{ Inorganic } & Antimony & $0.7-1.3$ & 4 & 0.80 \\
\hline & Arsenic & $1.7-12.5$ & 4 & 7.25 \\
\hline & Barium & $177.0-19.3 .0$ & 4 & 186.75 \\
\hline & Beryllium & $1.0-1.4$ & 4 & 1.25 \\
\hline & Cadmium & $6.3-7.4$ & 4 & 6.9 \\
\hline & Chromium & $26.9-31.8$ & 4 & 28.33 \\
\hline & Cobalt & $5.2-11.1$ & 4 & 7.57 \\
\hline & Copper & $28.0-54.9$ & 4 & 37.48 \\
\hline & Lead & $19.0-26.1$ & 4 & 23.50 \\
\hline & Mercury & $1.2-4\left(040.00^{\mathrm{a}}\right.$ & 4 & $\begin{array}{c}2.7 \\
(1012.0)^{n}\end{array}$ \\
\hline & Nickel & $29.4-.39 .8$ & 4 & 35.8 \\
\hline & Selenium & 1.0 & 4 & 1 \\
\hline & Silver & $1.8-4.1$ & 4 & 2.58 \\
\hline & Thallium & 0.30 & 4 & 0.30 \\
\hline & Tin & $883.0-1150.0$ & 4 & 977.0 \\
\hline & Vanadium & $26.0-27.8$ & 4 & 26.8 \\
\hline & Zinc & $190 .(1-385.0$ & 4 & 254.75 \\
\hline \multirow[t]{3}{*}{ Organic } & $\begin{array}{l}\text { Dichlorodilluoro- } \\
\text { methane }\end{array}$ & 12.0 & 1 & 12.0 \\
\hline & Tetrahydroluran & $0.016-(0.022$ & 3 & 0.018 \\
\hline & Methylene chloride & $0 .(00.3-1) .0(1) 5$ & 4 & 0.004 \\
\hline
\end{tabular}

a. Only one sample had a reported result that exceeded $5.5 \mathrm{mg} / \mathrm{kg}$. Two average values are presented. The first value averages the three results that were less than $5.5 \mathrm{mg} / \mathrm{kg}$. The value in parenthesis averages all four results.

Note: The calculation of average concentration includes the nondetects (averaged in as a zero value) and therefore muy be biased high. 
during the summer of 1988. Results trom this sampling effort were reported in ORNL/TM-11236 (DOE 1989b).

Sample collection points were identified by independent sample request number and by the location. The TSF-(07 disposal pond collection points were at the TAN/TSF surface water, the reduced flow area (Sumpling and Analysis Request 510-water), the TSF-07 disposal pond inlet (Sampling and Analysis Request 511-sediment), and the TAN/TSF-07 disposal pond (Sampling and Analysis Request 512-soil).

Eight surface water samples, four sediment sumples, and three subsurface soil samples were collected. A select number from each sample set collected, were analyzed for metals by ICP emission spectrometry (aluminum, barium, calcium, cobalt, copper, iron, magnesium, manganese, nickel, sodium, vanadium, and zinc), graphite furnace AA (antimony, arsenic, beryllium, cadmium, chromium, lead, selenium, and silver), mercury by cold vapor AA, anions by ion chromatography, gross alpha, gross beta, gamma-cmitting radionuclides by gamma spectrometry, and americium by alpha spectrometry. Not all the identified samples defined in the sampling and analysis plan were analyzed for each of the above specified contaminants. These samples were collected and shipped using EPA. approved procedures and protocols.

\subsubsection{Analytical Results}

Appendix E contains data results and analyte tables with the associated concentration range for each contaminant. A summary of the data results is presented in Tables 12 through 15.

The surface water samples were collected near the discharge point as indicated in Figure 9. The water samples were collected at the inlet and the surface of the pond. As seen in Table 12, acctone was detected in surface water at $0.011 \mathrm{mg} / \mathrm{L}$, which is slightly greater than the CRQL for CLP laboratories. One of the two samples was determined to be a nondetect. Mercury was also detected in the surface water in low concentrations (maximum of $0.00042 \mathrm{mg} / \mathrm{L}$ ). All other analytical parameters were within the expected range for this particular site. A radiological analysis for gross beta, gross alpha, Am-241, Co-60, Cs-137, H-3, and Sr (total) was also performed on three to four of the samples collected (see Table 13). Based on the analytical dala results it was determined that the inlet of the pond exhibited the highest concentration for $\mathrm{Co}-60)(31 \mathrm{pCi} / \mathrm{L}), \mathrm{Cs}-1.37(93 \mathrm{pCi} / \mathrm{L})$, and gross alpha $(22 \mathrm{pCi} / \mathrm{L})$.

Summary Table 14 presents inorganic and organic data for soil/sediment media for this particular sampling event. The surface sediment samples were collected, at depth, in the same locations as the surface water samples. Subsurfice soil samples were collected from auger holes initiated near the perimeter of the pond and angled (o) eollect soils from the area directly beneath the pond at depths to $13.7 \mathrm{~m}$ (45 ft). Chlorinated hydrocarbons were detected at concentrations greater than the contract required quantitation limit at all three subsurface locations. Chloroform was detected at all three locations, and trichloroethane was detected at two locations. Again, acetone and mercury were detected in all four samples. The average concentration for mercury is $0.31 \mathrm{mg} / \mathrm{kg}$, compared to the TAN hackground level of $0.06 \mathrm{mg} / \mathrm{kg}$. The average value for copper, $39.29 \mathrm{mg} / \mathrm{kg}$, is above the background level of $27.4 \mathrm{mg} / \mathrm{kg}$. Silver, with an average value of $6.36 \mathrm{mg} / \mathrm{kg}$, exceeds the background level of $3.5 \mathrm{mg} / \mathrm{kg}$. The average value for acetone was $0.042 \mathrm{mg} / \mathrm{kg}$. 
Table 12. Summary data table for the water samples collected during sampling event 3.

\begin{tabular}{|c|c|c|c|c|}
\hline Analysis & Contaminant & $\begin{array}{l}\text { Concentration } \\
\text { range } \\
(\mathrm{mg} / \mathrm{L})\end{array}$ & $\begin{array}{l}\text { Number of } \\
\text { samples }\end{array}$ & $\begin{array}{c}\text { Average } \\
\text { concentration } \\
(\mathrm{mg} / \mathrm{l})\end{array}$ \\
\hline \multirow[t]{18}{*}{ Inorganic } & Aluminum & $0.791-15.50$ & 4 & 5.32 \\
\hline & Barium & $0.072-0.241$ & 4 & 0.13 \\
\hline & Beryllium & $0.003-0.004$ & 4 & 0.0003 \\
\hline & Cadmium & $0.0(0) 1-0.0011$ & 2 & 0.001 \\
\hline & Calcium & $51.40-70.6$ & 4 & 61.38 \\
\hline & Chromium & $0.002-0.019$ & 4 & 0.008 \\
\hline & Cobalt & $0.002-0.0006$ & 2 & $0.0(0) 4$ \\
\hline & Copper & $0.012-0.102$ & 4 & $\begin{array}{c}0.015 \\
(0.037)^{a}\end{array}$ \\
\hline & Iron & $0.616-17.6$ & 4 & 5.74 \\
\hline & Magnesium & $17.0-24.9$ & 4 & 19.55 \\
\hline & Manganese & $0.028-0.217$ & 4 & 0.093 \\
\hline & Mercury & $0.0(0 \times) 2-0.0(0) 42$ & 4 & $0.00 \times 12$ \\
\hline & Nickel & $0 .(0) 6-0.029$ & 4 & 0.015 \\
\hline & Potassium & $5.5-11 .(0)$ & 4 & 7.20 \\
\hline & Silver & $0.0(06-0.0 .35$ & 2 & 0.021 \\
\hline & Sodium & $46.9-106.0$ & 4 & 75.7 \\
\hline & Vanadium & $0.017-0.048$ & 4 & 0.027 \\
\hline & Zinc & $0.057-0.389$ & 4 & 0.165 \\
\hline Organic & Acetone & $0.01-0,011$ & 2 & 0.011 \\
\hline
\end{tabular}

a. Only one sample was detected at a value exceeding $0.019 \mathrm{mg} / \mathrm{L}$. The value in the parenthesis averages all four sample points. The other value averages the three samples with results less than $0.102 \mathrm{mg} / \mathrm{L}$.

Note: The calculation of average concentration includes the nondetects (averaged in as a zero value) and therefore may be biased high. 
Table 13. Summary data table for the water samples collected during sampling event 3.

\begin{tabular}{llccc} 
Analysis & Contaminant & $\begin{array}{c}\text { Concentration } \\
\text { range } \\
(\mathrm{pCi} / \mathrm{L})\end{array}$ & $\begin{array}{c}\text { Number of } \\
\text { samples }\end{array}$ & $\begin{array}{c}\text { Average } \\
\text { concentration } \\
(\mathrm{pCi} / \mathrm{L})\end{array}$ \\
\hline Radiological & Am-241 & $0.07-0.13$ & 4 & 0.05 \\
& Co-60 & $5.9-31.0$ & 4 & 12.98 \\
& Cs-137 & $7.2-93.0$ & 4 & 8.4 \\
& Gross alpha & $8.0-22.0$ & 4 & $(29.5)^{\mathrm{a}}$ \\
& Gross beta & $30.0-85.0$ & 4 & 15.25 \\
& H-3 & ND-100.0 & 3 & 57.0 \\
& Strontium (total) & $3.5-12.0$ & 3 & 100.0 \\
\hline
\end{tabular}

a. Only one sample was deterted at a value exceeding $10 \mathrm{pCi} / \mathrm{L}$. The value in the parenthesis averages all four sample points. The other value averages the three samples with results less than $93.0 \mathrm{pCi} / \mathrm{L}$.

Note: The concentration includes the nondetects (averaged in as a zero value) and therefore may be biased high. 
Table 14. Summary data table for the soil/sediment samples collected during sampling event 3.

\begin{tabular}{|c|c|c|c|c|}
\hline Analyaia & Contaminant & $\begin{array}{c}\text { Concentration } \\
\text { range } \\
\text { (mekps) }\end{array}$ & $\begin{array}{c}\text { Number of } \\
\text { mamples }\end{array}$ & $\begin{array}{c}\text { Avernge } \\
\text { concenirilion } \\
\text { (men) }\end{array}$ \\
\hline \multirow[t]{21}{*}{ Inorganic } & Aluminum & $14,500.0-24,5(x) .0$ & 7 & 19.028 .71 \\
\hline & Antimony & $4.4-3.5$ & 3 & 51 \\
\hline & Arsenic & $9.1-11.0$ & 3 & 10.6 \\
\hline & Barium & $212.0-272.0$ & 7 & $2 \times 41$ \\
\hline & Beryllium & $1.8-2.4$ & 7 & 213 \\
\hline & Cadmium & $0.5-1.7$ & 7 & 113 \\
\hline & Calcium & $38.200 .0-76,7(00.0$ & 7 & $60,0 \times 0$ \\
\hline & Chrnmium & $22.0-39.0$ & 7 & $30 \mathrm{mos}$ \\
\hline & Coball & $7.9-11.0$ & 1 & 9.7 \\
\hline & Copper & $20.0-780$ & 7 & 30.20 \\
\hline & Iron & $19,0 \times 0.0-29,0 \times 0), 0$ & 7 & 24,6246 \\
\hline & Lead & $12.0-22.0$ & 7 & 17.0 \\
\hline & Magnesium & $12.2(M) .0-15,500.0$ & 7 & $13,924 \mathrm{~s}$ \\
\hline & Manganese & $202.0-645.0$ & 7 & 402.16 \\
\hline & Mercury & $0.04-1.7$ & 7 & 0.11 \\
\hline & Nickel & $31.0-45.0$ & 7 & $\mathbf{4 4 3}$ \\
\hline & Polassium & $2500.0-5000.0$ & 7 & 1785.71 \\
\hline & Silver & $0.84-26.0$ & 7 & 0.30 \\
\hline & Sodium & $391.0-844.0$ & 1 & 720.57 \\
\hline & Vanadium & $40.0-52.0$ & 1 & 4. 14 \\
\hline & Zinc & $85.0-243.0$ & 7 & 2040 \\
\hline \multirow[t]{7}{*}{ Organic } & Acetone & $0.018-1)\left(k_{n}\right)$ & 4 & 0042 \\
\hline & 1,1,1-Trichloroethane & $0.012-10.04 .3$ & 1 & 0024 \\
\hline & 1,1,2-Trichl-1,2,2-Trin & $0(K) \times-0.010$ & 1 & 0000 \\
\hline & Chloroform & $0.01 .3-0.018$ & 3 & 0.016 \\
\hline & Methylene Chloride & $0 .(x) 2-0.011$ & 7 & $0.00 \mathrm{~m}$ \\
\hline & Toluene & $0 .(00.5-1) .013$ & 3 & 0.010 \\
\hline & Thiobismeihane & 0.029 & 1 & 0.029 \\
\hline
\end{tabular}


Table 15. Summary data table for the soil sediment samples collected during sampling event 3.

\begin{tabular}{lllcc} 
Analysis & Contaminant & $\begin{array}{c}\text { Concentration } \\
\text { range } \\
\text { Radi/g) }\end{array}$ & $\begin{array}{c}\text { Number of } \\
\text { samples }\end{array}$ & $\begin{array}{c}\text { Average } \\
\text { concentration } \\
(\mathrm{pCi} / \mathrm{g})\end{array}$ \\
\hline Am-241 & $0.009-0.021$ & 7 & 0.13 \\
& Co-60 & $0.57-42.0$ & 4 & 20.39 \\
& Cs-137 & $4.4-59.0$ & 4 & 23.6 \\
& EL-155 & 0.13 & 1 & 0.13 \\
& Gross alpha & $3.9-9.1$ & 7 & 5.9 \\
& Gross beta & $4.9-34.0$ & 7 & 16.1 \\
H-3 & $0.2-1.2$ & 6 & 0.58 \\
K-40 & $14.0-19.0$ & 7 & 17.5 \\
Mn-40 & $0.18-0.28$ & 2 & 0.23 \\
Sr (total) & $0.26-3.0$ & 7 & 0.94
\end{tabular}

Note: The calculation of average concentration includes the nondetects (averaged in as a zero value) and therefore may be biased high.

Radiological data results for soil media are summarized in Table 15 . Cobalt- 60 was found at a maximum concentration of $42.0 \mathrm{pCi} / \mathrm{g}$ in the reduced flow area of the pond. Gross alpha ranged from $3.9 \mathrm{pCi} / \mathrm{g}$ to $9.1 \mathrm{pCi} / \mathrm{g}$. Cesium-137 was also found at levels ranging from 4.4 to $59.0 \mathrm{pCi} / \mathrm{g}$.

The data for this particular site were qualified as defined in DOE/EH-0053 (DOE 1989a). Independent EG\&G Idaho data verification of the data results has been performed. A review of the data by the Environmental Restoration Sample Management Office does not indicate any problems; therefore, the analytical results from this sampling event were used to determine whether contaminant migration is occurring from the pond. Section 4 includes an evaluation of the data results compared to screening levels. This information is then used to determine the significant contaminants at the TSF-07 disposal pond.

\subsection{Sampling Event 4}

\subsubsection{Subsurface Investigation for the TAN RCRA Facility Investigation}

The subsurface investigation was part of the TAN RFI. The information in this section is a summary of the information presented in the RFI, drilling logbooks, and the sampling and analysis plan for the TSF-07 disposal pond and waste sump (Hardy and Stanisich 1991). The investigation consisted of drilling and sampling seven auger holes from the TSF-07 disposal pond area to the top 


\section{TAN/TSF}

\section{Disposal Pond}

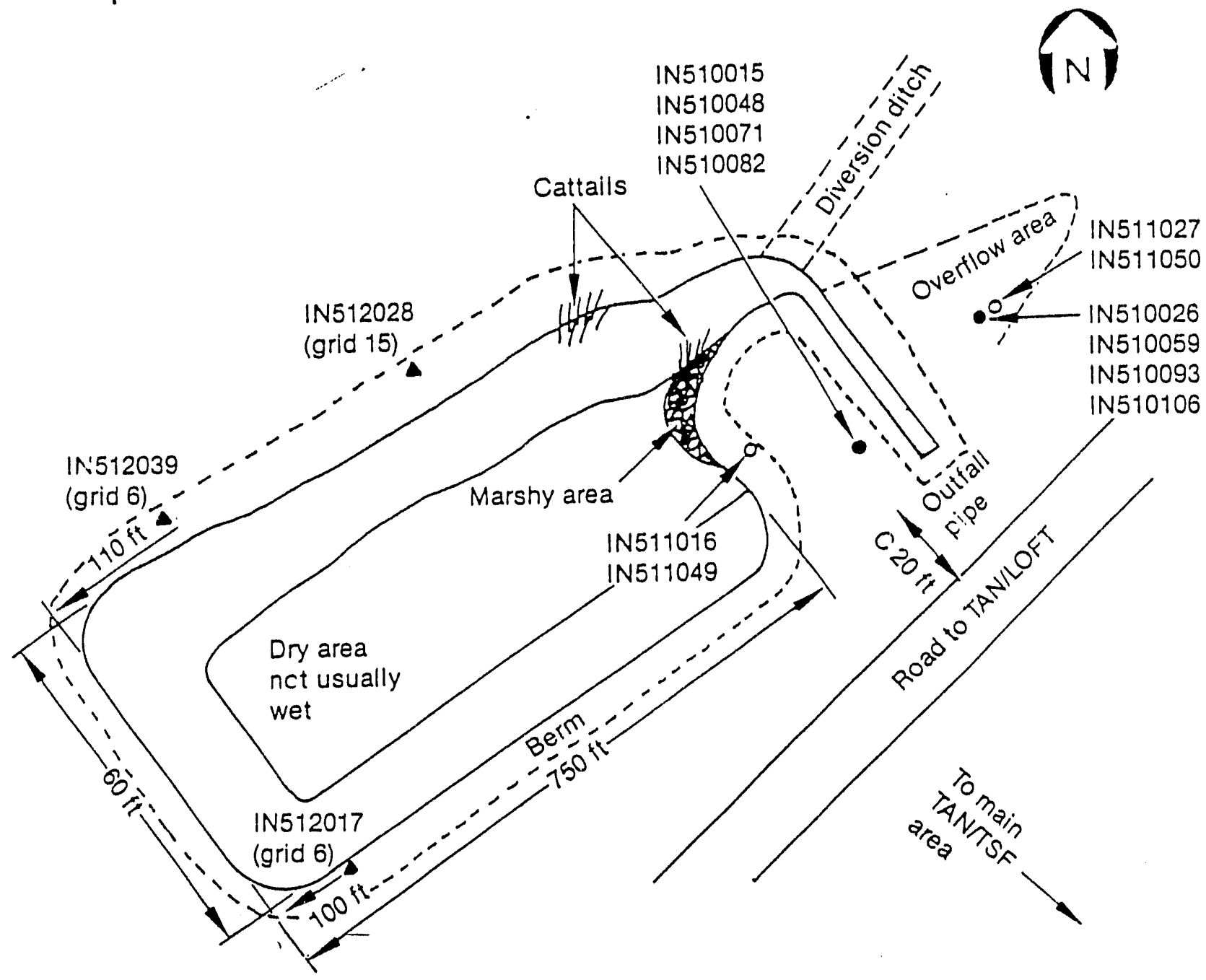

\section{LEGEND}

- Water samples

o- Surface sediment samples

^- Subsurface sediment samples

Figure 9. Sample locations for sampling event 3. 


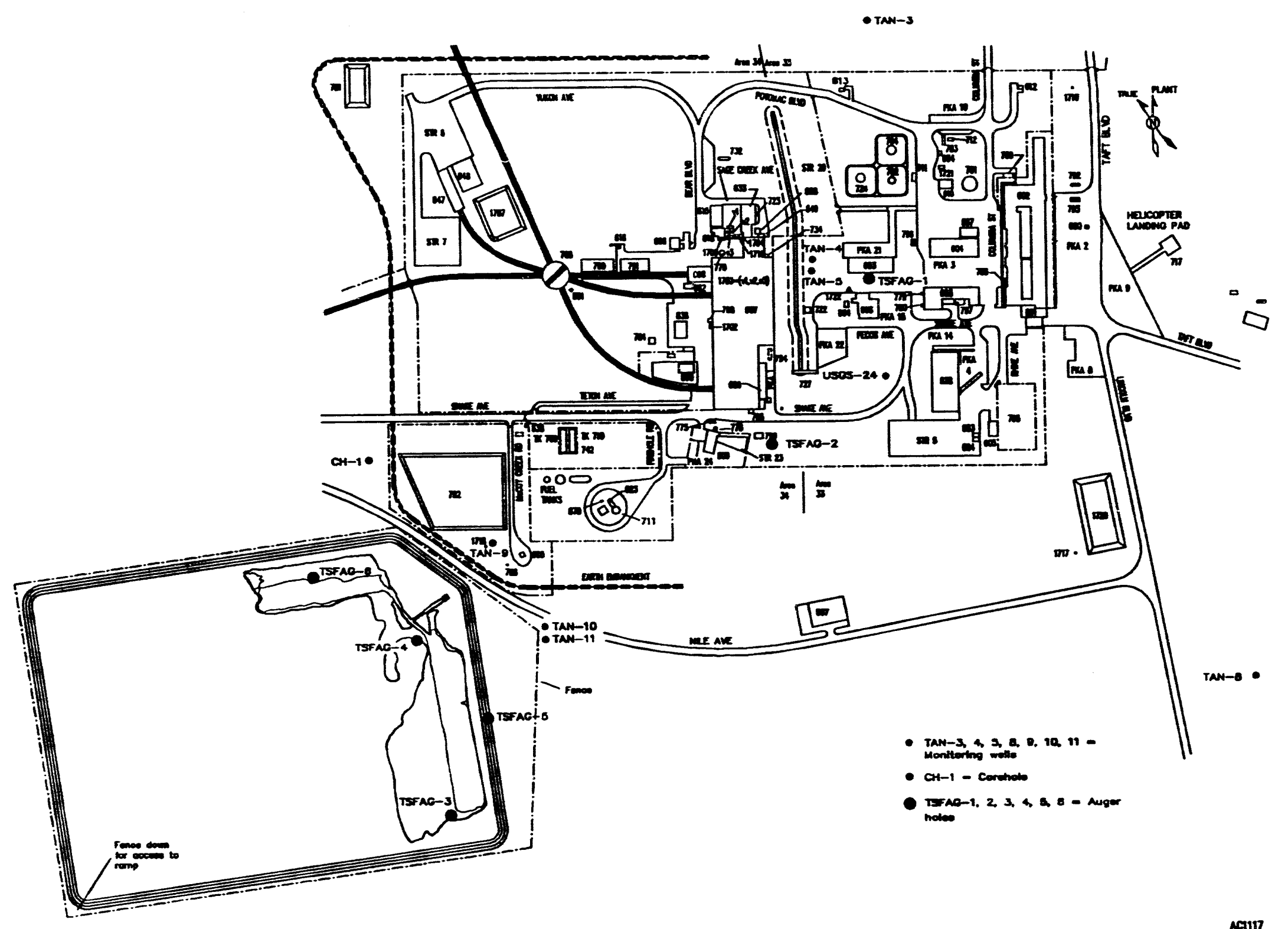

Figure 10. Sample locations for sampling event 4. 


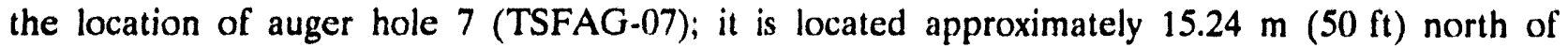
TSFAG-06. The locations of these boreholes were based on the results of a soil gas survey conducted at TAN that identified areas where elevated readings of volatile organics were detected. Field work for this investigation was performed during July and August 1989. The auger holes were drilled with a 10.2-cm (4-in.) inner-diameter hollow-stem auger through the surficial sediment to the basalt interface. The auger holes were identified as auger holes 3-7. Auger hole 5 and 7 were developed into perched water monitoring wells.

Split spoon samples were collected, beginning at the ground surface, over a $0.6-\mathrm{m}(2-\mathrm{ft})$ interval and continuing throughout the boreholes at $1.5-\mathrm{m}(5-\mathrm{ft})$ intervals until basalt was reached, except for the $0-1.5 \mathrm{~m}(0-5 \mathrm{ft})$ interval, which had two samples removed. The top of the basalt was encountered

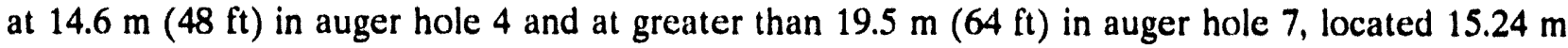
$(50 \mathrm{ft})$ north of TSFAG-06. Five samples from each borehole were collected and analyzed for metals by EPA methods 7191 and 7091, gamma-emitting radionuclides by gamma spectrometry, and volatile organic compounds by method 8240 . Extraction procedure for toxicity (EP TOX) was performed on samples if metals concentrations were greatly elevated. To determine if EP TOX was required, a dilution factor was applied to convert the proposed EP TOX regulatory limits $(\mathrm{mg} / \mathrm{L})$ to comparable units $(\mathrm{mg} / \mathrm{kg}$ ). For metals, the regulatory limits were adjusted to account for sample weights and volumes used in the toxicity characterization leaching procedure (TCLP) (multiplied by $2.0 \mathrm{~L}$ and divided by $0.1 \mathrm{~kg}$ ) to give a conversion factor of 20 . Subsurface soil samples were collected at the basalt sediment interface where perched water was found. Each of the samples removed from the borehole was screened with portable instruments to determine radioactivity above background or the presence of organic vapors.

Where perched water was encountered, $5.08 \mathrm{~cm}(2-i n$.$) monitoring wells were completed at the$ basalt sediment interface. These wells were not scheduled for water sampling at that time.

Upon completion of the drilling and sampling activities, the holes were backfilled with the cuttings, and grout was added to fill the hole to ground surface. This was done to avoid creating a conduit for water to enter the subsurface and possibly transport contaminants in the vadose zone. Cuttings from the first $3 \mathrm{~m}(10 \mathrm{ft})$ were containerized and were not returned to the hole.

\subsubsection{Analytical Results}

Appendix $\mathrm{F}$ contains data results and analyte tables with the associated concentration range for each contaminant. All data in the appendix have been validated to level B. Table 16 presents a summary of the data results obtained during the sampling effort. All the samples collected during this effort were from a soil media. However, some samples were subsequently leached with a weak acid using the TCLP method and the resulting liquid was analyzed using the SW-846 methods for the TCLP-regulated analytes. These results are reported in aqueous units $(\mu \mathrm{g} / \mathrm{L})$. Eight of these samples were collected from auger holes $3,4,5$, and 6 . All the samples analyzed were less than the associated TCLP value for hazardous waste as defined in 40 CFR 261 and as presented in Table 17. Therefore, the TCLP analytical results from sampling event 4 indicate that these contaminants are not considered to be leaching from the surrounding soil in the locations from which these samples were collected, although the contaminants have been detected. 
Table 16. Summary data table for the soil sediment samples collected during sampling event 4.

\begin{tabular}{|c|c|c|c|c|}
\hline Analysis & Contaminant & $\begin{array}{c}\text { Concentration } \\
\text { range } \\
(\mathbf{m g} / \mathbf{k g}) \\
\end{array}$ & $\begin{array}{c}\text { Number of } \\
\text { samples }\end{array}$ & $\begin{array}{c}\begin{array}{c}\text { Average } \\
\text { concentration } \\
\text { (mg/kg) }\end{array} \\
\end{array}$ \\
\hline \multirow[t]{23}{*}{ Inorganic } & Aluminum & $1400-31,400$ & 28 & $15,868.93$ \\
\hline & Antimony & $\mathrm{ND}(.0975)-1.1$ & 28 & 0.24 \\
\hline & Arsenic & $4.8-18.20$ & 28 & 10.56 \\
\hline & Barium & $199.0-1900.0$ & 28 & 326.05 \\
\hline & Beryllium & $0.81-8.6$ & 28 & 2.75 \\
\hline & Cadmium & $0.69-6.2$ & 28 & 1.21 \\
\hline & Calcium & $6720.0-213,000$ & 28 & $62,302.14$ \\
\hline & Chromium & $21.3-257.0$ & 28 & 47,19 \\
\hline & Cobalt & $6.8-69.1$ & 28 & 13.74 \\
\hline & Copper & $15.8-148.0$ & 28 & 29.99 \\
\hline & Iron & $13,700.0-36,800,0$ & 28 & $22,189.29$ \\
\hline & Lead & $12.0-30.5$ & 28 & 21.83 \\
\hline & Magnesium & $7,850.0-16,900.0$ & 28 & $11,988.21$ \\
\hline & Manganese & $345.0-1110.0$ & 28 & 577.25 \\
\hline & Mercury & $0.05-0.32$ & 28 & 0.09 \\
\hline & Nickel & $25.6-240.0$ & 28 & 47.27 \\
\hline & Potassium & $1510.0-6010.0$ & 28 & $3,016.79$ \\
\hline & Selenium & $0.22-0.63$ & 28 & 0.18 \\
\hline & Silver & $0.26-0.82$ & 28 & 0.15 \\
\hline & Sodium & $340.0-757.0$ & 28 & 499.68 \\
\hline & Thallium & $0.17-1.1$ & 28 & 0.18 \\
\hline & Vanadium & $30.4-333.0$ & 28 & 64.4 \\
\hline & Zinc & $20.0-892.0$ & 28 & 157.17 \\
\hline \multirow[t]{3}{*}{ Organic } & Toluene & $0.001-0.017$ & 28 & 2.43 \\
\hline & Acetone & $0.0166-0.12$ & 28 & 0.009 \\
\hline & Methylene Chloride & $0.001-0.004$ & 28 & 0.0004 \\
\hline
\end{tabular}

Note: The calculation of average concentration includes the (averaged in as a zero value) nondetects and therefore may be hiased high. 
Table 17. Summary data table for sampling event 4 (CLP and TCLP results).

\begin{tabular}{|c|c|c|c|c|}
\hline Contaminant & $\begin{array}{l}\text { Range of lotal } \\
\text { metals via CLP } \\
(m g / k g)\end{array}$ & $\begin{array}{l}\text { Concentration of } \\
\text { metals via TCLP } \\
(\mu \mathrm{g} / \mathrm{L})\end{array}$ & $\begin{array}{l}\text { Regulatory } \\
\text { TCLP } \\
\text { value } \\
(\mu \llbracket / L)\end{array}$ & $\begin{array}{c}\text { Number of } \\
\text { samples }\end{array}$ \\
\hline Arsenic & $4.8-18.2$ & $4.1-8.2$ & $s(x \times)$ & 5 \\
\hline Barium & $199-1900$ & $98.3-1520$ & $100,0 \times x)$ & 5 \\
\hline Cadmium & $0.69-6.2$ & $3-5$ & $1(x) 0$ & 5 \\
\hline Chromium & $21.3-257$ & $N D(0.250)^{n}$ & $50 \times 0$ & 5 \\
\hline Lead & $12 .(1)-30.5$ & $N D(0.250)-2.0$ & $\operatorname{six} \times 0$ & 5 \\
\hline Mercury & $0.05-10.32$ & $N D(0.0 \times 12)-1.24$ & 200 & $s$ \\
\hline Silver & $0.26-1) .82$ & $N D(0.250)$ & $S(x)$ & 5 \\
\hline 1,1 Dichloroethene & - & 5.0 & $7(x)$ & 8 \\
\hline Chloroform & - & 5.0 & $G(x)$ & 8 \\
\hline 1.2 Dichloroethane & - & 5.0 & $s(x)$ & 8 \\
\hline 2-Butanone & - & 10.0 & $2(x), 0 \times x)$ & 8 \\
\hline Carbon Tetrachloride & - & S.0 & $s(x)$ & 8 \\
\hline Trichloroethene & - & 5.0 & $\sin (x)$ & 8 \\
\hline Benzene & - & 5.0 & $5(x)$ & 8 \\
\hline Tetracholorethene & - & 5.0 & $7(x)$ & 8 \\
\hline
\end{tabular}

a. The value in parentheses after each ND is the detection limit for this constituent.

Note: The concentration includes the nondetects (averaged in as a ecro value) and therefore may be biased high. 
The samples delined in the Appendix F. Table F.6, were collected in accordance with the sampling and analysis plan. As presented in the summary table (Table 16), 28 soil samples were collected from the live auger holes. Beryllium, chromium, and mercury were found in elevaled concentrations in a majority of the samples. The averige concentrations for hurium, beryllium, copper. and mercury all exceeded the average inorganic hackground level for ench constituent in the TAN area. The maximum concentrations for beryllium and chromium were found in auger hole 6 at a depth of $3 \mathrm{~m}$ (10 $\mathrm{fl}$ ). Beryllium was detected at $8.6 \mathrm{mg} / \mathrm{kg}$ and chromium was delected at $257 \mathrm{mg} / \mathrm{kg}$. The maximum mercury concentration of $0.32 \mathrm{mg} / \mathrm{kg}$ was found in auger hole 5 at a $4.5 \mathrm{~m}$ (15 (i) depth.

Acetone, methylene chloride, and toluene were all delected in the organic CLP VOC analyais as noted in Table 16. Acetone concentrationa ranged between $0.0 \mathrm{Kh}$ and $0.12 \mathrm{mg} \mathrm{kg}$. Methylene chloride was detected between $0.0(0) 1$ and $0 .(x) 4$ me $/ \mathrm{kg}$. Toluene was detected between (0.(X)1 and 0.017 mekg.

Seven soll anmples were analyeed by the Radiation Measurementa Luboralory for gamma. emilting radionuclides. A radiological annlyais was not perfiormed for this particular sampling event. The radiological analywis performed was a shorl-counting. lime gamma sereening analyats rather than a full 16-hour count. Only " sereening survey was conducted; hence, these data were noll used. Section 4 includes an evaluation of the data rexulis compared o acreening levela. This information is then used 10 determine the signifleant contaminants at the 'TSF:(1)7 dispowal pond.

\subsection{Sampling Event 8}

\subsubsection{She Characterization of the TeF.07 Dleposal Pond}

The sile characterization of the "TSF.177 dispowal pund was conducted in 1969 . II consinted of collecting samples from along the length of the inlet pipe, at the point of eflluent diacharge to the main pond, from the dich connecting the sullet pipe and the main pond. from the diversion dilech between the main pond and overllow pond, and from the two depressions. A combination of hinsed and systematic random sumpling was employed in this olfort. Sumples were collected mainly from

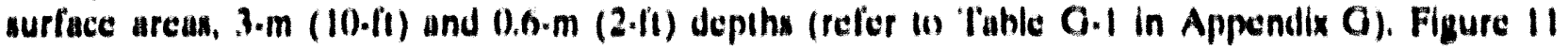
depicts the sample lecintions and asuxialed sumple identifieation numbers.

A large number of sumplen were collected during this sumpling event. The sumples eollected were unulyeed lor:

- Metals by ICP (EPA Method (x)II))

- Mercury by cold vapur (EPA Method 7471)

- Volatile orgunics by gas chromatugruphy/musn spectrometry (GC/MS) (EPA mothod $824(1)$ )

- Oamma radionuclides by gamma spectrumetry.

Additional analysis included SW.XAh melhods for all Appendix IX analyles fior nine selected samples. two of which were collected irom the same lecution (these are considered to he replicate samplex). 


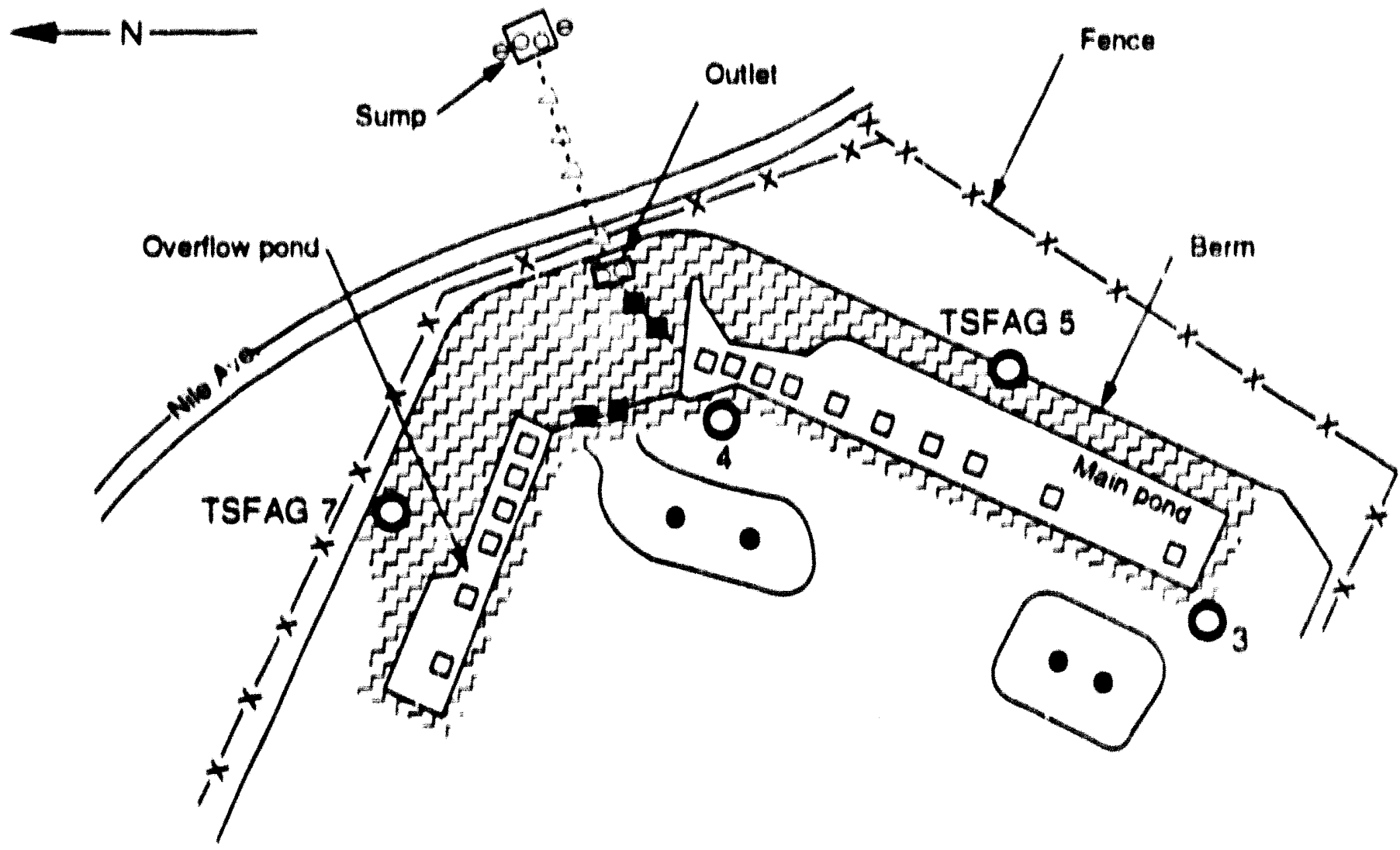

L98 014

\section{Legend}

D Pond be llom biased samples

Dirch biased samples

$\therefore$ Inlel pipe biased samples

- Sump and oullel biased samples

a Sump inargin samples

- Depresaional area biased samples

zp Systemalic random sample gind

OAuger holes

Ploure 11. Sample lociations for sampling event 9 and Sa. 
These analyse provided information lor additional contuminants not otherwise analyeed for in the other sampling events. The analyses performed (1) determine the Appendix IX analytes include methods for semivolatiles, organochlorine pesticides, orgunophosphorus pesticides, organochlorine, and herbicide contaminants. Quality control sumples, rinsates, field blanks, trip blanks, and field replicates were alas collected (these data are not included in the appendix).

\subsubsection{Analytical Reaults}

Table if presents "summary of the concentration rangea and average values of the radionuclides analyeed for this sampling event. The only signifleant radiological contaminants detected in this sampling event were Co.(0) and $\mathrm{Cs} \cdot 1.37$. Cobult.(x) activity ranged from $(1.11 .3 \mathrm{pCl} / \mathrm{g}$ 1087.7 $\mathrm{pCl} / \mathrm{g}$. Cesium=1.37 activity was detected from 0.051 pCi/g $10127.0 \mathrm{pCi} / \mathrm{s}$.

Beryllium, chromium, mercury and thallium were detected in a majorily of the sumples, an presented in Tubles 19 and 20. The maximum conceniralion for chromium and mercury were both found in the pond discharge aren (refer to Table 20). Mercury wan detected at 206.1) mp/kg. and chromium was detected at $150.0 \mathrm{mg} / \mathrm{kg}$.

High levels of thallium were found in the dilch, inlet pipe, depreswion area, and overflow aren. Thallium was detected in the woll samplew at a maximum conceniration of $\mathbf{4 . 2} \mathrm{mg} / \mathrm{kg}$ in the dich area. Concentralions of beryllium were within 1.0 mekg of the TAN background level. Beryllium was delected at a maximum concentrution of $2.2 \mathrm{mg} / \mathrm{kg}$.

\subsection{Sampling Event sa}

\subsubsection{Porched Wotor Sampling Actlvilies}

Sampling for the perched water atenen benewth the TSF.(1)7 dispowal pond was performed between July $\mid(x)$ and May $|(x)|$. A summary of the sumpling effort, anulywis, and data was compiled from the logheoks. sampling and anulyais plan, and validaled datu tables. The iwo perehed water

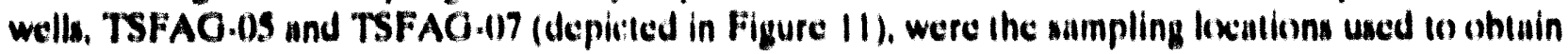

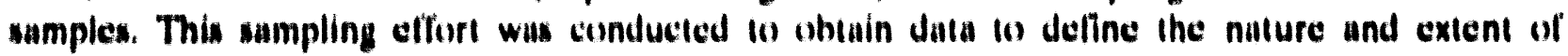
contamination in the perched water aine.

Sampling was performed hy the Environmental Technolosy Unit, with field measurements performed using a Hydrolu." Sampling wix conducted in accordance with Hardy and Stanisich (|WMI). Groundwater samples were collected for unalysis using the collection methods deseribed in Section E.4.4.4.4 of the DOE Environmental Survey Minual (DOE 1\%64a). Water samplea for chemical and gamma.emilling radiologicul analyses were collected directly inos laboratory-certifled clean sample boulles. Sumplen from ench well were collected and submilted for analysis for volatile

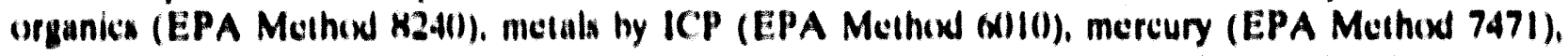
atronilum=-x), grous ulpha and beta emillers, and gamma-emilling radionuclides hy gamma

J. Mention of specilie products of manuficturers in this dexument implies neither endorsement of prelefence, nor disupprovil hy the U.S. Government, uny of ils ageneies, or EGi\&Q Idaho, Inc., of the use of a apecilic product lin any purpene. 
Table 18. Summary data table for the soil sumples collected during sampling event 5.

\begin{tabular}{|c|c|c|c|c|}
\hline Anulysis & Contaminant & $\begin{array}{l}\text { Concentration } \\
\text { range } \\
(\mathrm{pCi} / \mathrm{g})\end{array}$ & $\begin{array}{c}\text { Number of } \\
\text { sumples }\end{array}$ & $\begin{array}{c}\text { Average } \\
\text { concentration } \\
(\mathrm{pCi} / \mathrm{g})\end{array}$ \\
\hline \multirow[t]{3}{*}{ Radiological } & $\mathrm{Co} \cdot 6(0)$ & $0.11 .3-87.7$ & 37 & 9.40 \\
\hline & C. 1.34 & 0.01 .3 & 1 & 0.013 \\
\hline & C. 1.37 & $0.051-127.0$ & 53 & 10.2 \\
\hline
\end{tabular}

spectrometry. The chemical anulyses were perlormed hy Argonne Laboratories. East and Analytical Technologies Inc. The radiological anulysis was performed by the Radiation Mensurements Laboratory at TRA.

\subsubsection{Analyiloal Rosulis}

Tables $H .1$ and $H .2$ in Appendix $H$ identify the number of sumplew, depihs, and annlysis for each well. The appendix alao contains the complete analytical results alfiliated with this sampling effort.

Data from this particular sumpling event were collected hetween July $19 x($ ) and Muy $(9) 1$. No gamma.emilling radionuclides were determined to be true positive by the INEL Radiation Measurements Laborntory. Scveral samples were determined to be false pessitive. In addition, " lotal alpha and total beta analysis was conducted on sumples ohtained from beth wells. Tahle 21 summarizes the average values of the contaminunts analyeed, number of sumples, and asseciated concentration runge. Oroms alpha ranged from $3.210120 .0 \mathrm{pCi} / \mathrm{L}$. Gross beta ranged from 3.010120 .0 $\mathrm{pCl} / \mathrm{L}$. Sirontium.(x) was delected between 1.11 and $136.0 \mathrm{pCi} / \mathrm{L}$.

Tuble 22 summarizen the results fior inorganic and organic contaminants. Antimony was detected at concentrations ranging from (0.1).36 (1) $(1.142 \mathrm{mg} / \mathrm{L}$. Thullium wiss also detected helween the $0 .(x) 1$ and $0.101 \mathrm{me} / \mathrm{L}$ range in three of the 12 amples. Section 4 includes an eviluation of the data results compared to acreening levelx. This informution is then used to delermine the significant contuminants at the TSF.07 disposul pond. Orgunic contuminunis were not detected or were below the detection limit. 
Table 19. Summary data table tor the soil samples collected during sampling event 5 (for CLP analytes).

\begin{tabular}{|c|c|c|c|c|}
\hline Anatyais & Contaminant & $\begin{array}{c}\text { Concentration } \\
\text { range } \\
\text { (mukp) } \\
\end{array}$ & $\begin{array}{c}\text { Number of } \\
\text { samples }\end{array}$ & $\begin{array}{c}\text { Average } \\
\text { conceritration } \\
\text { (mekg) }\end{array}$ \\
\hline \multirow[t]{26}{*}{ Inorganic } & Aluminum & $8900,0-30,0 \times 0,0$ & 82 & 19,900 \\
\hline & Antimony & $19.20-27.4$ & 47 & 19.6 \\
\hline & Anenic & $3.9-19.2$ & 82 & 17.6 \\
\hline & Bartum & $152.0-579.0$ & 82 & 262.0 \\
\hline & Beryllium & $0.99-2.2$ & 82 & 1.72 \\
\hline & Cadmium & $1.10-5.9$ & 82 & 2.84 \\
\hline & Calcium & $36,60) 0-82,300$ & 82 & 98,000 \\
\hline & Chromium & $20.2-74.5$ & 82 & 47.7 \\
\hline & Cobnil & $4.0-17.2$ & 82 & 12.6 \\
\hline & Copper & $12.7-217.11$ & 82 & 37.8 \\
\hline & Cyanide & $0.26-0.34$ & 10 & 0.28 \\
\hline & Iron & $14,8000)-34,6(0)$ & 82 & 25,700 \\
\hline & Lend & $22.7-78.8$ & $\mathbf{B 2}$ & 41.5 \\
\hline & Magneaium & $0,720-16,900$ & $\mathbf{8 2}$ & 13,400 \\
\hline & Manganeae & $222-606$ & $B 2$ & 425 \\
\hline & Mercury & $0 .(14-4,3)$ & 83 & 0.23 \\
\hline & Nickel & $22.6-57.5$ & 82 & 44.2 \\
\hline & Poctanaium & $1.510-759000$ & 82 & 4330.0 \\
\hline & Selenium & $0.18-12.2$ & 82 & 10.9 \\
\hline & Silver & $4.5-77.2$ & 82 & 9.77 \\
\hline & soutium & $29.1-412.0$ & $\mathrm{~Hz}$ & 176 \\
\hline & Sirontium & $73.8-172$ & 42 & 108.0 \\
\hline & Thallium & $0.80-48.2$ & 12 & 20.6 \\
\hline & $\operatorname{Tin}$ & $14.8-190$ & 72 & 18.1 \\
\hline & Vanadium & $43.8-83.1$ & 12 & 60.1 \\
\hline & Zinc & (6) $x-60(y$ & 82 & 160 \\
\hline \multirow[t]{6}{*}{ Orgunic } & 2. Butanone & $0.01-0.064$ & 22 & 0.015 \\
\hline & 2. Hexanone & $0.0(x)-10.02 y$ & 22 & 0.011 \\
\hline & Acetone & $0.0(0)+-0.079$ & 18 & 0.026 \\
\hline & Melhylene Chloride & $0 .(00) 5-0.0 \times(x)$ & 71 & 0,009 \\
\hline & Toluene & $0.0013-1.052$ & 72 & 0.006 \\
\hline & Xylene (Io|al) & $0 .(0), 3-0.012$ & 12 & 0.005 \\
\hline vo sum & en) are included in & entrunon vilue. & & \\
\hline
\end{tabular}


Table 20. Summary data table for the soil samples collected and analyzed for Appendix IX analytes during sampling event 5 .

\begin{tabular}{|c|c|c|c|c|}
\hline Analyais & Contaminant & $\begin{array}{c}\text { Concentration } \\
\text { range } \\
\text { (meks) } \\
\end{array}$ & $\begin{array}{c}\text { Number of } \\
\text { samples }\end{array}$ & $\begin{array}{c}\text { Average } \\
\text { concentration } \\
(\mathbf{m p} / \mathbf{k})\end{array}$ \\
\hline & & & 9 & \\
\hline \multirow{17}{*}{$\begin{array}{l}\text { Inorganic } \\
\text { Appendix IX }\end{array}$} & Aluminum & $9740-23,1(x)$ & & 18,500 \\
\hline & Antimony & $0.62-5.00$ & 7 & 1.79 \\
\hline & Anenic & $3.3-19.6$ & 9 & 11.6 \\
\hline & Barium & $226.0-9740.0$ & 9 & 1310.0 \\
\hline & Beryllium & $1.50-2.10$ & 9 & 1.79 \\
\hline & Cadmium & $2.00-14.9$ & 9 & 40.1 \\
\hline & Chromium & $40.8-150.0$ & 9 & 60.1 \\
\hline & Cohalt & $11.0-17.7$ & 9 & 14.9 \\
\hline & Copper & $22.1-936.0$ & 9 & 149.0 \\
\hline & Lead & $26.4-210.0$ & 9 & 51.7 \\
\hline & Mercury & $0.06-206.0$ & 10 & 21.1 \\
\hline & Nickel & $37.01-78.2$ & 9 & 46.8 \\
\hline & Selenium & $0.31-4.60$ & 9 & 1.10 \\
\hline & Silver & $5.6-166.0$ & 9 & 29.8 \\
\hline & Thallium & $0.83-1.40$ & 9 & 1.05 \\
\hline & Vanadium & $53.4-74.2$ & 9 & 64.3 \\
\hline & Zinc & $115.0-2400.0$ & 9 & 438.0 \\
\hline \multirow[t]{3}{*}{ Organic } & Acetone & $0.049-0.150$ & 2 & 0.099 \\
\hline & Toluene & $0.005-0.063$ & 9 & 0.014 \\
\hline & $\begin{array}{l}\text { bis(2.elhylhexyl) } \\
\text { phihalate }\end{array}$ & $0.20-2.90$ & 9 & 0.637 \\
\hline
\end{tabular}

Table 21. Summary data table for the perched water samples collected during sampling event 5a.

\begin{tabular}{llccc}
\hline Analysis & Contaminant & $\begin{array}{c}\text { Concentration } \\
\text { range } \\
(\mathrm{pCi} / \mathrm{L})\end{array}$ & $\begin{array}{c}\text { Number of } \\
\text { samples }\end{array}$ & $\begin{array}{c}\text { Average } \\
\text { concentration } \\
(\mathrm{pCi} / \mathrm{L})\end{array}$ \\
\hline Radiological & Gross alpha & $3.2 \cdot 120.0$ & 12 & 18.40 \\
& Gross beta & $3.0-120.0$ & 12 & 21.67 \\
& Strontium.90 & $1.0-136.0$ & 16 & 12.97 \\
\hline
\end{tabular}

Note: The calculation of average concentration includes nondetects (averaged in as a zero value) and theretore may be biased high. 
Table 22. Summary data table for the perched water samples collected during sampling event 5 a.

\begin{tabular}{|c|c|c|c|c|}
\hline Analysis & Contaminant & $\begin{array}{c}\text { Concentration } \\
\text { range } \\
\text { (mgl) }\end{array}$ & $\begin{array}{c}\text { Number of } \\
\text { samples }\end{array}$ & $\begin{array}{c}\text { Average } \\
\text { concentration } \\
\text { (mel.) } \\
\end{array}$ \\
\hline \multirow[t]{24}{*}{ Inorganic } & Aluminum & $0.0395-7.25$ & 14 & 1.12 \\
\hline & Antimony & $0.036-0.142$ & 14 & 0.019 \\
\hline & Arsenic & $0.001-0.0042$ & 14 & 0.002 \\
\hline & Barium & $0.09-0.266$ & 14 & 0.183 \\
\hline & Beryllium & $\mathrm{ND}(0.00031)$ & 14 & $0.00 \times 03$ \\
\hline & Cadmium & $N D(0.00047)-0.002$ & 14 & 0.00014 \\
\hline & Caicium & $30.6-148.0$ & 14 & 73.47 \\
\hline & Chromium & $0.0096-0.0187$ & 14 & 0.0041 \\
\hline & Cobalt & $N D(0.006)$ & 14 & 0.006 \\
\hline & Copper & $0.005-0.018$ & 14 & 0.008 \\
\hline & Iron & $0.004-7.99$ & 14 & 0.345 \\
\hline & Lead & $0.001-0.0033$ & 14 & $0.00 \times 08$ \\
\hline & Magnesium & $6.7-32.80$ & 14 & 19.70 \\
\hline & Manganese & $0.002-0.111$ & 14 & 0.022 \\
\hline & Mercury & $0.0001-0.0002$ & 14 & 0.00002 \\
\hline & Nickel & $0.016-0.064$ & 14 & 0.007 \\
\hline & Polasilum & $1.59-9.50$ & 14 & 2.99 \\
\hline & Selenium & $\mathrm{ND}(0.002)$ & 14 & $0 .(0) 2$ \\
\hline & Silver & $0.002-0.006$ & 14 & 0.00009 \\
\hline & Sodium & $9.65-127.0$ & 14 & 54.63 \\
\hline & Sironlium & $0.307-0.710$ & 14 & 0.07 .3 \\
\hline & Thallium & $0.001-0.101$ & 14 & $0.0 \times 49$ \\
\hline & Vanadium & $0.0054-0.04$ & 14 & 0.008 \\
\hline & Zinc & $0.008-0.07$ & 14 & 0.019 \\
\hline \multicolumn{5}{|c|}{$\begin{array}{l}\text { Organica all data reported are reported as a } U \mathrm{JJ}, \mathrm{U} \text {, or } \mathrm{R} \text { flag. Therefore, it is not reported here. } \\
\text { ND = not detected }\end{array}$} \\
\hline
\end{tabular}




\section{DATA EVALUATION AND APPLICATION OF SCREENING CRITERIA}

Data evaluation and screening were performed on samples originating from sampling events 2 through 5a. Data from sampling event 1 were not used because of factors that included lack of information for proper data validation.

\subsection{Screening Levels for Solls}

The concentrations of many of the contaminants detected have been analyzed and are lews than risk-based values. Many common laboratory contaminants, nutural background elements, and chemicals detected in the analysis can be eliminated as significant contaminants when screened by this process. The application of screening for both soil and water samples followed the logic as described below.

Initially the original data results were reviewed to confirm data usability. Soil samples analyzed for inorganic contaminants were then scrutinized by following a hierarchial screening process, as described below:

1. Eliminate aluminum, calcium, magnesium, potassium, iron, and sodium from the list of contaminants. These metals ar e not associated with human toxicity; therefore, they should not be considered as major risks to the site.

2. Compare the maximum concentration value of ench contaminant to a derived concentration value for soils posing a cancer risk of $10^{.9}$ and 10 a 0.1 hazurd quoticnt screening value. The risk-bused values are derived from EPA Region X Supplemental Risk Assessment Guidance for Superfund (EPA 1991a).

3. Eliminate inorganic chemicals at naturally occurring levels (this is site specific). For instance. if values defined in following the second eritcrion are less than natural background levels, the screening process should defiult to application of the background level for a comparison. Background levels for this report originate from the DOE/ID-1(1),34) (DOE 1992).

The same strategy is applied lor soil samples analyzed for organic contaminants. However, because organics are not found naturally in the environment, the third criterion is not used in assigning a risk factor.

Samples analyzed for radiological contaminants are evaluated against background levels to screen the data. The background values for screening of radiological contaminants for the soil samples are derived from the Track I Guidance Document (DOE 19/2). Note that cobalt-6x) is given a background value of zero hased on its short half-life of approximately live years.

\subsection{Screening Values for Water Samples}

Screening levels for water samples analyzed for inorganics are based on the same screening process as defined for soils. Comparison to background levels is omilted as a screcning factor hecousc 
background inorganic levels for water do not exist. The screening levels for organic contaminants are based on the same process for soil samples, as follows:

1. Maximum contaminant levels (MCLs), as referenced in 40 CFR 141, "National Primary Drinking Water Regulations."

2. A maximum concentration in water poses less than or equal to $10^{-6}$ cancer risk screening value and to a 0.1 hazard quotient screening value. The risk-based values are derived from EPA Region X Supplemental Risk Assessment Guidance for Superfund (EPA 1991a).

Water samples analyzed for radiological contaminants must also comply with the hierarchial screening process identified in the above two steps. If MCLs or risk-based levels were not available then the maximum concentration of the contaminant was compared to derived concentration guides as referenced in DOE Order 5400.5, "Radiation Protection of the Public and the Environment."

\subsection{Significant Contaminants}

Analytical results acquired from sampling events $2,3,4,5$, and 5 a provided the basis for evaluating sample contaminant concentrations against the identified screening levels. Results of data evaluation for these sampling events are presented in Tables 23 through 30 . Each of these tables includes:

- Contaminant

- Weight of evidence for each contaminant; this value defines the level of carcinogenicity as it correlates to each contaminant-a value of $A$ and $B$ (B1 or B2) designates that the contaminant is carcinogenic to humans and is a probable human carcinogen (EPA 1991b)

- Range of the contaminant concentration

- Number of sample collected from each event

- Screening value (e.g., risk-based level, background level, MCL)

- Number and percentage of samples that exceeded the defined screening value.

A significant contaminant is defined as a contaminant in which more than $25 \%$ of the samples analyzed report a concentration above the defined screening levels. In some instances, one or two samples will exceed the defined risk-based value. Each of these cases is discussed independently. The significant contaminants screened through this process for sampling events 2 through 5 a have been summarized and are presented in the following sections. 
Table 23. Screening application for soil inorganic analysis (sampling events 2-5).

\begin{tabular}{|c|c|c|c|c|c|c|c|c|c|c|}
\hline \multirow{2}{*}{$\begin{array}{l}\begin{array}{c}\text { Contaminant soil/ sediment media } \\
\text { for all SE } \\
(2-5)\end{array} \\
\end{array}$} & \multirow{2}{*}{$\begin{array}{l}\text { Weight of } \\
\text { evidence }\end{array}$} & \multirow{2}{*}{$\begin{array}{l}\text { Risk-based Screening } \\
\text { Concenyation } \\
10^{-} \\
(\mathrm{mg} / \mathrm{kg})\end{array}$} & \multirow{2}{*}{$\begin{array}{c}\text { Concentrations giving } \\
\text { a } \mathrm{HQ}=.1 \\
(\mathrm{mg} / \mathrm{kg})\end{array}$} & \multirow{2}{*}{$\begin{array}{c}\text { Background } \\
\text { levels } \\
(\mathrm{mg} / \mathrm{kg}) \\
\end{array}$} & \multirow{2}{*}{$\begin{array}{l}\text { Range of contaminant } \\
\text { concentration } \\
(\mathbf{m g} / \mathrm{kg})\end{array}$} & \multirow{2}{*}{$\begin{array}{l}\begin{array}{c}\text { Number } \\
\text { of } \\
\text { samples }\end{array} \\
\end{array}$} & \multicolumn{2}{|c|}{$\begin{array}{c}\text { Number of samples } \\
\text { exceeding risk or } \\
\text { background levels } \\
\end{array}$} & \multicolumn{2}{|c|}{$\begin{array}{c}\text { Significant } \\
\text { contaminant }\end{array}$} \\
\hline & & & & & & & Number & Percent & Yes & No \\
\hline Antimony & No data & NA & 10 & $24.7^{\mathrm{a}}$ & $0.62-27.4$ & 87 & $4 / 87$ & 5 & & $\alpha$ \\
\hline Arsenic & $\mathbf{A}$ & .04 & 8 & $38.4^{\mathrm{a}}$ & $1.7-49.20$ & 126 & $5 / 126$ & 4 & & $J$ \\
\hline Barium & No data & NA & $2000^{a}$ & 254 & $152-9740$ & 127 & $1 / 127$ & 1 & & 1 \\
\hline Beryllium & B2 & .01 & 100 & $1.5^{\mathrm{a}}$ & $0.81-8.6$ & 128 & $104 / 128$ & 81 & & b \\
\hline Cadmium & B1 & NA & NA & $4.6^{\mathrm{a}}$ & $0.50-14.90$ & 128 & $12 / 128$ & 9 & & 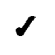 \\
\hline Chromium & No data & NA & NA & $38.9^{a}$ & $21.3-257.0$ & 128 & $91 / 128$ & 71 & $\alpha$ & \\
\hline Copper & D & NA & $2000^{a}$ & 27.4 & $12.7-936$ & 128 & $0 / 128$ & 0 & & $d$ \\
\hline Lead & B2 & NA & NA & $55.6^{\mathrm{a}}$ & $12.0-210.0$ & 128 & $9 / 128$ & 7 & & $\gamma$ \\
\hline Mercury & D & NA & NA & $0.06^{a}$ & $0.04-4040$ & 129 & $99 / 129$ & 77 & 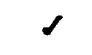 & \\
\hline Nickel & No data & NA & $500^{\mathrm{a}}$ & 42.5 & $22.6-240.0$ & 128 & $0 / 128$ & 0 & & $\checkmark$ \\
\hline Selenism & D & NA & $100^{\mathrm{a}}$ & 17.0 & $0.18-42.20$ & 128 & $0 / 128$ & $\mathbf{0}$ & & $\checkmark$ \\
\hline Silver & D & NA & $80^{\mathrm{a}}$ & 3.5 & $0.26-166.0$ & 128 & $1 / 128$ & 1 & & $d$ \\
\hline Strontium $^{c}$ & No data & NA & NA & $200^{\mathrm{a}}$ & $75.8-172.0$ & 89 & $1 / 89$ & 1 & & \\
\hline Thallium & NA & NA & 2 & $18.4^{\mathrm{a}}$ & $0.17-48.2$ & 121 & $41 / 121$ & 34 & 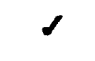 & \\
\hline Vanadium & NA & $\mathbf{N A}$ & $200^{a}$ & 53.7 & $26.0-333.0$ & 128 & $0 / 128$ & 0 & & $\gamma$ \\
\hline Zinc & NA & $\mathbf{N A}$ & $5000^{a}$ & 182.0 & $20.0-2400$ & 128 & $0 / 128$ & o & & $\alpha$ \\
\hline \multicolumn{11}{|l|}{$\overline{\mathrm{SE}}=$ sampling event } \\
\hline \multicolumn{11}{|c|}{$\begin{array}{l}\text { b. Beryllium is not considered to be a significant contaminant since only } 13 \text { of the } 133 \text { samples were not within } 1.0 \mathrm{mg} / \mathrm{kg} \text { of the background level. } \\
\text { c. The background level used was obtained from Table } 4.0 .7 \text { of the EGG-ES-8204 (DOE 1989), derived originally from the EPA Office of Solid Waste and Emergency Response, } \\
\text { Hazardous Waste Land Treament, SW-874 (April 1983). }\end{array}$} \\
\hline
\end{tabular}


Table 24. Screening application for surface water inorganic analysis (sampling event 3).

\begin{tabular}{|c|c|c|c|c|c|c|c|c|c|c|}
\hline \multirow[b]{2}{*}{$\begin{array}{c}\text { Analyte water } \\
\text { media SE } 3 \\
\end{array}$} & \multicolumn{2}{|c|}{$\begin{array}{c}\text { Concentration range and number of } \\
\text { samples }\end{array}$} & \multirow[b]{2}{*}{$\begin{array}{c}\mathrm{MCL} \\
(\mu \mathrm{g} / \mathrm{L})\end{array}$} & \multirow[b]{2}{*}{$\begin{array}{l}\mathrm{HI}=.1 \\
(\mu \mathrm{g} / \mathrm{L})\end{array}$} & \multirow[b]{2}{*}{$\begin{array}{c}\text { Risk at } \\
10^{-6}\end{array}$} & \multirow[b]{2}{*}{$\begin{array}{c}\text { Weight of } \\
\text { evidence }\end{array}$} & \multicolumn{2}{|c|}{$\begin{array}{c}\text { Number of samples exceeding } \\
\text { defined screening limit }\end{array}$} & \multicolumn{2}{|c|}{$\begin{array}{c}\text { Significant } \\
\text { contaminant }\end{array}$} \\
\hline & $\begin{array}{c}\text { Concentration range } \\
(\mu \mathrm{g} / \mathrm{L})\end{array}$ & $\begin{array}{c}\text { Number of } \\
\text { samples }\end{array}$ & & & & & Number & Percent & Yes & No \\
\hline Barium & $72.0-241.0$ & 4 & $2,000^{a}$ & 300 & NA & No data & $0 / 4$ & o & & $\gamma$ \\
\hline Beryllium & $2.5-4.4$ & 4 & $4^{a}$ & 20 & 0.02 & B2 & $1 / 4$ & 25 & $d$ & \\
\hline Cadmium & $1.0-1.1$ & 2 & $5^{a}$ & 20 & NA & B1 & $0 / 2$ & 0 & & 1 \\
\hline Chromium & $2.0-19.0$ & 4 & $100^{\mathrm{a}}$ & 20 & NA & No data & $0 / 4$ & 0 & & 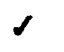 \\
\hline Copper & $12.0-102.0$ & 4 & $1,300^{\mathrm{a}}$ & 300 & NA & D & $0 / 4$ & o & & 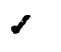 \\
\hline Mercury & $0.02-0.42$ & 4 & $2^{\mathbf{a}}$ & 1.0 & NA & D & $0 / 4$ & o & & 1 \\
\hline Nickel & $6.0-29.0$ & 4 & $100^{\mathrm{a}}$ & 70.0 & NA & No data & $0 / 4$ & o & & $\checkmark$ \\
\hline Silver & $6.0-35.0$ & 2 & NA & $10.0^{a}$ & NA & D & $1 / 2$ & 50 & 1 & \\
\hline Vanadium & $17.0-48.0$ & 4 & NA & $30.0^{\mathrm{a}}$ & NA & - & $1 / 4$ & 25 & 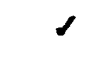 & \\
\hline Zinc & $57.0-389.0$ & 4 & NA & $700.0^{\mathrm{a}}$ & NA & - & $0 / 4$ & $\mathbf{0}$ & & $\alpha$ \\
\hline \multicolumn{11}{|c|}{$\mathrm{SE}=$ sampling event } \\
\hline
\end{tabular}


Table 25. Screening application for perched water inorganic analysis (sampling event 5a).

\begin{tabular}{|c|c|c|c|c|c|c|c|c|c|c|}
\hline \multirow[b]{2}{*}{$\begin{array}{l}\text { Analyte water } \\
\text { media SE 5a }\end{array}$} & \multicolumn{2}{|c|}{$\begin{array}{l}\text { Concentration range } \\
\text { and number of samples }\end{array}$} & \multirow[b]{2}{*}{$\begin{array}{c}M C L \\
(\mu g / L)\end{array}$} & \multirow[b]{2}{*}{$\begin{array}{l}H I=.1 \\
(\mu g / L)\end{array}$} & \multirow[b]{2}{*}{ Risk at $10^{-6}$} & \multirow[b]{2}{*}{$\begin{array}{l}\text { Weight of } \\
\text { evidence }\end{array}$} & \multicolumn{2}{|c|}{$\begin{array}{l}\text { Number of samples } \\
\text { exceeding lowest limit }\end{array}$} & \multicolumn{2}{|c|}{$\begin{array}{c}\text { Significant } \\
\text { contaminant }\end{array}$} \\
\hline & $\begin{array}{c}\text { Concentration range } \\
(\mu g /)\end{array}$ & $\begin{array}{c}\text { Number of } \\
\text { samples }\end{array}$ & & & & & Number & Percent & Yes & No \\
\hline Antimony & $36.4-142.0$ & 14 & $6^{a}$ & 1.0 & NA & No data & $4 / 14$ & 29 & $\alpha$ & \\
\hline Arsenic & $1.1-4.2$ & 14 & $50^{\mathrm{a}}$ & 1.0 & 0.05 & $\mathbf{A}$ & $0 / 14$ & o & & $\checkmark$ \\
\hline Barium & $90.4-266.0$ & 14 & $2,000^{\mathrm{a}}$ & 300 & $\mathbf{N A}$ & No data & $0 / 14$ & o & & $\gamma$ \\
\hline Beryllium & ND(0.31) & 14 & $4^{a}$ & 20 & 0.02 & B2 & $0 / 14$ & 0 & & 1 \\
\hline Cadmium & $N D(0.47)-2.0$ & 14 & $5^{a}$ & 20 & NA & B1 & $0 / 14$ & $\mathbf{0}$ & & 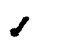 \\
\hline Chromium & $9.6-18.7$ & 14 & $100^{\mathrm{a}}$ & 20 & NA & No data & $0 / 14$ & o & & 1 \\
\hline Copper & $4.8-17.9$ & 14 & $1,300^{\mathrm{a}}$ & 300 & NA & D & $0 / 14$ & $\mathbf{0}$ & & 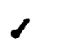 \\
\hline Lead & $1.0-3.3$ & 14 & $50^{2}$ & NA & NA & $\mathbf{B} 2$ & $0 / 14$ & o & & $d$ \\
\hline Mercury & $0.10-0.17$ & 14 & $2^{a}$ & 1.0 & NA & D & $0 / 14$ & o & & 1 \\
\hline Nickei & $15.9-64.0$ & 14 & $100^{2}$ & 70.0 & NA & No data & $0 / 14$ & $\mathbf{0}$ & & $\gamma$ \\
\hline Selenium & 2.0 & 14 & $50^{a}$ & 10.0 & NA & D & $0 / 14$ & o & & 1 \\
\hline Sitver & $2.4-5.6$ & 14 & NA & $10.0^{a}$ & $\mathbf{N A}$ & D & $0 / 14$ & o & & 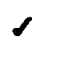 \\
\hline Thallium & $1.0-101.0$ & 14 & $5^{a}$ & 0.30 & $\mathbf{N A}$ & - & $4 / 14$ & 33 & 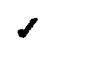 & \\
\hline Vanadium & $5.4-40.1$ & 14 & $\mathbf{N A}$ & $30.0^{2}$ & NA & - & $0 / 14$ & o & & $\alpha$ \\
\hline Zinc & $7.8-70.1$ & 14 & NA & $700.0^{\mathrm{a}}$ & NA & - & $0 / 14$ & $\mathbf{0}$ & & $\alpha$ \\
\hline \multicolumn{11}{|c|}{$\begin{array}{l}\text { SE = sampling event } \\
\text { a. Selected screening tevel. }\end{array}$} \\
\hline $\begin{array}{l}\text { Note: The cone } \\
\text { Organic }\end{array}$ & $\begin{array}{l}\text { ration includes the nonde } \\
\text { taminants were not detec }\end{array}$ & $\begin{array}{l}\text { ts (averaged i } \\
\text { in the perche }\end{array}$ & $\begin{array}{l}\text { a zero valt } \\
\text { ater zone; }\end{array}$ & $\begin{array}{l}\text { herefore } \mathrm{m} \\
\text { a table wa }\end{array}$ & $\begin{array}{l}\text { iased high. } \\
\text { repared for } p\end{array}$ & ad water orga & alysis. & & & \\
\hline
\end{tabular}


Table 26. Screening application for soil organic analysis (sampling events 2-5).

\begin{tabular}{|c|c|c|c|c|c|c|c|c|c|}
\hline \multirow{2}{*}{$\begin{array}{c}\text { Contaminant soilsediment } \\
\text { media for all SEs } \\
(2-5)\end{array}$} & \multirow[b]{2}{*}{$\begin{array}{c}\text { Weight of } \\
\text { evidence }\end{array}$} & \multirow{2}{*}{$\begin{array}{c}\text { Risk-based } \\
\text { Screening } \\
\text { Concentyation } \\
10 \\
(\mathbf{m g} / \mathbf{k g}) \\
\end{array}$} & \multirow{2}{*}{$\begin{array}{c}\text { Concentrations } \\
\text { giving a } \mathrm{HO}=.1 \\
(\text { me } / \mathrm{kg})\end{array}$} & \multirow{2}{*}{$\begin{array}{c}\text { Range of } \\
\text { contaminant } \\
\text { concentration } \\
(\mathrm{mg} / \mathrm{fR}) \\
\end{array}$} & \multirow[b]{2}{*}{$\begin{array}{c}\text { Number of } \\
\text { samples }\end{array}$} & \multicolumn{2}{|c|}{$\begin{array}{c}\text { Number of samples } \\
\text { ecoceding risk or } \\
\text { bactground levets }\end{array}$} & \multicolumn{2}{|c|}{$\begin{array}{c}\text { Significant } \\
\text { Contamimant } \\
\end{array}$} \\
\hline & & & & & & Number & Percent & Yes & No \\
\hline 1,1,1-trichloroethane & D (14) & NA & $2,000^{\mathrm{a}}$ & $0.012-0.043$ & 82 & 0,82 & 0 & & $\checkmark$ \\
\hline 2-butanone & D (13) & NA & $1,000^{\mathrm{a}}$ & $0.010-0.099$ & 22 & $0 / 22$ & 0 & & s \\
\hline 2-hexanone & NA & NA & NA & $0.006-0.029$ & 22 & $0 / 22$ & $\mathbf{0}$ & & 2 \\
\hline 4-methyl-2-penianone & NA & NA & NA & $0.01-0.020$ & 75 & 0775 & $\mathbf{0}$ & & 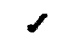 \\
\hline Acetone & $D(6)$ & NA & $3,000^{\mathrm{a}}$ & $0.004-0.15$ & 51 & ass 1 & o & & 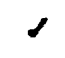 \\
\hline Bromomethane & $D(2)$ & NA & $40^{3}$ & 0.01 & 79 & $0 / 79$ & o & & 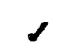 \\
\hline Chloroethane & (4) & NA & NA & 0.01 & 76 & $0 / 76$ & o & & J \\
\hline Chloroform & B2 (11) & $10^{a}$ & 300 & $0.013-0.018$ & 82 & $0 / 82$ & 0 & & 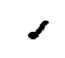 \\
\hline Chloromethane & $C(1)$ & $5^{a}$ & NA & 0.01 & 76 & $0 / 76$ & $\mathbf{0}$ & & ' \\
\hline Dichlorodifluoro-methane & ND & NA & NA & $\mathrm{ND}(0.05)-120$ & 8 & 088 & $\mathbf{0}$ & & , \\
\hline Ethylbenzene & D (32) & NA & $3,000^{2}$ & $0.002-0.012$ & 79 & $0 / 79$ & $\mathbf{0}$ & & $s$ \\
\hline $\begin{array}{l}\text { Methylene chloride } \\
\text { (dichloromethane) }\end{array}$ & B2 (5) & $9^{\mathbf{a}}$ & 2000 & $0.001-0.011$ & 117 & $0 / 17$ & o & & $\boldsymbol{J}$ \\
\hline Toluene & D (29) & NA & $5,000^{2}$ & $0.001-0.063$ & 110 & on10 & $\mathbf{0}$ & & 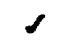 \\
\hline Thiobismethane & NA & NA & NA & 0.029 & 1 & on1 & $\mathbf{0}$ & & 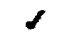 \\
\hline Vinyl acetate & (16) & NA & $30,000^{3}$ & $0.003-0.063$ & 79 & or79 & $\mathbf{0}$ & & $\checkmark$ \\
\hline Vinyl chloride & A (3) & $.03^{\mathrm{a}}$ & NA & 0.01 & 76 & $0 / 76$ & $\mathbf{0}$ & & $ر$ \\
\hline Xylene (total) & D (34) & NA & $50.000^{\mathrm{a}}$ & $0.003-0.012$ & 79 & ang & $\mathbf{0}$ & & 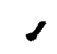 \\
\hline Fluoranthene (semi-app IX) & $D(86)$ & NA & $1,000^{\mathrm{a}}$ & $0.27-0.33$ & 9 & 09 & o & & 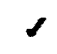 \\
\hline Pyrene (semi-app IX) & D (87) & NA & $800^{a}$ & $0.230-0.33$ & 9 & 09 & 0 & & 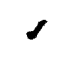 \\
\hline $\begin{array}{l}\text { bis(2-ethylhexyl)phthalate } \\
\text { (Semi-app IX) }\end{array}$ & B2 (92) & $5^{\mathrm{a}}$ & 500 & $0.26-29$ & 9 & 09 & 0 & & 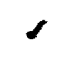 \\
\hline Aroctor-1254 (OC pest) ${ }^{b}$ & NA & NA & NA & $0.035-0.55$ & 9 & $0 / 9$ & o & & $ر$ \\
\hline Aroclor- $1260^{\mathrm{b}}$ (OC pest) & NA & NA & NA & $0.220-0.781$ & 9 & 09 & 0 & & s \\
\hline
\end{tabular}

SE = sampling event

a. Selected screening lewel.
b. 40 CFR 761.125 (b) defines clean soil at 1 ppm. Therefore this was used as the screening level. 
Table 27. Screening application for surface water organic analysis (sampling event 3).

\begin{tabular}{|c|c|c|c|c|c|c|c|c|c|}
\hline \multirow{2}{*}{$\begin{array}{l}\text { Contaminant water media for } \\
\text { all sampling events } \\
\text { (SE 3) } \\
\text { (VOAs) }\end{array}$} & \multirow[b]{2}{*}{$\underset{(\mu \& /)}{M C 1}$} & \multicolumn{2}{|c|}{ Rist-basod concentrations } & \multirow[b]{2}{*}{ Weight of evilkence } & \multirow[b]{2}{*}{ 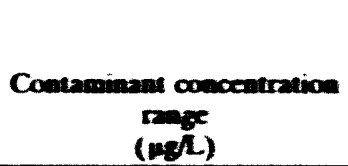 } & \multirow[b]{2}{*}{$\begin{array}{l}\text { Number of } \\
\text { semplex }\end{array}$} & \multirow[b]{2}{*}{ Percen } & \multicolumn{2}{|c|}{$\begin{array}{l}\text { Sigaticant } \\
\text { contaminame }\end{array}$} \\
\hline & & $\begin{array}{c}\text { Rist }=10^{-6} \\
(\mu \notin /)^{\prime}\end{array}$ & $\begin{array}{l}H !=1 \\
(\text { mel. })^{2}\end{array}$ & & & & & Yes & $\mathbf{N o}$ \\
\hline Acetone & NA & NA & 400 & $D(6)$ & ND(0.01)-11.0 & 2 & - & & 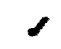 \\
\hline \multicolumn{10}{|l|}{$\mathrm{SE}=$ sampling event } \\
\hline a. Setected screening levet. & & & & & & & & & \\
\hline
\end{tabular}


Table 28. Screening application for soil radiological anabssis (sampling cvents 3 and 5).

\begin{tabular}{|c|c|c|c|c|c|c|c|}
\hline \multirow{2}{*}{$\begin{array}{c}\text { Aerivic solkediancal } \\
\text { odia for all } \\
\text { SEs (3.5) }\end{array}$} & \multirow{2}{*}{$\begin{array}{c}\text { Backeromad } \\
\text { keved } \\
\text { (pCigt) }\end{array}$} & \multirow{2}{*}{$\begin{array}{l}\text { Concesermion } \\
\text { renec (pCin) }\end{array}$} & \multirow{2}{*}{ of enporio } & \multicolumn{2}{|c|}{ Nomber of somplas acouthes } & \multicolumn{2}{|c|}{ Songen } \\
\hline & & & & Number & Pacen & Ya & No \\
\hline Cobah-60 & - & $0.113-87.7$ & $4 i$ & ง14a1 & 10 & 2 & \\
\hline Cosium -137 & 13 & $\operatorname{ees} 1-127$ & 57 & 2057 & $\omega$ & 2 & \\
\hline Ceswem-134 & No den & 0013 & 1 & Nodose & - & & ه \\
\hline $\begin{array}{l}\text { Sercontuan } \\
\text { (Lotal) }\end{array}$ & 0.53 & $0.3-30$ & 7 & $\mathbf{m}$ & 3 & 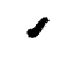 & \\
\hline $100-2+1$ & ecos & cescoens & 7 & $\leadsto$ & 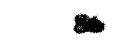 & 2 & \\
\hline Gross Apho & 194 & $39-1$ & 7 & en & $\bullet$ & & 2 \\
\hline Gross Beta & 315 & $4-340$ & 7 & $n$ & $\bullet$ & & , \\
\hline H.3 & $\operatorname{man}$ & $0.2-12$ & $\bullet$ & No data & - & & $\rho$ \\
\hline Eu-155 & mata & $\bullet 13$ & 1 & Nothes & - & & $p$ \\
\hline \multicolumn{8}{|l|}{$\mathrm{SE}=$ sampling crom } \\
\hline b. Given the the creace & scompined & $\csc 137,4$ & $=\infty$ & o be si & & & \\
\hline
\end{tabular}


Table 29. Scroening application for surface water radiologial analyis (smapling cvecu 3).

\begin{tabular}{|c|c|c|c|c|c|c|c|c|c|}
\hline \multirow[b]{2}{*}{ 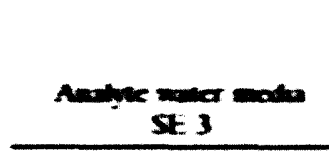 } & \multirow{2}{*}{${ }_{(\mathrm{P})}^{R}$} & \multirow[b]{2}{*}{$\operatorname{mon}^{2}$} & \multirow[b]{2}{*}{ Retriet hed } & \multirow{2}{*}{ nomed } & \multirow[b]{2}{*}{ ot } & \multicolumn{2}{|c|}{ 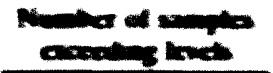 } & \multicolumn{2}{|c|}{ 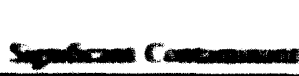 } \\
\hline & & & & & & $m$ & nowe & Yo & wo \\
\hline coses & $54-310$ & & 13 & & - & 4 & $\omega$ & 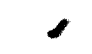 & \\
\hline C.137 & $72-930$ & & $\bullet$ & & 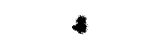 & $\omega$ & 10 & 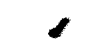 & \\
\hline Stromen- (now) & $35-12=$ & & & $=$ & , & $\omega$ & - & & 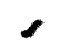 \\
\hline 211 & $097-13$ & & & 30 & + & 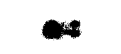 & $\bullet$ & & , \\
\hline 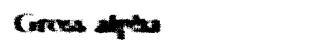 & $x a=0$ & 15 & & & 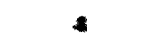 & 24 & 5 & 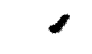 & \\
\hline Genes bets & tons: & & & $\boldsymbol{\omega}$ & + & $\bullet$ & - & & 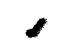 \\
\hline 113 & No-1000 & 300 & & & 3 & $\omega 3$ & - & & 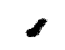 \\
\hline 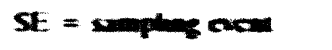 & & & & & & & & & \\
\hline Selociod sarecons has & & & & & & & & & \\
\hline
\end{tabular}




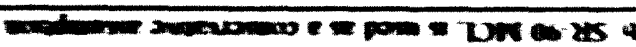

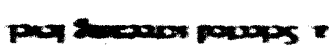

$002 \sin =35$

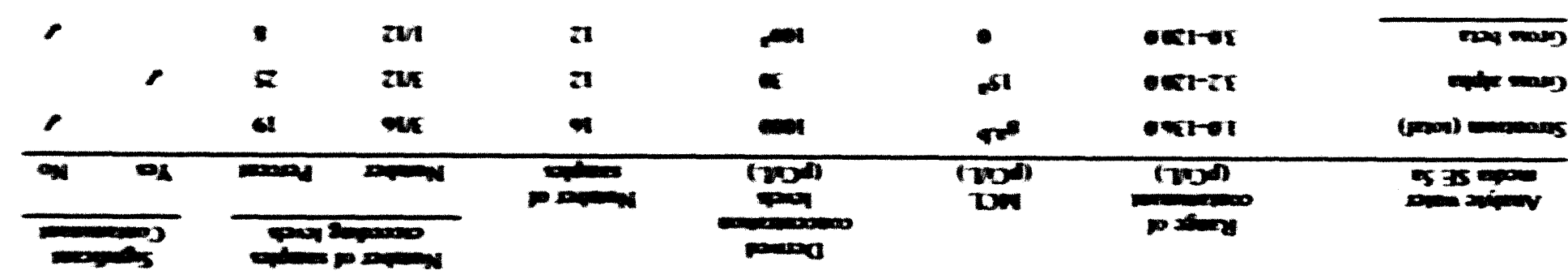

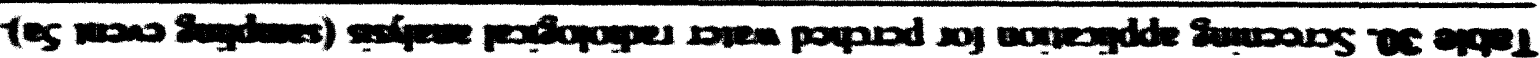




\subsection{Screening Resulte for Sample Data}

Data from sampling events 2 through 5 u were evaluated and screened aceording to the above criteria to determine the signilicant contaminants. Vertical distribution and plan view maps, exhibiting the contaminant concentrations, were prepared for the anulytes detected in concentrations $25 \%$ above the sureening level.

Soll, sediment, surface water, and perched water media types were analyzed for inorganica, organica, Appendix IX analytes, TCLP, and radiological contaminanis by the mechod specified in the preceding sections.

Inorgantos. Interpretation of the inorganic data results for soil medin indicates that beryllium, mercury, chromium, and thallium are considered to be signilicunt contaminants. Table 23 exhibits the screening level used (as denoted by foxunote a), the range of coniaminants, number of total samples from all the sampling eventx. and the total percentuge of samplen exceeding the defined screening level. Seventy-one percent of the sumplea exceeded the screening level of $38.9 \mathrm{mg} / \mathrm{kg}$ for chromium. Seventyaseven percent of the samples exceeded the $0.06 \mathrm{mg} / \mathrm{kg}$ screening level for mercury. Thirty. four percent of the samples exceeded the 18.4 mekg level for thallium. As nuted in the table, $81 \%$ of the samples analyaed for heryllium exceeded the $1.5 \mathrm{mgkg}$ screening level. Alihough a large percentage of samples exceeded the delined screening level for beryllium. upproximalely $(x) \%$ of the sumples are within the 1.10 meky TAN hackground level. Because a mujority of the sumples are within the background level of TAN, beryllium is not heing considered a significant contaminant.

A TCL.P analyaix was perfiormed on live to elght sumples collected during sampling event 4. All the data resulta were below the defined TCLP value for hazardous waste (refer 10 Table 17). These data indicate that the metal and organic contuminants in the pond soil are not likely to be signiflcanily leaching into the surrounding will.

Surface water samples were collected from sampling event 3. (Tahle 24), and perched water samples were collected from sumpling event su (Tuble 25). These tables summurize the sereening level for determining the significant contaminunt for the sampling events. Sample results from ampling event 3 indicate that $29 \%$ of surfice water sumplex analyed for beryllium exceed the $4 \mathrm{\mu g} / \mathrm{L}$ sereening level. Fifty percent of the sumples anulyed for silver exceed the $10 \mu \mathrm{gL} \mathrm{MCL}$, and $25 \%$ of the samples analyzed for vanadium exceed $30.0 \mu \mathrm{g} / \mathrm{L}$. which is the hazard index.

Perched water sumple results prescented in Table 25 indicale that $29 \%$ of the samples exceed the delined sereening level of $6 \mu \mathrm{BL}$. firr antimuny, und $3.3 \%$ of the sumplex exceed the $5 \mu \mathrm{g} / \mathrm{LCL}$. for thallium. These dila indicale that both of these contaminunis are found in the perched water zone.

Organles. Table 26 presents the sereening data evaluation for soil media. One-hundred percent of the soil samples anulyaed for aroclor-1254 and arocles-12(x) exceed the delined risk-hased screening level of 0.0018 mykg. Although this valus: was used as the screcening level, $40 \mathrm{CFR}$ 761.125(b) defines clean soil levels as less than I ppm. The maximum value for aroctor-1254 is 0.55 ppm while the maximum eoncentrution for aroctor-126) is $0.781 \mathrm{ppm}$. Both of these values are less 
than 1 ppm; therefore, these contaminants are not considered to be significant contaminants. No other organic compounds detected in the soil exceed the screening level.

Organic analyses for surface water sumples did not detect any contaminants other than acetone, which was measured at $11 \mathrm{\mu g} / \mathrm{L}$ (see Table 27). This value is well below the $4(X) \mu g / L$ screening level. No other organics were detected in the surface or perched water.

Aadlologleal. Soil samples from sampling events 3 and 5 were analyzed for Co-60, Cs-134, Cs. 137. Am-241, Sr (1otal), gross nlpha, gross heth, H-3, and Eu-155 (refer (o Tahle 28). It was determined through the screening crilcria that the following radiological contaminants are significant:

- Cobalt-60), ranging from 0.11 .3 to $87.7 \mathrm{pCi} / \mathrm{s}$ (41 of 41 samples)

- Cesium-1.37, ranging from 0.051 to $127.0 \mathrm{pCi} / \mathrm{g}$ (26 of 57 samples)

- Strontium (total), ranging from 0.26 to $3.0 \mathrm{pCi} / \mathrm{g}$ (3 of 7 samples)

- Americium-241, ranging from 0.009 to $0.021 \mathrm{pCl} / \mathrm{g}$ (6 of 7 samples).

Vertical distribution and plan view mups were not prepared for strontium (total) and amcricium 241 because only seven sumples were collected and analyzed for these contaminants.

Surface and perched water samples from sampling events 3 and $5 a$, respectively, were analyzed for radiological contaminants. Only three to four samples were collected from the pond's surface water in sampling event 3. Tubles 29 and 30 contain a summary of radiological contaminants that were detected and the significant contaminants. Data from sampling event 3 (Tuhle 29) show that four of four surface water samples analyzed lor $\mathrm{Co}-6(6)$ exceed the risk-hased level of $1.3 \mathrm{pCi} / \mathrm{L}$. Four of four samples analyzed for $\mathrm{Cs} .137$ exceed the $0.7 \mathrm{pCi} / \mathrm{L}$ screening level. Two of four of the samples analyzed for gross alphn exceed the $15 \mathrm{pCi} / \mathrm{L} \mathrm{MCL}$ value.

Data results presented in Table 30 from the perched water sampling effort indicate that $25 \%$ of samples analyzed for gross alpha exceed the $15 \mathrm{pCi} / \mathrm{L} \mathrm{MCL}$ valuc. Of the 12 samples collected, one of the samples was detected at the activity level of $120 \mathrm{pCi}$.

Strontium (total) was detected hetween 1.()-1.36.0 $\mathrm{pCi} / \mathrm{L}$, and gross heta was detected between 3-120 $\mathrm{pCi} / \mathrm{L}$. Three of 16 sumples analyzed for strontium (total) exceed the $\mathrm{MCL}$ value of $8 \mathrm{pCi} / \mathrm{L}$, and one of 12 samples unalyzed for gross heta exceeds the derived concentration level of $1(x) \mathrm{pCi} / \mathrm{L}$. 


\section{MAJOR CONTAMINANT MIGRATIUN EVALUATION}

Plan view and vertical profile maps exhibiting the major contaminants are presented in this section. The lower right-hand corner of the vertical protile maps identifies the location of the well or borehole at the TSF.(07 area. The plan view maps did not include data results from sampling event 5a (perched water sampling) because only two monitoring wells are located in the perched water zone (TSFAG-05 and TSFAG-07). All sample results were not plotted on these maps because some sample coordinates were unavailable.

TSFAG.03 and TSFAG.04 are auger holes drilled for the TAN RFI. As mentioned earlier, seven wells surrounding the TSF.07 disposal pond and three auger holes inside the area were drilled without encountering perched water. This information provides a constraint on the extent of perched water around the pond. Figure 4 portrays the approximate location of the perched water zone under the TSF-07 disposal pond, the approximate depth of surface to basalt, and the well/auger hole locations. The vertical distribution map defines the depth of the perched water zone.

The profile maps exhibit vertical migration of chromium, thallium, and mercury in the pond soils. Only three sample locations, at depth, were available to plot radiological data. These points are all located within $15.24 \mathrm{~m}(50 \mathrm{ft})$ of each other at the northeast end of the pond; therefore, these contaminants were not plotted vertically. Plan view maps were prepared for chromium, thallium, mercury, Co-60, and Cs-137. Vertical distribution and plan view maps were not prepared for Sr (total), Co-60, Cs-1.37 and Am-241 (significant contaminants) because only seven samples were collected and analyzed for the contaminants.

The following sections discuss whether contaminants are migrating outside the TSF-07 berm area, as portrayed in the plan view maps at the end of the section, and if contaminants have permeated the perched water zone, as illustrated in the vertical profile at the end of the section.

Mercury. Mercury was detected at a maximum depth of $3 \mathrm{~m}$ (10 ft) in TSFAG-06, indicating limited migration (Figure 12). The TSFAG-(04 location exhibits contamination at a depth of $13.7 \mathrm{~m}$ (45 $\mathrm{ft}$ ) beneath the land surface. The TSFAG-05 monitoring well exhibits mercury at approximately $15.24 \mathrm{~m}(50 \mathrm{ft})$. This indicates that mercury has permeated the perched water zone.

The plan view map (Figure 13) shows that the maximum concentration of mercury ranges between 0.05 and $3.9 \mathrm{mg} / \mathrm{kg}$ in the inlet basin area. One hot spot of $53.1 \mathrm{mg} / \mathrm{kg}$ is located in the overtlow pond. Another hot spot of $4.040 .0 \mathrm{mg} / \mathrm{kg}$ was detected in the inlet pipe area. This plan view shows that mercury is decreasing in concentration with increased distance from the inlet pipe area.

Thallium. TSFAG-06 and TSFAG-05, as illustrated in Figure 14, exhibit very little migration of thallium beneath the land surface. A value of $0.31 \mathrm{mg} / \mathrm{kg}$ of thallium was detected in TSFAG-04 at a depth of $15.24 \mathrm{~m}(50 \mathrm{ft})$. Thallium was detected in the TSFAG- 0.3 borchole at $0.21 \mathrm{mg} / \mathrm{kg}$ at a maximum depth of approximately $7.6 \mathrm{~m}$ (25 ft). Based on these data, thallium migration is limited.

The plan view map. Figure 15, shows thallium ranging from $1.0 \mathrm{mg} / \mathrm{kg}$ at the inlet area to 31.5 $\mathrm{mg} / \mathrm{kg}$ at the perimeter of the overllow pond. Thallium contamination appears to be within this concentration range throughout the pond. Horizontal migration outside of the bermed area is presumably not occurring, as illustrated in this plan view. 


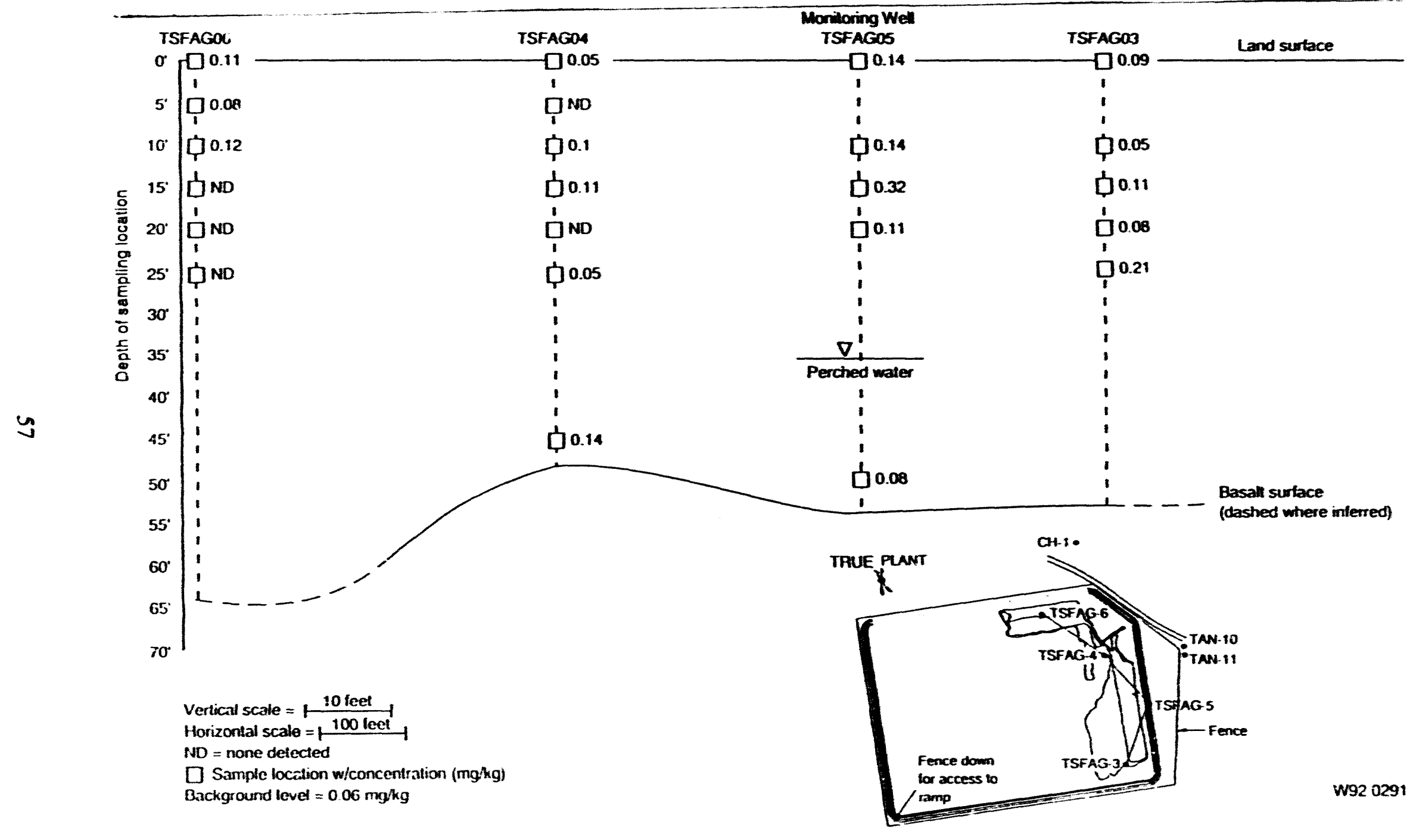

Figure 12 Vertical distribution of mercury in the TSF-07 disposal pond. 

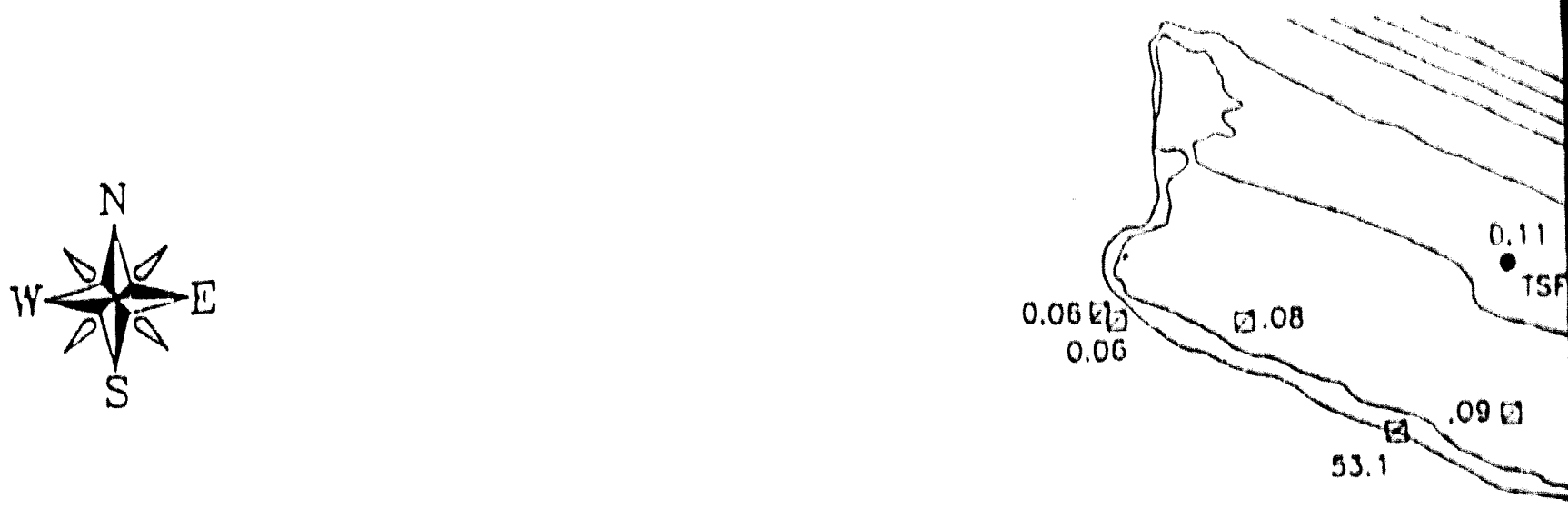


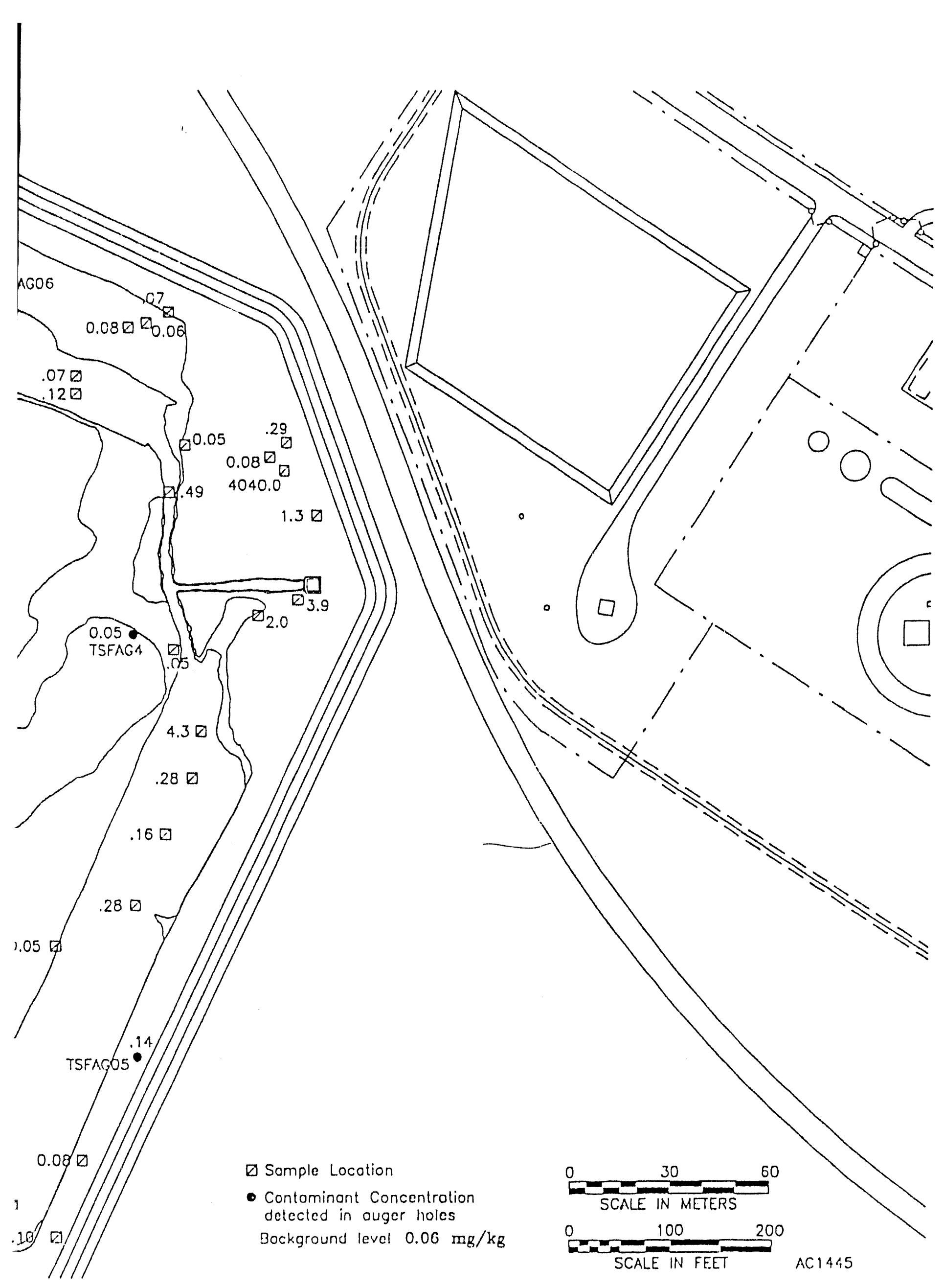




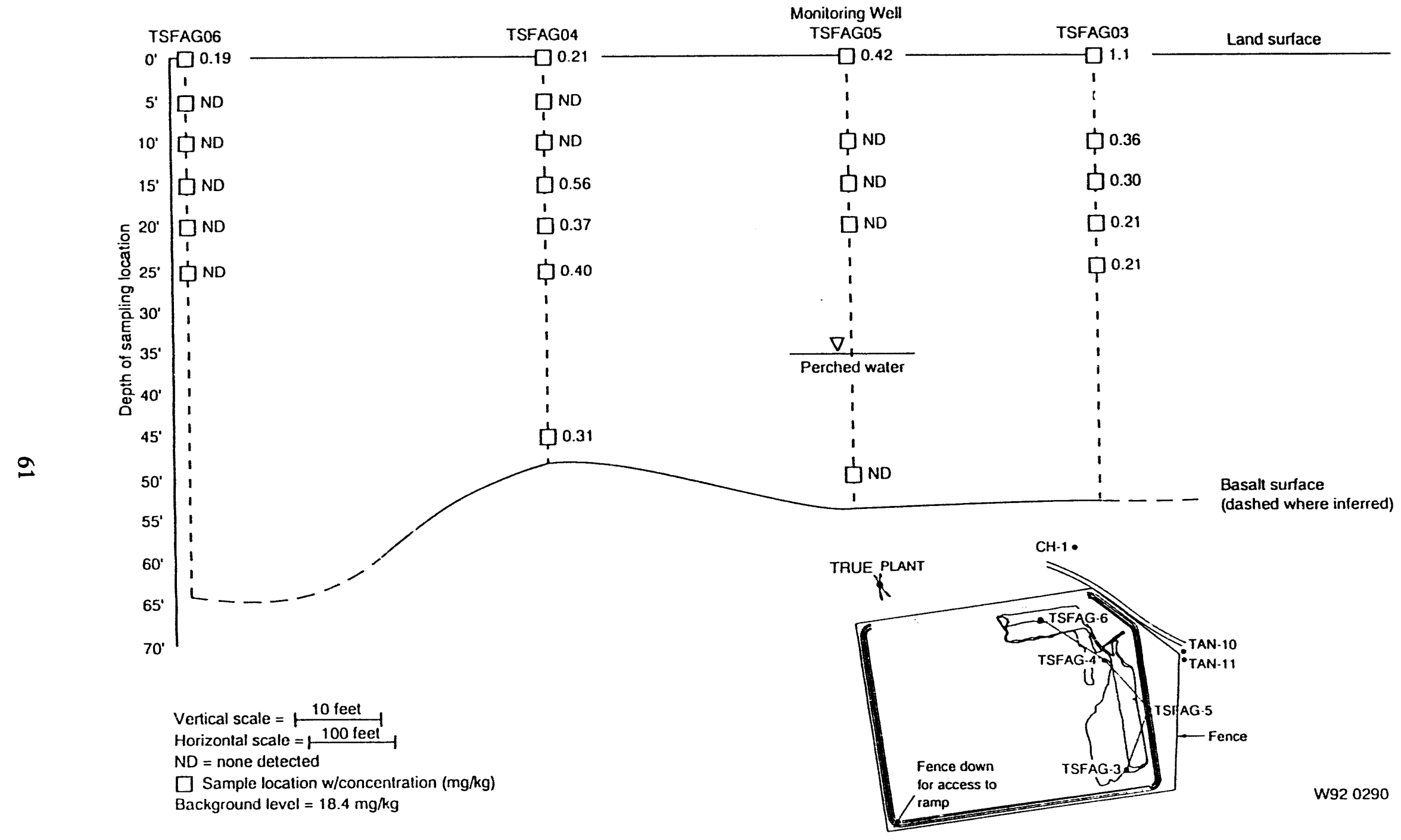

Figure 14. Vertical distribution of thallium in the TSF-07 disposal pond. 


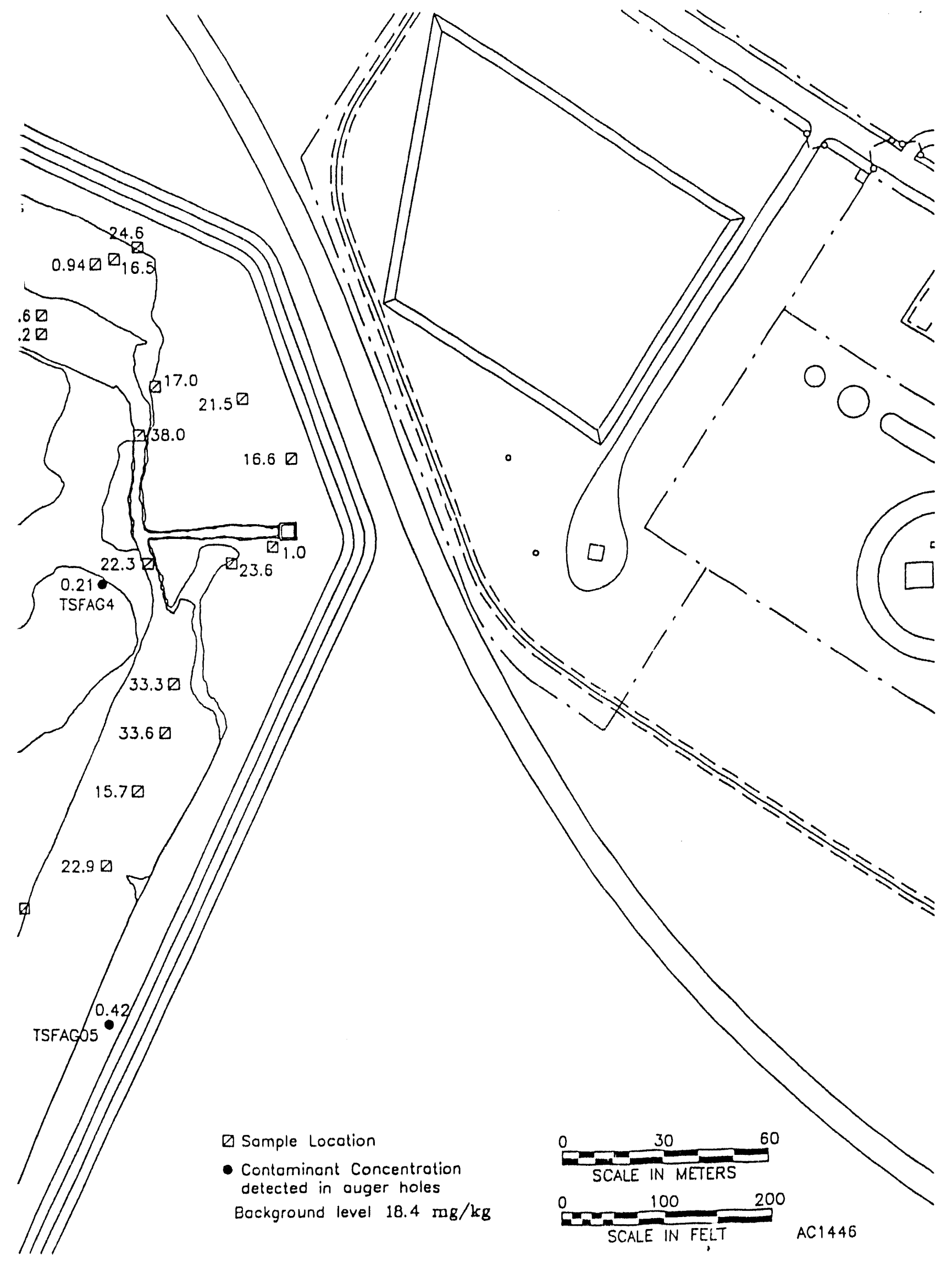


Chromium. Chromium contamination, ranging from 36.9 to $49.2 \mathrm{mg} / \mathrm{kg}$, has been detected at a maximum depth of $15.24 \mathrm{~m}(50 \mathrm{ft})$ beneath the land surface in boreholes TSFAG-06, TSFAG-03, and TSFAG-04 (see Figure 16). Monitoring well TSFAG-05 exhibits the presence of chromium in the soil at a depth of approximately $15.24 \mathrm{~m}(50 \mathrm{ft})$, thus indicating that chromium has reached the perched water zone.

The plan view (Figure 17) shows chromium concentrations ranging from $39.0 \mathrm{mg} / \mathrm{kg}$ to $74.5 \mathrm{mg} / \mathrm{kg}$. Based on the plan view map, chromium does not appear to be migrating outside of the bermed area of the pond, but concentrations of chromium above background levels are present throughout the area.

Cobalt-60. As illustrated in Figure 18, cobalt-60 contamination ranges from 0.139 to $87.7 \mathrm{pCi} / \mathrm{g}$. High concentration values are detected mainly in the inlet basin location. High levels of cobalt -60 were also detected in the ditch and inlet area between the disposal and overflow pond. Note that all sample points were not plotted therefore the entire range of this contaminant is not illustrated here. The plan view shows that cobalt -60 is not migrating outside of the bermed area.

Cesium-137. Cesium-137 contamination ranges from $0.347 \mathrm{pCi} / \mathrm{g}$ to $46.3 \mathrm{pCi} / \mathrm{g}$ around the perimeter of the TSF-07 disposal pond, as depicted in Figure 19. From the data illustrated in the plan view, cesium-137 does not appear to be migrating outside of the bermed area.

\subsection{Evaluation of Significant Contaminants}

Data collected from sampling events 2 through 5a, dating from 1982 through 1991, were used to determine significant contaminants through application of screening levels. Soil, sediment, and perched water media were sampled at surface locations and differing depths. Analytical data collected included organic, inorganic, and radiological analyses by defined methods as described in Section 3 for each sampling event.

\subsubsection{Soils}

Screening the data for samples collected in sampling events 2 through 5 indicates that chromium, mercury, and thallium are present above the defined screening levels for soils and are therefore considered significant contaminants. Chromium was detected above the background level of $\mathbf{3 8 . 9}$ $\mathrm{mg} / \mathrm{kg}$ in $71 \%$ of the samples. Mercury was found in $77 \%$ of the samples above the background level of $0.06 \mathrm{mg} / \mathrm{kg}$. One sample out of 129 samples analyzed for mercury shows an elevated concentration of $4040.0 \mathrm{mg} / \mathrm{kg}$. This sample was collected at the discharge to the pond. Thirty-four percent of the samples analyzed for thallium exceed the background level of $18.4 \mathrm{mg} / \mathrm{kg}$.

Co-60, Cs-137, strontium (total), and americium-241 are also considered to be significant contaminants. Three of seven samples analyzed for strontium (total) and six of seven samples analyzed for Am-241 exceed the radiological screening level for soil samples. One hundred percent of the samples analyzed for Co-60 exceed the screening level for this contaminant, and $46 \%$ exceed the background level for Cs- 137 .

No organic contaminants were detected above the defined screening levels. 


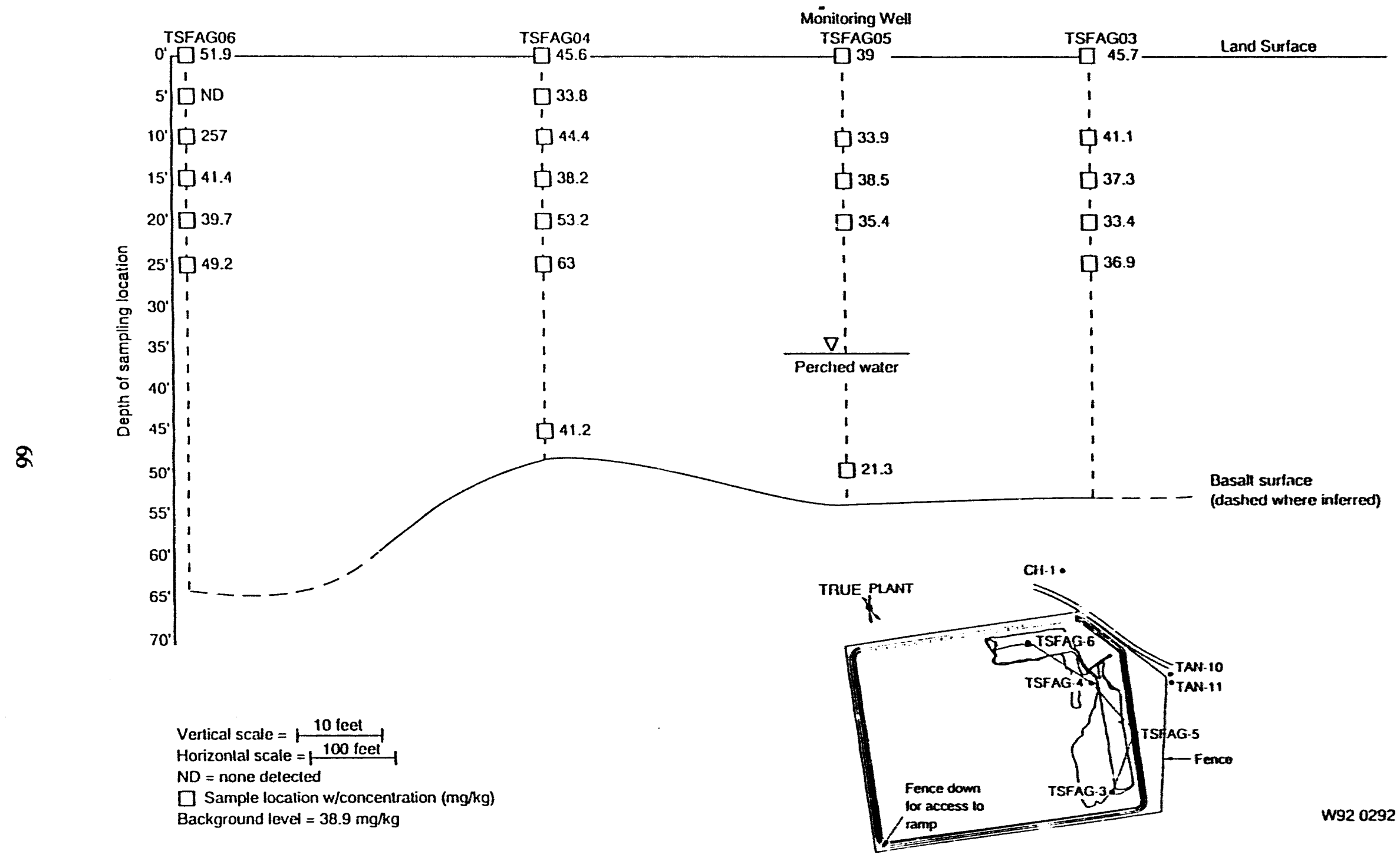

Figure 16. Vertical distribution of chromium in the TSF-07 disposal pond. 

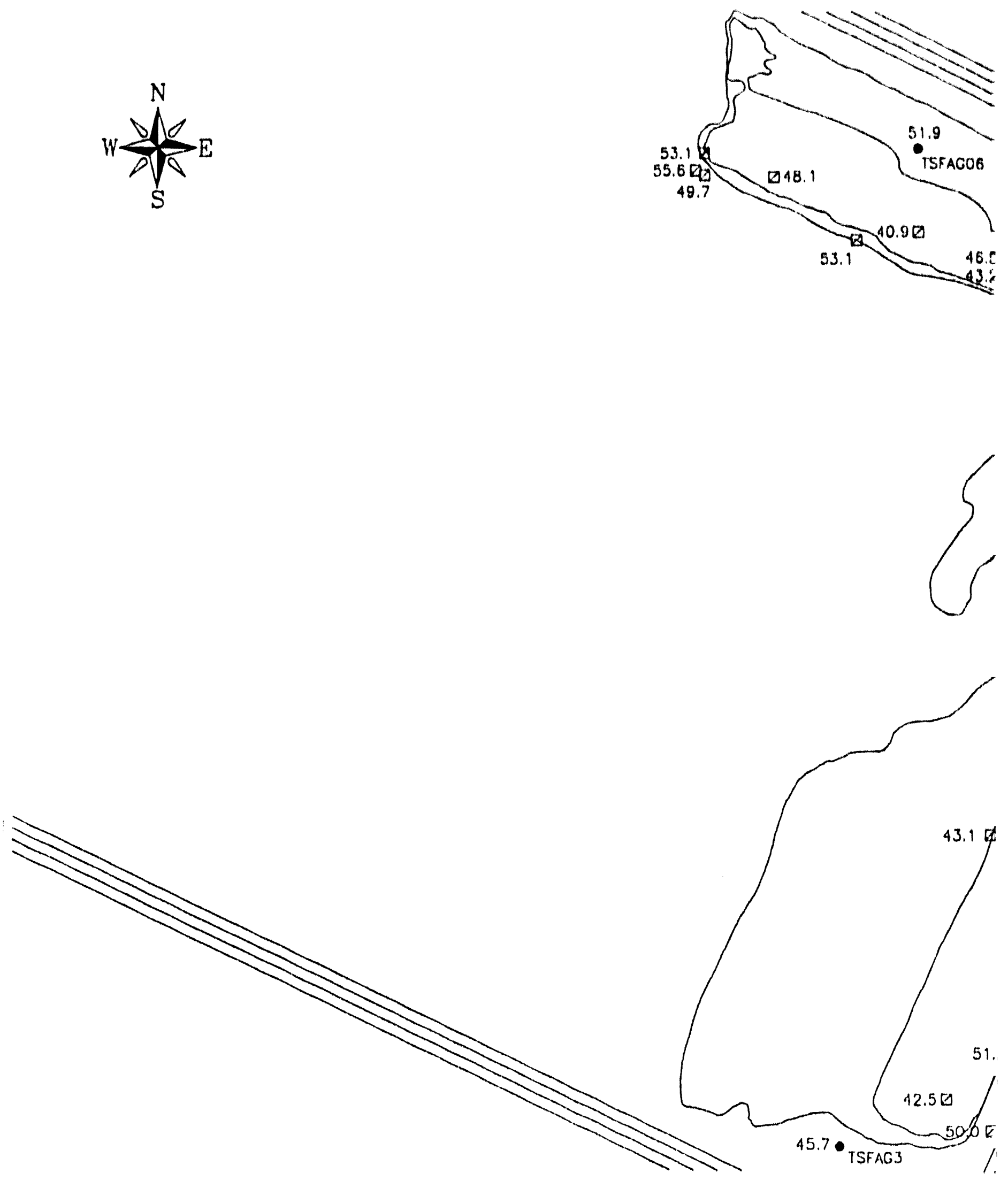

Figure 17. TAN TSF-07 pond chromium contaminant in surface soils (mg/kg). 


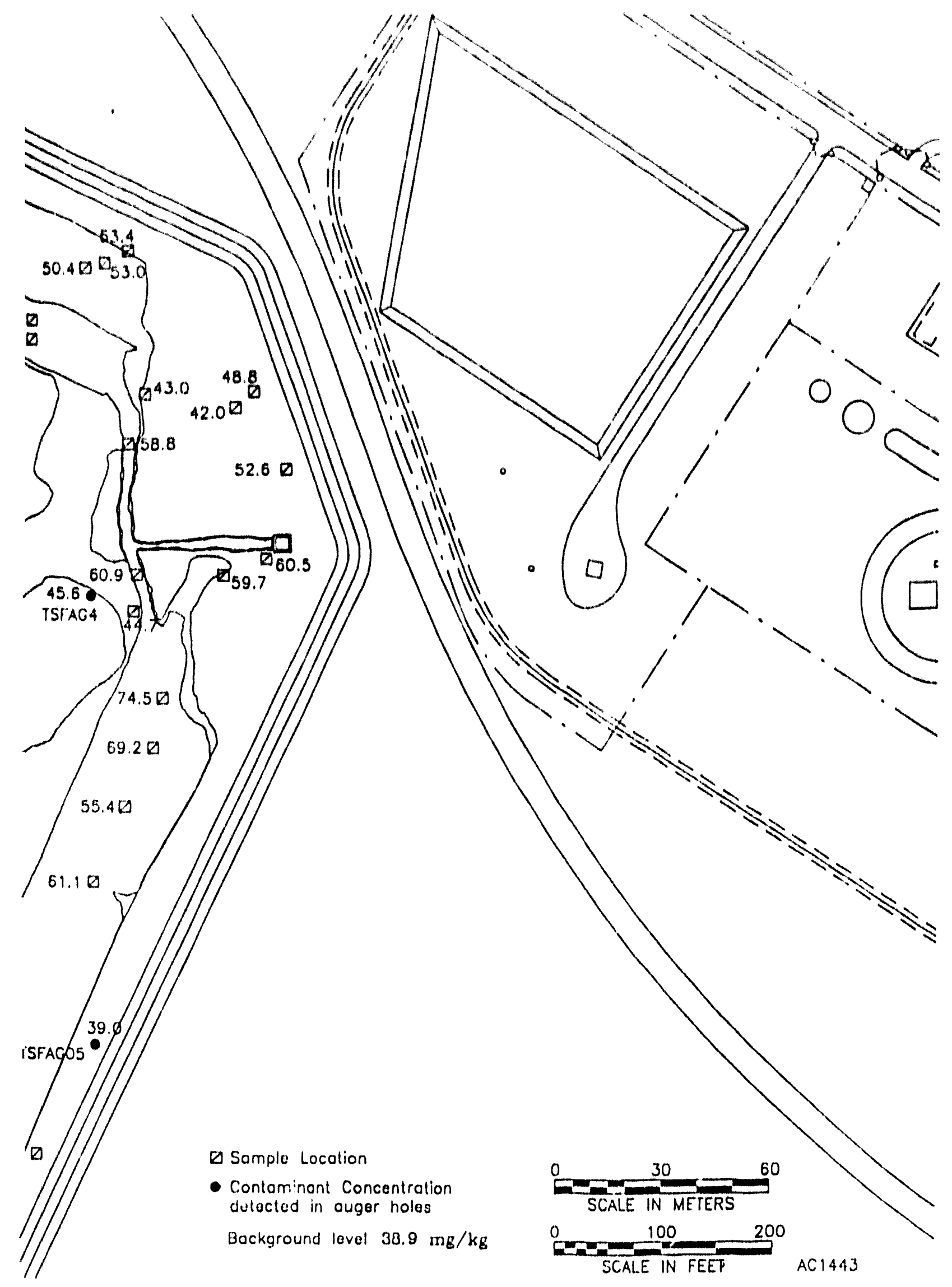



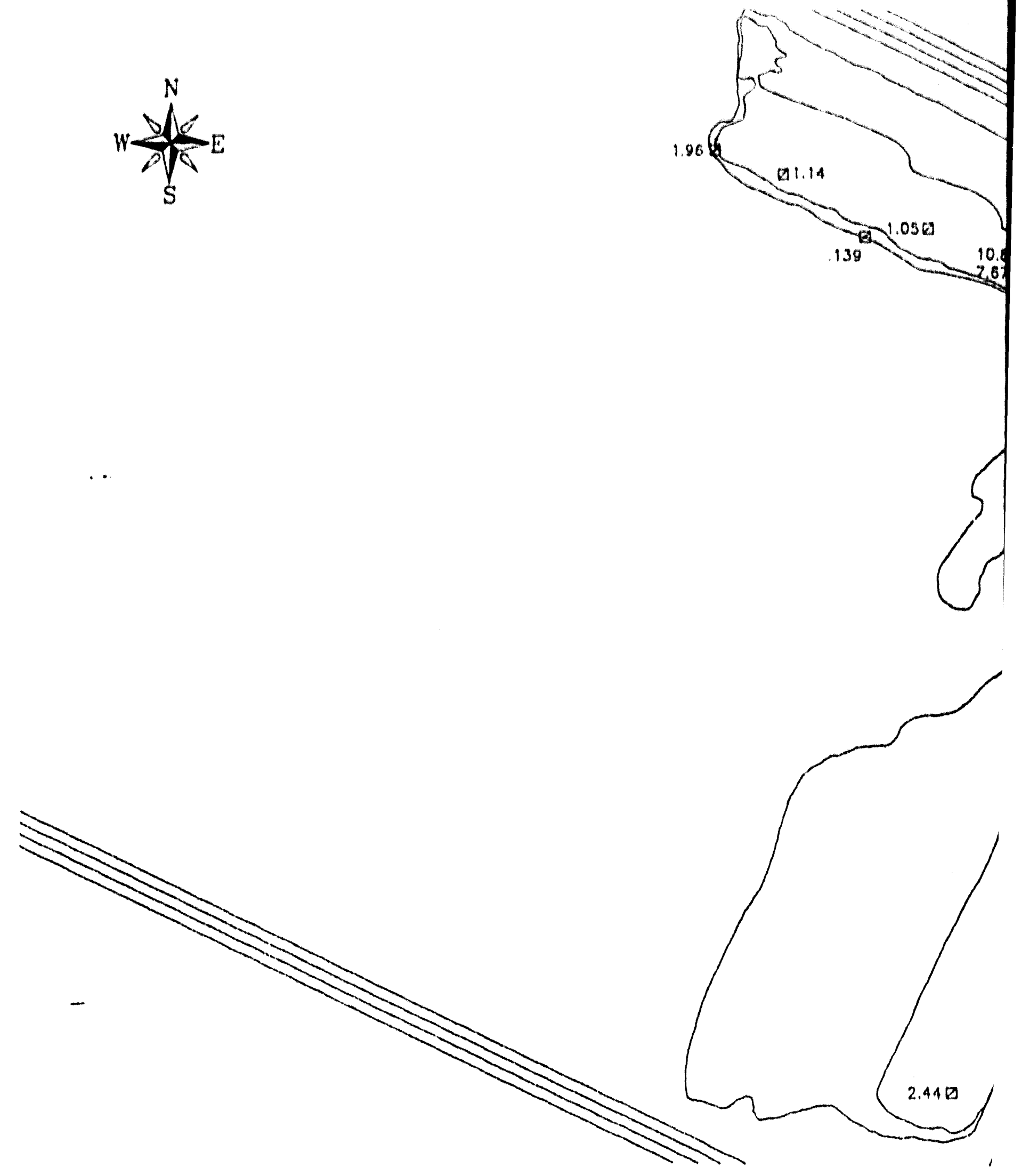

Figure 18. TAN TSF-07 pond cobalt-60 contaminant in surface soils (pCi/g). 



Flgure 19. TAN TSF-07 pond cesium contaminant in surface soils (pCi/g). 


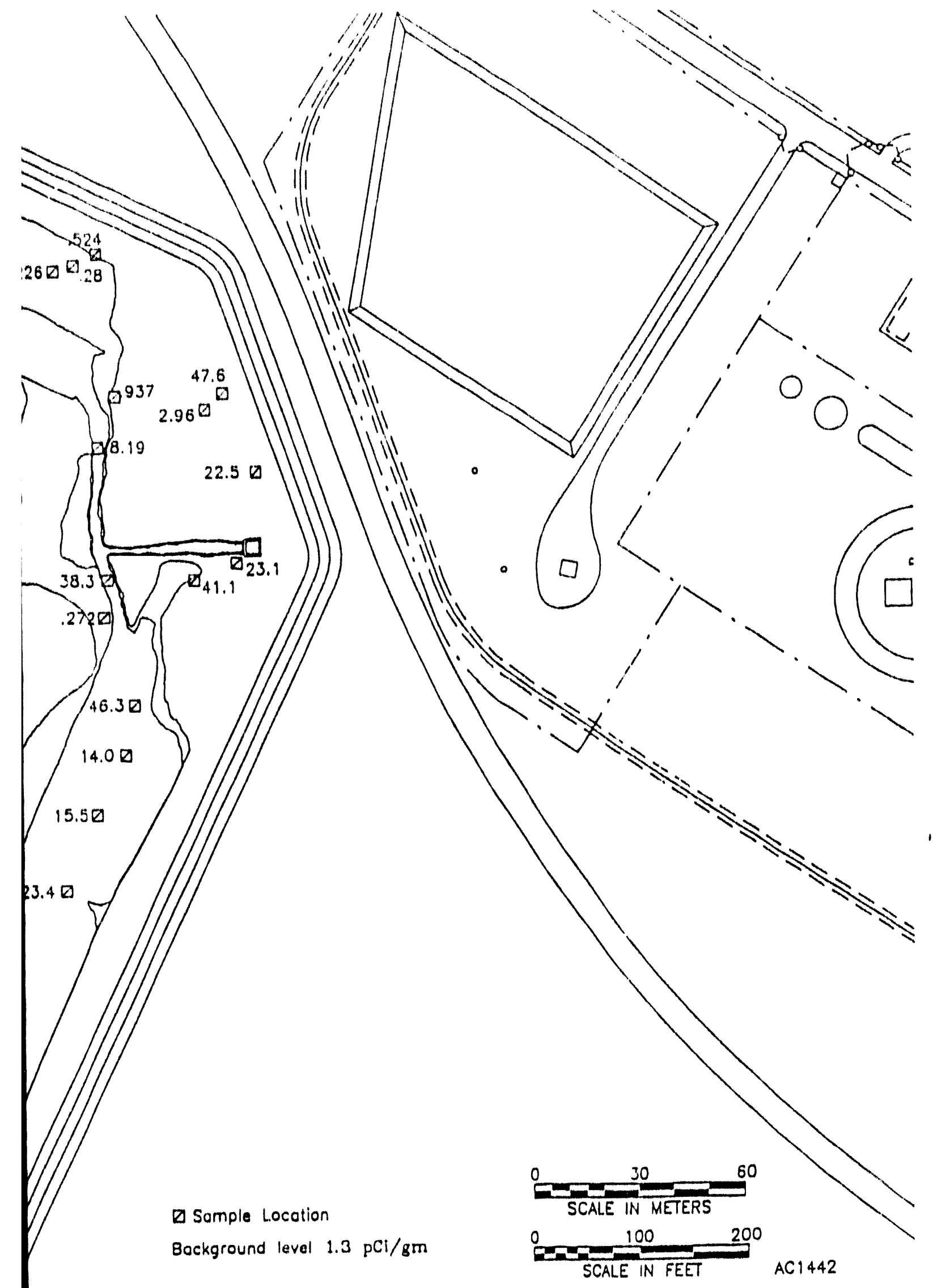




\subsubsection{Surface Water}

Beryllium, silver, and vanadium are considered to be significant inorganic contaminants for the surface water. One of four samples analyzed for beryllium exceeds the MCL screening level of $4 \mu \mathrm{g} / \mathrm{L}$. One of two samples analyzed for silver exceeds the hazard index (HI) value of $10.0 \mu \mathrm{g} / \mathrm{L}$. One of four samples analyzed for vanadium also exceeds the $\mathrm{HI}$ of $30.0 \mu \mathrm{g} / \mathrm{L}$.

Co-60, Cs-137, and gross alpha are considered to be a significant radiological contaminants in the surface water samples. $\mathrm{Co} .60$ ranged from 5.9 to $31.0 \mathrm{pCi} / \mathrm{L}$ in the water. Four of four samples exceed the risk-based levels of $1.3 \mathrm{pCi} / \mathrm{L}$. Cs-137 ranged between 7.2 and $93.0 \mathrm{pCi} / \mathrm{L}$. Four of four samples exceed the risk-based level of $0.7 \mathrm{pCi} / \mathrm{L}$ for this contaminant. The data results for the gross alpha analysis indicate that two of four of the samples exceeded the risk-based $\mathrm{MCL}$ of $15.0 \mathrm{pCi} / \mathrm{L}$.

No organic contaminants were detected in concentrations that exceed the screening levels.

\subsubsection{Porchod Water}

The perched water data for inorganic contaminants indicates that antimony and thallium are significant contaminants. Twenty-nine percent of the samples analyzed for antimony exceed the MCL value of $6 \mu \mathrm{g} / \mathrm{L}$, and $33 \%$ of the samiples analyzed for thallium exceed the $5 \mu \mathrm{g} / \mathrm{MCL}$ value.

The perched water data results indicate that gross alpha, gross beta, and strontium (total) have entered the perched water zone. Gross alpha is considered a significant radiological contaminant in the perched watcr. This contaminant was detected in three of 12 perched water samples. Of these three samples, one sample was found at an elevated concentration of $120.0 \mathrm{pCi} / \mathrm{L}$. Strontium (total) was found ranging between 1.0 and $136.0 \mathrm{pCi} / \mathrm{L}$. Three of 16 samples (19\%) analyzed for strontium (total) exceed the $8.0 \mathrm{pCi} / \mathrm{L} \mathrm{MCL}$ valuc. Gross beta ranged from 3.0 to $120.0 \mathrm{pCi} / \mathrm{L}$. Onc of 12 samples analyzed for this contaminant exceeds the screening level.

No organic contaminants were detected in concentrations that exceed the screening levels.

\subsection{Contaminant Migration to the Perched Water Zone}

It appears from the maps that mercury is migrating into the perched water zone. This contaminant, however, has not been found in minimal concentrations in the perched water itsclf. The TSFAG-05 monitoring well shows that mercury has infiltrated past the perched water zone and into the underlying sediment, at a slightly elevated concentration of approximately $0.02 \mathrm{mg} / \mathrm{kg}$ above the TAN background level.

Chromium has also infiltrated past the perched water zone and into the underlying sediment. The value detected is at $21.3 \mathrm{mg} / \mathrm{kg}$ which is well below the background level of $38.9 \mathrm{mg} / \mathrm{kg}$.

Co-60 and Cs-137 have not been found in the perched water zone, so gamma migration is limited. The perched water data results indicate that gross alpha, gross beta, and strontium (total) have entered the perched water zone. Gross alpha in the perched water ranges from 3.2 to 120.0 $\mathrm{pCi} / \mathrm{L}$, gross beta ranges from 3.0 to $120.0 \mathrm{pCi} / \mathrm{L}$, and strontium (total) was detected from 1.0 to 136.0 $\mathrm{pCi} / \mathrm{L}$.

Organic contaminants were not detected in the perched water zone. 


\section{CONCLUSIONS}

The plan view maps and the vertical distribution maps illustrate the horizontal migration occurring within the TSF-07 berm and the minimal migration of the contaminants into the perehed water zone. Much of the contamination for the significant contaminants appears to be higher within the TSF-07 disposal pond and the ditch location between the disposal and overflow pond. From all the data compiled to date, it appears that no significant migration of any of the major contaminants is occurring outside the established diked area for the TSF-07 disposal pond.

The only contaminant that is consistently spread horizontally and vertically in the TSF-(07 pond is chromium, which has been found above background levels at the perimeter of the pond areas and in the soils near or within the perched water zone.

In conclusion, contaminants appear to have migrated in a limited way both horizontally and vertically within the pond and are not known to have migrated outside of the berm area. With the exception of gross alpha, gross beta, strontium (total), thallium, and antimony, no surface contaminants in concentrations above the screening level are migrating into the perched water zonc. 


\section{REFERENCES}

DOE 1989a, Department of Energy Environmental Survey Manual, U.S. Department of Energy, DOE/EH-0053, 1989.

DOE 1989b, Idaho National Engineering Laboratory Sampling and Analysis Document, Volume I, U.S. Department of Energy, Environmental Survey, ORNL/TM-11236, September 1989.

DOE 1989c, Los Alamos National Laboratory Sampling and Analysis Data Document, Volume I, U.S. Department of Energy, Environmental Survey, EGG-ES-8204, November 1989.

DOE 1992, Track 1 Sites: Guidance for Assessing Low Probability Hazard Sites at the INEL, Revision 1, U.S. Department of Energy, DOE/ID-10340, July 1992.

EG\&G Idaho 1984, INEL Environmental Characterization Repoit, EGG-NFR-668, 1984.

EG\&G Idaho 1988, RCRA Facility Investigation Work Plan for Test Area North Groundwater, Vols. 1-3, EGG-ER-8084, Rev. 1, November 1988.

EG\&G Idaho 1990, Preliminary Assessment of Surface Soils at Active EG\&G Idaho Facilities Data Document, EGG-ESQ-9225, 1990.

EG\&G Idaho 1992, Remedial Investigation/Feasibility Study Work Plan and Addenda for the Test Area North Groundwater Unit at the Idaho National Engineering Laboratoly, EG\&G-WM-9905, Rev. 0, May 1992.

EPA 1991a, EPA Region 10 Supplemental Risk Assessment Guidance for Superfund, U.S. Environmental Protection Agency, August 1991.

EPA 1991b, Health Effects Assessment Summary Tables Annual FY-1991, U.S. Environmental Protection Agency, OSWER-230, January 1991.

Hardy, C. K., and S. N. Stanisich 1991, Sampling and Analysis Plan for the TSF-Disposal Ponds and Waste Sump (COCA Unit TSF-07), EGG-WM-8791, EG\&G Idaho, Inc., January 1991, Revision 1.

Nace, R. L. et al. 1956, "Geography, Geology, and Water Resources of the National Reactor Testing Station, Idaho: Part II," Geography and Geology, U.S. Geological Survey, IDO-22033.

Reed, W. G. et al. 1986, Archeological Investigations on the INEL, 1986.

Rightmire, C. T. 1984, Lantion and Hydrologic Implications of Cored Sedimentary Materiai from the 1975 Drilling Program at the Radioactive Waste Management Complex, Idaho, U.S. Geological Survey DOE-ID 22067. Open File Report 84-4071. 
Schmalz, B. L. 1977, Radionuclide Distribution in Soil Mantle of the Lithosphere as a Consequence of Wasie Disposal at the National Reactor Testing Station, U.S. Atomic Energy Commission IDO-10049.

\section{BIBLIOGRAPHY}

Code of Federal Regulations, 40 CFR Parts 100 to 149, "Protection of Environment," Office of the Federal Register, July 1, 1990.

Department of Energy Order 5400.5, "Radiation Protection of the Public and the Environment," U.S. Department of Energy, February 8, 1990.

Department of Energy, The Idaho National Engineering Laboratory Site Environmental Report for Calendar Year 1990, DOE/ID-12082, June 1991.

Environmental Protection Agency, Test Methods for Evaluating Solid Waste, Physical Chemical Methods, 3rd Ed. SW-846, 1986.

Kaminsky, J. F., et al., DRAFT Remedial Investigation Final Repoit with Addenda for the Test Area North Groundwater Operable Unit at the Idaho National Engineering Laboratory, EGG-ER10643, Vol. I \& II. February 1993.

Lewis, B. D., and R. G. Jensen, Hydrologic Conditions at the Idaho National Engineering Laboratory, Idaho: 1971-1981 Update. U.S. Geological Survey IDO-22066, Open-File Report 84-230.

Martin, K. L. et al., Preliminary Assessment of Surface Soils at Active EG\&G Idaho Facilities Data Document, EGG-ESQ-9225, EG\&G Idaho, Inc., September 1990.

McBride. T. R. et al., Vegetation Types and Surface Soils of the Idaho National Engineering Laboratory Site, U.S. Geological Survey, IDO-12084, April 1987.

Robertson, J. B. et al., Digital Modeling of Radioactive and Chemical Waste Transport in the Snake River Plain Aquifer at the National Reactor Testing Station, Idaho, U.S. Geological Survey IDO22054, 1974. 


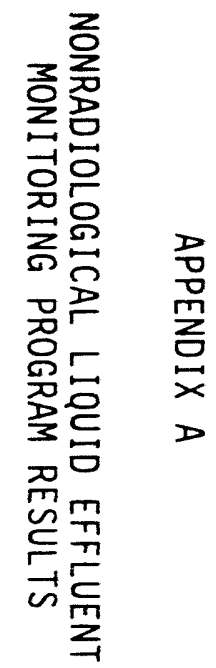




\section{APPENDIX A}

\section{NONRADIOLOGICAL LIQUID EFFLUENT \\ MONITORING PROGRAM RESULTS}

Table A-1. Second-quarter FY 1989 effluent-monitoring data for Stream 9.

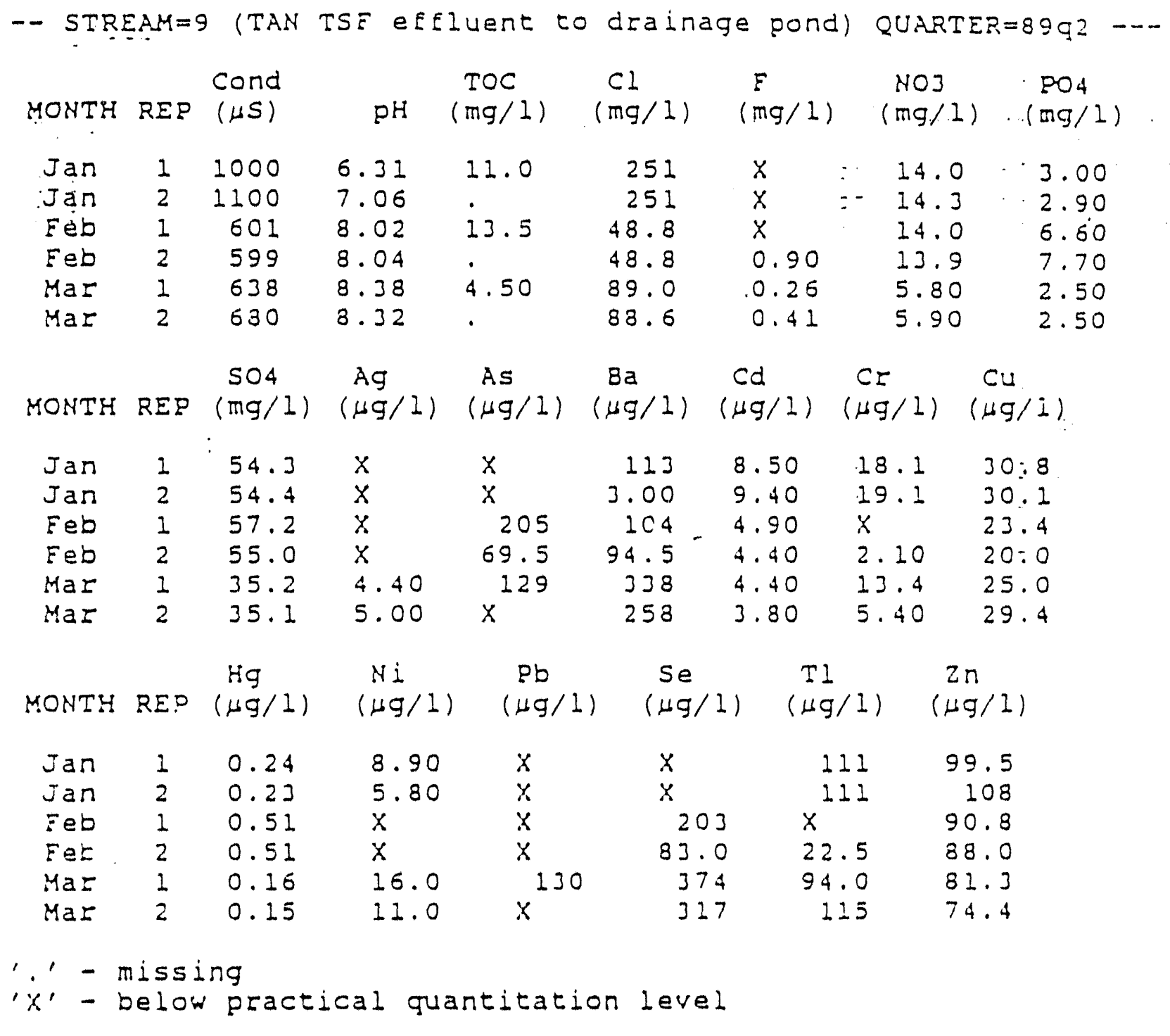


Table A-2. Third-quarter FY-1989 effluent-monitoring data for Stream 9.

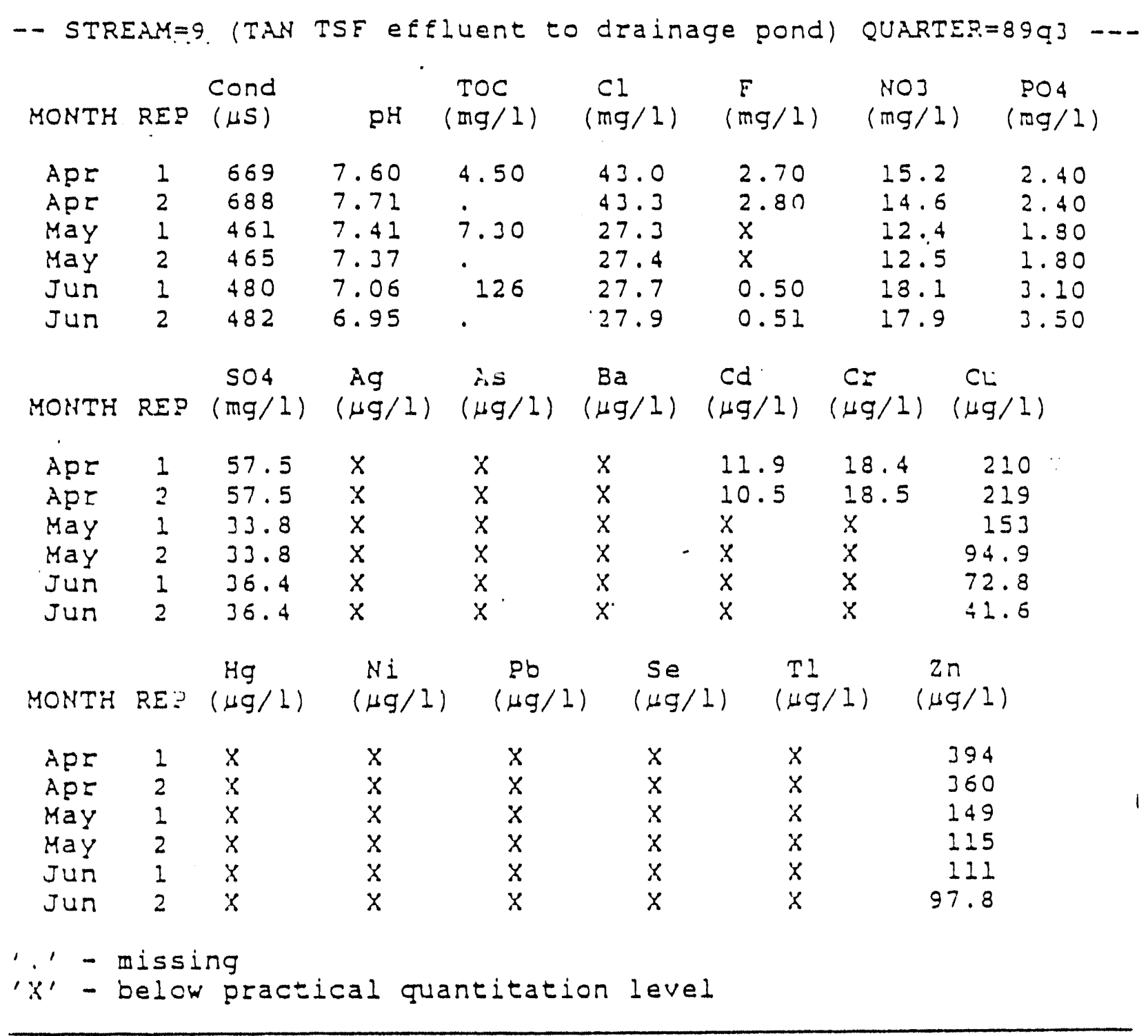


Table A-3. Fourth-quarter FY-1989 effluent-monitoring data for Stream 9.

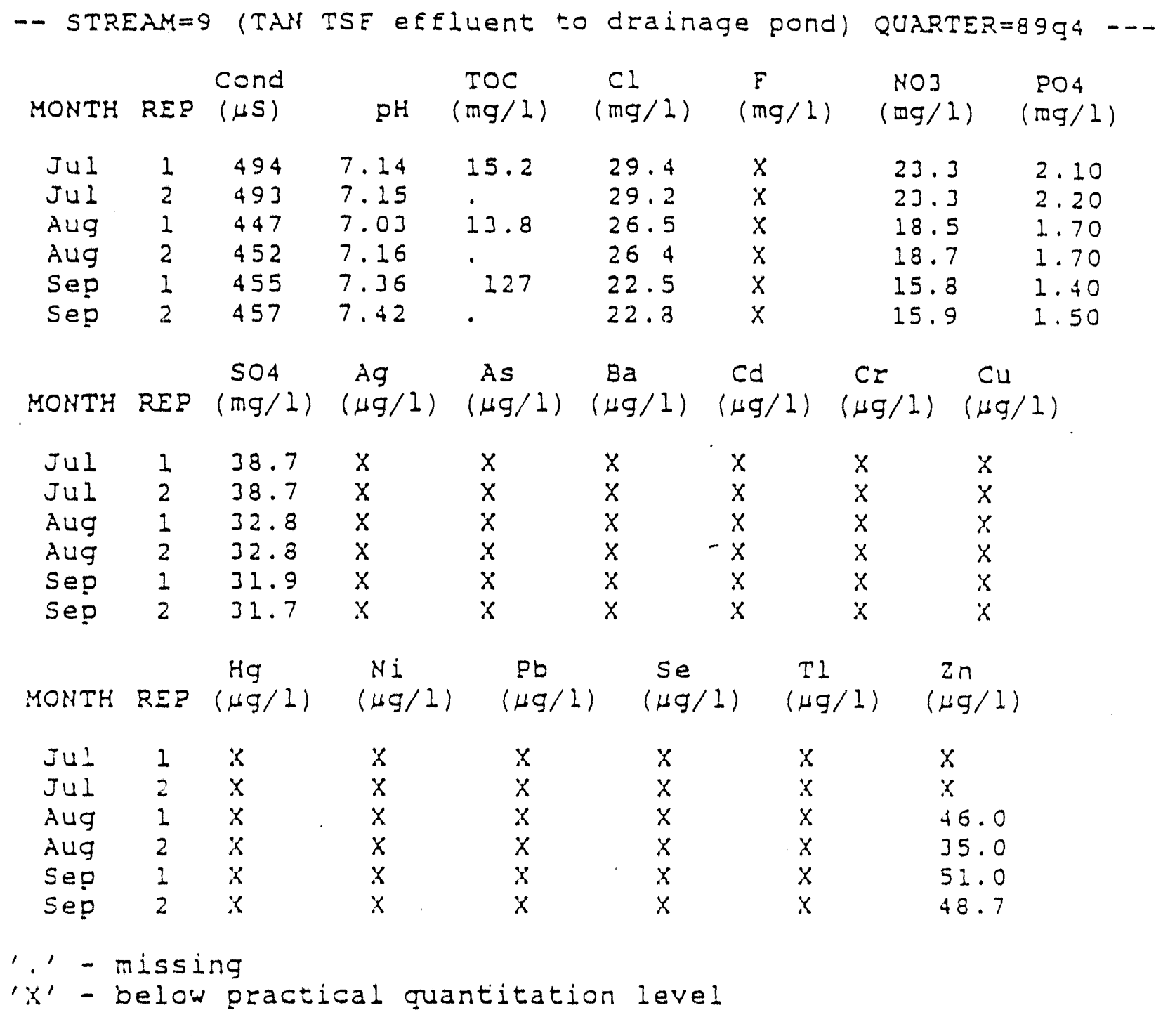




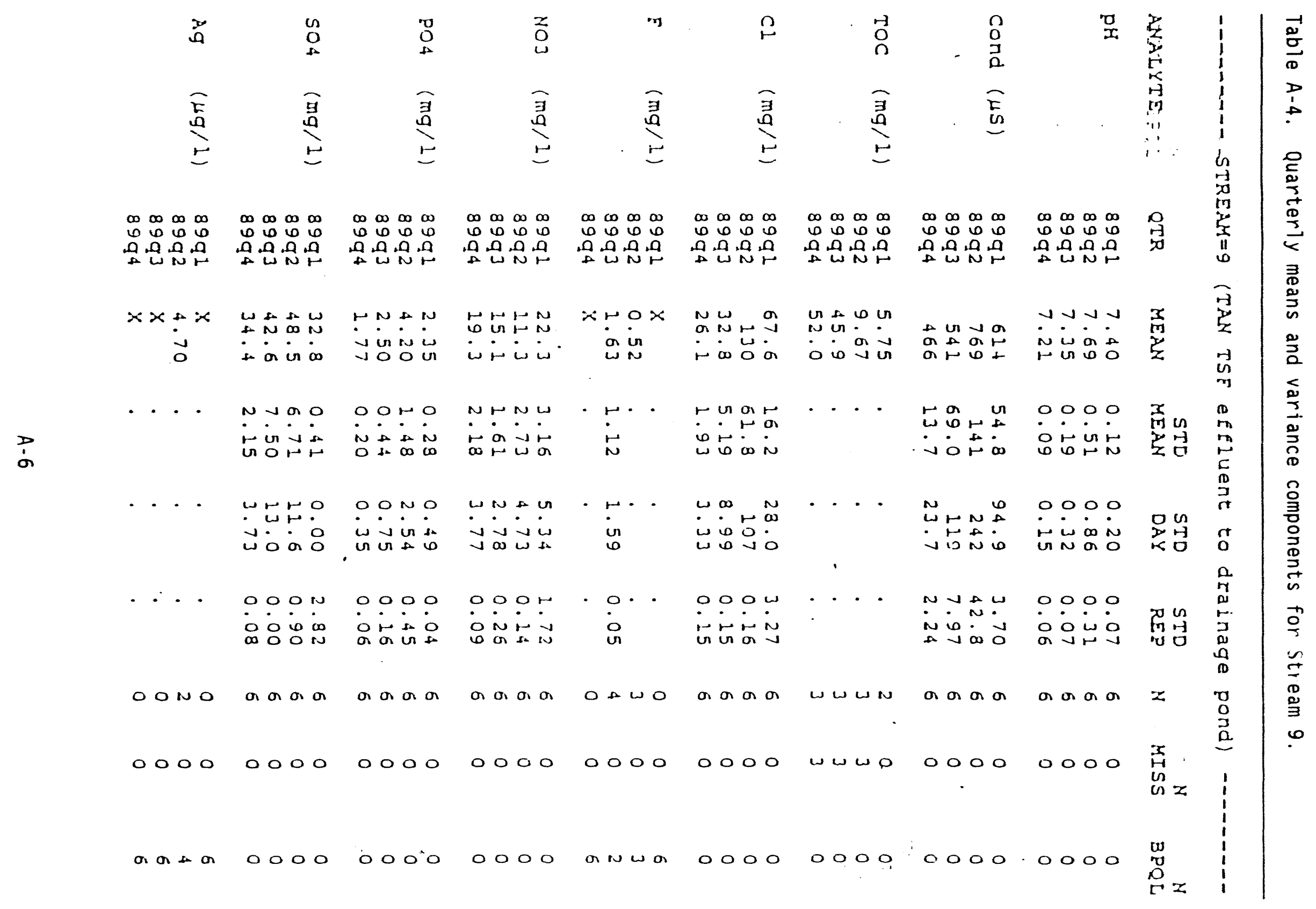


Table A-4. (continued).

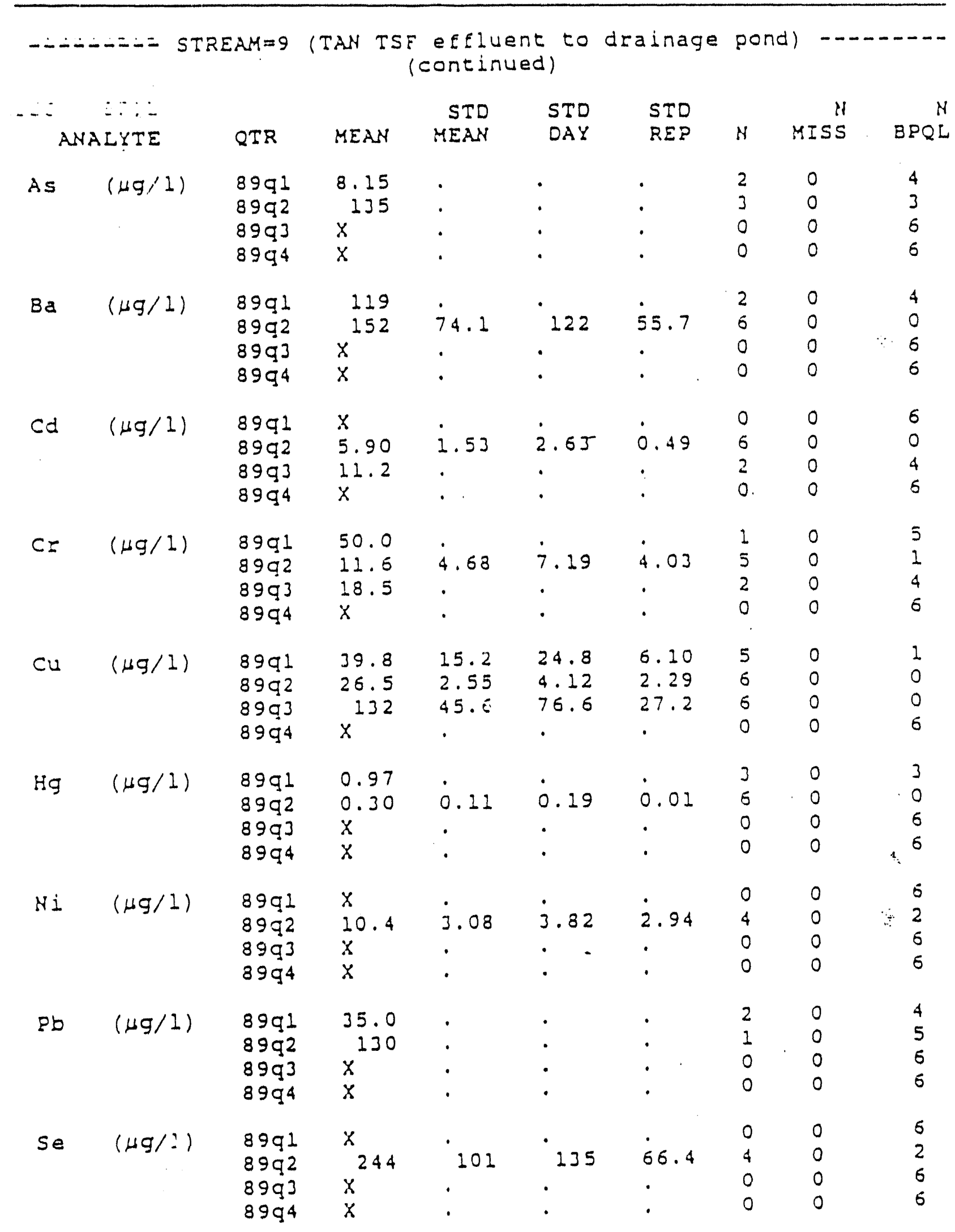


Table A-5. Control limits for Stream 9.

\begin{tabular}{|c|c|c|c|c|c|c|c|}
\hline ANALY & TTE & $\begin{array}{c}\text { TREAM }=9 \\
\text { FY } \\
\text { MEA / FY }\end{array}$ & $\begin{array}{l}\text { ITAN TSF } \\
88 \\
\text { STD }\end{array}$ & efeluent & to drainage & pond) & $\begin{array}{c}\text { Regulatory } \\
\text { Compl iance } \\
\text { Guidel ine } \\
\text { (RCG) }\end{array}$ \\
\hline cond & $(\mu S)$ & 593 & $1+0$ & 48 & 829 & 932 & $M / A$ \\
\hline $\mathrm{pH}$ & & 7.99 & 0.54 & 48 & $\begin{array}{ll}1 & 6.88 \\
4 & 9.09\end{array}$ & $\begin{array}{ll}1 & 6.51 \\
4 & 9.46\end{array}$ & $\begin{array}{ll}1 & 6.5 \\
4 & 8.5\end{array}$ \\
\hline TOC & $(\operatorname{mg} / 1)$ & 7.45 & 4.10 & 23 & 14.6 & 18.0 & $N / A$ \\
\hline$C L$ & $(m g / 1)$ & 62.3 & 41.7 & 46 & 133 & 264 & 250 \\
\hline$F$ & $(\mathrm{mg} / 1)$ & 0.34 & 0.29 & 26 & 0.84 & 1.07 & 4 \\
\hline $\mathrm{NO3}$ & $(m g / 1)$ & 17.9 & 7.14 & 47 & 30.0 & 35.3 & 10 \\
\hline PO4 & $(m g / 1)$ & 2.57 & 1.67 & 47 & $5: 40$ & 6.64 & $N / A$ \\
\hline 504 & $(m g / 1)$ & 38.7 & 10.1 & 48 & . $\quad 55.8$ & 63.3 & 250 \\
\hline Ag & $(\mu g / 1)$ & 17.1 & 14.6 & 9 & 45.7 & 61.7 & 50 \\
\hline As & $(\mu g / 1)$ & & & & & & 50 \\
\hline $\mathrm{Ba}$ & $(\mu g / 1)$ & 104 & 25.9 & 43 & 148 & 167 & 1000 \\
\hline c.d & $(\mu g / 1)$ & 5.44 & 1.86 & 16 & 8.80 & 10.4 & 10 \\
\hline$C I$ & $(\mu g / 1)$ & 11.9 & 7.92 & 27 & 25.7 & 31.9 & 50 \\
\hline $\mathrm{cu}$ & $(\mu g / 1)$ & 52.6 & 123 & 42 & 262 & 354 & 1000 \\
\hline $\mathrm{Hg}$ & $(\mu g / 1)$ & 0.72 & 0.66 & 23 & 1.88 & 2.41 & 2 \\
\hline $\mathrm{Ni}$ & $(\mu g / I)$ & & & & & & $N / A$ \\
\hline PD & $(\mu g / 1)$ & 32.2 & 42.0 & 15 & 109 & 146 & $=50$ \\
\hline $\mathrm{Se}$ & $(\mu g / I)$ & & & & $\cdot$ & & 10 \\
\hline$T 1$ & $(\mu g / 1)$ & & & & & & $N / A$ \\
\hline $2 n$ & $(\mu g / 1)$ & 165 & 136 & 48 & 396 & 497 & 5000 \\
\hline
\end{tabular}


APPENDIX B

ANALYTICAL RESULTS FOR SUMP (TAN 655)

B-1 
ISF Evaporation Pond SeA Data Document - Moveaber 1909 - Method Validation Level a

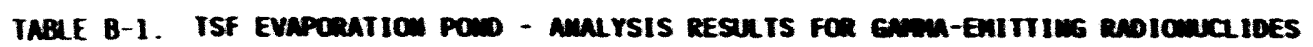

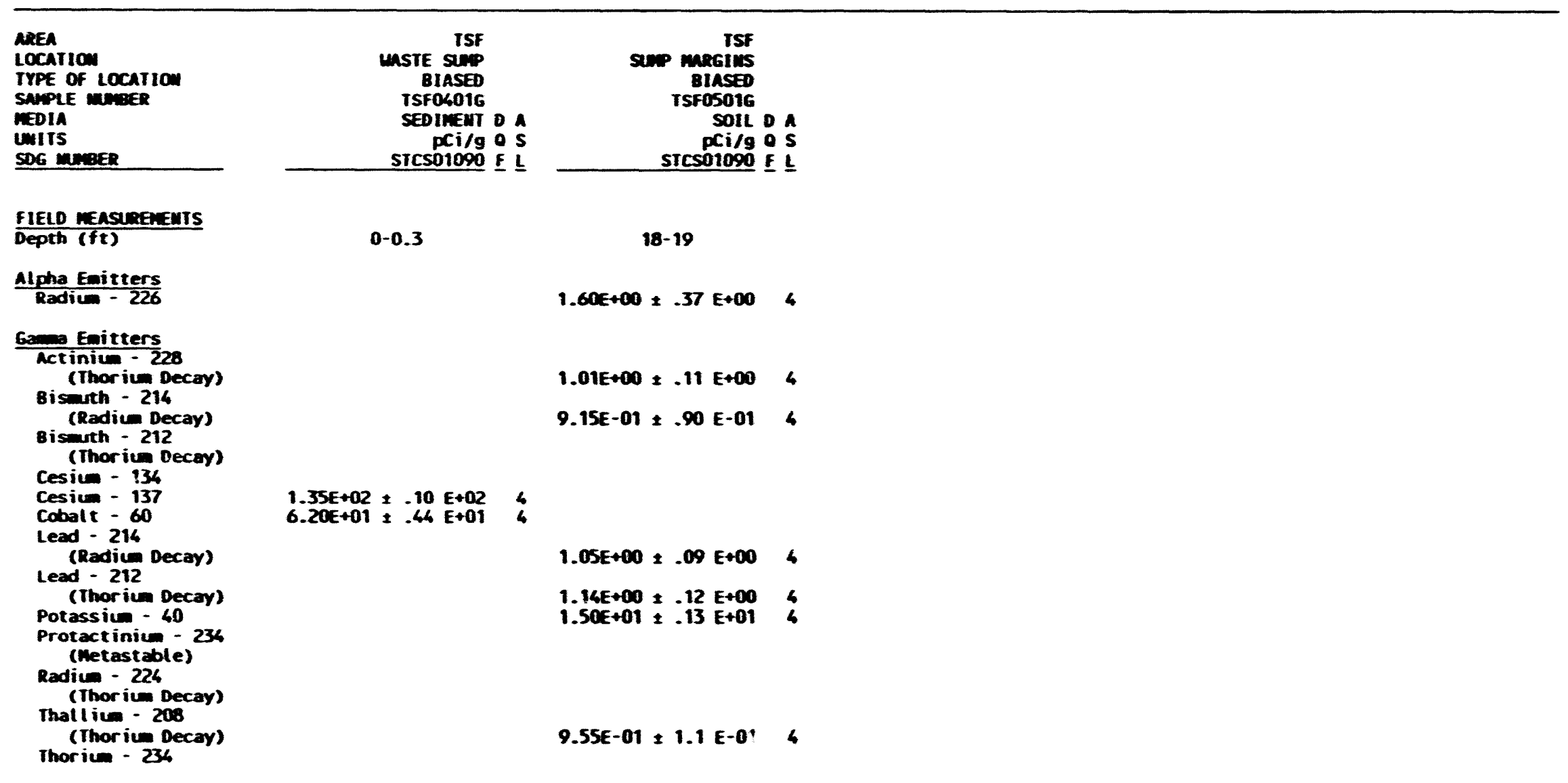

a. The Dof colum contains any data qualifier flogs.

b. The ASL colum contains the analytical support level.

2-15-93 
ISF Evaporation Pond seA Data Docunent - November 1909 - Nethod Validation Level

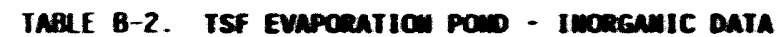

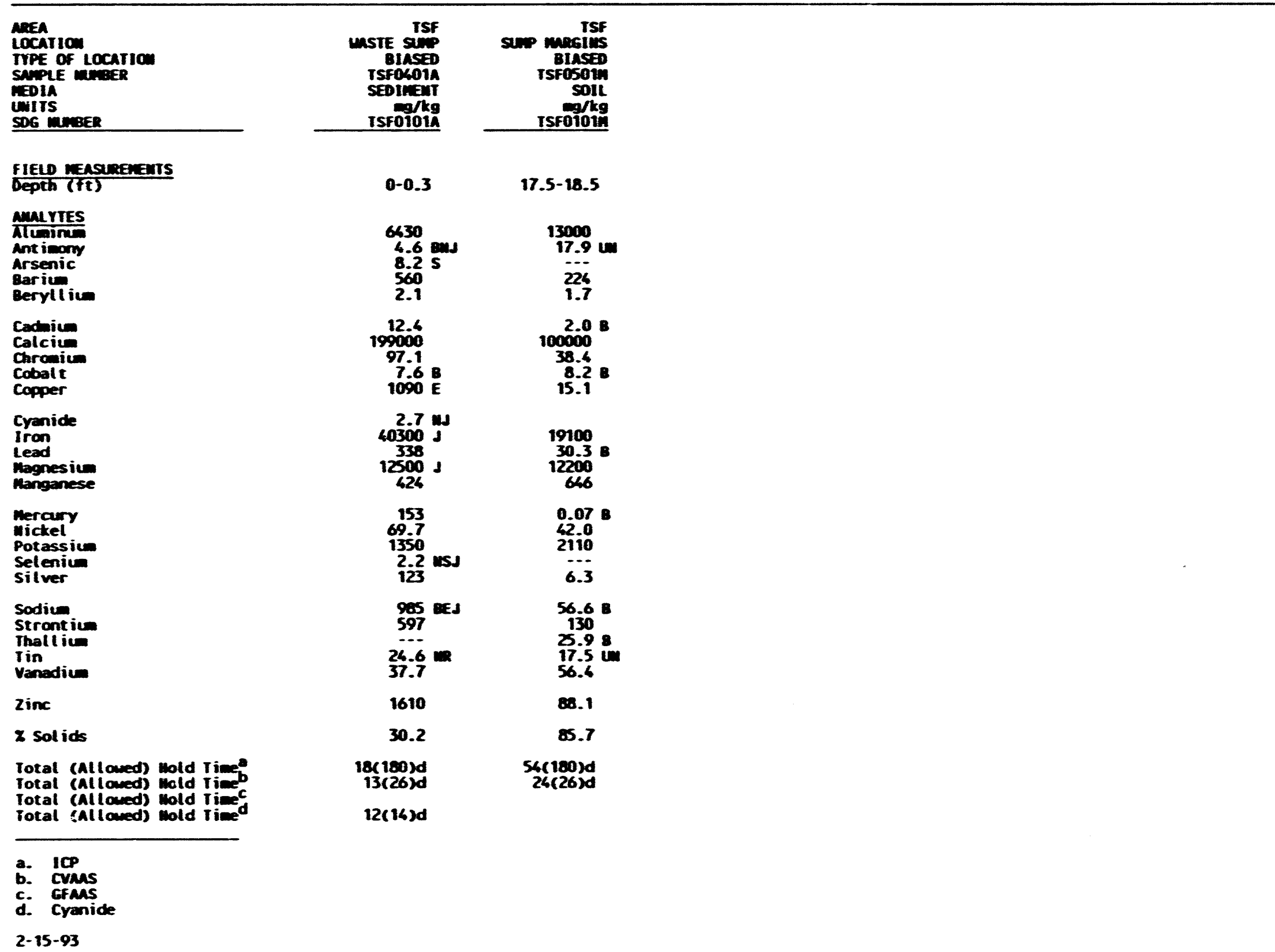


ISF Evaporation Pand seA Date Docament - Woveber 1909 - Method Val idation Level a

IABA B-3. TSF Evaponation paso - coenocmoaine wasicioe data

\begin{tabular}{|c|c|}
\hline 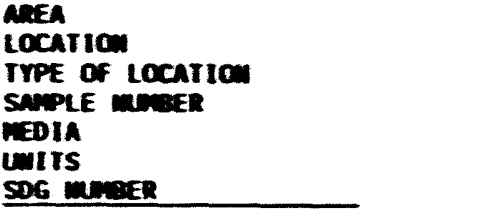 & 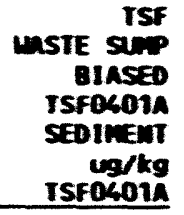 \\
\hline$\frac{\text { FIELD WEASUREIEUTS }}{\text { Depth (ft) }}$ & $0-0.3$ \\
\hline $\begin{array}{l}\text { Tarcet componos } \\
2,4-0 \\
\text { silvex } \\
2,4,5-1\end{array}$ & $\begin{array}{l}400 \mathrm{~W} \\
80 \mathrm{~W} \\
80 \mathrm{~W}\end{array}$ \\
\hline $\begin{array}{l}\text { Dilution factor } \\
\text { Extraction (Allowed) Wold Time } \\
\text { analytical (Allowed) wold tien }\end{array}$ & $\operatorname{mop}_{i}^{1.0}$ \\
\hline $\begin{array}{l}\text { wp - Extraction Date Mot Provid } \\
2-16-93\end{array}$ & Laboratory \\
\hline
\end{tabular}


ISF Evaporation Pond S\&A Data Document - Movenber 1989 - Method Validation Level A

TABLE B-4. TSF EVAPORATION POND - ORgANOCHLORIME PESTICIDE DATA

\begin{tabular}{|c|c|}
\hline $\begin{array}{l}\text { AREA } \\
\text { LOCATION } \\
\text { IYPE OF LOCATION } \\
\text { SAMPLE MUMBER } \\
\text { MEDIA } \\
\text { UNI IS } \\
\text { SDG MUMBER } \\
\end{array}$ & $\begin{array}{r}\text { TSF } \\
\text { WASTE SUMP } \\
\text { BIASED } \\
\text { ISF0401A } \\
\text { SEDIMENT } \\
\text { Ug/kg } \\
\text { TSF0401A }\end{array}$ \\
\hline $\begin{array}{l}\text { FIELD MEASUREMENTS } \\
\text { Depth }(\mathrm{ft})\end{array}$ & $0-0.3$ \\
\hline $\begin{array}{l}\text { TARGET COMPOUMDS } \\
\text { Aroclor- } 1221 \\
\text { Aroclor-1232 } \\
\text { Arocl or }-1254 \\
\text { Aroclor- } 1260\end{array}$ & $\begin{array}{rl}80 & R \\
80 & R \\
640 & J \\
1600 & J\end{array}$ \\
\hline $\begin{array}{l}\text { Dilution factor } \\
\text { Extraction (Allowed) Hold Time } \\
\text { Analytical (Allowed) Hold Time }\end{array}$ & $\begin{array}{l}1.0 \\
12(14) d \\
29(40) d\end{array}$ \\
\hline
\end{tabular}

2-16-93

$2(14) d$

$9(40) d$ 
ISF Evaporation Pond S\&A Data Document - Movenber 1989 - Method Validation Level A

TABLE B-5. TSF EVAPORATION POND - SEMIVOLATILE APPEMdIX IX ORGANIC DATA

\section{AREA}

LOCATION

TYPE OF LOCATIO

SAMPLE NUMBER

MEDIA

UNITS

SDG NUMBER

\section{FIELD MEASUREMENTS}

Depth ( $\mathrm{ft}$ )

TARGEI COMPOUMDS

Phenanthrene

Fluoranth
Pyrene

Pyrene

Benzo(a)anthracene

Chrysene

bis(2-Ethythexyl)phthalate

Di-n-octylphthalate

Dise

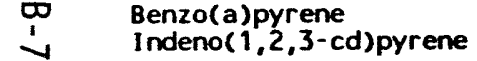

Benzo(g, i)perylene

Benzo( $g, h, i)$ perylene

$a, a-D$ imethyl phene thyl amine

4-Nitroquinol ine-1-oxide

Famphur

Hexachl orophene

Dilution Factor

Extraction (Allowed) Hold Time Analytical (Allowed) Hold Time

2-13-93
BIASED

TSFO401A

SEDIMENT

ISF0401A

$0-0.3$

$170 \mathrm{~J}$

$340 \mathrm{~J}$

$350 \mathrm{~J}$

$240 \mathrm{~J}$

3900

$310 \mathrm{~J}$

$210 \mathrm{~J}$

$200 \mathrm{~J}$

$230 \mathrm{~J}$

1700

$1700 R$

1700

$1700 \mathrm{R}$

$1700 R$

5.000

$12(14) d$

24(40)d 
TSF Evaporation Pond S\&A Data Document - Movember 1989 - Method Validation Level B

TABLE B-6. TSF EVAPORATION POND - SULFIDE DATA

\begin{tabular}{|c|c|}
\hline $\begin{array}{l}\text { AREA } \\
\text { LOCATION } \\
\text { TYPE OF LOCATION } \\
\text { SAMPLE NUMBER } \\
\text { MEDIA } \\
\text { UNITS } \\
\text { SDG NUMBER } \\
\end{array}$ & $\begin{array}{r}\text { TSF } \\
\text { WASTE SUMP } \\
\text { BIASED } \\
\text { ISF0401A } \\
\text { SEDIMENT } \\
\text { Mg/kg } \\
\text { TSF0401A } \\
\end{array}$ \\
\hline$\frac{\text { FIELD MEASUREMENTS }}{\text { Depth }(f t)}$ & $0-0.3$ \\
\hline \% Solids & 30.2 \\
\hline Total (Allowed) Hold Time & $9(7) d^{\star}$ \\
\hline
\end{tabular}


TABLE B-7. TSF EVAPORATION POND - VOLATILE APPEMDIX IX ORGANIC DATA

\begin{tabular}{|c|c|}
\hline $\begin{array}{l}\text { AREA } \\
\text { LOCATION } \\
\text { TYPE OF LOCATION } \\
\text { SAMPLE MUMBER } \\
\text { MEDIA } \\
\text { UNIIS } \\
\text { SDG NUMBER } \\
\end{array}$ & $\begin{array}{r}\text { TSF } \\
\text { WASTE SUMP } \\
\text { BIASED } \\
\text { TSF0401ARE } \\
\text { SEDIMENT } \\
\text { Ug/kg } \\
\text { TSF0401A } \\
\end{array}$ \\
\hline $\begin{array}{l}\text { FIELD MEASUREMENIS } \\
\text { Depth }(\mathrm{ft})\end{array}$ & $0-0.3$ \\
\hline $\begin{array}{l}\text { TARGET COMPOUNDS } \\
\text { Chloromethane } \\
\text { Acetone } \\
\text { Carbon Disulf ide } \\
\text { 2-Butanone } \\
\text { 4-Methyl-2-Pentanone }\end{array}$ & $\begin{array}{rl}10 & \mathrm{UJ} \\
91 & \mathrm{UJ} \\
5 & \\
10 \mathrm{R} \\
10 \mathrm{R}\end{array}$ \\
\hline $\begin{array}{l}\text { 2-Hexanone } \\
\text { Tetrachloroethene } \\
\text { 1,1,2,2-Tetrachloroethane } \\
\text { roluene } \\
\text { Chlorobenzene }\end{array}$ & $\begin{array}{rl}10 & R \\
5 & \text { UJ } \\
5 & \text { UJ } \\
4 & J \\
5 & \text { UJ }\end{array}$ \\
\hline $\begin{array}{l}\text { Ethylbenzene } \\
\text { Styrene } \\
\text { xylene (total) } \\
\text { Trichlorofluoromethane } \\
\text { Acrolein }\end{array}$ & $\begin{array}{rl}3 & J \\
5 & U J \\
3 & J \\
5 & R \\
50 & R\end{array}$ \\
\hline $\begin{array}{l}\text { I sobutyl al cohol } \\
\text { Irans-1,4-D ichloro-2-butene } \\
1,2-D \text { ibromo-3-chloropropane }\end{array}$ & $\begin{array}{rl}100 R & R \\
10 & R \\
10 & \text { UJ }\end{array}$ \\
\hline $\begin{array}{l}\text { Dilution Factor } \\
\text { Total (Allowed) Hold Time }\end{array}$ & $\begin{array}{l}1.000 \\
23(14) d^{\star}\end{array}$ \\
\hline
\end{tabular}

Total (Allowed) Hold Time

2-12-93 
ISF Evaporation Pond S\&A Data Document - November 1989 - Method Validation Level A

TABLE B-8. TSF EVAPORATION POND - VOLATILE ORGANIC DATA

\begin{tabular}{|c|c|}
\hline $\begin{array}{l}\text { AREA } \\
\text { LOCATION } \\
\text { TYPE OF LOCATION } \\
\text { SAMPLE NUABER } \\
\text { MEDIA } \\
\text { UNI IS } \\
\text { SDG NUMBER } \\
\end{array}$ & $\begin{array}{r}\text { ISF } \\
\text { SUMP MARGINS } \\
\text { BIASED } \\
\text { TSF05011 } \\
\text { SOIL } \\
\text { ug/kg } \\
\text { TSF04011 }\end{array}$ \\
\hline $\begin{array}{l}\text { FIELD MEASUREMENTS } \\
\text { Depth }(\mathrm{ft})\end{array}$ & $17.5-18.5$ \\
\hline $\begin{array}{l}\text { TARGET COMPOUNDS } \\
\text { Chloromethane } \\
\text { Acetone } \\
\text { Carbon Disulfide } \\
\text { 2-Butanone } \\
\text { 4-Methyl-2-Pentanone }\end{array}$ & $\begin{array}{l}10 R \\
10 R \\
10 R \\
10 R\end{array}$ \\
\hline $\begin{array}{l}\text { 2-Hexanone } \\
\text { Tetrachloroetherie } \\
\text { 1,1,2,2-Tetrachloroethane } \\
\text { óluene } \\
\text { Chlorobenzene }\end{array}$ & $\begin{array}{l}10 R \\
\cdots- \\
\cdots \\
\cdots \\
\cdots\end{array}$ \\
\hline $\begin{array}{l}\text { Ethylber:zene } \\
\text { Styrene } \\
\text { Xylene (total) }\end{array}$ & $\cdots$ \\
\hline $\begin{array}{l}\text { Dilution Factor } \\
\text { Total (Allowed) Hold Time }\end{array}$ & $21(14) d$ \\
\hline
\end{tabular}

2-12-93 
APPENDIX C

ANALYTICAL RESULTS FOR SAMPLING

EVENT 1-INITIAL SAMPLING EFFORT 
APPENDIX C

ANALYTICAL RESULTS FOR SAMPLING

EVENT 1-INITIAL SAMPLING EFFORT

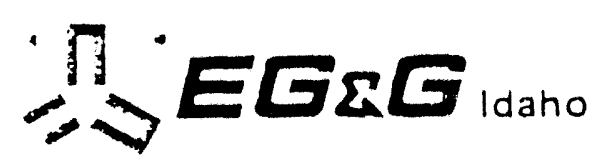

"Providing research and development services to the government"

\section{INTEROFFICE CORRESPONDENCE}

Date: July 23, 1992

To: J. R. Zimmerle, MS 1545

From: $\quad$ R. D. Grant, MS 3904RD 6

Subject: VALIDATION OF ANALYTICAL DATA FROM THE 1991 SAMPLING EFFORT AT THE TECHNICAL SUPPORT FACILITY (TSF); ANALYSES PERFORMED BY CALIFORNIA ANALYTICAL LABORATORIES, INC. - RG-71-92

The data in the attached reports were produced in 1982. No statement of work is available for evaluation and the analytical methods used are referred to in the attached reports only as "current Environmental Protection Agency (EPA) methods". The attached reports include no raw data or quality control sample data. These data can not be validated with out some knowledge of the analytical methods used and Quality Control (QC) sample results. The data in the attached reports are therefore of unknown quality.

ts

Attachments:

As Stated

CC: D. Jones, MS 3514

D. R. Kirchner, MS 3904

ARDC Files, MS 3904

Central Files, MS 1651

R. D. Grant File 


\section{California Analytical Laboratories, Inc.}

\author{
SEOS POWEA INN ROAO \\ SACAAMENTO, CALIFORNIA 95824 \\ (016) 381.5100
}

Cal Lab 14743

Received June 10, 1982

PO K-7036

August 23, 1982

Ms. Donna LaCombe

EG\&G Idaho

PO $80 \times 1625$

Idaho Falls, Idaho 83415

Dear Ms. LaCombe:

Enclosed ale data summary sheets for 17 water samples submitted for priority pollutant organics and metals as well as chloride, nitrate and sulfate. These samples were received June 10, 1982 and logged under Cal Lab number 14743.

Cal Lab Number

Sample Ident ification

$14743-1$

$14743-2$

$14743-3$

$14743-4$

$14743-5$

$14743-6$

$14743-7$

$14743-8$

$14743-9$

$14743-10$

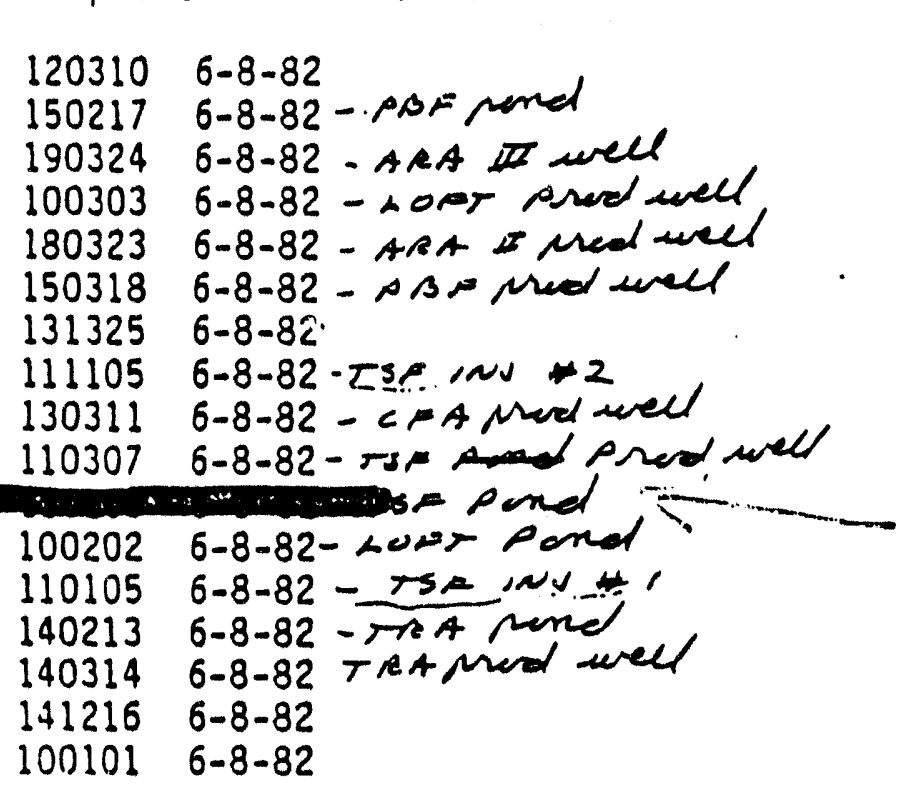

$14743-12$

$14743-13$

$14743-14$

$14743-15$

$14743-16$

$14743 \div 17$

These samples were andyzed according to current EPA methods for priority pollutants and according to Standard Methods (15th Edition, 1980) for chloride, nirate and sulfate.

Several samples were unusual. Sample 14743-11 (110206) yielded a bright yellow extract. We examined this sample very carefully and even added additional internal standards since we anticipated that this sample would have extractable priority pollutants. However, we did not detect extractable priortty pollutants at or above the $10 \mathrm{ug} / \mathrm{L}$ method detection limit. It is posstble that extractable priority pollut ants are present, but are present below $5 \mathrm{ug} / \mathrm{L}$. We were unable to ascertain why this sample extract is yellow. 
We are reasonably certain that the purgeable fraction of 14743-7 (131325) was spiked. We suspect that the methylene diloride reported was introduced as a contaminant in the spiking solution. We have repeatedly observed this in spiking solutions from some sources. We would be most interested in any feedback on comparisons between our results and the "true values".

The pesticide results require spectal comment. The pesticide fractions were first analyzed with a $1.5 \%$ SP-2250 + $1.95 \%$ SP2401 column, then posttive findings were conftrmed with 3\% SP-2100 column. Most samples were very clean. The few positives which passed the second column confimation were at very low levels. We selected the several of the fractions with the highest levels and attempted GCMS confirmation after concentration of the fraction to $0.2 \mathrm{ml}$. We were not able to confirm either Aroclor 1260 or any BHC by GCMS. Therefore we feel that the results must be used with great care. It may be that reextraction of a much larger sample volume and reanalys is of a much larger injection volume would result in successful GCMS confirmation.

When we report results on single phase aqueous samples to EPA on our enforcement contracts, it is customary to use an asterisk to indiciate positive pesticide and PCB results below $0.1 \mathrm{ug} / \mathrm{L}$. In this case we have reported actual numbers on the data stieets. Again these data should be used only with the realization that the GC results could not be confirmed by GCMS.

.everal samples had unusual values for metals or anions. Sample 131325 had detectable amounts of a number of metals, including berylium. In this respect the sample was unique in this set. Sample 110206 had 28 milligram/liter of boron. We hope this is a spike since this water would be toxic to most crop plants. Sample 150217 had unusual levels of chromium and zinc. Several samples had detectable arsenic and selentum values. Two samples had unusually high values for sulfate.

We would be most interested to learn if the inorganic results make sense to you.

If you have any questions about this data, please do not hesitate to call us.

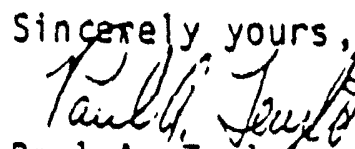

Paul A." Taylof, Pho President
Mark Masino Director of Inorganic Services

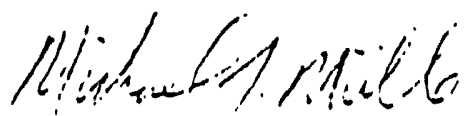

Michael Millle, Pho

Director of GCMS Services 
$E G \& G$

Lab No. 14743

RESULTS:

Arsenic

Antimony

Beryllium

Cadmi um

Chromium

Cobalt

Lead

Mercury

Nickel

Selenium

silver

Thallium

Zinc

Boron

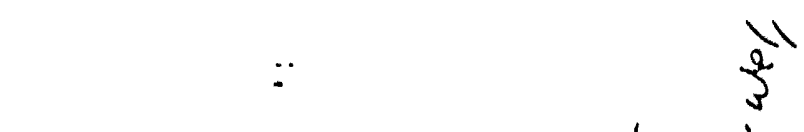

3

14743

$v^{c^{3}}$

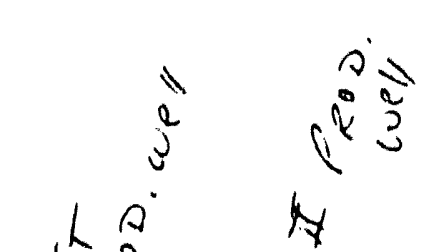

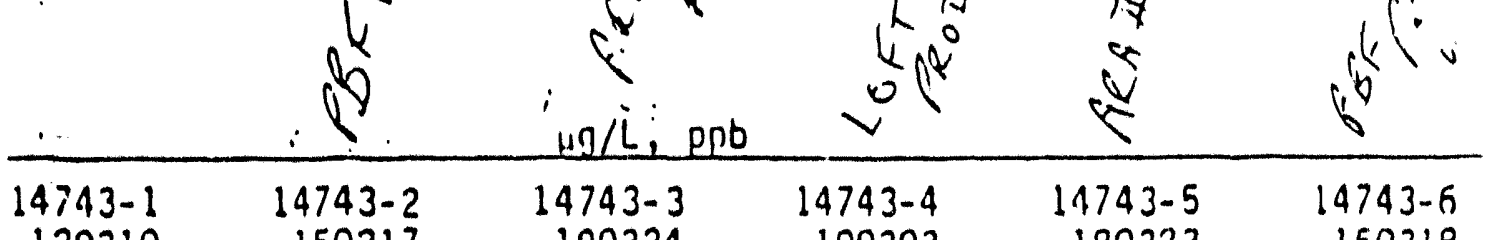

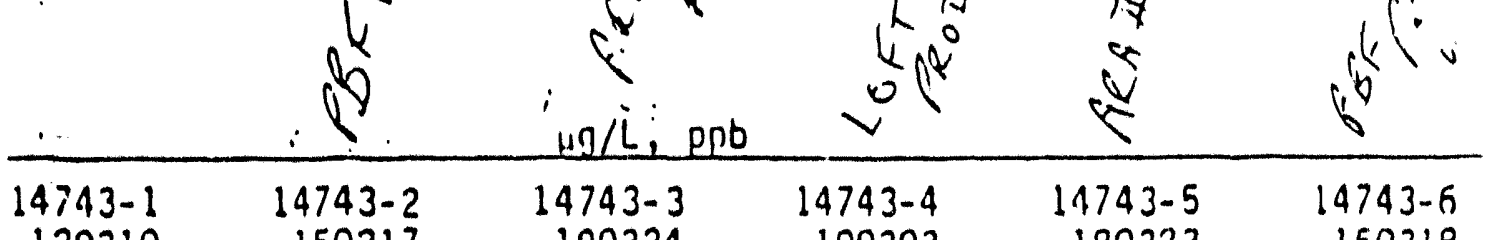
o 120310 25

$<20$

50217

190324

$<20$

100303

180323

$<20$

150318

$<5$

$<20$

$<20$

$<20$

$<20$

$<20$

$<5$

$<20$

$<5$

$<20$

$<25$

$<25$

$<5$

$<25$

$<5$

$<10$

$<10$

$<10$

$<50$

$<50$

$<10$

$<50$

$<10$

$<50$

$<50$

$<50$

$<50$

$<1$

$<50$

$<50$

$<50$

$<40<40$

$<1$

$<1$

$<1$

$<5 . \quad .<5$

$<40$

$<40$

$<40$

10

$<5$

$<40$

$<5$

$<5$

$<10$

$<10$

$<10$

$<20$

$<20$

$<20$

24

$<20$

$<20$

$<10$

2025

$<10$

$<20$

$<10$

$<10$

390

500

480

$<10$

470

130

$\mathrm{mg} / \mathrm{L}$

Sulfate

Nitrate

Chlorides

$\begin{array}{lll} & \mathrm{mg} / \mathrm{L} \\ 93 & 4725 & 280\end{array}$

0.85

0.13

280

250

68

81

20.2

128

0.96

0.75

0.78

1.6

17

17

17

26 
$E G \& G$

Lab. No. 14743

RESULTS:

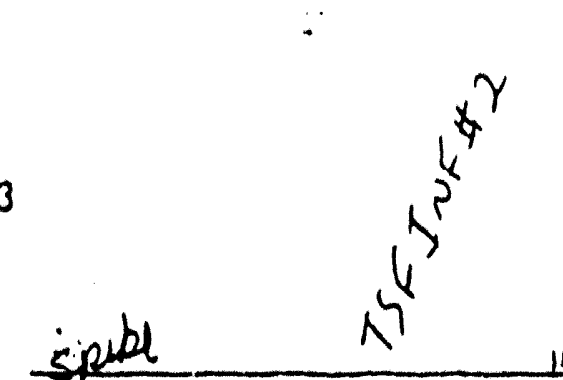

$i^{2}$ 141/L, ppo

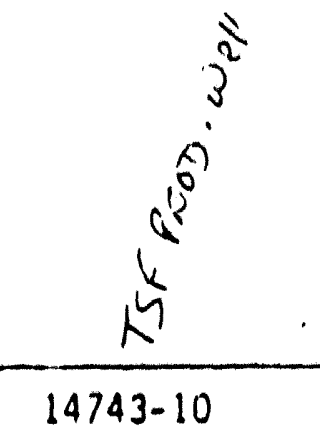

14743-7 14743-8 14743-9

14743-10

130311

Arsenic

$\frac{131325}{34}$

111105

Antimony

$<20$

34

$<20$

110307

Beryllium

$<20$

$<20$

$<20$

$<20$

$<5$

$<5$

$<5$

$<25$

Chromium

$<25$

44

$<10$

$<25$

$<25$

$<10$

$<10$

$<50$

$<50$

$<50$

$<50$

$<50$

$<50$

$<1$

Mercury

Nickel

2

31

$<1$

Selienium

9.6

$<40$

$<40$

$<1$

$<40$

$<5$

Silver

Tha 11 ium

Zinc

12

7.2

5.3

$<10 .<10$

$<20$

$<20$

$<20$

$<10$

$<20$

$<10$

$<10$

440

400

$\frac{110206}{<20}$

$14743-12$

24

$<10$

460

470

$\mathrm{mg} / \mathrm{L}$

Sulfate

Nitrate

Chlorides

$\begin{array}{lr}1 & 2400 \\ 0.01 & 2.2\end{array}$

250

95

1.2

89

61

0.85

225

200

19

8.5

0.19

0.297

17 
Lab No. 14743

RESULTS:

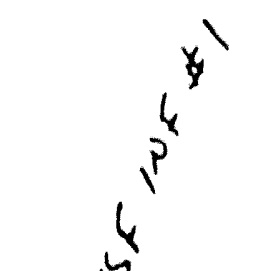

$\hat{k}^{2}$

\begin{tabular}{|c|c|c|c|c|c|}
\hline & $N^{\prime}$ & $\pi$ & $\mu g / L, \rho p 0$ & & \\
\hline . & $\begin{array}{l}14743-13 \\
110105 \\
\end{array}$ & $\begin{array}{l}14743-14 \\
140213 \\
\end{array}$ & $\begin{array}{l}14743-15 \\
14314 \\
\end{array}$ & $\begin{array}{l}14143.16 \\
141216 \\
\end{array}$ & $\begin{array}{l}14743.11 \\
100101 \\
\end{array}$ \\
\hline Arsentc & 36 & $<20$ & $<20$ & $<20$ & $<20$ \\
\hline Antimony & $<20$ & $<20$ & $<20$ & $<20$ & $<20$ \\
\hline Beryll fum & $<5$ & $<5$ & $<5$ & $<5$ & $<5$ \\
\hline Cadmium & $<25$ & $<25$ & $<25$ & $<25$ & $<25$ \\
\hline Chromium & $<10$ & 27 & $<10$ & 18 & $<10$ \\
\hline$-\operatorname{coball}$ & $<50$ & $<50$ & $\leqslant 50$ & $<50$ & (50 \\
\hline Lead & $<50$ & $<50$ & $<50$ & $<50$ & $<50$ \\
\hline Mercury & $<1$ & 1.8 & $<1$ & 4 & $<1$ \\
\hline Nickel & $<40$ & $<40$ & $<40$ & $<40$ & 840 \\
\hline Selenium & $<5$ & $<5$ & 12 & 12 & $c 5$ \\
\hline Silver & $<10$ & $<10$ & $<10$ & $<10$ & $(10$ \\
\hline Tha ll lum & $<20$ & $<20$ & $<20$ & $<20$ & $<20$ \\
\hline Zine & 10 & $<10$ & $<10$ & $<10$ & $<10$ \\
\hline \multirow[t]{2}{*}{ Boron } & 710 & 400 & 560 & 610 & 510 \\
\hline & \multicolumn{5}{|c|}{$\operatorname{lng} / L$} \\
\hline Sulfate & 950 & 4700 & 140 & 92 & 94 \\
\hline Nitrate & 2.3 & 2.4 & 0.809 & 0.852 & 0.719 \\
\hline Chlorides & 76 & 45 & 9 & 8.5 & 20 \\
\hline
\end{tabular}

C.8

California Analulical Labnralnries. Inc. 
Sedimentfimil moli.. rios)

\begin{tabular}{|c|c|c|c|c|c|c|c|c|}
\hline$\frac{\text { Elemeint }}{\text { Iron }}$ & $\frac{1.071}{0.24}$ & $\frac{T S F I}{<0.10}$ & $\frac{15 F 2 .}{<0.10}$ & $\frac{\text { IPf }}{34}$ & 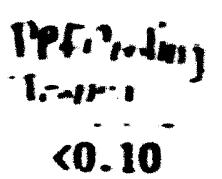 & $\begin{array}{l}\text { PATD } \\
<0.10\end{array}$ & 17t ligrd & MEA D \\
\hline Copper & $<0.1 C$ & $<0.10$ & $<0.10$ & $<0.10$ & $<0.10$ & $\begin{array}{l}<0.10 \\
<0.10\end{array}$ & $\begin{array}{l}74 \\
<0.10\end{array}$ & $\begin{array}{r}0.14 \\
<0.10\end{array}$ \\
\hline Zine & 0.34 & $<0.10$ & $<0.10$ & 1.9 & $<0.10$ & $<0.10$ & 110 & 0.12 \\
\hline Lead & $<0.15$ & $<0.15$ & $<0.15$ & $<0.15$ & $<0.15$ & $<0.15$ & $<0.15$ & $<0.15$ \\
\hline Chromium & $<0.05$ & $<0.05$ & $<0.05$ & 0.08 & $<0.05$ & $<0.05$ & 19 & 0.08 \\
\hline Nickel & $<0.08$ & $<0.08$ & $<0.08$ & $<0.08$ & $<0.08$ & $<0.08$ & $<0.08$ & $<9.08$ \\
\hline Cobalt & $<0.10$ & $<0.10$ & $<0.10$ & $<0.10$ & $<0.10$ & $<0.10$ & $<0.10$ & $<0.10$ \\
\hline Cadmium & $<0.15$ & $<0.15$ & $<0.15$ & $<0.15$ & $<0.15$ & $<0.15$ & $<0.15$ & $<0.15$ \\
\hline Barium & 5.2 & 7.0 & 4.6 & 0.66 & 5.3 & 5.6 & 0.64 & 5.5 \\
\hline Arsenic & $<0.60$ & $<0.60$ & $<0.60$ & $<0.60$ & $<0.60$ & $<0.60$ & $<0.60$ & $<0.60$ \\
\hline Selenium & $<0.50$ & $<0.50$ & $<0.50$ & $<0.50$ & $<0.50$ & $<0.50$ & $<0.50$ & $<0.50$ \\
\hline Beryllium & $<0.05$ & $<0.05$ & $<0.05$ & $<0.05$ & $<0.05$ & $<0.05$ & $<0.05$ & $<0.05$ \\
\hline Ant imony & $<0.40$ & $<0.40$ & $<0.40$ & $<0.40$ & $<0.40$ & $<0.40$ & $<0.40$ & $<0.40$ \\
\hline Vanadium & $<0.20$ & $<0.20$ & $<0.20$ & $<0.20$ & $<0.20$ & $<0.20$ & $<0.20^{\circ}$ & $<0.20$ \\
\hline Thall ium & $<0.20$ & $<0.20$ & $<0.20$ & $<0.20$ & $<0.20$ & $<0.20$ & $<0.20$ & $<0.20$ \\
\hline Molybdenum & $<0.50$ & $<0.50$ & $<0.50$ & $<0.50$ & $<0.50$ & $<0.50$ & $<0.50$ & $<0.50$ \\
\hline Silver & $<0.10$ & $<0.10$ & $<0.10$ & $<0.10$ & $<0.10$ & $<0.10$ & $<0.10$ & $<0.10$ \\
\hline Boron & $<0.20$ & 6.6 & 5.2 & $<0.20$ & $<0.20$ & $<0.20$ & $<0.20$ & $<0.20$ \\
\hline P:ercury & $<0.05$ & $<0.05$ & $<0.05$ & $<0.05$ & $<0.05$ & $<0.05$ & $<0.05$ & $<0.05$ \\
\hline Sul.fate & 8.1 & 23 & 7.9 & 830 & 1550 & 0.51 & 1900 & 9.6 \\
\hline Chloride & 5.8 & 46 & 35 & 42 & 19 & $<3.8$ & 130 & 3.9 \\
\hline : Nitrate & $<0.1$ & 0.11 & $<0.1$ & 0.40 & $<0.1$ & $<0.1$ & $<0.1$ & $<0.1$ \\
\hline
\end{tabular}




\title{
California Analytical I aboratories, Inc.
}

\author{
5895 Power Inn Road \\ Sacramento, California 95824 \\ (916) $381-5105$ \\ PRIORITY POLLUTANT DATA SHEET--page 2
}

CLIENT EG \& $G$

\section{VOLATILES}

?V acrole in

3V acrylonitrile ND Spiked

iv benzene ND

jw

$7 V$

\section{$\frac{1}{1}$}

in $\mu \mathrm{g} / \mathrm{L}$

$\therefore \quad \mu g / L$

1,2-dichloroethane $\quad 40$

Iiv 1,1,1-trichloroethane 38

$\frac{13 \mathrm{~V}}{14 \mathrm{~V} 1,1-\text { dichloroe thane } 1,2 \text {-trichloroethane }}$

5 chloroe thane $\frac{1,1,2,2 \text { - te trachloroe thane }}{\text { chlo }}$

1,2-trans-dichloroe thy lene

\section{4}

\begin{tabular}{|c|c|}
\hline $16 \mathrm{~V}$ methyl bromide & NO \\
\hline 179 bromioform & 50 \\
\hline $18 V$ dichlorobromome thane & 40 \\
\hline 19v trichlorofluorome thane & * \\
\hline iov dirhlorodifluorome thane & ND \\
\hline ilv chlorodibromome thane & 40 \\
\hline 35" te trachloroe thylene & 20 \\
\hline ig colvene & (30) \\
\hline $37 \mathrm{~V}$ trichloroe thylene & 46 \\
\hline 38v vinyl_chloride & ND \\
\hline
\end{tabular}

Igv 2-chloroethylvinyl ether ND

$3 v$ chloroform

\section{$\frac{309}{324}$}

6V methyl bromide

50
50

CAL LAB NO. 14743-7
CLIENT I.D. 131325

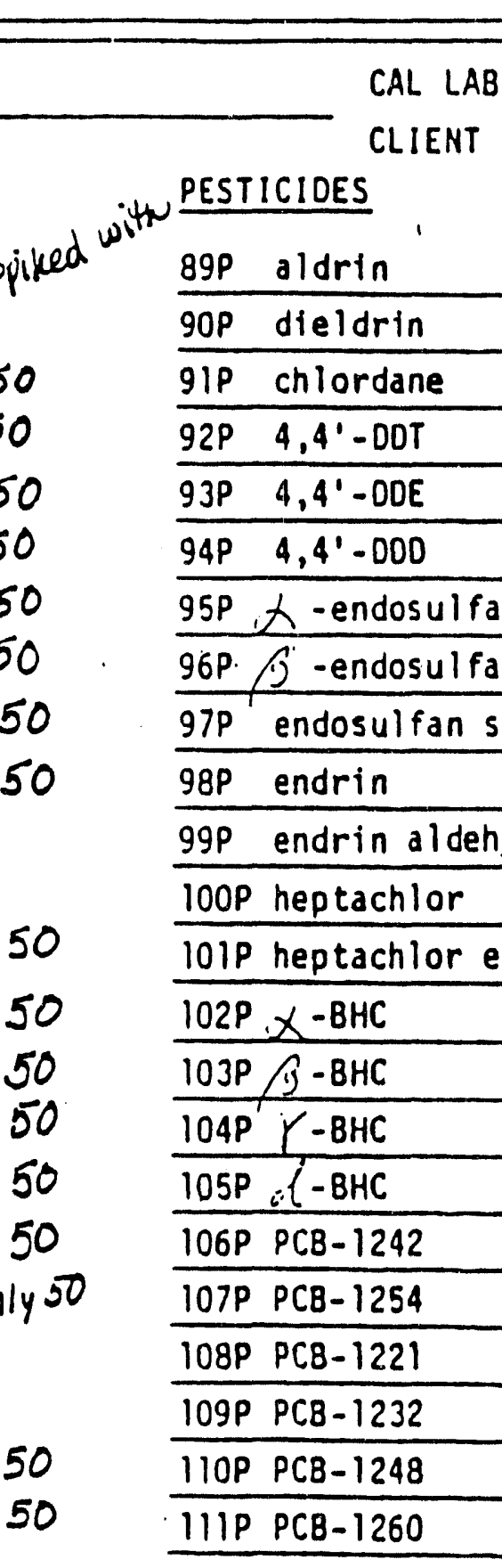

$\mu g / L$ ND

NO

ND

ND
ND NO ND ND

ND

$112 P$ PCB-1016

$113 P$ toxaphene

DIOXINS

\section{$12982,3,7,8$ - te trachlorodibenzo-} p-dioxin

- Less than $10 \mu \mathrm{g} / \mathrm{L}$ (pesticldes less than $5 \mu g / L$ ND = not detected 


\title{
California Analytical Laboratories, Inc.
}

\author{
SOS POWEA INN ROAO \\ SACRAMENTO, CALIFORNLA 95824 \\ (810) 301.6108
}

PRIORITY POLLUTANT DATA SHEET

LIENT

EG \& E

ACID COMPOUNOS

$\mu g / L$

21A 2,4,5-trichlorophenol

ND

22A p-chloro-m-cresol

24A 2-chlorophenol

$31 A$ 2,4-dichlorophenol

$34 A \quad 2,4$-dimethylphenol

57A 2-nitrophenol

58A 4-nitrophenol

59A 2,4-dini troptienol

60A 4,6-dinitrn-0-cresol

$64 A$ pentachlorophenol

65A phenol

BASE/NEUTRAL COMPOUNDS

IB acenaphthene

ND

58 benzidine

NO

$88 \quad$ 1,2,4-trichlorobenzene

NO

98 hexachlorobenzene

ND

128 hexachloroe thane

ND

188 bis(2-chloroethyl)e ther

ND

208 2-chloronaph thalene

ND

25B 1,2-dichlorobenzene

268 1,3-dichlorobenzene

NO

278 1,4-dichlorobenzene

ND

$2883.3^{\prime}$-dichlorobenzidine

358 2,4-dinitrotoluene

368 2,6-dinitrotoluene

ND

ND

ND

ND

37B 1,2-diphenylhydrazine

(as azobenzene)

398 fluoranthene

ND

ND

40B 4-chlorophenyl phenyl ether

NO
CAL LAB NO. 14743-7

CLIENT I.D. 131325 SPIKE

BASE/NEUTRAL COMPOUNDS

$\| \mathrm{g} / \mathrm{L}$

418 4-bromophenyl phenyl ether ND

$42 B$ bis(2-chloroisopropyl)ether NO

438 bis(2-chloroethoxy)methane NL

$52 B$ bexachlorobutadiene

NO

538 hexachlorocyclopentadiene ND

548 isophorone NO

558 naphthalene - ND

568 nitrobenzene

$618 \quad N$-nitrosodime thylanine

ND

$62 B N$-nitrosodiphenylamine

638.N-nitrosodi-n-propylamine

No

66B bis(2-ethylhexy) phthalate

ND

678 butyl benzyl phthalate

ND

$68 B$ di-n-butyl phthalate

ND

698 di-n-octyl phthalate

ND

$70 B$ diethyl phthalate

ND

$71 B$ dimethyl phthalate

NO

$72 B$ benzo(a)anthracene

ND

$73 B$ benzo(a)pyrene

ND

748 3,4-benzofluoranthene

NO

$75 B$ benzo( $k$ ) fluoranthene

NO

$76 \mathrm{~B}$ chrysene

ND

778 acenaph thy lene

788 anthracene

ND

798 benzo(ghi)perylene

ND

808 fluorene

ND

818 phenanthrene

$82 B$ dibenzo(a,h)anthracene

ND

838 indeno $(1,2,3-c d)$ pyrene

ND

848 pyrene

NO

NQ

(1)

-

NO

D

No

D




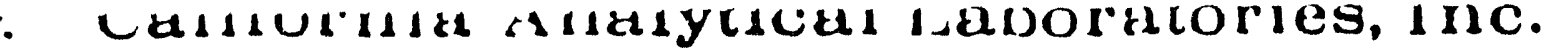

5895 Power Inn Road

Sacramento, Cal ifornia 95824

(916) $381-5105$

PRIORITY POLLUTANT DATA SHEET--page 2

CLIENT EG\&G

\section{VOLATILES}

$\mu \mathrm{g} / \mathrm{L}$

2V acrolein

ND

3v acrylonitrile

ND

av benzene

ND

6V carbon tetrachloride.

NO

7V chlorobenzene

iND

lov 1,2-dichloroethane

ND

IIV 1,1,1-trichloroethane

NO

$13 \mathrm{~V}$ 1.1-dichloroe thane

ND

I4V 1,1,2-trichloroethane ND

15V 1,1,2,2-tetrachloroe thane

ND

$16 \mathrm{~V}$ chloroe thane ND

$19 \mathrm{~V}$ 2-chloroethylvinyl ether

23v chloroform NO

$29 \mathrm{~V}$ 1.1-dichloroe thylene NiD

30V 1,2-trans-dichloroethylene ND

324 1,2-dichloropropane ND

$33 \mathrm{~V}$-1,3-dichloropropylene

$38 \mathrm{~V}$ ethylbonzene ND

44 V Ine thylene chloride NO

$45 \mathrm{~V}$ methyl chloride ND

$46 \mathrm{~V}$ me thyl bromide ND

$47 \mathrm{~V}$ bromoform ND

$48 \mathrm{~V}$ dichlorobromome thane ND

$49 \mathrm{~V}$ trichlorofluoromethane $\quad$ MD

$50 \mathrm{~V}$ dichlorodifluorome thane ND

5IV chlorodibromome thane ND

$85 \mathrm{~V}$ te trachloroe thylene ND

$86 \mathrm{~V}$ toluene NO

$87 \mathrm{~V}$ trichloroe thylene NO

88V vinyl_thloride ND
CAL LAB NO. 14743-8

CLIENT I.D. 111105

PESTICIOES

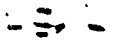

89p aldrin

90p dieldrin

$91 p$ chlordane

$92 P \quad 4,4^{\prime}-00 T$

93P $4,4^{\prime}-00 E$

$94 P \quad 4,4^{\prime}-000$

$95 \mathrm{P} \alpha$-endosulfan

96P $\beta$-endosulfan

$97 P$ endosulfan sulfate

$98 \mathrm{p}$ endrin

g9p endrin aldehyde

100P heptachlor

101P heptachlor epoxide

$102 P \alpha-B H C$

$103 P \beta-B H C$

$104 P Y-B H C$

$105 P C(-B H C$

106P PC8-1242

107 P PCB-1254

$108 P$ PCB-1221

$109 P$ PCB -1232

$110 P$ PCB -1248

$111 P$ PCB -1260

$112 P$ PCB-1016

$113 P$ toxaphene

(0.06)

×

VI

vo

VD

10

10

YO

10

10

YD

10

10

DIOXINS

1298 2,3,7,8-te trachlorodibenzop-dioxin

- Less than $10 \mu \mathrm{g} / \mathrm{L}$ (pesticides less than $5 \mu \mathrm{g} / \mathrm{L}$ )

NO = not detected 


\title{
California Analytical Laboratories, Inc.
}

\author{
SOSS POWEA INN AOAD \\ SACRAMENTO. CALIFORNIA 05824 \\ (010) 201.6106
}

PRIORITY POLLUTANT DATA SHEET

LIENT EG \& G

ACIO COMPOUNDS

21A 2,4,6-trichlorophenol

22A p-chloro-m-cresol

24A 2-chlorophenol

$31 \mathrm{~A}$ 2,4-dichlorophenol

34 A 2,4-dimethylphenol

$57 A$ 2-nitrophenol

58A 4-nitrophenol

59A 2,4-dini trophenol

60A 4,6-dinitrn-o-cresol

$64 \mathrm{~A}$ pentachlorophenol

oA phenol

\section{BASE/NEUTRAL COMPOUNOS}

\section{8 acenaphthene}

58 benzidine

88 1,2,4-trichlorobenzene

98 hezachlorobenzene

128 hexachloroe thane

188 bis (2-chloroethy 1 )ether

208 2-chloronaphthalene

- 25B 1,2-dichlorobenzene

268 1,3-dichlorobenzene

- 278 1,4-dichlorobenzene

$2883,3^{\prime}$-dichlorobenzidine

$35 \mathrm{~B}$ 2,4-dinitrotoluene

368 2,6-dinitrotoluene

?B 1,2-diphenylhydrazine

(as azobenzene)

398 fluoranthene

$40 B$ 4-chlorophenyl phenyl ether
NO

ND ND NO

NO

$\mu \mathrm{g} / \mathrm{L}$

NO

ND

ND

NO

ND

ND

NO

ND

NO

ND

NO

ND

ND

NO

ND

NO

ND

ND

NO

NO

ND

ND
CAL LAB NO. $14743-8$

CLIENT 1.D. 111105TSFInf $\$ 2$ BASE/NEUTRAL COMPOUNOS

$\| \mathrm{g} / \mathrm{L}$

4.9 4-bromophenyl phenyl ether NO

$42 B$ bis(2-chloroisopropyl)ether ND

438 bis (2-chloroethoxy)me thane NO

528 bexachlorobutadiene

538 hexachlorocyclopentadiene

NN

548 isophorone

ND

$55 B$ naphthalene

- ND

568 nitrobenzene

ND

$618 \quad \mathrm{~N}$-nitrosodille thyl anline ND

$62 \mathrm{~B} \quad \mathrm{~N}$-nitrosodiphenylamine

ND

$63 B . N$-nitrosodi-n-propylamine ND

66B bis(2-ethylhexyl)phthalate ND

678 butyl benzyl phthalate NO

688 di-n-butyl phthalate NO

698 di-n-octyl onthalate ND

708 diethyl phthalate NO

718 dimethyl phthalate ND

$72 B$ benzo(a) anthracene ND

738 benzo(a)pyrene NO

748 3,4-benzofluoran thene ND

758 benzo( $k$ ) fluoranthene NO

768 chrysene ND

778 acenaphthylene ND

788 anthracene NO

798 benzo(ghi)perylene ND

$80 B$ fluorene

818 phenanthrene ND

828 dibenzo $(a, h)$ anthracene ND

838 indeno $(1,2,3-c d)$ pyrene NO 848 pyrene 
5895 Power Inn Road

Sacramento, California 95824

(916) $381-5105$

PRIORITY POLLUTANT DATA SHEET--page 2

CLIENT EG\&G

VOLATILES

$\mu g / L$

2V acrolein

ND

3V acrylonitrile

ND

4V benzene

NO

6V carton tetrachloride

ND

IV chlorobenzene NO

lov 1,2-dichloroethane

ND

IIV 1,1,1-trichloroe thane

ND.

$13 V$ 1.1-dicnloroe thane

I4V 1,1,2-trichloroethane

$1,1,2,2$ - te trachloroe thane

chloroe thane

$19 \mathrm{~V}$ 2-chloroe thylvinyl ether

23v chloroform

$29 \mathrm{~V}, 1,1$-dichloroe thylene

$30 \mathrm{~V}$ 1,2-trans-dichloroe thylene

$32 \mathrm{~V}$ 1,2-dichloropropane

$33 \mathrm{~V}$ - 1,3-dichloropropylene

38 y etlyylbenzene

$44 \mathrm{~V}$-ine thylene chloride

45V nethyl chloride

$46 \mathrm{~V}$ me thyl bromide

$47 \mathrm{~V}$ bronoform

$48 \mathrm{~V}$ dichlorobromome thane

$49 \mathrm{~V}$ trichlorofluorome thane

$50 \mathrm{~V}$ dichlorodifluorome thane

$51 \mathrm{~V}$ chlorodibromome thane

85 te trachloroe thylene
$8 \mathrm{~g}$ toluene
$87 \mathrm{~V}$ trichloroe thylene
$88 \mathrm{~V}$ viny! chloride

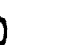




\title{
California Analytical Laboratories, Inc.
}

\author{
SOOS POWER INN ROAO \\ SACAAMENTO. CALIFORNIA 95824 \\ (010) 321.6100
}

PRIORITY POLLUTANT DATA SHEET

-IENT EG \& G

\section{ACID COMPUUNOS}

21A 2,4,6-trichlorophenol

$22 A$ p-chloro-m-cresol

24A 2-chlorophenol

31A 2,4-dichlorophenol

34 A 2,4-dimethylphenol

57A 2-nitrophenol

58A 4-nitrophenol

59A 2,4-dinitrophenol

60A 4,6-dintern-o-cresol

$64 A$ pentachlorophenol

$65 A$ phenol

BASE/NEUTRAL COMPOUNDS

18 acenaphthene

58 benzidine

$88 \quad 1,2,4$-trichlorobenzene

98 hexachlorobenzene

128 hexachloroe thane

188 bis (2-chloroethyl)ether

2082 -chloronaphthalene

25B 1,2-dichlorobenzene

- 268 1,3-dichlorobenzene

27B 1,4-dichlorobenzene

- $2883,3^{\prime}$-dichlorobenzidine

35B 2,4-dinitrotolvene

368 2,6-dinitrotoluene

378 1,2-diphenylhydrazine

(as azobenzene)

398 fluoranthene

408 a-chlorophenyl phenyl ether

ND

ND

ND

NO

ND

$\mu g / L$

ND

NO

ND

NO

ND

NO

NO

ND

ND

ND

NO

NO

NO

NO

NO

ND

NO

ND

NO

NO

NO

NO
CAL LAB NO. 14743-11

CLIENT 1.0. 110206 TSF POnd BASE/NEUTRAL COMPOUNOS $\| \mathrm{g} / \mathrm{L}$

41B 4-bromophenyl phenyl ether ND

428 bis(2-chloroisopropyl)ether NO

438 bis (2-chloroethoxy) me thane NO

$52 B$ bexachlorobutadiene NO

538 hexachlorocyclopentadiene NO

548 isophorone ND

558 naphthalene

- NO

568 nitrobenzene ND

618 - N-nitrosodime thy lamine $N$ NO

$62 B \quad N$-nitrosodiphenylamine ND

638. N-nitrosodi-n-propylamine ND

668 bis(2-ethylhexyl)phthalate NO

678 butyl benzyl phthalate ND

$68 B$ di-n-butyl phthalate ND

698 di-n-octyl phthalate ND

708 diethyl phthalate NO

718 dimethyl phthalate NO

728 benzo(a) anthracene NO

738 benzo(a)pyrene NO

748 3,4-benzofluoranthene

758 benzo( $k$ ) fluoranthene NO

768 chrysene NO

778 acenaph thy lene ND

788 anthracene

798 benzo(ghi)perylene NO

808 fluorene

818 phenanthrene ND

828 dibenzo(a,h)anthracene NO

838 indeno $(1,2,3$-cd) pyrene NO

848 pyrene ND NO 


\title{
Callornia Analytical Laboratories, Inc.
}

\author{
SOS POWER INN ROAD \\ SACRAMENTO. CALIFORNLA 05824 \\ (010) 321.6106
}

PRIORITY POLLUTANT DATA SHEET

.IENT EG \& G

ACID COMPOUNOS

$\mu g / L$

21A 2,4,6-trichlorophenol

ND

$22 \mathrm{~A} p$-chloro-m-cresol

NO

24A 2-chlorophenol

ND

$31 \mathrm{~A}$ 2,4-dichlorophenol

NO

$34 \mathrm{~A}$ 2,4-dime thylphenol

ND

57A 2-nitrophenol NO

$58 \mathrm{~A} \quad 4-n i$ trophenol

NO

59A 2,4-dini.trophenol

60A 4,6-dinitrn-0-cresol

4 A pentachlorophenol

A phenol

BASE/MEUTRAL COMPOUNDS

18 acenaphthene

NO

$5 B$ benzidine

ND

$8 B \quad 1,2,4$-trichlorobenzene

MO

98 hexachlorobenzene

ND

128 hexachloroethane

ND

188 bis (2-chioroethyl)ether

ND

2082 -chloronaph thalene

NO

258 1,2-dichlorobenzene

NO

26B 1,3-dichlorobenzene

NO

278 1,4-dichlorobenzene

ND

$2883,3^{\prime}$-dichlorobenzidine

358 2,4-dinitrotoluene

ND

368 2.6-dinitrotoluene

ND

ND

1,2-dipheny lhydrazine

(as azobenzene)

NO

398 fluoranthene

ND

408 4-chlorophenyl phenyl ether

ND

ND

ND

NO

No


Callornia Analytical Laboratories, Inc.

\author{
5895 Power Inn Road \\ Sacramento, California 95824 \\ (916) $381-5105$ \\ PRIORITY POLLUTANT DATA SHEET--page 2
}

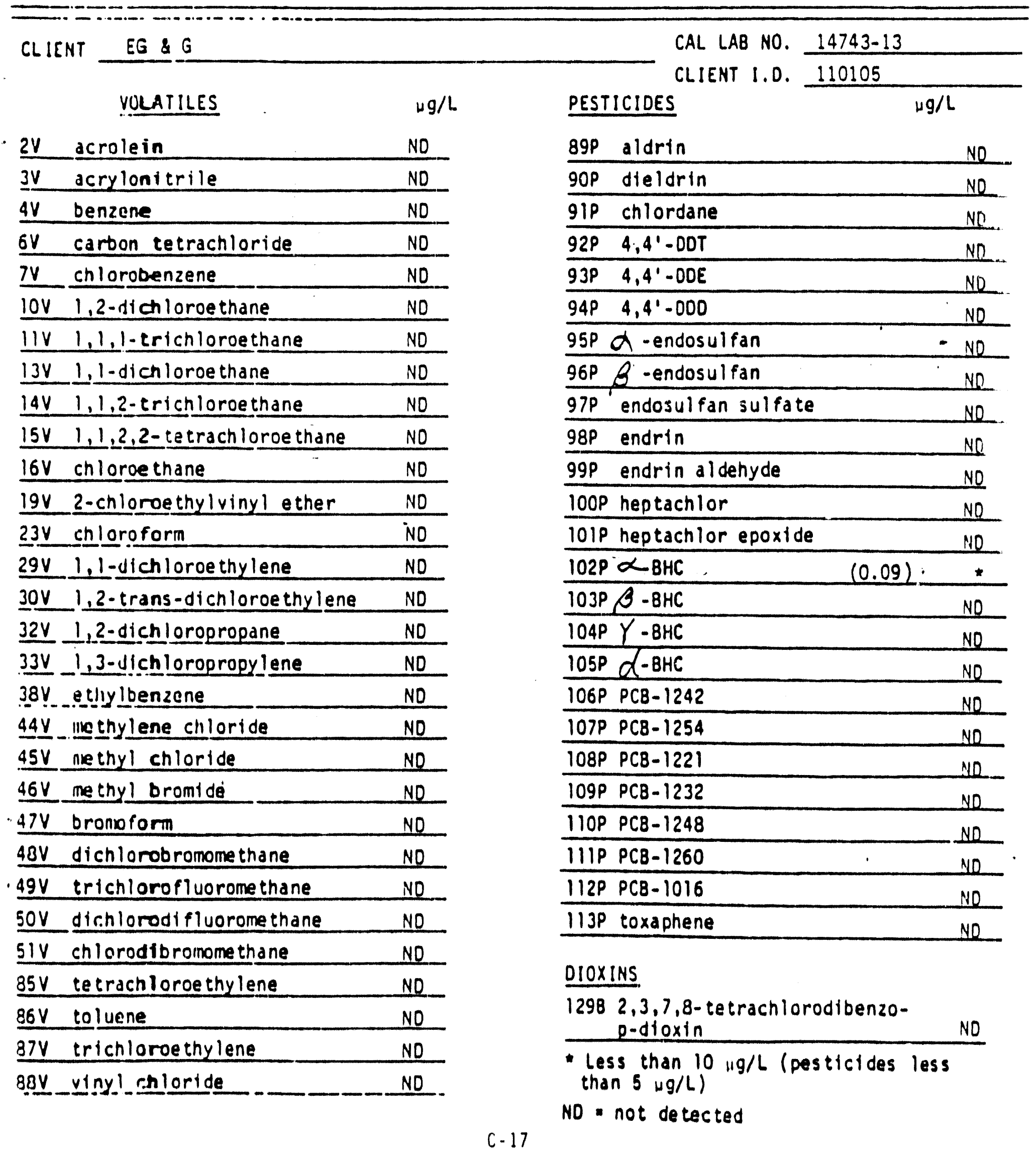


California Analytical Laboratories, Inc.

Oonna LaCombe

EGRG Idaho

P.0. Box 1625

idaho Falls, Idaho 83415

S895 POWER INN ROAD

SACAAMENTO. CALIFORNIA 95824

(916) 391.5105
November 5, 1982

Lab No. 15131

Received: $9 / 3 / 82$

$P 0 \# K-7036$

Dear Donna:

Enclosed please find results on the sixteen water samples submitted on September 3, 1982 for priority oroanic pollutants and metals as well as chloride, nitrate and sulfate.

\begin{tabular}{c} 
CAL 1.0 \\
\hline $15131-1$ \\
-2 \\
-3 \\
-4 \\
-5 \\
-6 \\
-7 \\
-8 \\
-9 \\
-10 \\
-11 \\
-12 \\
-13 \\
-14 \\
-15 \\
-16
\end{tabular}

SAMPLE I.D.

101 LOFT INEL

102 LOFT PONO

103 LOFT PROD. WELL

104 TST INEL

105 TSF POND-1

$+\operatorname{sic}^{1}$

106 TSF.POND-2

107 TSF. PROO.WELL

108 WRRTIF. PROPWELL

109 CFA PROD. WELL

110 TRRA DEMIN POND.

111 TRA INEW POND

112 TRA PROD WELL

$-13$

113 PBF POND

$-14$

114 PBF. POAPROD W SLL

$-16$

115 ARA.Z P PROD WELL

116. CFA-Motor Pool Pond 
Donna LaCombe EG\&E I Idaho

Lab No. 15131

Paoe 2

The priority pollutants and metals were analyzed according to current

EPA methods; chloride, nitrate and sulfate analyses were performed

accordina to Standard Methods For The Examination of Water And Wastewater

(15th Edition).

Al though we found aldrin in sample 113 (CAL I. n. 15131-13P), the level was too low for GC/MS confirmation.

If you have any questions, please feel free to contact us.

sincerely,

Anthony S. Hona, Pho

Vice President

Research and Analytical Services
Mark Masino

Inorganics Division

Supervisor $i j /$

Michael J. Milille, PhC

Director of GC/MS

Services

ASW: nc 


\title{
California Analytical Laboratories, Inc.
}

\author{
SWS POWER INN AOAD \\ SACRAMENTO. CALIFOANLA OSB24 \\ (010) 301.810S
}

QITEN: E.G. \& G.

\begin{tabular}{|c|c|c|c|}
\hline PP\# & CNS & Va ATIISS & ug/L \\
\hline $2 \mathrm{~V}$ & $107-02-8$ & acroletn & $\mathrm{ND}$ \\
\hline $3 \mathrm{~V}$ & $107-13-1$ & acrylonitrile & $\sqrt{10}$ \\
\hline $4 V$ & $71-43-2$ & berocenc & $N$ \\
\hline 6V & $56-23-5$ & carbon tetrachloride & $\mathrm{ND}$ \\
\hline$N$ & $10 B-90-7$ & chlorobenzere & ND \\
\hline $10 \mathrm{~V}$ & $107-\infty 5-2$ & 1,2-dichloroethane & $\sqrt{D}$ \\
\hline $11 \mathrm{~V}$ & $71-55-6$ & 1,1,1-trichloroethane & ND \\
\hline $13 \mathrm{~V}$ & $75-34-3$ & 1,1-dichloroethane & $\sqrt{\mathrm{N}}$ \\
\hline $14 \mathrm{~V}$ & $79-90-5$ & 1,1,2-trichloroethane. & $\sqrt{10}$ \\
\hline $15 \mathrm{~V}$ & $79-34-5$ & 1,1,2,2-tetrachloroethane & $\mathrm{ND}$ \\
\hline $16 \mathrm{~V}$ & $75-00-3$ & chlorocthane & $\sqrt{D}$ \\
\hline $19 \mathrm{~V}$ & $110-75-8$ & 2-chloroethyivinyl ether. & $N D$ \\
\hline $23 \mathrm{~V}$ & $67-66-3$ & chloroform & ND \\
\hline $29 \mathrm{~V}$ & $75-35-4$ & 1,1-dichloroethene & ND \\
\hline $30 \mathrm{~V}$ & $156-60-5$ & irous-1,2-dichlorocthene & $\sqrt{D}$ \\
\hline $32 \mathrm{~V}$ & $78-87-5$ & 1,2-rich] oropropane & $\overline{N D}$ \\
\hline $33 \mathrm{~V}$ & $10061-02-6$ & trans-1,3-dichloropropene & $\mathrm{ND}$ \\
\hline & $10061-01-5$ & cis-1,3-dichloropropene & $N D$ \\
\hline $38 V$ & $100-41-4$ & ethylberzene & ND \\
\hline 活V & $75-09-2$ & rethylene chloride. & $\frac{N D}{N}$ \\
\hline $\begin{array}{l}45 \mathrm{~V} \\
45 \mathrm{~V}\end{array}$ & $74-87-3$ & chloranethane. & $\frac{N D}{10}$ \\
\hline $46 \mathrm{~V}$ & $74-83-9$ & Gromonethane & ND \\
\hline $4 \pi$ & $75-25-2$ & bromoform - & $\frac{N D}{10}$ \\
\hline $48 \mathrm{~V}$ & $75-27-4$ & bromodichlotomethane & ND \\
\hline $49 \mathrm{~V}$ & $75-69-4$ & fluorotrichloranethane & $\mathrm{ND}$ \\
\hline $50 \mathrm{~V}$ & $75-71-8$ & dichlorodifluoramethene & $\mathrm{ND}$ \\
\hline $51 \mathrm{~V}$ & $124-48-1$ & chlorod ibramanethone. & $\sqrt{N}$ \\
\hline $85 V$ & $127-18-4$ & tetrachloroethene. & ND \\
\hline $86 \mathrm{~V}$ & $108-83-3$ & toluere & $\mathbb{N D}$ \\
\hline $87 \mathrm{~N}$ & $7201-6$ & trichlot & $\frac{N D}{N}$ \\
\hline & & & $\mathrm{ND}$ \\
\hline
\end{tabular}

CAL LAB NO: $15131-4$

QTENT I.D.: 104

\begin{tabular}{|c|c|c|c|}
\hline PPI & as & PESTICINES & $48 / 2$ \\
\hline 898 & $309-\infty-2$ & aldrin & $\mathrm{ND}$ \\
\hline $90 P$ & $60-57-1$ & dieldrin & $\mathrm{ND}$ \\
\hline $91 P$ & $57-74-9$ & chlordane. & $\sqrt{10}$ \\
\hline $97 \mathrm{P}$ & $50-29-3$ & $4,4^{\prime}-0 \pi$ & $\frac{N}{N}$ \\
\hline 938 & $72-55-9$ & $4,4^{\prime}-0, E$ & $\bar{N}$ \\
\hline 948 & $72-54-8$ & $4,4^{\prime}-100$ & $\sqrt{N}$ \\
\hline $95 P$ & $115-29-7$ & a-endosulfan & TI \\
\hline $96 P$ & $115-29-7$ & bendosulfan & $N$ \\
\hline $97 \mathrm{P}$ & $1031-07-8$ & endosulfan sulfate & NI \\
\hline 989 & $72-20-8$ & endris & $\sqrt{ }$ \\
\hline 999 & $7421-93-4$ & endrin aldehyde. & $\mathrm{NI}$ \\
\hline $100 P$ & $76-44-8$ & heptachlor. & $N$ \\
\hline $101 P$ & $1024-57-3$ & heptachlor epoxide & $\sqrt{N}$ \\
\hline $102 P$ & $319-84-6$ & a-ax & $\sqrt{N}$ \\
\hline $103 P$ & $319-85-7$ & $b-E x$ & $N$ \\
\hline 1048 & $319-86-8$ & DEAC & $\bar{y}$ \\
\hline 1058 & $58-89-9$ & $8-B \times$ (Iindare) & $N$ \\
\hline $106 \mathrm{P}$ & $53469-21-9$ & POB-1242 & $\bar{N}$ \\
\hline $107 \mathrm{P}$ & $11097-69-1$ & $P 08-1254$ & $y$ \\
\hline $108 P$ & $11104-28-2$ & $P O B-1221$ & $N$ \\
\hline 1098 & $11141-16-5$ & $P O B-1232$ & I \\
\hline 1100 & $12672-29-6$ & $P B-1248$ & 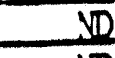 \\
\hline $111 \mathrm{P}$ & $11096-82-5$ & $P O B-1260$ & $y$ \\
\hline $112 \mathrm{P}$ & $12674-11-2$ & POB-1016 & -1 \\
\hline 1120 & $8001-35-2$ & toxaphene. & $\pi$ \\
\hline & & DTOXDS & \\
\hline $9 B$ & $1746-01-6$ & $\begin{array}{l}2,3,7,8 \text {-tetrachloro- } \\
\text { ibenzo-p-dioxdn }\end{array}$ & sio \\
\hline
\end{tabular}

Na-Not detected, *- detected below a detection limit of 10ug/L (volatiles) and 0.1-1.0ug/ (pesticides) 


\title{
California Analytical Laboratories, Inc.
}

\author{
ses DOWEA INH MOAO \\ SACAMMENTO. CALIFOANIA GUEA \\ (D10) 31-6106
}

QIENT: E.G.\& G.

PPI

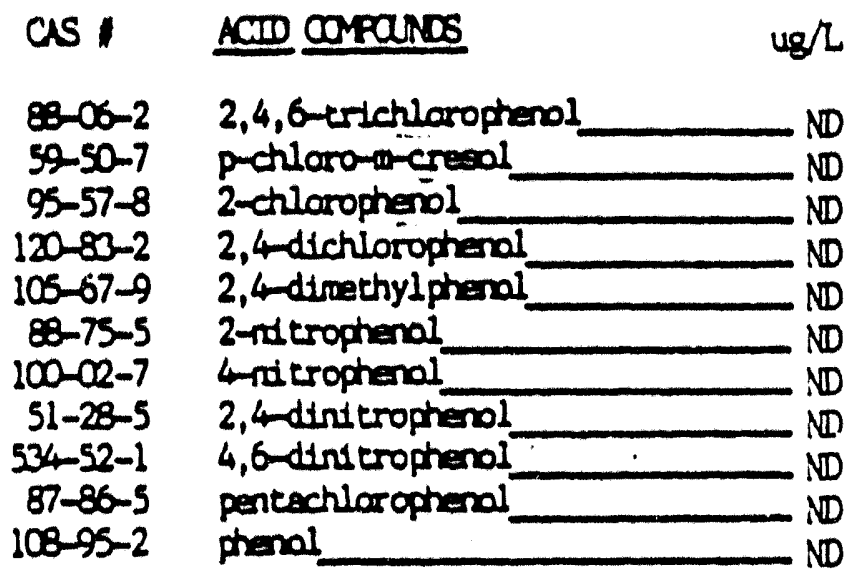

\section{BASENUTIRAL COMPONOS}

82-32-9 aceraphthene _ ND

92-87-5 berzidine ND

$120-82-1 \quad 1,2,4$ trichlaroberzene _ _ ND

118-74-1 hexachlorobercene__ ND

67-72-1 hexachloroethane - ND

$111-4$ bis(2-chlorcethyl)ether _ ND

$91-58-7$

2-chlororaphthalene

$95-50-1$

$541-73-1$

106-16-7

$91-4-1$

$121-14-2$

$606-20-2$

$122-66-7$

$206-44-0$

398

$40 B$ 1,2-dichloroberezene

1,3-dichlarobenzene

1,4-dichlarobenzene

3,3'-dichlarobenzidine

2,4-dinditrotoluene

2,6-dinitrotaluere

1,2-diphenyluydrazine

Elvaranthene

Lchlarophenyl phenyl ether
CAL LAB ND: $15131-4$

QTENT I.D.: 104
PPN

$41 B$

42B

438

$52 B$

53B

548

$55 B$

$56 \mathrm{~B}$

$61 \mathrm{~B}$

$62 B$

638

$66 \mathrm{~B}$

67B.

$68 B$

$69 \mathrm{~B}$

$70 B$

712

$72 B$

$73 B$

$74 \mathrm{~B}$

$75 B$

768

TTB

$78 B$

$79 B$

$80 B$

$81 B$

$82 B$

838

$84 B$
CAS

101-55-3 39638-32-9

111-91-1

87-68-3

$77-47-4$

$72-59-1$

91-22-5

9-95-3

$62-75-9$

86-30-6

$621-64-7$

117-81-7

85-68-7

$84-74-2$

$117-84-0$

84-66-2

131-11-3

56-55-3

50-32-8

$205-99-2$

207-08-9

218-01-9

208-96-8

120-12-7

$191-24-2$

86-73-7

85-01-8

53-70-3

193-39-5

$129-00-0$
BASE/NEURRL COMPONOS

48

4 bromophenyl phenyl ether bis(2-chloroisopropyl)ether. bis(2-chloroethaxy) wethene hexachlorobutadiene hexachlorocyclopentadiene isophorone raphthalene nitrobenzene N-nitrosodimethylawine Nind trosodipheny lemine N-nitrosodipropy lamine bis(2-ethylhexyl)phthalate. benzyl butyl phithalate di-n-butyl phitalate di-r-atyl phthalace diethyl phitalate dimethyl phthalace benzo(a) anthracene benzo(a)pyrene benzo(b) El woranchene bereo (k)fluaranthere chrysane acenaphthylene enturacene benzo(ghi) perylene fluorene phenanturene dibenzo $(a, h)$ enthracene Indeno( $1,2,3$-cd)pyrene pyrene

DD-Not detarted *-detected below a detection linit of $10 \mathrm{ug} / \mathrm{L}$ 


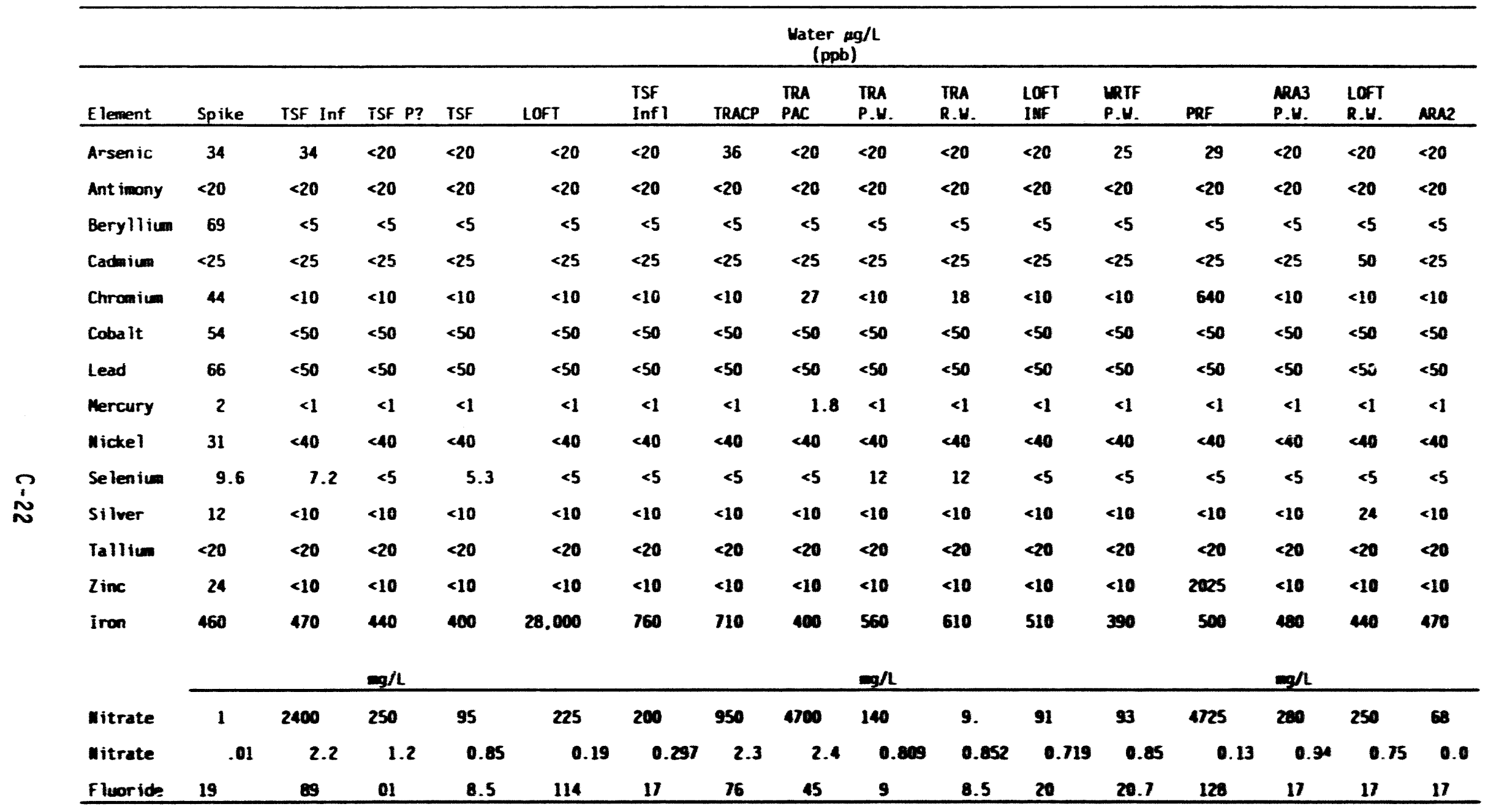




\section{INORGANIC ANALYSES IN WATER}

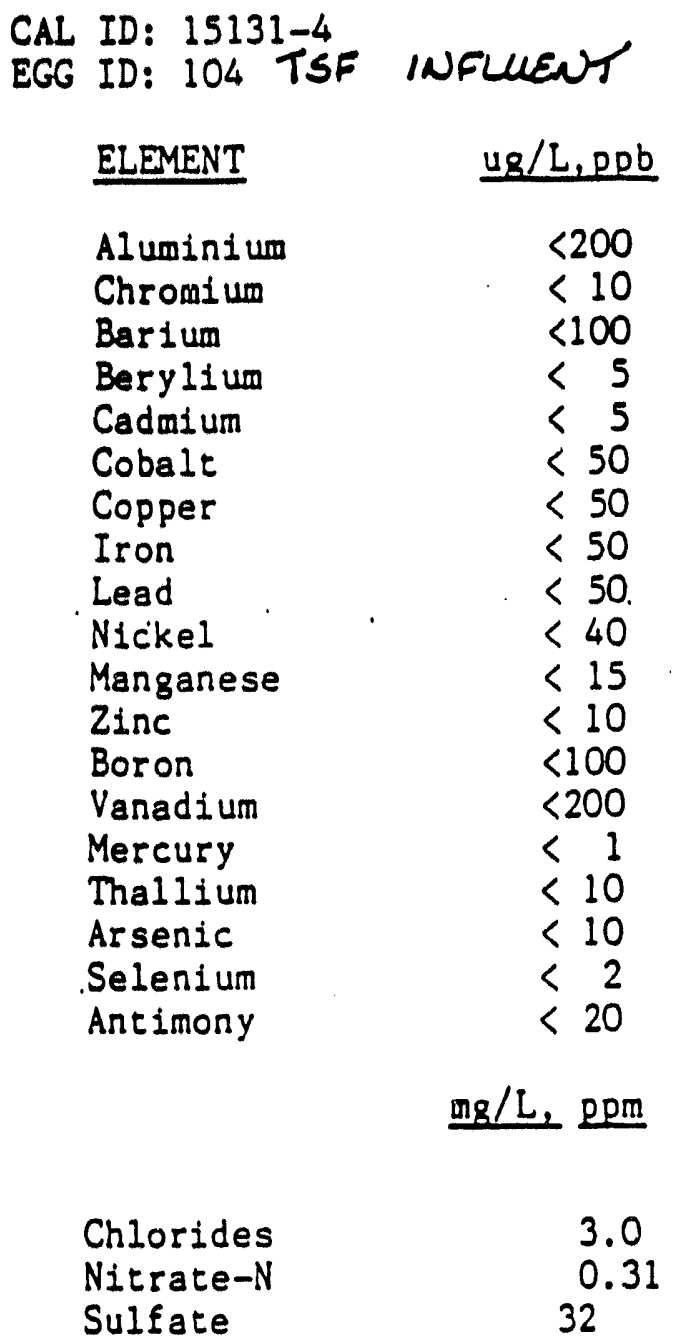

\section{C -23}




\title{
California Analytical Laboratories, Inc.
}

\author{
SEDS POWEA INN AOAD \\ SACAAMENTO. CALIFORNIA SSE24 \\ (O10) 301.510S
}

QIIEVT: E.G. \& G.

PP

\section{CAS \# VANTIES}

ug/

107-02-8 acrolein

ND

$3 \mathrm{~V} \quad 107-13-1$

4V 71-43-2

$6 \mathrm{~V}$ 56-23-5

TN 108-90-7

IOV 107-06-2

IIV 71-55-6

$13 \mathrm{~V} \quad 75-34-3$

$14 \mathrm{~V}$

$15 \mathrm{~V}$

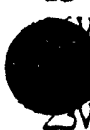

$29 \mathrm{~V}$

$30 \mathrm{~V}$

$32 \mathrm{~V}$

$33 \mathrm{~V} 10001-02-6$

$10061-01-5$

$38 \mathrm{~V} \quad 100-41-4$

$44 V \quad 75-09-2$

$45 \mathrm{~V} \quad 74-87-3$

$46 \mathrm{~V} 74-83-9$

47 75-25-2

$48 \mathrm{~V} \quad 75-27-4$

$49 \mathrm{~V} \quad 75-69-4$

SOV 75-71-8

$51 \mathrm{~V} 124-48-1$

$85 \mathrm{~V} \quad 127-18-6$

$86 \mathrm{~V} \quad 10 \mathrm{~s}-8 \mathrm{~s}-3$

$87 \mathrm{~V} 79-01-6$

$88 \mathrm{~V} 75-11-6$ beroerce

carban tetrachloride

chlorobenzene

1,2-dichloroethane

1,1,1-trichlorocthane

1,1-dichlorcethane

1,1,2-trichloroethane

chlorocthane

2-chloroethylvinyl ether

chloroform

1,1-dichloroethene

trans-1,2-dichloroethene

1,2-dichloropropane

trans-1,3-dichloropropene

cis-1,3-dichloropropene

ethylbenzene

methylene chloride

chloromethane

bramancthane

bromoform

bramodich loramethane

fluorotrichloramethane

dichlorodifluoromethane

chlorodibramanethane

tetrachloroethene

tolvene

trichlorocthone

vinyl chloride acrylonitrile ND

1, 1,2,2-tetrachloroet hane ND
CAL LAB NO: $15131-5$

ander I.D.: 105 TSF Poxd

ND-Not detected, *- detected below a detection limit of $10 \mathrm{gg} / \mathrm{L}$ (volatiles) and $0.1-1$. Oug/L (pesticides) 


\title{
California Analytical Laboratories, Inc.
}

\author{
SUSS POWER INN AOAD \\ SACRAMENTO. CALIFOANIA SSE24 \\ (016) 391.8105
}

QITENT: E.G. \& G.

\begin{tabular}{|c|c|c|c|}
\hline PP\# & CAs & VoutuES & ug/ \\
\hline $2 \mathrm{~V}$ & $107-02-8$ & acrolein & ND \\
\hline $3 \mathrm{~V}$ & $107-13-1$ & acrylonterile & ND \\
\hline $4 \mathrm{~V}$ & $71-43-2$ & beroene & ND \\
\hline $6 \mathrm{~V}$ & $56-23-5$ & carbon tetrachloride & $\frac{\pi}{N D}$ \\
\hline $7 N$ & $108-90-7$ & chloroberzene & ND \\
\hline $10 \mathrm{~V}$ & $107-06-2$ & 1,2-dichlotoethane & $\mathrm{ND}$ \\
\hline $11 \mathrm{~V}$ & $71-55-6$ & 1,1,1-trichlorocthane & $\sqrt{D}$ \\
\hline $13 \mathrm{~V}$ & $75-34-3$ & 1,1-dichloroethane & $\sqrt{N D}$ \\
\hline $14 \mathrm{~V}$ & $79-\infty-5$ & 1,1,2-trichloroethane & ND \\
\hline $15 \mathrm{~V}$ & $79-34-5$ & 1,1,2,2-tetrachloroethane & $\frac{100}{N D}$ \\
\hline $16 \mathrm{~V}$ & $75-\infty-3$ & chloroctrane & $\mathrm{ND}$ \\
\hline $19 \mathrm{~V}$ & $110-75-8$ & 2-chloroethylvimyl ether & $\mathrm{ND}$ \\
\hline $23 \mathrm{~V}$ & $67-66-3$ & chloroform & $\sqrt{10}$ \\
\hline $29 \mathrm{~V}$ & $75-35-4$ & 1,1-dichloroethene & $\frac{\mathrm{ND}}{\mathrm{ND}}$ \\
\hline $30 \mathrm{~V}$ & $156-60-5$ & trans-1,2-dichloroethene & $\frac{N}{N D}$ \\
\hline $32 \mathrm{~V}$ & $78-87-5$ & 1,2-dichloropropane & $\mathrm{ND}$ \\
\hline $33 \mathrm{~V}$ & $0061-02-6$ & trans-1,3-dichloropropene & $\mathrm{ND}$ \\
\hline & $0051-01-5$ & cis-1,3-dichlotopropene & ND \\
\hline $38 \mathrm{~V}$ & $100-41-4$ & ethylbenzene & $\sqrt{D}$ \\
\hline $44 \mathrm{~V}$ & $75-09-2$ & methylene chloride & $\mathrm{ND}$ \\
\hline $45 V$ & $74-87-3$ & chloramethane & $\overline{N D}$ \\
\hline $46 \mathrm{~V}$ & 74-83-9 & bramiancthene & $\overline{\mathrm{ND}}$ \\
\hline $4 \pi$ & $75-25-2$ & bramoform & $\overline{\mathrm{ND}}$ \\
\hline $48 \mathrm{~V}$ & $75-27-4$ & bramodich loramethane & $\overline{\mathrm{ND}}$ \\
\hline $49 \mathrm{~V}$ & $75-69-4$ & fluorotrichlorame thane & $\overline{\mathrm{ND}}$ \\
\hline $50 \mathrm{~V}$ & $75-71-8$ & dichlorodifluoramethene & $\overline{N D}$ \\
\hline $51 \mathrm{~V}$ & $124-48-1$ & chlorsdibromethane & $\overline{\mathrm{ND}}$ \\
\hline $85 V$ & $127-18-6$ & tetrachlotoethene & $\overline{\mathrm{ND}}$ \\
\hline $86 \mathrm{~V}$ & $108-89-3$ & toluese & $\overline{\mathrm{ND}}$ \\
\hline $8 \pi$ & $73-01-6$ & entchlorocthore & $\overline{\mathrm{ND}}$ \\
\hline $88 \mathrm{~V}$ & $75-01-6$ & vinyl chloride & $\overline{N D}$ \\
\hline
\end{tabular}

CAL LAB NO: $15131-6$

वrEN I.D.: 100 TSF PONA \#2

N-ilot detected, *- detected below a detection limit of $10 \mathrm{~g} / \mathrm{L}$ (volatiles) and $0.1-1.0_{\mathrm{g}} / \mathrm{L}$ (pesticides) 
INORGANIC ANALYSES IN WATER

CAL ID: $15131-5$
EGG ID: 105 TSF POND

\begin{tabular}{lr} 
ELEMENT & ug/L,ppb \\
\cline { 2 - 2 } Aluminium & $<200$ \\
-Cbromium & $<10$ \\
Barium & $<100$ \\
Berylium & $<5$ \\
Cadmium & $<5$ \\
Cobalt & $<50$ \\
Copper & $<50$ \\
Iron & 240 \\
Lead & $<50$ \\
Nickel & $<40$ \\
Manganese & $<16$ \\
Zinc & $<10$ \\
Boron & 30000 \\
Vanadium & $<200$ \\
Mercury & $<1$ \\
Thallium & $<10$ \\
Arsenic & $<10$ \\
Selenium & $<2$ \\
Antimony & $<20$
\end{tabular}

$\mathrm{mg} / \mathrm{L}, \mathrm{ppm}$

Chlorides

Nitrate-N

Sulfate

29

0.15

63

\section{C-26}


INORGANIC ANALYSES IN WATER

CAL ID: $15131-6$

EGG ID: 106 TSF POND

ELEMENT

Aluminium

Chromium

Barium

Berylium

Cadmium

Cobalt

Copper

Iron

Lead

Nickel

Manganese

Zinc

Boron

Vanadium

Mercury

Thallium

Arsenic

Seleniu

Antimony

Chlorides

Nitrate-iN

Sulfate
Ug/L,PpD

$<200$

$<10$

$<100$

$<5$

$<5$

$<50$

$<50$

110

$<50$

$<40$

$<15$

$<10$

30000

$<200$

$<1$

$<10$

$<10$

$<2$

$<20$

$\mathrm{ms} / \mathrm{L}, \mathrm{ppm}$

\section{2}

0.17

61 
APPENDIX D

ANALYTICAL RESULTS FOR SAMPLING

EVENT 2-PRELIMINARY ASSESSMENT 
APPENDIX D

ANALYTICAL RESULTS FOR SAMPLING

EVENT 2-PREL IMINARY ASSESSMENT

\section{ANALYTICAL DATA}

This appendix contains the analytical data for the TSF Disposal Pond soll samples, as reported in September of 1988 .

SUMMARY OF :NORGANICS AEOVE DETECTION FOR TSF OISPOSAL POND VOLATILE ORGANICS CREATER THAN BACKGROUND FOR TSF DISPOSAL POND TIC VOLATILES .. TSF DISPOSAL. POND INORGANICS

\begin{tabular}{lc} 
Sample No & - Lecation \\
\hline TSF078801 & $S 1$ \\
TSF078802 & $S 2$ \\
TSF078803 & $S 3$ \\
TSF078804 & $S 4$
\end{tabular}




\section{SUMMARY OF INORGANICS ABOVE DETECTION}

FOR TSF DISPOSAL POND

\begin{tabular}{|c|c|c|}
\hline Analyse & $\begin{array}{l}\text { Mean } \\
\text { Concen- } \\
\text { tration } \\
\text { (oom) }\end{array}$ & Qualifier \\
\hline $\begin{array}{l}\text { Antimony } \\
\text { Antimony } \\
\text { Arsente } \\
\text { Barlum } \\
\text { Beryllium } \\
\text { Cadmium } \\
\text { Chromium } \\
\text { Cobalt } \\
\text { Copper } \\
\text { Lead } \\
\text { Mercury } \\
\text { Nickel } \\
\text { Slliver } \\
\text { Thallium } \\
\text { Tin } \\
\text { Vanadium } \\
\text { Zinc }\end{array}$ & $\begin{array}{r}1.30 \\
0.95 \\
8.30 \\
186.75 \\
1.25 \\
6.90 \\
28.33 \\
7.57 \\
37.48 \\
21.45 \\
1012.02 \\
35.80 \\
3.30 \\
0.30 \\
977.00 \\
25.80 \\
254.75\end{array}$ & $\begin{array}{c}B \\
B W \\
B \\
B \\
B\end{array}$ \\
\hline
\end{tabular}

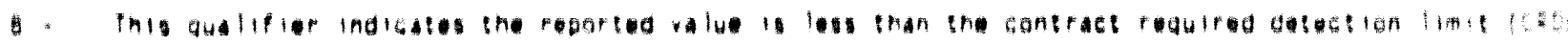

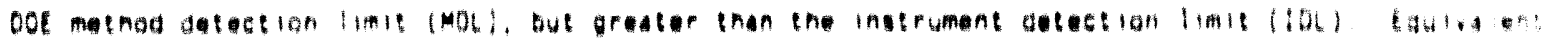

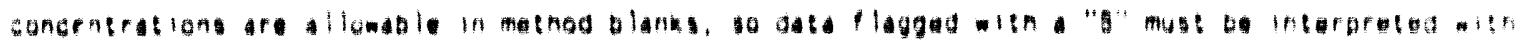
cantion

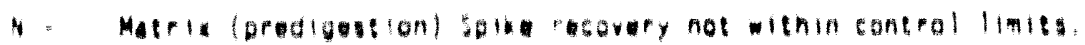

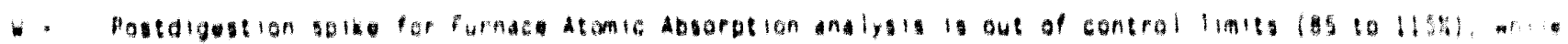

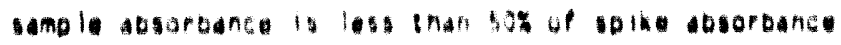




\begin{tabular}{lccc} 
Andlyte & Samele 10 & $\begin{array}{c}\text { Concen. } \\
\text { tration } \\
\text { CepbL }\end{array}$ Qualifier \\
\hline Dichlorodifluoromethane & TSF0788001 & 12 & \\
Methylene Chloride & TSF0788001 & 4 & BJ \\
Methylene Chloride & TSF0788002 & 3 & BJ \\
Methylene Chloride & TSF0788003 & 3 & BJ \\
Methylone Chloride & TSF0788004 & 5 & BJ
\end{tabular}

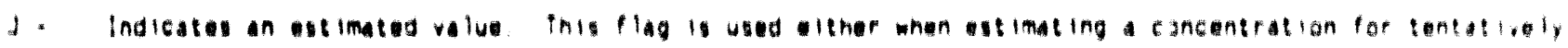

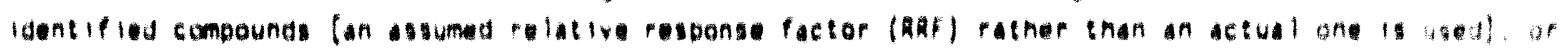

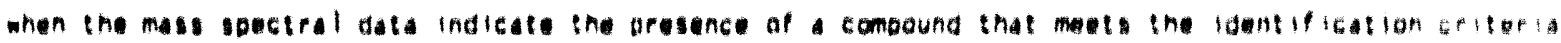
but the rebule in lese than the sample guaneltation limis (CRQL) for examble. if the sample

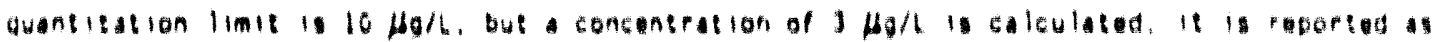

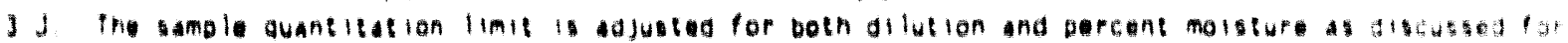
the $y+1,0$

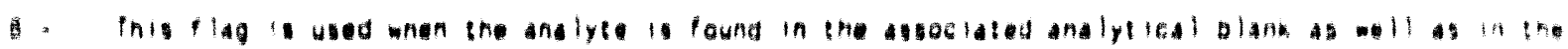

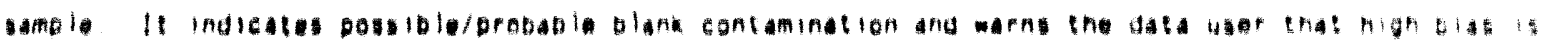

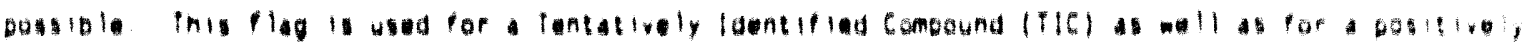

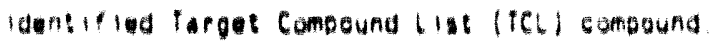

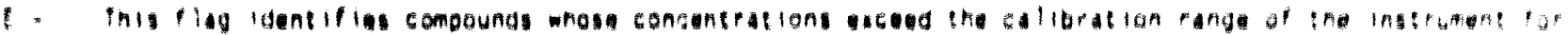
that souerfic ondyis

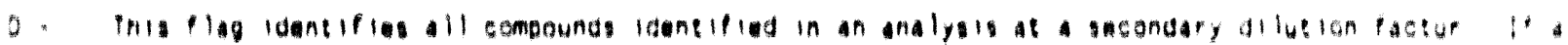

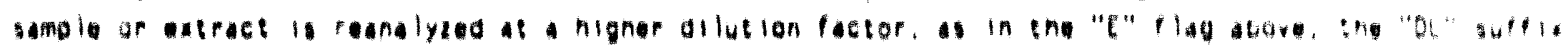

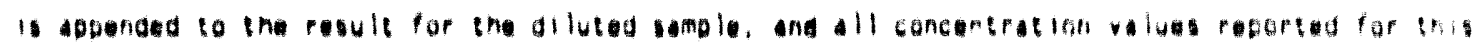

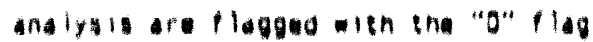




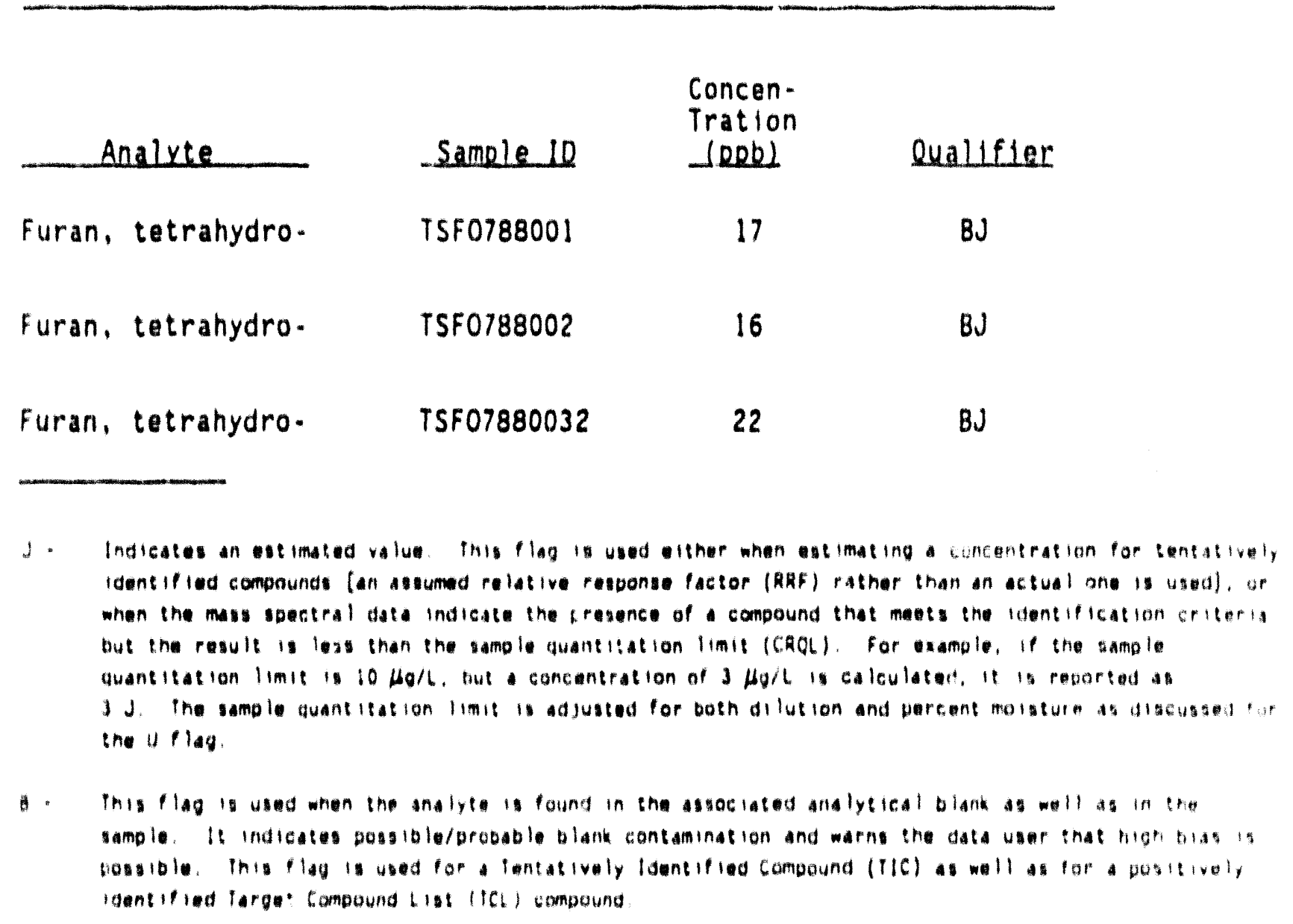


INORGANICS

\begin{tabular}{|c|c|c|c|}
\hline Analyte & Sample ID & $\begin{array}{l}\text { Concen- } \\
\text { tration } \\
\text { (oom) }\end{array}$ & Qualifier \\
\hline 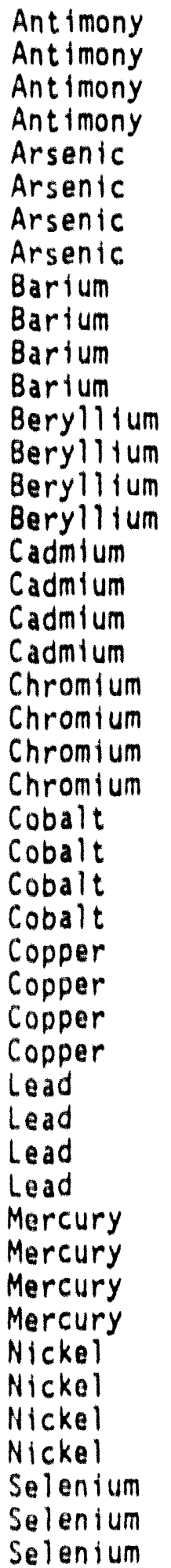 & 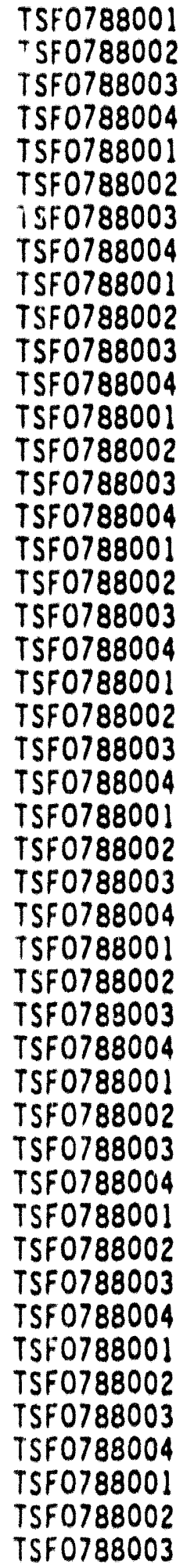 & $\begin{array}{r}1.2 \\
0.6 \\
0.7 \\
1.3 \\
1.7 \\
6.5 \\
12.5 \\
8.3 \\
191.0 \\
193.0 \\
17 . .0 \\
186.0 \\
1.0 \\
1.4 \\
1.2 \\
1.4 \\
7.2 \\
7.4 \\
6.3 \\
6.7 \\
31.8 \\
27.6 \\
26.9 \\
27.0 \\
6.6 \\
7.4 \\
5.2 \\
11.1 \\
31.5 \\
28.0 \\
54.9 \\
35.5 \\
26.1 \\
23.9 \\
19.0 \\
25.0 \\
1.2 \\
4040.0 \\
5.5 \\
1.4 \\
39.8 \\
38.9 \\
35.1 \\
29.4 \\
1.0 \\
1.0 \\
1.0\end{array}$ & $\begin{array}{l}S \\
+ \\
+ \\
N \\
N \\
N\end{array}$ \\
\hline
\end{tabular}




\section{INORGANICS (continued)}

\begin{tabular}{llrl} 
Analyte_ & Sample 10 & $\begin{array}{r}\text { Concen- } \\
\text { tration } \\
\text { IopmL }\end{array}$ & Qualifier \\
\hline Selenium & TSF0788004 & 1.0 & $U$ \\
Silver & TSF0788001 & 1.9 & $U$ \\
Siliver & TSF0788002 & 1.8 & $U$ \\
Silver & TSF0788003 & 2.5 & \\
Silver & TSF0788004 & 4.1 & $W$ \\
Thallium & TSF0788001 & 0.3 & UW \\
Thallium & TSF0788002 & 0.3 & UW \\
Thallium & TSF0788003 & 0.3 & \\
Thallium & TSF0788004 & 0.3 & \\
Tin & TSF0788001 & 886.0 & \\
Tin & TSF0788002 & 1150.0 & \\
Tin & TSF0788003 & 883.0 & \\
Tin & TSF0788004 & 989.0 & \\
Vanadium & TSF0788001 & 27.8 & \\
Vanadium & TSF0788002 & 26.3 & \\
Vanadium & TSF0788003 & 26.0 & \\
Vanadium & TSF0788004 & 27.1 & \\
Zine & TSF0788001 & 241.0 & \\
Zinc & TSF0788002 & 203.0 & \\
Zinc & TSF0788003 & 385.0 & \\
Zinc & TSF0788004 & 190.0 & \\
& & &
\end{tabular}

B - This qualifier indicates the reported value is less than the contract required detection limit (CROL) or DDE mathod detection limit (MOL), but greater than the instrument detection limit (IOL). Equivalent concentrations are allowable in method blanks, so data flagged with a " $B$ " must be interpreted with caution.

U. This qualifier indicates the analyte was analyzed for, but not detected at or above the IDL (e.9., a value of 150 indicates that the analyte was not present in concentrations equal to or greater than 15 $\mu_{g} / \mathrm{h}$ or $(5 \mathrm{mg} / \mathrm{kg})$. A dashed line. "...." is substituted for U-qualified data in the Section 4 results tables.

N- Matrix (predigestion) Spike recovery not within control limits.

$S$ - The raported value was determined by the Method of Standard Additions (MSA)

W - Postdigestion spike for Furnace Atomic Absorption and lys is is out of control $11 \mathrm{mits}(85$ to $115 \%$ ). while sample absorbance is less than $50 \%$ of spike absorbance.

- Correlation coefficient for the MSA is less than 0.995 . 


\section{APPENDIX E}

ANALYTICAL RESULTS FOR SAMPLING

EVENT 3-DOE-HQ INVESTIGATION

$E-1$ 
DOE Headquarters Environmental IMEL Survey Data SH Data Document - June 1988 - Validatior. Level B

Table E-1. Analytical data summary by medium for Environmental Problem 3 leaching ponds.

\begin{tabular}{|c|c|c|c|c|c|}
\hline $\begin{array}{l}\text { AREA } \\
\text { LOCAT ION } \\
\text { TYPE OF LOCATION } \\
\text { SAMPLE MUUBER } \\
\text { MEDIA } \\
\text { UNIIS } \\
\text { SOG MUMBER } \\
\end{array}$ & $\begin{array}{r}\text { TSF } \\
\text { TAN/ISF-07 } \\
\text { DISPOSAL POWD } \\
\text { INS10015A } \\
\text { WATER } \\
\text { Ug/L } \\
\text { INSI30180 } \\
\end{array}$ & $\begin{array}{r}\text { TSF } \\
\text { IAM/ISF-07 } \\
\text { DISPOSAL POOED } \\
\text { INS10015A } \\
\text { UAIER } \\
\text { Ug/L } \\
\text { INS10015A } \\
\end{array}$ & $\begin{array}{r}\text { TSF } \\
\text { TAN/TSF-0? } \\
\text { DISPOSAL POWD } \\
\text { INS10015B } \\
\text { WAIER } \\
\text { U9/2 } \\
\text { IN4010131 } \\
\end{array}$ & 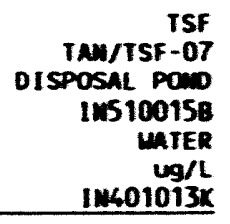 & $\begin{array}{r}\text { TSF } \\
\text { TAM/TSF-07 } \\
\text { DISPOSAL POND } \\
\text { INS } 10026 A \\
\text { UATER } \\
\text { Ug/h } \\
\text { INS130180 } \\
\end{array}$ \\
\hline $\begin{array}{l}\text { FIELD MEASUREMENTS } \\
\text { pH } \\
\text { Conductivity (ms/cm) } \\
\text { Temperature (c) } \\
\text { Depth (ft) }\end{array}$ & $\begin{array}{r}9.3 \\
0.76 \\
18.0 \\
1.5\end{array}$ & $\begin{array}{r}9.3 \\
0.76 \\
18.0 \\
1-5\end{array}$ & $\begin{array}{r}9.3 \\
0.76 \\
18.0 \\
1-5\end{array}$ & $\begin{array}{r}9.3 \\
0.76 \\
18.0 \\
1.5\end{array}$ & $\begin{array}{r}8.7 \\
0.58 \\
18.0 \\
1.5\end{array}$ \\
\hline $\begin{array}{l}\text { AmaLYIES } \\
\text { Aliminum } \\
\text { Ant imony } \\
\text { Arsenic } \\
\text { Barium } \\
\text { Beryllicas }\end{array}$ & & & $\begin{array}{c}3850 \\
\cdots \\
72.0 \\
3.3 \\
3.3\end{array}$ & & \\
\hline $\begin{array}{l}\text { Cadmium } \\
\text { Calcium } \\
\text { Chromiun } \\
\text { Chromium+6 } \\
\text { Cobalt }\end{array}$ & $5.8 \mathrm{gJ}$ & & $\begin{array}{c}51400 \\
9.18 \\
\ldots\end{array}$ & & $2.0 \mathrm{BJ}$ \\
\hline $\begin{array}{l}\text { Ccpper } \\
\text { lron } \\
\text { Lead } \\
\text { Magnesiu } \\
\text { Manganese }\end{array}$ & & & $\begin{array}{c}12.0 \mathrm{~g} \\
3720 \\
10100 \\
12.0\end{array}$ & & \\
\hline $\begin{array}{l}\text { Mercury } \\
\text { wickel } \\
\text { Potassium } \\
\text { Seleniu } \\
\text { Silver }\end{array}$ & & 0.028 & $\begin{array}{c}11.0 \mathrm{~s} \\
\ldots \\
\ldots\end{array}$ & 6790 & \\
\hline $\begin{array}{l}\text { Sodiu } \\
\text { Vanadiu } \\
\text { Zinc }\end{array}$ & & & $\begin{array}{l}9500 \\
22.0 \\
57.0\end{array}$ & & \\
\hline 2 Solids & & & & & \\
\hline $5-18-93$ & & & & & \\
\hline
\end{tabular}


DOE Headquarters Emironmental IMEL Survey Data S\&A Data Document - June 1988 - Validation Level B

Table E-1. (continued).

\begin{tabular}{|c|c|c|c|c|c|}
\hline $\begin{array}{l}\text { AREA } \\
\text { LOCATION } \\
\text { IYPE OF LOCATION } \\
\text { SAMPLE NUMBER } \\
\text { MEDIA } \\
\text { UNI IS } \\
\text { SDG NUMBER } \\
\end{array}$ & $\begin{array}{r}\text { TSF } \\
\text { TAN/TSF-07 } \\
\text { DISPOSAL POND } \\
\text { INS10026A } \\
\text { HATER } \\
\text { Ug/L } \\
\text { IN510015A } \\
\end{array}$ & $\begin{array}{r}\text { TSF } \\
\text { TAN/TSF-07 } \\
\text { DISPOSAL POND } \\
\text { IN510026B } \\
\text { WATER } \\
\text { Ug/L } \\
\text { IN401013I } \\
\end{array}$ & $\begin{array}{r}\text { TSF } \\
\text { TAN/TSF-07 } \\
\text { DISPOSAL POND } \\
\text { IHS } 100268 \\
\text { HATER } \\
\text { Ug/L } \\
\text { IN401013KK }\end{array}$ & $\begin{array}{r}\text { TSF } \\
\text { TAN/TSF-07 } \\
\text { DISPOSAL POND } \\
\text { IN510048A } \\
\text { UATER } \\
\text { Ug/L } \\
\text { IN5130180 } \\
\end{array}$ & $\begin{array}{r}\text { TSF } \\
\text { TAN/TSF-07 } \\
\text { DISPOSAL POAD } \\
\text { INS 10048A } \\
\text { WATER } \\
\text { Ug/L } \\
\text { IN510015A } \\
\end{array}$ \\
\hline \multicolumn{6}{|l|}{ FIELD MEASUREMENTS } \\
\hline $\begin{array}{l}\text { pH } \\
\text { Conductivity (mS/cm) } \\
\text { Temperature (C) } \\
\text { Depth }(\mathrm{ft})\end{array}$ & $\begin{array}{r}8.7 \\
0.58 \\
18.0 \\
1-5\end{array}$ & $\begin{array}{r}8.7 \\
0.58 \\
18.0 \\
1-5\end{array}$ & $\begin{array}{r}8.7 \\
0.58 \\
18.0 \\
1-5\end{array}$ & $\begin{array}{r}9.5 \\
0.76 \\
18.0 \\
1.5\end{array}$ & $\begin{array}{r}9.5 \\
0.76 \\
18.0 \\
1-5\end{array}$ \\
\hline $\begin{array}{l}\text { ANALYTES } \\
\text { Aluminum } \\
\text { Antimony } \\
\text { Arsenic } \\
\text { Barium } \\
\text { Beryllium }\end{array}$ & & $\begin{aligned} 791 \\
\cdots . . \\
90.0 \\
2.5 \text { B }\end{aligned}$ & & & \\
\hline $\begin{array}{l}\text { Cadmium } \\
\text { Calcium } \\
\text { Chromium } \\
\text { Chromium+6 } \\
\text { Cobalt }\end{array}$ & & $\begin{array}{r}56700 \\
28.0 \\
\ldots\end{array}$ & & $18.6 \mathrm{~J}$ & \\
\hline $\begin{array}{l}\text { Copper } \\
\text { I ron } \\
\text { Lead } \\
\text { Magnesium } \\
\text { Manganese }\end{array}$ & & $\begin{array}{c}13.0 \mathrm{~B} \\
616 \\
\cdots \\
17200 \\
28.0\end{array}$ & & & \\
\hline $\begin{array}{l}\text { Mercury } \\
\text { Nickel } \\
\text { Potassium } \\
\text { Selenium } \\
\text { Silver }\end{array}$ & 0.42 & $\begin{array}{l}15.0 \mathrm{~B} \\
\cdots \\
\cdots\end{array}$ & 5600 & & 0.048 \\
\hline $\begin{array}{l}\text { Sodium } \\
\text { Vanadium } \\
\text { Zinc }\end{array}$ & & $\begin{array}{c}50600 \\
17.0 \mathrm{~B} \\
124\end{array}$ & & & \\
\hline
\end{tabular}

\% Solids

5-18-93 
DOE Headquarters Environmental INEL Survey Data S\&A Data Document - June 1988 - Validation Level B

Table E-1. (continued).

\begin{tabular}{|c|c|c|c|c|c|}
\hline $\begin{array}{l}\text { AREA } \\
\text { LOCATION } \\
\text { TYPE OF LOCATION } \\
\text { SAMPLE NUMBER } \\
\text { MEDIA } \\
\text { UNITS }\end{array}$ & $\begin{array}{r}\text { TSF } \\
\text { TAN } / T S F-07 \\
\text { DISPOSAL POND } \\
\text { IN510048B } \\
\text { WATER } \\
\mathrm{Ug} / \mathrm{L}\end{array}$ & $\begin{array}{r}\text { TSF } \\
\text { TAN/TSF-07 } \\
\text { DISPOSAL POND } \\
\text { IN5 10048B } \\
\text { HATER } \\
\text { Ug/L }\end{array}$ & $\begin{array}{r}\text { TSF } \\
\text { TAN/TSF-07 } \\
\text { DISPOSAL POND } \\
\text { IN510059A } \\
\text { WATER } \\
\text { Ug/L }\end{array}$ & $\begin{array}{r}\text { TSF } \\
\text { TAN/TSF-07 } \\
\text { DISPOSAL POND } \\
\text { INS10059A } \\
\text { WATER } \\
\text { Ug/L }\end{array}$ & $\begin{array}{r}\text { TSF } \\
\text { TAN/TSF-07 } \\
\text { DISPOSAL POND } \\
\text { IN5 10059B } \\
\text { WATER } \\
\text { Ug/L }\end{array}$ \\
\hline SDG NUMBER & IN401013I & IN401013K & IN5130180 & IN510015A & IN4010131 \\
\hline $\begin{array}{l}\text { FIELD MEASUREMENTS } \\
\text { pH } \\
\text { Conductivity }(\mathrm{mS} / \mathrm{cm}) \\
\text { Temperature (c) } \\
\text { Depth }(\mathrm{ft})\end{array}$ & $\begin{array}{r}9.5 \\
0.76 \\
18.0 \\
1-5\end{array}$ & $\begin{array}{r}9.5 \\
0.76 \\
18.0 \\
1-5\end{array}$ & $\begin{array}{r}8.7 \\
0.58 \\
18.0 \\
1.5\end{array}$ & $\begin{array}{r}8.7 \\
0.58 \\
18.0 \\
1.5\end{array}$ & $\begin{array}{r}8.7 \\
0.58 \\
18.0 \\
1.5\end{array}$ \\
\hline $\begin{array}{l}\text { ANALYTES } \\
\text { Aluminum } \\
\text { Antimony } \\
\text { Arsenic } \\
\text { Barium } \\
\text { Beryllium }\end{array}$ & $\begin{array}{c}15500 \\
-.- \\
-. \\
241 \\
4.4 \mathrm{~B}\end{array}$ & & & & $\begin{array}{l}1140 \\
\cdots .- \\
\cdots 14 \\
114 \\
2.8 \\
8\end{array}$ \\
\hline $\begin{array}{l}\text { Cadmium } \\
\text { Calcium } \\
\text { Chromium } \\
\text { Chromium+6 } \\
\text { Cobalt }\end{array}$ & $\begin{array}{c}1.1 \mathrm{~B} \\
70600 \\
42.0 \\
6.0 \mathrm{~B}\end{array}$ & & $3.4 \mathrm{BJ}$ & & $\begin{array}{c}66800 \\
6.8 \mathrm{~B} \\
\ldots\end{array}$ \\
\hline $\begin{array}{l}\text { Copper } \\
\text { Iron } \\
\text { Lead } \\
\text { Magnesium } \\
\text { Manganese }\end{array}$ & $\begin{array}{r}102 \\
17600 \\
21- \\
24900 \\
217\end{array}$ & & & & $\begin{array}{c}19.0^{B} \\
1010^{-1} \\
17000 \\
53.0\end{array}$ \\
\hline $\begin{array}{l}\text { Mercury } \\
\text { Nickel } \\
\text { Potassium } \\
\text { Selenium } \\
\text { Silver }\end{array}$ & $\begin{array}{l}29.0 \mathrm{~B} \\
35.0\end{array}$ & 11000 & & $0.14 \mathrm{~B}$ & $\cdots$ \\
\hline $\begin{array}{l}\text { Sodium } \\
\text { Vanadium } \\
\text { Zinc }\end{array}$ & $\begin{array}{c}106000 \\
48.0 \mathrm{~B} \\
389\end{array}$ & & & & $\begin{array}{c}46900 \\
21.0 \mathrm{~B} \\
90.0\end{array}$ \\
\hline \multicolumn{6}{|l|}{$\%$ Solids } \\
\hline $5-18-93$ & & & & & \\
\hline
\end{tabular}


DOE Headquarters Environmental INEL Survey Data S\&A Data Document - June 1988 - Validation Level B

Table E-1. (continued).

\begin{tabular}{|c|c|c|c|c|c|}
\hline $\begin{array}{l}\text { AREA } \\
\text { LOCATION } \\
\text { TYPE OF LOCATION } \\
\text { SAMPLE NUMBER } \\
\text { MEDIA } \\
\text { UNITS } \\
\text { SDG NUMBER } \\
\end{array}$ & $\begin{array}{r}\text { TSF } \\
\text { IAN/TSF-07 } \\
\text { DISPOSAL POND } \\
\text { INS 10059B } \\
\text { WATER } \\
\text { Ug/L } \\
\text { IN401013K } \\
\end{array}$ & $\begin{array}{r}\text { TSF } \\
\text { TAN/TSF-07 } \\
\text { DISPOSAL POND } \\
\text { IN510253A } \\
\text { WATER } \\
\text { Ug/L } \\
\text { INS13018D } \\
\end{array}$ & $\begin{array}{r}\text { TSF } \\
\text { TAN/TSF-07 } \\
\text { DISPOSAL POND } \\
\text { IN5 10253A } \\
\text { WATER } \\
\text { ug/ } / \mathrm{L} \\
\text { INS10015A } \\
\end{array}$ & $\begin{array}{r}\text { TSF } \\
\text { TAN/TSF-07 } \\
\text { DISPOSAL POND } \\
\text { INS PO253B } \\
\text { UATER } \\
\text { Ug/L } \\
\text { IN4010131 } \\
\end{array}$ & $\begin{array}{r}\text { TSF } \\
\text { TAN/TSF-07 } \\
\text { DISPOSAL POND } \\
\text { IN510253B } \\
\text { WATER } \\
\text { Ug/L } \\
\text { IN401013K } \\
\end{array}$ \\
\hline $\begin{array}{l}\text { FIELD MEASUREMENTS } \\
\text { pH } \\
\text { Conductivity (mS/cm) } \\
\text { Temperature (C) } \\
\text { Depth ( } \mathrm{ft})\end{array}$ & $\begin{array}{r}8.7 \\
0.58 \\
18.0 \\
1.5\end{array}$ & $1-5$ & $1-5$ & $1-5$ & $1-5$ \\
\hline $\begin{array}{l}\text { ANALYTES } \\
\text { Alluminum } \\
\text { Antimony } \\
\text { Arsenic } \\
\text { Barium } \\
\text { Beryllium }\end{array}$ & & & & $\begin{array}{c}304 \\
\cdots \\
12.0 \\
\cdots\end{array}$ & \\
\hline $\begin{array}{l}\text { Cadmium } \\
\text { Calcium } \\
\text { Chromium } \\
\text { Chromium+6 } \\
\text { Cobalt }\end{array}$ & & $31.0 \mathrm{~J}$ & & $\begin{array}{l}1330 \text { B } \\
20.0 \\
\ldots\end{array}$ & \\
\hline $\begin{array}{l}\text { Copper } \\
\text { I ron } \\
\text { Lead } \\
\text { Magnes ium } \\
\text { Manganese }\end{array}$ & & & & $\begin{array}{l}78.0 \\
300 \\
2088 \\
9.7 \mathrm{~B}\end{array}$ & \\
\hline $\begin{array}{l}\text { Mercury } \\
\text { Nickel } \\
\text { Potassium } \\
\text { Selenium } \\
\text { Silver }\end{array}$ & 5500 & & $0.08 \mathrm{~B}$ & $\begin{array}{c}14.0 \mathrm{~B} \\
\ldots \\
\ldots\end{array}$ & $400 \mathrm{~B}$ \\
\hline $\begin{array}{l}\text { Sodium } \\
\text { Vanadium } \\
\text { Zinc }\end{array}$ & & & & $\begin{array}{l}\cdots \\
358\end{array}$ & \\
\hline
\end{tabular}

$\%$ solids

5-18-93 
DOE Headquarters Environmental INEL Survey Data S\&A Data Document - June 1988 - Validation Level B

Table E-1. (continued).

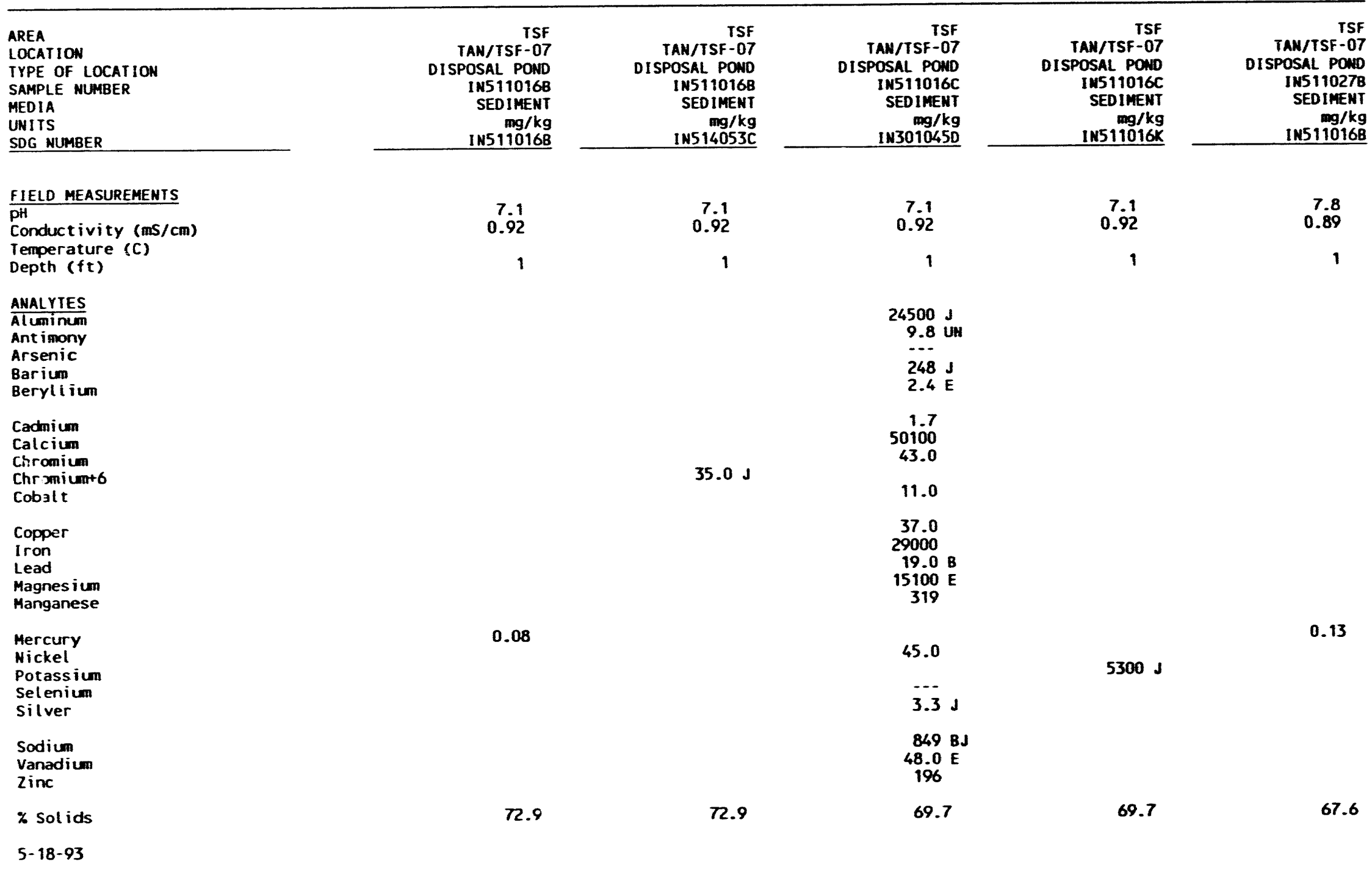


DOE Headquarters Environmental IWEL Survey Data S\&A Data Document - June 1988 - Validation Level B

Table E-1. (continued).

\begin{tabular}{|c|c|c|c|c|c|}
\hline $\begin{array}{l}\text { AREA } \\
\text { LOCATION } \\
\text { IYPE OF LOCATION } \\
\text { SAMPLE MUMBER } \\
\text { MEDIA } \\
\text { UNIIS } \\
\text { SOG MUMBER } \\
\end{array}$ & $\begin{array}{r}\text { TSF } \\
\text { TAN/TSF-D7 } \\
\text { DISPOSAL POND } \\
\text { INSI11027B } \\
\text { SED IMENT } \\
\text { mg/kg } \\
\text { INS16053C } \\
\end{array}$ & $\begin{array}{r}\text { TSF } \\
\text { IAM/TSFF-07 } \\
\text { DISPOSAL POWD } \\
\text { IMS11027C } \\
\text { SED IMENT } \\
\text { mg/kg } \\
\text { IN3010450 } \\
\end{array}$ & $\begin{array}{r}\text { TSF } \\
\text { TAH/ISF-07 } \\
\text { DISPOSAL POND } \\
\text { INS11027C } \\
\text { SEDIIHENT } \\
\text { m/kg } \\
\text { INS11016K } \\
\end{array}$ & $\begin{array}{r}\text { TSF } \\
\text { TAN/TSF-07 } \\
\text { DISPOSAL POWD } \\
\text { INSI110498 } \\
\text { SED IMENT } \\
\text { mg/kg } \\
\text { INS110168 } \\
\end{array}$ & $\begin{array}{r}\text { TSF } \\
\text { TAM/TSF-07 } \\
\text { DISPOSAL POWD } \\
\text { IUS110498 } \\
\text { SED IMENT } \\
\text { mg/kg } \\
\text { IUS14053C }\end{array}$ \\
\hline $\begin{array}{l}\text { FIELD MEASUREMENTS } \\
\text { PH } \\
\text { Conductivity (wS/cm) } \\
\text { Temperature (C) } \\
\text { Depth ( } f t)\end{array}$ & $\begin{array}{r}7.8 \\
0.89 \\
1\end{array}$ & $\begin{array}{r}7.8 \\
0.89 \\
1\end{array}$ & $\begin{array}{r}7.8 \\
0.89 \\
1\end{array}$ & $\begin{array}{r}7.9 \\
0.81 \\
1\end{array}$ & $\begin{array}{r}7.9 \\
0.81 \\
1\end{array}$ \\
\hline $\begin{array}{l}\text { A AlityES } \\
\text { Aluminum } \\
\text { Antimory } \\
\text { Arsenic } \\
\text { Barium } \\
\text { Beryllium }\end{array}$ & & \begin{tabular}{c}
$17100 \mathrm{~J}$ \\
$9.0 \mathrm{UW}$ \\
\hdashline $222 \mathrm{~J}$ \\
$2.1 \mathrm{E}$
\end{tabular} & & & \\
\hline $\begin{array}{l}\text { Cadmium } \\
\text { Calcium } \\
\text { Chromican } \\
\text { Chromiunt6 } \\
\text { Cobalt }\end{array}$ & $29.1 \mathrm{~J}$ & $\begin{array}{r}1.3 \\
76700 \\
33.0 \\
9.8\end{array}$ & & & $39.4 \mathrm{~d}$ \\
\hline $\begin{array}{l}\text { Copper } \\
\text { Iron } \\
\text { Lead } \\
\text { Magnesium } \\
\text { Manganese }\end{array}$ & & $\begin{array}{c}37.0 \\
26700 \\
19.0 \mathrm{~B} \\
14600 \mathrm{E} \\
480\end{array}$ & & & \\
\hline $\begin{array}{l}\text { Mercury } \\
\text { Mickel } \\
\text { Potassium } \\
\text { Selenium } \\
\text { Silver }\end{array}$ & & $\begin{array}{l}36.0 \\
3.5 \mathrm{~d}\end{array}$ & $3500 \mathrm{~J}$ & 1.7 & \\
\hline $\begin{array}{l}\text { Sodium } \\
\text { vanadium } \\
\text { Zinc }\end{array}$ & & $\begin{array}{l}599 \mathrm{BJ} \\
48.0 \mathrm{E} \\
137\end{array}$ & & & \\
\hline z Sol ids & 67.6 & 76.0 & 76.0 & 46.4 & 46.4 \\
\hline
\end{tabular}

5-18-93 
DOE Headquarters Emirormental Inel Survey Data Su Data Document - June 1983 - Validation Level

Table E-1. (continued).

\begin{tabular}{|c|c|c|c|c|c|}
\hline $\begin{array}{l}\text { AREA } \\
\text { LOCATION } \\
\text { IYFE OF LOCATION } \\
\text { SAMPLE WREER } \\
\text { MEDIA } \\
\text { UWIIS } \\
\text { SOG UMBER } \\
\end{array}$ & 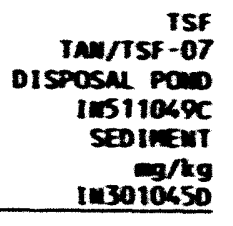 & 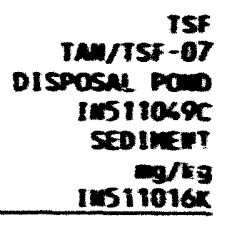 & 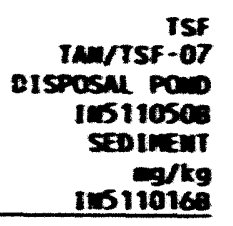 & 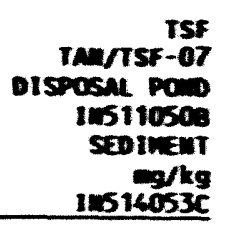 & 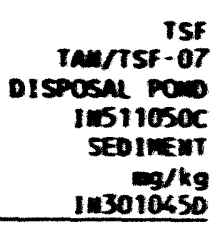 \\
\hline \multicolumn{6}{|l|}{ FIELD KEASUREAEMIS } \\
\hline $\begin{array}{l}\text { Conductivity (as/Ca) } \\
\text { Temperature (C) }\end{array}$ & $\begin{array}{l}7.9 \\
0.81\end{array}$ & $\begin{array}{r}79 \\
0.81\end{array}$ & $\begin{array}{l}7.1 \\
0.68\end{array}$ & $\begin{array}{r}7.1 \\
0.68\end{array}$ & $\begin{array}{l}7.1 \\
0.60\end{array}$ \\
\hline Depth ( $f(t)$ & 1 & 1 & 1 & 1 & 1 \\
\hline $\begin{array}{l}\text { amerifs } \\
\text { Alwine } \\
\text { antimony } \\
\text { Arsenic } \\
\text { Bariu } \\
\text { Berviliu }\end{array}$ & \begin{tabular}{c}
$21300 \mathrm{~J}$ \\
$11.0 \mathrm{U}$ \\
\hdashline $226 \mathrm{~J}$ \\
$2.3 \mathrm{E}$
\end{tabular} & & & & $\begin{array}{c}15400 \mathrm{~J} \\
11.0 \mathrm{in} \\
\ldots 212 \mathrm{~J} \\
2.1 \mathrm{E}\end{array}$ \\
\hline 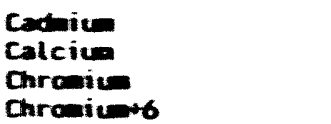 & $\begin{array}{r}1.6 \\
30200 \\
42.0\end{array}$ & & & 205 & $\begin{array}{r}1.4 \\
69200 \\
32.0\end{array}$ \\
\hline Cobalt & $10.0=$ & & & $2 \pi+3$ & 9.15 \\
\hline $\begin{array}{l}\text { Copper } \\
\text { iron } \\
\text { lead } \\
\text { magnes iun } \\
\text { manganese }\end{array}$ & $\begin{array}{c}78.0 \\
20200 \\
21.0 \\
15500 \mathrm{E} \\
202\end{array}$ & & & & $\begin{array}{c}50.0 \\
23700 \\
16.0 \\
14600 \mathrm{E} \\
361\end{array}$ \\
\hline $\begin{array}{l}\text { Mercury } \\
\text { wicket }\end{array}$ & 4.0 & & 0.13 & & \\
\hline $\begin{array}{l}\text { Potassium } \\
\text { Setenic }\end{array}$ & $-\infty$ & $5000 \mathrm{~J}$ & & & 36.2 \\
\hline silver & $26.0 \mathrm{~J}$ & & & & 9.01 \\
\hline $\begin{array}{l}\text { Sodice } \\
\text { vanadiu } \\
\text { Zinc }\end{array}$ & $\begin{array}{l}238 \mathrm{E} \\
22.03\end{array}$ & & & & $\begin{array}{c}591 \mathrm{E} \\
40.6 \mathrm{E} \\
202\end{array}$ \\
\hline 2 solids & 56.8 & 54.8 & 70.3 & $\mathbf{7 0 . 3}$ & $\infty .0$ \\
\hline
\end{tabular}

5-18-93 


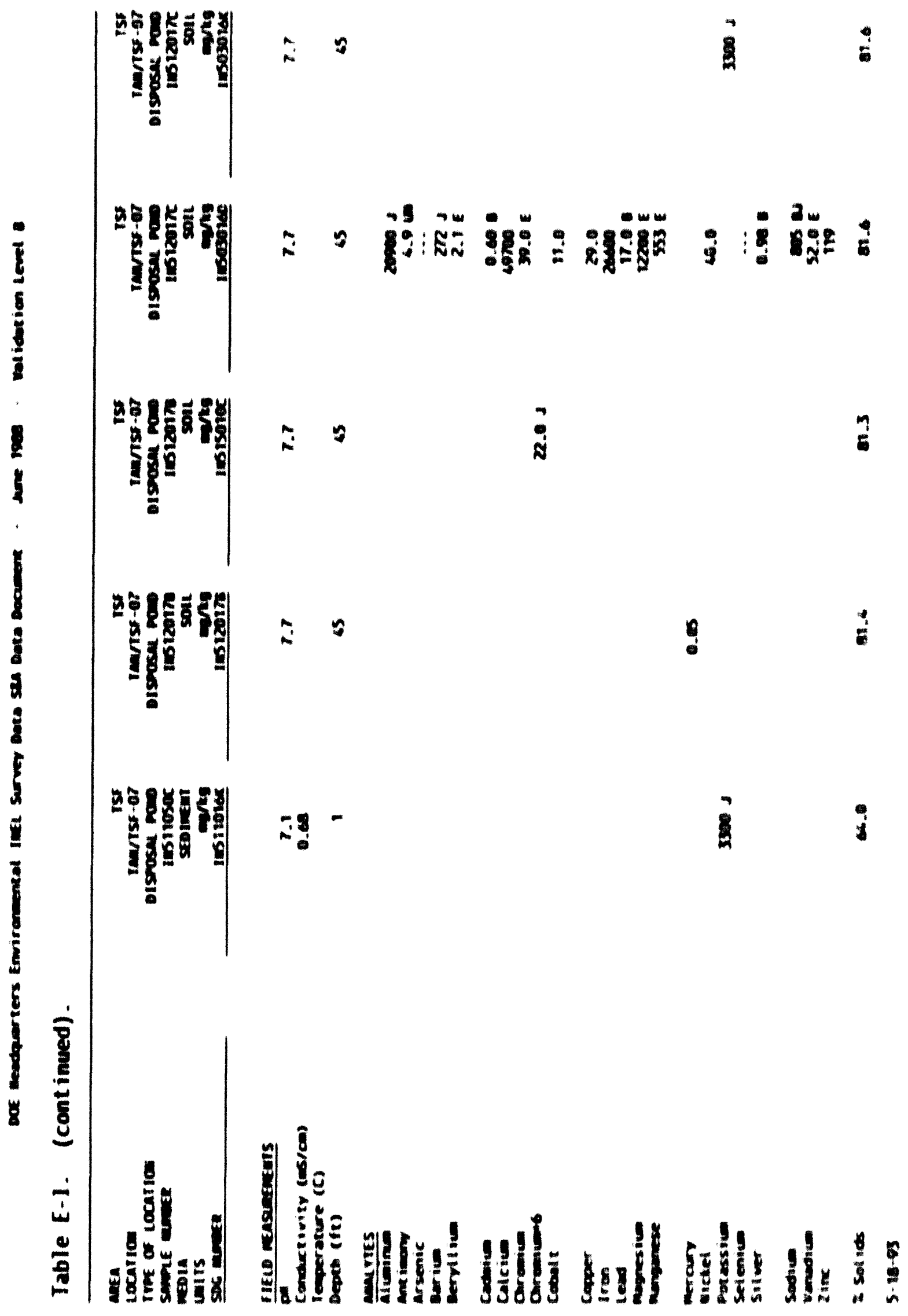




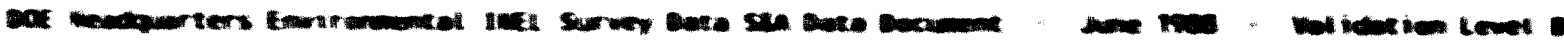

Table E-1. (cont inued).

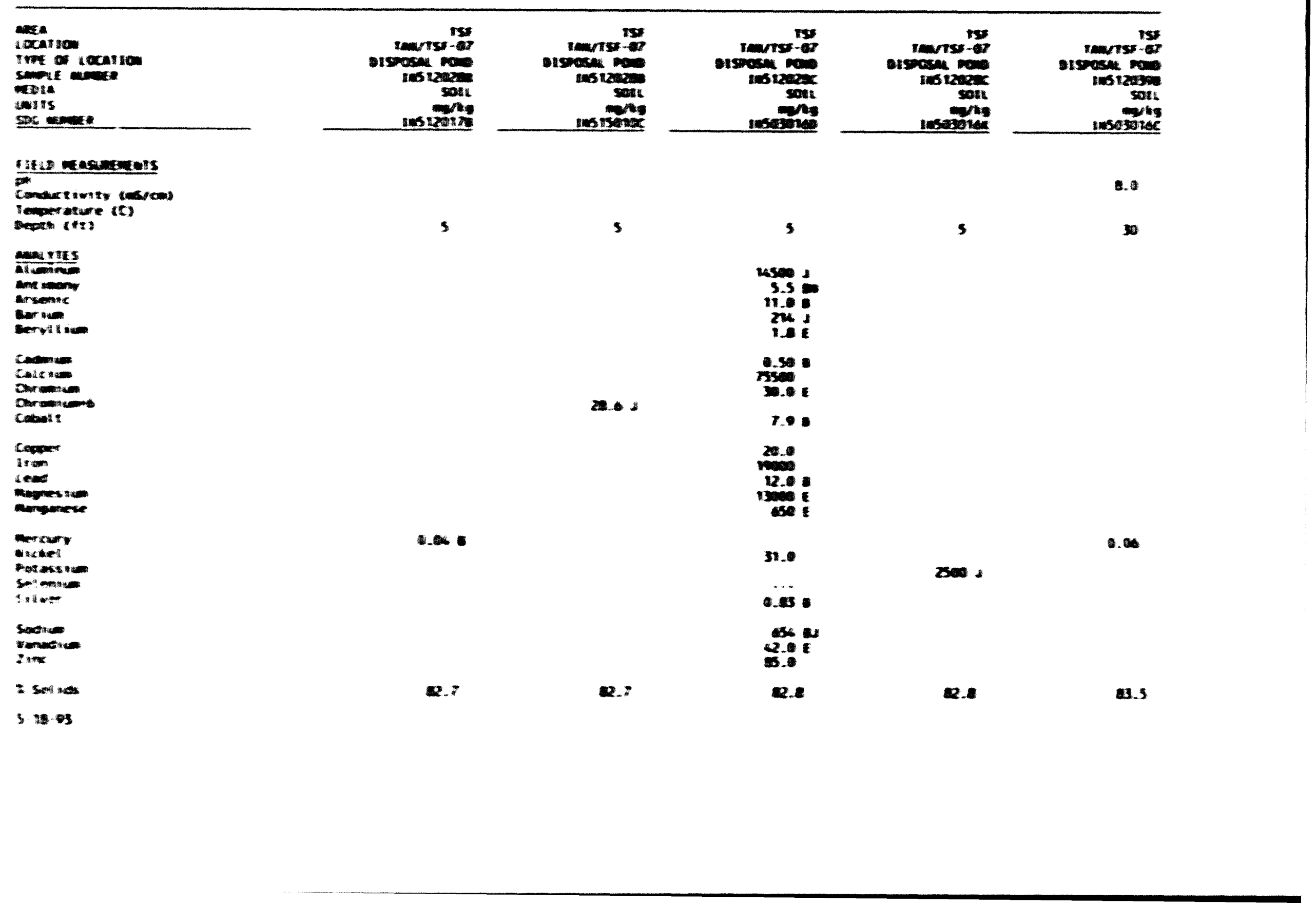




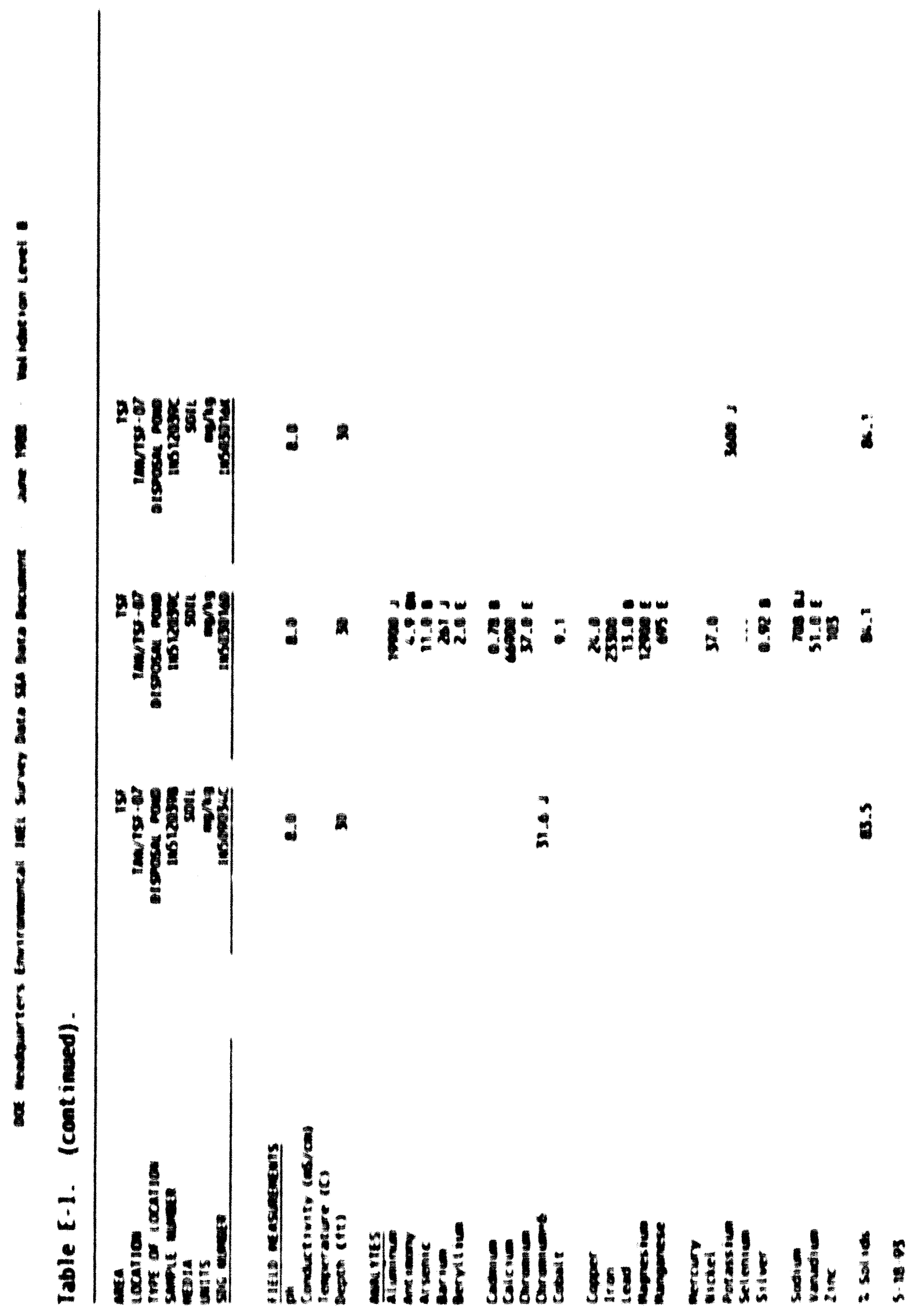




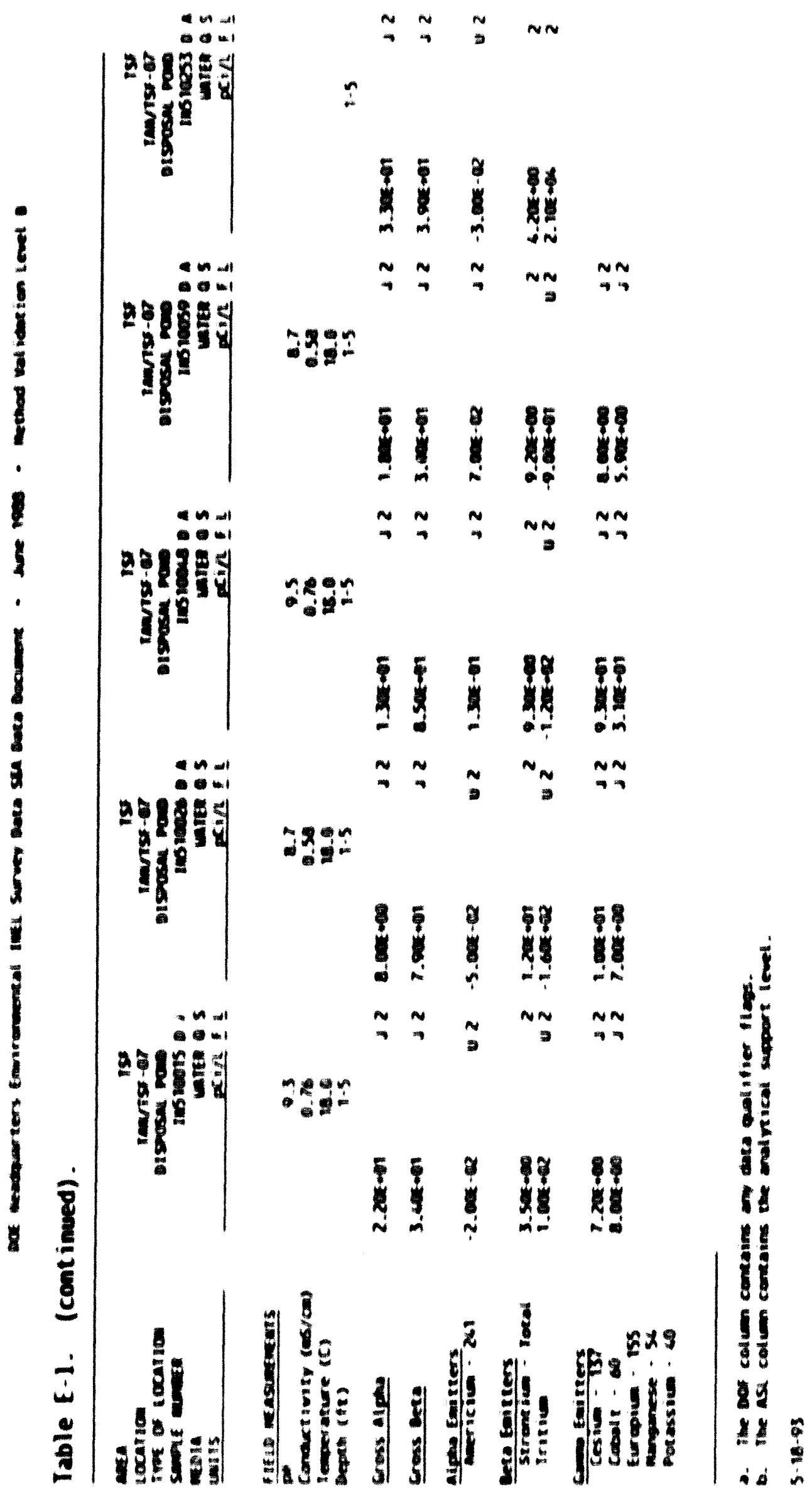




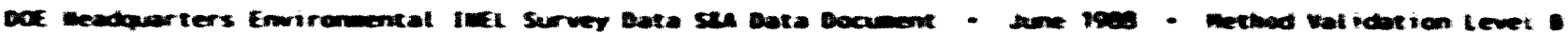

Table E-1. (cont inued).

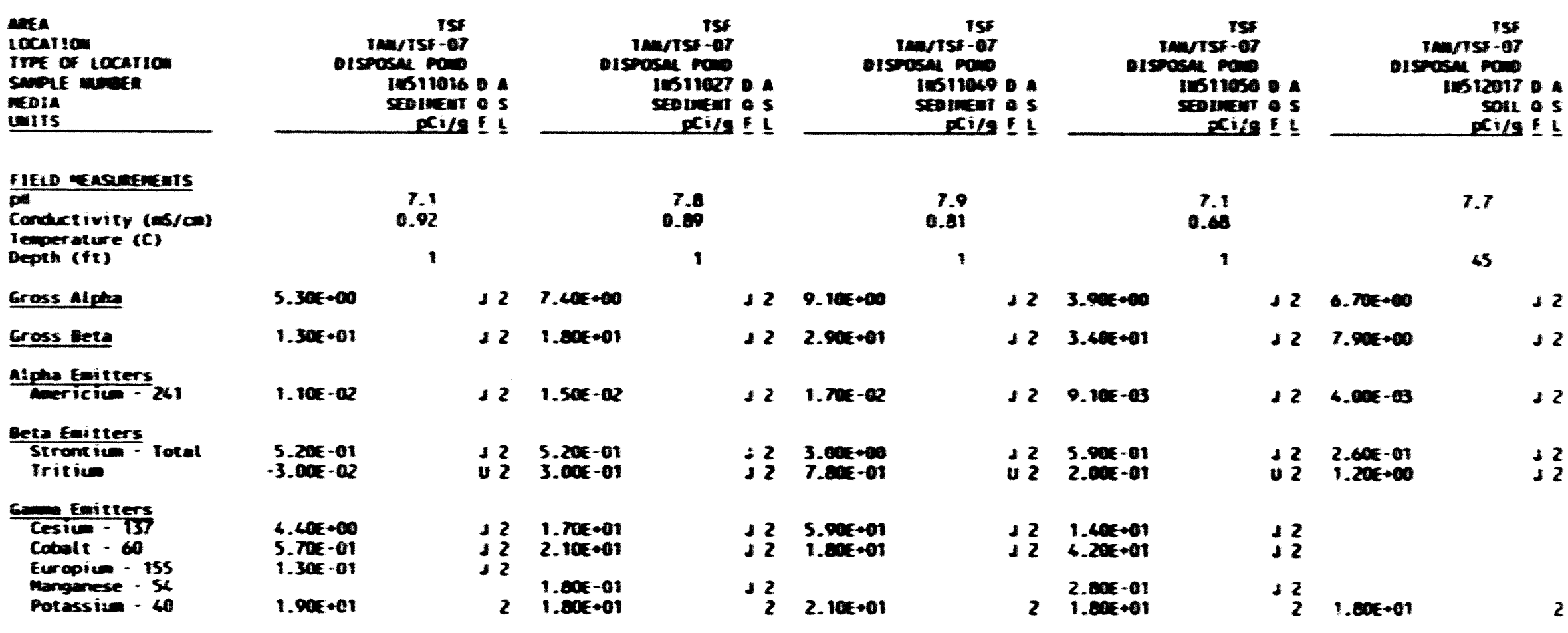

a. The oof coluen contains any data golifier flegs.

b. The ast colum contains the analvical sepport level.

5-18-93 
DCE Meadquarters Enwironental IuEt Survey Date Seh Date Document - Jure 1900 - Method Vel idotion Level

Table E-1. (cont inued).

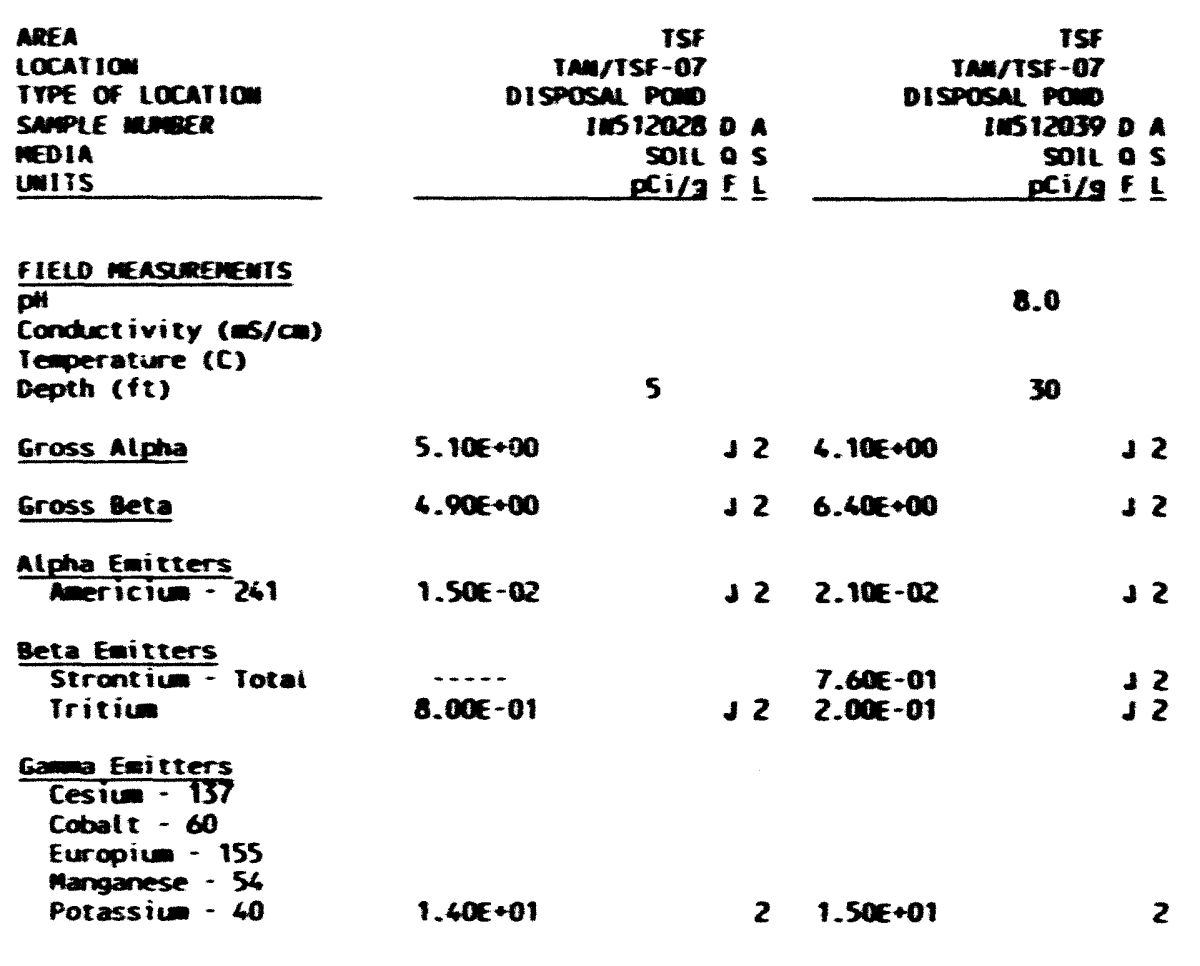

a. The Dof colum contains any cate qualifier flags.

b. The Ast colim contains the analyticat support levet.

5-18-93 
DOE Headquarters Environmental INEL Survey Data SeA Data Document

Table E-1. (continued).

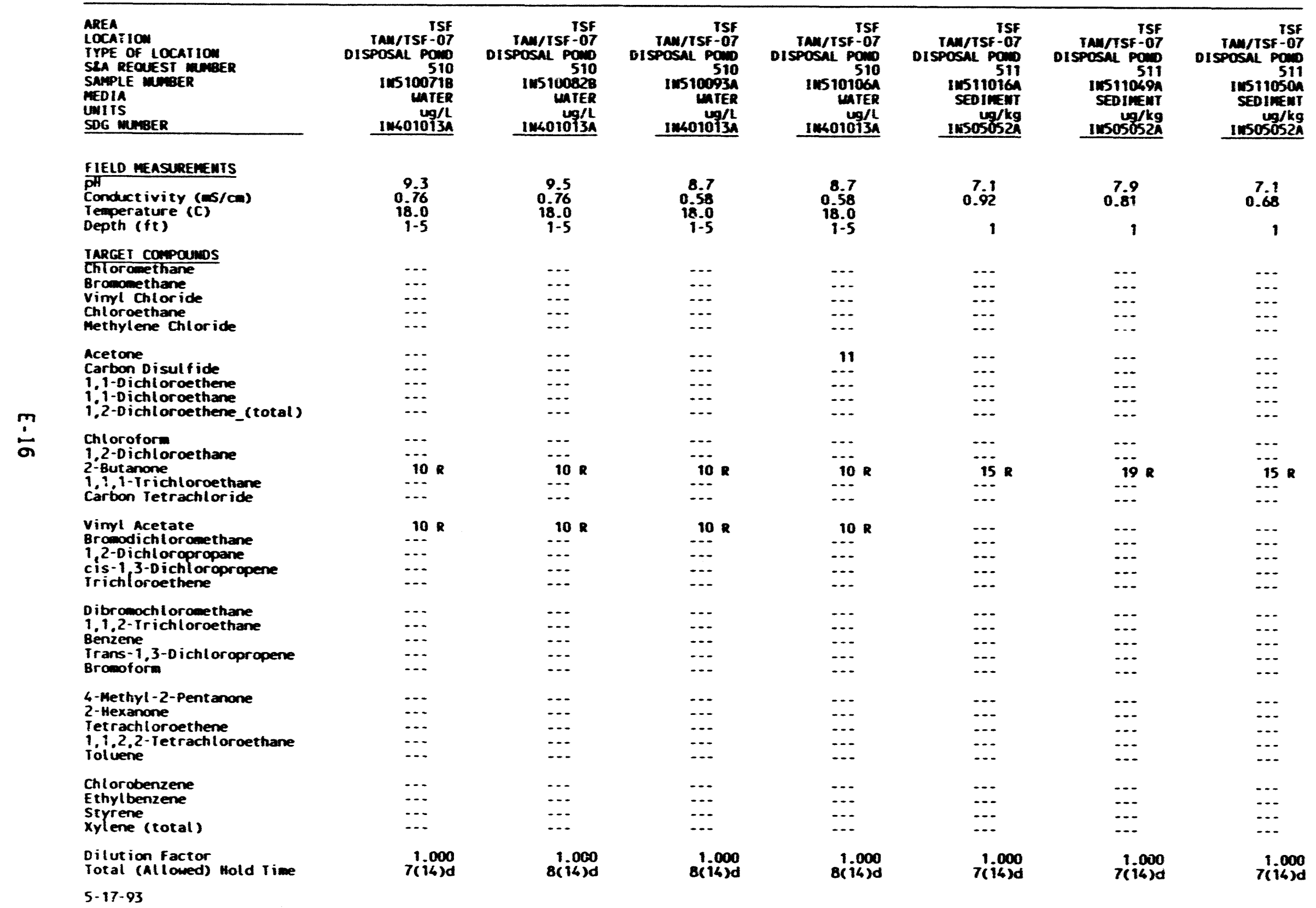


DOE Headquarters Environmental Imel Survey Data SeA Data Document - June 1998 - Method Validation Level B Table E-1. (continued).

\begin{tabular}{|c|c|c|c|c|}
\hline 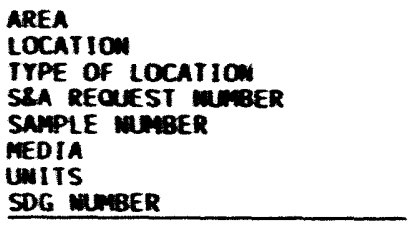 & 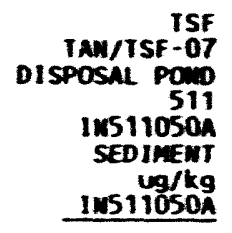 & $\begin{array}{r}\text { ISF } \\
\text { IAW/TSF-07 } \\
\text { DISPOSAL PODD } \\
511 \\
\text { Ins12017A } \\
5011 \\
501 \mathrm{~kg} \\
\text { Ins03027A } \\
\end{array}$ & 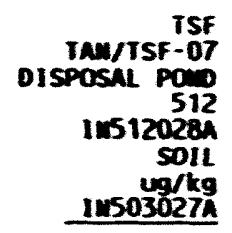 & $\begin{array}{r}\text { ISF } \\
\text { IAM/TSF-07 } \\
\text { DISPOSAL POWD } \\
512 \\
\text { Insizo39A } \\
5011 \\
\text { ug/kg } \\
\text { Inso3027A } \\
\end{array}$ \\
\hline $\begin{array}{l}\text { FIELD MEASUREMEMTS } \\
\text { PH } \\
\text { Conductivity }(\mathrm{m} / \mathrm{cm}) \\
\text { Temperature }(\mathrm{c}) \\
\text { Depth (ft) }\end{array}$ & $\begin{array}{r}7.1 \\
0.68 \\
1\end{array}$ & $\begin{array}{l}7.7 \\
45\end{array}$ & 5 & $\begin{array}{l}8.0 \\
30\end{array}$ \\
\hline 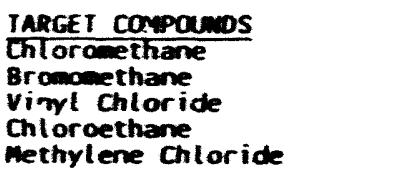 & $\begin{array}{l}\cdots \\
\cdots \\
\cdots- \\
\cdots \\
\cdots\end{array}$ & $\begin{array}{l}25 \\
25 \\
25 \\
25 \\
\\
w \\
w\end{array}$ & $\begin{array}{l}26 \text { w } \\
26 \text { w } \\
26 \text { w } \\
24 \mathrm{~J} \\
11 \mathrm{~J}\end{array}$ & $\begin{array}{l}29 \text { us } \\
29 \text { uf } \\
29 \text { us } \\
29 \text { uJ } \\
8 \mathrm{~J}\end{array}$ \\
\hline $\begin{array}{l}\text { Acetone } \\
\text { Carbon Disul fide } \\
\text { 1,i-Dichloroethene } \\
\text { 1,j-Dichloroethane } \\
\text { 1,2-Dichloroethene_(total) }\end{array}$ & \begin{tabular}{l}
18 \\
\hdashline- \\
\hdashline- \\
$\cdots$
\end{tabular} & $\begin{array}{l}25 \text { w } \\
13 \text { w } \\
13 \text { w } \\
13 \text { w }\end{array}$ & $\begin{array}{l}26 \\
12 \\
12 \\
12 \\
12\end{array}$ & $\begin{array}{l}29 \text { w } \\
15 \text { us } \\
15 \text { w } \\
15 \text { w } \\
15 \text { w }\end{array}$ \\
\hline $\begin{array}{l}\text { Chloroform } \\
1,2-\text { Dichloroethane } \\
2-\text { Butanone } \\
1,1,1-\text { Irichloroethane } \\
\text { carbon Tetrachloride }\end{array}$ & $\begin{array}{ll}\cdots \\
16 \\
\cdots\end{array}$ & $\begin{array}{l}18 \mathrm{~J} \\
13 \mathrm{w} \\
25 \\
43 \mathrm{u} \\
13 \mathrm{us}\end{array}$ & $\begin{array}{l}13 \mathrm{~J} \\
12 \mathrm{w} \\
26 \mathrm{k} \\
12 \mathrm{~J} \\
12 \mathrm{uJ}\end{array}$ & $\begin{array}{l}17 \mathrm{~J} \\
15 \mathrm{~W} \\
29 \mathrm{R} \\
18 \mathrm{~J} \\
\text { is } \mathrm{W}\end{array}$ \\
\hline $\begin{array}{l}\text { Vimyl Acetate } \\
\text { Bromodichl orcanethane } \\
\text { 1,2-Dich loropropane } \\
\text { cis-1, 3-Dichloropropene } \\
\text { Trichloroethene }\end{array}$ & $\begin{array}{l}\cdots \\
\cdots \\
\cdots \\
\cdots\end{array}$ & $\begin{array}{l}25 \text { w } \\
13 \text { w } \\
13 \text { w } \\
13 \text { u. }\end{array}$ & $\begin{array}{l}24 \\
12 \\
12 \\
w \\
12 \\
12 \\
w\end{array}$ & $\begin{array}{l}29 \mathrm{w} \\
15 \mathrm{w} \\
15 \mathrm{w} \\
15 \mathrm{w} \\
15 \mathrm{w}\end{array}$ \\
\hline $\begin{array}{l}\text { Cibromochloramethane } \\
1,1,2 \text {-Irichloroethane } \\
\text { Benzene } \\
\text { irams-1,3-0ichloropropene } \\
\text { Branoform }\end{array}$ & $\begin{array}{l}\cdots \\
\cdots \\
\cdots \\
\cdots \\
\cdots\end{array}$ & $\begin{array}{l}13 \text { w } \\
13 \text { w } \\
13 \text { w } \\
13 \text { w }\end{array}$ & $\begin{array}{l}12 \text { w } \\
12 \text { w } \\
12 \text { w } \\
12 \text { w }\end{array}$ & $\begin{array}{l}15 \text { us } \\
15 \text { us } \\
15 \text { w } \\
15 \text { us } \\
15 \text { w }\end{array}$ \\
\hline $\begin{array}{l}\text { 4-Methyl-2-Pentanone } \\
\text { 2-Mexanone } \\
\text { Tetrachloroethene } \\
\text { i, } 1,2,2 \text {-Tetrachloroethane } \\
\text { ?olvene }\end{array}$ & $\begin{array}{l}\cdots \\
\cdots \\
\cdots \\
\cdots\end{array}$ & $\begin{array}{l}25 \text { w } \\
25 \text { w } \\
13 \text { w } \\
13 \text { w }\end{array}$ & $\begin{array}{l}26 \mathrm{w} \\
26 \mathrm{w} \\
12 \mathrm{w} \\
12 \mathrm{w} \\
12 \mathrm{w}\end{array}$ & $\begin{array}{l}29 \mathrm{w} \\
29 \mathrm{w} \\
15 \mathrm{w} \\
15 \mathrm{w} \\
5 \mathrm{~J}\end{array}$ \\
\hline $\begin{array}{l}\text { Chlorobenzene } \\
\text { Ethylbenzene } \\
\text { styrene (total) } \\
\text { xylene (tot }\end{array}$ & $\begin{array}{l}\cdots \\
\cdots \\
\cdots \\
\cdots\end{array}$ & $\begin{array}{l}13 \text { w } \\
13 \text { w } \\
13 \text { w }\end{array}$ & $\begin{array}{l}12 w \\
12 w \\
12 w \\
12 w\end{array}$ & $\begin{array}{l}15 \mathrm{w} \\
15 \mathrm{w} \\
15 \mathrm{w} \\
15 \mathrm{w}\end{array}$ \\
\hline $\begin{array}{l}\text { Dilution factor } \\
\text { Jotal (Allowed) wold liee } \\
5-17-93\end{array}$ & $8(16) d$ & $22(16) d$ & not Avaitibile & $17(16) 0$ \\
\hline
\end{tabular}




\section{APPENDIX $F$}

ANALYTICAL RESULTS FOR SAMPLING EVENT 4-SUBSURFACE INVESTIGATION

$F-1$ 
1989 TAN Hydrogeologic Investigation S\&A Data Document · July 1989

Table F-1. 1989 TAN hydrogeologic investigation-volatile organic data.

\begin{tabular}{|c|c|c|c|c|c|c|c|}
\hline $\begin{array}{l}\text { AREA } \\
\text { LOCATION } \\
\text { TYPE OF LOCATION } \\
\text { SAMPLE NUMBER } \\
\text { MEDIA } \\
\text { UNITS } \\
\text { SDG NUMBER }\end{array}$ & $\begin{array}{r}\text { TSF } \\
\text { DISPOSAL POND } \\
\text { AUGER HOLE \#3 } \\
\text { TAG0389A01A } \\
\text { SO1L } \\
\text { Ug/kg } \\
\text { TAGEO89001 }\end{array}$ & $\begin{array}{r}\text { TSF } \\
\text { DISPOSAL POND } \\
\text { AUGER HOLE \#3 } \\
\text { TAGO389BO1A } \\
\text { WATER/TCLP } \\
\text { Ug/L } \\
\text { TAGEO89001 }\end{array}$ & $\begin{array}{c}\text { TSF } \\
\text { DISPOSAL POND } \\
\text { AUGER HOLE \#3 } \\
\text { TAGO389B01B } \\
\text { WATER/TCLP } \\
\text { Ug/L } \\
\text { TAGE089001 }\end{array}$ & $\begin{array}{r}\text { ISF } \\
\text { DISPOSAL POND } \\
\text { AUGER HOLE \#3 } \\
\text { TAGO389BO2A } \\
\text { WATER/TCLP } \\
\text { Ug/L } \\
\text { TAGEO89001 }\end{array}$ & $\begin{array}{r}\text { TSF } \\
\text { DISPOSAL POND } \\
\text { AUGER HOLE \#3 } \\
\text { TAG0389B02ADL } \\
\text { WATER/TCLP } \\
\text { Ug/L } \\
\text { TAGEOBOON }\end{array}$ & $\begin{array}{c}\text { TSF } \\
\text { DISPOSAL POND } \\
\text { AUGER HOLE \#3 } \\
\text { TAGO389B02B } 1 \\
\text { WATER/TCLP } \\
\text { Ug/L } \\
\text { TAGEOBOON1 }\end{array}$ & $\begin{array}{r}\text { TSF } \\
\text { DISPOSAL POND } \\
\text { AUGER HOLE \#3 } \\
\text { TAG0389C01A } \\
\text { SOIL } \\
\text { Ug/kg } \\
\text { TAGFORO01 }\end{array}$ \\
\hline
\end{tabular}

\begin{tabular}{|c|}
\hline$\frac{\text { FIELD MEASUREMENTS }}{\text { Depth }(f t)}$ \\
\hline $\begin{array}{l}\text { TARGET COMPOUNDS } \\
\text { Methylene Chloride } \\
\text { Acetone } \\
\text { Carbon Disulfide } \\
1,1-D i c h l o r o e t h e n e \\
1,1-D i c h l o r o e t h a n e\end{array}$ \\
\hline $\begin{array}{l}\text { 1,2-Dichloroethene_(total) } \\
\text { Chloroform } \\
1,2 \text {-Dichloroethane } \\
2-\text { Butanone } \\
1,1,1 \text {-Trichloroethane }\end{array}$ \\
\hline $\begin{array}{l}\text { Carbon Tetrachloride } \\
\text { vinyl Acetate } \\
\text { Bromodichloromethane } \\
1,2-D \text { ichloropropane } \\
\text { cis-1,3-Dichloropropene }\end{array}$ \\
\hline $\begin{array}{l}\text { Trichloroethene } \\
\text { Dibromochlorome thane } \\
1,1,2-\text { Trichloroe thane } \\
\text { Benzene } \\
\text { Trans-1,3-Dichloropropene }\end{array}$ \\
\hline $\begin{array}{l}\text { Bromoform } \\
\text { 4-Methyl-2-Pentanone } \\
\text { 2-hexanone } \\
\text { Tetrachloroethene } \\
1,1,2,2-\text { Tetrachloroethane }\end{array}$ \\
\hline $\begin{array}{l}\text { Toluene } \\
\text { I sobutanol }\end{array}$ \\
\hline $\begin{array}{l}\text { Total (Allowed) Hold Time } \\
\text { Dilution Factor }\end{array}$ \\
\hline
\end{tabular}

\begin{tabular}{|c|c|}
\hline $0-2$ & $5-7$ \\
\hline$\cdots$ & $6 \mathrm{~J}$ \\
\hline$\cdots$ & $\begin{array}{r}42 \mathrm{~J} \\
\ldots \ldots\end{array}$ \\
\hline$\cdots$ & $\cdots$ \\
\hline$\ldots$ & $\cdots$ \\
\hline$\ldots$ & $\cdots$ \\
\hline$\ldots$ & $\cdots$ \\
\hline$\cdots$ & -- \\
\hline$\cdots$ & $\cdots$ \\
\hline$\ldots$ & $\ldots$ \\
\hline - - & $\cdots$ \\
\hline$\cdots$ & $\cdots$ \\
\hline$\cdots$ & $\cdots$ \\
\hline$\ldots$ & $\ldots$ \\
\hline - - & -.. \\
\hline$\cdots$ & $\cdots$ \\
\hline$\cdots$ & $\cdots$ \\
\hline & $\cdots$ \\
\hline - - & ... \\
\hline$\cdots$ & $\cdots$ \\
\hline$\cdots$ & $\cdots$ \\
\hline -. & - \\
\hline
\end{tabular}

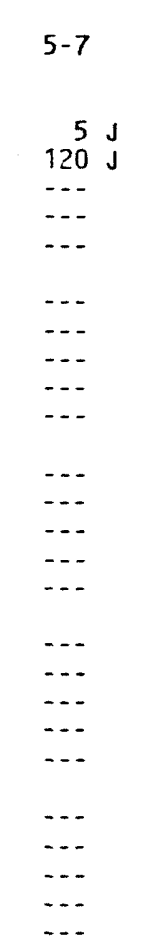

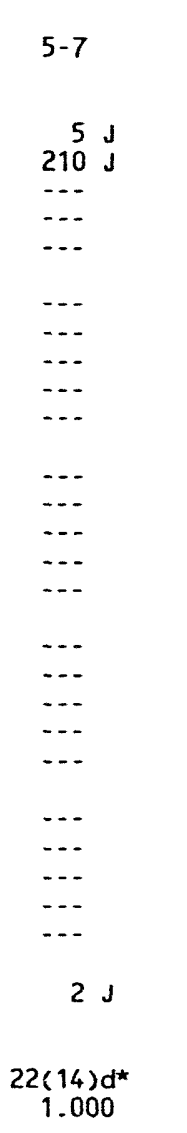

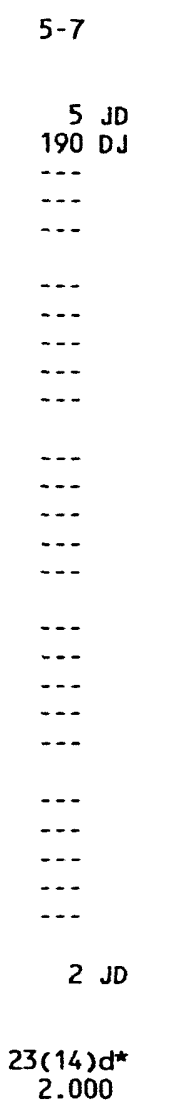

5-7

$10-12$

1 Sample was designated for metals analysis, but laboratory ren TCLP volatile organic analysis as well. 
Table F-1. (continued).

\begin{tabular}{|c|c|c|c|c|c|c|c|}
\hline $\begin{array}{l}\text { AREA } \\
\text { LOCAT ION } \\
\text { TYPE OF LOCATION } \\
\text { SAMPLE NUMBER } \\
\text { MEDIA } \\
\text { UNITS } \\
\text { SOG NUMBER } \\
\end{array}$ & $\begin{array}{r}\text { TSF } \\
\text { DISPOSAL POND } \\
\text { AUGER HOLE } \$ 3 \\
\text { TAG0389CO2A } \\
\text { SOIL } \\
\text { ug/kg } \\
\text { TAGEQ89001 } \\
\end{array}$ & $\begin{array}{r}\text { TSF } \\
\text { DISPOSAL POND } \\
\text { AUGER HOLE \#3 } \\
\text { TAG0389001A } \\
\text { SOIL } \\
\mathrm{ug} / \mathrm{kg} \\
\text { TAGEQ89001 } \\
\end{array}$ & $\begin{array}{r}\text { TSF } \\
\text { DISPOSAL POND } \\
\text { AUGER HOLE \#3 } \\
\text { TAG0389E01A } \\
\text { SOIL } \\
\text { ug/kg } \\
\text { TAGEO89001 } \\
\end{array}$ & $\begin{array}{r}\text { TSF } \\
\text { DISPOSAL POND } \\
\text { AUGER HOLE \#3 } \\
\text { TAG0389F01A } \\
\text { SOIL } \\
\text { Ug/kg } \\
\text { TAGEQ89001 } \\
\end{array}$ & $\begin{array}{r}\text { TSF } \\
\text { DISPOSAL POND } \\
\text { AUGER HOLE } \$ 4 \\
\text { TAG0489A01A } \\
\text { SOIL } \\
\text { Ug/kg } \\
\text { TAGEO89002 } \\
\end{array}$ & $\begin{array}{r}\text { TSF } \\
\text { DISPOSAL POND } \\
\text { AUGER HOLE \#4 } \\
\text { TAGO489BOIA } \\
\text { WATER/TCLP } \\
\text { Ug/L } \\
\text { TAGEQ89002 } \\
\end{array}$ & $\begin{array}{r}\text { TSF } \\
\text { DISPOSAL POND } \\
\text { AUGER HOLE \#4 } \\
\text { TAG0489BO2A } \\
501 \mathrm{~L} \\
\text { Ug } / \mathrm{kg} \\
\text { TAGEO89002 } \\
\end{array}$ \\
\hline$\frac{\text { FIELD MEASUREMENTS }}{\text { Depth }(\mathrm{ft})}$ & $10-12$ & $15-17$ & $20-22$ & $25-27$ & $0-2$ & $5-7$ & $5-7$ \\
\hline $\begin{array}{l}\text { TARGET COMPOUNDS } \\
\text { Methylene Chloride } \\
\text { Acetone } \\
\text { Carbon Disulfide } \\
1,1-0 \text { ichlorocthere } \\
1,1-\text { Dichlorocthane }\end{array}$ & $\begin{array}{ll}\cdots \\
27 \\
\cdots \\
\cdots\end{array}$ & $\begin{array}{ll}\cdots \\
10 \mathrm{~J} \\
\cdots \\
\cdots\end{array}$ & $\begin{array}{ll}\cdots \\
\cdots \\
\cdots \\
\cdots\end{array}$ & $\begin{array}{l}\cdots \\
\cdots \\
\cdots \\
\cdots\end{array}$ & $\begin{array}{l}\cdots \\
\cdots \\
\cdots \\
\cdots\end{array}$ & $\begin{array}{l}57 \mathrm{~J} \\
95 \\
\cdots \\
\cdots \\
\cdots\end{array}$ & $\begin{array}{l}\cdots \\
\cdots \\
\cdots \\
\cdots\end{array}$ \\
\hline $\begin{array}{l}\text { 1,2-Dichloroethene_(total) } \\
\text { chloroform } \\
1,2-D \text { ichloroethane } \\
\text { 2-8utanone } \\
1,1,1-\text { Trichloroethane }\end{array}$ & $\begin{array}{l}\cdots \\
\cdots \\
\cdots \\
\cdots \\
\cdots\end{array}$ & $\begin{array}{l}\cdots \\
\cdots \\
\cdots \\
\cdots\end{array}$ & $\begin{array}{l}\cdots \\
\cdots \\
\cdots \\
\cdots\end{array}$ & $\begin{array}{l}-\cdots \\
\cdots \\
\cdots \\
\cdots\end{array}$ & $\begin{array}{l}\cdots \\
\cdots \\
\cdots \\
\cdots\end{array}$ & $\begin{array}{l}\cdots \\
\cdots \\
\cdots \\
\cdots\end{array}$ & $\begin{array}{l}\cdots \\
\cdots \\
\cdots \\
\cdots\end{array}$ \\
\hline $\begin{array}{l}\text { Carbon Tetrachloride } \\
\text { Vinyl Acetate } \\
\text { Bromodichloromethane } \\
1,2-D \text { ichloropropane } \\
\text { cis-1,3-Dichloropropene }\end{array}$ & $\begin{array}{l}-- \\
\cdots \\
\cdots \\
\cdots\end{array}$ & $\begin{array}{l}\cdots \\
\cdots \\
\cdots \\
\cdots\end{array}$ & $\begin{array}{l}\cdots \\
\cdots \\
\cdots \\
\cdots\end{array}$ & $\begin{array}{l}\cdots \\
\cdots \\
\cdots \\
\cdots \\
\cdots\end{array}$ & $\begin{array}{l}\cdots \\
\cdots \\
\cdots \\
\cdots \\
\cdots\end{array}$ & $\begin{array}{l}\cdots \\
\cdots \\
\cdots \\
\cdots\end{array}$ & $\begin{array}{l}\cdots \\
\cdots \\
\cdots \\
\cdots\end{array}$ \\
\hline $\begin{array}{l}\text { Trichloroethene } \\
\text { Dibromochlorome thane } \\
1,1,2-\text { Trichloroe thane } \\
\text { Benzene } \\
\text { Trans-1,3-Dichloropropene }\end{array}$ & $\begin{array}{l}\cdots \\
\cdots \\
\cdots \\
\cdots\end{array}$ & $\begin{array}{l}\cdots \\
\cdots \\
\cdots \\
\cdots\end{array}$ & $\begin{array}{l}\cdots \\
\cdots \\
\cdots \\
\cdots\end{array}$ & $\begin{array}{ll}\cdots \\
\cdots \\
\cdots\end{array}$ & $\begin{array}{l}\cdots \\
\cdots \\
\cdots \\
\cdots\end{array}$ & $\begin{array}{l}\cdots \\
\cdots \\
\cdots \\
\cdots\end{array}$ & $\begin{array}{l}\cdots \\
\cdots \\
\cdots \\
\cdots\end{array}$ \\
\hline $\begin{array}{l}\text { Bromoform } \\
\text { 4-Methyl-2-Pentanone } \\
\text { 2-Hexanone } \\
\text { Tetrachloroethene } \\
1,1,2,2 \text { - Tetrachloroethane }\end{array}$ & $\begin{array}{l}\cdots \\
\cdots \\
\cdots \\
\cdots\end{array}$ & $\begin{array}{l}\cdots \\
\cdots \\
\cdots \\
\cdots\end{array}$ & $\begin{array}{l}\cdots \\
\cdots \\
\cdots \\
\cdots\end{array}$ & $\begin{array}{l}\cdots \\
\cdots \\
\cdots \\
\cdots\end{array}$ & $\begin{array}{l}\cdots \\
\cdots \\
\cdots \\
\cdots\end{array}$ & $\begin{array}{l}\cdots \\
\cdots \\
\cdots \\
\cdots \\
\cdots\end{array}$ & $\begin{array}{l}\cdots \\
\cdots \\
\cdots- \\
\cdots\end{array}$ \\
\hline $\begin{array}{l}\text { Toluene } \\
\text { I sobutanol }\end{array}$ & - - & $1 \mathrm{~J}$ & -. & $2 \mathrm{~J}$ & 13 & 24 & $3 \mathrm{~J}$ \\
\hline $\begin{array}{l}\text { Total (Allowed) Hold Time } \\
\text { Dilution factor }\end{array}$ & $\begin{array}{r}11(14) d \\
1.000\end{array}$ & $\begin{array}{r}11(14) d \\
1.000\end{array}$ & $\begin{array}{r}11(14) d \\
1.000\end{array}$ & $\begin{array}{r}11(14) d \\
1.000\end{array}$ & $\begin{array}{r}7(14) d \\
1.000\end{array}$ & $\begin{array}{r}11(14) d \\
1.000\end{array}$ & $\begin{array}{r}7(14) d \\
1.000\end{array}$ \\
\hline
\end{tabular}


1989 TAN Hydrogeologic Investigation S\&A Data Document - July 1989

Table F-1. (continued).

\begin{tabular}{|c|c|c|c|c|c|c|c|}
\hline $\begin{array}{l}\text { AREA } \\
\text { LOCATION } \\
\text { TYPE OF LOCATION } \\
\text { SAMPLE NUMBER } \\
\text { MEDIA } \\
\text { UNITS } \\
\text { SDG NUMBER } \\
\end{array}$ & $\begin{array}{r}\text { TSF } \\
\text { DISPOSAL POND } \\
\text { AUGER HOLE H4 } \\
\text { TAG0489C01A } \\
\text { SOIL } \\
\text { Ug/kg } \\
\text { TAGEO89002 } \\
\end{array}$ & $\begin{array}{r}\text { TSF } \\
\text { DISPOSAL POND } \\
\text { AUGER HOLE \#4 } \\
\text { TAG0489001A } \\
\text { SOIL } \\
\text { Ug/kg } \\
\text { TAGEO89002 } \\
\end{array}$ & $\begin{array}{r}\text { TSF } \\
\text { DISPOSAL POND } \\
\text { AUGER HOLE \#4 } \\
\text { TAG0489002A } \\
\text { SOIL } \\
\text { Ug/kg } \\
\text { TAGEOB9002 } \\
\end{array}$ & $\begin{array}{r}\text { TSF } \\
\text { DISPOSAL POND } \\
\text { AUGER HOLE \#4 } \\
\text { TAG0489E01A } \\
\text { SOIL } \\
\text { Ug/kg } \\
\text { TAGEO89002 } \\
\end{array}$ & $\begin{array}{r}\text { TSF } \\
\text { DISPOSAL POND } \\
\text { AUGER HOLE } \# 4 \\
\text { TAG0489FO1A } \\
\text { SOIL } \\
\text { ug/kg } \\
\text { TAGEO089002 } \\
\end{array}$ & $\begin{array}{r}\text { TSF } \\
\text { DISPOSAL POND } \\
\text { AUGER HOLE \#4 } \\
\text { TAG0489J01A } \\
\text { SOIL } \\
\text { Ug/kg } \\
\text { TAGEQ89002 } \\
\end{array}$ & $\begin{array}{r}\text { TSF } \\
\text { DISPOSAL POND } \\
\text { AUGER HOLE \#5 } \\
\text { TAGO5B9A01A } \\
\text { SOIL } \\
\text { Ug/kg } \\
\text { TAGEQ89001 } \\
\end{array}$ \\
\hline$\frac{\text { FIELD MEASUREMENTS }}{\text { Depth }(\mathrm{ft})}$ & $10-12$ & $15-17$ & $15-17$ & $20-22$ & $25-27$ & $45-47$ & $0-2$ \\
\hline $\begin{array}{l}\text { 1,2-Dichloroethene_(total) } \\
\text { chloroform } \\
1,2 \text {-0ichloroethane } \\
\text { 2-Butanone } \\
1,1,1 \text {-Trichloroethane }\end{array}$ & $\begin{array}{l}\cdots \\
\cdots \\
\cdots \\
\cdots \\
\cdots\end{array}$ & $\begin{array}{l}\cdots \\
\cdots \\
\cdots \\
\cdots\end{array}$ & $\begin{array}{l}\cdots \\
\cdots \\
\cdots \\
\cdots \\
\cdots\end{array}$ & $\begin{array}{l}\cdots \\
\cdots \\
\cdots- \\
\cdots \\
\cdots\end{array}$ & $\begin{array}{l}\cdots \\
\cdots \\
\cdots \\
\cdots\end{array}$ & $\begin{array}{l}\cdots \\
\cdots \\
\cdots \\
\cdots\end{array}$ & $\begin{array}{l}\cdots \\
\cdots \\
\cdots \\
\cdots\end{array}$ \\
\hline $\begin{array}{l}\text { Trichloroethene } \\
\text { Dibromochloromethane } \\
1,1,2-\text { Trichloroethane } \\
\text { Benzene } \\
\text { Trans-1,3-Dichloropropene }\end{array}$ & $\begin{array}{l}\cdots \\
\cdots \\
\cdots \\
\cdots\end{array}$ & $\begin{array}{l}\cdots \\
\cdots \\
\cdots \\
\cdots\end{array}$ & $\begin{array}{l}\cdots \\
\cdots \\
\cdots \\
\cdots\end{array}$ & $\begin{array}{l}\cdots \\
\cdots \\
\cdots \\
\cdots- \\
\cdots\end{array}$ & $\begin{array}{l}\cdots \\
\cdots \\
\cdots \\
\cdots\end{array}$ & $\begin{array}{ll}\cdots \\
\cdots \\
\cdots \\
\cdots\end{array}$ & $\begin{array}{l}\cdots \\
\cdots- \\
\cdots \\
\cdots\end{array}$ \\
\hline $\begin{array}{l}\text { Bromoform } \\
\text { 4-Methyl-2-Fentanone } \\
\text { 2-Hexanone } \\
\text { Tetrachloroethene } \\
1,1,2,2 \text {-Tetrachloroethane }\end{array}$ & $\begin{array}{l}\cdots \\
\cdots \\
\cdots \\
\cdots\end{array}$ & $\begin{array}{l}\cdots \\
\cdots \\
\cdots \\
\cdots \\
\cdots\end{array}$ & $\begin{array}{l}\cdots \\
\cdots \\
\cdots \\
\cdots\end{array}$ & $\begin{array}{l}\cdots \\
\cdots \\
\cdots \\
\cdots\end{array}$ & $\begin{array}{l}\cdots \\
\cdots \\
\cdots \\
\cdots\end{array}$ & $\begin{array}{l}\cdots \\
\cdots \\
\cdots \\
\cdots\end{array}$ & $\begin{array}{l}\cdots \\
\cdots \\
\cdots \\
\cdots\end{array}$ \\
\hline $\begin{array}{l}\text { Toluene } \\
\text { Isobutanol }\end{array}$ & $2 \mathrm{~J}$ & $3 \mathrm{~J}$ & $\cdots$ & $\ldots$ & $\ldots$ & ... & 17 \\
\hline $\begin{array}{l}\text { Total (Allowed) Hold Time } \\
\text { Dilution Factor }\end{array}$ & $\begin{array}{r}2(14) \mathrm{d} \\
1.000\end{array}$ & $\begin{array}{r}6(14) \mathrm{d} \\
1.000\end{array}$ & $\begin{array}{l}6(14) d \\
1.000\end{array}$ & $\begin{array}{r}6(14) d \\
1.000\end{array}$ & $\begin{array}{l}7(14) d \\
1.000\end{array}$ & $\begin{array}{r}6(14) d \\
1.000\end{array}$ & $\begin{array}{r}9(14) d \\
1.000\end{array}$ \\
\hline
\end{tabular}


1989 TAN Hydrogeologic Investigation S\&A Data Documerit - July 1989

Table F-1. (continued).

\begin{tabular}{|c|c|c|c|c|c|c|c|}
\hline $\begin{array}{l}\text { AREA } \\
\text { LOCATION } \\
\text { TYPE OF LOCATION } \\
\text { SAMPLE NUMBER } \\
\text { MEDIA } \\
\text { UNITS } \\
\text { SDG NUMBER } \\
\end{array}$ & $\begin{array}{r}\text { TSF } \\
\text { DISPOSAL POND } \\
\text { AUGER HOLE \#S } \\
\text { TAG0589801A } \\
\text { WATER/TCLP } \\
\text { Ug/L } \\
\text { TAGEQ89001 } \\
\end{array}$ & $\begin{array}{r}\text { TSF } \\
\text { DISPOSAL POND } \\
\text { AUGER HOLE \#5 } \\
\text { TAGOSB9B01ADL } \\
\text { WATER/TCLP } \\
\text { Ug/L } \\
\text { TAGEO89001 } \\
\end{array}$ & $\begin{array}{r}\text { TSF } \\
\text { DISPOSAL POND } \\
\text { AUGER HOLE HS } \\
\text { TAG0589C01A } \\
\text { SOIL } \\
\text { Ug } / \mathrm{kg} \\
\text { TAGEO89001 } \\
\end{array}$ & $\begin{array}{r}\text { ISF } \\
\text { DISPOSAL POND } \\
\text { AUGER HOLE } \$ 5 \\
\text { TAG0589C02A } \\
\text { SOIL } \\
\text { ug/kg } \\
\text { TAGEO89001 } \\
\end{array}$ & $\begin{array}{r}\text { TSF } \\
\text { DISPOSAL POND } \\
\text { AUGER HOLE } \$ S \\
\text { TAGOS89001A } \\
5011 \\
\text { ug/kg } \\
\text { TAGEOB9001 } \\
\end{array}$ & $\begin{array}{r}\text { TSF } \\
\text { DISPOSAL POND } \\
\text { AUGER HOLE \#S } \\
\text { TAGOSB9E01A } \\
\text { SOIL } \\
\text { Ug/kg } \\
\text { TAGEO89001 } \\
\end{array}$ & $\begin{array}{r}\text { TSF } \\
\text { DISPOSAL POND } \\
\text { AUGER HOLE } \$ 5 \\
\text { TAGO589K01K } \\
\text { SOIL } \\
\text { Ug/kg } \\
\text { TAGEO89001 } \\
\end{array}$ \\
\hline$\frac{\text { FIELD MEASUREMENTS }}{\text { Depth }(\mathrm{ft})}$ & $5-7$ & $5-7$ & $10-12$ & $10-12$ & $15-17$ & $20-22$ & $50-52$ \\
\hline $\begin{array}{l}\text { TARGET COMPOUNDS } \\
\text { Methylene Chloride } \\
\text { Acetone } \\
\text { Carbon Disulfide } \\
1,1-D \text { ichloroethene } \\
1,1-D \text { ichloroethane }\end{array}$ & $\begin{array}{rl}78 & \mathrm{~J} \\
280 & \mathrm{~J} \\
5 & \mathrm{~J} \\
5 & \mathrm{~J} \\
5 & \mathrm{~J}\end{array}$ & $\begin{array}{ll}41 & 0 \mathrm{~J} \\
180 & \mathrm{DJ} \\
\cdots & \\
\cdots & -\end{array}$ & $\begin{array}{l}4 \mathrm{~J} \\
\ldots \\
\cdots \\
\cdots \\
\cdots\end{array}$ & $\begin{array}{ll}1 & j \\
\ldots & \\
\cdots \\
\cdots \\
\ldots\end{array}$ & $\begin{array}{l}2 \mathrm{~J} \\
\cdots \\
\cdots \\
\cdots\end{array}$ & $\begin{array}{ll}2 \mathrm{~J} \\
\cdots \\
\cdots \\
\cdots \\
\cdots\end{array}$ & $\begin{array}{l}\cdots \\
\cdots \\
\cdots \\
\cdots\end{array}$ \\
\hline $\begin{array}{l}\text { 1,2-Dichloroethene_(total) } \\
\text { chloroform } \\
\text { 1,2-Dichloroethane } \\
\text {--Butanone } \\
1,1,1 \text { - Trichloroethane }\end{array}$ & $\begin{array}{rl}5 & \mathrm{~J} \\
5 & \mathrm{~J} \\
5 & \mathrm{~J} \\
10 & \mathrm{~J} \\
5 & \mathrm{~J}\end{array}$ & $\begin{array}{l}\cdots \\
\cdots \\
\cdots \\
\cdots\end{array}$ & $\begin{array}{l}\cdots \\
\cdots \\
\cdots \\
\cdots\end{array}$ & $\begin{array}{l}\cdots \\
\cdots \\
\cdots- \\
\cdots \\
\cdots\end{array}$ & $\begin{array}{l}-- \\
\cdots \\
\cdots \\
\cdots \\
--\end{array}$ & $\begin{array}{l}\cdots \\
\cdots \\
\cdots \\
\cdots\end{array}$ & $\begin{array}{l}\cdots \\
\cdots \\
\cdots \\
\cdots\end{array}$ \\
\hline $\begin{array}{l}\text { Carbon Tetrachloride } \\
\text { Vinyl Acetate } \\
\text { Bromodichloromethane } \\
1,2-D \text { ichloropropane } \\
\text { cis-1,3-D ichloropropene }\end{array}$ & $\begin{array}{rl}5 & \mathrm{~J} \\
10 & \mathrm{~J} \\
5 & \mathrm{~J} \\
5 & \mathrm{~J} \\
5 & \mathrm{~J}\end{array}$ & $\begin{array}{l}\cdots \\
\cdots \\
\cdots \\
\cdots\end{array}$ & $\begin{array}{l}\cdots \\
\cdots \\
\cdots \\
\cdots \\
--\end{array}$ & $\begin{array}{l}\cdots \\
\cdots \\
\cdots \\
\cdots\end{array}$ & $\begin{array}{l}\cdots \\
\cdots \\
\cdots \\
\cdots \\
\cdots\end{array}$ & $\begin{array}{l}\cdots- \\
\cdots \\
\cdots \\
\cdots\end{array}$ & $\begin{array}{l}\cdots- \\
\cdots \\
\cdots \\
\cdots\end{array}$ \\
\hline $\begin{array}{l}\text { Trichloroethene } \\
\text { Dibromochloromethane } \\
1,1,2-\text { Trichloroethane } \\
\text { Benzene } \\
\text { Trans-1,3-Dichloropropene }\end{array}$ & $\begin{array}{ll}5 & \mathrm{~J} \\
5 & \mathrm{~J} \\
5 & \mathrm{~J} \\
5 & \mathrm{~J} \\
5 & \mathrm{~J}\end{array}$ & $\begin{array}{l}\cdots \\
\cdots \\
\cdots \\
\cdots\end{array}$ & $\begin{array}{l}\cdots \\
\cdots \\
\cdots \\
\cdots\end{array}$ & $\begin{array}{l}\cdots \\
\cdots \\
\cdots \\
\cdots\end{array}$ & $\begin{array}{l}\cdots \\
\cdots \\
\cdots \\
\cdots \\
\cdots\end{array}$ & $\begin{array}{l}\cdots \\
\cdots \\
\cdots \\
\cdots\end{array}$ & $\begin{array}{l}\cdots \\
\cdots \\
\cdots \\
\cdots\end{array}$ \\
\hline $\begin{array}{l}\text { Bromoform } \\
\text { 4-Methyl-2-Pentanone } \\
\text { 2-Hexanone } \\
\text { Tetrachloroethene } \\
1,1,2,2 \text { - Tetrachloroethane }\end{array}$ & $\begin{array}{rl}5 & \mathrm{~J} \\
10 & \mathrm{~J} \\
10 \mathrm{~J} \\
5 & \mathrm{~J} \\
5 & \mathrm{~J}\end{array}$ & $\begin{array}{l}\cdots \\
\cdots \\
\cdots \\
\cdots\end{array}$ & $\begin{array}{l}\cdots \\
\cdots \\
\cdots \\
\cdots \\
-\cdots\end{array}$ & $\begin{array}{l}\cdots \\
\cdots \\
\cdots \\
\cdots\end{array}$ & $\begin{array}{l}\cdots \\
\cdots \\
\cdots \\
\cdots\end{array}$ & $\begin{array}{l}\cdots \\
\cdots \\
\cdots \\
\cdots\end{array}$ & $\begin{array}{l}\cdots \\
\cdots \\
\cdots \\
\cdots\end{array}$ \\
\hline $\begin{array}{l}\text { Toluene } \\
\text { I sobutanol }\end{array}$ & $33 \mathrm{~J}$ & $27 \mathrm{os}$ & $\ldots$ & $2 \mathrm{~J}$ & ... & $3 \mathrm{~J}$ & $\cdots$ \\
\hline $\begin{array}{l}\text { Total (Allowed) Hold Time } \\
\text { Dilution Factor }\end{array}$ & $\begin{array}{r}18(14) d^{*} \\
1.000\end{array}$ & $\begin{array}{r}18(14) d^{*} \\
2.000\end{array}$ & $\begin{array}{r}10(14) d \\
1.000\end{array}$ & $\begin{array}{r}9(14) d \\
1.000\end{array}$ & $\begin{array}{r}10(14) d \\
1.000\end{array}$ & $\begin{array}{r}9(14) d \\
1.000\end{array}$ & $\begin{array}{r}8(16) d \\
1.000\end{array}$ \\
\hline
\end{tabular}


1989 TAN Hydrogeologic Investigation SAA Data Dociment

July 1989

Table F-1. (continued).

\begin{tabular}{l} 
AREA \\
LOCATION \\
TYPE OF LOCAIION \\
SAMPLE MUMBER \\
MEDIA \\
UNITS \\
SOG MUMBER \\
\hline
\end{tabular}

$\begin{array}{r}\text { ISF } \\ \text { DISPOOSAL POND } \\ \text { AUGER HOLE \#6 } \\ \text { TAGOSB9AOIR } \\ \text { SOIL } \\ \text { Ug/k9 } \\ \text { TAGEOBOOOOI } \\ \hline\end{array}$

$\begin{array}{r}\text { TSF } \\ \text { DISPOSAL POND } \\ \text { AUGER HOLE W6 } \\ \text { TAGOSBSBOIA } \\ \text { UATER/TCLP } \\ \text { Ug/L } \\ \text { TAGEOBSO01 } \\ \hline\end{array}$

$\begin{array}{r}\text { ISF } \\ \text { DISPOSAL POWD } \\ \text { AUGER HOLE WO } \\ \text { TAGOSB9802A } \\ \text { SOIL } \\ \text { Ug/kg } \\ \text { TAGE089001 } \\ \hline\end{array}$
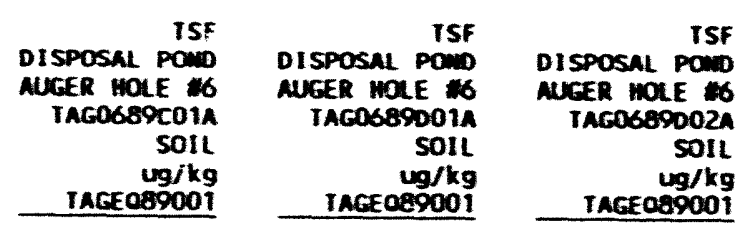

TSF
DISPOSAL PC=10
MUGER .10TE 16
IAGOSOSEOIA
SOIL
ug/kg
IACEOQ9001

FIELD MEASUREMENTS

Depth $(f t)$

$0-2$

$5-7$

$5-7$

$10-12$

15-17

$15-17$

$20-22$

Methylene chloride

Acetone

Carbon Disulfide

1,1-Dichiorcethene

1,1-Dichloroethane

1,2-Dichloroethene_(total)

chloroform

1,2-Dichloroethane

2-Butanone

1,1,1-Trichloroethane

IT Carbon Tetrachloride Vinyl Acetate

Gromodichloromethane

1,2-Dichloropropare

cis-1,3-0ichloropropene

Irichioroethene

Dibromochlor onethane

1,1,2-Irichloroethane

Benzene

Irans-1,3-Dichloropropene

Bromoform

4-Methyl-2-Pentancne

2 -Hexanone

etrachloroethene

1,1,2,2-Tetrachloroethane

ioluene

sobutanol

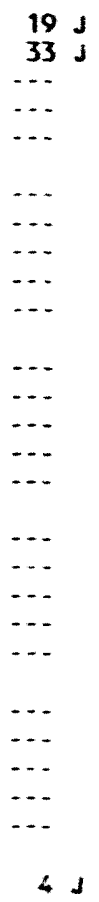

Iotal (All cwed) Hold Time ilution Factor

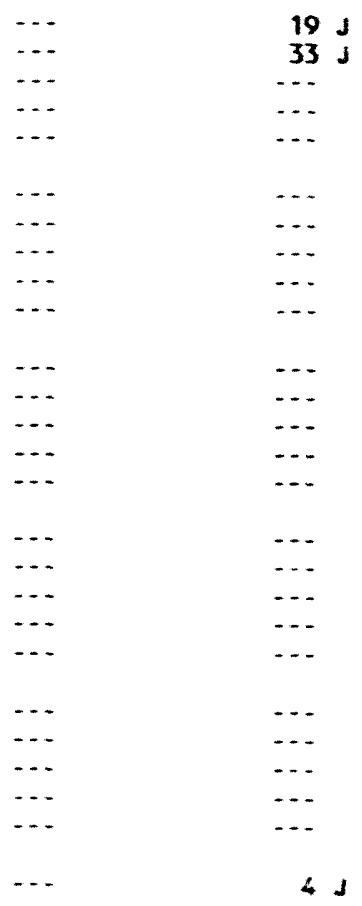

$$
\begin{aligned}
& \ldots \\
& \cdots \\
& \cdots \\
& \cdots \\
& \cdots \\
& \cdots \\
& \cdots \\
& \cdots \\
& \cdots \\
& \cdots \\
& \cdots \\
& \cdots \\
& \cdots \\
& \cdots \\
& \cdots \\
& \cdots \\
& \cdots \\
& \cdots \\
& \cdots \\
& \cdots \\
& \cdots \\
& \hline
\end{aligned}
$$

$9(14) d$

…

$\cdots$

...

$\cdots$

...

$\cdots$

-..

-..

6

10-3-92 
Table F-1. (continued).

\begin{tabular}{|c|c|c|}
\hline 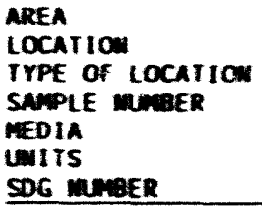 & 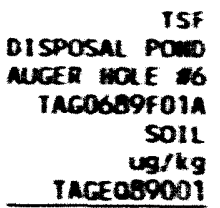 & 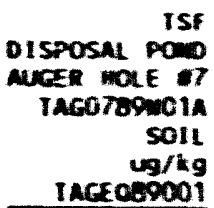 \\
\hline
\end{tabular}

\section{FIELL MEASURERENTS}

$25 \cdot 27$

$63 \cdot 64$

IARCET COPPCNOS

methylene chloride

Acetone

Cartion Disulfide

Ci-Dichloraethene

i. i-Dichloroethene

1.2-Dichioroethere_(total)

chlorofor:

1.2-Dichioroethane

$\dot{\infty}$

1.1.1-Trichloroethane

Carbon Tetrachioride

vinyt Acetate

1,2-Dichloropropane

cis-1,3-Dichlorcproper

Irichloroethene

Dibromochloromethane

1.1.2-Irichloroethan

Benzene

Ir ans-1,3-Dichloropropen

Bromofor

4-Methyl-2-Pent anone

2-Hexanone

retrachlorcethene

1,1,2,2-Tetrachloroethane

Tolvene

I sobut anol

Total (A.lomed) Hold Time

Dilution factor

(2)

$\begin{array}{ll}\ldots & \cdots \\ \cdots & \cdots \\ \cdots & \cdots\end{array}$

10-3-92

$\begin{array}{rr}1420 & 10(16) d \\ 1.000 & 1.000\end{array}$




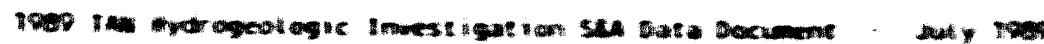

Iable F-2. 1989 IAM hydrogeologic investigation-seaivolatile organic data.

MREA

Locentio

rrpe of locaito

SepPLE WTEE

IDIIA

Unils

sor me

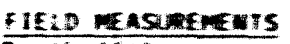

Defth $(t+)$

ineEl comanos

Prenol

2-Chtor sphenol

Sentrt aicotol

2-Methylpheno

- Met thy ipheno

2-vitropheno:

2.4-Dimethyl pheno

serzoic acid

2.6-0ichli or aphenol

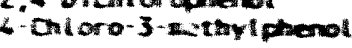

2.4.6-1rictil or ophenol

2. 6-D 2 mi traphene!

- vir reptieno

4.3-Dinstro-2-aethyil phenol

Oin butylphthatate

bist2-Ethylhexyl gantaallate

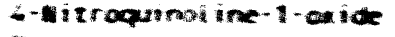

reporre

iotal (A: towed) wold time

Dilut ior. Factor

10. 3-93

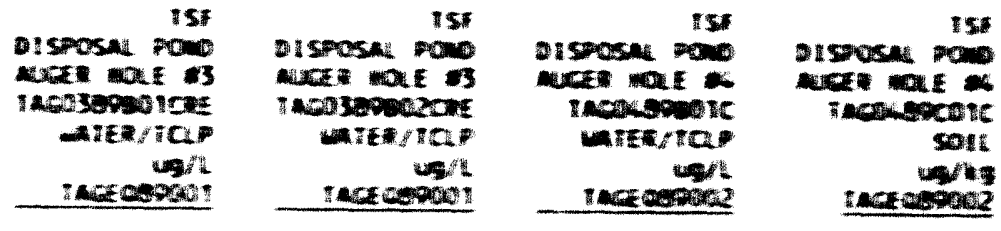

5.7

5.

5-

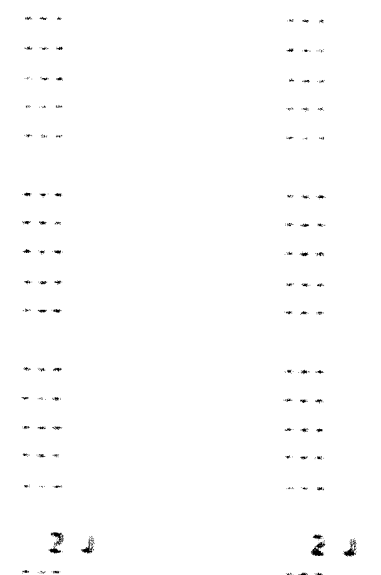

270
.

19

12.

‥

14.

5.

7.

蝳

5

5.

3

value
ขอ 2

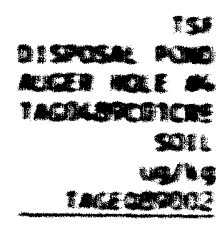

12

2000

$\cdots$

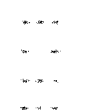

$\cdots$

…

400

$-1400$

…

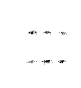

...

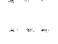

$-40$

\begin{tabular}{|c|c|}
\hline 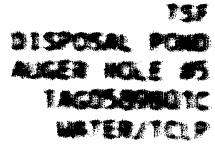 & 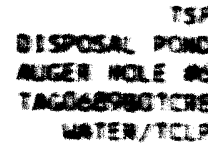 \\
\hline inctososis: & iaceesow \\
\hline
\end{tabular}

5.

5.

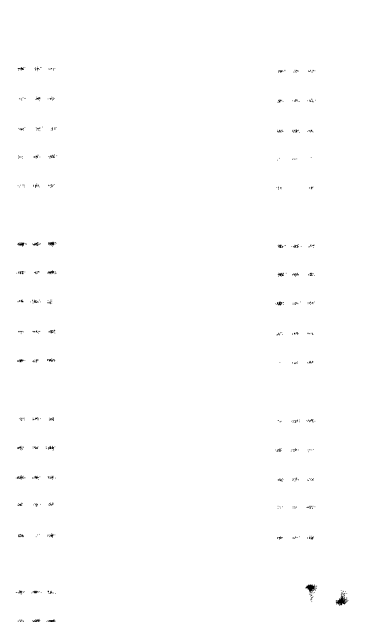

ractor 


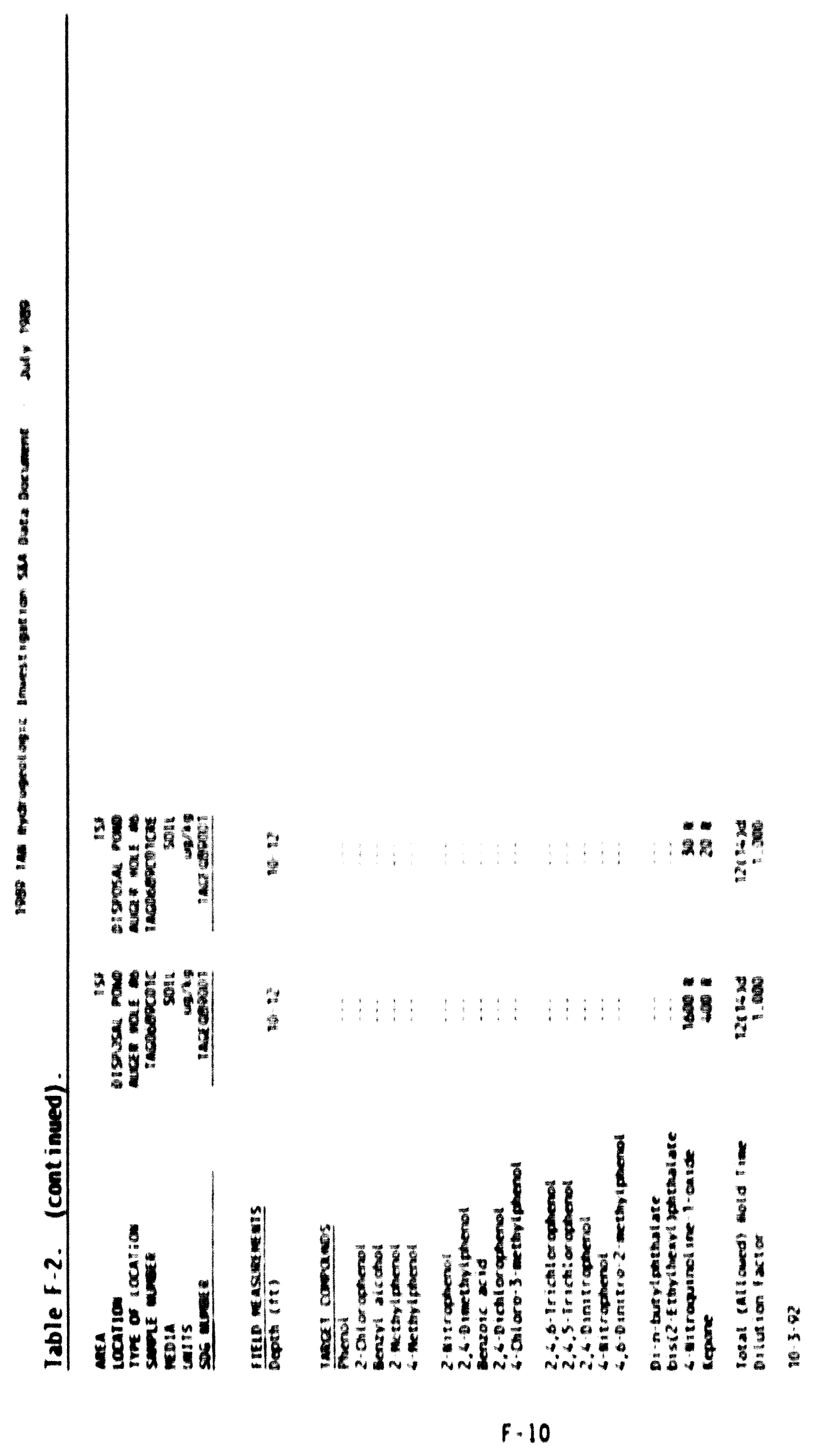




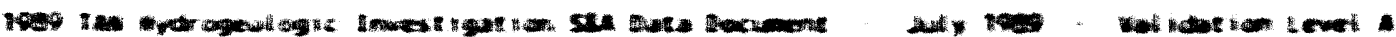

Iable F-3. 1989 IAM hydrogeologic investigation-volatile orgaaics suppleneatal data.

IAEA

Localion

irfer of cocarra

serpe tocartio

Serve

nein

Uwits

Sor ane

Acetonitritie

Acrolein

Actulicaivisie

it Dicume

Ditution factor

Percent moisture

Fieldrsinipoing Tive

Anal (Mllamed) wold lise

Total (Allowed: Hold ine

10- $10-92$

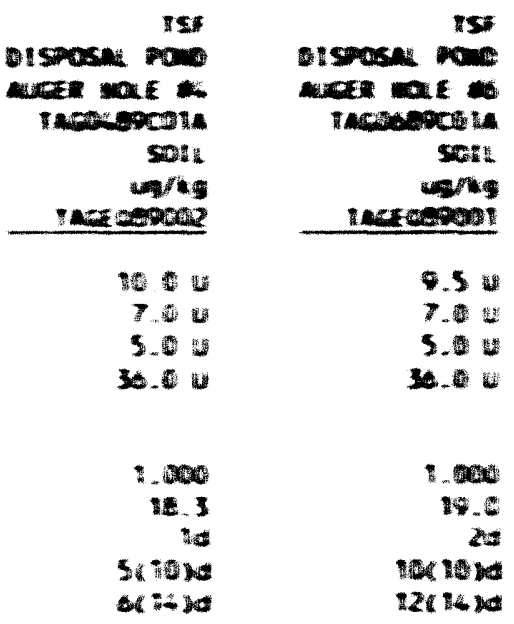




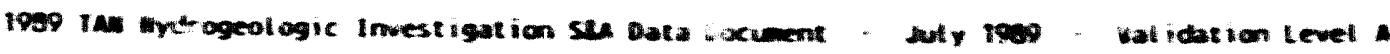

Table F-4. 1989 IAN hydrogeologic investigation-volatile organics supplemental QC data-SD6 TA6E089001.

\begin{tabular}{|c|c|c|c|c|c|c|}
\hline 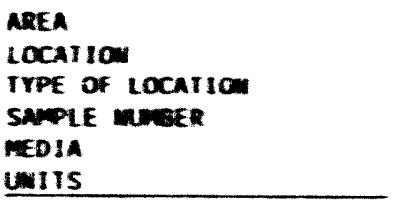 & 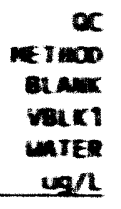 & 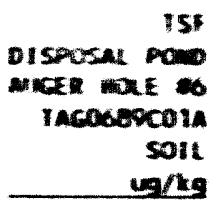 & 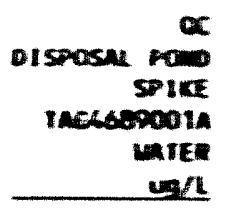 & 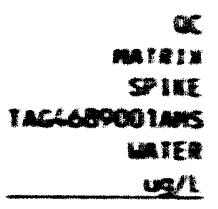 & 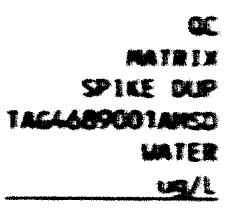 & 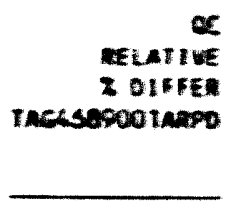 \\
\hline $\begin{array}{l}\text { Acetonitrite } \\
\text { Acrolein } \\
\text { Acrytonitrile } \\
1 . \text { O Dioxane }\end{array}$ & $\begin{array}{r}8.0 \mathrm{u} \\
6.0 \mathrm{U} \\
4.0 \mathrm{u} \\
30.0 \mathrm{u}\end{array}$ & $\begin{array}{r}9.5 \mathrm{u} \\
7.0 \mathrm{u} \\
5.0 \mathrm{u} \\
30.0 \mathrm{u}\end{array}$ & $\begin{array}{r}8.0 \mathrm{u} \\
6.0 \mathrm{u} \\
4.0 \mathrm{u} \\
30.0 \mathrm{u}\end{array}$ & $\begin{array}{r}82(02) \\
7(95 \pi) \\
59(99 \pi) \\
625(162 \pi)\end{array}$ & $\begin{array}{r}20(997) \\
79(1000) \\
61(161 x) \\
40(160 x)\end{array}$ & $\begin{array}{l}7.32 \\
5.12 \\
2.08 \\
2.06\end{array}$ \\
\hline $\begin{array}{l}\text { Dilution factor } \\
\text { Percent Moisture } \\
\text { field/Shipping Tide } \\
\text { anal (Allowed) Hold tile } \\
\text { lotal (Allowed) nold time }\end{array}$ & 1.000 & $\begin{array}{r}.000 \\
19.0 \\
2 d \\
10(10) d \\
12(14) d\end{array}$ & $\begin{array}{r}1.000 \\
1 d \\
10(10) d \\
11(14) d\end{array}$ & 1.000 & 1.000 & \\
\hline
\end{tabular}

$10-5-92$ 
1989 tan Bydrogeologic Imestigation SeA Data Dociment - July 1909

Table F-5. 1989 TAN hydrogeologic investigation-inorganic data.

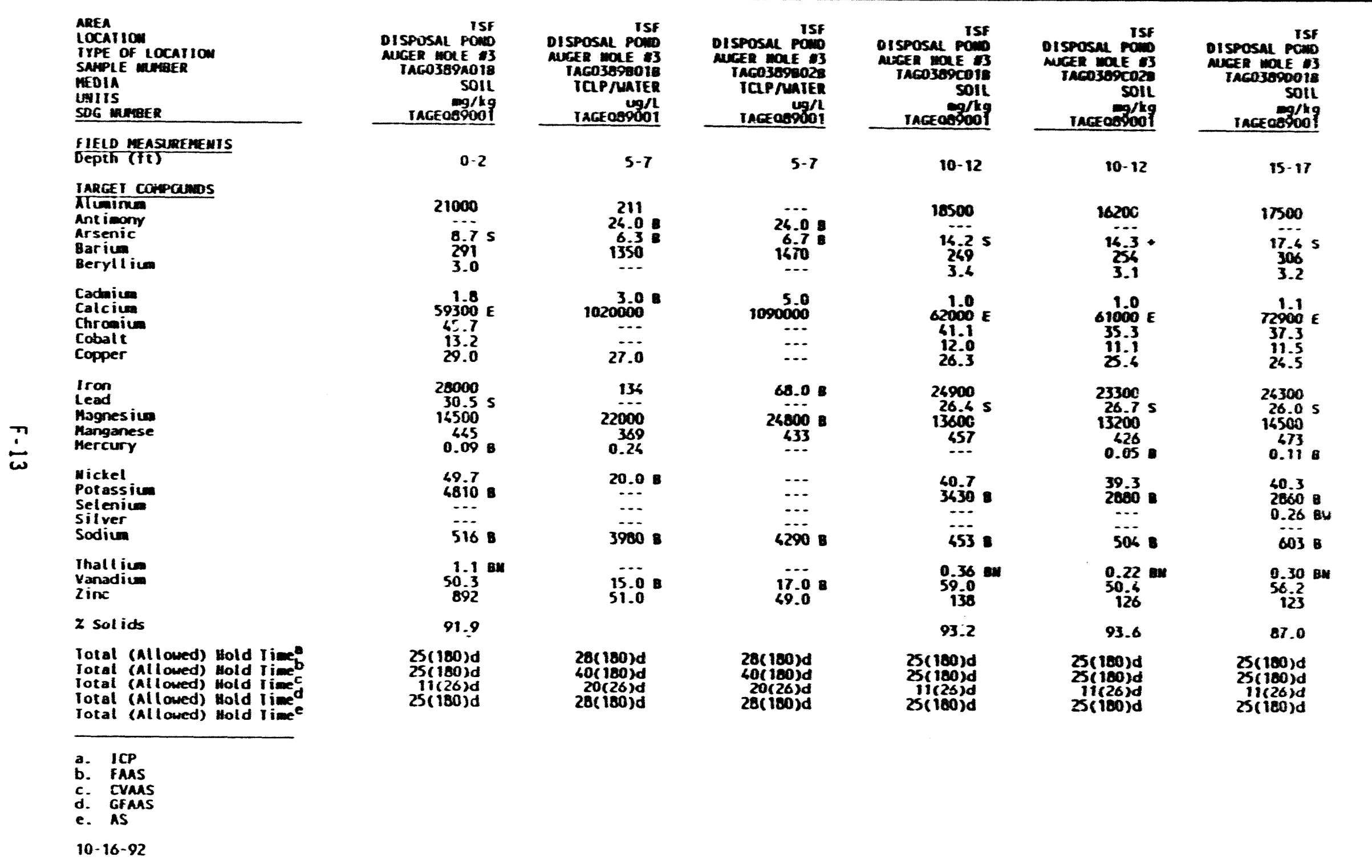


1989 IAN Hydrogeologic Investigation S\&A Date Document - July 1989

Table F-5. (cont inued).

\begin{tabular}{|c|c|c|c|c|c|c|}
\hline $\begin{array}{l}\text { AREA } \\
\text { LOCAIIOH } \\
\text { IYPE OF LOCAIIION } \\
\text { SNEPLE WWBER } \\
\text { MEDIA } \\
\text { LWIIS } \\
\text { SOG MUMBER } \\
\end{array}$ & 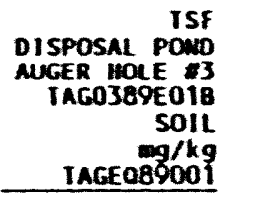 & 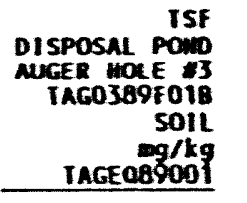 & 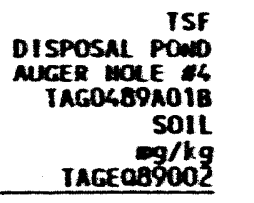 & 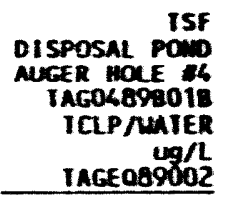 & 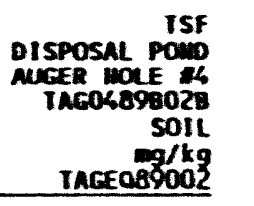 & 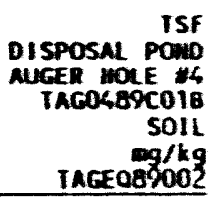 \\
\hline $\begin{array}{l}\text { FIELD MEASUREMENIS } \\
\text { Depth (it) }\end{array}$ & $20-22$ & $25-27$ & $0-2$ & $5-7$ & $5-7$ & $10-12$ \\
\hline $\begin{array}{l}\text { IARCEI COMPOUMS } \\
\text { Aluminum } \\
\text { Antimoony } \\
\text { Arsenic } \\
\text { Barium } \\
\text { Beryllim }\end{array}$ & $\begin{array}{c}1400 \\
13.7 \mathrm{~s} \\
253 \\
2.8\end{array}$ & $\begin{array}{l}16700 \\
11.4 \\
283 \\
3.6\end{array}$ & $\begin{array}{c}23400 \\
5.1 \\
293 \\
4.6\end{array}$ & \begin{tabular}{l}
954 \\
\hdashline .11 \\
983 \\
.--
\end{tabular} & $\begin{array}{c}16100 \\
17.5 \mathrm{~s} \\
260 \\
3.6\end{array}$ & $\begin{array}{r}10.2 \\
356\end{array}$ \\
\hline $\begin{array}{l}\text { Cactaium } \\
\text { Calcium } \\
\text { Chromium } \\
\text { Cobalt } \\
\text { Copper }\end{array}$ & $\begin{array}{l}1.2 \\
70700 \mathrm{E} \\
33.4 \\
10.8 \\
21.9\end{array}$ & $\begin{array}{c}0.69 \mathrm{~B} \\
19600 \mathrm{E} \\
36.9 \\
11.7 \\
22.3\end{array}$ & $\begin{array}{r}1.7 \\
50500 \\
45.6 \\
12.6 \\
27.3\end{array}$ & $\begin{array}{c}3.0 \\
725000 \\
\cdots \\
\cdots \\
\cdots\end{array}$ & $\begin{array}{c}1.0 \mathrm{~B} \\
83200 \\
33.8 \\
11.7 \\
26.2\end{array}$ & $\begin{array}{l}0.978 \\
44.4 \\
13.8 \\
39.5\end{array}$ \\
\hline $\begin{array}{l}\text { Iron } \\
\text { Lead } \\
\text { Magnesium } \\
\text { Manganese } \\
\text { Mercury }\end{array}$ & $\begin{array}{c}20700 \\
21.4 \mathrm{~s} \\
13000 \\
495 \\
0.08 \mathrm{~B}\end{array}$ & $\begin{array}{c}25200 \\
26.2 \mathrm{~s} \\
9230 \\
482 \\
0.21\end{array}$ & $\begin{array}{c}28400 \\
30.4 \mathrm{~s} \\
14400 \\
345 \\
0.05 \mathrm{~B}\end{array}$ & $\begin{array}{c}685 \\
2.3 \mathrm{~s} \\
25800 \mathrm{~B} \\
129 \\
\ldots\end{array}$ & $\begin{array}{c}24000 \\
29.25 \\
14600 \\
501 \\
\ldots\end{array}$ & $\begin{array}{l}23.6 \\
0.108\end{array}$ \\
\hline $\begin{array}{l}\text { Nickel } \\
\text { Potassium } \\
\text { Seleniu } \\
\text { Silver } \\
\text { Sodium }\end{array}$ & $\begin{array}{c}36.7 \\
3010 \mathrm{~B} \\
\ldots \ldots \\
500 \mathrm{~B}\end{array}$ & $\begin{array}{c}36.9 \\
2660 \\
\cdots \\
612\end{array}$ & \begin{tabular}{l}
48.8 \\
6010 \\
0.26 BH \\
\hdashline 723 8
\end{tabular} & $\begin{array}{c}1820 \\
\ldots \\
4030 \\
0\end{array}$ & $\begin{array}{l}39.1 \\
3160 \mathrm{~B} \\
0.63 \text { हn } \\
570 \mathrm{~B}\end{array}$ & $\begin{array}{c}46.6 \\
\ldots \\
\cdots\end{array}$ \\
\hline $\begin{array}{l}\text { Thallium } \\
\text { Vanadius } \\
\text { Zinc }\end{array}$ & $\begin{array}{l}0.21 \text { an } \\
49.3 \\
96.0\end{array}$ & $\begin{array}{c}0.2181 \\
46: 9 \\
105 .\end{array}$ & $\begin{array}{c}0.21 \text { Bn } \\
54.7 \\
201\end{array}$ & $\begin{array}{l}15.0 \\
49.0\end{array}$ & 56.8 & $\begin{array}{r}51.9 \\
126\end{array}$ \\
\hline$x$ Sol ids & 88.2 & 85.1 & 90.6 & & 90.3 & 81.7 \\
\hline $\begin{array}{l}\text { Iotal (Allowed) Hold Iime } \\
\text { Iotal (Allowed) Hold I ime } \\
\text { lotal (Allosed) Hold Iime } \\
\text { Ictal (Allowed) Hold Iimed } \\
\text { lotal (Allowed) Hold I ime }\end{array}$ & $\begin{array}{l}25(180) d \\
25(180) d \\
11(26) d \\
25(180) d\end{array}$ & $\begin{array}{l}25(180) d \\
25(180) d \\
11(26) d \\
25(180) d\end{array}$ & $\begin{array}{l}13(180) d \\
13(180) d \\
27(26) d \\
13(180) d\end{array}$ & $\begin{array}{l}16(180) d \\
16(180) d \\
28(26) d \\
16(180) d\end{array}$ & $\begin{array}{l}13(180) d \\
13(180) d \\
27(26) d \\
13(180) d\end{array}$ & $\begin{array}{l}38(180) d \\
36(26) d^{*} \\
38(180) d \\
26(12) d^{*}\end{array}$ \\
\hline $\begin{array}{l}\text { a. ICP } \\
\text { b. IAAS } \\
\text { c. CVAAS } \\
\text { d. GFAAS } \\
\text { e. AS } \\
10-16-92\end{array}$ & & & & & & \\
\hline
\end{tabular}


Iable F-5. (cont inued).

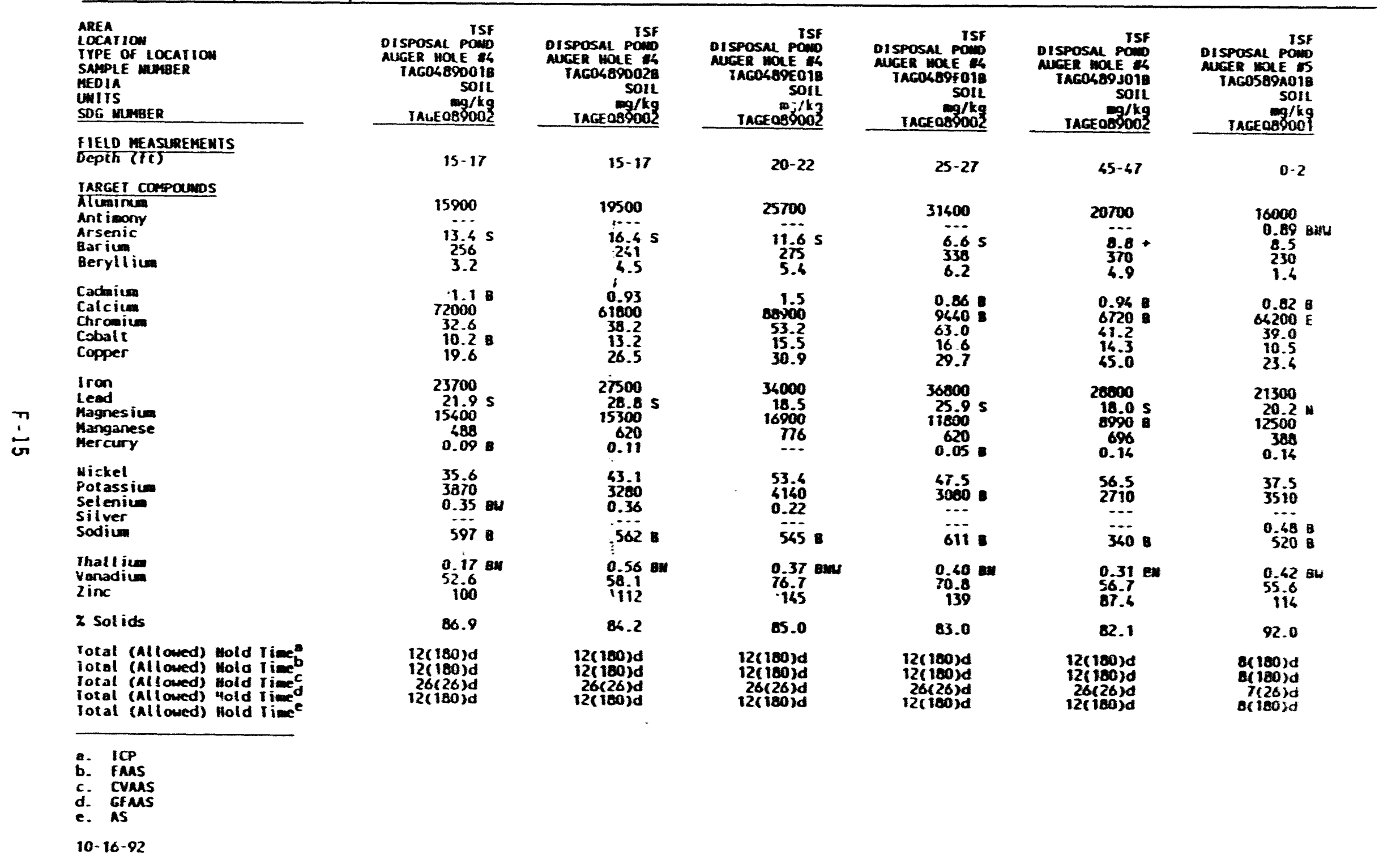


1989 IAN Ilydrogeologic Investigation S\& Dato Document - July 1909

Table F-5. (cont inued).

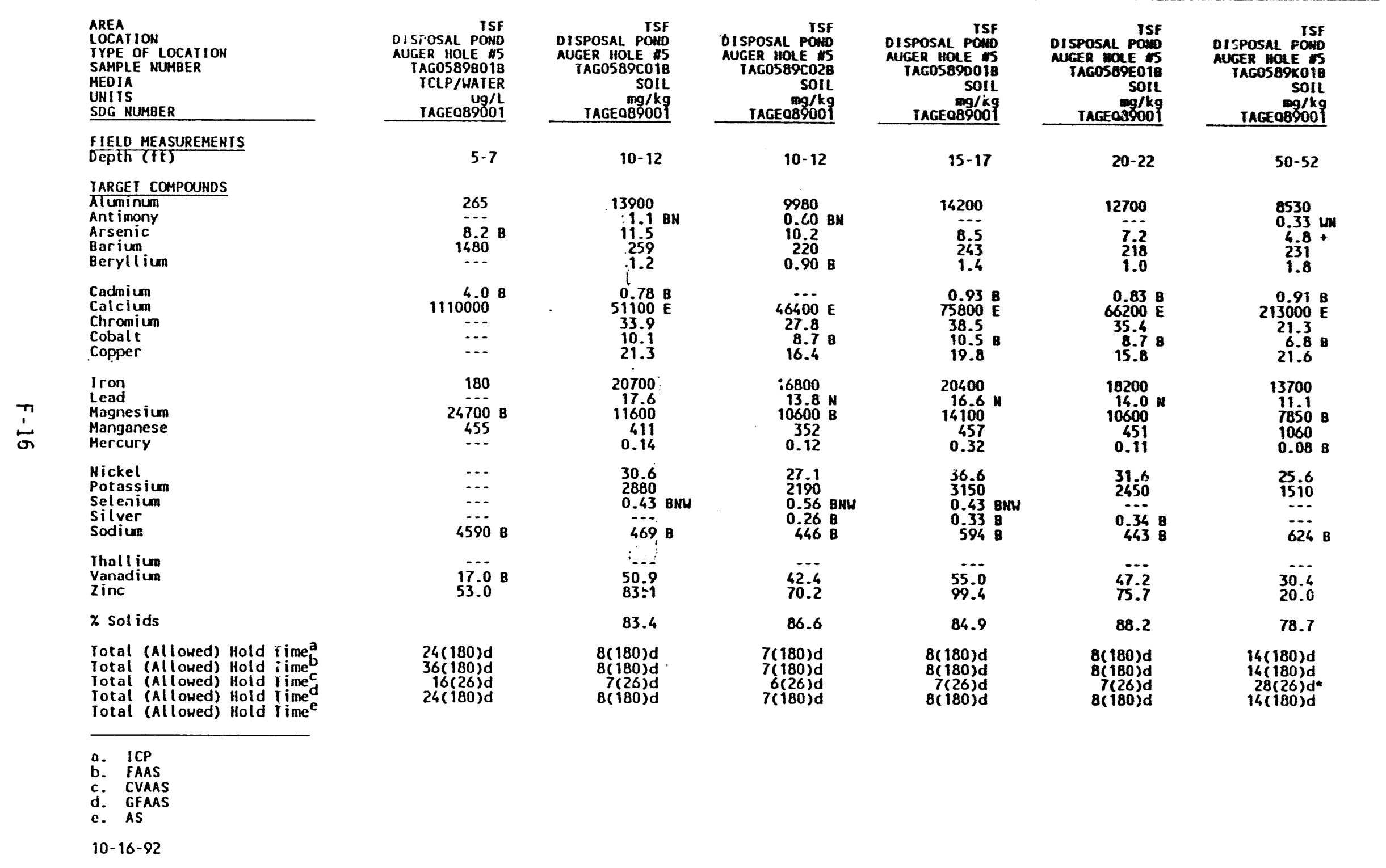


1989 IAN Hydrogeologic Investigation S\&A Data Document • July 1989

Table F-5. (continued).

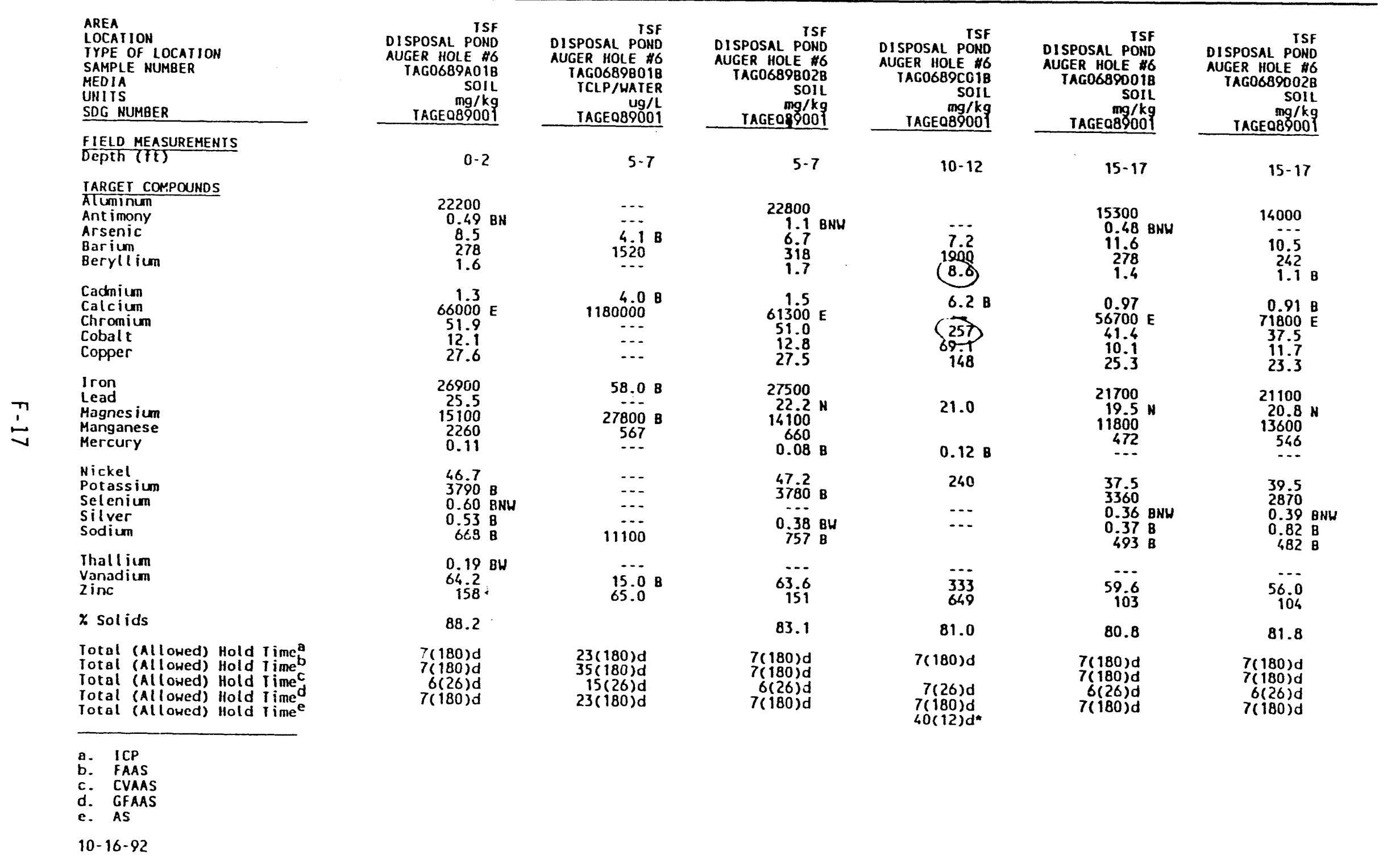


Table F-5. (continued).

1989 TAN Hydrogeologic Investigation S\&A Data Document · July 1989

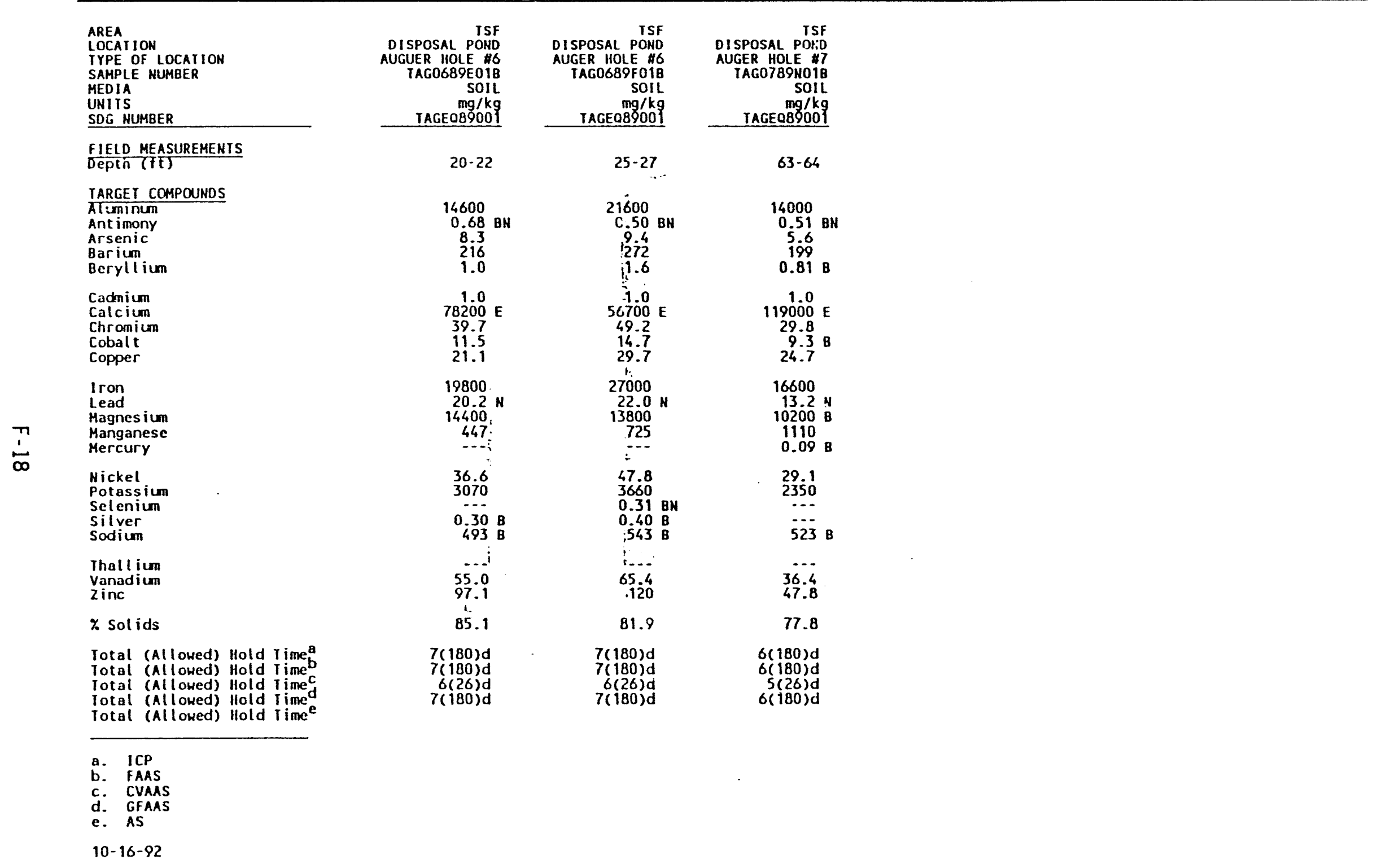


Table F-6. Summary of analyses.

Anulytical Melloods

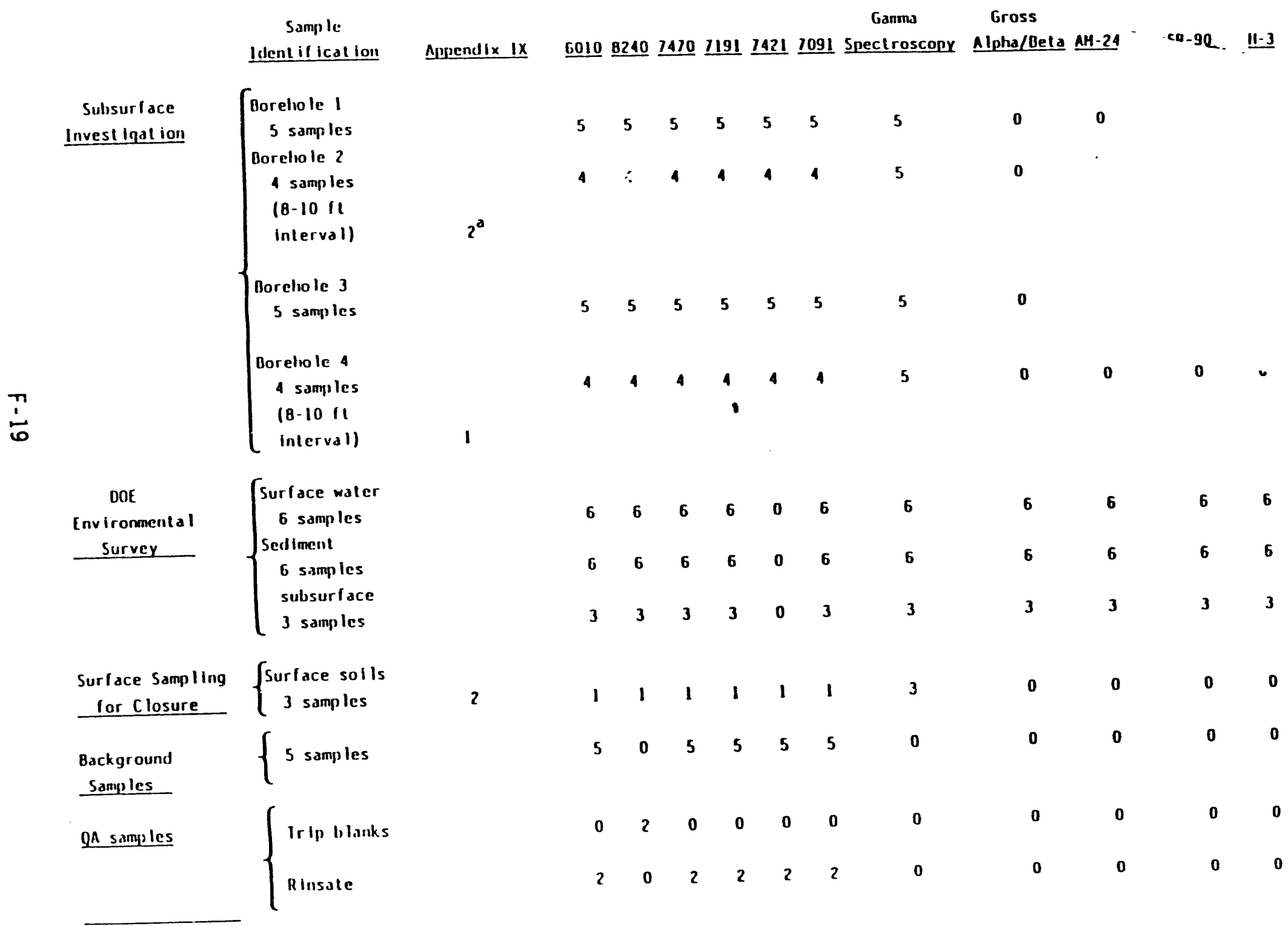

a. Methods for Appendix IX constituents are presented in the analytical methods section of EPA's Test Methods for Evaluating Solid Waste, Physical Chemical Methods, 3rd Ed. SW-846, 1986. 
APPENDIX G

ANALYTICAL RESULTS FOR SAMPLING EVENT 5

G-1 
ISF Evaporation Pond S\&A Data Document - Movember 1989 - Method Validation Level B

TABLE 6-1. TSF EVAPORATION POMD - AMALYSIS RESULTS FOR GAMA-EMITIING RADIOMUCLIDES

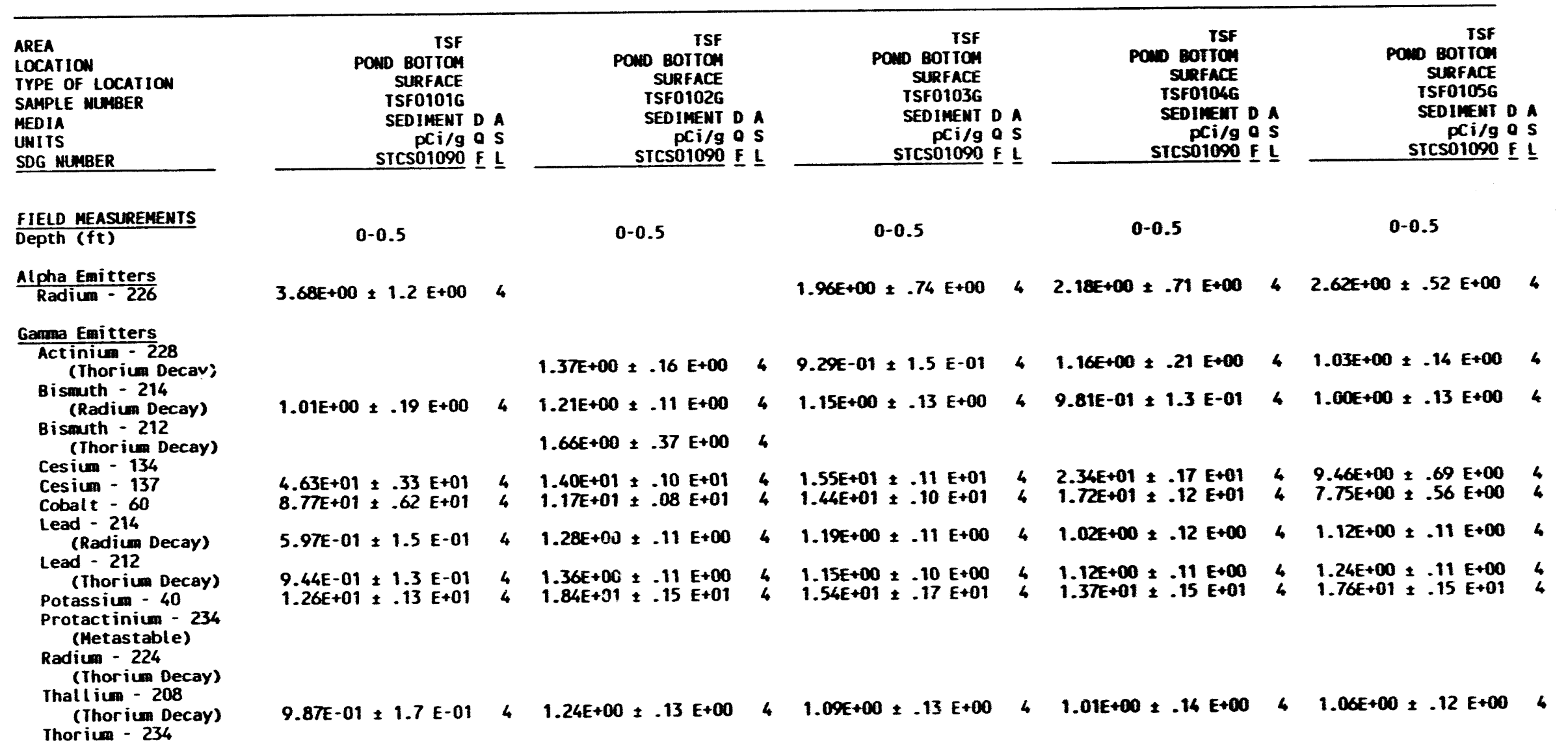

a. The DOF colum contains any data qualifier flags.

b. The ASL colum contains the analytical support level.

2-15-93

NOTE: Table 6-10, page 6-78, summarizes all analytical results for sampling event 5. 
ISF Evaporation Pond SeA Data Document - November 1989 - Method Validation Level B

TABLE 6-1. TSF EVAPORATION POW - AMAYSIS RESULIS FOR GAma-EMITIIMG RADIOWUaldes (Continued)

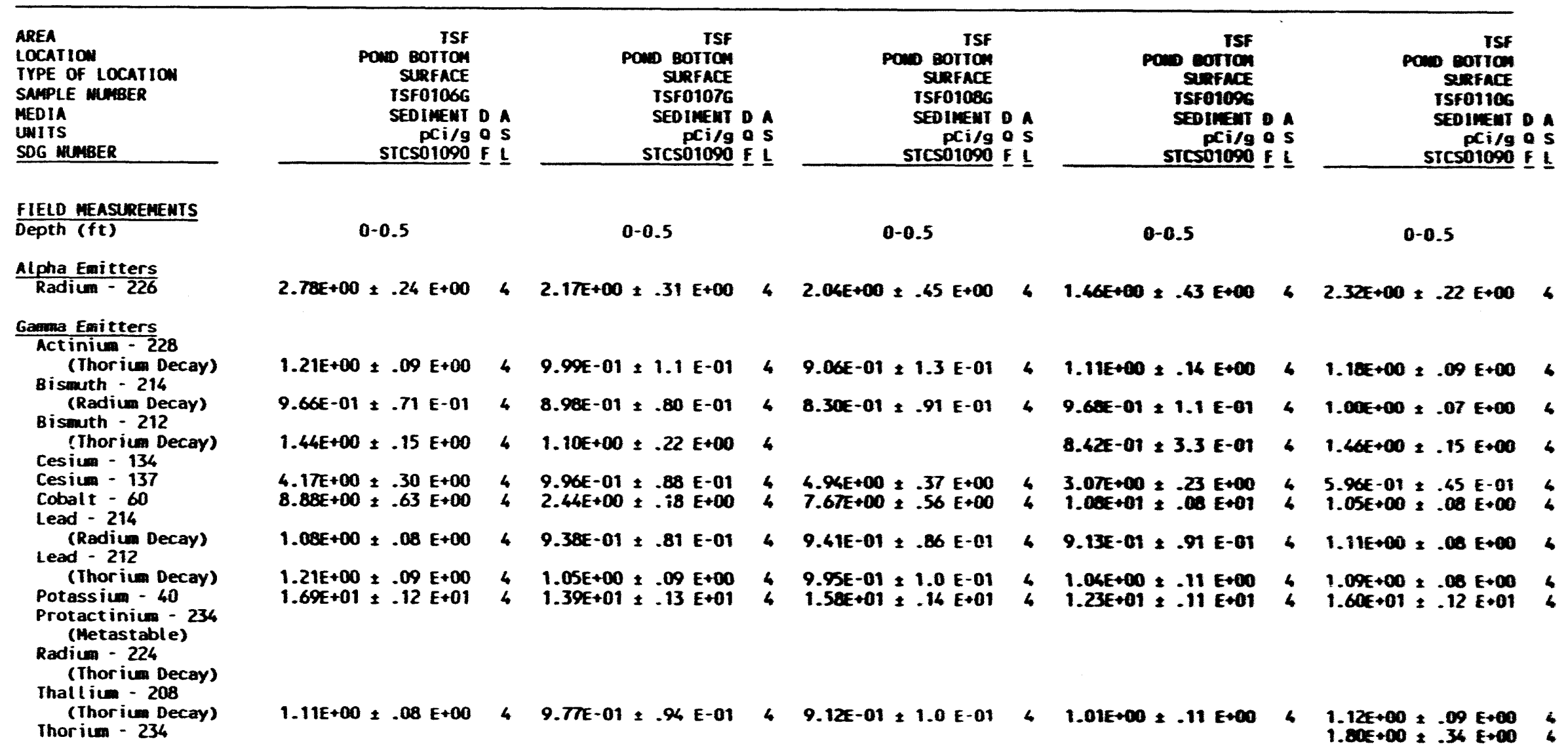

a. The Daf colum contains any data qualifier flags.

b. The ASL colum contains the analytical support level.

2-15-93 
ISF Evaporation Pond Sel Data Document - Movenber 3909 - Method Val idbtion Level

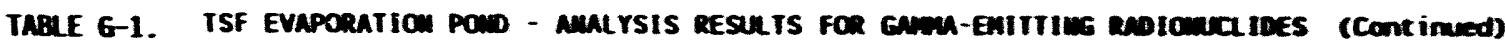

\begin{tabular}{|c|c|c|c|c|c|c|c|c|c|}
\hline $\begin{array}{l}\text { AREA } \\
\text { LOCATION } \\
\text { TYPE OF LOCATION } \\
\text { SAMPLE MRBER } \\
\text { MEDIA } \\
\text { UNITS } \\
\text { SDG MAMBER } \\
\end{array}$ & $\begin{array}{r}\text { ISF } \\
\text { POND BOTIOH } \\
\text { SURFACE } \\
\text { TSFO111G } \\
\text { SEDINEMT } \\
\text { PCi/g } \\
\text { SICSO1090 }\end{array}$ & & 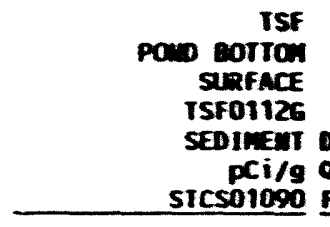 & & 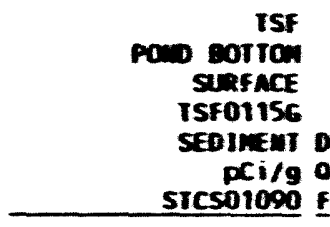 & & 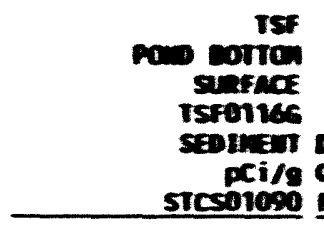 & & 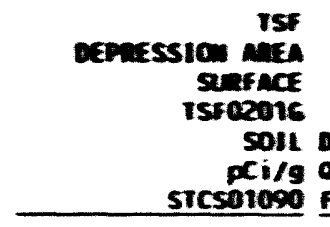 \\
\hline$\frac{\text { FIELD MEASUREMEMTS }}{\text { Depth }(\mathrm{ft})}$ & $0-0.5$ & & 0.0 .5 & & $0-0.5$ & & $0-0.5$ & & $0-0.3$ \\
\hline$\frac{\text { Alpha Emitters }}{\text { Radium }-226}$ & $1.96 E+\infty 0.19 E+00$ & 4 & $2.53 E+00=.34 E+\infty 0$ & 4 & $2.7 x+60 \geq-40 \mathrm{E}+60$ & 4 & $2.0 x+60=.71 \in+\infty$ & 6 & $2.61 E+60=.22 E+60$ \\
\hline 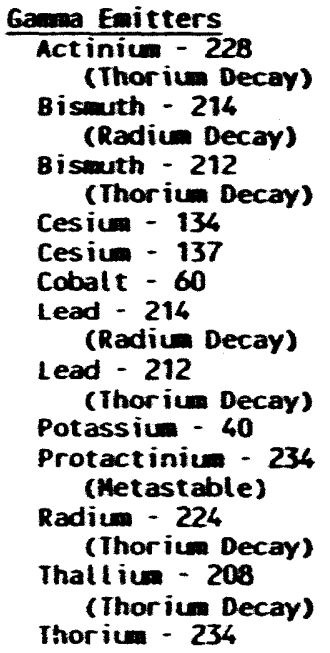 & $\begin{array}{l}9.66 E-01 \div .73 \mathrm{E}-01 \\
8.70 E-01 \pm .65 \mathrm{E}-01 \\
1.26 \mathrm{E}+00 \geq .13 \mathrm{E}+00 \\
6.33 E-01 \pm .46 \mathrm{E}-01 \\
9.82 E-01 \pm .71 \mathrm{E}-01 \\
8.56 \mathrm{E}-01 \pm .65 \mathrm{E}-01 \\
1.01 E+00 \pm .08 \mathrm{E}+00 \\
1.36 \mathrm{E}+01 \pm .10 \mathrm{E}+01\end{array}$ & $\begin{array}{l}4 \\
4 \\
4\end{array}$ & 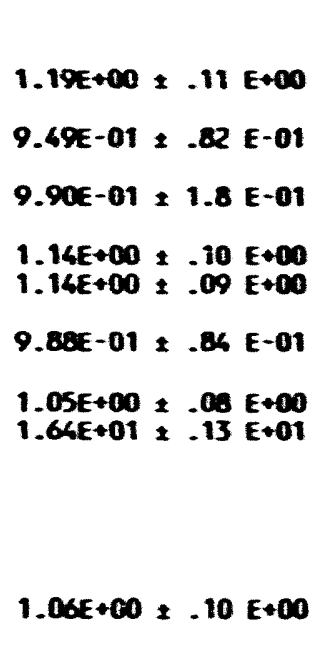 & $\begin{array}{l}4 \\
4 \\
4 \\
4 \\
4 \\
4 \\
4 \\
4\end{array}$ & 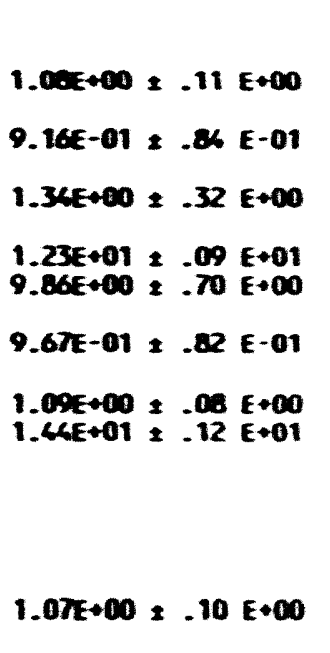 & 4 & $\begin{array}{l}3.42 \mathrm{E}+61=.25 \mathrm{E}+01 \\
6.32 \mathrm{E}+60=.67 \mathrm{E}+60 \\
1.02 \mathrm{E}+60=.13 \mathrm{E}+60 \\
1.24 \mathrm{E}+60 \geq .12 \mathrm{E}+60 \\
1.32 \mathrm{E}+01=-12 \mathrm{E}+01\end{array}$ & $\begin{array}{l}4 \\
4 \\
4 \\
4\end{array}$ & 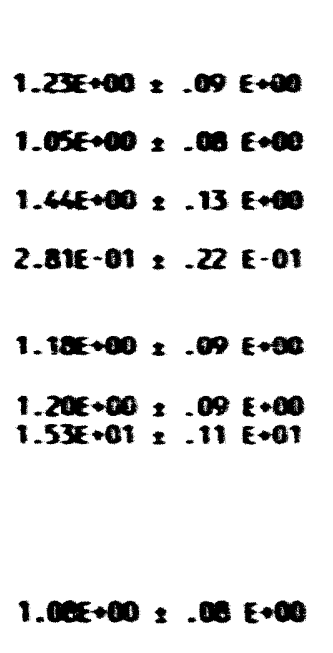 \\
\hline
\end{tabular}

a. The Dof colum contains any data qualifier flegs.

b. The ASt colum contains the analytical support level.

2-15-93 
ISF Eveporation Pond SeA Data Bocenent - November 1909 - Method Vel idetion Levet a

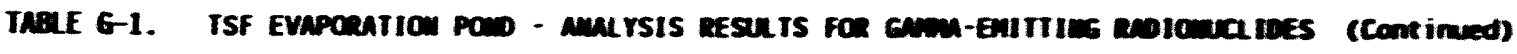

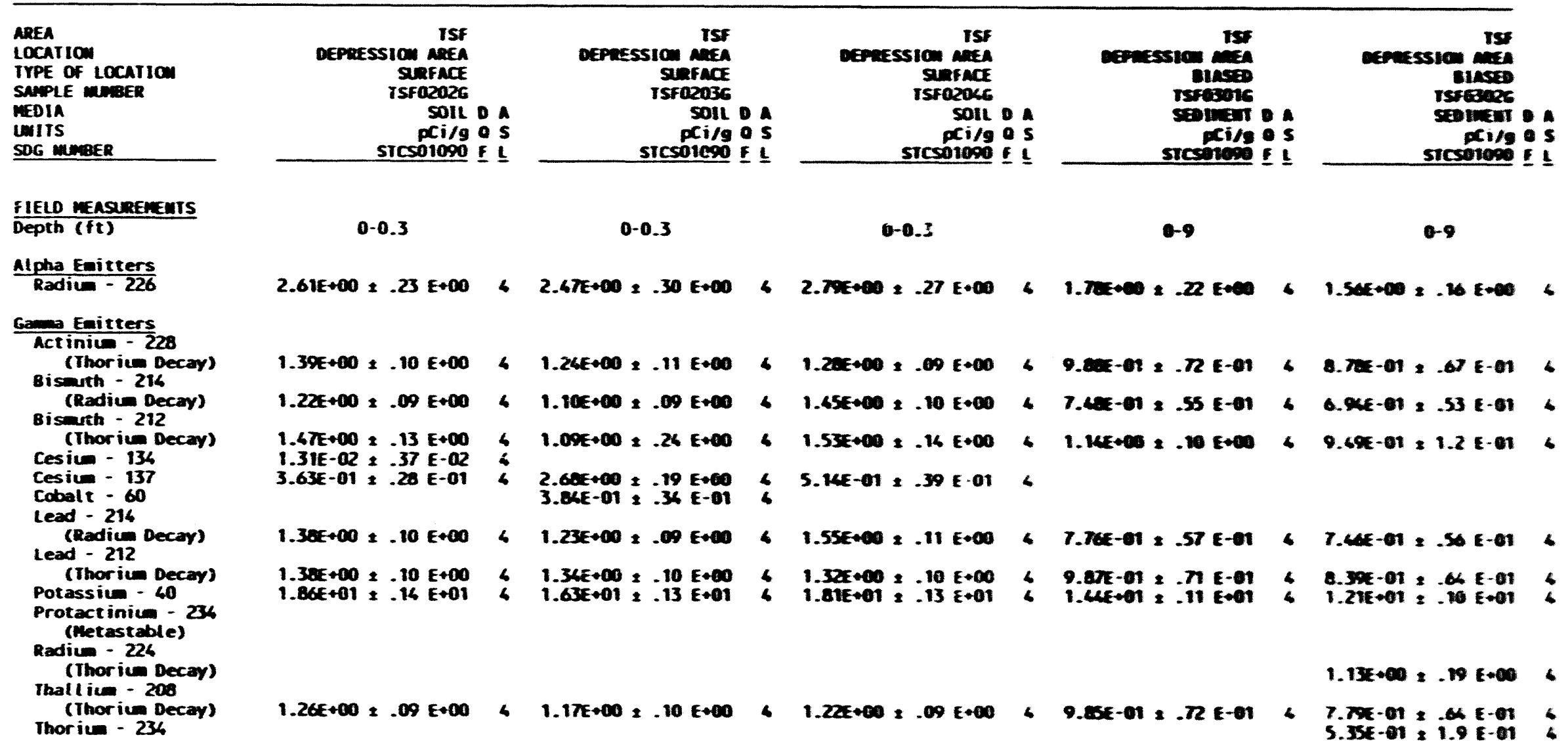

a. The Dof colum contains any data qalifier flags.

b. The ASt colum contains the analytical support level.

2-15-93 


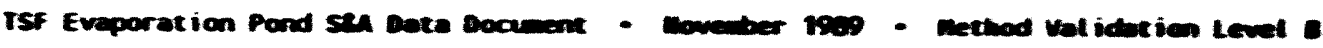

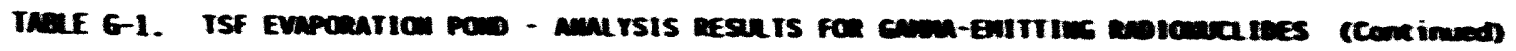

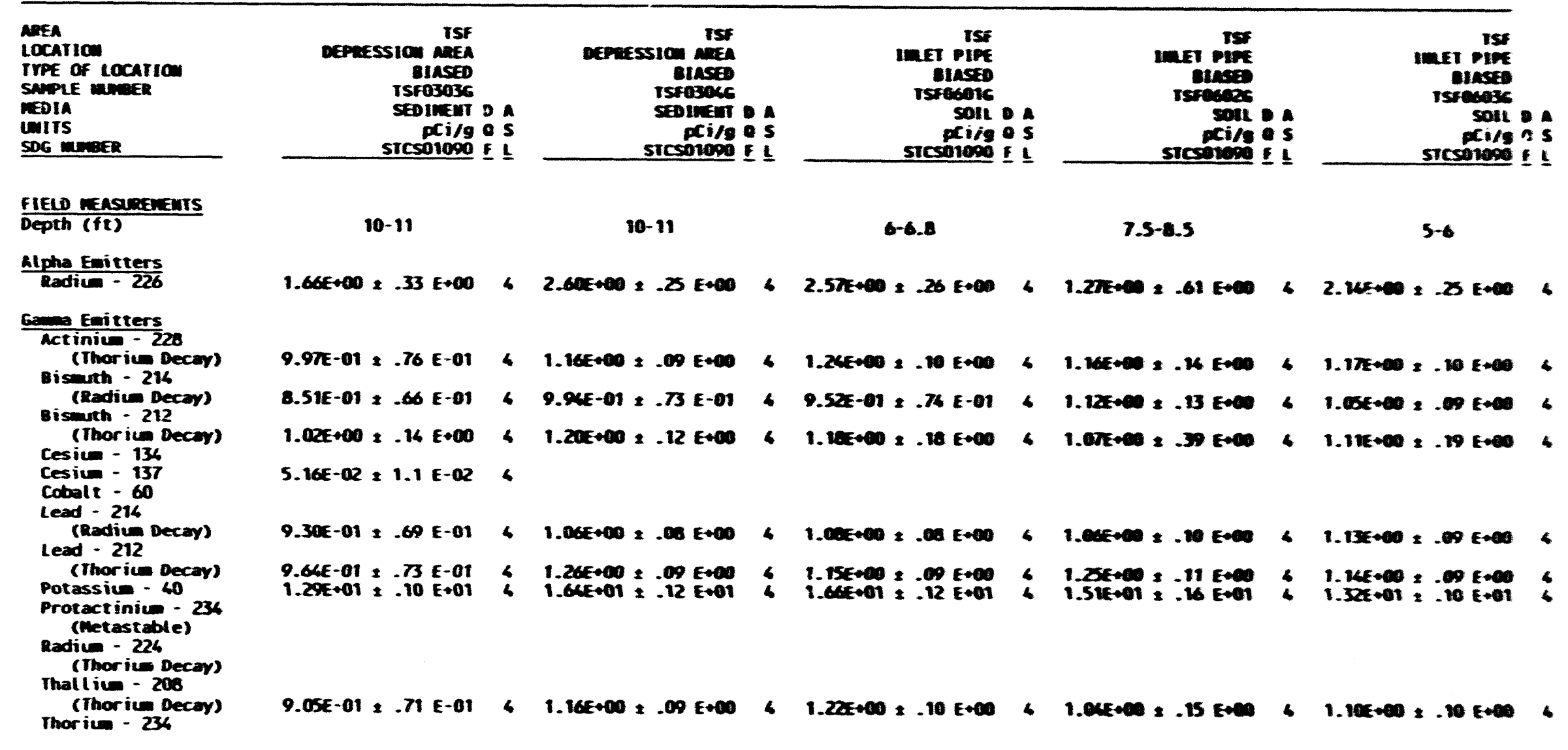

a. The Dof colum contains any data qualifier flags.

b. The ASI colum contains the analytical support level.

2-15-93 
ISf Eveporation Pond Sen Date Docament - Wovenber 1909 - Method Val idetion Levet

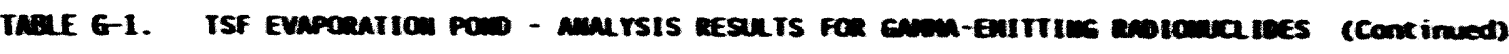

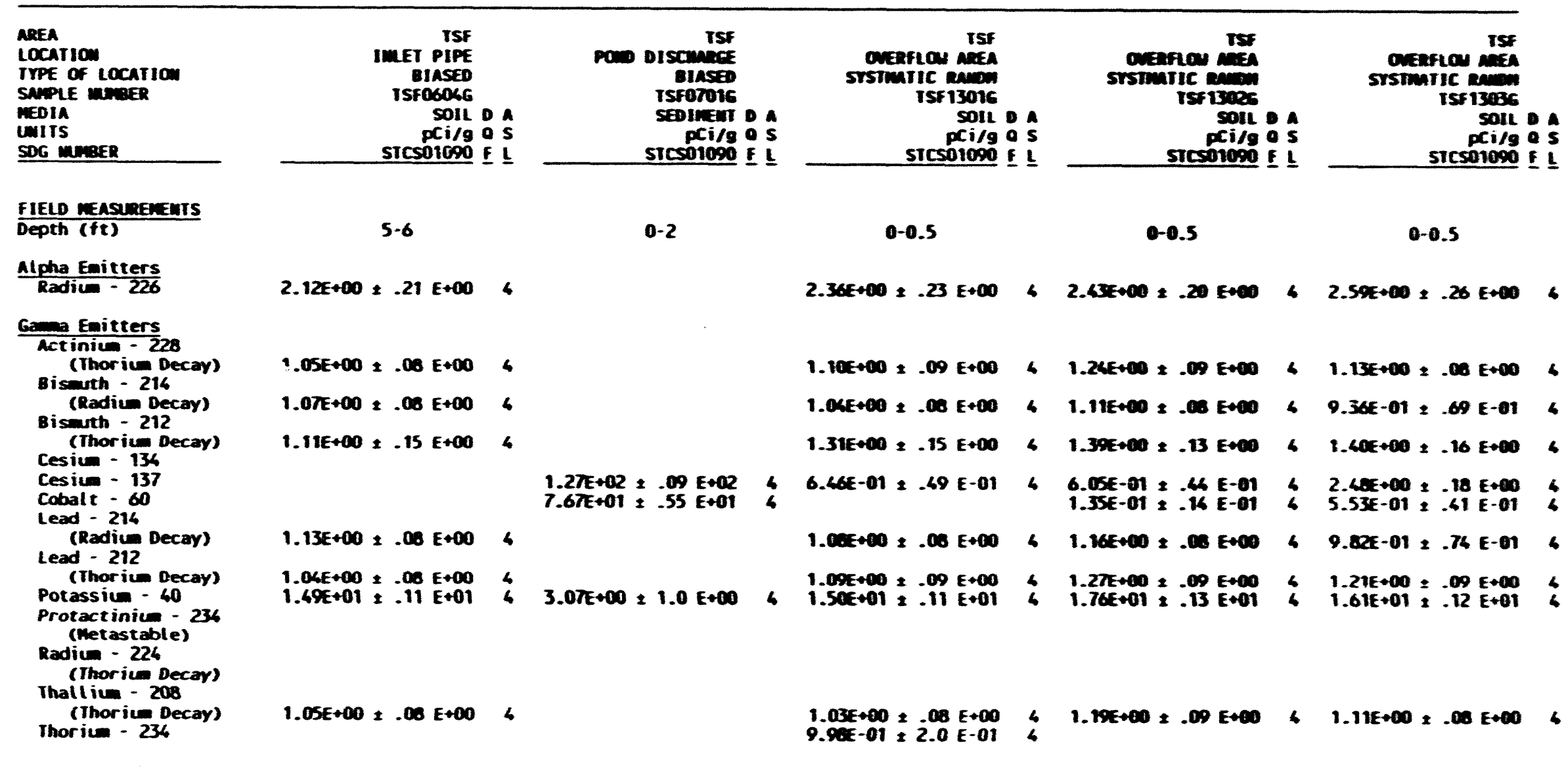

a. The DOF colum contains any data qualifier flags.

b. The ASt colum contains the analytical support level.

2-15-93 
ISF Evaporation Pond Sel Date Document - Novemer 1909 - Method Validution Level

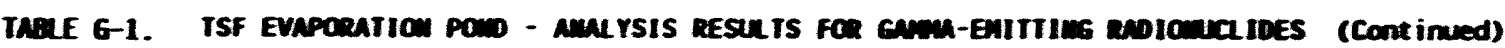

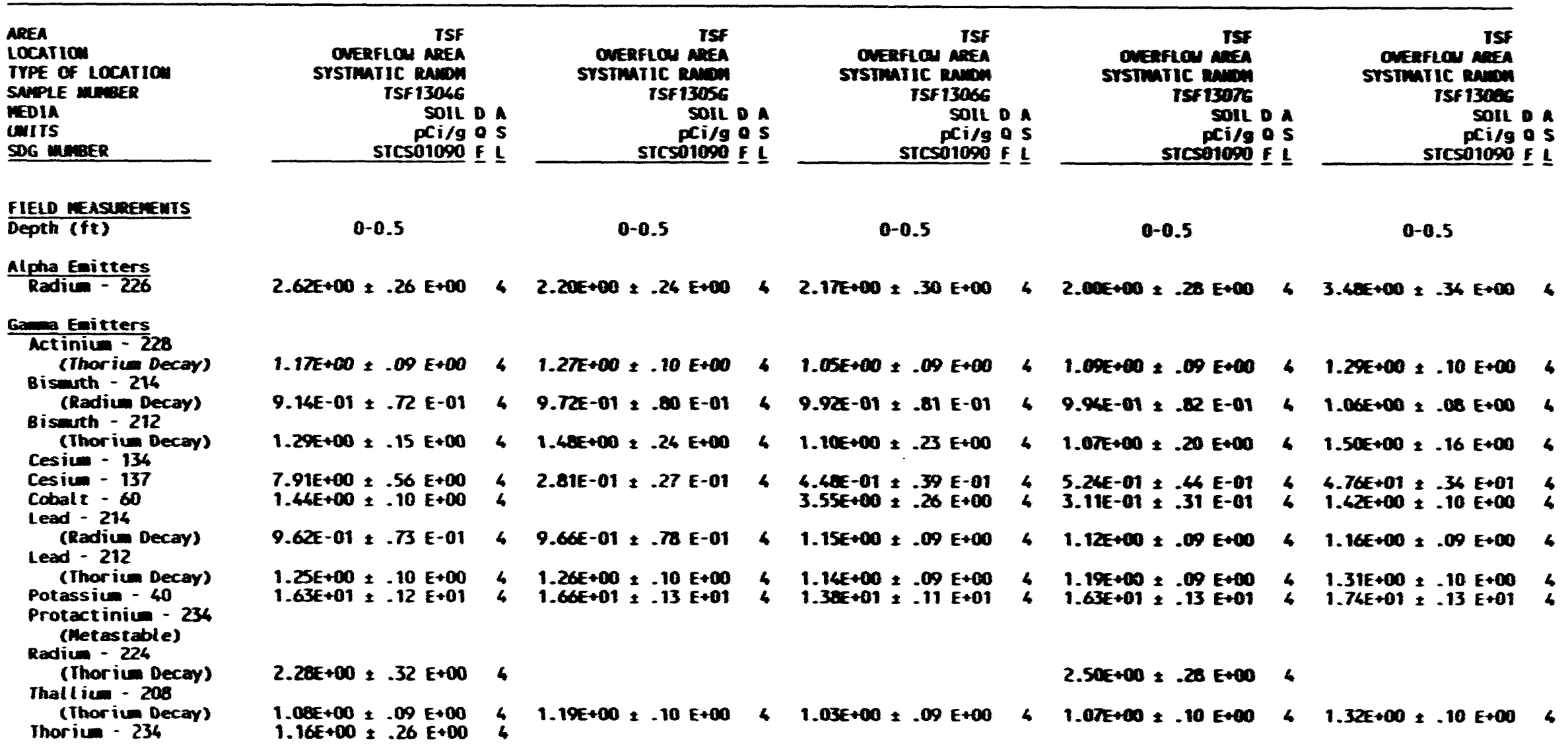

a. The DOF colum contains any data qualifier flags.

b. The ASL colum contains the analytical support level.

2-15-93 
TSF Evaporation Pond SeA Date Document - November 1909 - nethod Validation Level :

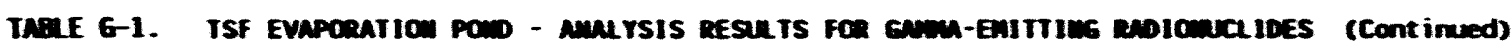

\begin{tabular}{|c|c|c|c|c|c|c|c|c|c|}
\hline 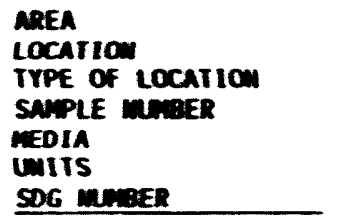 & $\begin{array}{r}\text { TSF } \\
\text { ONERFLOU AREA } \\
\text { STSTMAIC RANBH } \\
\text { ISF 13096 } \\
\text { SOIL } \\
\text { pCi/g } \\
\text { SICSOI090 }\end{array}$ & & 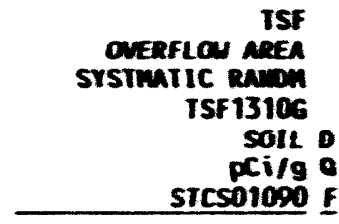 & & $\begin{array}{r}\text { ISF } \\
\text { ONERFION AREA } \\
\text { STSTMAIT RAMOH } \\
\text { ISF } 13116 \\
\text { SOIL } \\
\text { PCi/g } \\
\text { SICSOIO90 E }\end{array}$ & & 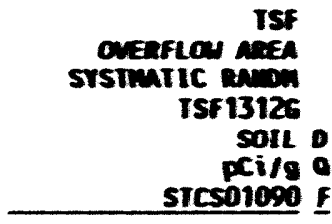 & & 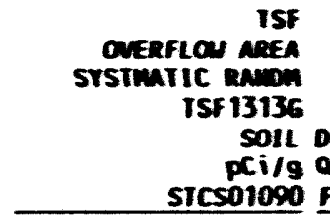 \\
\hline$\frac{\text { FIELD WEASTMENENTS }}{\text { Depth (ft) }}$ & $0-0.5$ & & $0-0.5$ & & $0-0.5$ & & $0-0.5$ & & $0-0.5$ \\
\hline$\frac{\text { Alpha Enitters }}{\text { Radium }-226}$ & $2.20 E+00=.30 \mathrm{E}+\infty 0$ & 4 & $2.51 E+00 \geq .26 E+00$ & 6 & $3.36 E+00 \pm .50 E+00$ & 4 & $2.90 \leq+60 \pm .58 E+00$ & 4 & $2.48 E+00=-23 E+60$ \\
\hline 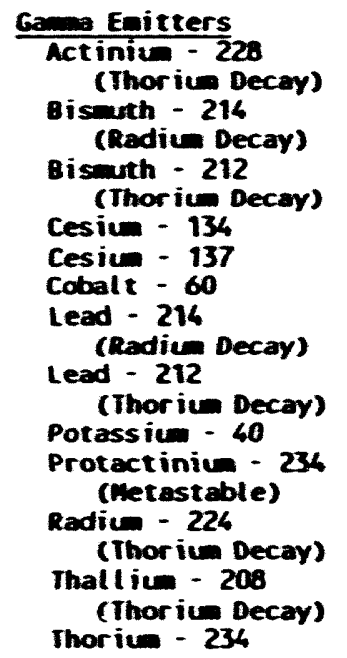 & $\begin{array}{l}1.0 \% E+00 \pm .08 E+00 \\
1.00 E+00 \pm .09 E+00 \\
1.21 E+00 \pm .15 E+00 \\
2.72 E-01 \pm .23 E-01 \\
1.10 E+00 \pm .08 E+00 \\
1.16 E+00 \pm .09 E+00 \\
1.50 E+01 \pm .11 E+01\end{array}$ & $\begin{array}{l}4 \\
4\end{array}$ & $\begin{array}{l}1.14 E+00 \pm .09 E+00 \\
1.23 E+00 \pm .09 E+00 \\
1.28 E+00 \pm .17 E+00 \\
4.29 E-01 \pm .36 E-01 \\
1.96 E+00 \pm .16 E+00 \\
1.36 E+00 \pm .10 E+00 \\
1.19 E+00 \pm .10 E+00 \\
1.54 E+01 \pm .12 E+01\end{array}$ & $\begin{array}{l}6 \\
4 \\
4\end{array}$ & $\begin{array}{l}1.44 E+00 \pm .14 E+00 \\
1.55 E+00 \pm .13 E+00 \\
1.7 E E+01=.17 E+01\end{array}$ & $\begin{array}{l}4 \\
4 \\
4\end{array}$ & $\begin{array}{l}2.25 E+01 \geq .16 \mathrm{E}+01 \\
6.90 E+00 \geq .49 \mathrm{E}+00 \\
1.06 E+00 \geq .09 \mathrm{E}+00 \\
1.06 E+00 \geq .09 \mathrm{E}+00 \\
1.38 \pm+01 \geq .11 \mathrm{E}+01\end{array}$ & $\begin{array}{l}4 \\
4 \\
4 \\
4 \\
4\end{array}$ & $\begin{array}{l}1.18 E+00 \pm .09 E+00 \\
1.00 E+00 \pm .00 E+00 \\
1.34 E+00 \pm .16 E+00 \\
5.74 E-01 \pm .44 E-01 \\
1.03 E+00 \pm .08 E+00 \\
1.17 E+00 \pm .09 E+00 \\
1.69 E+01 \geq .13 E+01 \\
3.89 E+00 \pm 1.4 E+00\end{array}$ \\
\hline
\end{tabular}

a. The Dof colum contains any data qualifier flags.

b. The ASL colum contains the amalytical support level.

2-15-93 
ISF Evapuration Pond SeA Data Docament - Movember 1909 - Method Val idetion Level

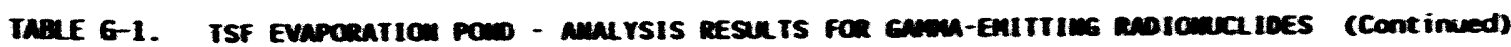

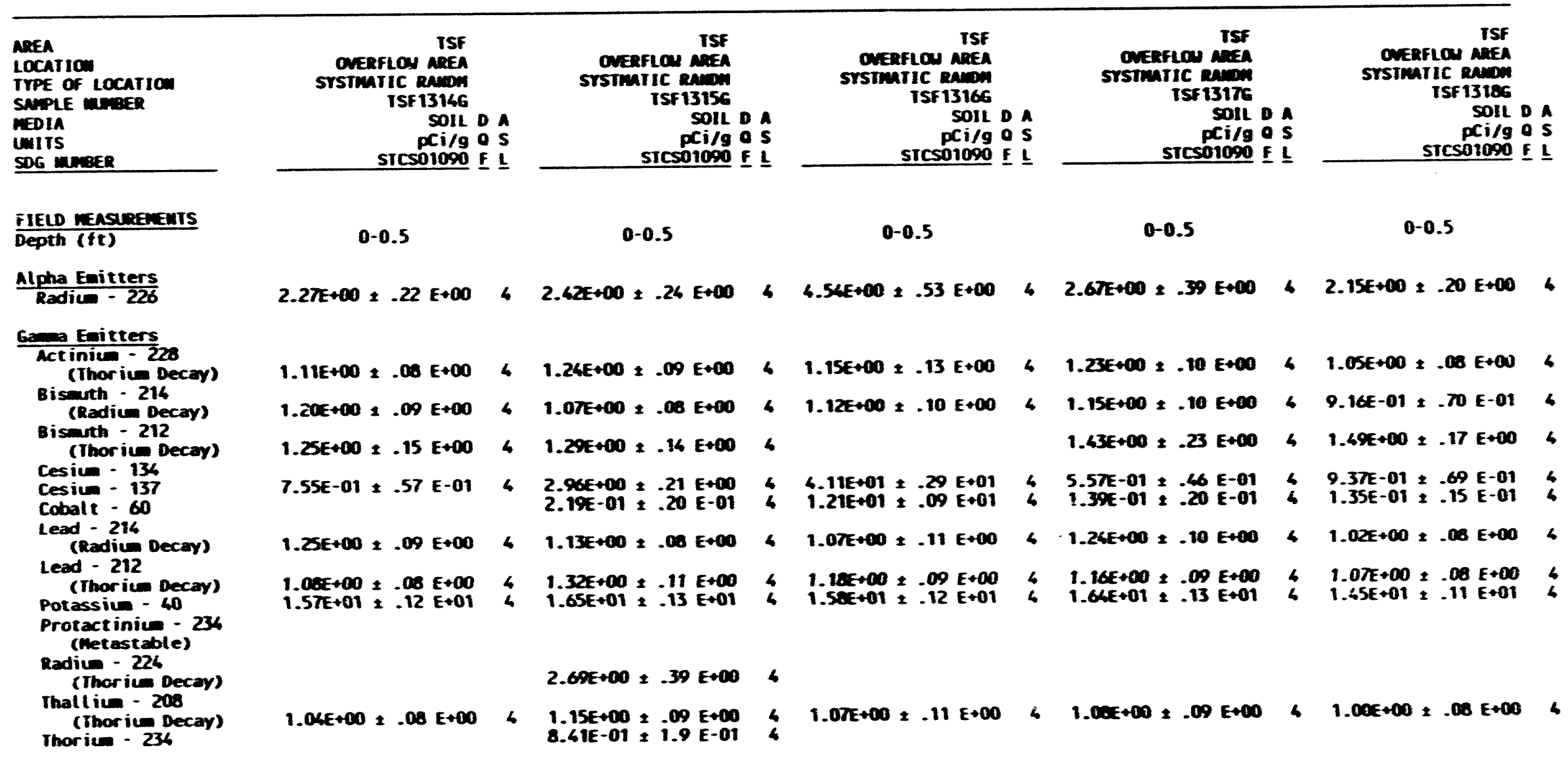

a. The Dof colun contains any daia qualifier flags.

b. The ASt colum contains the analytical support level.

2-15-93 
ISF Evaporation Pond S\&A Data Document - Movenber 1989 - Method Validation Level B

TABZE 6-1. TSF EVAPORATION POND - ANALYSIS RESULTS FOR GAMMA-EMITTIMG RADIOMUCLIDES (CONtinUed)



a. The Dof colum contains any data qual ifier flags.

b. The ASL colum contains the analytical support level.

2-15-93 
ISF Evaporation Pond S\&A Data Document - Movember 1989 - Method Validation Level B

IABE 6-1. ISF EVAPORATION POND - AMALYSIS RESULTS FOR GAMA-EMITIIING RADIONUCLIDES (CONT inUed)

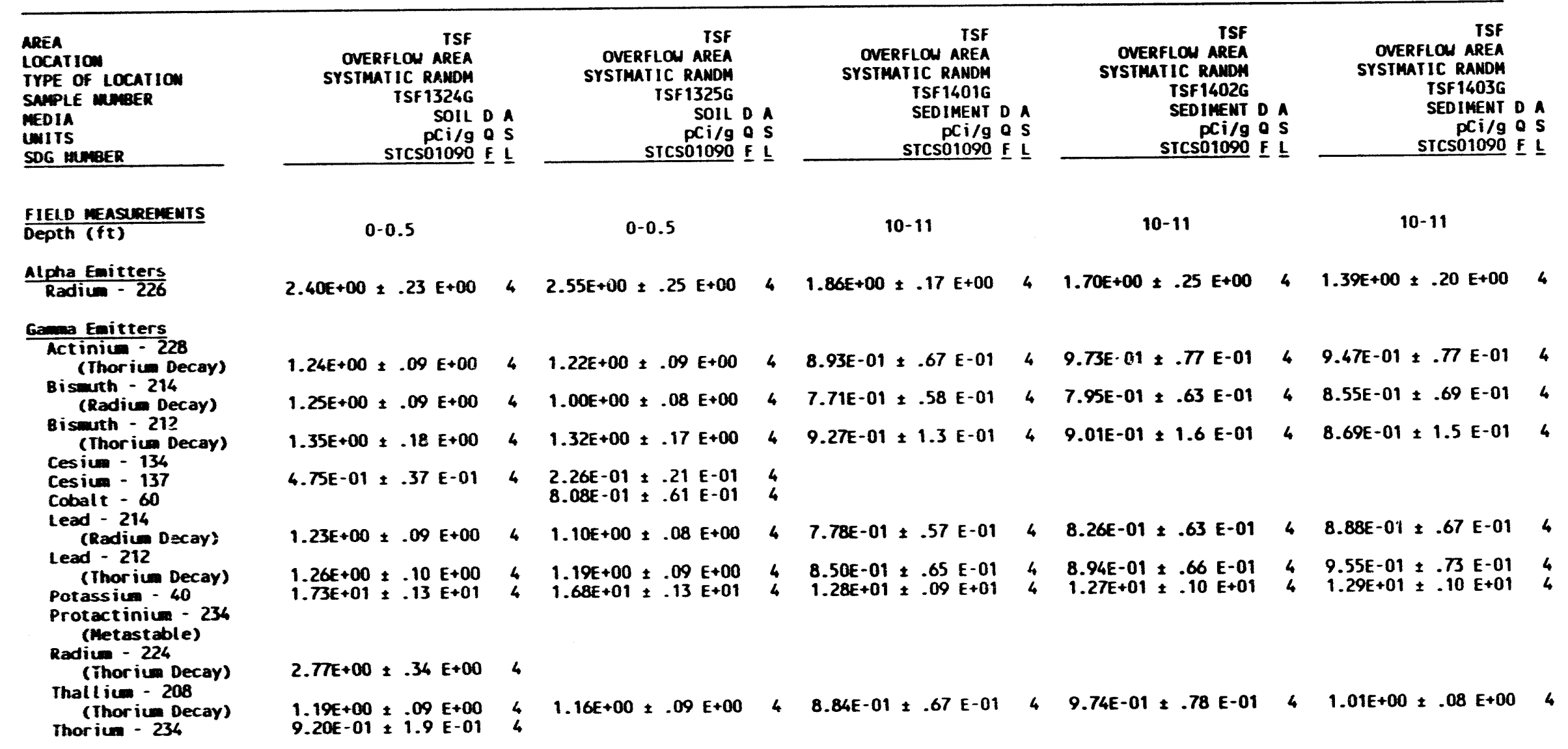

a. The Daf colum contains any data qualifier flags.

b. The ASL colum contains the analytical support level.

2-15-93 
ISF Evaporation Pond SeA Data Document - Movember 1989 - Method Validation Level B

TAQLE G-1. ISF EVAPORATIOU POWD - AMALYSIS RESULTS FOR GAMA-EMITIIMG RADIOMUCLIDES (Continued)

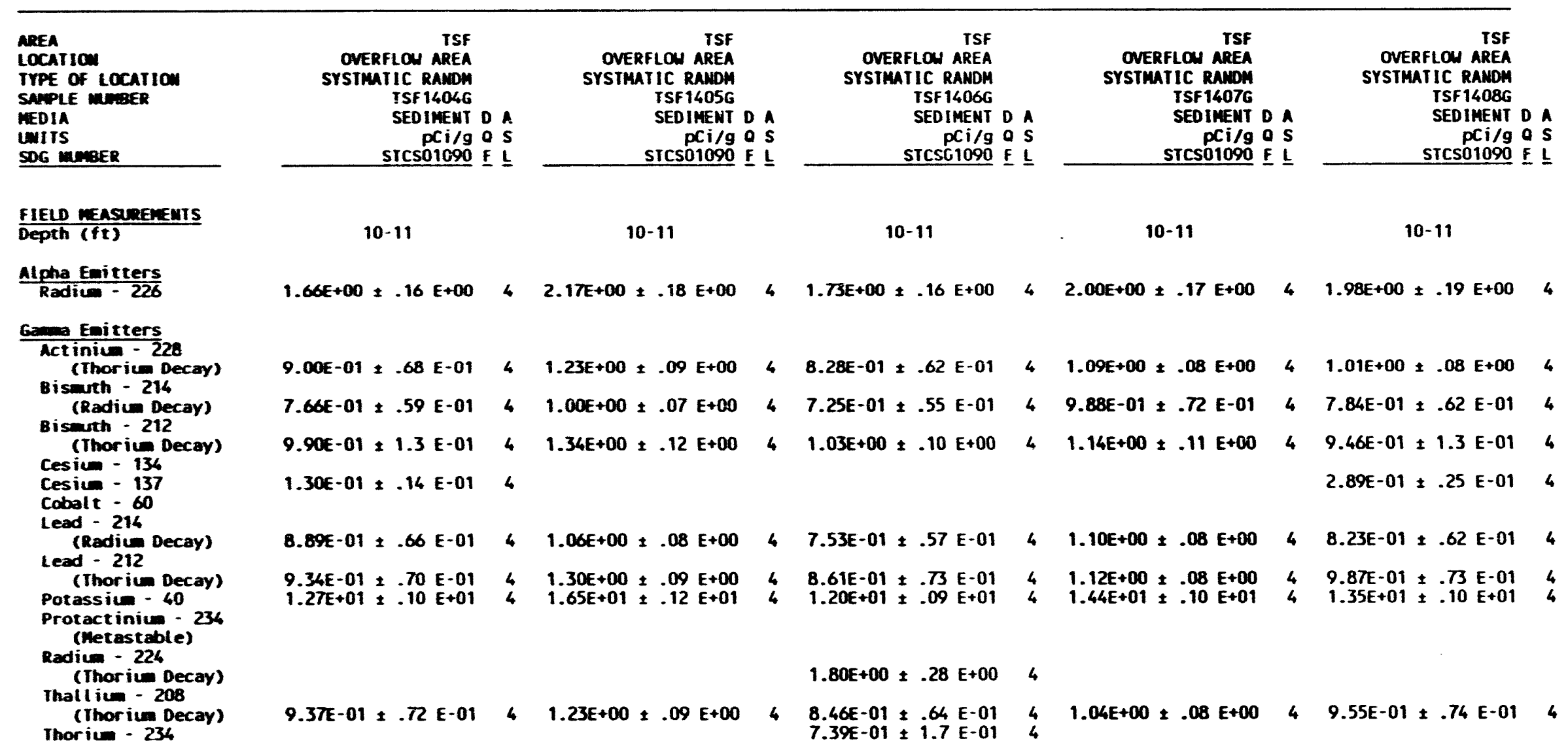

a. The Dof colum contains any data qualifier flags.

b. The ASL colum contains the analytical support level.

2-15-93 
ISF Evaporation Pond SeA Data Document - November 1989 - Method Val idation Level B

IMBLE G-1. TSF EVAPORATIOU POND - AMULYSIS RESULTS FOR GAMA-EMITIIHG RADIOHUCLIDES (Cont inued)

MREA
LOCATIOW
TYPE OF LOCATION
SAMPLE WRBER
MEDIA
UNIIS
SOG MERER

FIELD MEASUREREMTS

$\frac{\text { Alpha Enitters }}{\text { Radiu }-226}$

Gana Enitters

(Thor iu Decay)

Bismuth - 214

(Radiua Decay)

Bismuth - 212
in
(Thoriu Decay)

Cesiu - 137

Cobalt - 60

Lead - 214 Decay)

(Radiu

(Thorium Decay)

Potassium - 40

Protactinium - 23

(Metastable)

Radiu - 224

(Thoriun Decay)

Thallium - 208

(Thoriun Decay)

Thorium - 234

$\begin{array}{r}\text { TSF } \\ \text { OVERFLON AREA } \\ \text { SYSTMATIC RANDH } \\ \text { TSF1409G } \\ \text { SEDIMENT D A } \\ \text { PCI/g O S } \\ \text { STCSO1090 E } 1 \\ \hline\end{array}$

10-11

\begin{tabular}{|c|}
\hline $\begin{array}{r}\text { ISF } \\
\text { OVERFLOW AREA } \\
\text { SYSTHATIC RANDH } \\
\text { ISF } 1610 G \\
\text { SEDIMENT D A } \\
\text { PCi/g a S } \\
\text { STCSO1090 F L }\end{array}$ \\
\hline
\end{tabular}

$10-11$

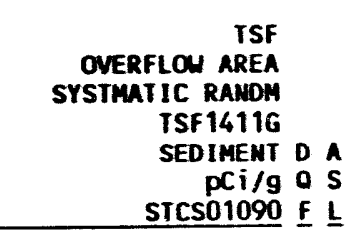

10-11

TSF
OVERFLOA AREA
SYSTMATIC RADDH
TSF1412G
SEDIMENT D A
PCi/g Q S
STCSO1090 F L

10-11

OVERFLON AREA

OVERFLON AREA
SYSTMATIC RANDM

TSF 14136

SEDIMENT D A

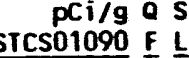

$1.80 E+00 \pm .15 E+00 \quad 4 \quad 1.38 E+00 \pm .14 E+00 \quad 4 \quad 1.83 E+00 \pm .31 E+00 \quad 4 \quad 2.10 E+00 \pm .23 E+00 \quad 4 \quad 1.81 E+00 \pm .21 E+00 \quad 4$

9.03E-01 $\pm .65 E-01 \quad 4 \quad 9.30 E-01 \pm .71 E-01 \quad 4 \quad 1.10 E+00 \pm .09 E+00 \quad 4 \quad 9.59 E-01 \pm .81 E-01 \quad 4 \quad 1.12 E+00 \pm .09 E+00 \quad 4$

7.74E-01 \pm .57 E-01 $4 \quad 8.53 E-01 \pm .64$ E-01 $4 \quad 8.82 E-01 \pm .73$ E-01 $4 \quad 8.53 E-01 \pm .70$ E-01 $4 \quad 9.72 E-01 \pm .79 E-01 \quad 4$

$9.88 E-01 \pm .87$ E-01 $4 \quad 9.82 E-01 \pm 1.2$ E-01 $4 \quad 9.85 E-01 \pm 1.6 E-01 \quad 4 \quad 1.13 E+00 \pm .21 E+004 \quad 1.43 E+00 \pm .19 E+00 \quad 4$

$4.38 E-01 \pm .36 \mathrm{E}-01 \quad 4$

$8.10 E-01 \pm .59$ E-01 $4 \quad 8.23 E-01 \pm .61$ E-01 $4 \quad 9.92 E-01 \pm .78 E-01 \quad 4 \quad 9.21 E-01 \pm .70 E-01 \quad 4 \quad 1.00 E+00 \pm .08 E+00 \quad 4$ $\begin{array}{lllllllllllllllll}8.87 E-01 & \pm .65 E-01 & 4 & 8.65 E-01 \pm .65 E-01 & 4 & 1.18 E+00 \pm .09 E+00 & 4 & 9.70 E-01 \pm .74 & E-01 & 4 & 1.16 E+00 \pm .09 E+00 & 4 \\ 1.30 E+01 \pm .09 E+01 & 4 & 1.15 E+01 \pm .09 E+01 & 4 & 1.47 E+01 \pm .11 E+01 & 4 & 1.18 E+01 \pm .10 & E+01 & 4 & 1.46 E+01 \pm .11 E+01 & 4\end{array}$

$8.93 E-01 \pm .66 E-01 \quad 4 \quad 8.20 E-01 \pm .63 E-01 \quad 4 \quad 1.12 E+00 \pm .09 E+00 \quad 4 \quad 9.13 E-01 \pm .77 E-01 \quad 4 \quad 1.05 E+00 \pm .10 E+00 \quad 4$

a. The Dof colum contains any data qualifier flags.

b. The ASL colum contains the analytical support level.

2-15-93 
ISf Evaporation Pond SeA Data Document - November 1989 - Method Validation Level B

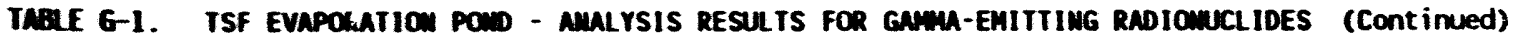

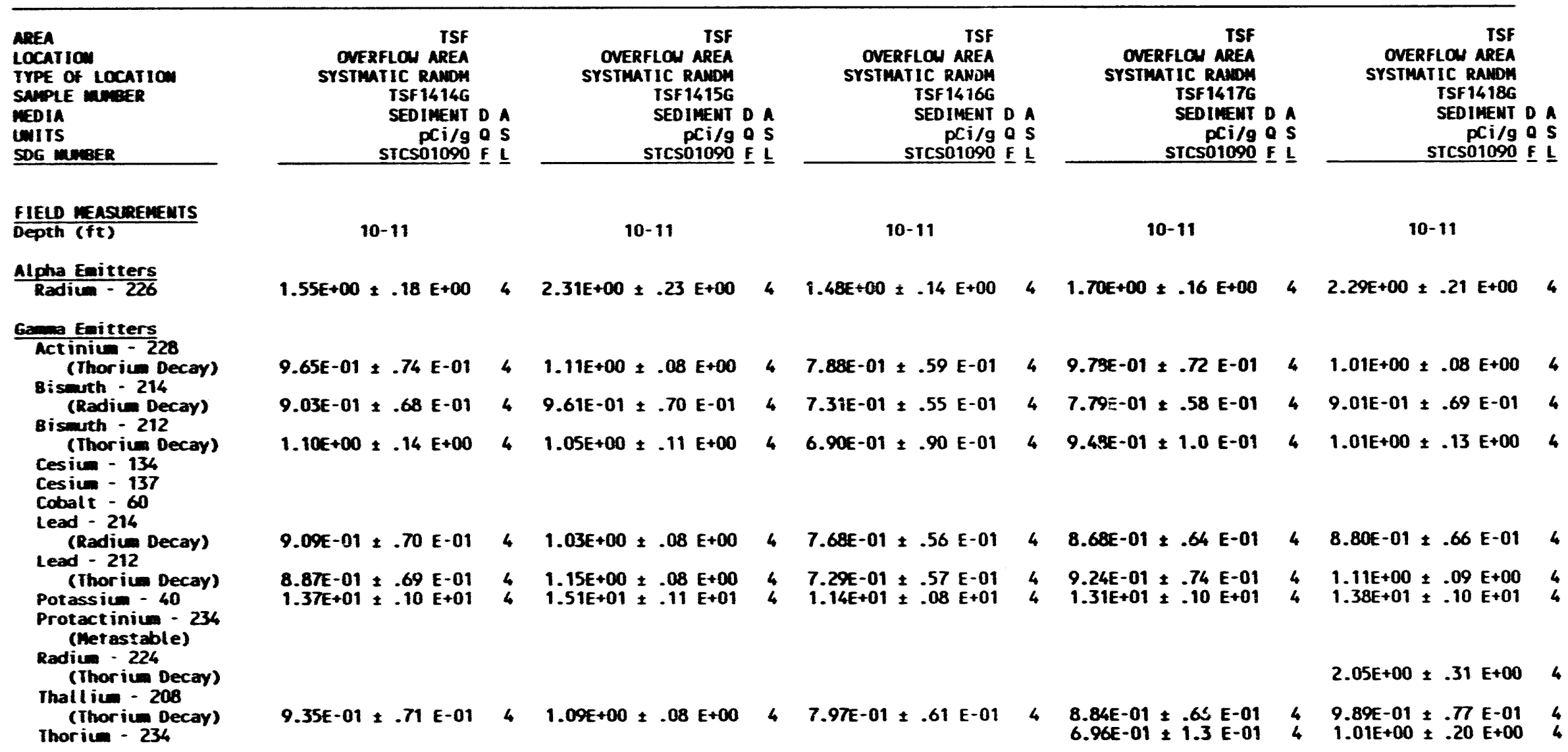

a. The Dof colum contains any data qualifier flags.

b. The ASL colum contains the analytical support level.

2-15-93 
ISF Evaporation Pond SeA Data Document - Noveaber 1989 - Method Validation Level B

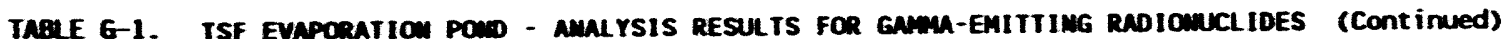

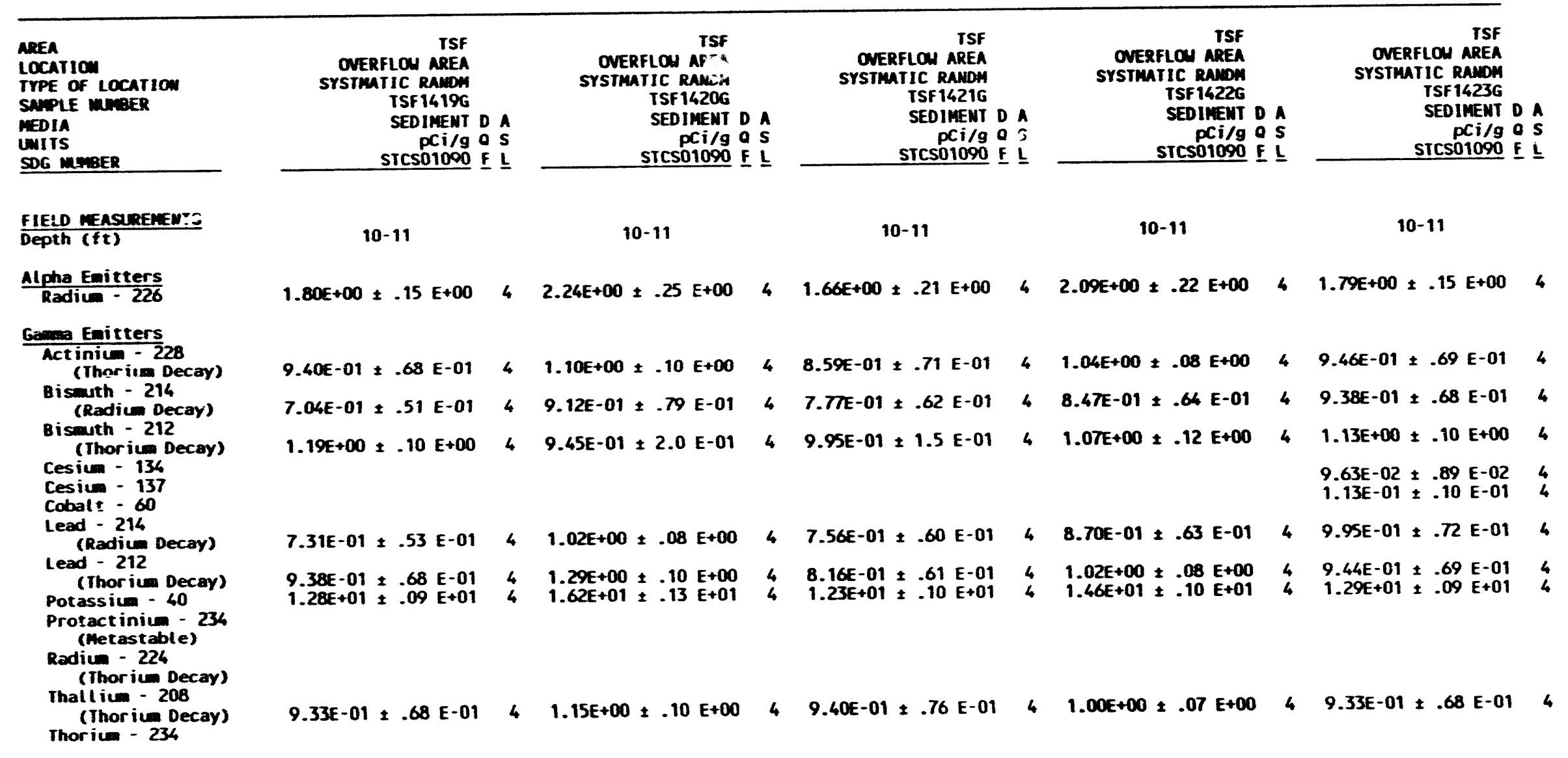

a. The Daf colum contains any data qual ifier flags.
b. The ASL colum contains the analytical support level.

2-15-93 
ISF Evaporation Pond SeA Data Document - November 1989 - Method Validation Level B

TABLE G-1. ISF EVAPORATIOU POND - AMALYSIS RESULIS FOR GAMA-EMITTIMG RADIOUUCLIDES (COnt incued)

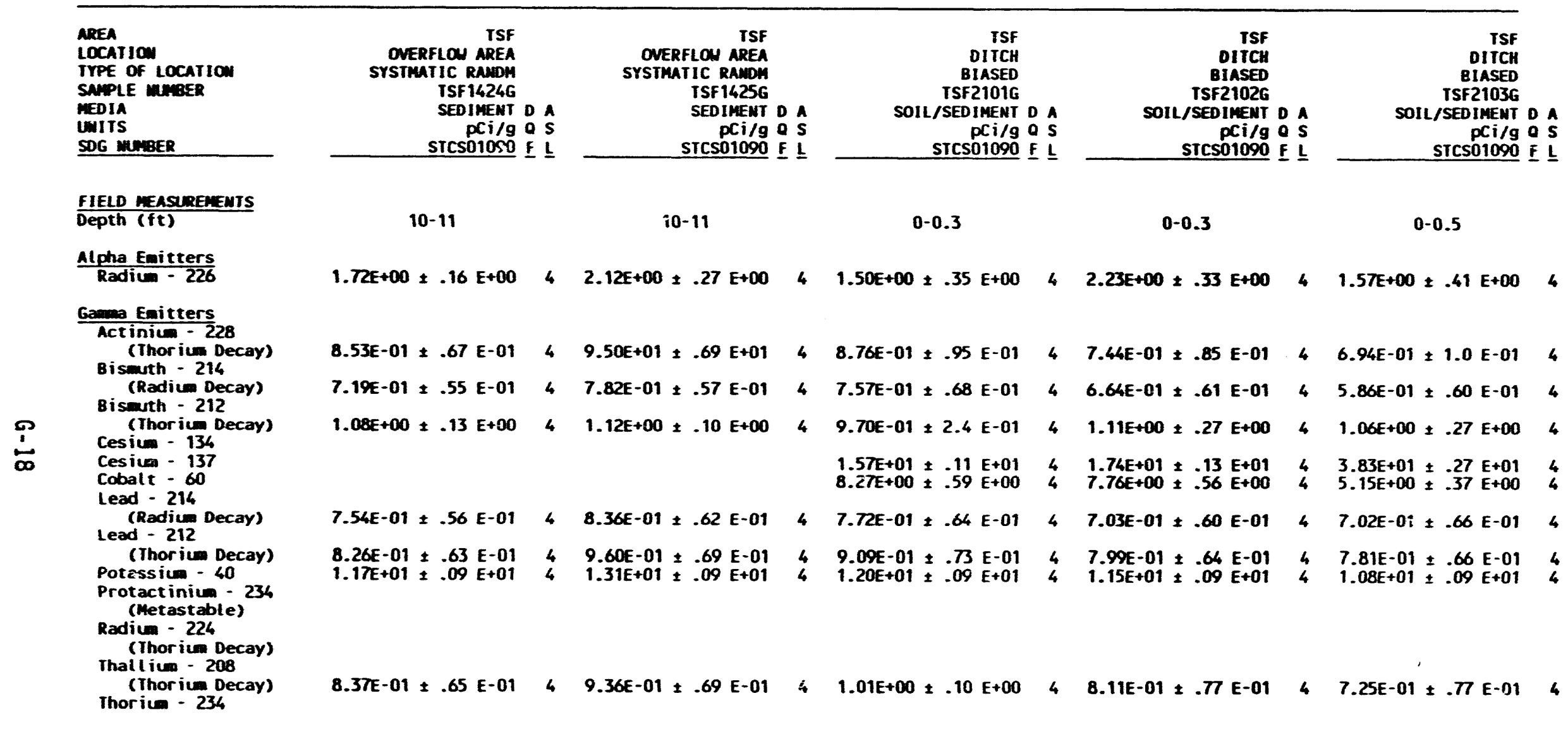

a. The DOF colum contains any data qual ifier flags.

b. The ASL colcun contains the analytical support level.

2-15-93 
ISF Evaporation Pond S\&A Data Document - Movenber 1989 - Method Validation Level B

IABAE 6-1. ISF EVAPORATION POND - AMALYSIS RESULTS FOR GAMA-EMIITIMG RADIOWCLIDES (CONtinued)

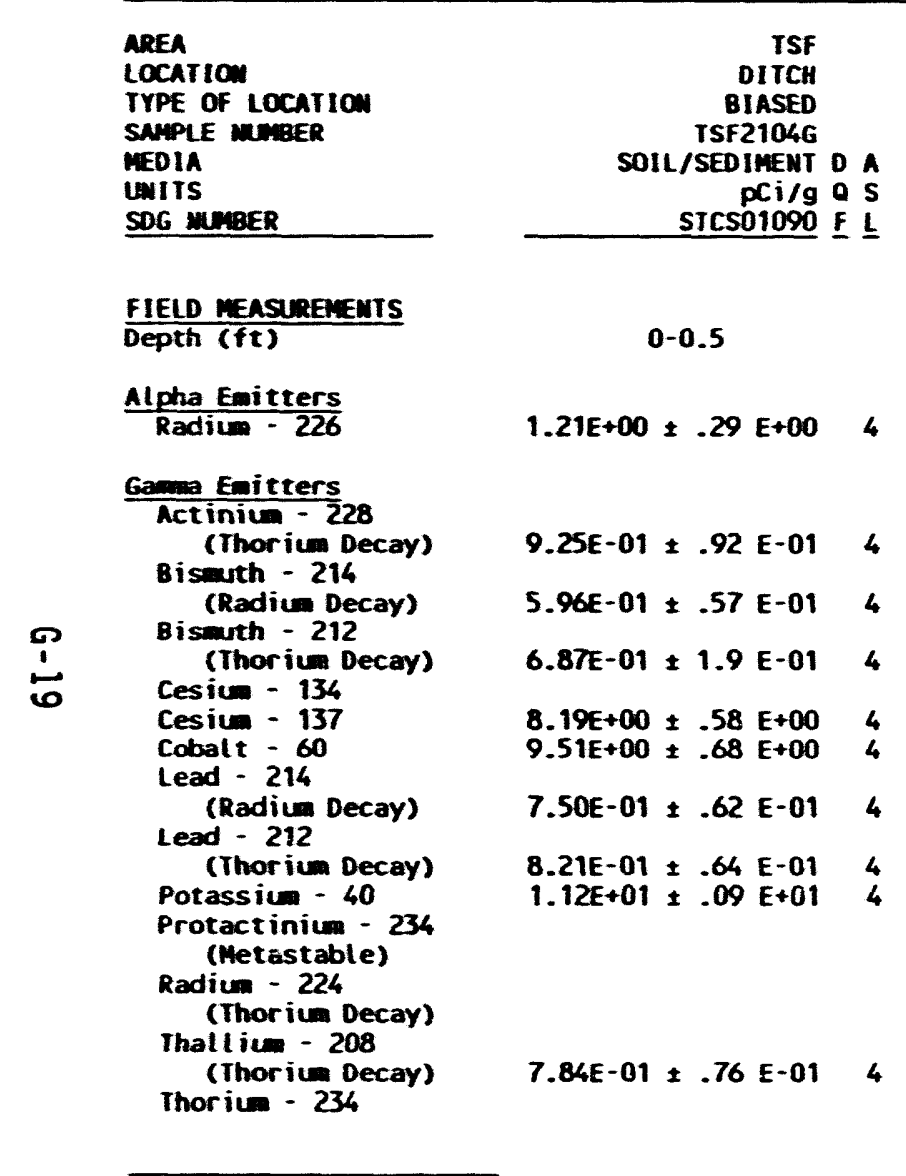

a. The Dof colum contains any data qualifier flags.

b. The ASL colum contains the analytical support level.

2-15-93 
ISF Exaporation Pond SeA Data Document - Movember 1989 - Method Validation Level B

TARLE 6-2. ISF EVAPORATION POND - INORGAMIC DATA

\begin{tabular}{|c|c|c|c|c|c|c|}
\hline $\begin{array}{l}\text { AREA } \\
\text { LOCATION } \\
\text { IYPE OF LOCATION } \\
\text { SAMPLE WUBER } \\
\text { MEDIA } \\
\text { UWITS } \\
\text { SOG MUEBER } \\
\end{array}$ & $\begin{array}{r}\text { TSF } \\
\text { POAd BOTTOA } \\
\text { SURFACE } \\
\text { TSFO101A } \\
\text { SEDIIEMT } \\
\text { mg/kg } \\
\text { TSF0101A } \\
\end{array}$ & $\begin{array}{r}\text { TSF } \\
\text { POWD BOTTOM } \\
\text { SURFACE } \\
\text { TSFOIOIM } \\
\text { SEDIMENT } \\
\text { og/kg } \\
\text { TSF0101M } \\
\end{array}$ & $\begin{array}{l}\text { TSF } \\
\text { POD EOTTOM } \\
\text { SURFACE } \\
\text { ISF0102A } \\
\text { SEDIMENT } \\
\text { Eg/kg } \\
\text { ISF0101A } \\
\end{array}$ & 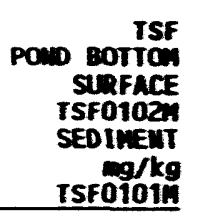 & 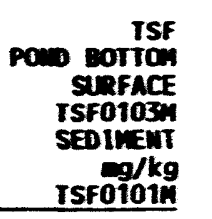 & 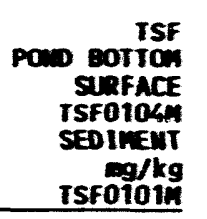 \\
\hline $\begin{array}{l}\text { FIELD MEASUREMENIS } \\
\text { DEPth (ft) }\end{array}$ & $0-0.5$ & $0-0.5$ & $0-0.5$ & $0-0.5$ & $0-0.5$ & $0-0.5$ \\
\hline $\begin{array}{l}\text { Amalries } \\
\text { Aluminum } \\
\text { Ant imony } \\
\text { Arsenic } \\
\text { Barium } \\
\text { Beryllium }\end{array}$ & $\begin{array}{c}22100 \\
0.68 \mathrm{wR} \\
14.6 \mathrm{~s} \\
293 \\
1.9\end{array}$ & $\begin{array}{c}22300 \\
18.4 \mathrm{un} \\
-\ldots \\
338 \\
2.1\end{array}$ & $\begin{array}{c}19000 \\
0.57 \mathrm{mR} \\
10.9 \mathrm{~s} \\
237 \\
1.5\end{array}$ & $\begin{array}{c}22900 \\
18.6 \mathrm{w} \\
15.4 \mathrm{~B} \\
301 \\
2.1\end{array}$ & \begin{tabular}{c}
21500 \\
15.5 uw \\
\hdashline 262 \\
1.9
\end{tabular} & $\begin{array}{c}22900 \\
16.7 \mathrm{um} \\
-290 \\
2.1\end{array}$ \\
\hline $\begin{array}{l}\text { Cachium } \\
\text { Calcium } \\
\text { Chromiun } \\
\text { Cobalt } \\
\text { Copper }\end{array}$ & $\begin{array}{r}3.3 \\
88900 \\
58.4 \\
12.8 \\
83.4 \mathrm{E}\end{array}$ & $\begin{array}{r}4.4 \\
77500 \\
74.5 \\
15.0 \\
180\end{array}$ & $\begin{array}{r}2.8 \\
65800 \\
47.8 \\
11.6 \\
74.8 \mathrm{E}\end{array}$ & $\begin{array}{c}2.9 \\
80500 \\
69.2 \\
13.3 \\
62.0\end{array}$ & $\begin{array}{c}2.4 \\
73800 \\
55.4 \\
71.8 \\
43.6\end{array}$ & $\begin{array}{c}2.3 \mathrm{~s} \\
82300 \\
61.1 \\
13.1 \\
46.0\end{array}$ \\
\hline $\begin{array}{l}\text { Cyanide } \\
\text { Iron } \\
\text { Lead } \\
\text { Magnesici. } \\
\text { Manganese }\end{array}$ & $\begin{array}{c}29100 \mathrm{~J} \\
34.8 \mathrm{~S} \\
17800 \mathrm{~J} \\
492\end{array}$ & $\begin{array}{r}27200 \\
64.8 \\
15600 \\
389\end{array}$ & $\begin{array}{r}0.15 \mathrm{~B} \\
25200 \mathrm{~J} \\
32.8 \mathrm{~S} \\
14200 \mathrm{~J} \\
454\end{array}$ & $\begin{array}{r}28600 \\
45.8 \\
16500 \\
425\end{array}$ & $\begin{array}{r}25400 \\
38.7 \\
14500 \\
310\end{array}$ & $\begin{array}{r}28800 \\
45.0 \\
16400 \\
395\end{array}$ \\
\hline $\begin{array}{l}\text { Mercury } \\
\text { Nickel } \\
\text { Potassium } \\
\text { Selenium } \\
\text { Silver }\end{array}$ & $\begin{array}{l}0.45 \\
46.3 \\
4560 \\
1.2 \text { BusJ } \\
22.1\end{array}$ & $\begin{array}{r}4.3 \\
49.3 \\
4720 \\
28.5\end{array}$ & $\begin{array}{l}0.23 \\
38.9 \\
3900 \\
0.31 \text { gnSJ } \\
5.6 \mathrm{~J}\end{array}$ & $\begin{array}{l}0.28 \\
47.8 \\
4770 \\
30.9\end{array}$ & $\begin{array}{l}0.16 \\
42.0 \\
6560 \\
22.1\end{array}$ & $\begin{array}{l}0.28 \\
45.4 \\
4550 \\
13.1\end{array}$ \\
\hline $\begin{array}{l}\text { Sodium } \\
\text { Strontium } \\
\text { Thall ium } \\
\text { I in } \\
\text { Vanadium }\end{array}$ & $\begin{array}{c}390 \text { BEJ } \\
167 \\
-\therefore \\
19.1 \text { WR } \\
74.2\end{array}$ & $\begin{array}{l}363 \mathrm{~B} \\
160 \\
33.3 \mathrm{~B} \\
18.0 \mathrm{~W} \\
77.3\end{array}$ & $\begin{array}{c}259 \mathrm{BEJ} \\
122 \\
-15.9 \mathrm{WR} \\
62.5\end{array}$ & $\begin{array}{ll}236 & \mathrm{~B} \\
172 & \\
33.6 & \mathrm{~B} \\
18.1 \mathrm{U} & \\
83.1\end{array}$ & $\begin{array}{l}224 \mathrm{~B} \\
146 \\
15.7 \mathrm{~B} \\
15.1 \mathrm{in} \\
76.1\end{array}$ & $\begin{array}{l}193 \mathrm{~B} \\
154 \\
22.9 \mathrm{~B} \\
16.3 \mathrm{im} \\
78.7\end{array}$ \\
\hline 2 inc & 257 & 609 & 204 & 187 & 164 & 190 \\
\hline$x$ Solids & 54.3 & 49.2 & 63.7 & 61.2 & 65.3 & 56.4 \\
\hline $\begin{array}{l}\text { Total (Allowed) Hold Timea } \\
\text { Iotal (All owed) Hold Timed } \\
\text { Total (Allowed) Hold Timec } \\
\text { Iotal (Allowed) Hold Time }\end{array}$ & $\begin{array}{l}32(180) d \\
\left.2^{c} \cdot 26\right) d \\
47(.80) d \\
13(14) d\end{array}$ & $\begin{array}{l}55(180) d \\
20(26) d\end{array}$ & $\begin{array}{l}31(180) d \\
26(26) d \\
46(180) d \\
12(14) d\end{array}$ & $\begin{array}{l}55(180) d \\
20(26) d\end{array}$ & $\begin{array}{l}55(180) d \\
20(26) d\end{array}$ & $\begin{array}{l}55(180) d \\
20(26) d\end{array}$ \\
\hline
\end{tabular}
a. ICP
b. CVMAS
c. Granide

2-15-93 
TSF Evaporation Pond SeA Data Document - November 1989 - Method validation Level B

TABLE 6-2. TSF EVAPOAation POWD - ImorGanic DATA (Cont inved)

\begin{tabular}{|c|c|c|c|c|c|c|}
\hline $\begin{array}{l}\text { AREA } \\
\text { LOCATIOA } \\
\text { IYPE OF LOCATION } \\
\text { SANPE WHBER } \\
\text { MEDIA } \\
\text { inITS } \\
\text { SOG MnBER } \\
\end{array}$ & 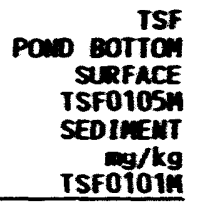 & 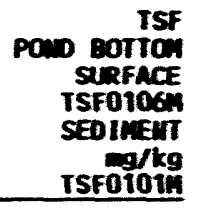 & 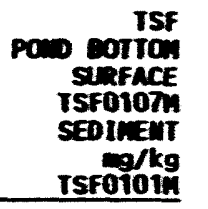 & 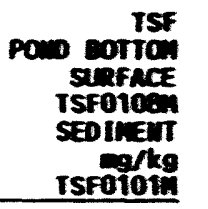 & 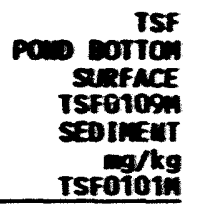 & 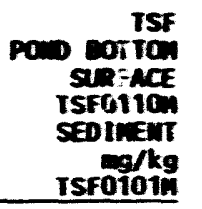 \\
\hline $\begin{array}{l}\text { FIELD MEASUREMEUIS } \\
\text { Depth (fE) }\end{array}$ & $0-0.5$ & $0-0.5$ & $0-0.5$ & $0-0.5$ & $0-0.5$ & $0-0.5$ \\
\hline 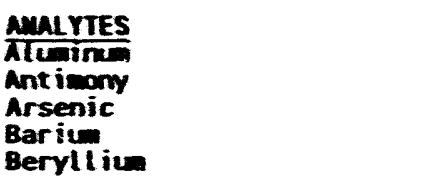 & $\begin{array}{c}20900 \\
15.7 \mathrm{w} \\
266 \\
1.9\end{array}$ & $\begin{array}{c}17200 \\
15.2 \mathrm{um} \\
-235 \\
232 \\
1.6\end{array}$ & \begin{tabular}{c}
17400 \\
$16.3 \mathrm{wn}$ \\
\hdashline 26 \\
242 \\
1.7
\end{tabular} & $\begin{array}{c}16900 \\
17.9 \mathrm{um} \\
16.0 \mathrm{~g} \\
30.8 \\
1.7\end{array}$ & $\begin{array}{c}19300 \\
16.2 \mathrm{um} \\
-253 \\
1.8\end{array}$ & $\begin{array}{c}10200 \\
15.8 \mathrm{um} \\
17.5 \mathrm{~B} \\
256 \\
1.6\end{array}$ \\
\hline $\begin{array}{l}\text { Cachium } \\
\text { Calcium } \\
\text { Chroaic } \\
\text { Cobalt } \\
\text { Copper }\end{array}$ & $\begin{array}{c}2.48 \\
79400 \\
57.5 \\
12.0 \\
41.5\end{array}$ & $\begin{array}{c}2.08 \\
67200 \\
43.8 \\
10.0 \\
25.6\end{array}$ & $\begin{array}{c}1.7 \mathrm{~B} \\
71600 \\
42.5 \\
10.4 \\
24.8\end{array}$ & $\begin{array}{c}2.6 \\
73900 \\
43.2 \\
11.2 \\
44.1\end{array}$ & $\begin{array}{c}2.0 \mathrm{~B} \\
76000 \\
46.5 \\
13.2 \\
30.0\end{array}$ & $\begin{array}{c}2.0= \\
73700 \\
40.9 \\
11.5 \\
23.9\end{array}$ \\
\hline $\begin{array}{l}\text { Cyanide } \\
\text { Iron } \\
\text { Lead } \\
\text { Magnesilu } \\
\text { Manganese }\end{array}$ & $\begin{array}{r}26900 \\
49.0 \\
15700 \\
398\end{array}$ & $\begin{array}{r}24900 \\
42.1 \\
13900 \\
358\end{array}$ & $\begin{array}{r}23200 \\
35.6 \\
13900 \\
440\end{array}$ & $\begin{array}{r}23000 \\
39.7 \\
14300 \\
515\end{array}$ & $\begin{array}{r}26200 \\
44.3 \\
14000 \\
296\end{array}$ & $\begin{array}{r}23900 \\
43.5 \\
13800 \\
534\end{array}$ \\
\hline $\begin{array}{l}\text { Mercury } \\
\text { lickel } \\
\text { Potassiu } \\
\text { Seleniu } \\
\text { Silver }\end{array}$ & $\begin{array}{l}0.24 \\
44.6 \\
4460 \\
20.0\end{array}$ & $\begin{array}{r}0.11 \\
37.6 \\
3490 \\
1 . .1\end{array}$ & $\begin{array}{c}0.07 \\
45.2 \\
3520 \\
6.6\end{array}$ & $\begin{array}{c}0.12 \\
46.9 \\
3560 \\
10.0\end{array}$ & $\begin{array}{c}0.07 \mathrm{~B} \\
45.5 \\
4060 \\
0.5 \\
8.9\end{array}$ & $\begin{array}{c}0.098 \\
37.5 \\
3230 \\
6.7\end{array}$ \\
\hline $\begin{array}{l}\text { Sodium } \\
\text { Strontium } \\
\text { Thatlice } \\
\text { Tin } \\
\text { Vanadicm }\end{array}$ & $\begin{array}{r}278 \mathrm{~B} \\
153 \\
23.8 \mathrm{~B} \\
15.3 \mathrm{in} \\
77.3\end{array}$ & $\begin{array}{l}151 \mathrm{~B} \\
122 \\
30.8 \mathrm{~B} \\
14.8 \mathrm{Um} \\
68.9\end{array}$ & $\begin{array}{l}150 \mathrm{~B} \\
127 \\
16.6 \mathrm{~B} \\
15.9 \mathrm{in} \\
66.1\end{array}$ & $\begin{array}{l}140 \mathrm{~B} \\
123 \\
37.2 \mathrm{~g} \\
17.5 \mathrm{in} \\
68.8\end{array}$ & $\begin{array}{l}240 \mathrm{~B} \\
133 \\
26.6 \mathrm{~B} \\
15.8 \mathrm{um} \\
71.6\end{array}$ & $\begin{array}{l}179 \mathrm{~B} \\
123 \\
18.3 \mathrm{~B} \\
15.4 \mathrm{i} \\
65.8\end{array}$ \\
\hline Zinc & 174 & 121 & 120 & 159 & 160 & 118 \\
\hline$x$ Solids & 63.4 & 71.0 & 76.5 & 77.0 & 73.3 & $\pi .7$ \\
\hline $\begin{array}{l}\text { Total (Allowed) Hold Time } \\
\text { Total (Allowed) Hold time } \\
\text { Iotal (Allowed) Hold timed } \\
\text { Total (Allowed) Hold Iimed }\end{array}$ & $\begin{array}{l}55(180) d \\
20(26) d\end{array}$ & $\begin{array}{l}55(180) d \\
20(26) d\end{array}$ & $\begin{array}{l}54(180) d \\
19(26) d\end{array}$ & $\begin{array}{l}54(180) d \\
19(26) d\end{array}$ & $\begin{array}{l}54(180) d \\
26(26) d\end{array}$ & $\begin{array}{l}54(180) d \\
24(26) d\end{array}$ \\
\hline
\end{tabular}
a. ICP
b. cvalas
c. GraAs
2-15-93 
ISF Evaporation Pond SeA Data Document

Moveber 1909 . Method Validation Level B

Thal 6-2. ISF EVAPORATION pOWD - Imorgailc DATA (Continued)

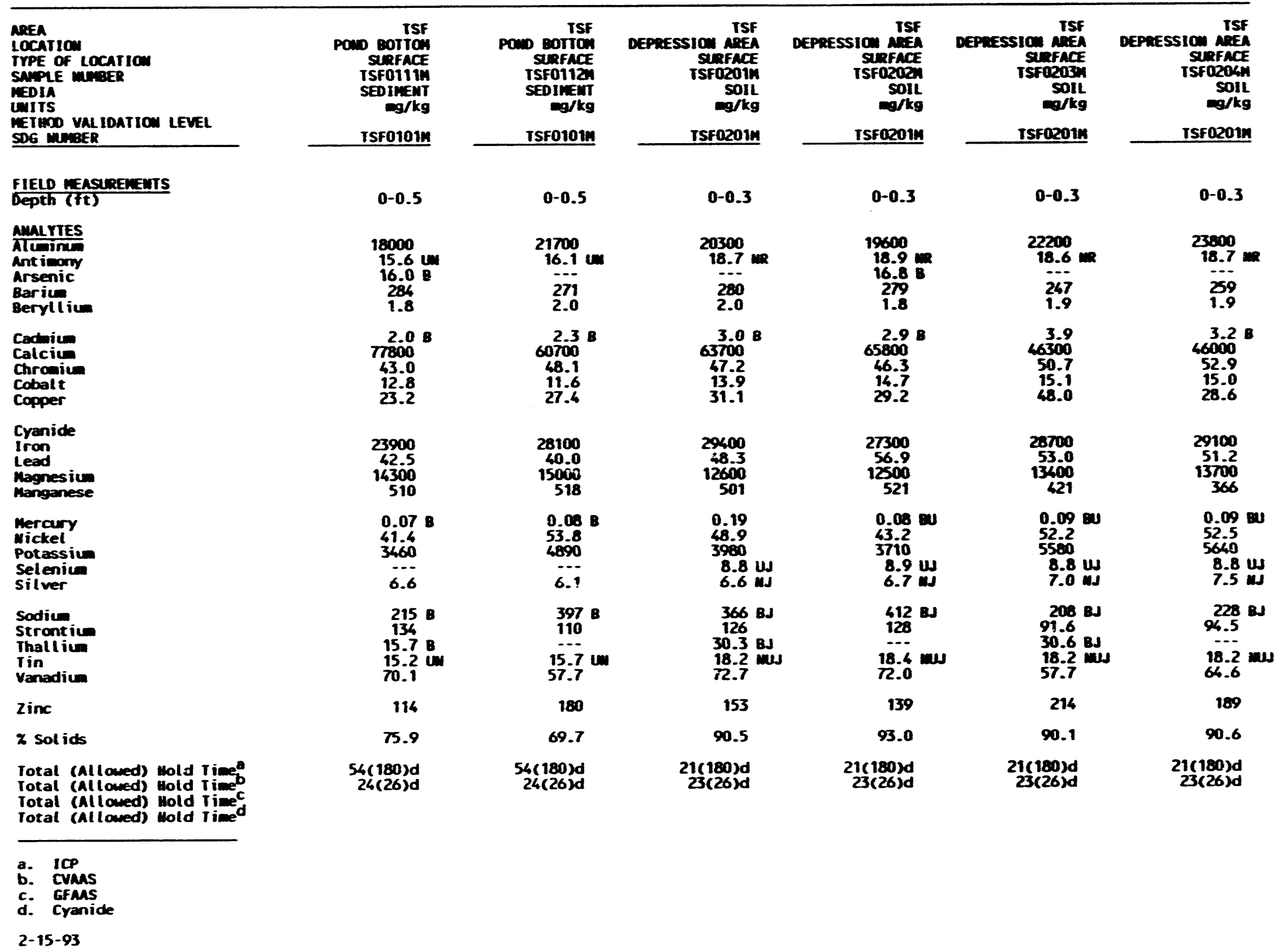


ISF Evaporation Pond Sen Data Document - Novenber 1909 - Method Validation Level 8

IAse 6-2. ISF Evaporation powd - Imorcaulc Data (Continued)

\begin{tabular}{|c|c|c|c|c|c|c|}
\hline 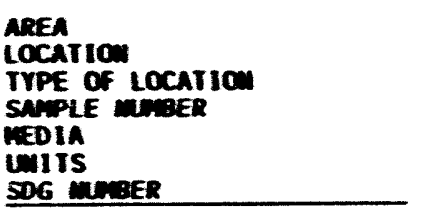 & $\begin{array}{r}\text { TSF } \\
\text { DEPRESSIOW AREA } \\
\text { BIASED } \\
\text { ISFO3011 } \\
\text { SEDIMEUT } \\
\text { ISF0201M } \\
\end{array}$ & 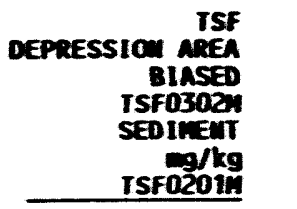 & 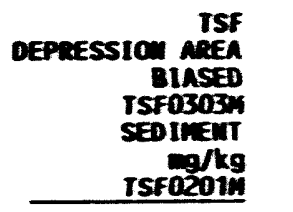 & 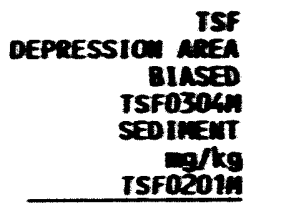 & $\begin{array}{r}\text { TSF } \\
\text { IMET PIPE } \\
\text { BIASED } \\
\text { TSFo6011 } \\
\text { SolL } \\
\text { rajkg } \\
\text { TSFoloin }\end{array}$ & $\begin{array}{r}\text { ISF } \\
\text { IMET PIPE } \\
\text { BIASED } \\
\text { ISF0602 } \\
\text { SOIL } \\
\text { To/kg } \\
\text { ISF01014 } \\
\end{array}$ \\
\hline $\begin{array}{l}\text { FIELD MEASUREMEMTS } \\
\text { Depth (ft) }\end{array}$ & - & - & - & - & $6-6.8$ & $7.5-8.5$ \\
\hline 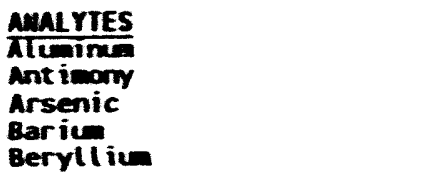 & \begin{tabular}{c}
16600 \\
18.7 \\
\hdashline 231 \\
231 \\
1.7
\end{tabular} & $\begin{array}{c}11200 \\
18.2 \mathrm{w} \\
-212 \\
212 \\
1.6\end{array}$ & $\begin{array}{c}15900 \\
19.8= \\
256 \\
256 \\
1.4\end{array}$ & $\begin{array}{c}13600 \\
19.8 \mathrm{~m} \\
17.2 \mathrm{~B} \\
2.07 \\
1.5\end{array}$ & \begin{tabular}{c}
10100 \\
$17.4 \mathrm{~m}$ \\
\hdashline 155 \\
1.0
\end{tabular} & $\begin{array}{c}18000 \\
17.6 \mathrm{~cm} \\
38.6 \mathrm{~B} \\
262 \\
1.6\end{array}$ \\
\hline $\begin{array}{l}\text { Cachium } \\
\text { Calcium } \\
\text { Chromium } \\
\text { Cobalt } \\
\text { Copper }\end{array}$ & $\begin{array}{c}1.8 \\
61500 \\
39.8 \\
14.7 \\
19.6\end{array}$ & $\begin{array}{c}1.6{ }^{8} \\
79000^{8} \\
34.3 \\
12.0 \\
13.8\end{array}$ & $\begin{array}{c}1.7 \\
50000 \\
39.2 \\
12.5 \\
22.6\end{array}$ & $\begin{array}{c}2.3 \\
66.00 \\
35.1 \\
14.1 \\
17.6\end{array}$ & $\begin{array}{c}1.4^{8} \\
45600 \\
30.4 \\
8.8 \\
15.5\end{array}$ & $\begin{array}{c}1.9 \\
67000 \\
44.9 \\
12.4 \\
27.7\end{array}$ \\
\hline $\begin{array}{l}\text { Cyanide } \\
\text { Iron } \\
\text { Lead } \\
\text { Magnesiu } \\
\text { Manganese }\end{array}$ & $\begin{array}{c}23400 \\
36.1 \\
10500 \\
482\end{array}$ & $\begin{array}{c}19100 \\
27.3 \mathrm{~B} \\
13000 \\
569\end{array}$ & $\begin{array}{c}22000 \\
29.5 \\
11200 \\
416\end{array}$ & $\begin{array}{c}19000 \\
38.0 \\
12700 \\
412\end{array}$ & $\begin{array}{c}17100 \\
27.5 \mathrm{a} \\
9960 \\
331\end{array}$ & $\begin{array}{r}25300 \\
41.3 \\
13200 \\
507\end{array}$ \\
\hline $\begin{array}{l}\text { Mercary } \\
\text { Mickel } \\
\text { Potassium } \\
\text { Selenil } \\
\text { Silver }\end{array}$ & $\begin{array}{l}0.08 \mathrm{wJ} \\
40.9 \\
2550 \\
8.8 \mathrm{wJ} \\
6.3 \mathrm{wJ}\end{array}$ & $\begin{array}{c}0.07 \mathrm{bu} \\
36.0 \\
1700 \\
8.6 \mathrm{wJ} \\
5.5 \mathrm{Eu}\end{array}$ & $\begin{array}{c}0.07 \mathrm{w} \\
37.0 \\
2860 \\
9.3 \mathrm{ws} \\
7.1 \mathrm{ws}\end{array}$ & $\begin{array}{l}0.06 \mathrm{w} \\
33.7 \\
2610 \\
9.3 \mathrm{WJ} \\
6.6 \mathrm{wd}\end{array}$ & $\begin{array}{c}0.07 \mathrm{~B} \\
27.5 \\
1890 \\
6.5 \\
6.3\end{array}$ & $\begin{array}{c}0.08 \mathrm{~B} \\
52.3 \\
3700 \\
\overline{7.6}\end{array}$ \\
\hline $\begin{array}{l}\text { Sodiue } \\
\text { Strontiu } \\
\text { Ihall iu } \\
\text { I in } \\
\text { Vanadiu }\end{array}$ & $\begin{array}{c}100 \mathrm{BS} \\
102 \\
18.3 \mathrm{~m} \\
56.5\end{array}$ & $\begin{array}{l}123 \mathrm{BJ} \\
114 \\
36.3 \mathrm{BJ} \\
17.8 \mathrm{~mJ} \\
50.4\end{array}$ & $\begin{array}{ll}284 & 8 \mathrm{~J} \\
94.3 & \\
29.3 & \mathrm{BJ} \\
19.3 & \mathrm{wJ} \\
61.6\end{array}$ & $\begin{array}{l}231 \mathrm{BJ} \\
104 \\
35.1 \mathrm{gJ} \\
19.3 \mathrm{mu} \\
57.2\end{array}$ & $\begin{array}{l}1868 \\
86.1 \\
23.0 \mathrm{~g} \\
17.0 \mathrm{ll} \\
51.6\end{array}$ & $\begin{array}{l}47.6 \mathrm{~B} \\
119 \\
16.3 \mathrm{~B} \\
17.2 \mathrm{Im} \\
74.4\end{array}$ \\
\hline Zinc & 106 & 83.7 & 98.4 & 91.5 & 71.5 & 124 \\
\hline$x$ Solids & 82.9 & 85.3 & 81.0 & K. 0 & 8.6 & 91.9 \\
\hline $\begin{array}{l}\text { Total (Allowed) Wold time } \\
\text { Total (Allowed) Wold time } \\
\text { Total (Allowed) Wold timec } \\
\text { Total (Allowed) Wold timed }\end{array}$ & $\begin{array}{l}21(180) d \\
23(26) d\end{array}$ & $\underset{23(26) d}{21(180) d}$ & $\begin{array}{l}21(180) d \\
23(26) d\end{array}$ & $\begin{array}{l}21(180) d \\
23(26) d\end{array}$ & $\begin{array}{l}41(180) d \\
11(26) d\end{array}$ & $\begin{array}{l}\text { 41(180)d } \\
11(26) d\end{array}$ \\
\hline $\begin{array}{l}\text { a. ICP } \\
\text { b. CvMis } \\
\text { c. GFMAS } \\
\text { d. Cyanide }\end{array}$ & & & & & & \\
\hline $2-15-93$ & & & & & & \\
\hline
\end{tabular}


ISF Evaporation Pond Sen Data Dxament - November 1909 - Method Val idation Level B

TABLE 6-2. TSF EVAPORATIOA PODO - ImoreanIC DAIA (Continued)

Page 5 of 16

\begin{tabular}{|c|}
\hline 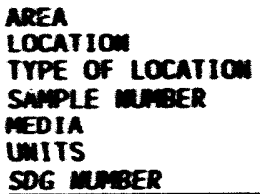 \\
\hline
\end{tabular}

FIELO MEASUREIENTS

bepth (ft)

AMAL rTES

Aluine

Arsenic

Bariu

Berylliu

\section{Cadniu}

Calcium

Chronim

Cobalt

i cyanide

Cyanid

Lead

Manganese

\section{wickel}

Potassium

Silver

Sodiun

Thall iu

That in

Vin

Zinc

$x$ solids

Total (Allowed) Hold Tinea Total (Allowed) Hold Tine Total (Allowed) Hold Timed
Total (Allowed) Hold Timed
a. ICP
b. cruas
c. GFMAS
d. Cyanid
2-15-93

\begin{tabular}{|c|c|c|c|c|c|}
\hline $\begin{array}{r}\text { TSF } \\
\text { IMLET PIPE } \\
\text { BIASED } \\
\text { TSFOS63H } \\
\text { SOIL } \\
\text { D9/kg } \\
\text { ISF0101M }\end{array}$ & 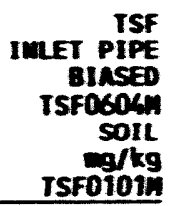 & $\begin{array}{r}\text { TSF } \\
\text { IUET PIPE } \\
\text { BIASED } \\
\text { TSF0604 } \\
\text { SOIL } \\
\text { 9/kg } \\
\text { TSFolo1h } \\
\end{array}$ & $\begin{array}{r}\text { TSF } \\
\text { POS DIScmaneE } \\
\text { BIASED } \\
\text { TSF0701A } \\
\text { SEDInEMT } \\
\text { TSFolkg } \\
\text { ISFO101A } \\
\end{array}$ & 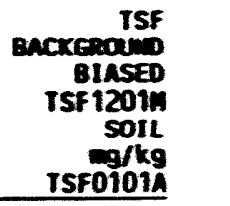 & 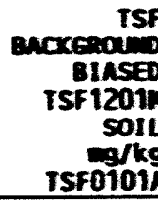 \\
\hline $5-6$ & $5-6$ & $5-6$ & $0-2$ & $0-0.4$ & $0-0.4$ \\
\hline $\begin{array}{c}16900 \\
17.6 \mathrm{~lm} \\
22.4 \mathrm{~B} \\
235 \\
1.6\end{array}$ & $\begin{array}{c}17600 \\
18.1 \mathrm{um} \\
32.0 \mathrm{~B} \\
261 \\
1.7\end{array}$ & & $\begin{array}{c}9740 \\
5.0 \mathrm{Bus} \\
10.1 \mathrm{~s} \\
9740 \\
2.1\end{array}$ & $\begin{array}{c}30000 \\
0.68 \mathrm{~m} \\
6.1 \mathrm{~s} \\
306 \\
1.8\end{array}$ & \\
\hline $\begin{array}{c}72000 \\
41.8 \\
11.7 \\
21.7\end{array}$ & $\begin{array}{r}1.7 \mathrm{a} \\
71100 \\
43.0 \\
11.3 \\
22.8\end{array}$ & & $\begin{array}{c}14.9 \\
179000 \\
150 \\
11.0 \mathrm{E} \\
936 \mathrm{E}\end{array}$ & $\begin{array}{r}3.7 \\
37200 \\
63.6 \\
15.7 \\
32.6 \mathrm{E}\end{array}$ & \\
\hline $\begin{array}{r}23200 \\
38.5 \\
13700 \\
463\end{array}$ & $\begin{array}{c}23500 \\
33.0 \mathrm{~B} \\
13.00 \\
493\end{array}$ & & $\begin{array}{c}2.9 \mathrm{~m} \\
38400 \mathrm{~J} \\
210 \\
13500 \mathrm{~J} \\
490\end{array}$ & $\begin{array}{c}33600 \\
30.0 \\
15000 \\
384 \\
d\end{array}$ & 55.6 \\
\hline $\begin{array}{c}0.11 \\
38.2 \\
3310 \\
\ldots . . \\
7.3\end{array}$ & $\begin{array}{r}0.10 \\
39.3 \\
3490 \\
7 .- \\
7.4\end{array}$ & 0.10 & $\begin{array}{c}206 \\
78.2 \\
2150 \\
4.6 \text { usJ } \\
166\end{array}$ & $\begin{array}{l}0.05 \mathrm{~B} \\
54.0 \\
7590 \\
0.62 \mathrm{ansJ} \\
7.2 \mathrm{~J}\end{array}$ & \\
\hline $\begin{array}{l}49.9 \mathrm{~B} \\
118 \\
25.3 \mathrm{~B} \\
17.2 \mathrm{II} \\
69.3\end{array}$ & $\begin{array}{l}119 \\
37.6 \mathrm{~B} \\
17.6 \mathrm{ull} \\
72.4\end{array}$ & & $\begin{array}{l}1110 \text { BeJ } \\
58.5 \\
28.1 \mathrm{a} \\
53.4\end{array}$ & \begin{tabular}{l}
273 BEJ \\
82.6 \\
\hdashline$\not 1.0$ \\
77.4
\end{tabular} & \\
\hline 116 & 113 & & 2600 & 212 & \\
\hline 88.5 & 87.7 & 87.7 & 31.3 & 92.2 & 92.2 \\
\hline $\begin{array}{r}36(180) d \\
8(26) d\end{array}$ & $\begin{array}{r}36(180) d \\
8(26) d\end{array}$ & $8(26) d$ & $\begin{array}{c}18(180) d \\
13(26) d \\
33(100) d \\
12(14) d\end{array}$ & $\begin{array}{l}32(180) d \\
25(26) d \\
47(180) d \\
13(14) d\end{array}$ & \\
\hline
\end{tabular}


ISF Evporation Pond sen Date Document - Novenber 1909 - Wethod val idation Level

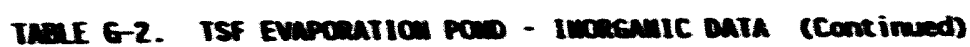

\begin{tabular}{|c|c|c|c|c|c|c|}
\hline 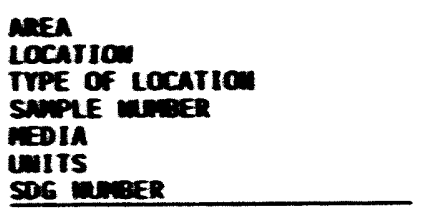 & 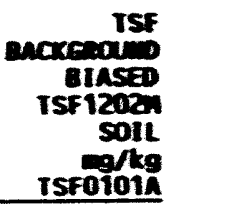 & 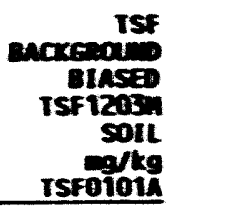 & 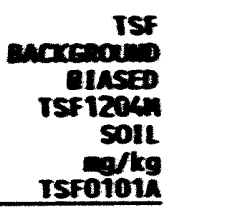 & 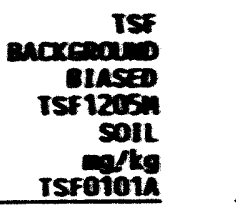 & 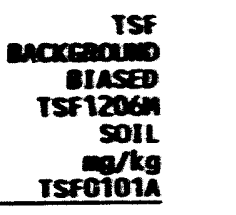 & 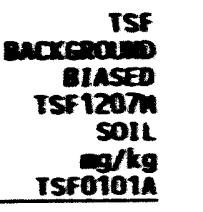 \\
\hline $\begin{array}{l}\text { FIELO EASUREREIS } \\
\text { Depth (ft) }\end{array}$ & $0-0.6$ & $0-0.6$ & $0-0.4$ & $0-0.4$ & $0-0.6$ & $0-0.6$ \\
\hline 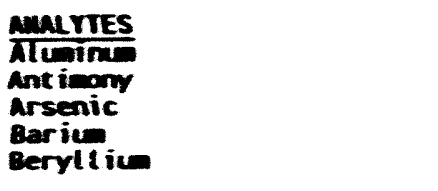 & $\begin{array}{c}26600 \\
0.50 \\
6.45 \\
2.05 \\
1.8\end{array}$ & $\begin{array}{c}26000 \\
0.56=5 \\
5.35 \\
270 \\
1.7\end{array}$ & $\begin{array}{c}28109 \\
0.62 \\
5.25 \\
292 \\
1.8\end{array}$ & $\begin{array}{c}29100 \\
0.63 \\
7.0+ \\
2 \% 3 \\
1.7\end{array}$ & $\begin{array}{c}29700 \\
0.66 \mathrm{~s} \\
3.9 \mathrm{~s} \\
303 \\
1.8\end{array}$ & $\begin{array}{c}29700 \\
0.67 \text { um } \\
7.3 \mathrm{~s} \\
313 \\
1.8\end{array}$ \\
\hline $\begin{array}{l}\text { Cadniu } \\
\text { Calciu } \\
\text { Chroium } \\
\text { Cobalt } \\
\text { Copper }\end{array}$ & $\begin{array}{r}3.0 \\
43600 \\
55.5 \\
13.6 \\
29.9 \mathrm{E}\end{array}$ & $\begin{array}{l}2.8 \\
30300 \\
54.2 \\
13.7 \\
30.7 \mathrm{E}\end{array}$ & $\begin{array}{r}2.7 \\
37460 \\
58.2 \\
15.0 \\
32.3 \mathrm{E}\end{array}$ & $\begin{array}{r}2.9 \\
36600 \\
60.1 \\
14.8 \\
32.7 \mathrm{E}\end{array}$ & $\begin{array}{r}2.8 \\
37600 \\
61.1 \\
12.9 \\
34.0 \mathrm{E}\end{array}$ & $\begin{array}{r}3.1 \\
32300 \\
61.5 \\
17.2 \\
33.6 \mathrm{E}\end{array}$ \\
\hline $\begin{array}{l}\text { Cranide } \\
\text { Iron } \\
\text { Lead } \\
\text { Magresiue } \\
\text { Manganese }\end{array}$ & $\begin{array}{c}31200 \text { d } \\
28.1+d \\
14400 \text { d } \\
413\end{array}$ & $\begin{array}{c}33000 \\
31.9 \\
1400 \\
416\end{array}$ & $\begin{array}{c}33900 \mathrm{~J} \\
29.7 \mathrm{~s} \\
14000 \mathrm{~J} \\
343\end{array}$ & $\begin{array}{c}36500 \mathrm{~d} \\
27.7 \mathrm{~s} \\
15100 \mathrm{~J} \\
363\end{array}$ & $\begin{array}{c}0.26 \\
36600 \\
26.0 \\
15300 \\
270\end{array}$ & $\begin{array}{c}0.27 \\
36000 \mathrm{~J} \\
26.1 \mathrm{~s} \\
15200 \mathrm{~J} \\
352\end{array}$ \\
\hline $\begin{array}{l}\text { Mercary } \\
\text { Wickel } \\
\text { Potassiu } \\
\text { Seleniul } \\
\text { Silver }\end{array}$ & $\begin{array}{l}0.05 \mathrm{~B} \\
50.2 \\
6030 \\
0.22 \mathrm{ess} \\
6.0 \mathrm{~J}\end{array}$ & $\begin{array}{l}0.05 \mathrm{~B} \\
54.4 \\
6370 \\
0.19 \mathrm{usw} \\
5.8 \mathrm{~J}\end{array}$ & $\begin{array}{l}0.06 \mathrm{~B} \\
56.9 \\
6200 \\
0.39 \mathrm{~J} \text { J J } \\
6.0 \mathrm{~J}\end{array}$ & $\begin{array}{l}0.05 \mathrm{~B} \\
56.6 \\
7290 \\
0.35 \mathrm{ess} \\
7.1 \mathrm{~J}\end{array}$ & $\begin{array}{l}0.04 \mathrm{~B} \\
57.5 \\
7210 \\
0.21 \mathrm{bus} \\
5.4 \mathrm{~J}\end{array}$ & $\begin{array}{l}0.04 \\
56.6 \\
7160 \\
0.64 \text { mas } \\
5.5\end{array}$ \\
\hline Sodiun & 91.6 & 83.8 & 86.1 & $\begin{array}{c}257 \text { Eed } \\
81.8\end{array}$ & $\frac{281}{8.5}$ & 2698 \\
\hline $\begin{array}{l}\text { Thaltiun } \\
\text { Iin } \\
\text { Vanadion }\end{array}$ & $\begin{array}{l}16.2 \\
67.1\end{array}$ & $\begin{array}{l}15.6 \mathrm{~m} \\
61.2\end{array}$ & $\begin{array}{l}17.3 \\
6.4\end{array}$ & $17.8 \mathrm{~m}$ & 78.6 & $78.7=$ \\
\hline Zinc & 191 & 202 & 208 & 213 & 207 & 214 \\
\hline$x$ Solids & 92.2 & 92.3 & 92.1 & 92.6 & 92.6 & 92.3 \\
\hline 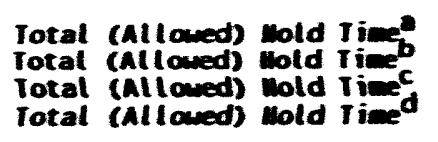 & $\begin{array}{l}32(180) d \\
25(26) d \\
47(180) d \\
13(16) d\end{array}$ & $\begin{array}{l}32(100) d \\
25(26) d \\
47(100) d \\
13(14) d\end{array}$ & $\begin{array}{l}32(100) d \\
2(26) d \\
67(100) d \\
13(16) d\end{array}$ & $\begin{array}{l}32(183) d \\
25(26) d \\
47(180) d \\
13(16) d\end{array}$ & $\begin{array}{l}32(100) d \\
25(26) d \\
67(100) d \\
13(16) d\end{array}$ & $\begin{array}{l}32(100) d \\
25(26) d \\
67(100) d \\
13(14) d\end{array}$ \\
\hline
\end{tabular}
a. ICP
b. CVNAS
c. Grans
2-15-93 
ISF Evaporation Pond S\&A Data Document - Movember 1989 - Method Validation Level B

TABLE 6-2. TSF EVAPORATION YOND - IMORgANIC DATA (Cont inued)

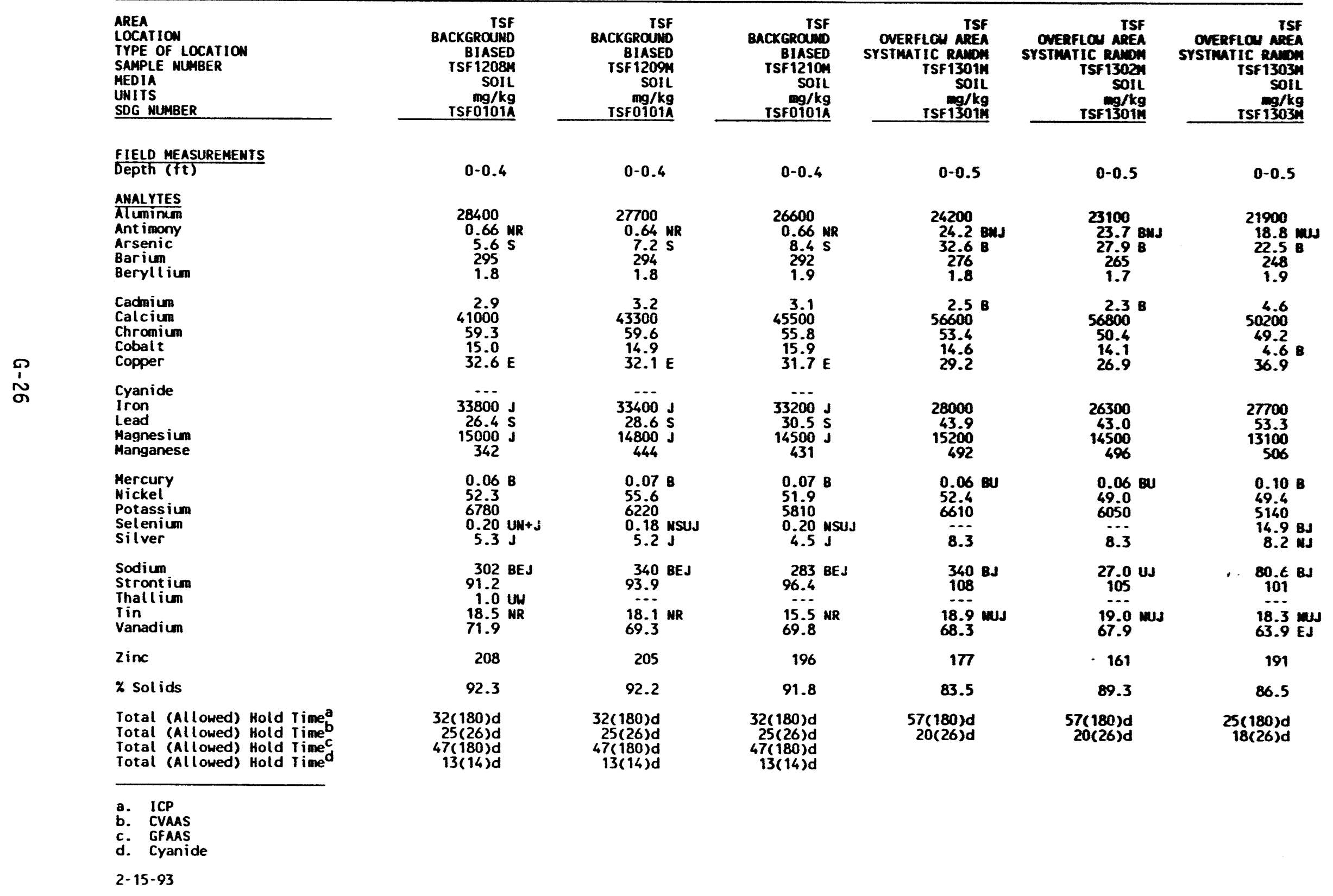


ISF Evaporation Pond S\&A Data Document - Movenber 1989 - Method Validation Level B

TABLE G-2. TSF EVAPORATION POND - INORGANIC DATA (Continued)

\begin{tabular}{|c|c|c|c|c|c|c|}
\hline $\begin{array}{l}\text { AREA } \\
\text { LOCATION } \\
\text { TYPE OF LOCATION } \\
\text { SAMPLE MUMBER } \\
\text { MEDIA } \\
\text { UNITS } \\
\text { SDG NUMBER } \\
\end{array}$ & $\begin{array}{r}\text { TSF } \\
\text { OVERFLON AREA } \\
\text { SYSTMATIC RANDH } \\
\text { TSF 1304H } \\
\text { SOIL } \\
\mathrm{mg} / \mathrm{kg} \\
\text { TSF1303M } \\
\end{array}$ & $\begin{array}{r}\text { TSF } \\
\text { OVERFLOW AREA } \\
\text { SYSTMATIC RANDH } \\
\text { TSF } 1305 M \\
\text { SOIL } \\
\mathrm{mg} / \mathrm{kg} \\
\text { TSF } 1303 \mathrm{M} \\
\end{array}$ & $\begin{array}{r}\text { TSF } \\
\text { OVERFLOU AREA } \\
\text { SYSTMATIC RANDH } \\
\text { TSF1306H } \\
\text { SOIL } \\
\text { mg/kg } \\
\text { TSF1301M } \\
\end{array}$ & $\begin{array}{r}\text { TSF } \\
\text { OVERFLON AREA } \\
\text { SYSIMATIC RAMDH } \\
\text { TSF1307H } \\
\text { SOIL } \\
\text { TSg/kg } \\
\text { TSF1301M } \\
\end{array}$ & $\begin{array}{r}\text { TSF } \\
\text { ONERFLOU AREA } \\
\text { SYSTMUTIC RRNDH } \\
\text { ISF 1308M } \\
\text { SOIL } \\
\text { ag/kg } \\
\text { TSF1303m } \\
\end{array}$ & $\begin{array}{r}\text { TSF } \\
\text { OVERFLOM AREA } \\
\text { SYSTMATIC RANDH } \\
\text { TSF 1309\% } \\
\text { SOIL } \\
09 / \mathrm{kg} \\
\text { TSF } 1303 \text {. } \\
\end{array}$ \\
\hline $\begin{array}{l}\text { FIELD MEASUREMENTS } \\
\text { Depth }(\mathrm{ft})\end{array}$ & $0-0.5$ & $0-0.5$ & $0-0.5$ & $0-0.5$ & $0-0.5$ & $0-0.5$ \\
\hline $\begin{array}{l}\text { ANALYTES } \\
\text { ALuminum } \\
\text { Ant imony } \\
\text { Arsenic } \\
\text { Barium } \\
\text { Beryllium }\end{array}$ & $\begin{array}{c}22200 \\
20.2 \text { BNJ } \\
\ldots .- \\
236 \\
2.0\end{array}$ & $\begin{array}{c}22400 \\
19.5 \mathrm{nUJ} \\
17.5 \mathrm{~B} \\
252 \\
2.0\end{array}$ & $\begin{array}{c}25100 \\
24.9 \text { BNJ } \\
49.2 \\
278 \\
1.8\end{array}$ & $\begin{array}{c}25200 \\
21.0 \mathrm{BNJ} \\
22.8 \mathrm{~B} \\
262 \\
1.7\end{array}$ & \begin{tabular}{c}
20300 \\
$19.4 \mathrm{muJ}$ \\
\hdashline 219 \\
1.9
\end{tabular} & $\begin{array}{c}20300 \\
18.7 \mathrm{mu} \\
234 \\
2.0\end{array}$ \\
\hline $\begin{array}{l}\text { Cadmium } \\
\text { Calcium } \\
\text { Chromium } \\
\text { Cobalt } \\
\text { Copper }\end{array}$ & $\begin{array}{r}4.2 \\
44600 \\
51.0 \\
12.0 \\
30.0\end{array}$ & $\begin{array}{r}4.8 \\
40700 \\
48.5 \\
15.1 \\
28.8\end{array}$ & $\begin{array}{c}2.18 \\
63000 \\
54.2 \\
14.5 \\
27.4\end{array}$ & $\begin{array}{c}2.48 \\
49600 \\
53.4 \\
14.5 \\
28.6\end{array}$ & $\begin{array}{r}4.0 \\
49600 \\
48.8 \\
15.5 \\
40.6\end{array}$ & $\begin{array}{c}4.0 \\
45600 \\
44.7 \\
7.28 \\
27.6\end{array}$ \\
\hline $\begin{array}{l}\text { Cyanide } \\
\text { Iron } \\
\text { Lead } \\
\text { Magnesium } \\
\text { Manganese }\end{array}$ & $\begin{array}{r}27000 \\
56.6 \\
13200 \\
290\end{array}$ & $\begin{array}{r}29000 \\
41.7 \\
12500 \\
395\end{array}$ & $\begin{array}{r}25800 \\
43.0 \\
15000 \\
490\end{array}$ & $\begin{array}{r}27600 \\
46.8 \\
14700 \\
442\end{array}$ & $\begin{array}{r}26100 \\
44.0 \\
13000 \\
309\end{array}$ & $\begin{array}{r}26800 \\
45.4 \\
12700 \\
359\end{array}$ \\
\hline $\begin{array}{l}\text { Mercury } \\
\text { Nickel } \\
\text { Potassium } \\
\text { Selenium } \\
\text { Silver }\end{array}$ & $\begin{array}{l}0.12 \\
45.0 \\
5410 \\
42.2 \mathrm{BJ} \\
12.1 \mathrm{NJ}\end{array}$ & $\begin{array}{l}0.05 \text { B } \\
50.1 \\
5360 \\
32.8 \text { BJ } \\
6.9 \text { NJ }\end{array}$ & \begin{tabular}{c}
$0.06 \mathrm{BU}$ \\
44.7 \\
5920 \\
\hdashline .0 \\
9.0
\end{tabular} & $\begin{array}{c}0.07 \text { BU } \\
48.8 \\
6890 \\
-1 . \\
8.4\end{array}$ & $\begin{array}{l}0.29 \\
44.2 \\
4370 \\
20.3 \mathrm{BJ} \\
24.1 \mathrm{NJ}\end{array}$ & $\begin{array}{l}0.05 \mathrm{~B} \\
46.6 \\
4740 \\
25.1 \mathrm{BJ} \\
5.8 \mathrm{MJ}\end{array}$ \\
\hline $\begin{array}{l}\text { Sodium } \\
\text { Strontium } \\
\text { Thall ium } \\
\text { Tin } \\
\text { Vanadium }\end{array}$ & $\begin{array}{l}181 \mathrm{BJ} \\
90.9 \mathrm{~g} \\
16.7 \mathrm{BJ} \\
19.0 \mathrm{NUJ} \\
64.0 \mathrm{EJ}\end{array}$ & $\begin{array}{l}27.1 \mathrm{UJ} \\
82.3 \\
-19.0 \mathrm{NUJ} \\
19.0 .5 \mathrm{EJ}\end{array}$ & $\begin{array}{l}26.4 \mathrm{UJ} \\
120 \\
24.1 \mathrm{BJ} \\
18.5 \text { NUJ } \\
76.2\end{array}$ & $\begin{array}{l}35.5 \mathrm{BJ} \\
97.4 \\
24.6 \mathrm{BJ} \\
18.9 \mathrm{~mJ} \\
70.0\end{array}$ & $\begin{array}{l}160 \mathrm{BJ} \\
97.5 \\
19.0 \mathrm{mUJ} \\
61.6 \mathrm{EJ}\end{array}$ & $\begin{array}{l}66.7 \mathrm{BJ} \\
86.7 \\
-\overline{18.2} \mathrm{~mJ} \\
55.6 \mathrm{EJ}\end{array}$ \\
\hline Zinc & 184 & 193 & 154 & 175 & 190 & 174 \\
\hline \% Solids & 87.0 & 87.6 & 90.0 & 90.8 & 89.6 & 88.3 \\
\hline $\begin{array}{l}\text { Total (Allowed) Hold Timea } \\
\text { Total (Allowed) Hold Time } \\
\text { Total (Allowed) Hold Timec } \\
\text { Total (All owed) Hold Timed }\end{array}$ & $\begin{array}{l}25(180) d \\
18(26) d\end{array}$ & $\begin{array}{r}26(180) d \\
19(26) d\end{array}$ & $\begin{array}{r}57(180) d \\
20(26) d\end{array}$ & $\begin{array}{r}58(180) d \\
21(26) d\end{array}$ & $\begin{array}{l}26(180) d \\
19(26) d\end{array}$ & $\begin{array}{l}25(180) d \\
18(26) d\end{array}$ \\
\hline $\begin{array}{l}\text { a. ICP } \\
\text { b. CVAAS } \\
\text { c. GFAAS } \\
\text { d. Cyanide }\end{array}$ & & & & & & \\
\hline $2-15-93$ & & & & & & \\
\hline
\end{tabular}


TSF Evaporation Pond S\&A Data Document - Noveaber 1989 - Method Validation Level B

TABLE G-2. TSF EVAPORATION POND - IMORGANIC DATA (Cont inued)

\begin{tabular}{|c|c|c|c|c|c|c|}
\hline $\begin{array}{l}\text { AREA } \\
\text { LOCATION } \\
\text { TYPE OF LOCATION } \\
\text { SAMPLE MUMBER } \\
\text { MEDIA } \\
\text { UNIIS } \\
\text { SDG NUMBER } \\
\end{array}$ & $\begin{array}{r}\text { TSF } \\
\text { OVERFLOW AREA } \\
\text { SYSTMATIC RANDH } \\
\text { TSF } 1310 \text { M } \\
\text { SOIL } \\
\mathrm{mg} / \mathrm{kg} \\
\text { TSF } 1301 \mathrm{M} \\
\end{array}$ & $\begin{array}{r}\text { TSF } \\
\text { OVERFLON AREA } \\
\text { SYSTMATIC RAMDM } \\
\text { ISFI311M } \\
\text { SOIL } \\
\mathrm{mg} / \mathrm{kg} \\
\text { ISF } 1303 \mathrm{M} \\
\end{array}$ & $\begin{array}{r}\text { TSF } \\
\text { OVERFLON AREA } \\
\text { SYSTMATIC RAMDH } \\
\text { TSF 1312M } \\
\text { SOIL } \\
\mathrm{mg} / \mathrm{kg} \\
\text { TSF } 1303 \mathrm{M} \\
\end{array}$ & $\begin{array}{r}\text { TSF } \\
\text { OVERFLOW AREA } \\
\text { SYSTMATIC RANDH } \\
\text { TSF 1313H } \\
\text { SOIL } \\
\mathrm{mg} / \mathrm{kg} \\
\text { TSF1303H } \\
\end{array}$ & $\begin{array}{r}\text { TSF } \\
\text { OVERFLON RREA } \\
\text { SYSTMATIC RANDM } \\
\text { TSF 1314M } \\
\text { SOIL } \\
\text { mg/kg } \\
\text { TSF1301M } \\
\end{array}$ & $\begin{array}{r}\text { TSF } \\
\text { OVERFLOW AREA } \\
\text { SYSTMATIC RANDM } \\
\text { TSF 1315M } \\
\text { SOIL } \\
\mathrm{mg} / \mathrm{kg} \\
\text { TSF1303M } \\
\end{array}$ \\
\hline $\begin{array}{l}\text { FIELD MEASUREMENTS } \\
\text { Depth }(f t)\end{array}$ & $0-0.5$ & $0-0.5$ & $0-0.5$ & $0-0.5$ & $3-0.5$ & $0-0.5$ \\
\hline $\begin{array}{l}\text { ANALYTES } \\
\text { Aluminum } \\
\text { Antimony } \\
\text { Arsenic } \\
\text { Barium } \\
\text { Beryllium }\end{array}$ & $\begin{array}{r}23600 \\
19.5 \text { NR } \\
14.2 \mathrm{~B} \\
301 \\
1.8\end{array}$ & $\begin{array}{c}19200 \\
19.5 \text { muJ } \\
15.8 \text { 8 } \\
248 \\
2.2\end{array}$ & $\begin{array}{c}19800 \\
19.1 \text { NUJ } \\
-.- \\
214 \\
1.9\end{array}$ & $\begin{array}{c}21000 \\
18.3 \text { wuJ } \\
-\ldots- \\
236 \\
2.0\end{array}$ & $\begin{array}{c}25400 \\
27.0 \mathrm{BNJ} \\
29.4 \mathrm{~B} \\
284 \\
1.8\end{array}$ & $\begin{array}{c}18200 \\
19.9 \text { BuJ } \\
18.4 \text { B } \\
207 \\
1.8\end{array}$ \\
\hline $\begin{array}{l}\text { Cadmium } \\
\text { Calcium } \\
\text { Chromium } \\
\text { Cobalt } \\
\text { Copper }\end{array}$ & $\begin{array}{c}1.9 \mathrm{~B} \\
66100 \\
53.1 \\
13.7 \\
26.8\end{array}$ & $\begin{array}{r}4.3 \\
56100 \\
43.1 \\
13.4 \\
25.8\end{array}$ & $\begin{array}{c}4.0 \\
55000 \\
52.6 \\
9.4 \mathrm{~B} \\
82.3\end{array}$ & $\begin{array}{r}4.5 \\
39600 \\
45.9 \\
16.0 \\
29.2\end{array}$ & $\begin{array}{c}2.28 \\
55800 \\
55.6 \\
13.8 \\
28.0\end{array}$ & $\begin{array}{c}3.5 \mathrm{~B} \\
49100 \\
42.0 \\
8.0 \mathrm{~B} \\
25.6\end{array}$ \\
\hline $\begin{array}{l}\text { Cyanide } \\
\text { Iron } \\
\text { Lead } \\
\text { Magnesium } \\
\text { Manganese }\end{array}$ & $\begin{array}{r}26400 \\
39.7 \mathrm{~B} \\
15300 \\
515\end{array}$ & $\begin{array}{r}25800 \\
37.1 \mathrm{~B} \\
12800 \\
539\end{array}$ & $\begin{array}{r}24700 \\
44.8 \\
12000 \\
222\end{array}$ & $\begin{array}{r}27800 \\
45.6 \\
12600 \\
371\end{array}$ & $\begin{array}{r}27800 \\
52.0 \\
15100 \\
492\end{array}$ & $\begin{array}{r}24800 \\
35.6 \mathrm{~B} \\
12400 \\
317\end{array}$ \\
\hline $\begin{array}{l}\text { Mercury } \\
\text { Nickel } \\
\text { Potassium } \\
\text { Selenium } \\
\text { Silver }\end{array}$ & $\begin{array}{r}48.5 \\
5600 \\
-8.6\end{array}$ & $\begin{array}{l}0.05 \mathrm{~B} \\
46.1 \\
4410 \\
15.0 \mathrm{BJ} \\
5.6 \mathrm{BNJ}\end{array}$ & $\begin{array}{l}1.3 \\
44.8 \\
4690 \\
9.0 \mathrm{UJ} \\
31.8 \mathrm{NJ}\end{array}$ & $\begin{array}{l}0.05 \text { B } \\
49.9 \\
5810 \\
38.6 \mathrm{BJ} \\
5.9 \mathrm{NJ}\end{array}$ & $\begin{array}{c}0.06 \text { Bu } \\
51.4 \\
7210 \\
-8.7\end{array}$ & $\begin{array}{c}0.08 \text { B } \\
43.0 \\
4070 \\
30.3 \text { BJ } \\
8.9 \text { NJ }\end{array}$ \\
\hline $\begin{array}{l}\text { Sodium } \\
\text { Stront ium } \\
\text { Thall ium } \\
\text { Tin } \\
\text { Vanadium }\end{array}$ & $\begin{array}{l}331 \text { BJ } \\
121 \\
31.5 \text { BJ } \\
19.0 \text { NUJ } \\
77.1\end{array}$ & $\begin{array}{l}140 \mathrm{BJ} \\
105 \\
24.4 \mathrm{BJ} \\
19.0 \mathrm{NUJ} \\
58.7 \mathrm{EJ}\end{array}$ & $\begin{array}{l}26.6 \mathrm{UJ} \\
111 \\
16.6 \mathrm{BJ} \\
18.7 \mathrm{NUJ} \\
57.9 \mathrm{EJ}\end{array}$ & $\begin{array}{l}107 \mathrm{BJ} \\
79.3 \mathrm{BJ} \\
18.9 \mathrm{BJ} \\
17.8 \mathrm{mUJ} \\
56.1 \mathrm{EJ}\end{array}$ & $\begin{array}{l}113 \mathrm{BJ} \\
103 \\
19.0 \mathrm{mUJ} \\
73.4\end{array}$ & $\begin{array}{l}114 \mathrm{BJ} \\
92.9 \\
21.5 \mathrm{BJ} \\
18.6 \mathrm{NUJ} \\
55.1 \mathrm{EJ}\end{array}$ \\
\hline Zinc & 155 & 160 & 302 & 185 & 174 & 159 \\
\hline * Sol ids & 88.8 & 90.3 & 86.4 & 88.0 & 89.6 & 90.7 \\
\hline $\begin{array}{l}\text { Total (Allowed) Hold Time } \\
\text { Iotal (Allowed) Hold Time } \\
\text { Iotal (Allowed) Hold Time } \\
\text { otal }\end{array}$ & $\begin{array}{l}57(180) d \\
20(26) d\end{array}$ & $\begin{array}{r}26(180) d \\
19(26) d\end{array}$ & $\begin{array}{r}26(180) d \\
19(26) d\end{array}$ & $\begin{array}{r}26(180) d \\
19(26) d\end{array}$ & $\begin{array}{l}57(180) d \\
20(26) d\end{array}$ & $\begin{array}{r}26(180) d \\
19(26) d\end{array}$ \\
\hline
\end{tabular}
a. ICP
c. GFAAS
d. Cyanide
$2-15-93$ 
ISF Evaporation Pond S\&A Data Document - Novenber 1989 - Method Validation Level $B$

TABLE G-2. ISF EVAPORATION POND - INORGANIC DATA (Continued)

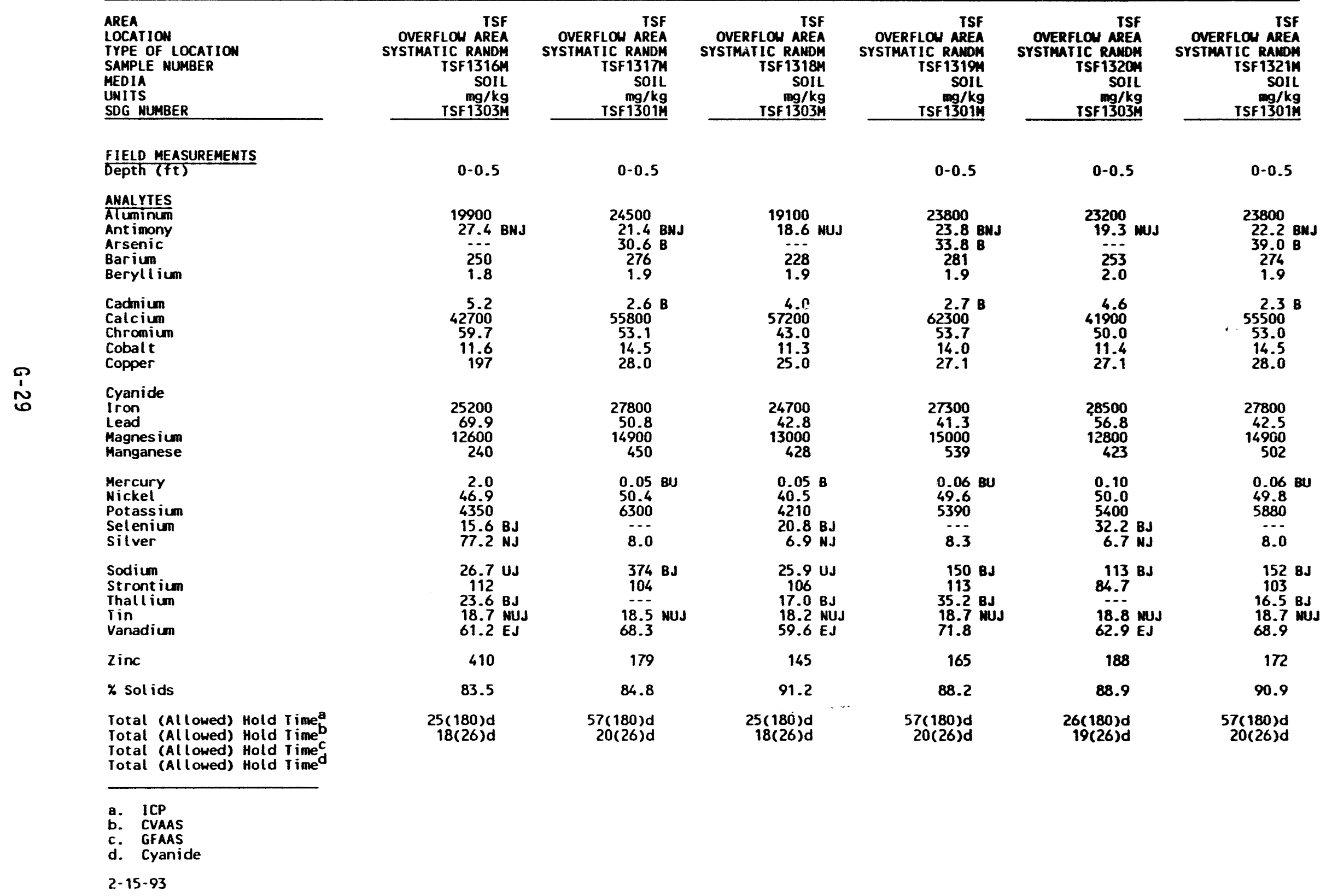


TSF Evaporation Pond S\&A Data Document - November 1989 - Method Validation Level B

TABLE 6-2. TSF EVAPORATION POND - InORgAMIC DATA (Continued)

\begin{tabular}{|c|c|c|c|c|c|c|}
\hline $\begin{array}{l}\text { AREA } \\
\text { LOCATION } \\
\text { IYPE OF LOCATION } \\
\text { SAMPLE MUMBER } \\
\text { MEDIA } \\
\text { UNITS } \\
\text { SDG MUMBER } \\
\end{array}$ & $\begin{array}{r}\text { TSF } \\
\text { OVERFLOW AREA } \\
\text { SYSTMATIC RANDM } \\
\text { ISF 1322M } \\
\text { SOIL } \\
\mathrm{mg} / \mathrm{kg} \\
\text { TSF 1303M } \\
\end{array}$ & $\begin{array}{r}\text { TSF } \\
\text { OVERFLON AREA } \\
\text { SYSTMATIC RANDM } \\
\text { TSF 1323A } \\
\text { SOIL } \\
\mathrm{mg} / \mathrm{kg} \\
\text { TSF 1323A } \\
\end{array}$ & $\begin{array}{r}\text { TSF } \\
\text { OVERFLOW AREA } \\
\text { SYSTMATIC RAMDM } \\
\text { TSF } 1324 A \\
\text { SOIL } \\
\mathrm{mg} / \mathrm{kg} \\
\text { TSF1323A } \\
\end{array}$ & $\begin{array}{r}\text { TSF } \\
\text { OVERFLOA AREA } \\
\text { SYSTMAIIC RANDM } \\
\text { TSF 1325A } \\
\text { SOIL } \\
\text { rog/kg } \\
\text { TSF 1323A } \\
\end{array}$ & $\begin{array}{r}\text { TSF } \\
\text { ONERFLOH AREA } \\
\text { SYSTMATIC RANDH } \\
\text { TSF 14011 } \\
\text { SED IMENT } \\
\text { mg/kg } \\
\text { TSF } 1301 \% \\
\end{array}$ & $\begin{array}{r}\text { TSF } \\
\text { OVERFLOW AREA } \\
\text { SYSTMATIC RAMDM } \\
\text { TSF 1402M } \\
\text { SEDIMENT } \\
\text { mg/kg } \\
\text { TSF1301M }\end{array}$ \\
\hline $\begin{array}{l}\text { FIELD MEASUREMENTS } \\
\text { Depth (ft) }\end{array}$ & $0-0.5$ & $0-0.5$ & $0-0.5$ & $0-0.5$ & $10-11$ & $10-11$ \\
\hline $\begin{array}{l}\text { ANALYTES } \\
\text { Aluminum } \\
\text { Ant imony } \\
\text { Arsenic } \\
\text { Barium } \\
\text { Beryllium }\end{array}$ & $\begin{array}{c}23300 \\
24.5 \text { BNJ } \\
--- \\
257 \\
1.9\end{array}$ & $\begin{array}{l}19200 \\
1.7 \mathrm{BNJ} \\
7.5 \mathrm{~S} \\
246 \\
1.7\end{array}$ & $\begin{array}{l}22900 \\
2.0 \mathrm{BNJ} \\
5.4 \mathrm{~S} \\
264 \\
2.0\end{array}$ & $\begin{array}{r}23100 \\
1.5 \mathrm{BNJ} \\
5.3 \mathrm{~S} \\
263 \\
1.9\end{array}$ & $\begin{array}{c}19600 \\
18.6 \% 8 \\
24.45 \\
293 \\
1.5\end{array}$ & $\begin{array}{c}18000 \\
19.0 \mathrm{MR} \\
46.8 \mathrm{~B} \\
277 \\
1.2\end{array}$ \\
\hline $\begin{array}{l}\text { Cadmium } \\
\text { Calcium } \\
\text { Chromium } \\
\text { Cobalt } \\
\text { Copper }\end{array}$ & $\begin{array}{r}5.7 \\
46200 \\
51.5 \\
11.8 \\
27.5\end{array}$ & $\begin{array}{r}3.1 \\
60200 \\
60.5 \mathrm{EJ} \\
16.4 \\
123\end{array}$ & $\begin{array}{c}3.0 \\
53500 \\
49.7 \mathrm{~J} \\
17.7 \\
27.6\end{array}$ & $\begin{array}{c}2.7 \\
51000 \\
50.4 \mathrm{~J} \\
16.4 \\
29.0\end{array}$ & $\begin{array}{c}2.1 \text { B } \\
63700 \\
47.2 \\
13.8 \\
25.7\end{array}$ & $\begin{array}{c}1.5 \mathrm{~B} \\
50700 \\
41.8 \\
12.5 \\
22.8\end{array}$ \\
\hline $\begin{array}{l}\text { Cyanide } \\
\text { Iron } \\
\text { Lead } \\
\text { Magnesium } \\
\text { Manganese }\end{array}$ & $\begin{array}{r}28600 \\
45.2 \\
13000 \\
460\end{array}$ & $\begin{array}{c}0.62 \mathrm{BJ} \\
25100 \\
43.3 \mathrm{~s} \\
13500 \\
237\end{array}$ & $\begin{array}{r}0.10 \mathrm{BJ} \\
27700 \\
30.1 \mathrm{~s} \\
14500 \\
477\end{array}$ & $\begin{array}{c}0.21 \mathrm{BJ} \\
27500 \\
29.6 \mathrm{~s} \\
14200 \\
486\end{array}$ & $\begin{array}{r}24900 \\
33.7 \mathrm{~B} \\
13300 \\
451\end{array}$ & $\begin{array}{r}22200 \\
34.18 \\
12000 \\
420\end{array}$ \\
\hline $\begin{array}{l}\text { Mercury } \\
\text { Nickel } \\
\text { Potassium } \\
\text { Selenium } \\
\text { Silver }\end{array}$ & $\begin{array}{l}0.08 \mathrm{~B} \\
47.2 \\
5920 \\
16.2 \mathrm{BJ} \\
7.4 \mathrm{NJ}\end{array}$ & $\begin{array}{r}3.9 \\
42.7 \\
3990 \\
1.0 \mathrm{BN}=\mathrm{SJ} \\
37.6\end{array}$ & $\begin{array}{l}0.06 \text { B } \\
48.3 \\
6180 \\
0.39 \text { BN*SJ } \\
7.7\end{array}$ & $\begin{array}{l}0.08 \text { B } \\
46.4 \\
5690 \\
0.39 \text { BN+SJ } \\
7.0\end{array}$ & $\begin{array}{r}39.2 \\
4180 \\
9.0\end{array}$ & $\begin{array}{c}0.07 \mathrm{BU} \\
34.3 \\
3530 \\
-. . \\
8.6\end{array}$ \\
\hline $\begin{array}{l}\text { Sodium } \\
\text { Strontium } \\
\text { Thall ium } \\
\text { Iin } \\
\text { Vanadium }\end{array}$ & $\begin{array}{l}201 \mathrm{BJ} \\
92.7 \\
18.9 \mathrm{mUJ} \\
67.8 \mathrm{EJ}\end{array}$ & $\begin{array}{c}274 \mathrm{~B} \\
118 \\
1.0 \mathrm{USN} \\
15.1 \mathrm{NR} \\
65.1 \mathrm{EJ}\end{array}$ & $\begin{array}{l}263 \mathrm{R} \\
100 \\
0.94 \mathrm{USH} \\
18.5 \mathrm{NR} \\
60.8 \mathrm{~J}\end{array}$ & $\begin{array}{l}340 \text { B } \\
98.7 \text { USM } \\
0.94 \text { USM } \\
18.9 \text { NR } \\
64.7 \mathrm{~J}\end{array}$ & $\begin{array}{ll}232 & \mathrm{BJ} \\
121 & \\
22.4 & \mathrm{BJ} \\
18.1 & \mathrm{MU} \\
81.2 & \end{array}$ & $\begin{array}{l}48.0 \mathrm{BJ} \\
100 \\
19.0 \mathrm{BJ} \\
18.6 \mathrm{~mJ} \\
69.1\end{array}$ \\
\hline Zinc & 180 & 381 & 175 & 169 & 112 & 91.7 \\
\hline \% Solids & 86.2 & 88.0 & 89.7 & 91.1 & 79.2 & 78.3 \\
\hline $\begin{array}{l}\text { Total (Allowed) Hold Timea } \\
\text { Total (Allowed) Hold Time } \\
\text { Total (Allowed) Hold Timec } \\
\text { Total (All owed) Hold Time }\end{array}$ & $\begin{array}{l}26(180) d \\
19(26) d\end{array}$ & $\begin{array}{l}38(180) d \\
27(26) d^{\star} \\
41(180) d \\
24(14) d^{\star}\end{array}$ & $\begin{array}{l}34(180) d \\
23(26) d \\
37(180) d \\
20(14) d^{\star}\end{array}$ & $\begin{array}{l}34(180) d \\
23(26) d \\
37(180) d \\
20(14) d^{\star}\end{array}$ & $\begin{array}{r}57(180) d \\
20(26) d\end{array}$ & $\begin{array}{r}57(180) d \\
20(26) d\end{array}$ \\
\hline $\begin{array}{l}\text { a. ICP } \\
\text { b. CVAAS } \\
\text { c. GFAAS } \\
\text { d. Cyanide }\end{array}$ & & & & & & \\
\hline $2-15-93$ & & & & & & \\
\hline
\end{tabular}


ISF Evaporation Pond S\&A Data Document - Movenber 1989 - Method Validation Level B

TABLE 6-2. TSF EVAPORATION POND - IMORGANIC DATA (Cont inued)

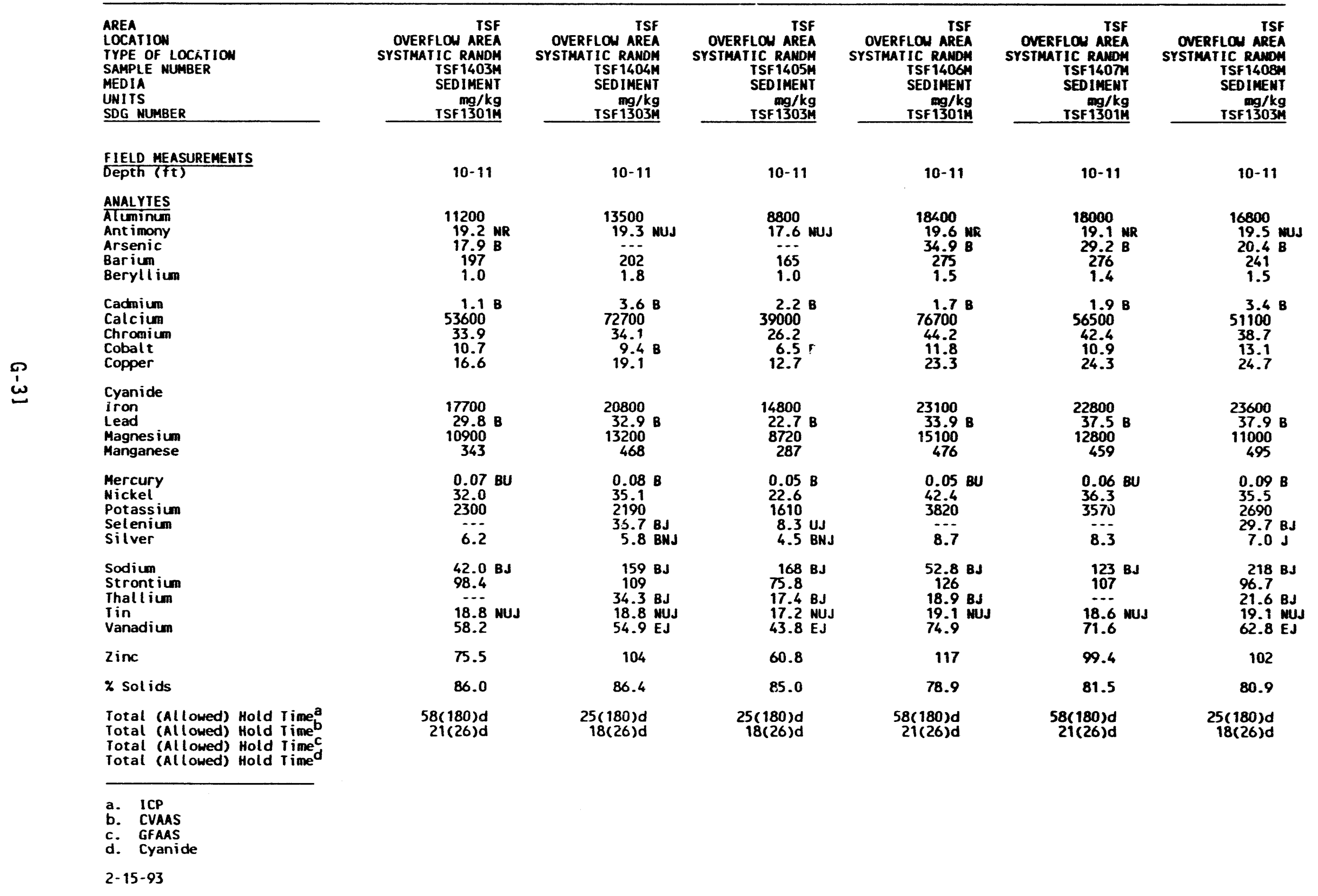


ISF Evaporation Pond S\&A Data Document - Moveaber 1989 - Method Validation Level B

TABLE 6-2. TSF EVAPORATION POND - IMORGANIC DATA (Cont inued)




ISF Evaporation Pond S\&A Data Document - Moveaber 1989 - Method Validation Level B

TABLE 6-2. TSF EVAPORATION POND - INORganiC DATA (Continued)

\begin{tabular}{|c|c|c|c|c|c|c|}
\hline $\begin{array}{l}\text { AREA } \\
\text { LOCATION } \\
\text { TYPE OF LOCATION } \\
\text { SAMPLE MUABER } \\
\text { MEDIA } \\
\text { UNITS } \\
\text { SDG MUMBER } \\
\end{array}$ & $\begin{array}{r}\text { TSF } \\
\text { OVERFLON AREA } \\
\text { SYSTMATIC RANDM } \\
\text { TSF1415M } \\
\text { SEDIMENT } \\
\text { mg/kg } \\
\text { TSF1303M } \\
\end{array}$ & $\begin{array}{r}\text { TSF } \\
\text { OVERFLON AREA } \\
\text { SYSTMATIC RANDM } \\
\text { TSF1416H } \\
\text { SEDIMENT } \\
\text { mg/kg } \\
\text { TSF1301M } \\
\end{array}$ & $\begin{array}{r}\text { TSF } \\
\text { OVERFLLN AREA } \\
\text { SYSTMATIC RANDH } \\
\text { TSF 1417M } \\
\text { SEDIMENT } \\
\text { mg/kg } \\
\text { TSF0201M } \\
\end{array}$ & $\begin{array}{r}\text { TSF } \\
\text { OVERFLOU AREA } \\
\text { SYSTMATIC RAMDH } \\
\text { TSF1418M } \\
\text { SEDINENT } \\
\text { Thg/kg } \\
\text { TSF1303in } \\
\end{array}$ & $\begin{array}{r}\text { TSF } \\
\text { OVERFLOU AREA } \\
\text { SYSTMATIC RANDH } \\
\text { TSF1419M } \\
\text { SEDINENT } \\
\text { Ta/kg } \\
\text { TSF0201M } \\
\end{array}$ & $\begin{array}{r}\text { TSF } \\
\text { ONERFLOA AREA } \\
\text { SYSTMATIC RAMDH } \\
\text { TSF 1420H } \\
\text { SEDIMENT } \\
\text { Og/kg } \\
\text { TSF0201M } \\
\end{array}$ \\
\hline $\begin{array}{l}\text { FIELD MEASUREMEMIS } \\
\text { Depth }(t \bar{t})\end{array}$ & $10-11$ & $10-11$ & & $10-11$ & $10-11$ & $10-11$ \\
\hline $\begin{array}{l}\text { AWALYTES } \\
\text { Riuminum } \\
\text { Ant imony } \\
\text { Arsenic } \\
\text { Barium } \\
\text { Beryllium }\end{array}$ & $\begin{array}{c}12900 \\
19.0 \text { mJ } \\
-. . \\
213 \\
1.5\end{array}$ & $\begin{array}{c}16000 \\
18.9 \mathrm{MR} \\
25.4 \mathrm{~B} \\
248 \\
1.2\end{array}$ & $\begin{array}{c}17100 \\
19.6 \mathrm{MR} \\
17.6 \mathrm{~B} \\
280 \\
1.3\end{array}$ & $\begin{array}{c}13700 \\
19.3 \mathrm{mus} \\
-\ldots . \\
230 \\
1.8\end{array}$ & \begin{tabular}{c}
17000 \\
18.4 MR \\
\hdashline 28 \\
282 \\
1.5
\end{tabular} & $\begin{array}{c}19900 \\
17.9 \text { Mr } \\
-. . \\
290 \\
1.6\end{array}$ \\
\hline $\begin{array}{l}\text { Cadmium } \\
\text { Calcium } \\
\text { Chromium } \\
\text { Cobalt } \\
\text { Copper }\end{array}$ & $\begin{array}{c}2.8 \mathrm{~B} \\
59900 \\
33.6 \\
8.2 \mathrm{~B} \\
18.6\end{array}$ & $\begin{array}{c}1.68 \\
53900 \\
39.8 \\
10.4 \\
23.3\end{array}$ & $\begin{array}{c}2.48 \\
52200 \\
40.1 \\
14.3 \\
24.4\end{array}$ & $\begin{array}{c}3.0 \mathrm{~B} \\
72600 \\
33.6 \\
9.1 \mathrm{~B} \\
17.7\end{array}$ & $\begin{array}{c}2.28 \\
54600 \\
41.1 \\
10.8 \\
25.0\end{array}$ & $\begin{array}{c}2.4 \mathrm{~B} \\
56600 \\
44.0 \\
13.9 \\
31.3\end{array}$ \\
\hline $\begin{array}{l}\text { Cyanide } \\
\text { Iron } \\
\text { Lead } \\
\text { Magnesium } \\
\text { Manganese }\end{array}$ & $\begin{array}{r}19900 \\
27.1 \mathrm{~B} \\
12200 \\
406\end{array}$ & $\begin{array}{r}21000 \\
34.3 \mathrm{~B} \\
11800 \\
409\end{array}$ & $\begin{array}{r}24000 \\
49.8 \\
11200 \\
461\end{array}$ & $\begin{array}{r}20200 \\
32.1 \mathrm{~B} \\
13400 \\
427\end{array}$ & $\begin{array}{r}23900 \\
44.1 \\
11600 \\
490\end{array}$ & $\begin{array}{r}27000 \\
36.8 \\
11300 \\
522\end{array}$ \\
\hline $\begin{array}{l}\text { Mercury } \\
\text { Nickel } \\
\text { Potassium } \\
\text { Selenium } \\
\text { Silver }\end{array}$ & $\begin{array}{l}0.06 \mathrm{~B} \\
33.2 \\
2230 \\
9.0 \mathrm{uJ} \\
6.3 \mathrm{WJ}\end{array}$ & \begin{tabular}{c}
0.07 bu \\
34.3 \\
3210 \\
\hdashline$\ldots$ \\
8.4
\end{tabular} & $\begin{array}{r}37.3 \\
3000 \\
9.2 \text { us } \\
8.1 \text { WJ }\end{array}$ & $\begin{array}{l}0.08 \mathrm{~B} \\
35.6 \\
2280 \\
9.1 \mathrm{UJ} \\
5.6 \text { BNJ }\end{array}$ & $\begin{array}{l}0.09 \text { bu } \\
42.9 \\
3130 \\
8.6 \text { uJ } \\
7.1 \text { us }\end{array}$ & $\begin{array}{c}0.06 \text { bu } \\
43.0 \\
3520 \\
8.4 \text { UJ } \\
7.5 \text { uJ }\end{array}$ \\
\hline $\begin{array}{l}\text { Sodium } \\
\text { Strontium } \\
\text { Thall ium } \\
\text { Tin } \\
\text { Vanadium }\end{array}$ & $\begin{array}{l}164 \mathrm{BJ} \\
98.4 \\
29.6 \mathrm{BJ} \\
18.6 \mathrm{WJ} \\
56.0 \mathrm{EJ}\end{array}$ & $\begin{array}{c}121 \mathrm{BJ} \\
104 \\
\cdots \\
18.4 \text { wUJ } \\
66.2\end{array}$ & $\begin{array}{c}240 \mathrm{BJ} \\
102 \\
19.0 \mathrm{BJ} \\
19.2 \mathrm{NJ} \\
67.7\end{array}$ & $\begin{array}{l}119 \mathrm{BJ} \\
110 \\
-- \\
18.8 \mathrm{~mJ} \\
54.6 \mathrm{EJ}\end{array}$ & $\begin{array}{l}148 \mathrm{BJ} \\
105 \\
31.8 \mathrm{BJ} \\
17.9 \mathrm{wJ} \\
70.3\end{array}$ & $\begin{array}{l}165 \text { BJ } \\
114 \\
33.3 \text { BJ } \\
17.5 \text { w. } \\
73.4\end{array}$ \\
\hline 2 in $x$ & 93.6 & 93.7 & 101 & 98.8 & 114 & 123 \\
\hline X Solids & 84.1 & 80.6 & 77.8 & 79.2 & 78.3 & 79.5 \\
\hline $\begin{array}{l}\text { Total (Allowed) Hold Time a } \\
\text { Total (Allowed) Hold Time } \\
\text { Total (Allowed) Hold I ime } \\
\text { Total (All lowed) Hold I ime }\end{array}$ & $\begin{array}{l}25(180) d \\
18(26) d\end{array}$ & $\begin{array}{l}58(180) d \\
21(26) d\end{array}$ & $\begin{array}{r}27(180) d \\
23(26) d\end{array}$ & $\begin{array}{l}25(180) d \\
18(26) d\end{array}$ & $\begin{array}{l}28(180) d \\
24(26) d\end{array}$ & $\begin{array}{l}31(180) d \\
27(26) d^{*}\end{array}$ \\
\hline
\end{tabular}

a. ICP

b. CVAAS

c. GFAAS

2-15-93 
TSF Evaporation Pond S\&A Data Document - November 1989 - Method Validation Level B

TABLE 6-2. ISF EVAPORATION POND - IMORGANIC DATA (Contimued)

\begin{tabular}{|c|c|c|c|c|c|c|}
\hline $\begin{array}{l}\text { AREA } \\
\text { LOCATION } \\
\text { TYPE OF LOCATION } \\
\text { SAMPLE MUABER } \\
\text { MEDIA } \\
\text { UNITS } \\
\text { SDG MUMBER } \\
\end{array}$ & $\begin{array}{r}\text { TSF } \\
\text { OVERFLOW AREA } \\
\text { SYSTMATIC RANDM } \\
\text { ISF } 1421 M \\
\text { SEDIMENT } \\
\text { MG/kg } \\
\text { TSFOZOIM } \\
\end{array}$ & $\begin{array}{r}\text { TSF } \\
\text { OVERFLOW AREA } \\
\text { SYSTMATIC RANDH } \\
\text { TSF1422N } \\
\text { SEDIMENT } \\
\text { mg/kg } \\
\text { TSF1303M } \\
\end{array}$ & $\begin{array}{r}\text { TSF } \\
\text { OVERFLOW AREA } \\
\text { SYSTMATIC RAMDH } \\
\text { TSF 1423A } \\
\text { SEDIMEMT } \\
\text { mg/kg } \\
\text { TSF 1323A } \\
\end{array}$ & $\begin{array}{r}\text { TSF } \\
\text { OVERFLOW AREA } \\
\text { SYSIMATIC RANDA } \\
\text { TSF 1424A } \\
\text { SEDIIMEMT } \\
\text { Tg/kg } \\
\text { TSF1323A }\end{array}$ & $\begin{array}{r}\text { TSF } \\
\text { OVERFLOW AREA } \\
\text { SYSTMATIC RANDH } \\
\text { TSF1426A } \\
\text { SEDIMENT } \\
\text { TSF0/kg } \\
\text { TSFO201H } \\
\end{array}$ & $\begin{array}{r}\text { ISF } \\
\text { OVERFLOW AREA } \\
\text { SYSTMATIC RAMDN } \\
\text { TSF1425A } \\
\text { SEDIMENT } \\
\text { mg/kg } \\
\text { TSF1323A } \\
\end{array}$ \\
\hline $\begin{array}{l}\text { FIELD MEASUREMEMTS } \\
\text { Depth }(t t)\end{array}$ & $10-11$ & $10-11$ & $10-11$ & $10-11$ & $10-11$ & $10-11$ \\
\hline $\begin{array}{l}\text { ANALYTES } \\
\text { Aluminum } \\
\text { Ant imony } \\
\text { Arsenic } \\
\text { Barium } \\
\text { Beryllium }\end{array}$ & $\begin{array}{c}17000 \\
19.3 \text { MR } \\
-\ldots \\
345 \\
1.6\end{array}$ & $\begin{array}{c}14700 \\
19.5 \text { wJ } \\
21.8 \mathrm{~B} \\
250 \\
1.6\end{array}$ & $\begin{array}{l}17000 \\
0.62 \text { wu } \\
18.75 \\
256 \\
1.6\end{array}$ & $\begin{array}{c}16700 \\
0.75 \mathrm{mw} \\
19.6 \mathrm{~s} \\
275 \\
1.8\end{array}$ & & $\begin{array}{l}17200 \\
0.97 \text { gind } \\
12.5+J \\
226 \\
1.6\end{array}$ \\
\hline $\begin{array}{l}\text { Cadmium } \\
\text { Calcium } \\
\text { Chromium } \\
\text { Cobalt } \\
\text { Copper }\end{array}$ & $\begin{array}{c}2.3{ }^{8} \\
70500 \\
42.0 \\
12.3 \\
24.4\end{array}$ & $\begin{array}{c}3.4 B \\
53300 \\
35.1 \\
11.3 \\
24.6\end{array}$ & $\begin{array}{c}2.1 \\
77700 \\
40.8 \mathrm{~d} \\
15.6 \\
22.1\end{array}$ & $\begin{array}{c}2.2 \\
80600 \\
42.1 \mathrm{~J} \\
16.6 \\
23.1\end{array}$ & & $\begin{array}{c}2.0 \\
74300 \\
40.8 \mathrm{~J} \\
15.7 \\
22.6\end{array}$ \\
\hline $\begin{array}{l}\text { Cyanide } \\
\text { Iron } \\
\text { Lead } \\
\text { Magnesium } \\
\text { Manganese }\end{array}$ & $\begin{array}{r}24400 \\
52.1 \\
13600 \\
507\end{array}$ & $\begin{array}{r}23200 \\
43.9 \\
10700 \\
495\end{array}$ & $\begin{array}{c}0.20 \mathrm{BJ} \\
22700 \\
27.4 \mathrm{~S} \\
14800 \\
539\end{array}$ & $\begin{array}{c}0.17 \mathrm{BJ} \\
24400 \\
30.5 \mathrm{~s} \\
15500 \\
535\end{array}$ & & $\begin{array}{c}0.10 \mathrm{BJ} \\
23800 \\
26.4 \\
14500 \\
489\end{array}$ \\
\hline $\begin{array}{l}\text { Mercury } \\
\text { Nickel } \\
\text { Potassium } \\
\text { Selenium } \\
\text { Silver }\end{array}$ & $\begin{array}{l}0.07 \mathrm{Bu} \\
42.8 \\
3130 \\
9.1 \mathrm{uJ} \\
7.2 \mathrm{NJ}\end{array}$ & $\begin{array}{l}0.09 \mathrm{~B} \\
34.9 \\
2460 \\
9.2 \mathrm{uJ} \\
6.2 \mathrm{MJ}\end{array}$ & $\begin{array}{l}0.12 \\
37.0 \\
3140 \\
0.858 \\
7.5\end{array}$ & $\begin{array}{l}0.09 \text { B } \\
43.4 \\
3080 \\
0.59 \text { Bn*SJ } \\
7.2\end{array}$ & $0.09 \mathrm{~B}$ & $\begin{array}{l}0.13 \\
40.1 \\
3390 \\
0.53 \text { BN=SJ } \\
7.4\end{array}$ \\
\hline $\begin{array}{l}\text { Sodium } \\
\text { Strontium } \\
\text { Thallium } \\
\text { Tin } \\
\text { Vanadium }\end{array}$ & $\begin{array}{l}115 \mathrm{BJ} \\
118 \\
47.5 \mathrm{BJ} \\
18.8 \mathrm{mUJ} \\
70.7\end{array}$ & $\begin{array}{l}1133 \mathrm{BJ} \\
102 \\
-19.1 \mathrm{MJ} \\
59.9 \mathrm{EJ}\end{array}$ & $\begin{array}{l}328 \text { BN*SJ } \\
121 \\
1.0 \text { USN } \\
17.3 \text { WR } \\
64.0\end{array}$ & $\begin{array}{l}307 \mathrm{~B} \\
128 \mathrm{USN} \\
1.1 \mathrm{USN} \\
21.0 \mathrm{mR} \\
67.4 \mathrm{~J}\end{array}$ & & $\begin{array}{l}408 \mathrm{~B} \\
117 \\
0.91 \mathrm{USW} \\
17.2 \mathrm{MR} \\
66.8 \mathrm{~J}\end{array}$ \\
\hline Zinc & 126 & 105 & 115 & 122 & & 119 \\
\hline X Sol ids & 80.7 & 79.5 & 80.8 & 80.9 & 80.9 & 83.9 \\
\hline $\begin{array}{l}\text { Total (Allowed) Hold I imea } \\
\text { Total (All owed) Hold Iime } \\
\text { Total (Allowed) Hold Timec } \\
\text { Total (All lowed) Hold Iimed }\end{array}$ & $\begin{array}{r}28(180) d \\
24(26) d\end{array}$ & $\begin{array}{r}26(180) d \\
19(26) d\end{array}$ & $\begin{array}{l}34(180) d \\
23(26) d \\
37(180) d \\
20(14) d^{*}\end{array}$ & $\begin{array}{l}34(180) d \\
23(26) d \\
37(180) d \\
20(14) d^{*}\end{array}$ & $\begin{array}{r}27(180) d \\
23(26) d\end{array}$ & $\begin{array}{l}34(180) d \\
23(26) d \\
37(180) d \\
20(14) d\end{array}$ \\
\hline $\begin{array}{l}\text { a. ICP } \\
\text { b. CVAAS } \\
\text { c. GFAAS } \\
\text { d. Cyanide }\end{array}$ & & & & & & \\
\hline $2-15-93$ & & & & & & \\
\hline
\end{tabular}


ISF Evaporation Pond SeA Data Document - Movember 1989 - Method Validetion Level B

TABLE 6-2. ISF EVAPORATION POND - IMORganic DATA (Contimued)

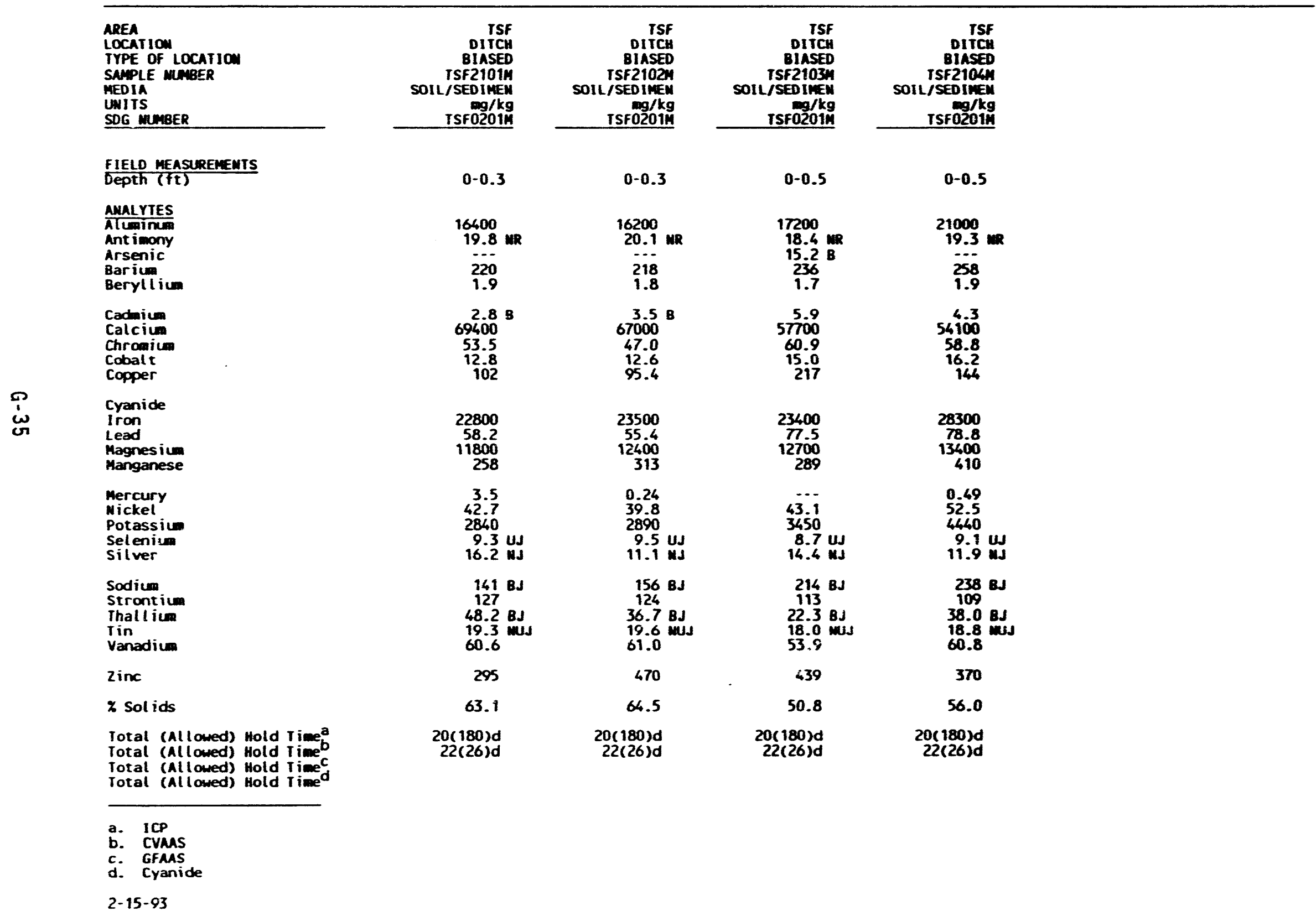


ISf Evaporation Pond S\&A Data Document - Wovember 1989 - Method Val idation Level A

TABLE 6-3. TSF EVAPORATION POND - ORGAMOCHLORINE MERBICIDE DATA

\begin{tabular}{|c|c|c|c|c|c|c|}
\hline $\begin{array}{l}\text { AREA } \\
\text { LOCATION } \\
\text { IYPE OF LOCATION } \\
\text { SAMPLE MUABER } \\
\text { MEDIA } \\
\text { UWITS } \\
\text { SDG MUMBER } \\
\end{array}$ & $\begin{array}{r}\text { TSF } \\
\text { POND BOTILA } \\
\text { SURFACE } \\
\text { TSFO101A } \\
\text { SEDIMENT } \\
\text { Ug/kg } \\
\text { TSF0101A } \\
\end{array}$ & $\begin{array}{r}\text { TSF } \\
\text { POND BOTTOM } \\
\text { SURFACE } \\
\text { TSF0102A } \\
\text { SEDIMENT } \\
\text { Ug/kg } \\
\text { TSF0101A } \\
\end{array}$ & $\begin{array}{r}\text { ISF } \\
\text { POND DISCHARGE } \\
\text { BIASED } \\
\text { TSFOTO1A } \\
\text { SEDIHEWT } \\
\text { Ug/kg } \\
\text { TSFOTO1A } \\
\end{array}$ & 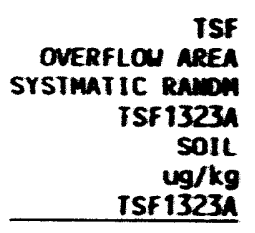 & 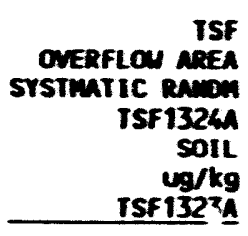 & $\begin{array}{r}\text { ISF } \\
\text { OVERFLOU NREA } \\
\text { STSTIMIIIC RANDM } \\
\text { ISF 1325A } \\
\text { SOIL } \\
\text { ug/k9 } \\
\text { ISF 13234 } \\
\end{array}$ \\
\hline$\frac{\text { FIELD MEASUREMEMTS }}{\text { Depth }(f t)}$ & $0-0.5$ & $0-0.5$ & $0-2$ & $0-0.5$ & $0-0.5$ & $0-0.5$ \\
\hline $\begin{array}{l}\text { TARGEI COAPQUNDS } \\
2,4-D \\
\text { Sitivex } \\
2,4,5-T\end{array}$ & $\begin{array}{l}\cdots \\
\cdots\end{array}$ & $\cdots$ & $\begin{array}{l}\cdots \\
\cdots \\
\cdots\end{array}$ & $\begin{array}{l}400 R \\
80 R \\
80 R\end{array}$ & $\begin{array}{l}\cdots \\
\cdots \\
\cdots\end{array}$ & $\begin{array}{l}\cdots \\
\cdots \\
\cdots\end{array}$ \\
\hline $\begin{array}{l}\text { Dilution factor } \\
\text { Extraction (Allowed) Hold time } \\
\text { Analytical (Allowed) Hold Time } \\
2-16-93\end{array}$ & $\begin{array}{r}1.0 \\
10(14) d \\
14(40) d\end{array}$ & $\begin{array}{r}1.0 \\
9(14) d \\
14(40) d\end{array}$ & $\begin{array}{r}1.0 \\
14(14) d \\
44(40) d^{*}\end{array}$ & $\begin{array}{c}1.0 \\
17(14) d^{*} \\
22(40) d\end{array}$ & $\begin{array}{r}1.0 \\
13(14) d \\
22(40) d\end{array}$ & $\begin{array}{r}1.0 \\
14(16) d \\
22(40) d\end{array}$ \\
\hline
\end{tabular}


ISF Evaporation Pond SRA Dato Document - November 1969 - Method Validation Level A

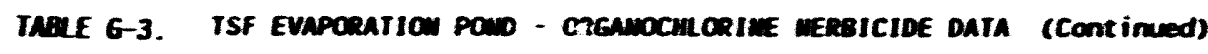

\begin{tabular}{|c|c|c|c|}
\hline $\begin{array}{l}\text { AREA } \\
\text { LOCATION } \\
\text { IYPE OF LOCATION } \\
\text { SAMPLE WIABER } \\
\text { MEDIA } \\
\text { UNITS } \\
\text { SOG MUBER } \\
\end{array}$ & $\begin{array}{r}\text { ISF } \\
\text { OFERFLON RREA } \\
\text { SYSTMATIC RANOM } \\
\text { TSF 1423A } \\
\text { SED IIIENT } \\
\text { Ug/kg } \\
\text { ISF 1323A }\end{array}$ & 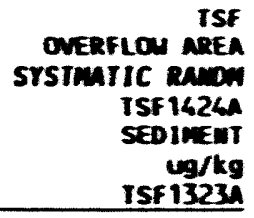 & 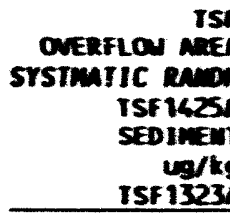 \\
\hline $\begin{array}{l}\text { FIELD MEASUREMENIS } \\
\text { Depth (ft) }\end{array}$ & $10-11$ & $10-11$ & \\
\hline $\begin{array}{l}\text { IARGET COPQunos } \\
2.4-D \\
\text { sitvex } \\
2.4,5-1\end{array}$ & $\begin{array}{l}\cdots \\
\cdots \\
\cdots\end{array}$ & $\begin{array}{ll}\cdots \\
\cdots\end{array}$ & $\cdots$ \\
\hline $\begin{array}{l}\text { Dilution factor } \\
\text { Extraction (Allowed) wold tise } \\
\text { Anatytical (Allowed) wold tive } \\
11-5-9 \text { ? }\end{array}$ & $\begin{array}{r}1.0 \\
14(16) d \\
22(40) d\end{array}$ & $\begin{array}{l}13(16) d \\
22(60) d\end{array}$ & $\begin{array}{l}16116 \\
22160\end{array}$ \\
\hline
\end{tabular}


ISF Evaporation Pand SeA Data Document

noveber 1909 - Method validation Level a

TABLE 6-4. ISF EVAPORATIOA POND - ORGAMOCMLORINE PESTICIDE DATA

\begin{tabular}{|c|c|c|c|c|c|c|}
\hline $\begin{array}{l}\text { AREA } \\
\text { LOCATION } \\
\text { TYPE OF LOCATION } \\
\text { SAMPLE MUABER } \\
\text { MEDIA } \\
\text { UNITS } \\
\text { SDG MUMBER } \\
\end{array}$ & $\begin{array}{r}\text { TSF } \\
\text { POND BOTIOA } \\
\text { SURFACE } \\
\text { TSFOIOIA } \\
\text { SEDIMENT } \\
\text { Ug/kg } \\
\text { ISF0101A } \\
\end{array}$ & $\begin{array}{r}\text { TSF } \\
\text { POWD BOTIOA } \\
\text { SURFACE } \\
\text { TSFOIO2A } \\
\text { SEDIMENT } \\
\text { Ug/kg } \\
\text { TSF01014 } \\
\end{array}$ & $\begin{array}{r}\text { ISF } \\
\text { POM DIscuarce } \\
\text { 8IASED } \\
\text { TSFOT01A } \\
\text { SEDIMEMT } \\
\text { U9/kg } \\
\text { ISF0401A }\end{array}$ & 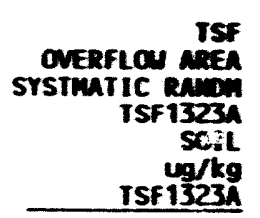 & 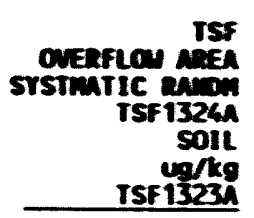 & 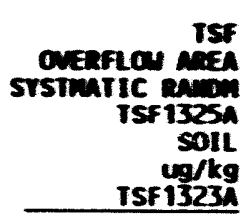 \\
\hline $\begin{array}{l}\text { FIELD MEASUREMEMTS } \\
\text { Depth (ft }(t)\end{array}$ & $0-0.5$ & $0-0.5$ & $0-2$ & $0-0.5$ & $0-0.5$ & $0-0.5$ \\
\hline $\begin{array}{l}\text { IARGET COMPQUNDS } \\
\text { alpha-BHC } \\
\text { beta-BHC } \\
\text { delta-BHC } \\
\text { gamma-BHC (Lindane) } \\
\text { Heptachlor }\end{array}$ & $\begin{array}{ll}8 & U J \\
8 & U J \\
8 & U J \\
8 & R \\
8 & R\end{array}$ & $\begin{array}{l}8 \text { UJ } \\
8 \text { UJ } \\
8 \text { UJ } \\
8 \text { UJ } \\
8 \text { UJ }\end{array}$ & $\begin{array}{l}\cdots \\
\cdots \\
\cdots- \\
\cdots \\
\cdots-\end{array}$ & $\begin{array}{l}\cdots \\
\cdots \\
\cdots\end{array}$ & $\begin{array}{l}\cdots \\
\cdots \\
\cdots \\
\cdots\end{array}$ & $\begin{array}{l}\cdots \\
\cdots \\
\cdots \\
\cdots\end{array}$ \\
\hline $\begin{array}{l}\text { Aldrin } \\
\text { Heptachlor epoxide } \\
\text { Endosulfan I } \\
\text { Dieldrin } \\
4,4^{\prime}-D D E\end{array}$ & $\begin{array}{rl}8 & R \\
8 & U J \\
8 & U J \\
16 & R \\
16 & U J\end{array}$ & $\begin{aligned} 8 & \text { UJ } \\
8 & \text { UJ } \\
8 & \text { UJ } \\
16 & \text { UJ } \\
16 & \text { UJ }\end{aligned}$ & $\begin{array}{l}\cdots \\
\cdots \\
\cdots \\
\cdots \\
\cdots\end{array}$ & $\begin{array}{l}\cdots- \\
\cdots \\
\cdots \\
\cdots \\
\cdots\end{array}$ & $\begin{array}{l}\cdots \\
\cdots \\
\cdots \\
\cdots\end{array}$ & $\begin{array}{l}\cdots \\
\cdots \\
\cdots \\
\cdots\end{array}$ \\
\hline $\begin{array}{l}\text { Endrin } \\
\text { Endosul fan II } \\
4,4 \cdot 0 D D \\
\text { Endosulf fan sul fate } \\
4,44^{\circ}-D D T\end{array}$ & $\begin{array}{ll}16 & R \\
16 & U J \\
16 & U J \\
16 & U J \\
16 & R\end{array}$ & $\begin{array}{l}16 \text { UJ } \\
16 \text { UJ } \\
16 \text { UJ } \\
16 \text { UJ } \\
16 \text { UJ }\end{array}$ & $\begin{array}{l}\cdots \\
\cdots \\
\cdots \\
\cdots \\
\cdots\end{array}$ & $\begin{array}{l}\cdots \\
\cdots \\
\cdots \\
\cdots \\
\cdots\end{array}$ & $\begin{array}{l}\cdots \\
\cdots \\
\cdots \\
\cdots\end{array}$ & $\begin{array}{l}\cdots \\
\cdots \\
\cdots- \\
\cdots\end{array}$ \\
\hline $\begin{array}{l}\text { Methoxychlor } \\
\text { Endrin ketone } \\
\text { al pha-Chlordane } \\
\text { gamma-Chlordaane } \\
\text { Toxaphene }\end{array}$ & $\begin{array}{l}80 \text { UJ } \\
16 \text { UJ } \\
80 \text { UJ } \\
80 \text { UJ } \\
160 \text { UJ }\end{array}$ & $\begin{array}{l}80 \mathrm{UJ} \\
16 \mathrm{UJ} \\
80 \mathrm{UJ} \\
80 \mathrm{UJ} \\
160 \mathrm{UJ}\end{array}$ & $\begin{array}{l}\cdots \\
\cdots \\
\cdots \\
\cdots\end{array}$ & $\begin{array}{l}\cdots \\
\cdots \\
\cdots \\
\cdots \\
\cdots\end{array}$ & $\begin{array}{l}\cdots \\
\cdots \\
\cdots \\
\cdots\end{array}$ & $\begin{array}{l}\cdots \\
\cdots \\
\cdots- \\
\cdots \\
\cdots-\end{array}$ \\
\hline $\begin{array}{l}\text { Aroclor }-1016 \\
\text { Aroclor }-1221 \\
\text { Aroclor }-1232 \\
\text { Aroclor }-1242 \\
\text { Aroclor }-1248\end{array}$ & $\begin{array}{l}80 \mathrm{UJ} \\
80 \mathrm{R} \\
80 \mathrm{R} \\
80 \mathrm{UJ} \\
80 \mathrm{UJ}\end{array}$ & 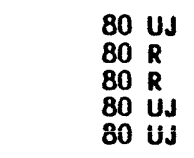 & $\begin{array}{l}\because \cdots \\
80 R \\
80 R \\
\cdots-.\end{array}$ & $\begin{array}{l}\cdots \\
\cdots \\
\cdots \\
\cdots\end{array}$ & $\begin{array}{l}\cdots \\
\cdots \\
\cdots \\
\cdots \\
\cdots\end{array}$ & $\begin{array}{l}\cdots \\
\cdots \\
\cdots \\
\cdots\end{array}$ \\
\hline $\begin{array}{l}\text { Aroclor }-1254 \\
\text { Aroclor-1260 } \\
\text { I sodrin } \\
\text { Kepone } \\
\text { Endrin Al dehyde }\end{array}$ & $\begin{array}{rl}35 & \mathrm{~J} \\
220 & \mathrm{UJ} \\
8 & \mathrm{UJ} \\
16 & \mathrm{UJ} \\
16 & \mathrm{UJ}\end{array}$ & $\begin{array}{rl}220 & \mathrm{UJ} \\
220 \mathrm{UJ} \\
8 \mathrm{UJ} \\
16 \mathrm{UJ} \\
16 \mathrm{UJ}\end{array}$ & $\begin{array}{c}550 \mathrm{~J} \\
780 \mathrm{~J} \\
\cdots \\
\cdots \\
\cdots\end{array}$ & $\begin{array}{l}220 \\
220 \\
\cdots \\
\cdots\end{array}$ & $\begin{array}{l}\cdots \\
\cdots \\
\cdots \\
\cdots\end{array}$ & $\begin{array}{l}\cdots \\
\cdots \\
\cdots \\
\cdots\end{array}$ \\
\hline $\begin{array}{l}\text { Di-allate } \\
\text { Chlordane (Technical) } \\
\text { Chlorobenzilate }\end{array}$ & $\begin{array}{l}80 \text { UJ } \\
80 \text { UJ } \\
80 \text { UJ }\end{array}$ & $\begin{array}{l}80 \text { UJ } \\
80 \text { UJ } \\
80 \text { UJ }\end{array}$ & $\begin{array}{l}- \\
\cdots \\
\cdots\end{array}$ & $\begin{array}{l}\cdots \\
\cdots \\
\cdots\end{array}$ & $\begin{array}{l}-\cdots \\
\cdots \\
\cdots\end{array}$ & $\begin{array}{ll}- \\
\cdots \\
\cdots\end{array}$ \\
\hline $\begin{array}{l}\text { Dilution factor } \\
\text { Extraction (Allowed) Hold time } \\
\text { Analytical (All owed) Hold time }\end{array}$ & $\begin{array}{l}19.0 \\
19(14) \mathrm{d}^{\star} \\
37(40) \mathrm{d}\end{array}$ & $\begin{array}{l}1 j^{0} \\
18(14) d^{\star} \\
37(40) d\end{array}$ & $\begin{array}{r}1.0 \\
14(14) d \\
29(40) d\end{array}$ & $\begin{array}{l}1.0 \\
17(14) d^{*} \\
27(40) d\end{array}$ & $\begin{array}{r}1.0 \\
13(14) d \\
27(40) d\end{array}$ & $\begin{array}{r}1.0 \\
14(14) d \\
27(40) d\end{array}$ \\
\hline
\end{tabular}


ISF Evaporation Pond S\&A Data Document - Movember 1989 - Method Validation Level A

TABLE 6-4. TSF EVAPORATION POND - ORgANOCHLORINE PESTICIDE DATA (Continued)

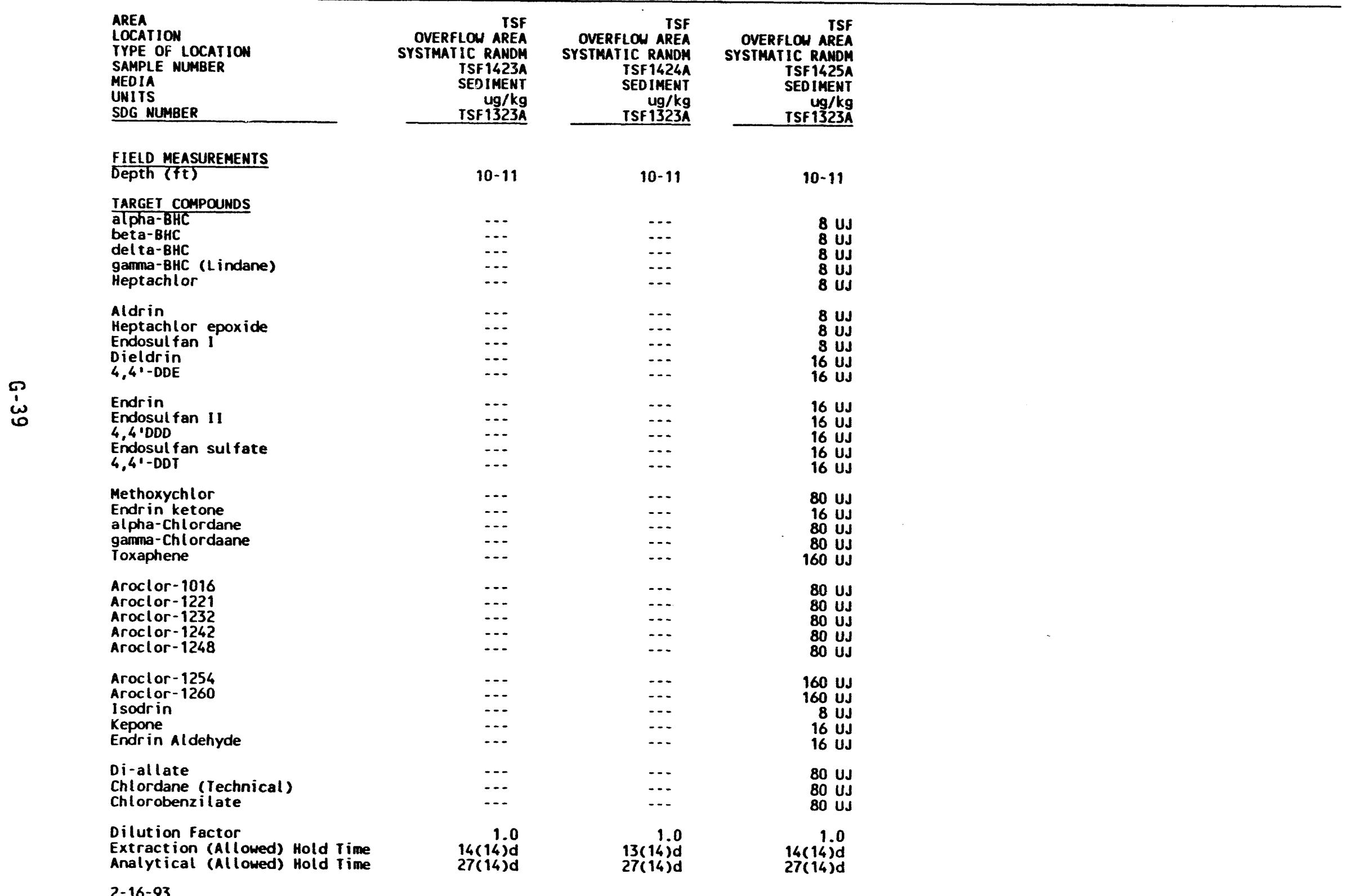


ISF Evaporation Pond S\&A Data Document - Novenber 1989 - Method Validation Level A

TABLE 6-5. TSF EVAPORATION POND - ORGAMOPHOSPHORUS PESTICIDE DATA

\begin{tabular}{|c|c|c|c|c|c|c|}
\hline $\begin{array}{l}\text { AREA } \\
\text { LOCATION } \\
\text { TYPE OF LOCATION } \\
\text { SAMPLE NUMBER } \\
\text { MEDIA } \\
\text { UNITS } \\
\text { SDG NUMBER } \\
\end{array}$ & $\begin{array}{r}\text { TSF } \\
\text { POND BOTTOM } \\
\text { SURFACE } \\
\text { TSF0101A } \\
\text { SEDIMENT } \\
\text { Ug/kg } \\
\text { ISF0101A } \\
\end{array}$ & $\begin{array}{r}\text { TSF } \\
\text { POND BOTIOM } \\
\text { SURFACE } \\
\text { TSF0102A } \\
\text { SEDIMENT } \\
\text { ug/kg } \\
\text { TSF0101A } \\
\end{array}$ & $\begin{array}{r}\text { TSF } \\
\text { POND DISCHARGE } \\
\text { BIASED } \\
\text { TSFO701A } \\
\text { SEDIMENT } \\
\text { Ug/kg } \\
\text { TSF0701A } \\
\end{array}$ & $\begin{array}{r}\text { TSF } \\
\text { OVERFLOW AREA } \\
\text { SYSTMATIC RANDH } \\
\text { TSF 1323A } \\
\text { SOIL } \\
\text { ug/kg } \\
\text { TSF } 1323 \mathrm{k} \\
\end{array}$ & $\begin{array}{r}\text { TSF } \\
\text { OVERFLOU AREA } \\
\text { SYSTHATIC RANDM } \\
\text { TSF 1324A } \\
\text { SOIL } \\
\text { ug/kg } \\
\text { TSF 1323A } \\
\end{array}$ & $\begin{array}{r}\text { TSF } \\
\text { OVERFLON AREA } \\
\text { SYSTMATIC RANDH } \\
\text { TSF 1325A } \\
\text { SOIL } \\
\text { Ug/kg } \\
\text { TSF } 1323 A \\
\end{array}$ \\
\hline$\frac{\text { FIELD MEASUREMENTS }}{\text { Depth }(\mathrm{ft})}$ & $0-0.5$ & $0-0.5$ & $0-2$ & $0-0.5$ & $0-0.5$ & $0-0.5$ \\
\hline $\begin{array}{l}\text { TARGET COMPOUNDS } \\
\text { Phorate } \\
\text { Sulfotepp } \\
\text { Dilsulfoton } \\
\text { Dimethoate } \\
\text { Methyl Paration }\end{array}$ & $\begin{array}{l}\cdots \\
\cdots \\
\cdots \\
\cdots\end{array}$ & $\begin{array}{r}10 \mathrm{UJ} \\
7 \\
\mathrm{UJJ} \\
9 \mathrm{UJ} \\
20 \mathrm{UJ} \\
13 \mathrm{UJ}\end{array}$ & $\begin{array}{l}\cdots \\
\cdots \\
\cdots \\
\cdots \\
\cdots\end{array}$ & $\begin{array}{l}\cdots \\
\cdots \\
\cdots \\
\cdots\end{array}$ & $\begin{array}{l}\cdots \\
\cdots \\
\cdots \\
\cdots \\
\cdots\end{array}$ & $\begin{array}{l}- \\
\cdots \\
\cdots \\
\cdots\end{array}$ \\
\hline Parathion & -. & $14 \mathrm{UJ}$ & $\cdots$ & $\cdots$ & $\cdots$ & -- \\
\hline $\begin{array}{l}\text { Dilution Factor } \\
\text { Extraction (Allowed) Hold Time } \\
\text { Analytical (Allowed) Hold Time }\end{array}$ & $\begin{array}{r}1.7 \\
11(14) d \\
14(40) d\end{array}$ & $\begin{array}{r}1.5 \\
10(14) d \\
14(40) d\end{array}$ & $\begin{array}{l}3.5 \\
9(14) d \\
4(40) d\end{array}$ & $\begin{array}{r}1.1 \\
14(14) d \\
3(40) d\end{array}$ & $\begin{array}{r}1.1 \\
10(14) d \\
3(40) d\end{array}$ & $\begin{array}{r}1.1 \\
11(14) d \\
3(40) d\end{array}$ \\
\hline
\end{tabular}


TSF Evaporation Pond S\&A Data Document - November 1989 - Method Validation Level A

TABLE 6-5. TSF EVAPORATION POND - ORGANOPHOSPHORUS PESTICIDE DATA (Cont inued)

\begin{tabular}{|c|c|c|c|c|c|c|}
\hline $\begin{array}{l}\text { AREA } \\
\text { LOCATION } \\
\text { TYPE OF LOCATION } \\
\text { SAMPLE NUMBER } \\
\text { MEDIA } \\
\text { UNITS } \\
\text { SDG MUMBER } \\
\end{array}$ & $\begin{array}{r}\text { TSF } \\
\text { OVERFLOW AREA } \\
\text { SYSTMATIC RANDM } \\
\text { TSF 1423A } \\
\text { SEDIMENT } \\
\text { Ug/kg } \\
\text { TSF } 1323 \mathrm{~A} \\
\end{array}$ & $\begin{array}{r}\text { TSF } \\
\text { OVERFLOU AREA } \\
\text { SYSTMATIC RANDH } \\
\text { TSF1424A } \\
\text { SEDIMENT } \\
\text { Ug/kg } \\
\text { TSF } 1323 \mathrm{k} \text {. } \\
\end{array}$ & $\begin{array}{r}\text { TSF } \\
\text { OVERFLOW AREA } \\
\text { SYSTMATIC RANDH } \\
\text { TSF 1425A } \\
\text { SEDIMENT } \\
\text { Ug/kg } \\
\text { TSF 1323A } \\
\end{array}$ & & & \\
\hline$\frac{\text { FIELD MEASUREMENTS }}{\text { Depth }(\mathrm{ft})}$ & $10-11$ & $10-11$ & $10-11$ & & & \\
\hline TARGET COMPOUNDS & & & & & & \\
\hline Phorate & $\cdots$ & $\cdots$ & -- & $\cdots$ & -- & -- \\
\hline Sul fotepp & -- & -- & $\cdots$ & $\cdots$ & $\cdots$ & $\cdots$ \\
\hline Dilsul foton & $\cdots$ & $-\cdot$ & $-\cdot$ & $\cdots$ & $\cdots$ & $\cdots$ \\
\hline $\begin{array}{l}\text { Dimethoate } \\
\text { Methyl Paration }\end{array}$ & $\cdots$ & $\cdots$ & $\cdots$ & -.. & $\cdots$ & $\cdots$ \\
\hline Parathion & $\cdots$ & 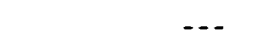 & $\ldots$ & $\ldots$ & $\ldots$ & $\cdots$ \\
\hline $\begin{array}{l}\text { Dilution Factor } \\
\text { Extraction (Allowed) Hold Time } \\
\text { Analytical (All lowed) Hold Time }\end{array}$ & $\begin{array}{r}1.2 \\
11(14) d \\
3(40) d\end{array}$ & $\begin{array}{r}1.2 \\
10(14) \mathrm{d} \\
3(40) \mathrm{d}\end{array}$ & $\begin{array}{r}1.2 \\
11(14) d \\
3(40) d\end{array}$ & & & \\
\hline
\end{tabular}

2-16-93 
ISF Evaporation Pond S\&A Data Document - November 1989 - Method Val idation Level A

TABLE 6-6. ISF EVAPORATION POND - SEMIVOLATILE APPENDIX IX ORGANIC DATA

\begin{tabular}{|c|c|c|c|c|c|}
\hline $\begin{array}{l}\text { AREA } \\
\text { LOCATION } \\
\text { TYPE OF LOCATION } \\
\text { SAMPLE NUMBER } \\
\text { MEDIA } \\
\text { UNIIS } \\
\text { SOG MUMBER } \\
\end{array}$ & $\begin{array}{r}\text { TSF } \\
\text { POND BOTIOA } \\
\text { SURFACE } \\
\text { TSFO101A } \\
\text { SEDIMENT } \\
\text { Ug/kg } \\
\text { TSF0101A } \\
\end{array}$ & $\begin{array}{r}\text { TSF } \\
\text { POND BOTIOMA } \\
\text { SURFACE } \\
\text { TSF0102A } \\
\text { SEDIMENT } \\
\text { Ug/kg } \\
\text { TSF01014 } \\
\end{array}$ & $\begin{array}{r}\text { TSF } \\
\text { POND DISCHARGE } \\
\text { BIASED } \\
\text { TSF0701A } \\
\text { SED IMENT } \\
\text { Ug/kg } \\
\text { TSF0401A } \\
\end{array}$ & $\begin{array}{r}\text { TSF } \\
\text { OVERFLOW AREA } \\
\text { SYSTMATIC RANDAH } \\
\text { ISF 1323A } \\
\text { SOIL } \\
\text { ug/kg } \\
\text { TSF } 13231 \\
\end{array}$ & $\begin{array}{r}\text { TSF } \\
\text { OVERFLON AREA } \\
\text { SYSTMATIC RANDM } \\
\text { TSF1324A } \\
\text { SOIL } \\
\text { ug/kg } \\
\text { TSF1323A }\end{array}$ \\
\hline$\frac{\text { FIELD MEASUREMENIS }}{\text { Depth }(\mathrm{ft})}$ & $0-0.5$ & $0-0.5$ & $0-2$ & $0-0.5$ & $0-0.5$ \\
\hline $\begin{array}{l}\text { TARGET CONPOUMS } \\
\text { Phinol } \\
\text { bis(2-Chloroethyl)ether } \\
\text { 2-Chlorophenol } \\
1,3 \text {-Dichlorobenzene } \\
\text { 1,4-Dichlorobenzene }\end{array}$ & $\begin{array}{l}330 \text { UJ } \\
330 \text { UJ } \\
330 \text { UJ } \\
330 \text { UJ } \\
330 \text { UJ }\end{array}$ & $\begin{array}{l}330 \text { UJ } \\
330 \text { UJ } \\
330 \text { UJ } \\
330 \text { UJ } \\
330 \text { UJ }\end{array}$ & $\begin{array}{l}\cdots \\
\cdots \\
\cdots\end{array}$ & $\begin{array}{l}330 \text { UJ } \\
330 \text { UJ } \\
330 \text { UJ } \\
330 \text { UJ } \\
330 \text { UJ }\end{array}$ & $\begin{array}{ll}\cdots \\
\cdots \\
\cdots \\
\cdots\end{array}$ \\
\hline $\begin{array}{l}\text { Benzyl alcohol } \\
1,2 \text {-D ichlorobenzene } \\
\text { 2-Methylphenol } \\
\text { bis(2-Chloroisopropyl )ether } \\
\text { 4-Methyl phenol }\end{array}$ & $\begin{array}{l}330 \text { UJ } \\
330 \text { UJ } \\
330 \text { UJ } \\
330 \text { UJ } \\
330 \text { UJ }\end{array}$ & $\begin{array}{l}330 \text { UJ } \\
330 \text { UJ } \\
330 \text { UJ } \\
330 \text { UJ } \\
330 \text { UJ }\end{array}$ & $\begin{array}{ll}\cdots \\
\cdots \\
\cdots\end{array}$ & $\begin{array}{l}330 \text { UJ } \\
330 \text { UJ } \\
330 \text { UJ } \\
330 \text { UJ } \\
33 n \text { UJ }\end{array}$ & $\begin{array}{l}\cdots \\
\cdots- \\
\cdots\end{array}$ \\
\hline $\begin{array}{l}\text { N-Nitroso-di-n-propylamine } \\
\text { Hexachloroethane } \\
\text { Nitrobenzene } \\
\text { I sophorone } \\
\text { 2-Nitrophenol }\end{array}$ & $\begin{array}{l}330 \text { UJ } \\
330 \text { UJ } \\
330 \text { UJ } \\
330 \text { UJ } \\
330 \text { UJ }\end{array}$ & $\begin{array}{l}330 \text { UJ } \\
330 \text { UJ } \\
330 \text { UJ } \\
330 \text { UJ } \\
330 \text { UJ }\end{array}$ & $\begin{array}{l}\cdots \\
\cdots- \\
\cdots- \\
\cdots\end{array}$ & $\begin{array}{l}330 \text { UJ } \\
330 \text { UJ } \\
330 \text { UJ } \\
330 \text { UJ } \\
330 \text { UJ }\end{array}$ & $\begin{array}{l}\cdots \\
\cdots \\
\cdots- \\
\cdots \\
\cdots\end{array}$ \\
\hline $\begin{array}{l}\text { 2,4-D imethylphenol } \\
\text { Benzoic acid } \\
\text { bis(2-Chloroethoxy) methane } \\
2,4-D \text { ichlorophenol } \\
\text { 1,2,4-Trichlorobenzene }\end{array}$ & $\begin{array}{r}330 \text { UJ } \\
1600 \text { UJ } \\
330 \text { UJ } \\
330 \text { UJ } \\
330 \text { UJ }\end{array}$ & $\begin{array}{r}330 \text { UJ } \\
1600 \text { UJ } \\
330 \text { UJ } \\
330 \text { UJ } \\
330 \text { UJ }\end{array}$ & $\begin{array}{l}\cdots \\
\cdots \\
\cdots \\
\cdots\end{array}$ & $\begin{array}{l}330 \text { UJ } \\
1600 \text { UJ } \\
330 \text { UJ } \\
330 \text { UJ } \\
330 \text { UJ }\end{array}$ & $\begin{array}{l}\cdots \\
\cdots \\
\cdots \\
\cdots\end{array}$ \\
\hline $\begin{array}{l}\text { Maphthal ene } \\
\text { 4-Chloroaniline } \\
\text { Hexachlorobutadiene } \\
\text { 4-Chloro-3-methyl phenol } \\
\text { 2-Methyl naphthal ene }\end{array}$ & $\begin{array}{l}330 \text { UJ } \\
330 \text { UJ } \\
330 \text { UJ } \\
330 \text { UJ } \\
330 \text { UJ }\end{array}$ & $\begin{array}{l}330 \text { UJ } \\
330 \text { UJ } \\
330 \text { UJ } \\
330 \text { UJ } \\
330 \text { UJ }\end{array}$ & $\begin{array}{l}\cdots \\
\cdots \\
\cdots \\
\cdots\end{array}$ & $\begin{array}{l}330 \text { UJ } \\
330 \text { UJ } \\
330 \text { UJ } \\
330 \text { UJ } \\
330 \text { UJ }\end{array}$ & $\begin{array}{ll}\cdots \\
\cdots \\
\cdots- \\
\cdots\end{array}$ \\
\hline $\begin{array}{l}\text { Hexach lorocyclopentadiene } \\
2,4,6-\text { Irichlorophenol } \\
2,4,5 \text { - Irichlorophenol } \\
2-\text { chiloronaphthalene } \\
\text { 2-Nitroanil ine }\end{array}$ & $\begin{array}{r}330 \text { UJ } \\
330 \text { UJ } \\
1600 \text { UJ } \\
330 \text { UJ } \\
1600 \text { UJ }\end{array}$ & $\begin{array}{r}330 \text { UJ } \\
330 \text { UJ } \\
1600 \text { UJ } \\
330 \text { UJ } \\
1600 \text { UJ }\end{array}$ & $\begin{array}{l}\cdots \\
\cdots \\
\cdots \\
\cdots \\
\cdots\end{array}$ & $\begin{array}{l}330 \text { UJ } \\
330 \text { UJ } \\
1600 \text { UJ } \\
330 \text { UJ } \\
1600 \text { UJ }\end{array}$ & $\begin{array}{l}\cdots \\
\cdots \\
\cdots \\
\cdots\end{array}$ \\
\hline
\end{tabular}


ISF Evaporation Pond SeA Data Document - Movember 1989 - Method Validation Level A

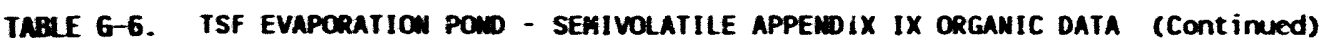

\begin{tabular}{|c|c|c|c|c|c|}
\hline $\begin{array}{l}\text { AREA } \\
\text { LOCATION } \\
\text { TYPE OF LOCATION } \\
\text { SUMPLE MUBER } \\
\text { MEDIA } \\
\text { UNIIS } \\
\text { SOG MUABER } \\
\end{array}$ & $\begin{array}{r}\text { TSF } \\
\text { POND BOTTOM } \\
\text { SURFACE } \\
\text { TSFO101A } \\
\text { SED IMENT } \\
\text { Ug/kg } \\
\text { TSFO101A } \\
\end{array}$ & $\begin{array}{r}\text { TSF } \\
\text { POND BOTTOM } \\
\text { SURFACE } \\
\text { TSFO102A } \\
\text { SEDIMENT } \\
\text { Ug/kg } \\
\text { TSFO101A } \\
\end{array}$ & $\begin{array}{r}\text { TSF } \\
\text { POND DISCHARGE } \\
\text { BIASED } \\
\text { TSFO701A } \\
\text { SEDIMENT } \\
\text { Ug/kg } \\
\text { TSF0401A } \\
\end{array}$ & $\begin{array}{r}\text { TSF } \\
\text { OVERFLON AREA } \\
\text { SYSTMATIC RANDH } \\
\text { TSF 1323A } \\
\text { SOIL } \\
\text { ug/kg } \\
\text { TSF1323A }\end{array}$ & $\begin{array}{r}\text { TSF } \\
\text { ONERFLON AREA } \\
\text { SYSTMATIC RANDH } \\
\text { TSF 1324A } \\
\text { SOIL } \\
\text { Ug/kg } \\
\text { TSF } 1323 \mathrm{~A} \\
\end{array}$ \\
\hline $\begin{array}{l}\text { Dimethylphthal ate } \\
\text { Acenaphthylene } \\
2.6-\text { Dinitrotoluene } \\
3 \text { - Mitroanil inc } \\
\text { Acenaphthene }\end{array}$ & $\begin{aligned} 330 & \text { UJ } \\
330 & \text { UJ } \\
330 & \text { UJ } \\
1600 & \text { UJ } \\
330 & \text { UJ }\end{aligned}$ & $\begin{array}{r}330 \text { UJ } \\
330 \text { UJ } \\
330 \text { UJ } \\
1600 \text { UJ } \\
330 \text { UJ }\end{array}$ & $\begin{array}{l}\cdots \\
\cdots \\
\cdots \\
\cdots\end{array}$ & $\begin{array}{r}330 \text { UJ } \\
330 \text { UJ } \\
330 \text { UJ } \\
1600 \text { UJ } \\
330 \text { UJ }\end{array}$ & $\begin{array}{l}\cdots \\
\cdots \\
\cdots \\
\cdots \\
\cdots\end{array}$ \\
\hline $\begin{array}{l}\text { 2,4-Dinitrophenol } \\
\text { 4-Mitrophenol } \\
\text { Dibenzofuran } \\
\text { 2,4-Dinitrotoluene } \\
\text { Diethylphthalate }\end{array}$ & $\begin{array}{l}1600 \text { UJ } \\
1600 \text { UJ } \\
330 \text { UJ } \\
330 \text { UJ } \\
330 \text { UJ }\end{array}$ & $\begin{array}{l}1600 \text { UJ } \\
1600 \text { UJ } \\
330 \text { UJ } \\
330 \text { UJ } \\
330 \text { UJ }\end{array}$ & $\begin{array}{l}\cdots \\
\cdots \\
\cdots \\
\cdots\end{array}$ & $\begin{array}{l}1600 \text { UJ } \\
1600 \text { UJ } \\
330 \text { UJ } \\
330 \text { UJ } \\
330 \text { UJ }\end{array}$ & $\begin{array}{l}\cdots \\
\cdots \\
\cdots \\
\cdots \\
\cdots\end{array}$ \\
\hline $\begin{array}{l}\text { 4-Chlorophenyl-phenylether } \\
\text { Flworene } \\
\text { 4-witroanil ine } \\
\text { 4.6-D ini tro-2-methylphenol } \\
\text {-witrosodiphenylamine (1) }\end{array}$ & $\begin{aligned} & 330 \text { UJ } \\
& 330 \text { UJ } \\
& 1600 \text { UJ } \\
& 1600 \text { UJ } \\
& 330 \text { UJ }\end{aligned}$ & $\begin{array}{l}330 \text { UJ } \\
330 \text { UJ } \\
1600 \text { UJ } \\
1600 \text { UJ } \\
330 \text { UJ }\end{array}$ & $\begin{array}{l}\cdots \\
\cdots \\
\cdots \\
\cdots\end{array}$ & $\begin{array}{l}330 \text { UJ } \\
330 \text { UJ } \\
1600 \text { UJ } \\
1600 \text { UJ } \\
330 \text { UJ }\end{array}$ & $\begin{array}{l}\cdots \\
\cdots \\
\cdots \\
\cdots \\
\cdots\end{array}$ \\
\hline $\begin{array}{l}\text { Di-n-butylphthal ate } \\
\text { Fluoranthene } \\
\text { Pyrene } \\
\text { Butylbenzylphthal ate } \\
\text { 3,3'-Dichlorobenzidine }\end{array}$ & $\begin{array}{l}330 \text { UJ } \\
330 \text { UJ } \\
330 \text { UJ } \\
330 \text { UJ } \\
630 \text { UJ }\end{array}$ & $\begin{array}{l}330 \text { UJ } \\
330 \text { UJ } \\
330 \text { UJ } \\
330 \text { UJ } \\
660 \text { UJ }\end{array}$ & $\begin{array}{ll}\cdots \\
270 & \mathrm{~J} \\
230 & \mathrm{~J} \\
\cdots & -\end{array}$ & $\begin{array}{l}330 \text { UJ } \\
330 \text { UJ } \\
330 \text { UJ } \\
330 \text { UJ } \\
660 \text { UJ }\end{array}$ & $\begin{array}{l}\cdots \\
\cdots \\
\cdots- \\
\cdots \\
\cdots\end{array}$ \\
\hline $\begin{array}{l}\text { Benzo(a)anthracene } \\
\text { Chrysene } \\
\text { bis(2-Ethylhexyl)phthal ate } \\
\text { Di-n-octylphthal ate } \\
\text { Benzo(b)fluoranthene }\end{array}$ & $\begin{array}{l}330 \text { UJ } \\
330 \text { UJ } \\
260 \text { UJ } \\
330 \text { UJ } \\
330 \text { UJ }\end{array}$ & $\begin{array}{l}330 \mathrm{UJ} \\
330 \mathrm{UJ} \\
380 \mathrm{UJ} \\
62 \mathrm{~J} \\
330 \mathrm{UJ}\end{array}$ & $\begin{array}{c}\cdots \\
\cdots \\
2900 \mathrm{~J} \\
\cdots \\
\cdots\end{array}$ & $\begin{array}{l}330 \text { UJ } \\
330 \text { UJ } \\
330 \text { UJ } \\
330 \text { UJ }\end{array}$ & $\begin{array}{l}\cdots \\
\cdots \\
\cdots \\
\cdots\end{array}$ \\
\hline
\end{tabular}

2-13-93 
ISF Evaporation Pond SeA Data Document - Movember 1989 - Method Validation Level A

TABLe 6-6. ISF EVAPCaATION POND - SEMIVOLATILE APPEMDIX IX ORGANIC DATA (Cont inued)

\begin{tabular}{|c|c|c|c|c|c|}
\hline $\begin{array}{l}\text { AREA } \\
\text { LOCAIION } \\
\text { TYPE Of LOCATIOW } \\
\text { SAMPLE WMER } \\
\text { MEDIA } \\
\text { UWIIS } \\
\text { SDG MUBER } \\
\end{array}$ & $\begin{array}{r}\text { ISF } \\
\text { POMD BOIIIOA } \\
\text { SURFACE } \\
\text { TSF0101A } \\
\text { SEDINENI } \\
\text { U9/kg } \\
\text { TSF0101A } \\
\end{array}$ & $\begin{array}{r}\text { TSF } \\
\text { POWD BOITOK } \\
\text { SURFACE } \\
\text { TSFOIO2A } \\
\text { SEDIIENT } \\
\text { ug/kg } \\
\text { TSF0101A } \\
\end{array}$ & $\begin{array}{r}\text { TSF } \\
\text { POMD DISCHARGE } \\
\text { BIASED } \\
\text { TSFO701A } \\
\text { SEDIMEMT } \\
\text { Ug/kg } \\
\text { TSFOSO1A }\end{array}$ & $\begin{array}{r}\text { TSF } \\
\text { OVERFLOW AREA } \\
\text { SYSTMATIC RAMDM } \\
\text { TSF 1323A } \\
\text { SOIL } \\
\text { ug/kg } \\
\text { TSF1323A } \\
\end{array}$ & $\begin{array}{r}\text { TSF } \\
\text { OVERFLOW AREA } \\
\text { SYSTMATIC RANDM } \\
\text { TSF 1324A } \\
\text { SOIL } \\
\text { ug/kg } \\
\text { TSF } 1323 A \\
\end{array}$ \\
\hline $\begin{array}{l}\text { Benzo(k)fluoranthene } \\
\text { Benzo(a)pyrene } \\
\text { Indeno(1,2,3-cd)pyrene } \\
\text { Dibenz(a,h)anthracene } \\
\text { Benzo( } 9 . h, i) \text { perylene }\end{array}$ & $\begin{array}{l}330 \text { UJ } \\
330 \text { UJ } \\
330 \text { UJ } \\
330 \text { UJ } \\
330 \text { UJ }\end{array}$ & $\begin{array}{l}330 \text { UJ } \\
330 \text { UJ } \\
330 \text { UJ } \\
330 \text { UJ } \\
330 \text { UJ }\end{array}$ & $\begin{array}{l}\cdots \\
\cdots \\
\cdots \\
\cdots\end{array}$ & $\begin{array}{l}330 \text { us } \\
330 \text { UJ } \\
330 \text { Us } \\
330 \text { UJ } \\
330 \text { is }\end{array}$ & $\begin{array}{l}\cdots \\
\cdots \\
\cdots \\
\cdots \\
\cdots\end{array}$ \\
\hline $\begin{array}{l}\text { Pyridine } \\
\text { N-Mitrosodimethylamine } \\
\text { Ethyi ethacrylate } \\
\text { Methyl pethacrylate } \\
\text { 2-Picol ine }\end{array}$ & $\begin{array}{l}330 \text { UJ } \\
330 \text { UJ } \\
330 \text { UJ } \\
330 \text { R } \\
330 \text { U. }\end{array}$ & $\begin{array}{l}330 \text { UJ } \\
330 \text { UJ } \\
330 \text { UJ } \\
330 \mathrm{R} \\
330 \mathrm{UJ}\end{array}$ & $\begin{array}{l}\cdots \\
\cdots \\
\cdots \\
660 R \\
\cdots\end{array}$ & $\begin{array}{l}10 \mathrm{UJ} \\
10 \mathrm{UJ} \\
10 \mathrm{UJ} \\
10 \mathrm{R} \\
10 \mathrm{UJ}\end{array}$ & $\begin{array}{l}\cdots \\
\cdots \\
\cdots \\
\cdots\end{array}$ \\
\hline $\begin{array}{l}\text { M-Mitrosomethylethylamine } \\
\text { Methyl methanesul fonate } \\
\text { W-nitrosodiethylamine } \\
\text { Ethyl methanesul fonate } \\
\text { Pentachloroethane }\end{array}$ & $\begin{array}{l}330 \text { U. } \\
330 \text { UJ } \\
330 \text { UJ } \\
330 \text { UJ } \\
330 \text { UJ }\end{array}$ & $\begin{array}{l}330 \text { UJ } \\
330 \text { UJ } \\
330 \text { Us } \\
330 \text { UJ } \\
330 \text { UJ }\end{array}$ & $\begin{array}{l}\cdots \\
\cdots \\
\cdots \\
\cdots\end{array}$ & 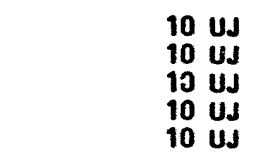 & $\begin{array}{l}\cdots \\
\cdots \\
\cdots \\
\cdots \\
\cdots\end{array}$ \\
\hline $\begin{array}{l}\text { Aniline } \\
\text { w-Mitrosopyrrol idine } \\
\text { Acetophenone } \\
\omega-N \text { itrosomorphol ine } \\
\text { O-Toluidine }\end{array}$ & $\begin{array}{l}330 \text { UJ } \\
330 \text { UJ } \\
330 \text { UJ } \\
330 \text { UJ } \\
330 \text { UJ }\end{array}$ & $\begin{array}{l}330 \text { UJ } \\
330 \text { UJ } \\
330 \text { UJ } \\
330 \text { UJ } \\
330 \text { UJ }\end{array}$ & $\begin{array}{l}\cdots \\
\cdots \\
\cdots \\
\cdots\end{array}$ & $\begin{array}{l}10 \mathrm{UJ} \\
10 \mathrm{UJ} \\
10 \mathrm{UJ} \\
10 \mathrm{UJ} \\
10 \mathrm{UJ}\end{array}$ & $\begin{array}{l}\cdots \\
\cdots \\
\cdots- \\
\cdots \\
\cdots-\end{array}$ \\
\hline $\begin{array}{l}\text { 3-Methylphenol } \\
\text { M-Mitrosopiperidine } \\
0,0,0 \text {-Iriethylphosphorothioate } \\
\text { a, a-D imethyl phenethyl amine } \\
2,6 \text {-Dichl orophenol }\end{array}$ & $\begin{array}{l}330 \text { UJ } \\
330 \text { UJ } \\
330 \text { UJ } \\
330 \text { R } \\
330 \text { UJ }\end{array}$ & $\begin{array}{l}330 \text { UJ } \\
330 \text { UJ } \\
330 \text { UJ } \\
330 \text { R } \\
330 \text { UJ }\end{array}$ & $660 R$ & $\begin{array}{l}10 \text { UJ } \\
10 \text { UJ } \\
10 \text { UJ } \\
10 \text { R } \\
10 \text { UJ }\end{array}$ & $\begin{array}{ll}\cdots \\
\cdots \\
\cdots \\
\cdots\end{array}$ \\
\hline $\begin{array}{l}\text { Hexachloropropene } \\
1,4-\text {-Phenylenediamine } \\
\text { w-witroso-di-n-butylamine } \\
\text { Safrole } \\
1,2,4,5 \text {-Tetrachlorobenzene }\end{array}$ & $\begin{array}{l}330 \text { UJ } \\
330 \text { UJ } \\
330 \text { UJ } \\
330 \text { UJ } \\
330 \text { UJ }\end{array}$ & $\begin{array}{l}330 \text { UJ } \\
330 \text { UJ } \\
330 \text { UJ } \\
330 \text { UJ } \\
330 \text { UJ }\end{array}$ & $\begin{array}{l}\cdots \\
\cdots \\
\cdots \\
\cdots\end{array}$ & $\begin{array}{l}10 \mathrm{UJ} \\
10 \mathrm{UJ} \\
10 \mathrm{UJ} \\
10 \mathrm{UJ} \\
10 \mathrm{UJ}\end{array}$ & $\begin{array}{l}\cdots \\
\cdots \\
\cdots \\
\cdots \\
\cdots\end{array}$ \\
\hline
\end{tabular}


ISF Evaporation Pond SeA Data Document - November 1989 - Method Val idation Leyel A

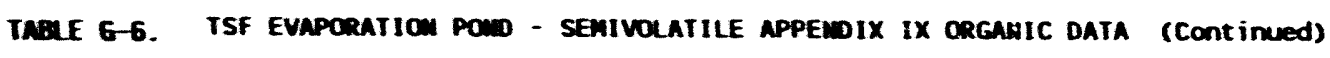

\begin{tabular}{|c|c|c|c|c|c|}
\hline $\begin{array}{l}\text { AREA } \\
\text { LOCATIOW } \\
\text { TYPE OF LOCATIOM } \\
\text { SAMPIS WMBER } \\
\text { MEDIA } \\
\text { UEIIS } \\
\text { SOG MUBER } \\
\end{array}$ & $\begin{array}{r}\text { TSF } \\
\text { POND BOTIOA } \\
\text { SURFACE } \\
\text { TSF0101A } \\
\text { SED INEMT } \\
\text { Ug/kg } \\
\text { TSF0101A }\end{array}$ & $\begin{array}{r}\text { ISF } \\
\text { POND BOTIOM } \\
\text { SURFACE } \\
\text { TSFO102A } \\
\text { SEDIMENT } \\
\text { Ug/kg } \\
\text { TSF0101A }\end{array}$ & $\begin{array}{r}\text { TSF } \\
\text { POMD DISCHARGE } \\
\text { BIASED } \\
\text { TSF0701A } \\
\text { SEDIMFNT } \\
\text { Ug/kg } \\
\text { TSF0401A } \\
\end{array}$ & $\begin{array}{r}\text { TSF } \\
\text { ONERFLOU AREA } \\
\text { SYSTHATIC RAMDM } \\
\text { TSF 1323A } \\
\text { SOIL } \\
\text { ug/kg } \\
\text { TSF 1323A } \\
\end{array}$ & $\begin{array}{r}\text { TSF } \\
\text { OVERFLON AREA } \\
\text { SYSTMATIC RAMDM } \\
\text { TSF 1324A } \\
\text { SOIL } \\
\text { ug/kg } \\
\text { TSF1323A }\end{array}$ \\
\hline $\begin{array}{l}\text { I sosafrole } \\
1: 4 \text { - Maphthoquinone } \\
1,3 \text {-D ini trobenzene } \\
\text { Pentachl orobenzene } \\
\text { 1- Maphthyl anine }\end{array}$ & $\begin{array}{l}330 \text { uJ } \\
330 \text { uJ } \\
330 \text { uJ } \\
330 \text { uJ } \\
330 \text { u.j }\end{array}$ & $\begin{array}{l}330 \text { us } \\
330 \text { U. } \\
330 \text { Us } \\
330 \text { UJ } \\
330 \text { UJ }\end{array}$ & $\begin{array}{l}\cdots \\
\cdots \\
\cdots \\
\cdots\end{array}$ & $\begin{array}{l}10 \mathrm{UJ} \\
10 \mathrm{UJ} \\
10 \mathrm{UJ} \\
10 \mathrm{UJ} \\
10 \mathrm{UJ}\end{array}$ & $\begin{array}{l}\cdots \\
\cdots \\
\cdots \\
\cdots\end{array}$ \\
\hline $\begin{array}{l}\text { 2- - } 2 \text { aphthyl amine } \\
2,3,4,6 \text {-Tetrachlorophenol } \\
5 \text {-witro-o-toluidine } \\
\text { Dipherylamine } \\
\text { 1,3,5-Irinitrobenzene }\end{array}$ & $\begin{array}{l}330 \text { us } \\
330 \text { UJ } \\
330 \text { UJ } \\
330 \text { UJ } \\
330 \text { UJ }\end{array}$ & $\begin{array}{l}330 \text { UJ } \\
330 \text { UJ } \\
330 \text { UJ } \\
330 \text { UJ } \\
330 \text { UJ }\end{array}$ & $\begin{array}{l}\cdots \\
600 R \\
\cdots \\
\cdots \\
\cdots\end{array}$ & $\begin{array}{l}10 \mathrm{UJ} \\
10 \mathrm{UJ} \\
10 \mathrm{UJ} \\
10 \mathrm{UJ} \\
10 \mathrm{UJ}\end{array}$ & $\begin{array}{ll}\cdots \\
\cdots \\
\cdots \\
\cdots\end{array}$ \\
\hline $\begin{array}{l}\text { Phenacet in } \\
\text { Thionaz in } \\
\text { 6-Anincbiphemyl } \\
\text { Pentach toronit robenzene } \\
\text { Pronadide }\end{array}$ & $\begin{array}{l}330 \text { UJ } \\
330 \text { UJ } \\
330 \text { U.J } \\
330 \text { UJ } \\
330 \text { UJ }\end{array}$ & $\begin{array}{l}330 \text { uJ } \\
330 \text { UJ } \\
330 \text { Us } \\
330 \text { uJ } \\
330 \text { uJ }\end{array}$ & $\begin{array}{l}\cdots \\
\cdots \\
\cdots \\
\cdots\end{array}$ & $\begin{array}{l}10 \text { UJ } \\
10 \text { UJ } \\
10 \text { UJ } \\
10 \text { UJ } \\
10 \text { UJ }\end{array}$ & $\begin{array}{l}\cdots \\
\cdots \\
\cdots \\
\cdots\end{array}$ \\
\hline $\begin{array}{l}\text { Dinoseb } \\
\text { 6-Mitroquinol ine-1-oxide } \\
\text { Methapyrilene } \\
\text { Aramite } \\
\text { p-(D imethylamino)azobenzene }\end{array}$ & $\begin{array}{l}330 \text { UJ } \\
330 \text { R } \\
330 \text { UJ } \\
330 \text { UJ } \\
330 \text { UJ }\end{array}$ & $\begin{array}{l}330 \text { UJ } \\
330 \mathrm{R} \\
330 \mathrm{UJ} \\
330 \mathrm{UJ} \\
330 \mathrm{UJ}\end{array}$ & $\begin{array}{l}\cdots \\
660 R \\
\cdots- \\
\cdots\end{array}$ & $\begin{array}{l}10 \mathrm{UJ} \\
10 \mathrm{R} \\
10 \mathrm{UJ} \\
10 \mathrm{UJ} \\
10 \mathrm{UJ}\end{array}$ & $\begin{array}{l}-\cdots \\
10 R \\
\cdots- \\
\cdots\end{array}$ \\
\hline $\begin{array}{l}\text { 3,3-Dimethyt benzidine } \\
\text { Fampur } \\
\text { 2-Acetyl aninof l worene } \\
\text { 7.12-Dimethylbenz (a)anthracene } \\
\text { 3-Methylchol anthrene }\end{array}$ & $\begin{array}{l}330 \text { UJ } \\
330 \mathrm{R} \\
330 \mathrm{UJ} \\
330 \text { UJ } \\
330 \text { UJ }\end{array}$ & $\begin{array}{l}330 \text { UJ } \\
330 \text { R } \\
330 \text { UJ } \\
330 \text { UJ } \\
330 \text { UJ }\end{array}$ & $\begin{array}{l}\cdots \\
660 R \\
\cdots \\
\cdots\end{array}$ & $\begin{array}{l}10 \text { UJ } \\
10 \mathrm{R} \\
10 \mathrm{UJ} \\
10 \mathrm{UJ} \\
10 \mathrm{UJ}\end{array}$ & $\begin{array}{l}-\ldots \\
10 R \\
-.- \\
-\cdots\end{array}$ \\
\hline Hexachl orophene & $330 R$ & $330 R$ & $660 R$ & $10 R$ & $10 R$ \\
\hline $\begin{array}{l}\text { Dilution factor } \\
\text { Extraction (Allowed) Hold Time } \\
\text { Analytical (Allowed) Hold Time }\end{array}$ & $\begin{array}{c}1.000 \\
19(14) d^{*} \\
3(4 C) d\end{array}$ & $\begin{array}{c}1.000 \\
18(14) d^{*} \\
4(40) d\end{array}$ & $\begin{array}{r}2.000 \\
14(14) d \\
18(40) d\end{array}$ & $\begin{array}{l}1.000 \\
17(14) d^{ \pm} \\
17(40) d\end{array}$ & $\begin{array}{l}1.000 \\
13(14) d \\
18(40) d\end{array}$ \\
\hline
\end{tabular}


ISF Evaporation Pond SeA Data Document - Movember 1989 - Method Validation Level A

TMQLE G-6. ISF EVAPORATIOU POIO - SEMIVOLATILE APPEIDIX IX ORGAMIC DATA (Cont inued)

\begin{tabular}{|c|c|c|c|c|}
\hline $\begin{array}{l}\text { AREA } \\
\text { LOCATIOW } \\
\text { TYPE OF LOCATION } \\
\text { SAMLE WUAER } \\
\text { MEDIA } \\
\text { UWI IS } \\
\text { SOG MABER } \\
\end{array}$ & $\begin{array}{r}\text { TSF } \\
\text { ONERFLOU AREA } \\
\text { SYSTMATIC RAMDM } \\
\text { TSF 1325A } \\
\text { SOIL } \\
\text { Ug/kg } \\
\text { TSF 1323A } \\
\end{array}$ & $\begin{array}{r}\text { TSF } \\
\text { OVERFLON AREA } \\
\text { SYSTMUIIC RANOM } \\
\text { TSF1423A } \\
\text { SED IMENT } \\
\text { Ug/kg } \\
\text { TSF1323A }\end{array}$ & $\begin{array}{r}\text { TSF } \\
\text { ONERFLOW AREA } \\
\text { SYSTMATIC RAMDH } \\
\text { ISF 1424A } \\
\text { SED IMENT } \\
\text { Ug/kg } \\
\text { ISF 1323A }\end{array}$ & $\begin{array}{r}\text { TSF } \\
\text { OVERFLLN AREA } \\
\text { SYSTMAIIC RANDM } \\
\text { TSF 1625A } \\
\text { SEDIMENT } \\
\text { U9/kg } \\
\text { TSF1323A }\end{array}$ \\
\hline$\frac{\text { FIELD MEASUREMENIS }}{\text { Depth (tt) }}$ & $0-0.5$ & $10-11$ & $10-11$ & $10-11$ \\
\hline $\begin{array}{l}\text { TARGET COMPOUDS } \\
\text { Phenol } \\
\text { bis(2-Chl oroethyl )ether } \\
\text { 2-Chl orophenol } \\
\text { 1,3-Dich lorobenzene } \\
1,4-\text { Dichl orobenzene }\end{array}$ & $\begin{array}{l}\cdots \\
\cdots \\
\cdots \\
\cdots\end{array}$ & $\begin{array}{l}\cdots \\
\cdots \\
\cdots \\
\cdots\end{array}$ & $\begin{array}{ll}\cdots \\
\cdots \\
\cdots \\
\cdots\end{array}$ & $\begin{array}{l}330 \text { UJ } \\
330 \text { UJ } \\
330 \text { UJ } \\
330 \text { UJ } \\
330 \text { UJ }\end{array}$ \\
\hline $\begin{array}{l}\text { Benzyl al cohol } \\
\text { 1,2-Dichlorobenzene } \\
\text { 2-Methylphenol } \\
\text { bis(2-Chl oroisopropyl )ether } \\
\text { 4-Hethylphenol }\end{array}$ & $\begin{array}{l}\cdots \\
\cdots \\
\cdots \\
\cdots \\
\cdots\end{array}$ & $\begin{array}{l}\cdots \\
\cdots \\
\cdots \\
\cdots \\
\cdots\end{array}$ & $\begin{array}{l}\cdots \\
\cdots \\
\cdots \\
\cdots\end{array}$ & $\begin{array}{l}330 \text { uJ } \\
330 \text { UJ } \\
330 \text { UJ } \\
330 \text { UJ } \\
330 \text { UJ }\end{array}$ \\
\hline $\begin{array}{l}\text { M-Witroso-di-n-propviamine } \\
\text { Hexachiloroethane } \\
\text { mitrobenzene } \\
\text { I sophorone } \\
\text { 2-Mitrophenol }\end{array}$ & $\begin{array}{l}\cdots \\
\cdots \\
\cdots- \\
\cdots \\
\cdots\end{array}$ & $\begin{array}{l}\cdots \\
\cdots \\
\cdots \\
\cdots \\
\cdots\end{array}$ & $\begin{array}{l}\cdots \\
\cdots \\
\cdots \\
\cdots\end{array}$ & $\begin{array}{l}330 \text { UJ } \\
330 \text { UJ } \\
330 \text { UJ } \\
330 \text { UJ } \\
330 \text { UJ }\end{array}$ \\
\hline $\begin{array}{l}\text { 2,4-Dimethyl phenol } \\
\text { berzoic acid } \\
\text { bis(2-cchloroethoxy) methane } \\
2,4-0 \text { ichlorophenol } \\
1,2,4 \text { - Irichlorobenzene }\end{array}$ & $\begin{array}{l}\cdots \\
\cdots \\
\cdots \\
\cdots\end{array}$ & $\begin{array}{l}\cdots \\
\cdots \\
\cdots \\
\cdots\end{array}$ & $\begin{array}{l}\cdots \\
\cdots \\
\cdots \\
\cdots\end{array}$ & $\begin{array}{l}330 \text { UJ } \\
1600 \text { UJ } \\
330 \text { UJ } \\
330 \text { UJ } \\
330 \text { UJ }\end{array}$ \\
\hline $\begin{array}{l}\text { Maphthal ene } \\
\text { 4-Chloroanil ine } \\
\text { Mexachlorobutadiene } \\
\text { 4-Chloro-3-methylphenol } \\
\text { 2-Methylnaphtinalene }\end{array}$ & $\begin{array}{l}\cdots \\
\cdots \\
\cdots \\
\cdots\end{array}$ & $\begin{array}{l}\cdots \\
\cdots \\
\cdots \\
\cdots\end{array}$ & $\begin{array}{l}\cdots \\
\cdots \\
\cdots \\
\cdots\end{array}$ & $\begin{array}{l}330 \text { UJ } \\
330 \text { Us } \\
330 \text { UJ } \\
330 \text { UJ } \\
330 \text { UJ }\end{array}$ \\
\hline $\begin{array}{l}\text { Hexach lorocycl opentadiene } \\
2,4,6-\text { Trichlorophenol } \\
2,4,5 \text { - Trichlorophenol } \\
2-\text { chiloronaphthal ene } \\
\text { 2-mitroanil ine }\end{array}$ & $\begin{array}{l}\cdots \\
\cdots \\
\cdots \\
\cdots \\
\cdots\end{array}$ & $\begin{array}{l}\cdots \\
\cdots \\
\cdots \\
\cdots \\
\cdots\end{array}$ & $\begin{array}{l}\cdots \\
\cdots \\
\cdots \\
\cdots \\
\cdots\end{array}$ & $\begin{array}{l}330 \text { UJ } \\
330 \text { UJ } \\
1600 \text { UJ } \\
330 \text { UJ } \\
1600 \text { UJ }\end{array}$ \\
\hline
\end{tabular}


ISF Evaporation Pond SeA Data Document - Movember 1989 - Method Val idation Level A

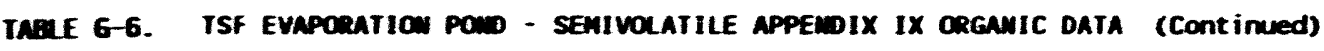

\begin{tabular}{|c|c|c|c|c|}
\hline $\begin{array}{l}\text { AREA } \\
\text { LOCATION } \\
\text { IYPE OF LOCATION } \\
\text { SAMPLE WMBER } \\
\text { MEDIA } \\
\text { UMITS } \\
\text { SDG MURER } \\
\end{array}$ & $\begin{array}{r}\text { ISF } \\
\text { ONERFLOW AREA } \\
\text { STSTMMTIC RAMOH } \\
\text { TSF 1325A } \\
\text { SOIL } \\
\text { U9/kg } \\
\text { TSF1323A } \\
\end{array}$ & $\begin{array}{r}\text { TSF } \\
\text { OUERFLOW AREA } \\
\text { SYSTMATIC RANOH } \\
\text { TSF1423A } \\
\text { SED 1WEMT } \\
\text { Ug/kg } \\
\text { ISF1323A }\end{array}$ & $\begin{array}{r}\text { TSF } \\
\text { ONERFLLU AREA } \\
\text { SYSTMAIIC RANDH } \\
\text { TSF1424A } \\
\text { SED IHENT } \\
\text { Ug/kg } \\
\text { TSF } 1323 \text { A } \\
\end{array}$ & 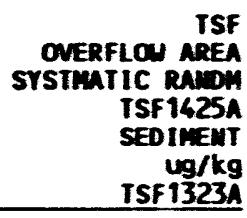 \\
\hline $\begin{array}{l}\text { Dimethylphthalate } \\
\text { Acenaphthylene } \\
\text { 2.6-Dini trotoluene } \\
\text { 3-- witroanil ine } \\
\text { Aceraphthene }\end{array}$ & $\begin{array}{l}\cdots \\
\cdots \\
\cdots- \\
\cdots\end{array}$ & $\begin{array}{l}\cdots \\
\cdots \\
\cdots- \\
\cdots \\
\cdots\end{array}$ & $\begin{array}{l}\cdots \\
\cdots \\
\cdots \\
\cdots\end{array}$ & $\begin{aligned} 330 & \text { UJ } \\
330 & \text { UJ } \\
330 & \text { UJ } \\
1600 & \text { UJ } \\
330 & \text { UJ }\end{aligned}$ \\
\hline $\begin{array}{l}\text { 2,4-Dinitrophenol } \\
\text { 4- witrophenol } \\
\text { Dibenzofuran } \\
\text { 2,4-Dinitrotol uene } \\
\text { Diethyiphthat ate }\end{array}$ & $\begin{array}{l}\cdots \\
\cdots \\
\cdots \\
\cdots \\
\cdots\end{array}$ & $\begin{array}{l}\cdots \\
\cdots \\
\cdots \\
\cdots\end{array}$ & $\begin{array}{l}\cdots \\
\cdots \\
\cdots \\
\cdots\end{array}$ & $\begin{array}{l}1600 \text { U.J } \\
1600 \text { U.J } \\
330 \text { UJ } \\
330 \text { UJ } \\
330 \text { UJ }\end{array}$ \\
\hline $\begin{array}{l}\text { 6-Chlorogheryl-pherylether } \\
\text { fluorene } \\
\text { 4-Mitroanil ine } \\
\text { 4,6-Dinitro-2-methylphenol } \\
\text { "-Mitrosodiphenyladine (1) }\end{array}$ & $\begin{array}{l}\cdots \\
\cdots \\
\cdots- \\
\cdots\end{array}$ & $\begin{array}{l}\cdots \\
\cdots \\
\cdots- \\
\cdots\end{array}$ & $\begin{array}{ll}\cdots \\
\cdots \\
\cdots \\
\cdots\end{array}$ & $\begin{aligned} 330 & \text { UJ } \\
330 & \text { UJ } \\
1600 & \text { UJ } \\
1600 & \text { UJ } \\
330 & \text { UJ }\end{aligned}$ \\
\hline $\begin{array}{l}\text { Di-n-butylphthalate } \\
\text { Fluoranthene } \\
\text { Pyrene } \\
\text { Butylbenzylphthalate } \\
3,3^{-} \text {-Dichlorobenzidine }\end{array}$ & $\begin{array}{l}\cdots \\
\cdots \\
\cdots \\
\cdots\end{array}$ & $\begin{array}{ll}\cdots \\
\cdots \\
\cdots \\
\cdots\end{array}$ & $\begin{array}{l}\cdots \\
\cdots \\
\cdots \\
\cdots\end{array}$ & $\begin{array}{l}330 \text { UJ } \\
330 \text { UJ } \\
330 \text { UJ } \\
330 \text { UJ } \\
660 \text { UJ }\end{array}$ \\
\hline $\begin{array}{l}\text { Benzo(a)anthracene } \\
\text { Chrysene } \\
\text { bis(2-Ethylhexyl)phthat ate } \\
\text { Di-n-octylphthalate } \\
\text { Benzo(b)flworanthene }\end{array}$ & $\begin{array}{l}\cdots \\
\cdots \\
\cdots \\
\cdots\end{array}$ & $\begin{array}{l}\cdots \\
\cdots \\
\cdots- \\
\cdots \\
\cdots\end{array}$ & $\begin{array}{l}\cdots \\
\cdots \\
\cdots \\
\cdots \\
\cdots\end{array}$ & $\begin{array}{l}330 \text { UJ } \\
330 \text { UJ } \\
330 \text { UJ } \\
330 \text { UJ }\end{array}$ \\
\hline
\end{tabular}


ISF Evaporation Pond SeA Data Doament - Movember 1989 - Method Validation Level A

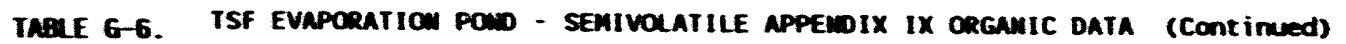

\begin{tabular}{|c|c|c|c|c|}
\hline $\begin{array}{l}\text { NREA } \\
\text { LOCATIOW } \\
\text { IYPE OF LOCATION } \\
\text { SAMPLE WMBER } \\
\text { MEDIA } \\
\text { UWIIS } \\
\text { SDG MUABER }\end{array}$ & $\begin{array}{r}\text { ISF } \\
\text { ONERFLOU AREA } \\
\text { SYSTMATIC RANOH } \\
\text { ISF 1325A } \\
\text { SOIL } \\
\text { ug/kg } \\
\text { ISFT323A }\end{array}$ & 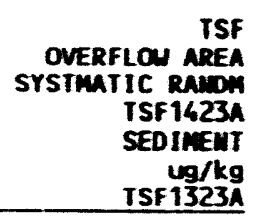 & $\begin{array}{r}\text { ISF } \\
\text { ONERFLLN AREA } \\
\text { SYSTMATIC RAMDH } \\
\text { ISF1424A } \\
\text { SEDINEMT } \\
\text { U9/kg } \\
\text { TSF 1323A }\end{array}$ & $\begin{array}{r}\text { TSF } \\
\text { ONERFLOA AREA } \\
\text { SYSTMATIC RAVOM } \\
\text { ISF 1625A } \\
\text { SED IMENT } \\
\text { Ug/kg } \\
\text { ISF1323A }\end{array}$ \\
\hline $\begin{array}{l}\text { Benzo(k)f luoranthene } \\
\text { Benzo(a)pyrene } \\
\text { Indeno(1,i,3-cd)pyrene } \\
\text { Dibenz }(a, h) \text { anthracene } \\
\text { Benzo(g, } h, i) \text { perylene }\end{array}$ & $\begin{array}{l}\cdots \\
\cdots \\
\cdots \\
\cdots\end{array}$ & $\begin{array}{l}\cdots \\
\cdots \\
\cdots \\
\cdots \\
\cdots\end{array}$ & $\begin{array}{l}\cdots \\
\cdots \\
\cdots \\
\cdots\end{array}$ & $\begin{array}{l}330 \text { uJ } \\
330 \text { Ud } \\
330 \text { Ud } \\
330 \text { Ud } \\
330 \text { us }\end{array}$ \\
\hline $\begin{array}{l}\text { Pyridine } \\
\text { w- }- \text { it rosodimethylamine } \\
\text { Ethyl methacrylate } \\
\text { methyl methacrylate } \\
\text { 2-Picol ine }\end{array}$ & $\begin{array}{l}\cdots \\
\cdots \\
10 R \\
\cdots\end{array}$ & $\begin{array}{ll}\cdots \\
\cdots \\
\cdots\end{array}$ & $\begin{array}{ll}\cdots \\
\cdots \\
\cdots \\
10\end{array}$ & $\begin{array}{l}10 \mathrm{WJ} \\
10 \mathrm{UJ} \\
10 \mathrm{UJ} \\
10 \mathrm{R} \\
10 \mathrm{UJ}\end{array}$ \\
\hline 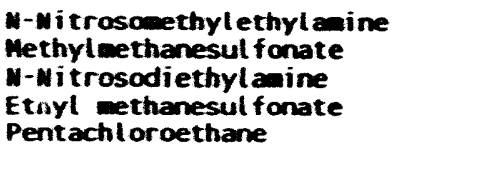 & $\begin{array}{l}\cdots \\
\cdots \\
\cdots \\
\cdots \\
\cdots\end{array}$ & $\begin{array}{l}\cdots \\
\cdots \\
\cdots \\
\cdots\end{array}$ & $\begin{array}{l}\cdots \\
\cdots \\
\cdots \\
\cdots\end{array}$ & $\begin{array}{l}10 \text { UJ } \\
10 \text { UJ } \\
10 \text { UJ } \\
10 \text { UJ } \\
10 \text { UJ }\end{array}$ \\
\hline $\begin{array}{l}\text { 3-Methylphencl } \\
\text { W-Mitrosopiperidine } \\
0,0,0 \text {-Iriethyl phosphorothioate } \\
\text { a, a-D imethylphenethylamine } \\
\text { 2,6-Dichl orophenol }\end{array}$ & $\begin{array}{ll}\cdots \\
\cdots \\
\cdots\end{array}$ & $\begin{array}{ll}\cdots \\
\cdots \\
10 \\
\cdots\end{array}$ & $\begin{array}{ll}\cdots \\
\cdots \\
10 \\
\cdots\end{array}$ & $\begin{array}{l}10 \mathrm{UJ} \\
10 \mathrm{UJ} \\
10 \mathrm{UJ} \\
10 \mathrm{R} \\
10 \mathrm{UJ}\end{array}$ \\
\hline $\begin{array}{l}\text { Hexachloropropene } \\
1,4 \text {-Phemylenediamine } \\
\text { w-witroso-di-n-butylamine } \\
\text { Safrole } \\
1,2,4,5 \text { - Tetrachlorobenzene }\end{array}$ & $\begin{array}{l}\cdots \\
\cdots \\
\cdots \\
\cdots\end{array}$ & $\begin{array}{l}\cdots \\
\cdots \\
\cdots \\
\cdots \\
\cdots\end{array}$ & $\begin{array}{l}\cdots \\
\cdots \\
\cdots \\
\cdots\end{array}$ & $\begin{array}{l}10 \mathrm{UJ} \\
10 \mathrm{UJ} \\
10 \mathrm{UJ} \\
10 \mathrm{UJ} \\
10 \mathrm{UJ}\end{array}$ \\
\hline
\end{tabular}


ISF Evaporation Pand SeA Data Document - November 1909 - Method Val idation Level A

TABLE 6-6. ISF EVAPCRATIOU POID - SEMIVOLATILE APPEDIX IX CRGAMIC DATA (Continued)

\begin{tabular}{|c|c|c|c|c|}
\hline $\begin{array}{l}\text { AREA } \\
\text { LOCAIION } \\
\text { TYPE OF LOCATION } \\
\text { SAMPLE WUBBER } \\
\text { MEDIA } \\
\text { UWITS } \\
\text { SDG WUBER } \\
\end{array}$ & $\begin{array}{r}\text { TSF } \\
\text { OVERFLOU AREA } \\
\text { SYSTMATIC RAMIDI } \\
\text { ISF 1325A } \\
\text { SOIL } \\
\text { ug/k9 } \\
\text { ISF1323A } \\
\end{array}$ & $\begin{array}{r}\text { TSF } \\
\text { OVERFLOW AREA } \\
\text { SYSTMATIC RMWDH } \\
\text { TSF 1423A } \\
\text { SEDIIMEMT } \\
\text { Ug/kg } \\
\text { TSF1323A }\end{array}$ & $\begin{array}{r}\text { TSF } \\
\text { ONERFLOW AREA } \\
\text { SYSTMATIC RANDH } \\
\text { TSF1424A } \\
\text { SEDIMENT } \\
\text { Ug/kg } \\
\text { TSF13233 }\end{array}$ & 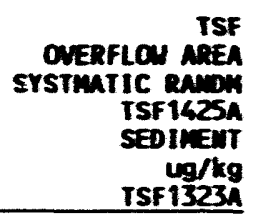 \\
\hline $\begin{array}{l}\text { 1 sosafrole } \\
\text { 1,4-Maphthoquinone } \\
\text { 1,3-Dinitrobenzene } \\
\text { Pentachl orabenzene } \\
\text { 1-Naphthylamine }\end{array}$ & $\begin{array}{l}\cdots \\
\cdots \\
\cdots \\
\cdots\end{array}$ & $\begin{array}{l}\cdots \\
\cdots \\
\cdots \\
\cdots\end{array}$ & $\begin{array}{l}\cdots \\
\cdots \\
\cdots \\
\cdots\end{array}$ & $\begin{array}{l}10 \mathrm{us} \\
10 \mathrm{UJ} \\
10 \mathrm{UJ} \\
10 \mathrm{UJ} \\
10 \mathrm{UJ}\end{array}$ \\
\hline $\begin{array}{l}\text { 2-Maphthyl amine } \\
2,3,4,6-\text { Tetrachlorophenol } \\
5 \text {-Nitro-0-toluidine } \\
\text { Diphenylamine } \\
1,3,5 \text {-Trini trobenzene }\end{array}$ & $\begin{array}{l}\cdots \\
\cdots \\
\cdots \\
\cdots \\
\cdots\end{array}$ & $\begin{array}{l}\cdots \\
\cdots \\
\cdots \\
\cdots\end{array}$ & $\begin{array}{l}\cdots \\
\cdots \\
\cdots \\
\cdots\end{array}$ & $\begin{array}{l}10 \mathrm{U} \\
10 \mathrm{~W} \\
10 \mathrm{U} \\
10 \mathrm{~W} \\
10 \mathrm{UJ}\end{array}$ \\
\hline $\begin{array}{l}\text { Phenacet in } \\
\text { Thionaz in } \\
\text { 6-Aminobiphemyl } \\
\text { Pentachloroni trobenzene } \\
\text { Pronamide }\end{array}$ & $\begin{array}{l}\cdots \\
\cdots \\
\cdots \\
\cdots\end{array}$ & $\begin{array}{l}\cdots \\
\cdots \\
\cdots \\
\cdots\end{array}$ & $\begin{array}{l}\cdots \\
\cdots \\
\cdots \\
\cdots\end{array}$ & $\begin{array}{l}10 \text { UJ } \\
10 \text { UJ } \\
10 \text { UJ } \\
10 \text { WJ } \\
10 \text { UJ }\end{array}$ \\
\hline $\begin{array}{l}\text { Dinoseb } \\
\text { 4-Witroquinol ine-1-oxide } \\
\text { Hethapyrilene } \\
\text { Aramite } \\
\text { p-(Dimethylamino)azobenzene }\end{array}$ & $\begin{array}{l}\cdots \\
10 \\
\cdots- \\
\cdots \\
\cdots\end{array}$ & $\begin{array}{l}\cdots \\
10 R \\
\cdots- \\
\cdots \\
\cdots\end{array}$ & $\begin{array}{l}-. \\
10 R \\
\cdots- \\
\cdots \\
\cdots\end{array}$ & $\begin{array}{l}10 \mathrm{~W} \\
10 \mathrm{R} \\
10 \mathrm{~W} \\
10 \mathrm{WJ} \\
10 \mathrm{UJ}\end{array}$ \\
\hline $\begin{array}{l}\text { 3.3'-D imethylbenzidine } \\
\text { Famphur } \\
\text { 2-Acetyl aminofl luorene } \\
\text { 7.12-0 imethylbenz (a)anthracene } \\
\text { 3--Hethylchol anthrene }\end{array}$ & $\begin{array}{l}\cdots \\
10 R \\
\cdots-. \\
\cdots \\
\cdots\end{array}$ & $\begin{array}{l}\cdots \\
10 R \\
\cdots \\
\cdots \\
\cdots\end{array}$ & $\begin{array}{l}\ldots \\
10 R \\
\cdots \\
\cdots \\
\cdots\end{array}$ & $\begin{array}{l}10 \mathrm{UJ} \\
10 \mathrm{R} \\
10 \mathrm{UJ} \\
10 \mathrm{UJ} \\
10 \mathrm{WJ}\end{array}$ \\
\hline Hexachlorophere & $10 \mathrm{R}$ & $10 \mathrm{R}$ & $10 R$ & $10 \mathrm{R}$ \\
\hline $\begin{array}{l}\text { Dilution Factor } \\
\text { Extraction (Allowed) Hold time } \\
\text { Analytical (Allowed) Hold iime }\end{array}$ & $\begin{array}{r}1.000 \\
14(14) d \\
17(40) d\end{array}$ & $\begin{array}{r}1.000 \\
14(14) d \\
17(40) d\end{array}$ & $\begin{array}{r}1.000 \\
13(14) d \\
17(40) d\end{array}$ & $\begin{array}{l}1.000 \\
25(14) d \\
10(40) d\end{array}$ \\
\hline
\end{tabular}


TSF Evaporation Pond Sen Data Document - Movenber 1999 - Method Validation Level 8

TABRE 6-7. TSF EVAPORATION POWD - SULFIDE DATA

\begin{tabular}{|c|c|c|c|c|c|}
\hline $\begin{array}{l}\text { AREA } \\
\text { LOCATION } \\
\text { IYPE OF LOCATION } \\
\text { SAMPLE MUBER } \\
\text { MEDIA } \\
\text { UNITS } \\
\text { SDG MUABER } \\
\end{array}$ & $\begin{array}{r}\text { TSF } \\
\text { POND BOTIOA } \\
\text { SURFACE } \\
\text { TSFO101A } \\
\text { SEDIMENT } \\
\text { Jag/kg } \\
\text { TSFO101A } \\
\end{array}$ & $\begin{array}{r}\text { TSF } \\
\text { POW BOTIOA } \\
\text { SURFACE } \\
\text { TSFOTO2A } \\
\text { SEDIIEET } \\
\text { TSg/kg } \\
\text { TSFO101A } \\
\end{array}$ & $\begin{array}{r}\text { ISF } \\
\text { POND DISCHAREE } \\
\text { BIASED } \\
\text { TSF0701A } \\
\text { SEDIMEMT } \\
\text { mo/kg } \\
\text { TSF0601R }\end{array}$ & $\begin{array}{r}\text { TSF } \\
\text { aAcrerould } \\
\text { BIASED } \\
\text { ISF1201M } \\
\text { SOIL } \\
\text { ag/kg } \\
\text { TSF01014 } \\
\end{array}$ & $\begin{array}{r}\text { TSF } \\
\text { Eackeroind } \\
\text { BIASED } \\
\text { ISF120zM } \\
\text { SOIL } \\
\text { ng/kg } \\
\text { ISF0101A }\end{array}$ \\
\hline$\frac{\text { FIELD MEASUREMENTS }}{\text { Depth }(\mathrm{ft})}$ & $0-0.5$ & $0-0.5$ & $0-2$ & $0-0.6$ & $0-0.4$ \\
\hline$\frac{\text { ANALYTES }}{\text { Sulfide }}$ & $1120 \mathrm{~J}$ & $208 \mathrm{~J}$ & $3560 \mathrm{med}$ & 10.7 Ud & 9.9 us \\
\hline$x$ Solids & 54.3 & 63.7 & 31.3 & 92.2 & 92.2 \\
\hline Total (Allowed) Hold Time & $5(7) d$ & $6(7) d$ & $9(7) d^{*}$ & $5(7) d$ & $5(7) d$ \\
\hline
\end{tabular}


ISF Eveporation Pond SeA Data Docament - Wovesber 1999 - Method Volidation Level B

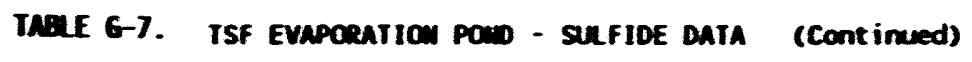

\begin{tabular}{|c|c|c|c|c|c|}
\hline $\begin{array}{l}\text { AREA } \\
\text { LOCATION } \\
\text { TYPE OF LOCATIOO } \\
\text { SAMPLE WRBER } \\
\text { MEDIA } \\
\text { UWIIS } \\
\text { SOG MMBER } \\
\end{array}$ & 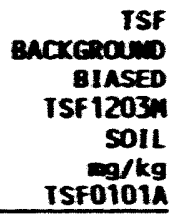 & 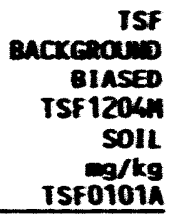 & 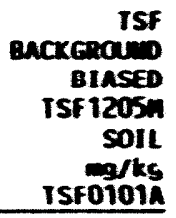 & 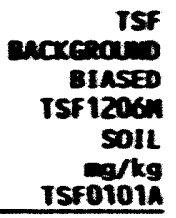 & 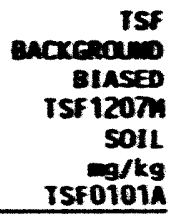 \\
\hline$\frac{\text { FIELD WEASUREMEWTS }}{\text { Depth }(f t)}$ & $0-0.4$ & $0-0.6$ & $0-0.4$ & $0-0.4$ & $0-0.6$ \\
\hline$\frac{\text { Amalrites }}{\text { Sulfide }}$ & $14.4 \mathrm{~J}$ & $10.9 \mathrm{u}$ & $22.6 \mathrm{~J}$ & $11.2 \mathrm{w}$ & $10.8 \mathrm{w}$ \\
\hline$x$ Solids & 92.3 & 92.1 & 92.6 & 92.4 & 92.3 \\
\hline Total (Allowed) Mold time & $5(7) d$ & $5(7) d$ & $5(7) d$ & o(t)d & $6(7) d$ \\
\hline
\end{tabular}

9 a. Method 9030

on $2-15-93$ 
TSF Evaporation Pond S\&A Data Document - November 1989 - Method Validation Level B

TABLE 6-7. ISF EVAPORATION POND - SULFIDE DATA (Continued)

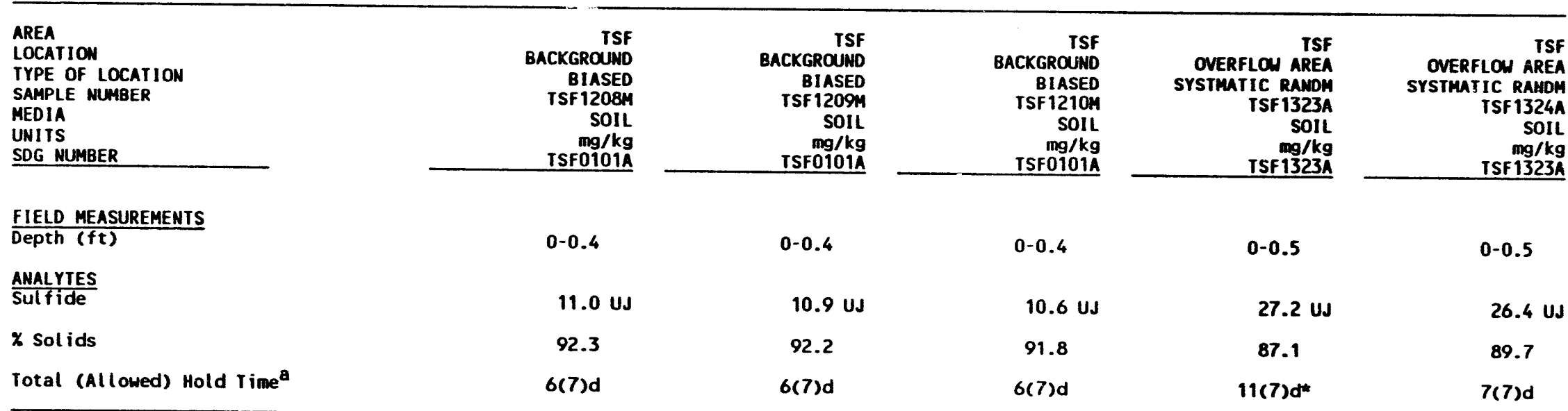

in a. Method 9030

2-15-93 
ISF Evaporation Pond S\&A Data Document - November 1989 - Method Validation Level B

TABLE 6-7. TSF EVAPORATION POND - SULFIDE DATA (Continued)

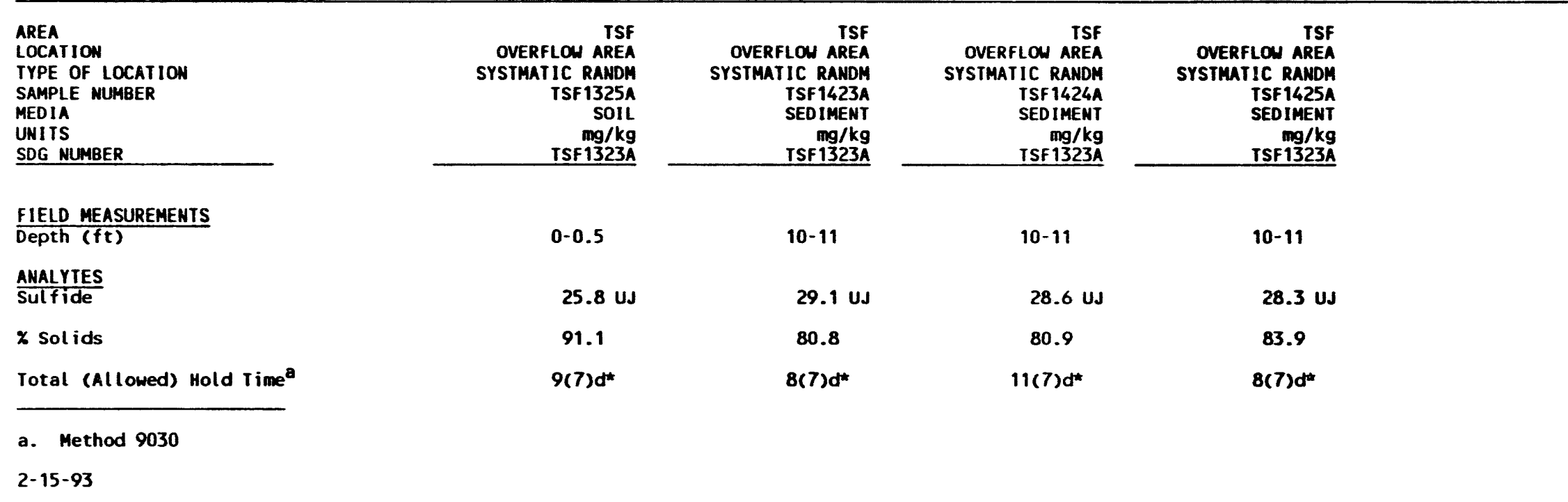


ISF Evaporation Pond S\&A Data Document - Movenber 1989 - Method Validation Level A

TABLE 6-8. TSF EVAPORATION POND - VOLATILE APPENDIX IX ORgANIC DATA

\begin{tabular}{|c|c|c|c|c|c|}
\hline $\begin{array}{l}\text { AREA } \\
\text { LOCATION } \\
\text { TYPE OF LOCATION } \\
\text { SAMPLE MUHBER } \\
\text { MEDIA } \\
\text { UNITS } \\
\text { SDG MUMEER } \\
\end{array}$ & $\begin{array}{r}\text { TSF } \\
\text { POND BOTIOA } \\
\text { SURFACE } \\
\text { TSFO101A } \\
\text { SEDIMENT } \\
\text { Ug/kg } \\
\text { TSFO101A } \\
\end{array}$ & $\begin{array}{r}\text { TSF } \\
\text { POND BOTIOM } \\
\text { SURFACE } \\
\text { TSFO102A } \\
\text { SEDIMENT } \\
\text { Ug/kg } \\
\text { TSFO101A } \\
\end{array}$ & $\begin{array}{r}\text { TSF } \\
\text { POND DISCHARGE } \\
\text { BIASED } \\
\text { TSF0701A } \\
\text { SEDIMENT } \\
\text { U9/kg } \\
\text { TSF0401A } \\
\end{array}$ & $\begin{array}{r}\text { TSF } \\
\text { OVERFLOW AREA } \\
\text { SYSTMATIC RANDA } \\
\text { TSF1323A } \\
\text { SOIL } \\
\text { ug/kg } \\
\text { TSF13233A }\end{array}$ & $\begin{array}{r}\text { TSF } \\
\text { OVERFLOU AREA } \\
\text { SYSTMATIC RAMDM } \\
\text { TSF1324A } \\
\text { SOIL } \\
\text { Ug/kg } \\
\text { TSF1323A } \\
\end{array}$ \\
\hline $\begin{array}{l}\text { FIELD MEASUREMENTS } \\
\text { Depth (ft) }\end{array}$ & $0-0.5$ & $0-0.5$ & $0-2$ & $0-0.5$ & $0-0.5$ \\
\hline $\begin{array}{l}\text { TARGET CoMPOUNDS } \\
\text { Chlorome:hane } \\
\text { Bromomethane } \\
\text { vinyl Chloride } \\
\text { Chloroethane } \\
\text { Methylene Chloride }\end{array}$ & $\begin{array}{l}10 \mathrm{UJ} \\
10 \mathrm{UJ} \\
10 \mathrm{UJ} \\
10 \mathrm{UJ} \\
5 \text { UJ }\end{array}$ & $\begin{array}{l}10 \text { UJ } \\
10 \text { UJ } \\
10 \text { UJ } \\
10 \text { UJ } \\
5 \text { UJ }\end{array}$ & $\begin{array}{l}\cdots \\
\cdots \\
\cdots \\
\cdots \\
\cdots\end{array}$ & $\begin{array}{l}10 \mathrm{UJ} \\
10 \mathrm{UJ} \\
10 \mathrm{UJ} \\
10 \mathrm{UJ} \\
5 \text { UJ }\end{array}$ & $\begin{array}{l}\cdots \\
\cdots \\
\cdots- \\
\cdots \\
\cdots-\end{array}$ \\
\hline $\begin{array}{l}\text { Acetone } \\
\text { Carbon Disulfide } \\
\text { 1,1-Dichloroethene } \\
\text { 1,1-Dichloroethane } \\
\text { 1,2-Dichloroethene_(total) }\end{array}$ & $\begin{array}{rl}150 & \mathrm{~J} \\
5 & \text { UJ } \\
5 & \text { UJ } \\
5 & \text { UJ } \\
5 & \text { UJ }\end{array}$ & $\begin{array}{rl}47 & R \\
5 & \text { UJ } \\
5 & \text { UJ } \\
5 & \text { UJ } \\
5 & \text { UJ }\end{array}$ & $\begin{array}{l}49 \text { Ud } \\
\cdots \\
\cdots- \\
\cdots\end{array}$ & $\begin{array}{rl}10 & R \\
5 & U J \\
5 & R \\
5 & U J \\
5 & U J\end{array}$ & \begin{tabular}{l}
$10 R$ \\
\hdashline $5 R$ \\
$\cdots$ \\
$\cdots$
\end{tabular} \\
\hline $\begin{array}{l}\text { Chloroform } \\
1,2-\text { ichloroethane } \\
2-\text { Butanone } \\
1,1,1-\text { Trichloroethane } \\
\text { Carbon Tetrachloride }\end{array}$ & $\begin{array}{rl}5 & \text { UJ } \\
5 & \text { UJ } \\
40 & R \\
5 & \text { UJ } \\
5 & \text { UJ }\end{array}$ & $\begin{array}{l}5 \text { UJ } \\
5 \\
7 \\
7 \\
5 \\
5 \\
5\end{array}$ & $\begin{array}{ll}\cdots \\
10 R \\
\cdots-\end{array}$ & $\begin{array}{rl}5 & U J \\
5 & U J \\
10 & R \\
5 & U J \\
5 & U J\end{array}$ & $\begin{array}{l}\cdots \\
10 \\
10 \\
\cdots \\
\cdots\end{array}$ \\
\hline $\begin{array}{l}\text { Vinyl Acetate } \\
\text { Bromodichloromethane } \\
1,2-D \text { ichloropropane } \\
\text { cis-1, 3-D ichloropropene } \\
\text { Trichloroethene }\end{array}$ & $\begin{aligned} 10 & \text { UJ } \\
5 & \text { UJ } \\
5 & \text { UJ } \\
5 & \text { UJ } \\
5 & \text { UJ }\end{aligned}$ & $\begin{aligned} 10 & \text { UJ } \\
5 & \text { UJ } \\
5 & \text { UJ } \\
5 & \text { UJ } \\
5 & \text { UJ }\end{aligned}$ & $\begin{array}{l}\cdots \\
\cdots \\
\cdots \\
\cdots \\
\cdots\end{array}$ & $\begin{array}{rl}10 & \text { UJ } \\
5 & \text { UJ } \\
5 & U J \\
5 & U J \\
5 & U J\end{array}$ & $\begin{array}{l}\cdots \\
\cdots \\
\cdots \\
\cdots\end{array}$ \\
\hline $\begin{array}{l}\text { Dibromochloromethane } \\
1,1,2-\text { Trichloroethane } \\
\text { Benzene } \\
\text { Trans-1,3-Dichloropropene } \\
\text { Bromoform }\end{array}$ & $\begin{array}{l}5 \\
5 \\
\text { UJ } \\
5 \\
5 \\
\text { UJ } \\
5 \\
\text { UJ }\end{array}$ & 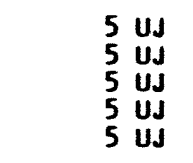 & $\begin{array}{l}\cdots \\
\cdots \\
\cdots \\
\cdots\end{array}$ & 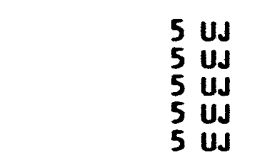 & $\begin{array}{l}\cdots \\
\cdots \\
\cdots \\
\cdots \\
\cdots\end{array}$ \\
\hline $\begin{array}{l}\text { 4-Methyl-2-Pentanone } \\
\text { 2-Hexanone } \\
\text { Tetrachloroethene } \\
1,1,2,2 \text {-Tetrachloroethane } \\
\text { Toluene }\end{array}$ & $\begin{array}{rl}10 & \text { UJ } \\
10 & R \\
5 & \text { UJ } \\
5 & \text { UJ } \\
63 & J\end{array}$ & $\begin{array}{rl}10 & \text { UJ } \\
10 & R \\
5 & \text { UJ } \\
5 & \text { UJ } \\
5 & \text { UJ }\end{array}$ & \begin{tabular}{l}
$10 R$ \\
$10 R$ \\
10 \\
\hdashline 28
\end{tabular} & $\begin{array}{rl}10 & R \\
10 & R \\
5 & U J \\
5 & U J \\
5 & U J\end{array}$ & $\begin{array}{l}10 R \\
10 R \\
10.8 \\
\cdots \\
\cdots\end{array}$ \\
\hline
\end{tabular}

2-12-93 
ISF Evaporation Pond S\&A Data Document - Wovember 1989 - Method Validation Level A

TABLE 6-8. ISF EVAPORATION POND - VOLATILE APPEMDIX IX ORGANIC DATA

\begin{tabular}{|c|c|c|c|c|c|}
\hline $\begin{array}{l}\text { LOCATION } \\
\text { TYPE OF LOCATION } \\
\text { SAMPLE MUBER } \\
\text { MEDIA } \\
\text { UNITS } \\
\text { SOG MUMBER } \\
\end{array}$ & $\begin{array}{r}\text { POND BOTTOH } \\
\text { SURFACE } \\
\text { TSFOIOIA } \\
\text { SEDIMENT } \\
\text { ug/kg } \\
\text { TSFO101A } \\
\end{array}$ & $\begin{array}{r}\text { POND BOTTOA } \\
\text { SURFACE } \\
\text { TSFO102A } \\
\text { SEDIMENT } \\
\text { Ug/kg } \\
\text { TSFOIO1A } \\
\end{array}$ & $\begin{array}{r}\text { POMD DISCHARGE } \\
\text { BIASED } \\
\text { TSFO701A } \\
\text { SEDIMENT } \\
\text { Ug/kg } \\
\text { ISF0401A } \\
\end{array}$ & $\begin{array}{r}\text { ONERFLON AREA } \\
\text { SYSTMATIC RAMDH } \\
\text { TSF 1323A } \\
\text { SOIL } \\
\text { ug/kg } \\
\text { TSF1323A }\end{array}$ & $\begin{array}{r}\text { OVERFLON AREA } \\
\text { SYSTMATIC RANDIA } \\
\text { TSF 1324A } \\
\text { SOIL } \\
\text { ug/kg } \\
\text { TSF 1323A } \\
\end{array}$ \\
\hline $\begin{array}{l}\text { Chlorobenzene } \\
\text { Ethylbenzene } \\
\text { Styrene } \\
\text { Xylene (total) } \\
\text { Dichlorodifluoromethane }\end{array}$ & 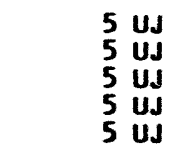 & $\begin{array}{l}5 \text { UJ } \\
5 \\
5 \\
\text { UJ } \\
5 \\
5 \\
\text { UJ }\end{array}$ & $\begin{array}{l}-- \\
2 \mathrm{~J} \\
\cdots- \\
\cdots\end{array}$ & $\begin{array}{l}5 \text { UJ } \\
5 \text { UJ } \\
5 \text { UJ } \\
5 \text { UJ } \\
5 \text { UJ }\end{array}$ & $\begin{array}{l}\cdots \\
\cdots \\
\cdots \\
\cdots \\
\cdots\end{array}$ \\
\hline $\begin{array}{l}\text { Trichlorofl woromethane } \\
\text { trans-1,2-Dichloroethene } \\
\text { Iodomethane } \\
\text { Allyl chloride } \\
\text { cis-1,2-Dichloroethene }\end{array}$ & 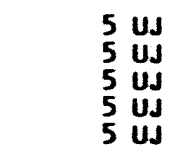 & $\begin{array}{l}5 \text { UJ } \\
5 \\
5 \\
\text { UJ } \\
5 \\
5 \\
\text { UJ UJ }\end{array}$ & \begin{tabular}{l} 
SR \\
\hdashline- \\
$\cdots$ \\
$\cdots$ \\
$\cdots$
\end{tabular} & $\begin{array}{l}5 \text { UJ } \\
5 \text { UJ } \\
5 \text { UJ } \\
5 \text { UJ } \\
5\end{array}$ & $\begin{array}{l}\cdots \\
\cdots \\
\cdots \\
\cdots\end{array}$ \\
\hline $\begin{array}{l}\text { Propionitrile } \\
\text { Acrolein } \\
\text { 2-Chloro-1,3-butadiene } \\
\text { Acrylonitrile } \\
\text { Methacrylonitrile }\end{array}$ & $\begin{array}{rl}20 & \text { UJ } \\
50 & R \\
5 & \text { UJ } \\
10 & \text { UJ } \\
5 & \text { UJ }\end{array}$ & $\begin{array}{rl}20 & \text { UJ } \\
50 & R \\
5 & U J \\
10 & U J \\
5 & U J\end{array}$ & $\begin{array}{l}-\cdots \\
50 R \\
\cdots- \\
\cdots \\
\cdots\end{array}$ & $\begin{array}{rl}20 & \text { UJ } \\
50 & R \\
5 & \text { UJ } \\
10 & \text { UJ } \\
5 & \text { UJ }\end{array}$ & $\begin{array}{l}\cdots \\
50 R \\
\cdots \\
\cdots \\
\cdots\end{array}$ \\
\hline $\begin{array}{l}\text { Methyl methacrylate } \\
\text { Dibromomethane } \\
\text { I sobutyl alcohol } \\
1,2-0 \text { ibromoethane } \\
\text { 1,1,1,2-Tetrachloroethane }\end{array}$ & $\begin{array}{rl}5 & \text { UJ } \\
5 & \text { UJ } \\
100 & R \\
5 & \text { UJ } \\
5 & \text { UJ }\end{array}$ & $\begin{array}{c}5 \text { UJ } \\
5 \text { UJ } \\
100 \quad R \\
\cdots \\
\cdots\end{array}$ & $\begin{array}{c}\cdots \\
100 R \\
\cdots\end{array}$ & $\begin{array}{rl}5 & \text { UJ } \\
5 & \text { UJ } \\
100 & R \\
5 & \text { UJ } \\
5 & \text { UJ }\end{array}$ & $\begin{array}{c}\cdots \\
100 \\
\cdots \\
\cdots\end{array}$ \\
\hline $\begin{array}{l}\text { Xylene (total meta \& para) } \\
\text { xylene (ortho) } \\
1,2,3-\text { Trichloropropane } \\
\text { Trans-1,4-Dichloro-2-butene } \\
1,2-D \text { ibromo-3-chloropropane }\end{array}$ & $\begin{array}{rl}5 & \text { UJ } \\
5 & U J \\
5 & U J \\
10 & R \\
10 & U J\end{array}$ & $\begin{array}{rl}5 & R \\
5 & R \\
5 & U J \\
10 & R \\
10 & U S\end{array}$ & $\begin{array}{l}\cdots \\
\cdots \\
10 \\
10 \\
10\end{array}$ & $\begin{array}{l}5 \text { UJ } \\
5 \text { UJ } \\
5 \text { UJ } \\
10 \text { R } \\
10 \text { UJ }\end{array}$ & $\begin{array}{l}\cdots \\
\cdots \\
10 R \\
\cdots\end{array}$ \\
\hline $\begin{array}{l}\text { Dilution factor } \\
\text { Total (Allowed) Hold time } \\
2-12-93\end{array}$ & $\begin{array}{c}1.000 \\
18(14) d^{*}\end{array}$ & $17(14) d^{*}$ & $\begin{array}{c}1.000 \\
23(14) d^{*}\end{array}$ & $15(14) d^{*}$ & $\begin{array}{r}1.000 \\
12(14) d\end{array}$ \\
\hline
\end{tabular}


ISF Evaporation Pond SeA Data Document

Method Validation Level A

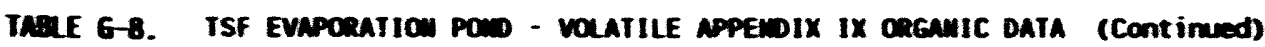

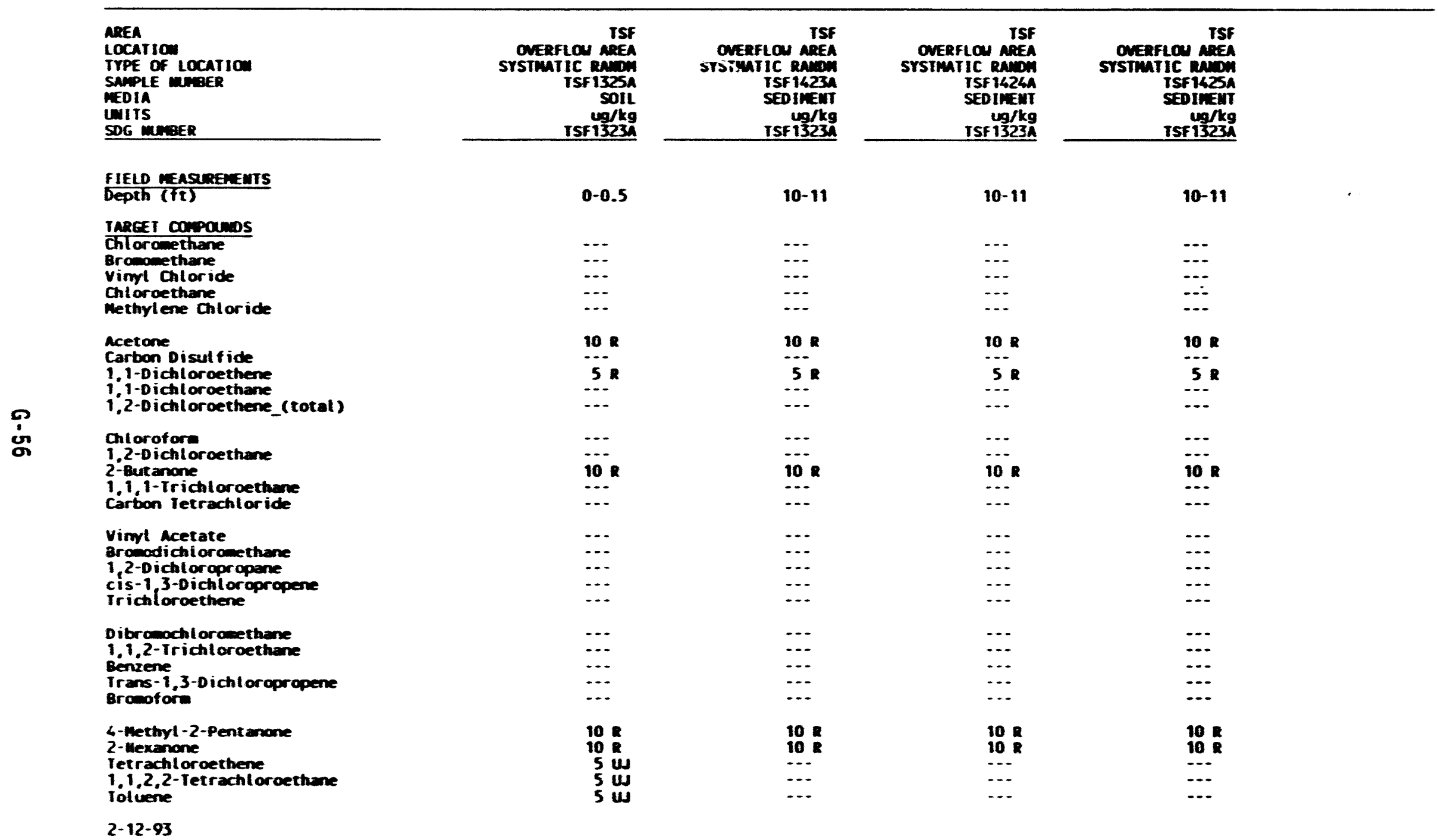


ISf Evaporation Fand sel Dote Bocument - Wovember 1909 - Method val idetion Level A

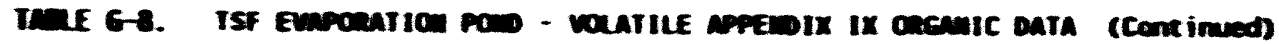

\begin{tabular}{|c|c|c|c|c|}
\hline 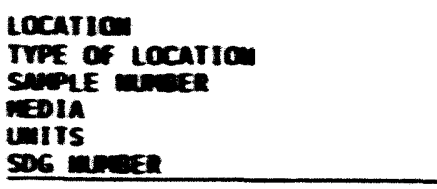 & 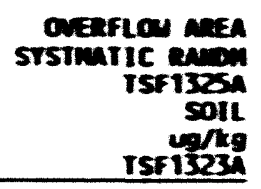 & 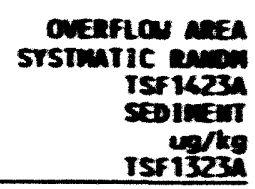 & 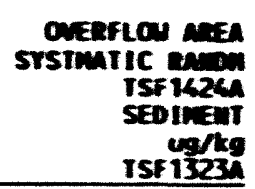 & 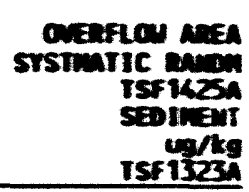 \\
\hline $\begin{array}{l}\text { Chloroberzene } \\
\text { Ethylbenzene } \\
\text { Styrene } \\
\text { xylene (total) } \\
\text { Dichtorodifluorenethane }\end{array}$ & $\begin{array}{l}5 \\
5 \\
5\end{array}$ & $\begin{array}{l}\cdots \\
\cdots \\
\cdots \\
\cdots\end{array}$ & $\begin{array}{l}\cdots \\
\cdots \\
\cdots \\
\cdots\end{array}$ & $\begin{array}{l}\cdots \\
\cdots \\
\cdots \\
\cdots\end{array}$ \\
\hline $\begin{array}{l}\text { Propionitrile } \\
\text { acrolein } \\
\text { 2-chloro-1,3-butadiene } \\
\text { acrylonitrile } \\
\text { Methacrylonitrile }\end{array}$ & $\begin{array}{l}\ldots . . \\
50.2 \\
\cdots \\
\cdots\end{array}$ & $\begin{array}{l}\ldots= \\
50 . \\
\cdots\end{array}$ & $\begin{array}{l}20 \\
\mathbf{5 0} \\
\cdots \\
\cdots\end{array}$ & $\begin{array}{l}30 . \\
50 \\
\cdots \\
\cdots\end{array}$ \\
\hline 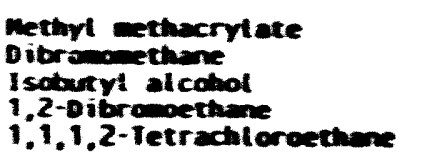 & $\frac{100}{\cdots}$ & 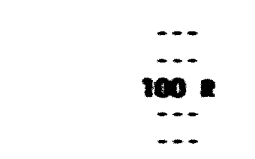 & $\frac{1}{\cdots}+\cdots$ & 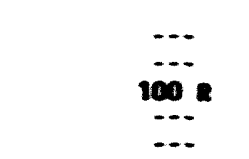 \\
\hline 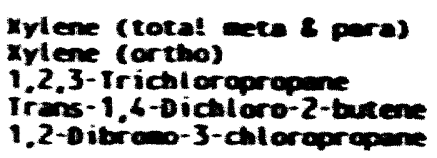 & $\begin{array}{ll}\cdots \\
\cdots \\
\cdots\end{array}$ & 10 & 10 & $\begin{array}{ll}\ldots \\
\cdots \\
\cdots\end{array}$ \\
\hline $\begin{array}{l}\text { Dilution factor } \\
\text { Total (Allowed) wold Tiere }\end{array}$ & $13(16) d$ & $13(16) d$ & $13(14) d$ & 13(16)d \\
\hline
\end{tabular}




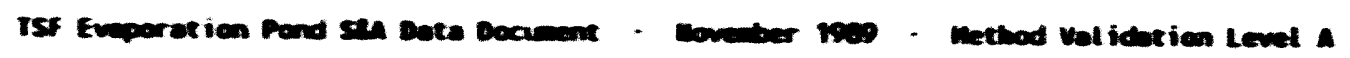

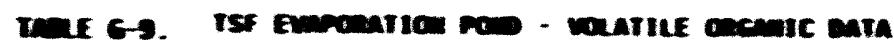

\begin{tabular}{|c|c|c|c|c|c|}
\hline 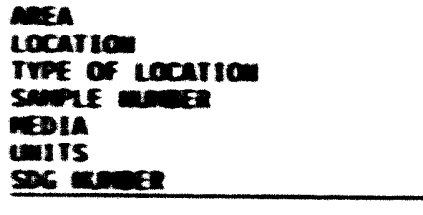 & 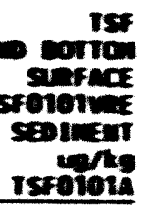 & 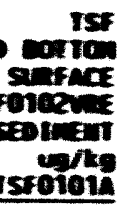 & 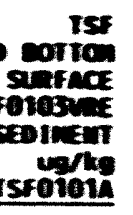 & 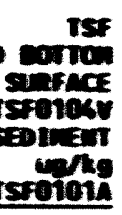 & 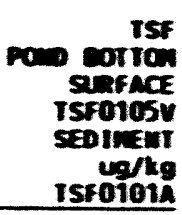 \\
\hline 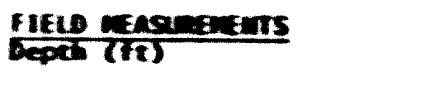 & $0-0.5$ & $0-0.5$ & $0-0.5$ & $0-0.5$ & $0-0.5$ \\
\hline 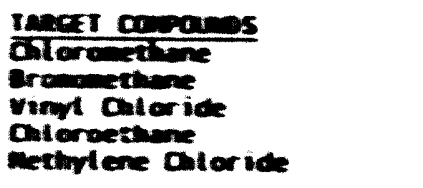 & $\begin{array}{ll}10 \\
\cdots \\
\cdots \\
\cdots\end{array}$ & $\begin{array}{ll}10 \\
\cdots \\
\cdots \\
\cdots\end{array}$ & $\begin{array}{l}10 \mathrm{u} \\
\ldots \\
\cdots \\
\cdots\end{array}$ & $\begin{array}{ll}10 \\
\cdots \\
\cdots- \\
\cdots\end{array}$ & $\begin{array}{l}10 \mathrm{u} \\
\cdots- \\
\cdots \\
\cdots \\
\cdots\end{array}$ \\
\hline 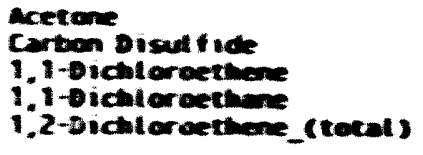 & $\begin{array}{l}40 . \\
\cdots \\
\cdots \\
\cdots\end{array}$ & $\begin{array}{l}29: \\
\cdots \\
\cdots \\
\cdots\end{array}$ & $\begin{array}{l}m \text { I } \\
\cdots \\
\cdots \\
\cdots\end{array}$ & $\begin{array}{l}20 . \\
\cdots . \\
\cdots \\
\cdots \\
\cdots\end{array}$ & $\begin{array}{l}212 \\
\cdots \\
\cdots \\
\cdots \\
\cdots\end{array}$ \\
\hline 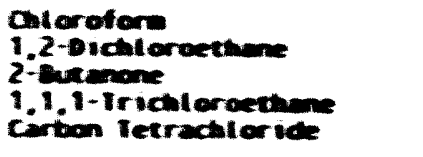 & $\begin{array}{ll}\cdots \\
\cdots \\
\cdots\end{array}$ & $\begin{array}{ll}\cdots \\
\cdots \\
\cdots\end{array}$ & $\begin{array}{l}\ldots \\
\cdots \\
\cdots\end{array}$ & $\begin{array}{l}\cdots \\
\cdots \\
\cdots\end{array}$ & $\begin{array}{ll}\cdots \\
10: \\
\cdots\end{array}$ \\
\hline 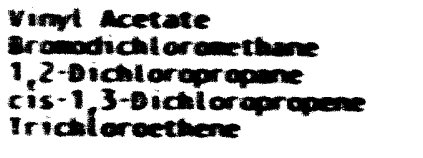 & $\begin{array}{l}\cdots \\
\cdots \\
\cdots\end{array}$ & $\begin{array}{ll}\cdots \\
\cdots \\
\cdots\end{array}$ & $\begin{array}{l}\cdots \\
\cdots \\
\cdots \\
\cdots\end{array}$ & $\begin{array}{ll}\cdots \\
\cdots \\
\cdots \\
\cdots\end{array}$ & $\begin{array}{l}\cdots \\
\cdots \\
\cdots \\
\cdots\end{array}$ \\
\hline 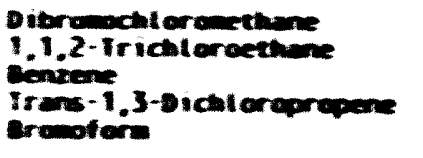 & $\begin{array}{l}\cdots \\
\cdots \\
\cdots \\
\cdots\end{array}$ & $\begin{array}{l}\cdots \\
\cdots \\
\cdots \\
\cdots\end{array}$ & $\begin{array}{l}\cdots \\
\cdots \\
\cdots\end{array}$ & $\begin{array}{l}\cdots \\
\cdots \\
\cdots \\
\cdots\end{array}$ & $\begin{array}{l}\cdots \\
\cdots \\
\cdots \\
\cdots \\
\cdots\end{array}$ \\
\hline 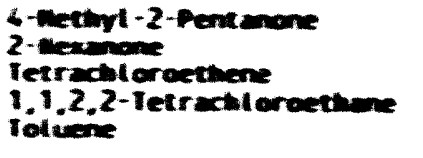 & $\begin{array}{l}10 \text { u } \\
10 . \\
\cdots \\
\cdots\end{array}$ & $\begin{array}{l}10 \mathbf{w} \\
10 \\
\cdots \\
\cdots\end{array}$ & $\begin{array}{l}10 \mathrm{w} \\
10:- \\
\cdots \\
\cdots\end{array}$ & $\begin{array}{l}19 \text { u } \\
10.2 \\
\cdots- \\
\cdots\end{array}$ & $\begin{array}{l}10 \mathrm{w} \\
10 \\
\cdots \\
\cdots\end{array}$ \\
\hline 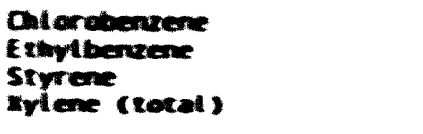 & $\begin{array}{l}\cdots \\
\cdots \\
\cdots \\
\cdots\end{array}$ & $\begin{array}{l}\cdots \\
\cdots \\
\cdots\end{array}$ & $\begin{array}{l}\cdots \\
\cdots \\
\cdots\end{array}$ & $\begin{array}{l}\cdots \\
\cdots \\
\cdots \\
\cdots\end{array}$ & $\begin{array}{l}\cdots \\
\cdots \\
\cdots \\
\cdots\end{array}$ \\
\hline 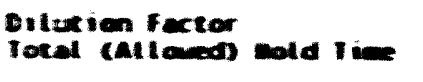 & 13(itida & $12(36)$ & $13(16)$ & $12(16) d$ & $\begin{array}{r}1.000 \\
13(14) d\end{array}$ \\
\hline
\end{tabular}




\begin{tabular}{|c|c|c|c|c|c|}
\hline $\begin{array}{l}p(r) r 1 \\
000-1\end{array}$ & presi & Protist & 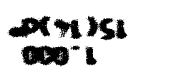 & 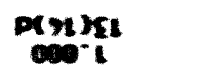 & 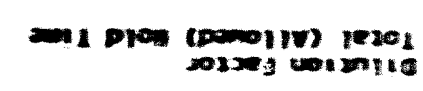 \\
\hline $\begin{array}{l}\cdots \\
\cdots \\
\cdots\end{array}$ & $\begin{array}{l}\cdots \\
\cdots \\
\cdots\end{array}$ & $\begin{array}{l}\cdots \\
\cdots \\
\cdots\end{array}$ & $\begin{array}{l}m s \\
m s \\
m s \\
m s\end{array}$ & $\begin{array}{l}\cdots \\
\cdots \\
\cdots\end{array}$ & 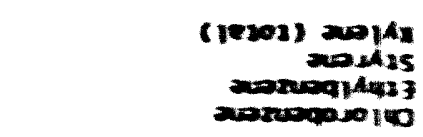 \\
\hline $\begin{array}{c}\ldots \\
\ldots \\
\ldots \\
0 .\end{array}$ & $\begin{array}{c}\ldots \\
\ldots \\
\cdots\end{array}$ & $\begin{array}{c}\cdots \\
\cdots \\
\cdots \\
\cdots\end{array}$ & $\begin{array}{l}m s \\
m s \\
m s \\
m \\
m\end{array}$ & $\underset{m}{\cdots}$ & 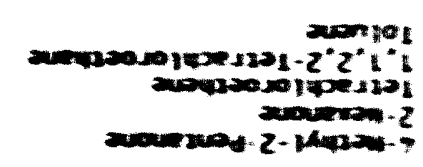 \\
\hline $\begin{array}{l}\cdots \\
\cdots \\
\cdots \\
\cdots \\
\cdots\end{array}$ & $\begin{array}{l}\cdots \\
\cdots \\
\cdots \\
\cdots\end{array}$ & $\begin{array}{l}\cdots \\
\cdots \\
\cdots \\
\cdots\end{array}$ & $\begin{array}{l}m s \\
m s \\
m s \\
m s \\
m s \\
m s\end{array}$ & $\begin{array}{l}\cdots \\
\cdots \\
\cdots \\
\cdots\end{array}$ & 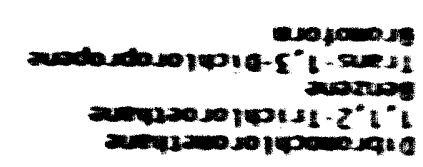 \\
\hline $\begin{array}{l}\cdots \\
\cdots \\
\cdots \\
\cdots\end{array}$ & $\begin{array}{l}\cdots \\
\cdots \\
\cdots \\
\cdots\end{array}$ & $\begin{array}{l}\cdots \\
\cdots \\
\cdots \\
\cdots\end{array}$ & $\begin{array}{l}m s \\
m s \\
m s \\
m s \\
m\end{array}$ & $\begin{array}{l}\cdots \\
\cdots \\
\cdots \\
\cdots\end{array}$ & 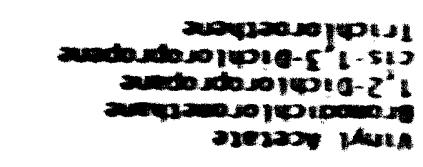 \\
\hline $\begin{array}{c}\cdots \\
\cdots \\
m s\end{array}$ & $\begin{array}{c}\cdots \\
\cdots \\
\cdots\end{array}$ & $\begin{array}{c}\cdots \\
\cdots \\
\cdots\end{array}$ & $\begin{array}{l}m s \\
m s \\
m s \\
m s \\
m \\
m\end{array}$ & $\ldots$ & 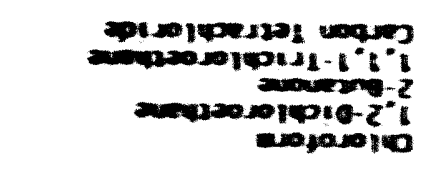 \\
\hline 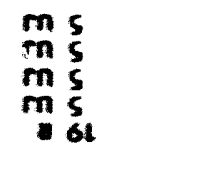 & $\begin{array}{c}\cdots \\
\cdots \\
\cdots \\
21\end{array}$ & $\begin{array}{l}\ldots \\
\cdots \\
\cdots \\
\cdots\end{array}$ & $\begin{array}{l}\operatorname{ms} \\
m 5 \\
m 5 \\
m s \\
m i l\end{array}$ & $\begin{array}{l}\cdots \\
\cdots \\
\cdots \\
\cdots\end{array}$ & (mo3) \\
\hline $\begin{array}{l}m \text { m } \\
\text { m or } \\
m \text { of } \\
\text { m or } \\
\text { m ot }\end{array}$ & $\ddot{a}$ & $\begin{array}{l}\cdots \\
\cdots a \\
0 a\end{array}$ & $\begin{array}{l}\mathbf{m} s \\
\mathbf{m} \\
\mathbf{m} \\
\mathbf{m} \\
\mathbf{m}\end{array}$ & $\begin{array}{c}\cdots \\
\cdots \\
\cdots \\
m o\end{array}$ & 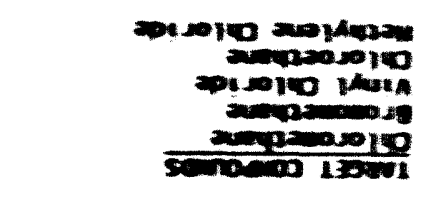 \\
\hline $5=0-0$ & $5=0$ & $5 \cdot 0-0$ & 5000 & $5.0-0$ & SIII) (21) \\
\hline 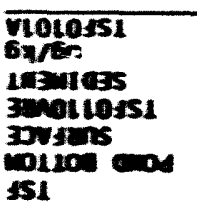 & 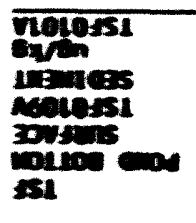 & 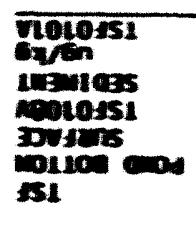 & 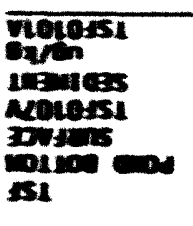 & 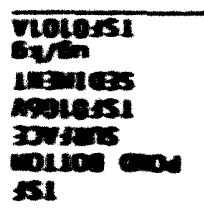 & 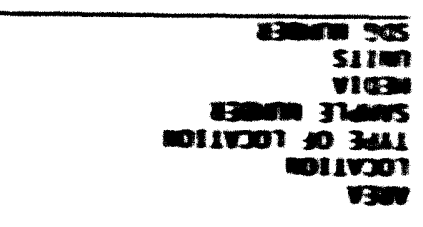 \\
\hline
\end{tabular}

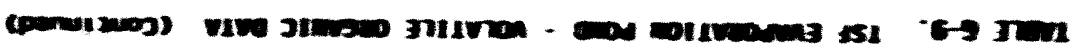

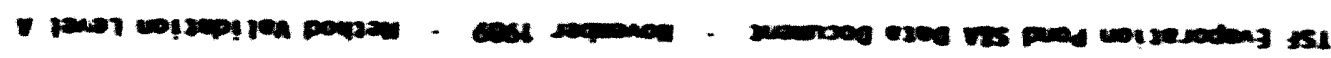




\begin{tabular}{|c|c|c|c|c|}
\hline $\log _{1} \times 1$ & $\cos ^{2}$ & $p_{000}(x) \times$ & $\frac{p+1) x}{60}$ & prix \\
\hline $\begin{array}{cl}r & 9 \\
\operatorname{m} & 5 \\
r & 21 \\
\min & \end{array}$ & $\begin{array}{l}m s \\
m s \\
m s\end{array}$ & $\begin{array}{l}m s \\
\operatorname{ms} s \\
m s\end{array}$ & 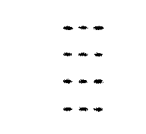 & 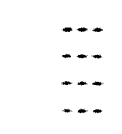 \\
\hline $\begin{array}{cc}r n & s \\
r n & s \\
m & s \\
o & \text { of } \\
m & \text { of }\end{array}$ & $\begin{array}{c}m \\
m \\
m \\
m s \\
m \\
m \text { of } \\
m \text { of }\end{array}$ & $\begin{array}{c}m s \\
m s \\
m 5 \\
m \text { ot } \\
m \text { ot }\end{array}$ & $\begin{array}{c}\cdots \\
\cdots \\
0\end{array}$ & $\ldots$ \\
\hline $\begin{array}{l}m s \\
m s \\
m s \\
m s \\
m s\end{array}$ & 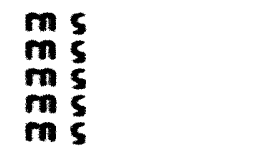 & $\begin{array}{l}m s \\
m 5 \\
m \\
m \\
m \\
m\end{array}$ & $\begin{array}{c}\ldots \\
\ldots \\
\cdots \\
\cdots \\
\cdots\end{array}$ & $\ldots$ \\
\hline $\begin{array}{l}m s \\
m s \\
m s \\
m s \\
m \text { ol }\end{array}$ & $\begin{array}{l}m s \\
m 5 \\
m \\
m \\
m \\
m\end{array}$ & 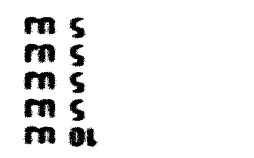 & $\begin{array}{l}\ldots \\
\cdots \\
\cdots \\
\cdots\end{array}$ & $\begin{array}{l}\ldots \\
\ldots \\
\cdots\end{array}$ \\
\hline $\begin{array}{ll}m & s \\
m & s \\
\text { os } & \\
m & s \\
m & s\end{array}$ & $\begin{array}{l}m \\
m \\
m \\
m \\
m \\
m \\
m \\
m\end{array}$ & 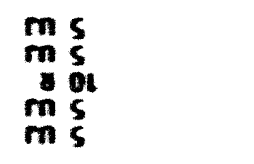 & $\begin{array}{l}\cdots \\
\cdots \\
\cdots \\
\cdots\end{array}$ & a \\
\hline $\begin{array}{ll}m & s \\
m & s \\
m & s \\
m & s \\
& 0 t\end{array}$ & $\begin{array}{l}m s \\
m \\
m \\
m \\
m \\
m \\
a\end{array}$ & $\begin{array}{l}m_{m} s \\
m \\
m \\
m \\
m \\
m \\
m\end{array}$ & $\begin{array}{c}\ldots \\
\cdots \\
\cdots 2\end{array}$ & $\ldots$ \\
\hline $\begin{array}{l}m s \\
m \text { ot } \\
m \text { of } \\
m \text { of } \\
m \text { of }\end{array}$ & 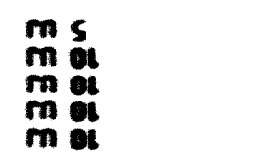 & $\begin{array}{l}m s \\
m \text { ot } \\
m \text { ot } \\
m \text { ot } \\
m \text { ot }\end{array}$ & $\begin{array}{l}\ldots \\
\cdots \\
\cdots \\
\cdots\end{array}$ & $=$ \\
\hline $50-50$ & $50-0$ & $5 \cdot 0-5 \cdot 0$ & $50 \cdot 0$ & $50-0$ \\
\hline 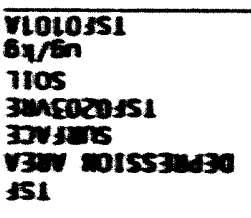 & 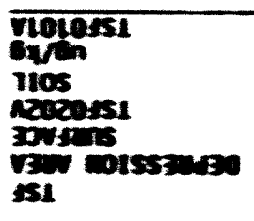 & 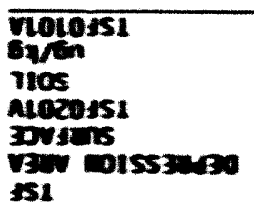 & 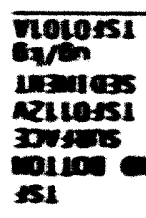 & 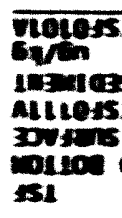 \\
\hline
\end{tabular}

wi prom (powoliv) ino:

(10203) 200 hix 2002uequan is 207090.010

-

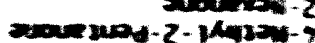

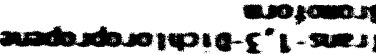
201

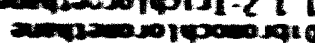

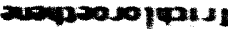

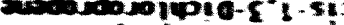

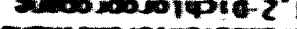
arp ojesoov phis

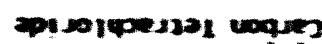

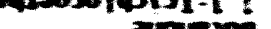

201020001910-2" toposolvo

(10003) '

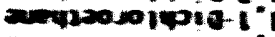
avasosolpia-1" apis mis vogies

20101000 Mupax anceroly

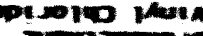
$\frac{200010}{5 \times 10001}$ (11) act 
ISF Evaporation Pond sen Dote bocument

nowber 1909 - Method Vel idotion Level A

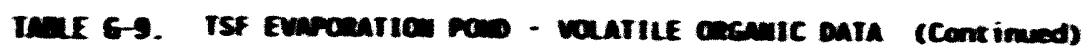

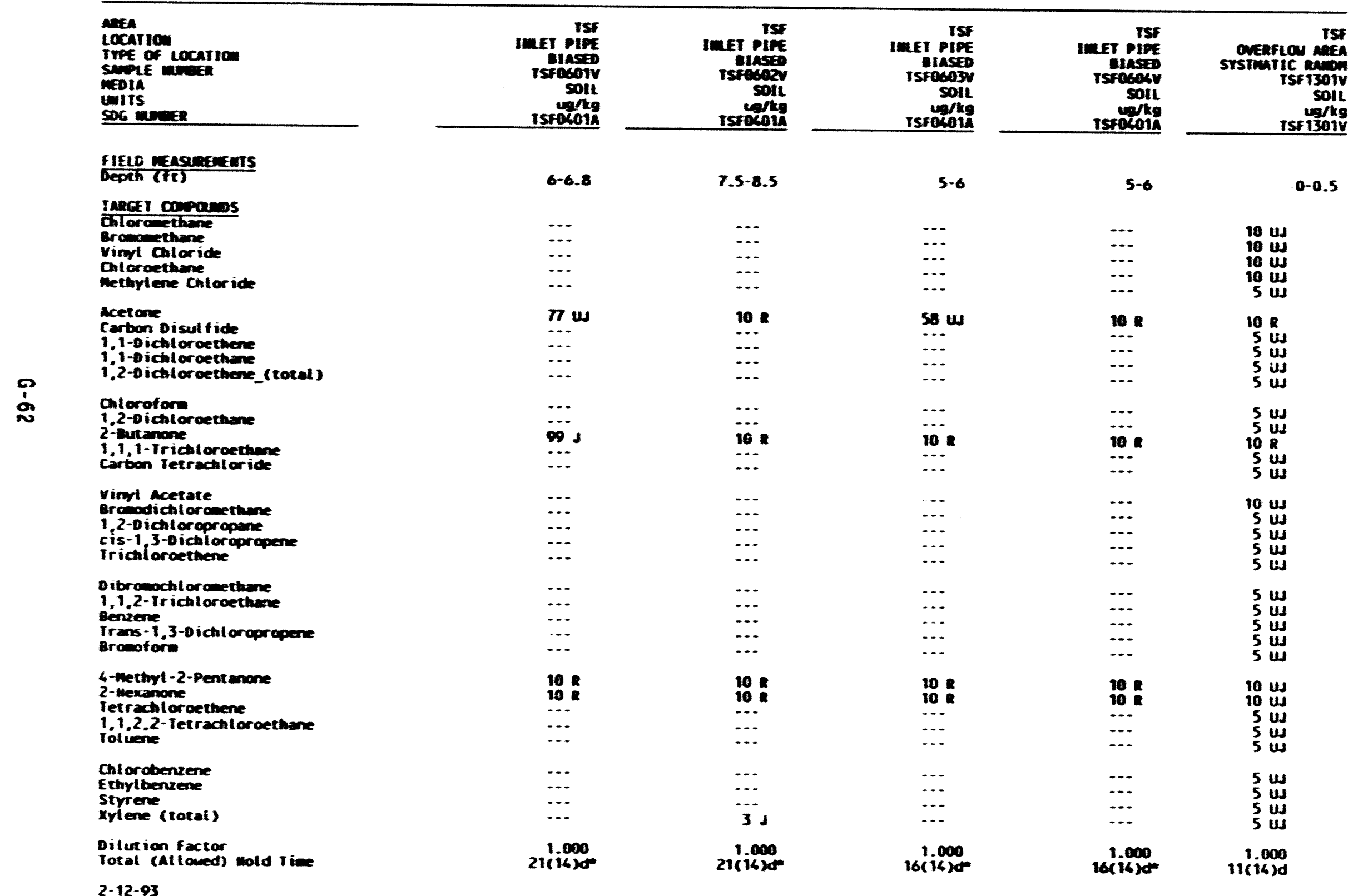


ISF Eveporation Pond SeA Data Docament

Nowemer 1909 - Method Val idetion Level A

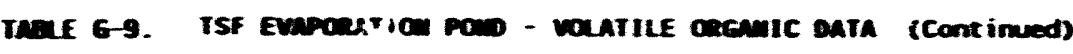

\begin{tabular}{|c|c|c|c|c|c|}
\hline 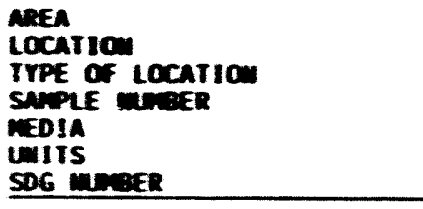 & 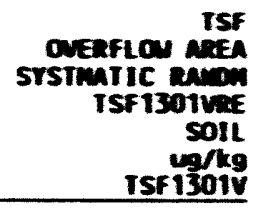 & 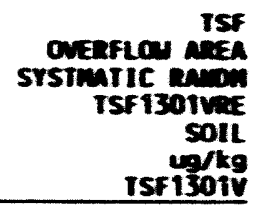 & 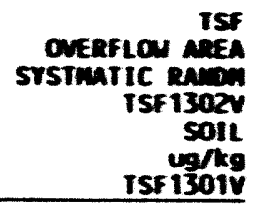 & 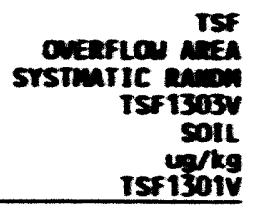 & 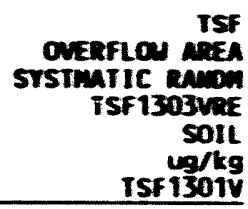 \\
\hline $\begin{array}{l}\text { FIELD FEASUREREUTS } \\
\text { Depth (IT) }\end{array}$ & $0-0.5$ & $0-0.5$ & $0-0.5$ & $0-0.5$ & $0-0.5$ \\
\hline 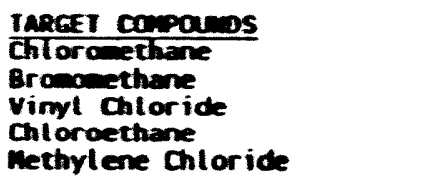 & $\begin{array}{ll}10 & R \\
10 & R \\
10 & R \\
10 & R \\
6 & J\end{array}$ & $\begin{array}{rl}10 & : \\
10 & : \\
10 & 0 \\
10 & : \\
5 & 0\end{array}$ & $\begin{array}{l}\cdots \\
\cdots \\
\cdots \\
\cdots\end{array}$ & $\begin{array}{l}10 \mathrm{w} \\
10 \mathrm{w} \\
10 \mathrm{w} \\
10 \mathrm{w} \\
5 \mathrm{w}\end{array}$ & $\begin{array}{rl}10 & R \\
10 & R \\
10 & R \\
10 & R \\
5 & R\end{array}$ \\
\hline $\begin{array}{l}\text { Acetone } \\
\text { Carbon Disul fide } \\
\text { 1.1-Dichloroethere } \\
\text { 1.1-Dichlorcethane } \\
\text { 1.2-Dichloroethene_(total) }\end{array}$ & $\begin{array}{ll}10 & R \\
5 & R \\
5 & R \\
5 & R \\
5 & R\end{array}$ & $\begin{array}{ll}22 & 1 \\
5 & R \\
5 & R \\
5 & R \\
5 & R\end{array}$ & $\begin{array}{l}10 R \\
\cdots \\
\cdots \\
\cdots \\
\cdots\end{array}$ & $\begin{array}{l}10 \\
5 \text { u } \\
5 \text { us } \\
5 \text { u } \\
5 \text { us }\end{array}$ & $\begin{array}{rl}10 & R \\
5 & R \\
5 & R \\
5 & R \\
5 & R\end{array}$ \\
\hline $\begin{array}{l}\text { Chloroform } \\
1,2-0 \text { ichlorcethane } \\
2-\text { Butanone } \\
1,1,1-\text { Irichloroettane } \\
\text { Carbon Tetrachloride }\end{array}$ & $\begin{array}{cl}5 & R \\
5 & R \\
10 & R \\
5 & R \\
5 & R\end{array}$ & $\begin{array}{rl}5 & R \\
5 & R \\
10 & R \\
5 & R \\
5 & R\end{array}$ & (10 & $\begin{array}{rl}5 & W \\
5 & W \\
10 & R \\
5 & W \\
5 & W\end{array}$ & $\begin{array}{rl}5 & R \\
5 & R \\
10 & R \\
5 & R \\
5 & R\end{array}$ \\
\hline $\begin{array}{l}\text { vinyl Acetate } \\
\text { Bromodichloromethare } \\
1,2-\text { ichloropropane } \\
\text { cis-1 3-0ichloropropene } \\
\text { Irichloroethene }\end{array}$ & $\begin{array}{rl}10 & R \\
5 & R \\
5 & R \\
5 & R \\
5 & R\end{array}$ & 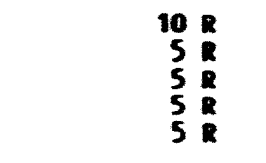 & $\begin{array}{l}\cdots \\
\cdots \\
\cdots \\
\cdots\end{array}$ & 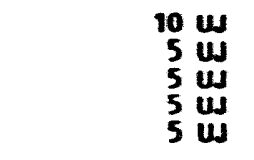 & $\begin{array}{l}10 R \\
5 \\
5 \\
5 \\
5 \\
5 R \\
5 R\end{array}$ \\
\hline $\begin{array}{l}\text { Dibramochloromethane } \\
\text { 1,1,2-Irichloroethane } \\
\text { Beniene } \\
\text { Irans-1,3-Dichl oropropene } \\
\text { Bromofori }\end{array}$ & $\begin{array}{ll}5 & R \\
5 & R \\
5 & R \\
5 & R \\
5 & R\end{array}$ & $\begin{array}{ll}5 & R \\
5 & R \\
5 & R \\
5 & R \\
5 & R\end{array}$ & $\cdots$ & $\begin{array}{l}5 \mathrm{w} \\
5 \mathrm{Wu} \\
5 \mathrm{Wu} \\
5 \mathrm{Wu} \\
5\end{array}$ & $\begin{array}{ll}5 & R \\
5 & 2 \\
5 & 8 \\
5 & 8 \\
5 & 8\end{array}$ \\
\hline $\begin{array}{l}\text { 4-Methyl-2-Pentanone } \\
\text { 2-Hexanone } \\
\text { Jetrachioroethene } \\
1,1,2,2 \text {-Tetrachloroethane } \\
\text { Ioluene }\end{array}$ & $\begin{array}{ll}10 & R \\
10 & R \\
5 & R \\
5 & R \\
5 & R\end{array}$ & $\begin{array}{ll}10 & R \\
10 & R \\
5 & R \\
5 & R \\
5 & R\end{array}$ & $\begin{array}{l}\cdots \\
10 \\
\cdots \\
\cdots\end{array}$ & $\begin{array}{rl}10 & \mathrm{~W} \\
10 & R \\
5 & \mathrm{~W} \\
5 & \mathrm{UJ} \\
5 & \mathrm{UJ}\end{array}$ & $\begin{array}{rl}10 & R \\
10 & R \\
5 & R \\
5 & R \\
3 & J\end{array}$ \\
\hline $\begin{array}{l}\text { Chlorobenzene } \\
\text { Ethylbenzene } \\
\text { Styrese } \\
\text { xylere (total) }\end{array}$ & $\begin{array}{ll}5 & R \\
5 & R \\
5 & R \\
5 & R\end{array}$ & $\begin{array}{ll}5 & R \\
5 & R \\
5 & R \\
5 & R\end{array}$ & $\begin{array}{l}\cdots \\
\cdots \\
\cdots\end{array}$ & $\begin{array}{l}5 \text { w } \\
5 \text { w } \\
5 \\
5\end{array}$ & $\begin{array}{ll}5 & R \\
2 & J \\
5 & R \\
8 & J\end{array}$ \\
\hline $\begin{array}{l}\text { Dilution factor } \\
\text { Jotal (All owed) Hold tice }\end{array}$ & $29(14) d^{1000}$ & $30(14) d^{1000}$ & $\begin{array}{r}1.000 \\
12(16) d\end{array}$ & $\begin{array}{r}1.000 \\
16(16) d\end{array}$ & $\begin{array}{l}1.000 \\
33(16) d^{*}\end{array}$ \\
\hline
\end{tabular}

2-12-93 
ISF Evaporation Pond Sen Date Document

November 1909 . Method Validation Level A

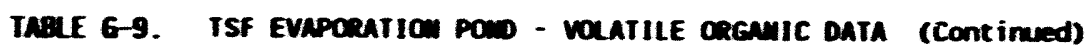

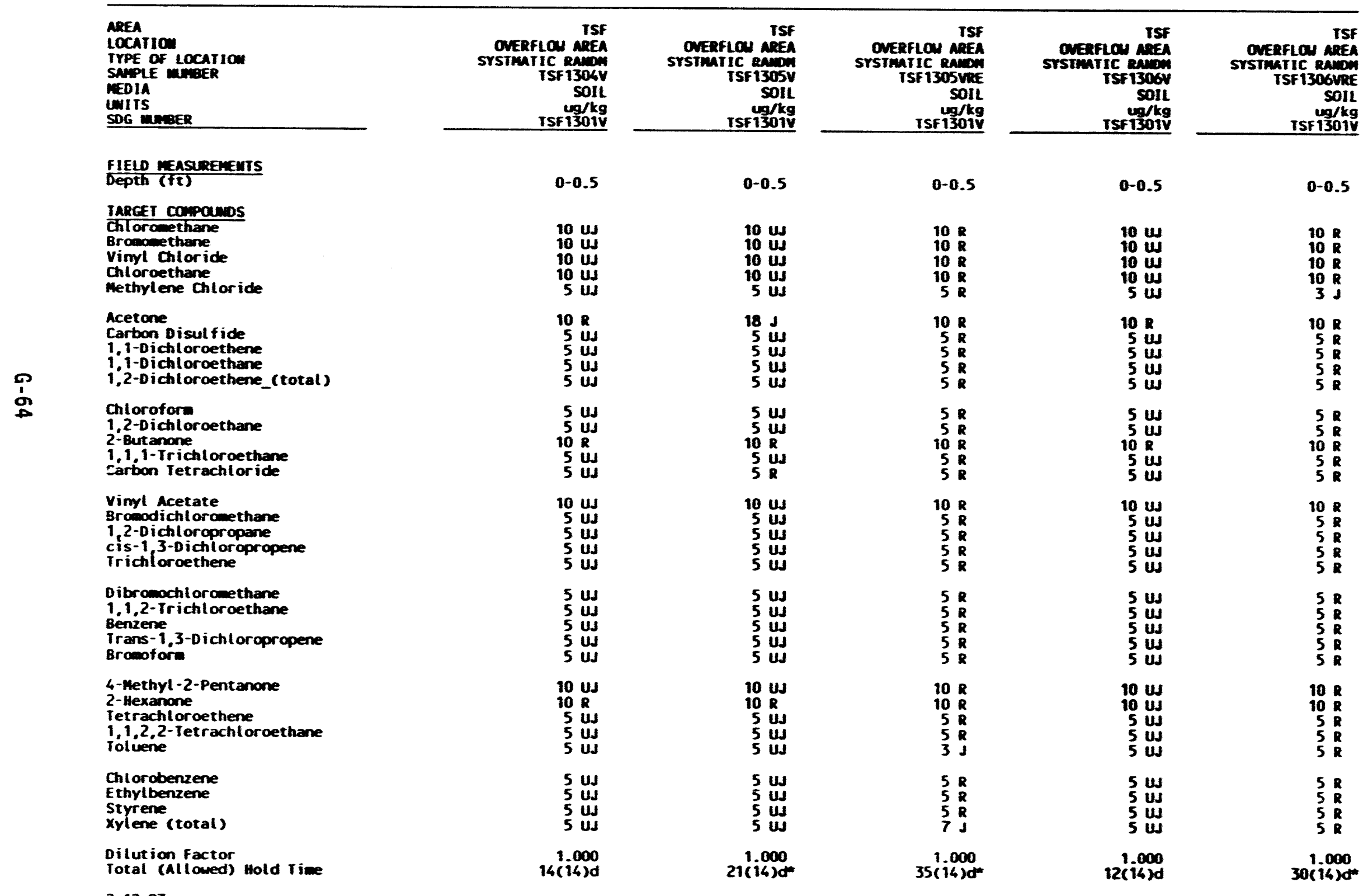


ISF Eveporation Pond SeA Data Document

Noverber 1909 - Method Validation Level a

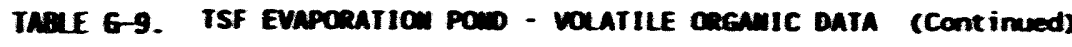

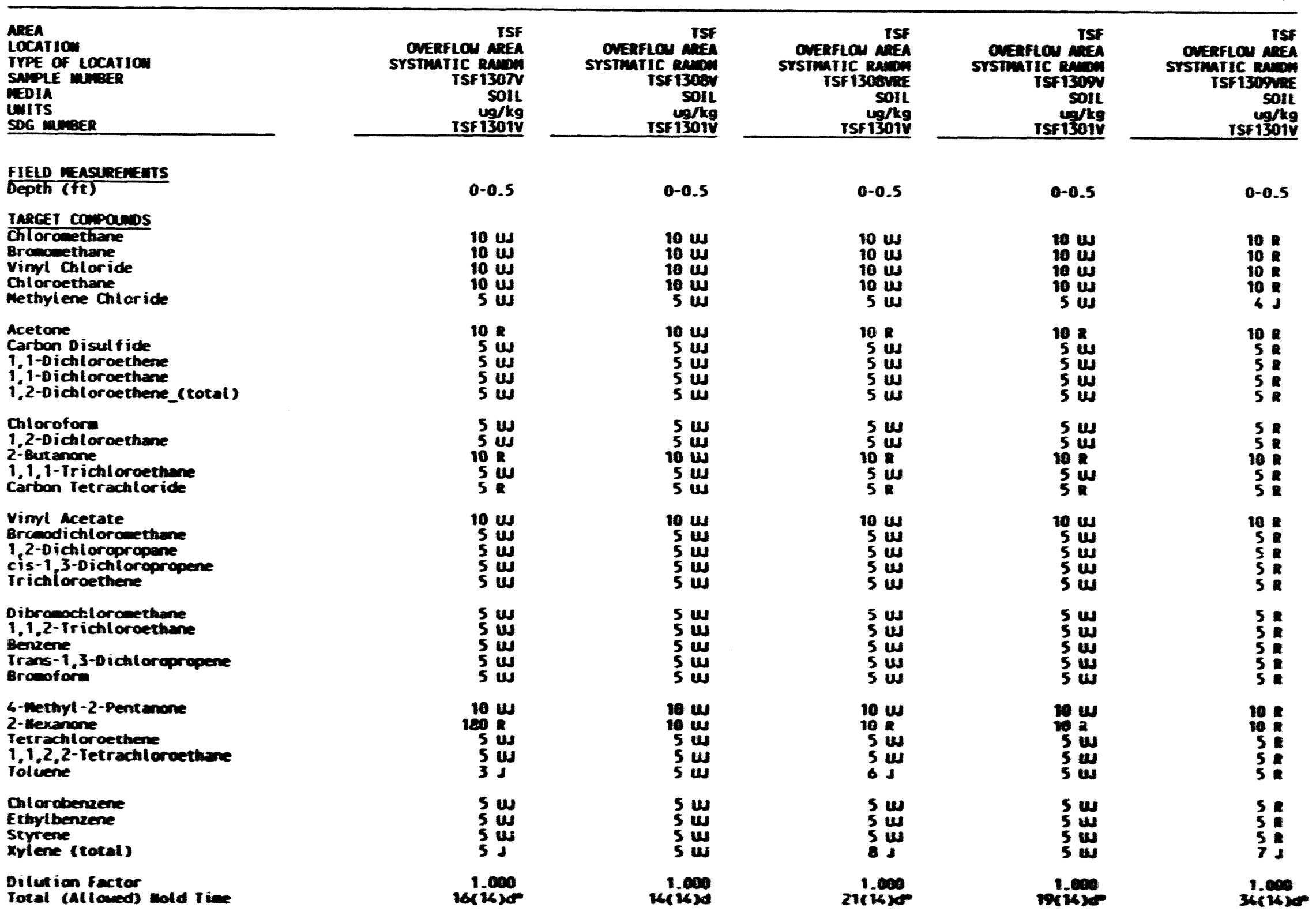

2-12-93 
ISF Evaporation Pond S\&A Data Document - Movember 1989 - Method Validation Level A

table 6-9. ISF eVAPORation POND - Volatile organic data (Cont inued)

\begin{tabular}{|c|c|c|c|c|c|}
\hline $\begin{array}{l}\text { AREA } \\
\text { LOCATIOM } \\
\text { TYPE OF LOCATION } \\
\text { SAMPLE MUMBER } \\
\text { MEDIA } \\
\text { UNITS } \\
\text { SDG NUMBER } \\
\end{array}$ & $\begin{array}{r}\text { TSF } \\
\text { OVERFLON AREA } \\
\text { SYSTMATIC RAHDH } \\
\text { TSF 1310V } \\
\text { SOIL } \\
\text { Ug/kg } \\
\text { TSFO101A } \\
\end{array}$ & $\begin{array}{r}\text { TSF } \\
\text { OVERFLON AREA } \\
\text { SYSTMATIC RANDM } \\
\text { TSF1310V } \\
\text { SOIL } \\
\text { Ug/kg } \\
\text { TSF1301V } \\
\end{array}$ & $\begin{array}{r}\text { TSF } \\
\text { OVERFLOW AREA } \\
\text { SYSTMATIC RANDH } \\
\text { ISF1310VRE } \\
\text { SOIL } \\
\text { ug/kg } \\
\text { ISF1301V } \\
\end{array}$ & $\begin{array}{r}\text { TSF } \\
\text { OVERFLOW AREA } \\
\text { SYSTMATIC RANOH } \\
\text { TSF 1310VRE } \\
\text { SOIL } \\
\text { Ug/kg } \\
\text { TSF 1301V } \\
\end{array}$ & $\begin{array}{r}\text { TSF } \\
\text { OVERFLOW AREA } \\
\text { SYSTMATIC RANDW } \\
\text { TSF 1310VRE } \\
\text { SOIL } \\
\text { ug/kg } \\
\text { TSF1301V } \\
\end{array}$ \\
\hline $\begin{array}{l}\text { FIELD MEASUREMENIS } \\
\text { Depth }(\mathrm{ft})\end{array}$ & $0-0.5$ & $0-0.5$ & $0-0.5$ & $0-0.5$ & $0-0.5$ \\
\hline $\begin{array}{l}\text { TARGET COMPOUNDS } \\
\text { Chloromethane } \\
\text { Bromomethane } \\
\text { Vinyl Chloride } \\
\text { Chloroethane } \\
\text { Methylene Chloride }\end{array}$ & $\begin{array}{l}10 \text { UJ } \\
10 \text { UJ } \\
10 \text { UJ } \\
10 \text { UJ } \\
5 \text { UJ }\end{array}$ & $\begin{array}{l}10 \text { UJ } \\
10 \text { UJ } \\
10 \text { UJ } \\
10 \text { UJ } \\
5 \text { UJ }\end{array}$ & $\begin{array}{l}10 \text { UJ } \\
10 \text { UJ } \\
10 \text { UJ } \\
10 \text { UJ } \\
5 \text { UJ }\end{array}$ & $\begin{array}{rl}10 & R \\
10 & R \\
10 & R \\
10 & R \\
5 & R\end{array}$ & $\begin{array}{rl}10 & R \\
10 & R \\
10 & R \\
10 & R \\
5 & R\end{array}$ \\
\hline $\begin{array}{l}\text { Acetone } \\
\text { Carbon Disulfide } \\
\text { 1,1-Dichloroethene } \\
\text { 1,1-Dichloroethane } \\
1,2-\text { Dichloroethene_(total) }\end{array}$ & $\begin{array}{rl}10 & R \\
5 & U J \\
5 & U J \\
5 & U J \\
5 & U J\end{array}$ & $\begin{array}{rl}10 & R \\
5 & U J \\
5 & U J \\
5 & U J \\
5 & U J\end{array}$ & $\begin{array}{rl}10 & R \\
5 & U J \\
5 & U J \\
5 & U J \\
5 & U J\end{array}$ & $\begin{array}{rl}10 & R \\
5 & R \\
5 & R \\
5 & R \\
5 & R\end{array}$ & $\begin{array}{ll}3 & J \\
5 & R \\
5 & R \\
5 & R \\
5 & R\end{array}$ \\
\hline $\begin{array}{l}\text { Chloroform } \\
1,2-D i c h l o r o e t h a n e \\
2-\text { Butanone } \\
1,1,1-\text { Trichloroethane } \\
\text { Carbon Tetrachloride }\end{array}$ & $\begin{aligned} 5 & \text { UJ } \\
5 & \text { UJ } \\
10 & \text { UJ } \\
5 & \text { UJ } \\
5 & \text { UJ }\end{aligned}$ & $\begin{array}{rl}5 & U J \\
5 & U J \\
10 & U J \\
5 & U J \\
5 & U J\end{array}$ & $\begin{array}{rl}5 & U J \\
5 & U J \\
10 & U J \\
5 & U J \\
5 & U J\end{array}$ & $\begin{array}{rl}5 & R \\
5 & R \\
10 & R \\
5 & R \\
5 & R\end{array}$ & $\begin{array}{rl}5 & R \\
5 & R \\
10 & R \\
5 & R \\
5 & R\end{array}$ \\
\hline $\begin{array}{l}\text { Vinyl Acetate } \\
\text { Bromodichloromethane } \\
1,2-D i c h l o r o p r o p a n e \\
\text { cis-1 3-Dichloropropene } \\
\text { Irichloroethene }\end{array}$ & $\begin{array}{rl}10 & \text { UJ } \\
5 & U J \\
5 & U J \\
5 & U J \\
5 & U J\end{array}$ & $\begin{aligned} 10 & \text { UJ } \\
5 & \text { UJ } \\
5 & \text { UJ } \\
5 & \text { U. } \\
5 & \text { UJ }\end{aligned}$ & $\begin{aligned} 10 & \text { UJ } \\
5 & \text { UJ } \\
5 & \text { UJ } \\
5 & \text { UJ } \\
5 & \text { UJ }\end{aligned}$ & $\begin{array}{rl}10 & R \\
5 & R \\
5 & R \\
5 & R \\
5 & R\end{array}$ & $\begin{array}{rl}10 & R \\
5 & R \\
5 & R \\
5 & R \\
5 & R\end{array}$ \\
\hline $\begin{array}{l}\text { Dibromochloromethane } \\
1,1,2-\text { Trichloroethane } \\
\text { Benzene } \\
\text { Irans-1,3-0 ichloropropene } \\
\text { Bromoform }\end{array}$ & $\begin{array}{l}5 \mathrm{UJ} \\
5 \mathrm{UJ} \\
5 \\
5 \mathrm{UJ} \\
5 \\
\mathrm{UJ}\end{array}$ & 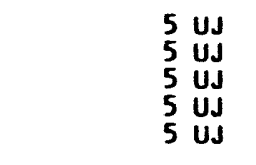 & $\begin{array}{l}5 \\
5 \\
\text { UJ } \\
5 \\
5 \\
\text { UJ } \\
5 \\
\text { UJ }\end{array}$ & $\begin{array}{ll}5 & R \\
5 & R \\
5 & R \\
5 & R \\
5 & R\end{array}$ & $\begin{array}{ll}5 & R \\
5 & R \\
5 & R \\
5 & R \\
5 & R\end{array}$ \\
\hline $\begin{array}{l}\text { 4-Methyl-2-Pentanone } \\
\text { 2-Hexanone } \\
\text { Jetrachloroethene } \\
\text { 1.1,2,2-Tetrachloroethane } \\
\text { Tolvene }\end{array}$ & $\begin{array}{rl}10 & \text { UJ } \\
10 & R \\
5 & U J \\
5 & U J \\
5 & U J\end{array}$ & $\begin{array}{l}10 \text { UJ } \\
10 \text { UJ } \\
5 \text { UJ } \\
5 \text { UJ } \\
5 \text { UJ }\end{array}$ & $\begin{array}{rl}10 & \text { UJ } \\
10 & R \\
5 & \text { UJ } \\
5 & \text { UJ } \\
5 & \text { UJ }\end{array}$ & $\begin{array}{ll}10 & R \\
10 & R \\
5 & R \\
5 & R \\
5 & R\end{array}$ & $\begin{array}{rl}10 & R \\
10 & R \\
5 & R \\
5 & R \\
5 & R\end{array}$ \\
\hline $\begin{array}{l}\text { Chlorobenzene } \\
\text { Ethylbenzene } \\
\text { Styrene } \\
\text { xylene (total) }\end{array}$ & $\begin{array}{l}5 \text { UJ } \\
5 \text { UJ } \\
5 \text { UJ } \\
4 \text { UJ }\end{array}$ & $\begin{array}{l}5 \text { UJ } \\
5 \\
5 \\
\end{array}$ & $\begin{array}{l}5 \mathrm{UJ} \\
5 \mathrm{UJ} \\
5 \mathrm{UJ} \\
4 \mathrm{~J}\end{array}$ & $\begin{array}{ll}5 & R \\
5 & R \\
5 & R \\
5 & J\end{array}$ & $\begin{array}{ll}5 & R \\
5 & R \\
5 & R \\
4 & J\end{array}$ \\
\hline $\begin{array}{l}\text { Dilution factor } \\
\text { Jotal (Allowed) Hoid time }\end{array}$ & $\begin{array}{c}1.000 \\
25(14) d^{\star}\end{array}$ & $\begin{array}{r}1.000 \\
13(14) d\end{array}$ & $25(14) d^{\star}$ & $\begin{array}{l}1.000 \\
30(16) d^{*}\end{array}$ & $\begin{array}{r}1.000 \\
.30(14) d^{\star}\end{array}$ \\
\hline
\end{tabular}


ISF Evaporation Pond S\&A Data Document - November 1989 - Method Validation Level A

TABIE 6-9. TSF EVAPORATION POND - VOLATILE ORGANIC DATA (Continued)

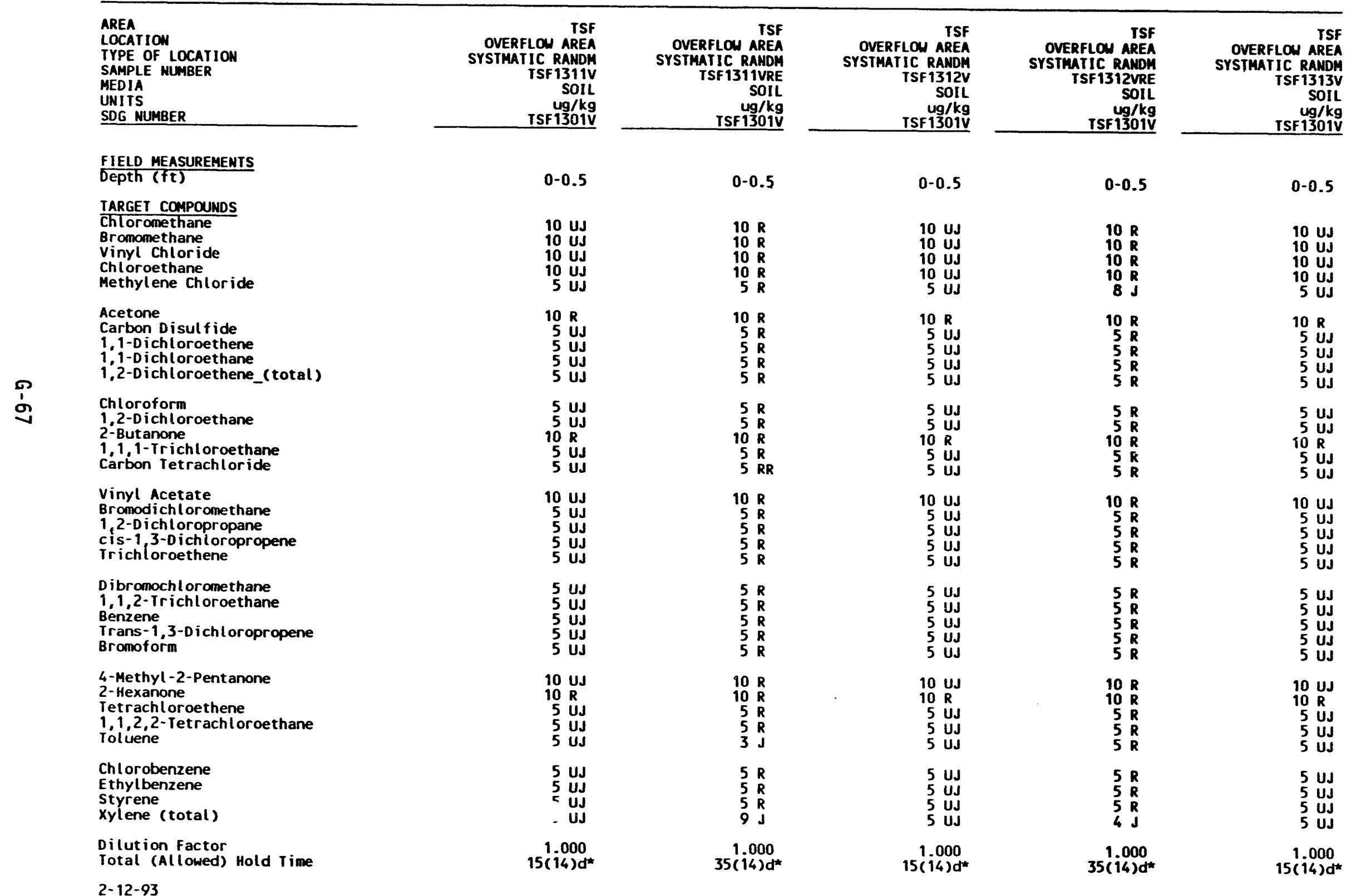


ISF Evaporation Pond S\&A Data Document

November 1989 - Method Validation Level A

TABLE 6-9. TSF EVAPORATION POND - VOLATILE ORgANIC DATA (Cont inued)

\begin{tabular}{|c|c|c|c|c|c|}
\hline $\begin{array}{l}\text { AREA } \\
\text { LOCATION } \\
\text { TYPE OF LOCATION } \\
\text { SAMPLE NUABER } \\
\text { MEDIA } \\
\text { UNITS } \\
\text { SDG NLWBER } \\
\end{array}$ & $\begin{array}{r}\text { TSF } \\
\text { OVERFLOW AREA } \\
\text { SYSTMATIC RANDH } \\
\text { TSF 1314V } \\
\text { SOIL } \\
\text { Ug/kg } \\
\text { TSF } 1301 \mathrm{k} \\
\end{array}$ & $\begin{array}{r}\text { TSF } \\
\text { OVERFLOW AREA } \\
\text { SYSTMAIIC RANDH } \\
\text { TSF 1314VRE } \\
\text { SOIL } \\
\text { ug/kg } \\
\text { TSF } 1301 \mathrm{k} \\
\end{array}$ & $\begin{array}{r}\text { TSF } \\
\text { OVERFLOW AREA } \\
\text { SYSTMATIC RANDM } \\
\text { TSF } 1314 \text { VRE } \\
\text { SOIL } \\
\text { ug/kg } \\
\text { TSF } 1301 \mathrm{~V} \\
\end{array}$ & $\begin{array}{r}\text { TSF } \\
\text { OVERFLON AREA } \\
\text { SYSTHATIC RAMOH } \\
\text { TSF 1314VRE } \\
\text { SOIL } \\
\text { Ug/kg } \\
\text { TSF1301V } \\
\end{array}$ & $\begin{array}{r}\text { TSF } \\
\text { OVERFLON AREA } \\
\text { SYSTMATIC RANDH } \\
\text { TSF1315V } \\
\text { SOIL } \\
\text { ugikg } \\
\text { TSF1301V } \\
\end{array}$ \\
\hline $\begin{array}{l}\text { FIELD MEASUREMENTS } \\
\text { Depth (ft })\end{array}$ & $0-0.5$ & $0-0.5$ & $0-0.5$ & $0-0.5$ & $0-0.5$ \\
\hline $\begin{array}{l}\text { IARGET CoMPOUNDS } \\
\text { Chloromethane } \\
\text { Bromomethane } \\
\text { Vinyl Chloride } \\
\text { Chloroethane } \\
\text { Methylene Chloride }\end{array}$ & $\begin{aligned} 10 & \text { UJ } \\
10 & \text { UJ } \\
10 & \text { UJ } \\
10 & \text { UJ } \\
5 & \text { UJ }\end{aligned}$ & $\begin{array}{l}10 \text { UJ } \\
10 \text { UJ } \\
10 \text { UJ } \\
10 \text { UJ } \\
5 \text { UJ }\end{array}$ & $\begin{aligned} 10 R \\
10 R \\
10 R \\
10 R \\
5 R\end{aligned}$ & $\begin{array}{l}10 R \\
10 R \\
10 R \\
10 R \\
5 R\end{array}$ & $\begin{aligned} 10 & \text { UJ } \\
10 & \text { UJ } \\
10 & \text { UJ } \\
10 & \text { UJ } \\
5 & \text { UJ }\end{aligned}$ \\
\hline $\begin{array}{l}\text { Acetone } \\
\text { Carbon Disulfide } \\
1,1-D i c h \text { icoroethene } \\
1,1-D i c h l o r o e t h a n e \\
1,2-D i c h \text { loroethene_(total) }\end{array}$ & $\begin{array}{l}4 \\
5 \\
5 \\
5 \\
J J \\
5 \\
5 \\
\text { UJ }\end{array}$ & $\begin{array}{rl}10 & R \\
5 & \text { UJ } \\
5 & \text { UJ } \\
5 & \text { UJ } \\
5 & \text { UJ }\end{array}$ & $\begin{array}{rl}10 & R \\
5 & R \\
5 & R \\
5 & R \\
5 & R\end{array}$ & $\begin{array}{rl}10 & R \\
5 & R \\
5 & R \\
5 & R \\
5 & R\end{array}$ & $\begin{array}{rl}10 & R \\
5 & \text { UJ } \\
5 & \text { UJ } \\
5 & \text { UJ } \\
5 & \text { UJ }\end{array}$ \\
\hline $\begin{array}{l}\text { Chloroform } \\
\text { 1,2-0ichloroethane } \\
\text { 2-Butanone } \\
1,1,1-\text { Trichloroethane } \\
\text { Carbon Tetrachloride }\end{array}$ & $\begin{aligned} 5 & \text { UJ } \\
5 & \text { UJ } \\
10 & \text { UJ } \\
5 & \text { UJ } \\
5 & \text { UJ }\end{aligned}$ & $\begin{array}{rl}5 & \text { UJ } \\
5 & \text { UJ } \\
10 & R \\
5 & \text { UJ } \\
5 & R\end{array}$ & $\begin{array}{rl}5 & R \\
5 & R \\
10 & R \\
5 & R \\
5 & R\end{array}$ & $\begin{array}{rl}5 & R \\
5 & R \\
10 & R \\
5 & R \\
5 & R\end{array}$ & $\begin{array}{rl}5 & \text { UJ } \\
5 & \text { UJ } \\
10 & R \\
5 & \text { UJ } \\
5 & \text { UJ }\end{array}$ \\
\hline $\begin{array}{l}\text { Vinyl Acetate } \\
\text { Bromodichloromethane } \\
1,2-D \text { ichloropropane } \\
\text { cis-1, 3-Dichloropropene } \\
\text { Trichloroethene }\end{array}$ & $\begin{aligned} 10 & \text { UJ } \\
5 & \text { UJ } \\
5 & \text { UJ } \\
5 & \text { UJ } \\
5 & \text { UJ }\end{aligned}$ & $\begin{aligned} 10 & \text { UJ } \\
5 & \text { UJ } \\
5 & \text { UJ } \\
5 & \text { UJ } \\
5 & \text { UJ }\end{aligned}$ & $\begin{array}{rl}10 & R \\
5 & R \\
5 & R \\
5 & R \\
5 & R\end{array}$ & $\begin{array}{rl}10 & R \\
5 & R \\
5 & R \\
5 & R \\
5 & R\end{array}$ & $\begin{aligned} 10 & \text { UJ } \\
5 & \text { UJ } \\
5 & \text { UJ } \\
5 & \text { UJ } \\
5 & \text { UJ }\end{aligned}$ \\
\hline $\begin{array}{l}\text { Dibromochloromethane } \\
1,1,2-\text { - Trichloroethane } \\
\text { Benzene } \\
\text { Irans-1,3-Dichloropropene } \\
\text { Bromoform }\end{array}$ & 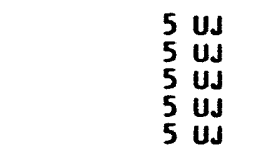 & $\begin{array}{l}5 \\
5 \\
\text { UJ } \\
5 \\
5 \mathrm{UJ} \\
5 \\
5 \\
\text { UJ }\end{array}$ & $\begin{array}{ll}5 & R \\
5 & R \\
5 & R \\
5 & R \\
5 & R\end{array}$ & $\begin{array}{ll}5 & R \\
5 & R \\
5 & R \\
5 & R \\
5 & R\end{array}$ & 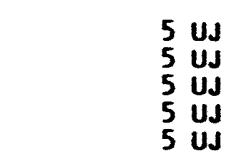 \\
\hline $\begin{array}{l}\text { 4-Methyl-2- sentanone } \\
\text { 2-Hexanone } \\
\text { Tetrachloroe :hene } \\
1,1,2,2-\text { Tetrichloroethane } \\
\text { Toluene }\end{array}$ & $\begin{aligned} 10 & \text { UJ } \\
10 & \text { UJ } \\
5 & \text { UJ } \\
5 & \text { UJ } \\
5 & \text { UJ }\end{aligned}$ & $\begin{array}{rl}10 & \text { UJ } \\
14 & R \\
5 & \text { UJ } \\
5 & \text { UJ } \\
5 & \text { UJ }\end{array}$ & $\begin{array}{rl}10 & R \\
10 & R \\
5 & R \\
5 & R \\
5 & J\end{array}$ & $\begin{array}{rl}10 & R \\
10 & R \\
5 & R \\
5 & R \\
4 & J\end{array}$ & $\begin{array}{rl}10 & \text { UJ } \\
10 & R \\
5 & \text { UJ } \\
5 & \text { UJ } \\
5 & \text { UJ }\end{array}$ \\
\hline $\begin{array}{l}\text { Chlorobenzene } \\
\text { Ethylbenzene } \\
\text { Styrene } \\
\text { xylene (total) }\end{array}$ & $\begin{array}{l}5 \text { UJ } \\
5 \\
5 \\
\text { UJ } \\
5 \\
\text { UJ }\end{array}$ & $\begin{array}{l}5 \text { UJ } \\
5 \\
5 \\
\text { UJ } \\
4 \\
J\end{array}$ & $\begin{array}{rl}5 & R \\
7 & J \\
5 & R \\
12 & J\end{array}$ & $\begin{array}{ll}5 & R \\
5 & J \\
5 & R \\
9 & J\end{array}$ & $\begin{array}{ll}5 & \text { UJ } \\
5 & U J \\
5 & U J \\
5 & U J\end{array}$ \\
\hline $\begin{array}{l}\text { Dilution factor } \\
\text { rotal (Allowed) Hold Time }\end{array}$ & $\begin{array}{r}1,000 \\
13(14) d\end{array}$ & $16(14) d^{*}$ & $30(14) d^{1 *}$ & $30(14) d^{*}$ & $15(14) d^{\star *}$ \\
\hline
\end{tabular}


ISF Evaporation Pond S\&A Data Document - Movember 1989 - Method Val idation Level A

TABLE 6-9. ISF EVAPORATION PONd - VOLATILE ORganic data (Cóntimued)

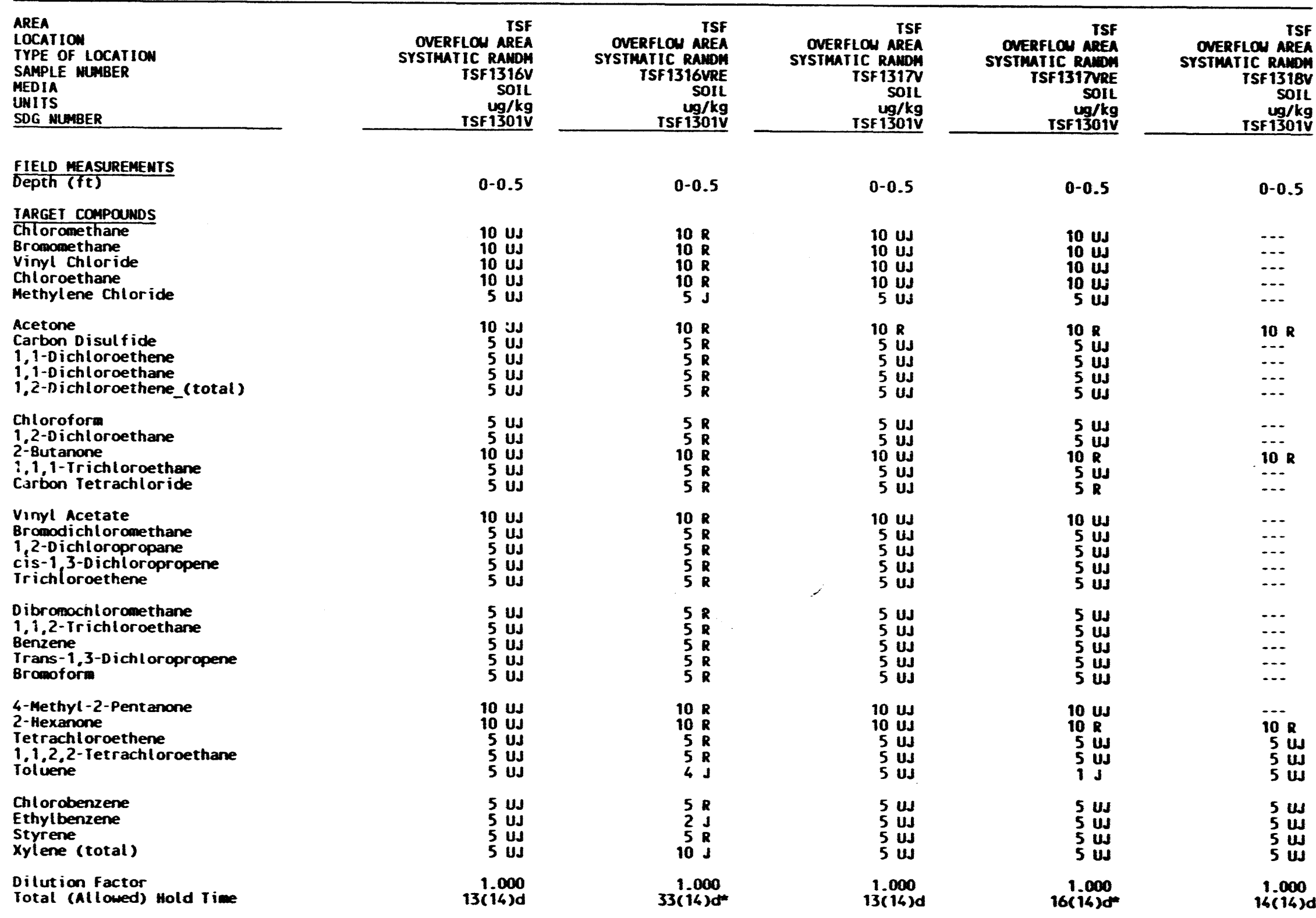


ISF Evaporation Pand SeA Data Document

Nove-ber 1909 - Method Validation Level A

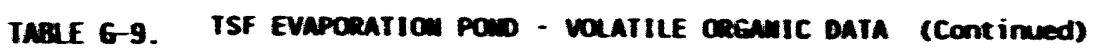

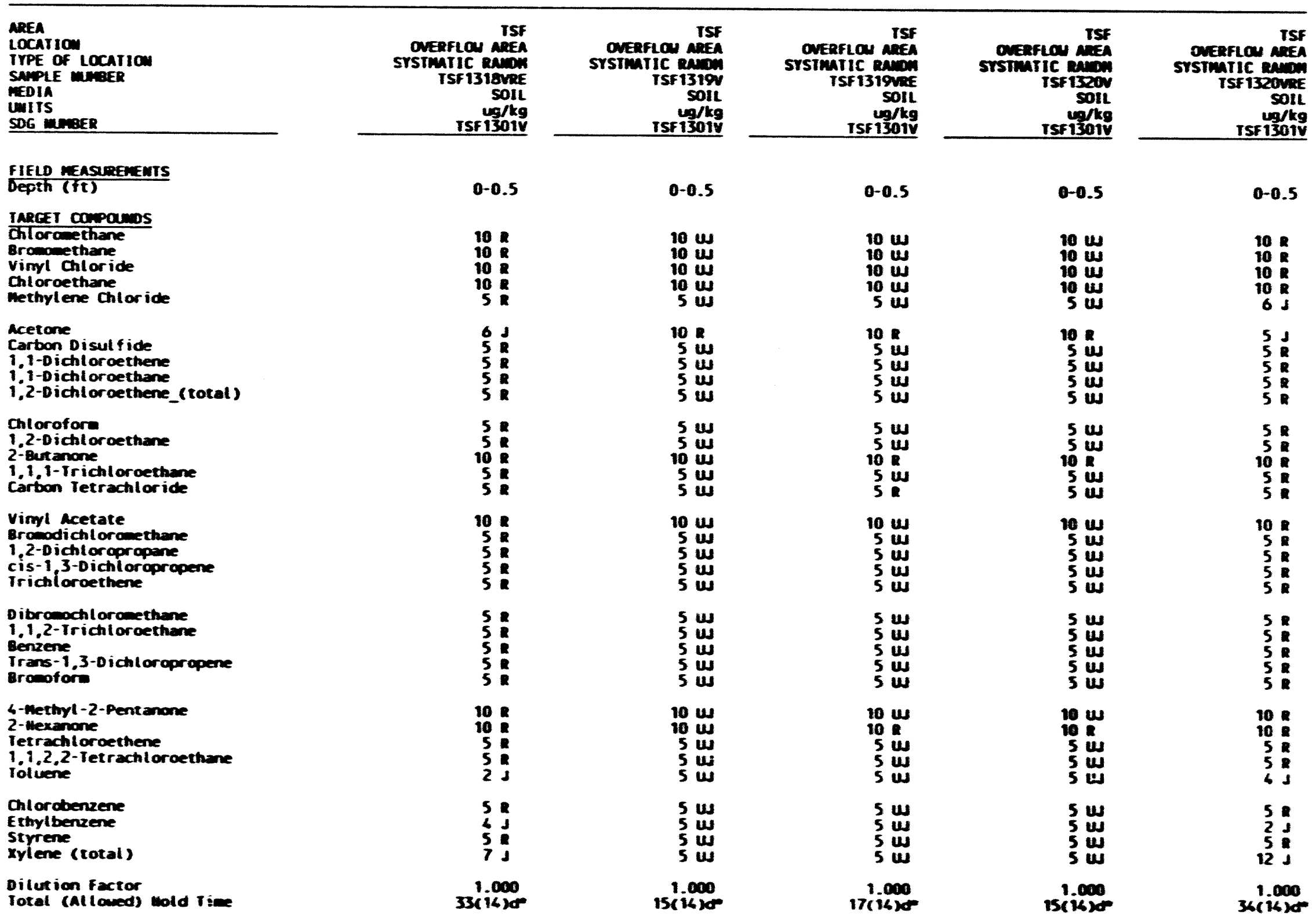

2-12-93 
ISf Eveporation Pand se Bata Document

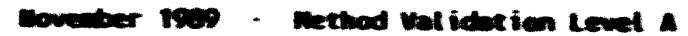

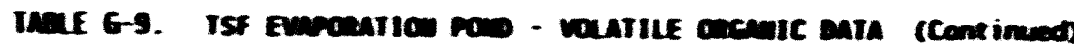

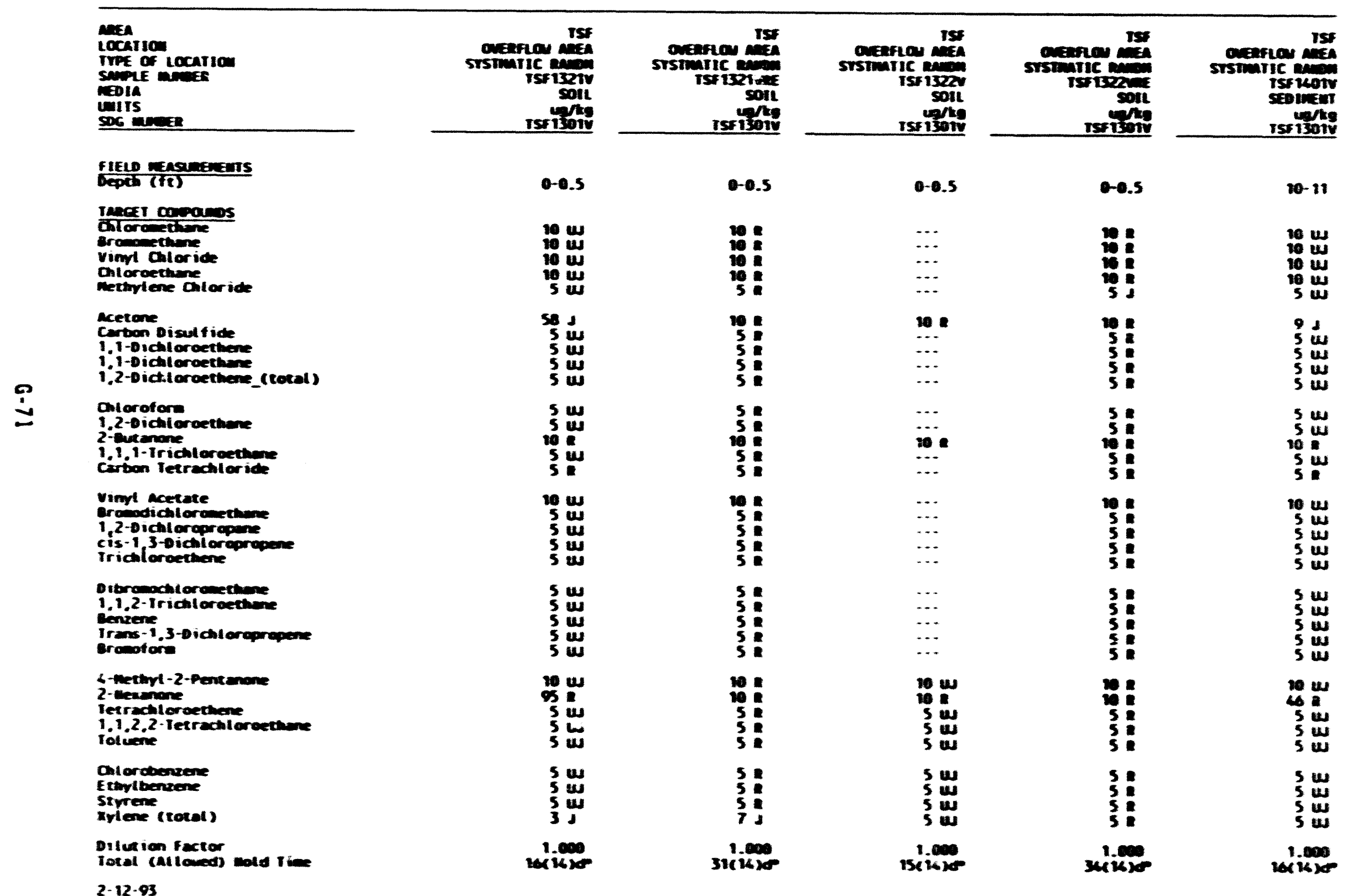




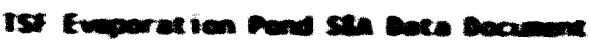
$\rightarrow$

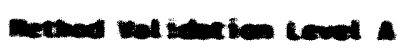

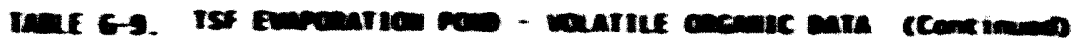

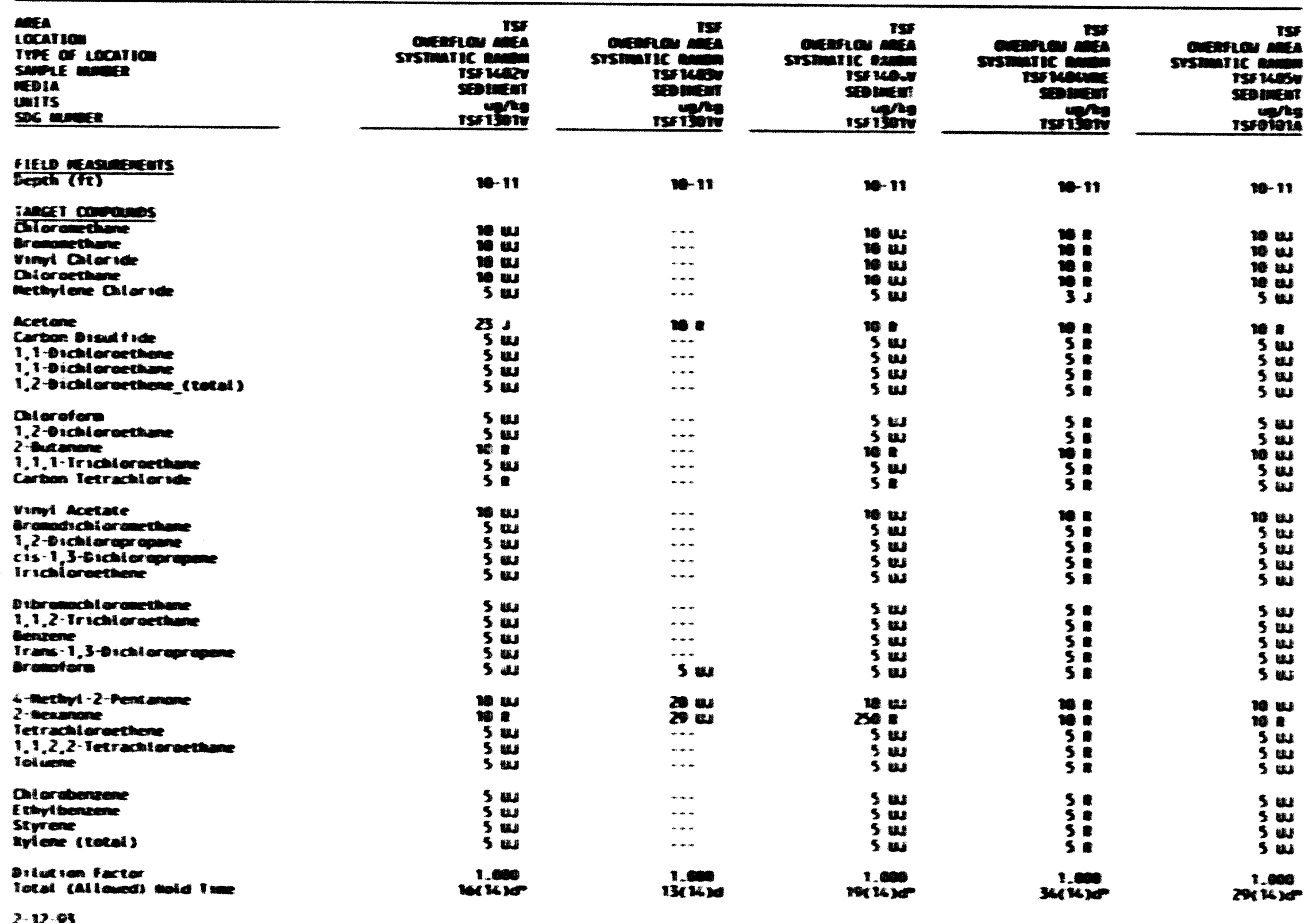




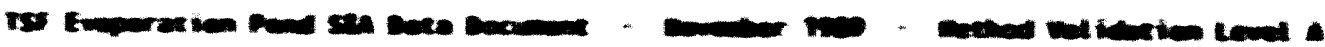

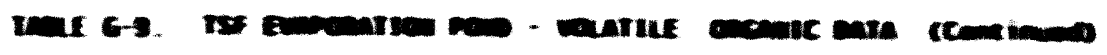

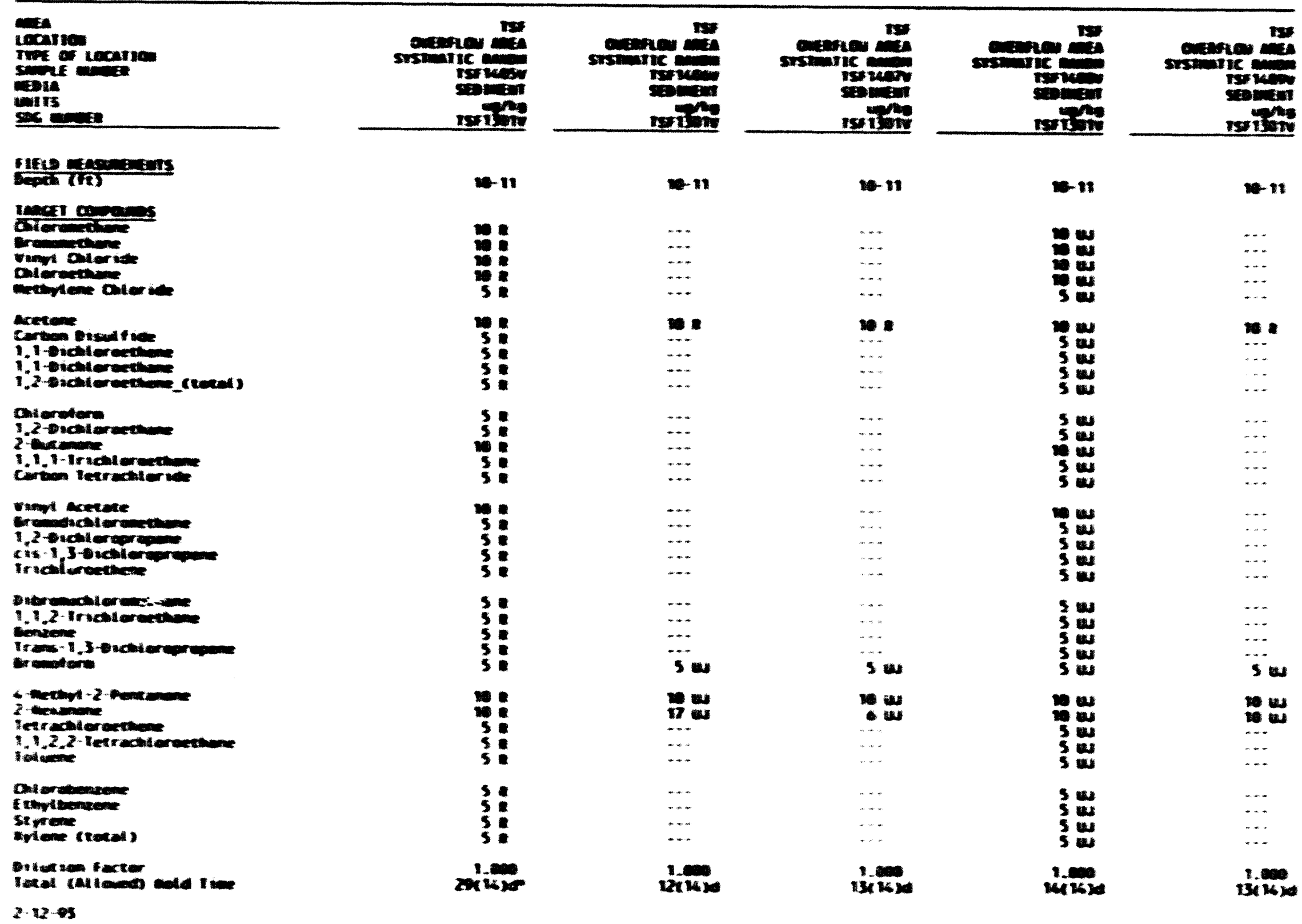




\begin{tabular}{|c|c|c|}
\hline arm & & ${ }^{\infty x / s}$ \\
\hline $\begin{array}{l}m s \\
m s \\
m s \\
m s \\
m s\end{array}$ & & $\begin{array}{l}\ldots \\
\ldots \\
\ldots\end{array}$ \\
\hline $\begin{array}{c}m 5 \\
m 5 \\
m 5 \\
m \\
m\end{array}$ & mexex & $\begin{array}{c}\cdots \\
\cdots \\
\cdots\end{array}$ \\
\hline $\begin{array}{l}m s \\
m s \\
m y s \\
m \\
m \\
m \\
m\end{array}$ & & $\begin{array}{c}\ldots \\
\cdots \\
\cdots \\
\cdots\end{array}$ \\
\hline $\begin{array}{l}m s \\
m 5 \\
m 5 \\
m 5 \\
m b\end{array}$ & & $\begin{array}{l}\cdots \\
\cdots \\
\cdots\end{array}$ \\
\hline 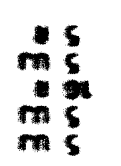 & & $\ddot{\cdots}$ \\
\hline 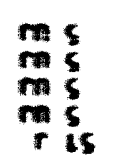 & & $\begin{array}{l}\ldots \\
\cdots \\
\cdots \\
\cdots\end{array}$ \\
\hline $\begin{array}{l}r q \\
m a \\
m a\end{array}$ & & $\ldots$ \\
\hline
\end{tabular}

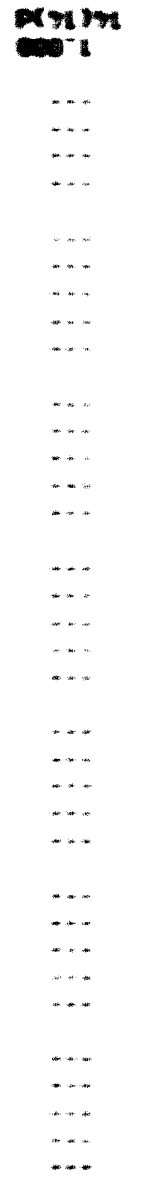

set 2

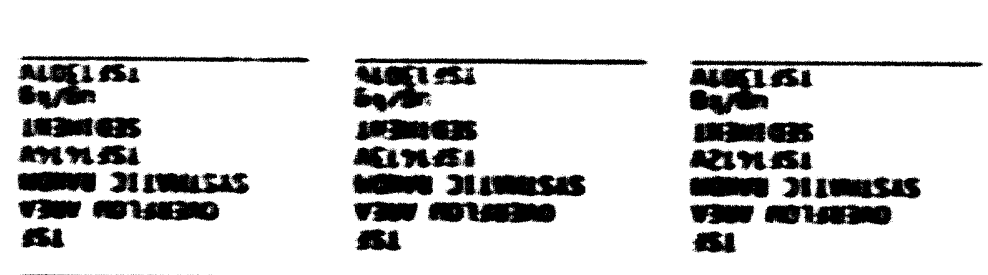

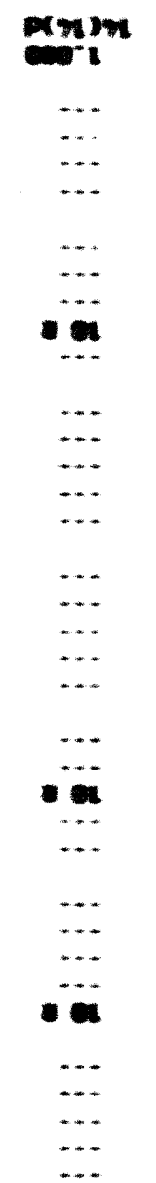

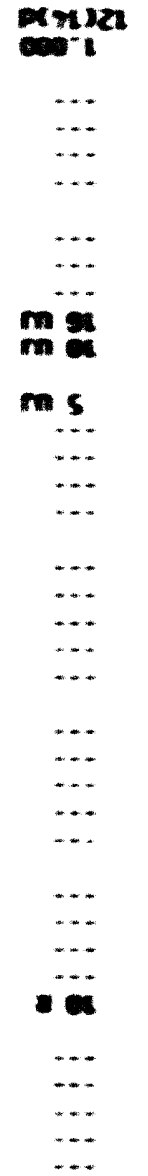

in

4at pre colvi mor (venes) anphy conoming moxuchom?

comasoromis and $2 \cdot \sin 2$ -

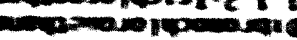

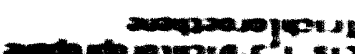
-

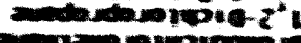

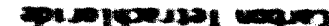

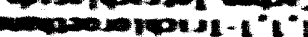
imparez"

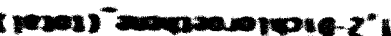
atomese 2000

Tho Ming Man (1) 010

जान (2)

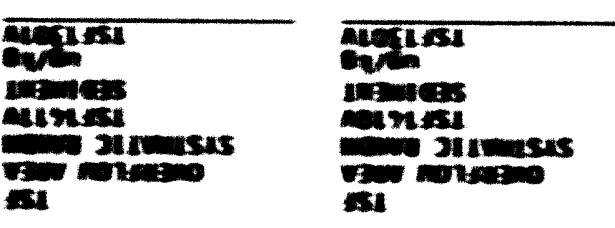
stive vien an 3hes mxos s 3ax wingen 


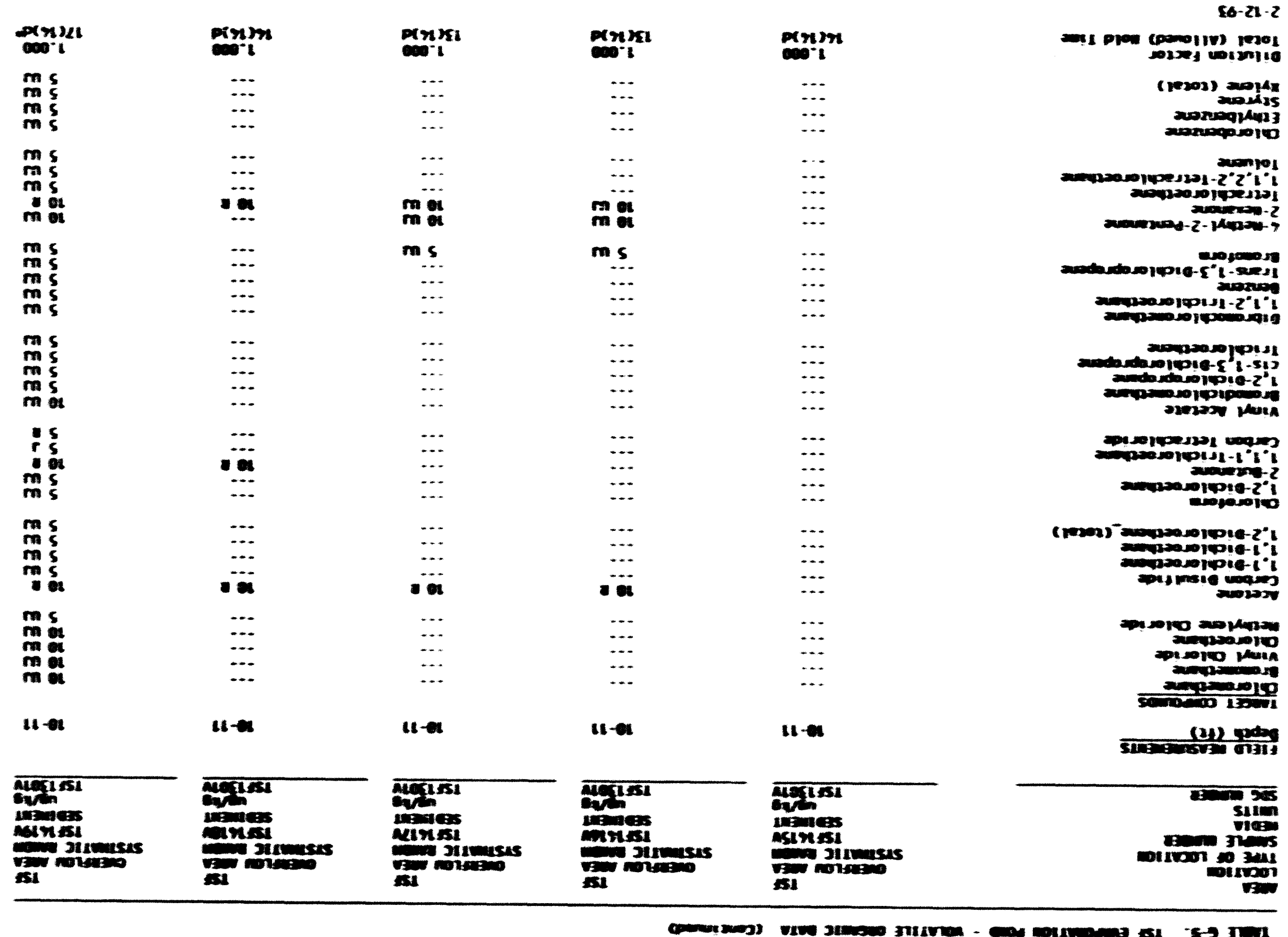

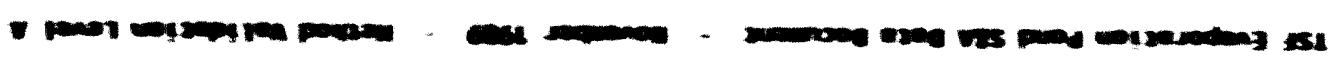




\begin{tabular}{|c|c|c|c|c|c|}
\hline$\left.{ }_{000}^{\infty}+1\right)$ & 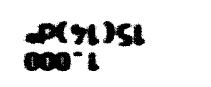 & Dedrist & $p_{0}(x)<1$ & p(r) & 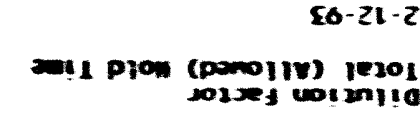 \\
\hline $\begin{array}{l}m s \\
m s \\
m s \\
m s \\
m s\end{array}$ & $\begin{array}{l}m_{n} s \\
m s \\
m s \\
m s \\
m\end{array}$ & $\begin{array}{l}\cdots \\
\cdots \\
\cdots\end{array}$ & $\begin{array}{l}\cdots \\
\cdots \\
\cdots\end{array}$ & $\begin{array}{l}\cdots \\
\cdots \\
\cdots\end{array}$ & 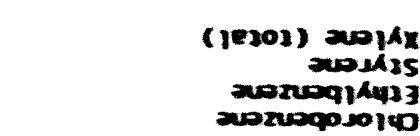 \\
\hline 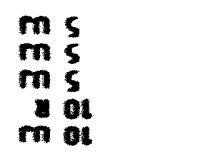 & 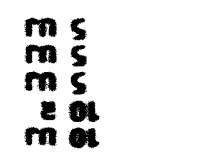 & $\begin{array}{c}\cdots \\
\cdots \\
\cdots\end{array}$ & $\begin{array}{c}\cdots \\
m \text { ou } \\
m\end{array}$ & $\begin{array}{c}\cdots \\
\cdots \\
m a\end{array}$ & 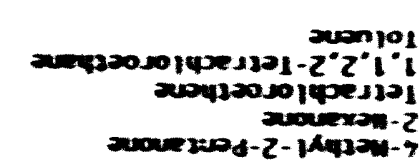 \\
\hline $\begin{array}{l}m s \\
m s \\
m s \\
m s \\
m s\end{array}$ & $\begin{array}{l}m s \\
m \\
m \\
m \\
m \\
m \\
m \\
m \\
m\end{array}$ & $\begin{array}{l}\cdots \\
\cdots \\
\cdots \\
\cdots\end{array}$ & $\begin{array}{c}m \mathbf{m} \\
\cdots \\
\cdots \\
\cdots\end{array}$ & $\begin{array}{l}\cdots \\
\cdots \\
\cdots \\
\cdots\end{array}$ & 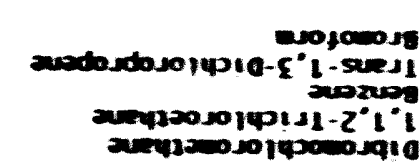 \\
\hline $\begin{array}{l}m s \\
m s \\
m s \\
m \text { s } \\
m \text { ou }\end{array}$ & $\begin{array}{l}\mathbf{m} s \\
\mathbf{m} s \\
\operatorname{ms} s \\
m \text { s } \\
m\end{array}$ & $\begin{array}{l}\cdots \\
\cdots \\
\cdots \\
\cdots\end{array}$ & $\begin{array}{l}\cdots \\
\cdots \\
\cdots \\
\cdots\end{array}$ & $\begin{array}{l}\cdots \\
\cdots \\
\cdots \\
\cdots\end{array}$ & 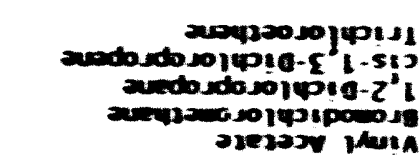 \\
\hline 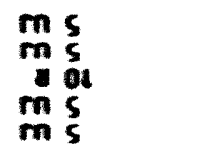 & $\begin{array}{l}m s \\
m s \\
m s \\
m s \\
m s\end{array}$ & $\begin{array}{c}\cdots \\
\cdots \\
\cdots\end{array}$ & $\begin{array}{l}\cdots \\
\cdots \\
\cdots \\
\cdots\end{array}$ & a & 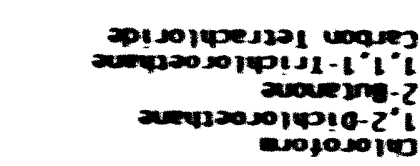 \\
\hline $\begin{array}{l}\min _{m} s \\
m s \\
m \\
m \\
m\end{array}$ & 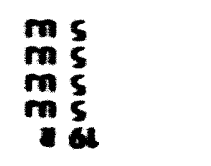 & $\begin{array}{c}\cdots \\
\cdots \\
\cdots \\
\cdots\end{array}$ & $\begin{array}{c}\cdots \\
\cdots \\
\cdots \\
\cdots\end{array}$ & $\begin{array}{c}\cdots \\
\cdots \\
\cdots \\
\cdots\end{array}$ & 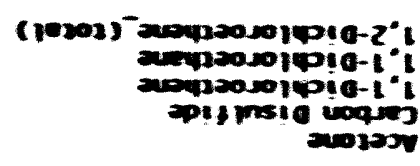 \\
\hline $\begin{array}{l}m s \\
m_{n} \text { or } \\
m \text { or } \\
m \text { or }\end{array}$ & $\begin{array}{l}\mathbf{m} s \\
\mathbf{m} \\
\mathbf{m} \\
\mathbf{m} \\
\mathbf{m}\end{array}$ & $\begin{array}{l}\cdots \\
\cdots \\
\cdots \\
\cdots\end{array}$ & $\begin{array}{l}\cdots \\
\cdots \\
\cdots \\
\cdots\end{array}$ & $\begin{array}{l}\cdots \\
\cdots \\
\cdots \\
\cdots\end{array}$ & 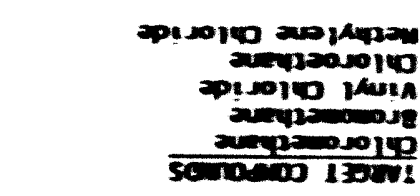 \\
\hline rop & re⿻ & $11-a$ & $18-a$ & 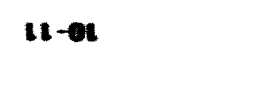 & 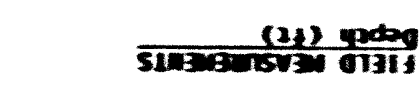 \\
\hline 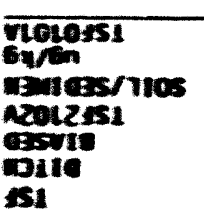 & 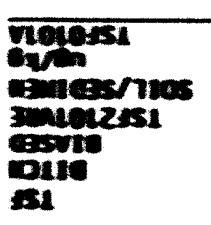 & 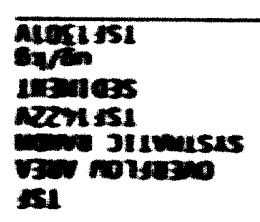 & 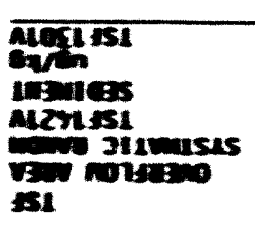 & 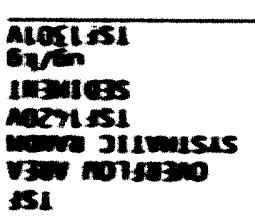 & 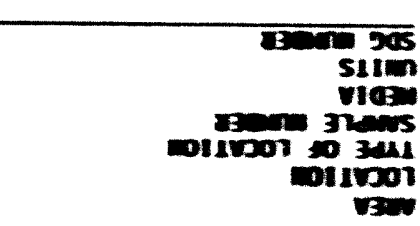 \\
\hline
\end{tabular}

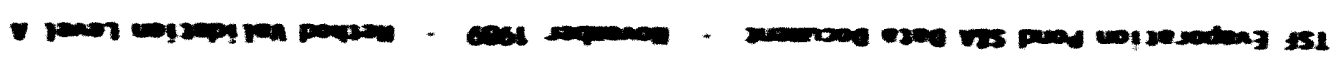




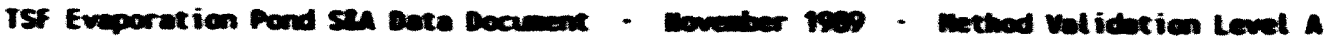

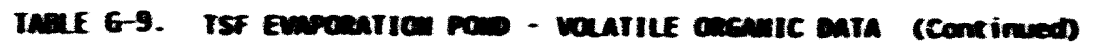

\begin{tabular}{|c|c|c|}
\hline 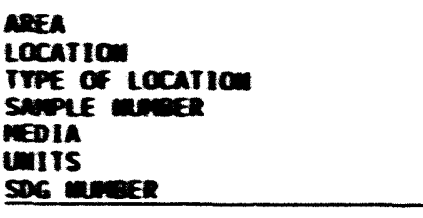 & 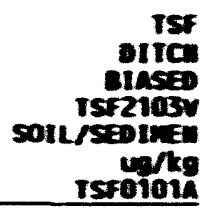 & 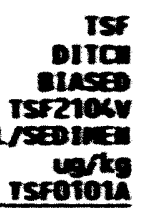 \\
\hline 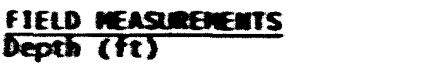 & $0-0.5$ & $0-0.5$ \\
\hline 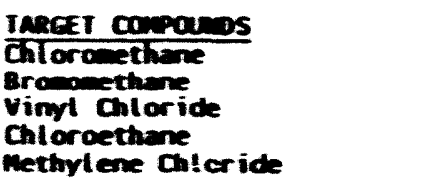 & $\begin{array}{l}10 \mathrm{w} \\
10 \mathrm{w} \\
10 \mathrm{w} \\
10 \mathrm{w} \\
5 \mathrm{w}\end{array}$ & $\begin{array}{l}10 \mathrm{~J} \\
10 \mathrm{u} \\
10 \mathrm{u} \\
10 \mathrm{u} \\
5 \mathrm{u}\end{array}$ \\
\hline 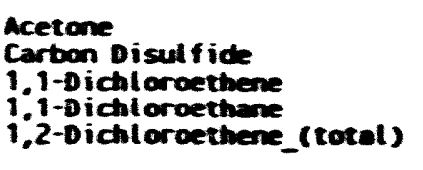 & $\begin{array}{l}19 \text { : } \\
5 \text { us } \\
5 \\
5 \\
5 \\
5\end{array}$ & $\begin{array}{l}10 \text { R } \\
5 \text { w } \\
5 \text { w } \\
5 \text { w } \\
5\end{array}$ \\
\hline 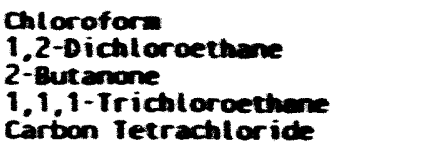 & $\begin{array}{rl}5 & w \\
5 & W \\
10 & 2 \\
5 & W \\
5 & W\end{array}$ & $\begin{array}{r}5 w \\
5 w \\
10 u \\
5 w \\
5 w\end{array}$ \\
\hline $\begin{array}{l}\text { Vimyl Acetate } \\
\text { 8romodichtorcathane } \\
\text { 1,2-Dichtoropropane } \\
\text { cis-1 3-Dichlorcpropene } \\
\text { Irichloroethene }\end{array}$ & $\begin{array}{l}10 \mathrm{w} \\
5 \\
5 \\
5 \\
5\end{array}$ & $\begin{array}{rl}10 & w \\
5 & w \\
5 & w \\
5 & w\end{array}$ \\
\hline $\begin{array}{l}\text { Dibromachloromethane } \\
\text { 1.1,2-Irichloroethame } \\
\text { Bemiene } \\
\text { Irans-1,3-Dichloropropene } \\
\text { Bromotorm }\end{array}$ & $\begin{array}{l}5 \text { w } \\
5 \\
5 \\
5 \\
5 \\
5\end{array}$ & $\begin{array}{l}5 \mathrm{w} \\
5 \mathrm{w} \\
5 \mathrm{w} \\
5 \mathrm{w} \\
5 \mathrm{~W}\end{array}$ \\
\hline 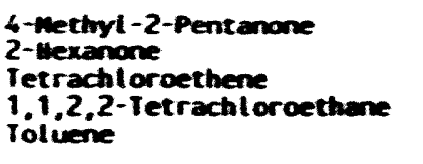 & $\begin{array}{l}10 \mathrm{w} \\
10 \mathrm{R} \\
5 \mathrm{~W} \\
5 \mathrm{Wu} \\
5 \mathrm{~W}\end{array}$ & $\begin{array}{l}10 \mathrm{~W} \\
10 \mathrm{~g} \\
5 \mathrm{Wu} \\
52 \mathrm{~J}\end{array}$ \\
\hline $\begin{array}{l}\text { Chlorabenzene } \\
\text { Ethylbenzene } \\
\text { styrene (total) } \\
\text { xylene (total) }\end{array}$ & $\begin{array}{l}5 \text { u } \\
5 \\
5 \\
5\end{array}$ & $\begin{array}{l}5 \mathrm{w} \\
5 \mathrm{w} \\
5 \mathrm{w} \\
5 \mathrm{w}\end{array}$ \\
\hline $\begin{array}{l}\text { Dilution Factor } \\
\text { Total (Allowed) woid Iive }\end{array}$ & $15^{1}(14) \alpha^{2000}$ & $\begin{array}{c}1.000 \\
15(16) d\end{array}$ \\
\hline
\end{tabular}


Table G-10. Sample numbers for the TSF disposal ponds and sump.

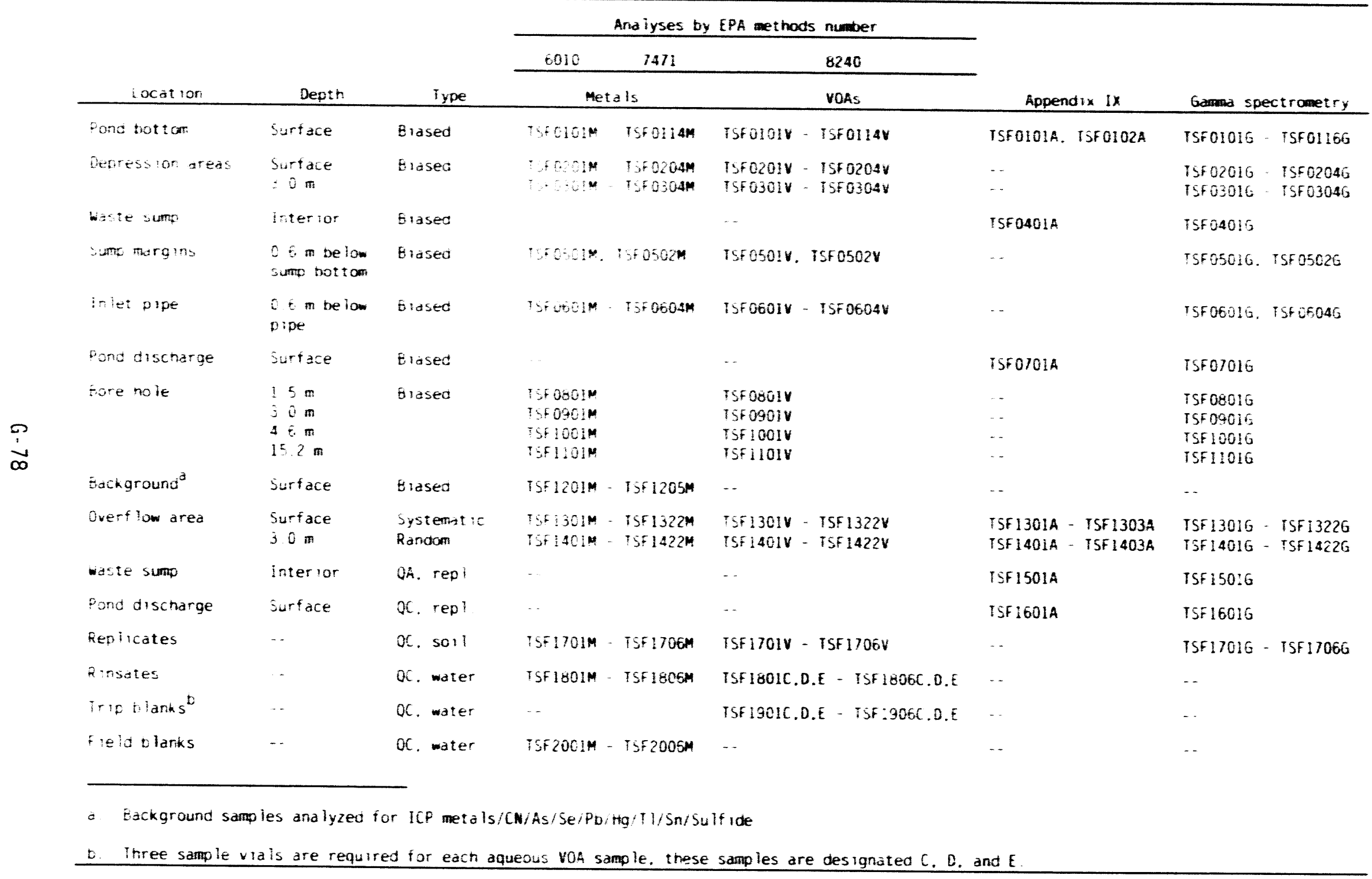




\section{APPENDIX $\mathrm{H}$}

\section{ANALYTICAL RESULTS FOR SAMPLING EVENT 5a}


Table H-1. TSF monitoring well sample analysis summary.

\begin{tabular}{|c|c|c|c|c|c|c|c|c|c|}
\hline \multirow[b]{2}{*}{ Location } & \multirow[b]{2}{*}{ Depth } & \multirow[b]{2}{*}{ Number } & \multirow[b]{2}{*}{ Type } & \multicolumn{6}{|c|}{ Ana lyfes by EPA Methods Mumber } \\
\hline & & & & $\begin{array}{l}\text { 60i0 } \\
\text { ICP }\end{array}$ & $\begin{array}{l}8240 \\
\text { VOAs }\end{array}$ & $\begin{array}{l}7471 / 7470 \\
\text { Mercury }\end{array}$ & $\begin{array}{l}\text { Ganna } \\
\text { Spect ross }\end{array}$ & $\begin{array}{c}\text { Gross } \\
\text { A:pha/Beta }\end{array}$ & $5 r-90$ \\
\hline \multicolumn{4}{|c|}{ 1-Chem Jar Size } & $250 \mathrm{ml}$ & $250 \mathrm{ml}$ & 250 แล1 & $500 \mathrm{ml}$ squats & $125 \mathrm{ml}$ & $1000 \mathrm{ml}$ \\
\hline $\begin{array}{l}\text { Existing } \\
\text { wells }\end{array}$ & $\approx 15.2 \mathrm{~m}$ & 20 & $\begin{array}{l}\text { Blased. } \\
\text { water grabs }\end{array}$ & $20^{b}$ & $20^{c}$ & $20^{b}$ & $20^{d}$ & 20 & 20 \\
\hline Totals & & $2 r$ & & 20 & 20 & 20 & 20 & 20 & 20 \\
\hline
\end{tabular}

I.

a. Gawna spectroscopy $w 111$ adhere to the procedures detailed in the SOPs prepared for the Radiation Measurements Laboratory.

b. Analyt Ical parameters: Melals ICP/As/Se/Pb/lly/TI/Sn (I L IDPF)

c. Analytical parameters: Volat ile organlcs $(3-40 \mathrm{ml})$

d. Analyt lcal parameters: Garma Spectroscopy $(540 \mathrm{ml}$ IIDPE) 
Table H-2. TSF monitoring well quality control sample analysis summary.

\begin{tabular}{|c|c|c|c|c|c|c|c|c|c|}
\hline \multirow[b]{2}{*}{ Location } & \multirow[b]{2}{*}{ Depth } & \multirow[b]{2}{*}{ Number } & \multirow[b]{2}{*}{ Type } & \multicolumn{6}{|c|}{ Analyses by EPA Methods Number } \\
\hline & & & & $\begin{array}{l}6010 \\
\text { ICP } \\
\end{array}$ & $\begin{array}{l}8240 \\
\text { VOAs } \\
\end{array}$ & $\begin{array}{l}7471 / 7470 \\
\text { Mercury }\end{array}$ & $\begin{array}{c}\text { Ganmia } \\
\text { Spect roscopy }^{\mathrm{a}}\end{array}$ & $\begin{array}{c}\text { Gross } \\
\text { Alpha/Beta }\end{array}$ & $\mathrm{Sr}-90$ \\
\hline 1-Chem Jar slze & & & & $250 \mathrm{ml}$ & $250 \mathrm{ml}$ & $250 \mathrm{ml}$ & $500 \mathrm{ml}$ squats & $125 \mathrm{ml}$ & $1000 \mathrm{ml}$ \\
\hline $\begin{array}{l}\text { Existing wells } \\
\text { Rinsates } \\
\text { Irlp blanks }\end{array}$ & & $\begin{array}{l}2 \\
1 \\
10\end{array}$ & $\mid \begin{array}{c}\text { QC replicate } \\
\text { water } \\
\text { QC. water } \\
\text { QC. water }\end{array}$ & $\begin{array}{l}1 \\
1^{c}\end{array}$ & $\begin{array}{c}1 \\
1 \\
10^{d}\end{array}$ & $\begin{array}{l}1 \\
1_{1}^{c}\end{array}$ & $\begin{array}{l}1 \\
1^{b}\end{array}$ & $\begin{array}{l}1 \\
1\end{array}$ & $\begin{array}{l}1 \\
1\end{array}$ \\
\hline Totals & & 13 & & 2 & 12 & 2 & 2 & 2 & 2 \\
\hline
\end{tabular}

a. Gamna spectroscopy analys Is will adhere to SOPs prepared for the Radiation Measurements Laboratory.

b. Aqueous gamina spectroscopy samples are placed $\ln 540-\mathrm{ml}$ bott les.

c. EPA method 7470 applies to aqueous 119 samples. $1000 \mathrm{ml}$ IIDPE bott les used to containerize these samples.

d. Irlp blanks and rinsates are placed in $40-\mathrm{ml}$ glass vials with no head space. Irip blanks are laboratory blank water supplied by the analytical laboratory. Fleld blanks consist of the IIPLC grade water used for final rinsing when collect Ing rinsates. 
ISF-07 Perched Hater Hells S\&A Data Document - October 1990

Table H-3. TSF-07 perched water wells-inorganic data.

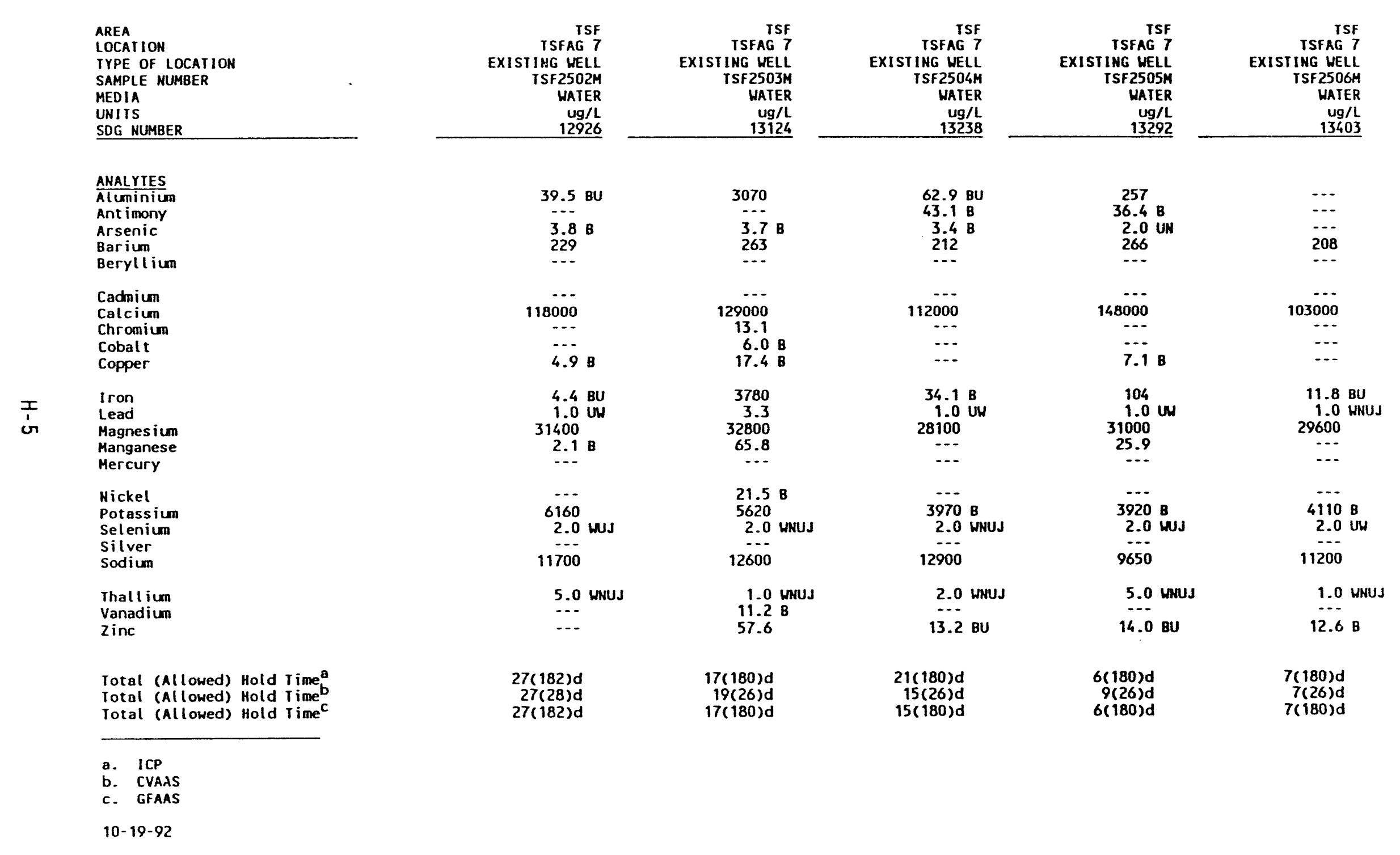


TSF-07 Perched Hater Hells S\&A Data Document - October 1990

Table H-3. (continued).


a. ICP
c. GFAAS
10-19-92 
ISF-07 Perched Water Wells S\&A Data Document - October 1990

Table H-3. (continued).

\begin{tabular}{|c|c|c|}
\hline $\begin{array}{l}\text { AREA } \\
\text { LOCATION } \\
\text { IYPE OF LOCATION } \\
\text { SAMPLE MUMBER } \\
\text { MEDIA } \\
\text { UNITS } \\
\text { SOG MUMBER } \\
\end{array}$ & $\begin{array}{r}\text { ISF } \\
\text { ISFAG } 5 \\
\text { EXISIING UELL } \\
\text { ISF2606H } \\
\text { UAIER } \\
\text { Ug/L } \\
13403 \\
\end{array}$ & $\begin{array}{r}\text { ISF } \\
\text { ISFAG } 5 \\
\text { EXISTING WELL } \\
\text { TSF2607M } \\
\text { WAIER } \\
\text { Ug/h } \\
05054 \\
\end{array}$ \\
\hline $\begin{array}{l}\text { ANALYIES } \\
\text { Aluminium } \\
\text { Antimony } \\
\text { Arsenic } \\
\text { Barium } \\
\text { Beryllium }\end{array}$ & $\begin{array}{c}\ldots .2 \\
90.48 \\
\ldots\end{array}$ & \begin{tabular}{ccc}
86.0 & $\mathrm{~B}$ \\
\hdashline 1.1 & 8 \\
131 & $\mathrm{~B}$
\end{tabular} \\
\hline $\begin{array}{l}\text { Cadnium } \\
\text { Calcium } \\
\text { Chromium } \\
\text { Cobalt } \\
\text { Copper }\end{array}$ & $\begin{array}{c}30600 \\
\cdots \\
7.7\end{array}$ & 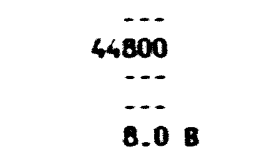 \\
\hline $\begin{array}{l}\text { Iron } \\
\text { Lead } \\
\text { Magnesium } \\
\text { Manganese } \\
\text { Mercury }\end{array}$ & $\begin{array}{c}45.2 \text { 8u } \\
1.0 \mathrm{imus} \\
6700 \\
7.2 \mathrm{~B} \\
. .\end{array}$ & $\begin{array}{c}10200 \\
3.5 \\
\ldots\end{array}$ \\
\hline $\begin{array}{l}\text { Nickel } \\
\text { Potassium } \\
\text { Selenium } \\
\text { Silver } \\
\text { Sodium }\end{array}$ & $\begin{array}{c}1590 \text { 8 } \\
2.0 \text { Uw } \\
\cdots \\
109000\end{array}$ & $\begin{array}{c}2740 \mathrm{gu} \\
2.0 \mathrm{um} \\
\cdots \\
12800\end{array}$ \\
\hline $\begin{array}{l}\text { Thallium } \\
\text { Vanadium } \\
\text { Zinc }\end{array}$ & $\begin{array}{l}1.0 \mathrm{umus} \\
\overline{70.1}\end{array}$ & $\begin{array}{l}1.0 \mathrm{mus} \\
7.3 \mathrm{~B} \\
\ldots\end{array}$ \\
\hline $\begin{array}{l}\text { Iotal (Allowed) Hold I ime } \\
\text { Iotal (All } \\
\text { Iotal (All lowed) Hold I Hold I imec }\end{array}$ & $\begin{array}{l}7(180) d \\
7(26) d \\
7(180) d\end{array}$ & $\begin{array}{l}\text { Mo Prep } \\
12(26) d \\
\text { Mo Prep }\end{array}$ \\
\hline $\begin{array}{l}\text { a. ICP } \\
\text { b. CVAAS } \\
\text { c. GFAAS }\end{array}$ & & \\
\hline $10-19-92$ & & \\
\hline
\end{tabular}


ISF-07 Perched Water Wells Su Date Document - Octcber 1990

Table H-4. TSF-07 perched water wells-inorganic Appendix IX data.

\begin{tabular}{|c|c|c|}
\hline $\begin{array}{l}\text { AREA } \\
\text { LOCAIION } \\
\text { TYPE OF LOCATION } \\
\text { SAMPLE MMEER } \\
\text { MEDIA } \\
\text { UNITS } \\
\text { SDG MUMBER } \\
\end{array}$ & $\begin{array}{r}\text { ISF } \\
\text { ISFAG } \\
\text { EXISIIMG UELL } \\
\text { ISF250IN } \\
\text { UAIER } \\
\text { Ug/L } \\
\text { ISF25014 }\end{array}$ & 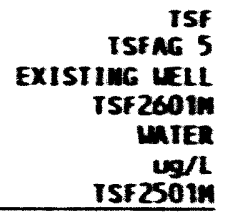 \\
\hline $\begin{array}{l}\text { ANALYIES } \\
\text { Alluginium } \\
\text { Antimony } \\
\text { Arsenic } \\
\text { Barium } \\
\text { Beryllium }\end{array}$ & $\begin{array}{l}4000 \mathrm{~mJ} \\
\ldots . . \\
265 \\
2.2 \mathrm{w}\end{array}$ & $\begin{array}{l}7250 \mathrm{~m} \\
142 \mathrm{~B} \\
2226 \\
1.6 \mathrm{ou}\end{array}$ \\
\hline $\begin{array}{l}\text { Cadmium } \\
\text { Calcium } \\
\text { Chromium } \\
\text { Cobalt } \\
\text { Copper }\end{array}$ & $\begin{array}{c}96400 \\
18.7 \\
5.9\end{array}$ & $\begin{array}{c}2.0 \\
70500 \\
16.0 \\
17.9 \\
17.900\end{array}$ \\
\hline $\begin{array}{l}\text { Iron } \\
\text { lead } \\
\text { Magnes ium } \\
\text { Manganese } \\
\text { Mercury }\end{array}$ & $\begin{array}{c}4590 \\
\ldots . \\
26100 \\
62.3 \\
0.17 \mathrm{BJ}\end{array}$ & $\begin{array}{c}7990 \\
\ldots \\
13900 \\
111 \\
0.10 \mathrm{w}\end{array}$ \\
\hline $\begin{array}{l}\text { Mickel } \\
\text { Potassium } \\
\text { Selenium } \\
\text { Silver } \\
\text { Sodium }\end{array}$ & $\begin{array}{c}9500 \\
\cdots .- \\
5.6 \\
14800\end{array}$ & $\begin{array}{c}3210 \\
2.4 \\
97300\end{array}$ \\
\hline $\begin{array}{l}\text { Stront ium } \\
\text { Thallium } \\
\text { Iin } \\
\text { Vanadium } \\
\text { Zine }\end{array}$ & $\begin{array}{c}710 \\
\ldots \\
40.1 \text { BES } \\
\ldots\end{array}$ & $\begin{array}{c}307 \\
101 \text { w } \\
39.6 \text { eEJ } \\
56.0\end{array}$ \\
\hline $\begin{array}{l}\text { Total (Allowed) Hold tiace } \\
\text { Iotal (Allowed) Hold I i=e }\end{array}$ & $\begin{array}{l}53(180) d \\
29(26) d^{4}\end{array}$ & $\begin{array}{l}53(180) d \\
29(26) d^{\circ}\end{array}$ \\
\hline
\end{tabular}
a. ICPS
b. crins
10-19-92 
ISf -07 Perched Water Wells sen oats Document - October 19\%d

Table H-5. TSF-07 perched water mells-analysis results for radionuclides.

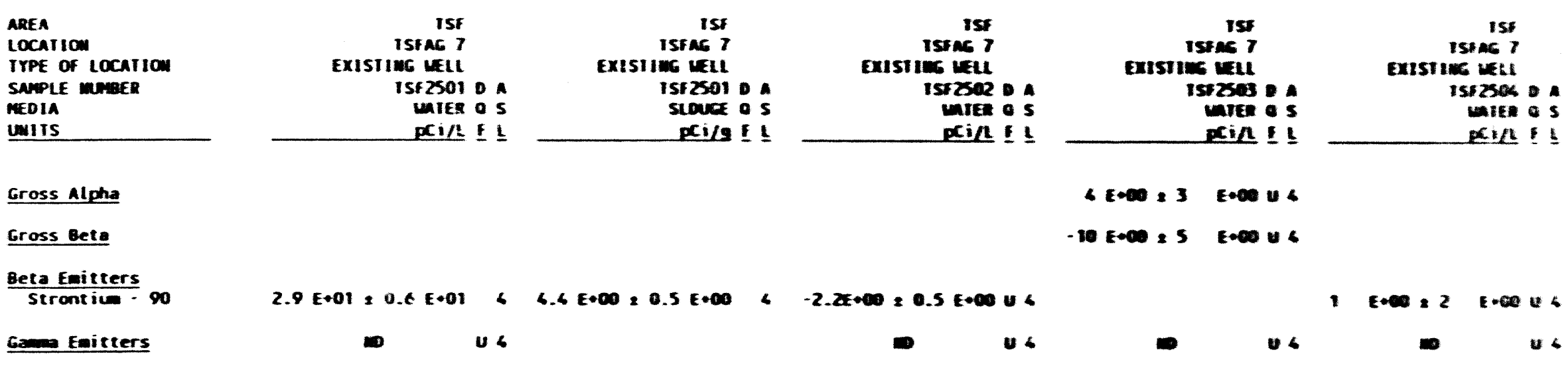

a. The Dof colum contains any data qual ifier flags.

b. The ast colum contains the enalytical support level. 


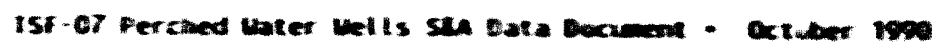

Table H-5. (cont inued).

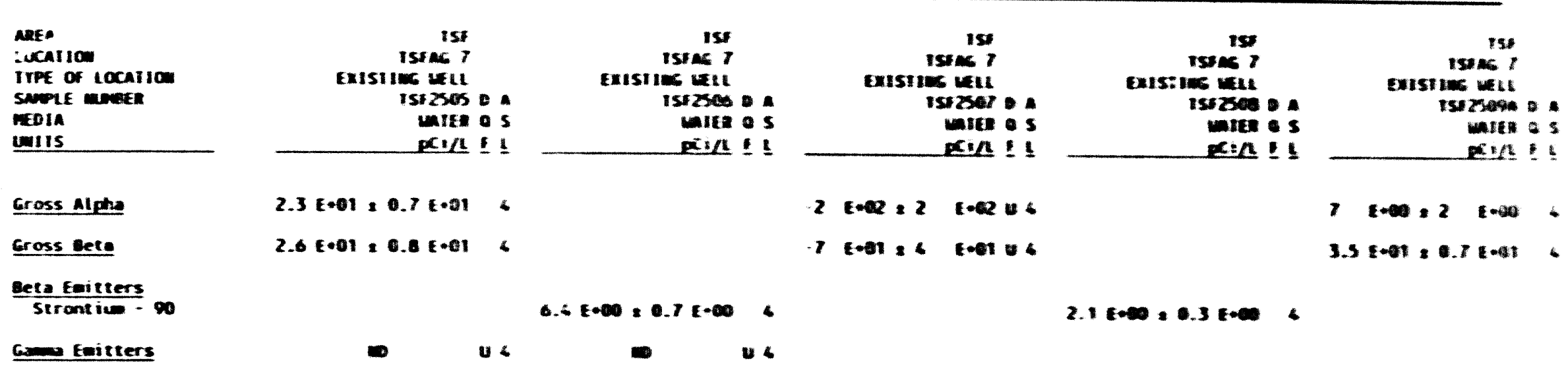

- The dof colum contains ay dote quat if ier tlass.

b. The ast colum contains the malve icat support lewe!

$\div \quad$ 10-21-92 


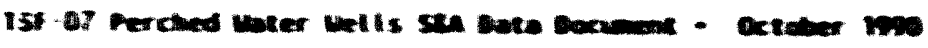

Table H-5. (cont inued).

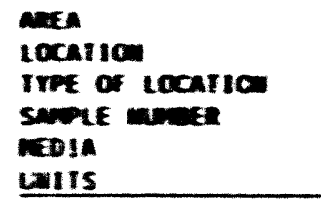

Gress Alpe

cross cere

Sete Emitters

strontive - so

conituers

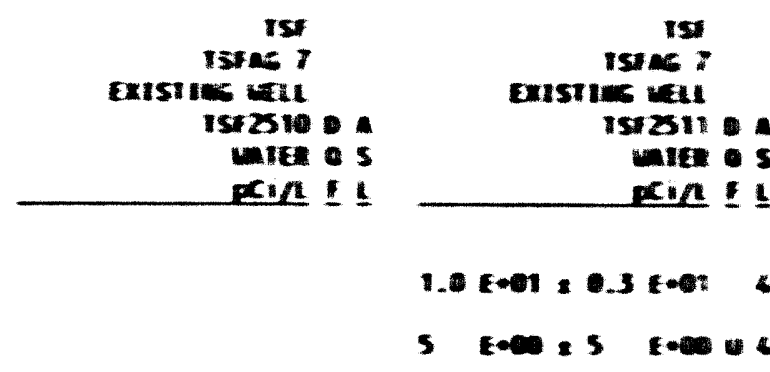

$-3.16+00 \times 0.600$ U 4

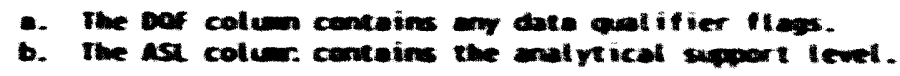

10-21-92 


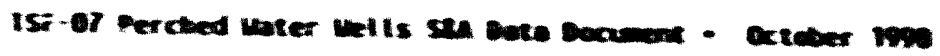

Table H-5. (cont inued).

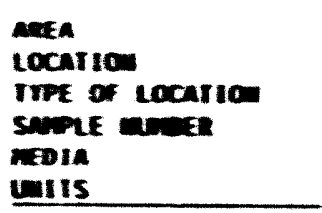

Gross Alpo

Gross ete

\section{Qeta Enitters}

strentien - 0

conitrers

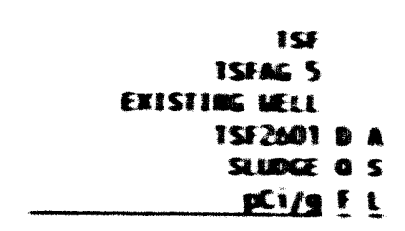$$
\text { , }
$$

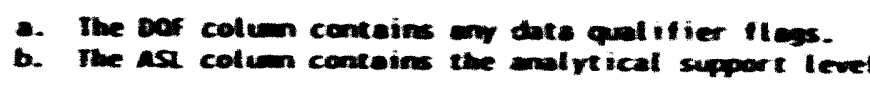

$\frac{1}{n}$

10-21-92 
15F-07 Percbed Water Uells Sen Data Bocument - Octeber 1996

Table H-5. (continued).

atea

IOCaI10

IrPE OF Locaito

SAvple wries

MEDIA

units

Gross Alphe

Gross Beta

Beta Eaitters Strontiu - 90

Gan Enitters

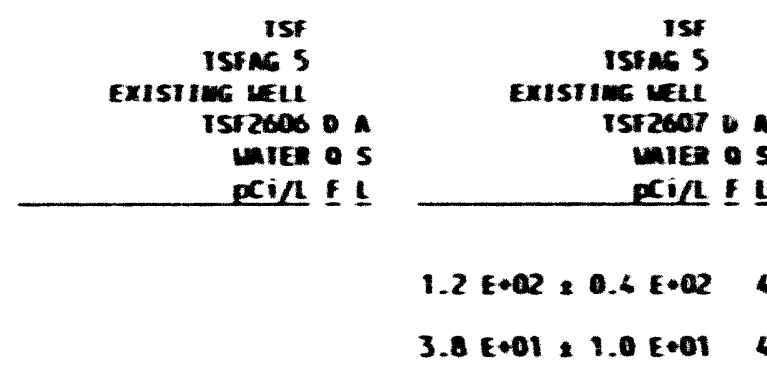

$6.5 E \cdot 00 \div 0.7 E *+004$
$1.2 E \cdot 02 * 0.4 E \cdot 024$
$3.8 E \cdot 01 \div 1.0 E \cdot 014$ b 46

158

Isencs

Israes

viten os

acis! 1

4

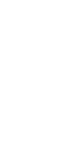

$2.0 \varepsilon+\infty 0 * 0.3 \varepsilon \cdot 00$

\begin{tabular}{|c|c|}
\hline 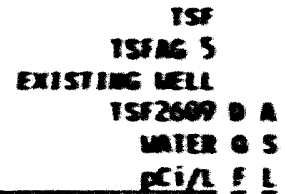 & 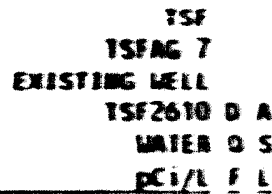 \\
\hline
\end{tabular}

$1.9 \pm 001=0.5 \mathrm{E} \cdot 91$

$1.2 E \cdot 02=0.2 E * 04$

$5.2 \leq * 00=0.7 \pm 0004$

a. The Daf colun contains any data qul ifier flags.
b. The ast colum contains the aralytical support level.
$\dot{\omega} \quad 10-21-92$ 
Table H-5. (continued).

AREA

LOCATION

TYPE OF LOCATIO

SAMPLE MUESER

MEDIA

Units

Gross Alpha

Gross Bete

Beta Enitters Strontium - 90

\section{Game Emitters}

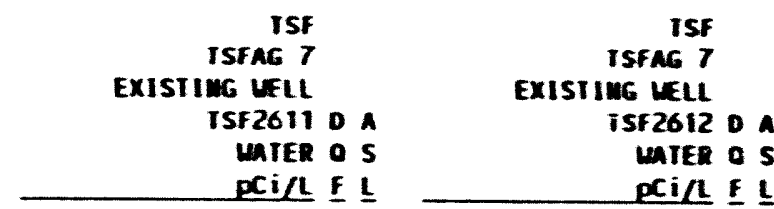

$1.3 E+01 \div 0.4 E \bullet 014$

$3 E+00 \pm 5 E+00 U$ U

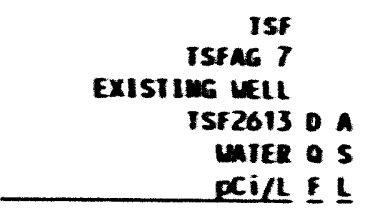

$3.2 E+C 0 \div 1.9 E+00 \mathrm{U}$

$1.2 E+01 \geq 0.3 E+01$
ISF
ISFing 5

epricate

ISF 2801 D A

WAIER O 5

PCi/L E

a. The Dof colum conteins any data qualifier flags.

b. The ASL colum contains the analytical support level.

10-21-92 
Table H-5. (cont inued).

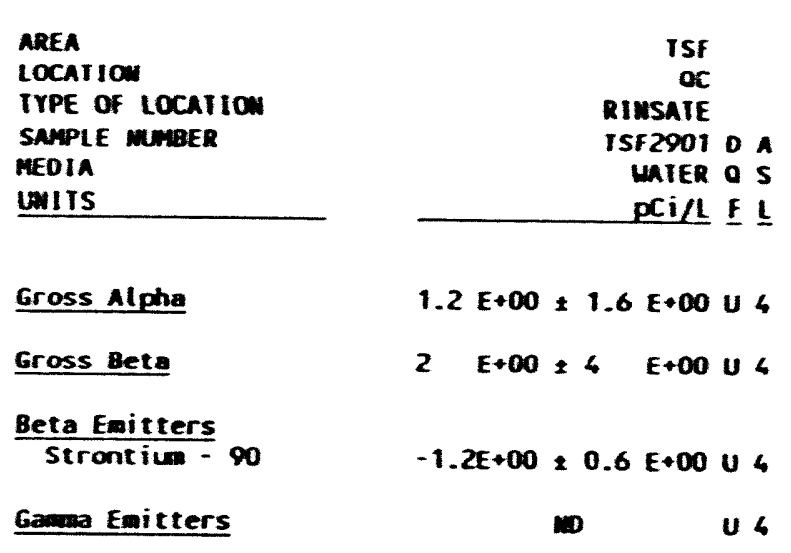

a. The DOF colum contains any data qualifier flags.

b. The ASL colum contains the analytical support level.

I $\quad 10-21-92$ 
ISF-07 Perched Water Wells Sin Dete Document - Octeber 1992

Table H-6. TSF-07 perched water wells-volatile organic data.

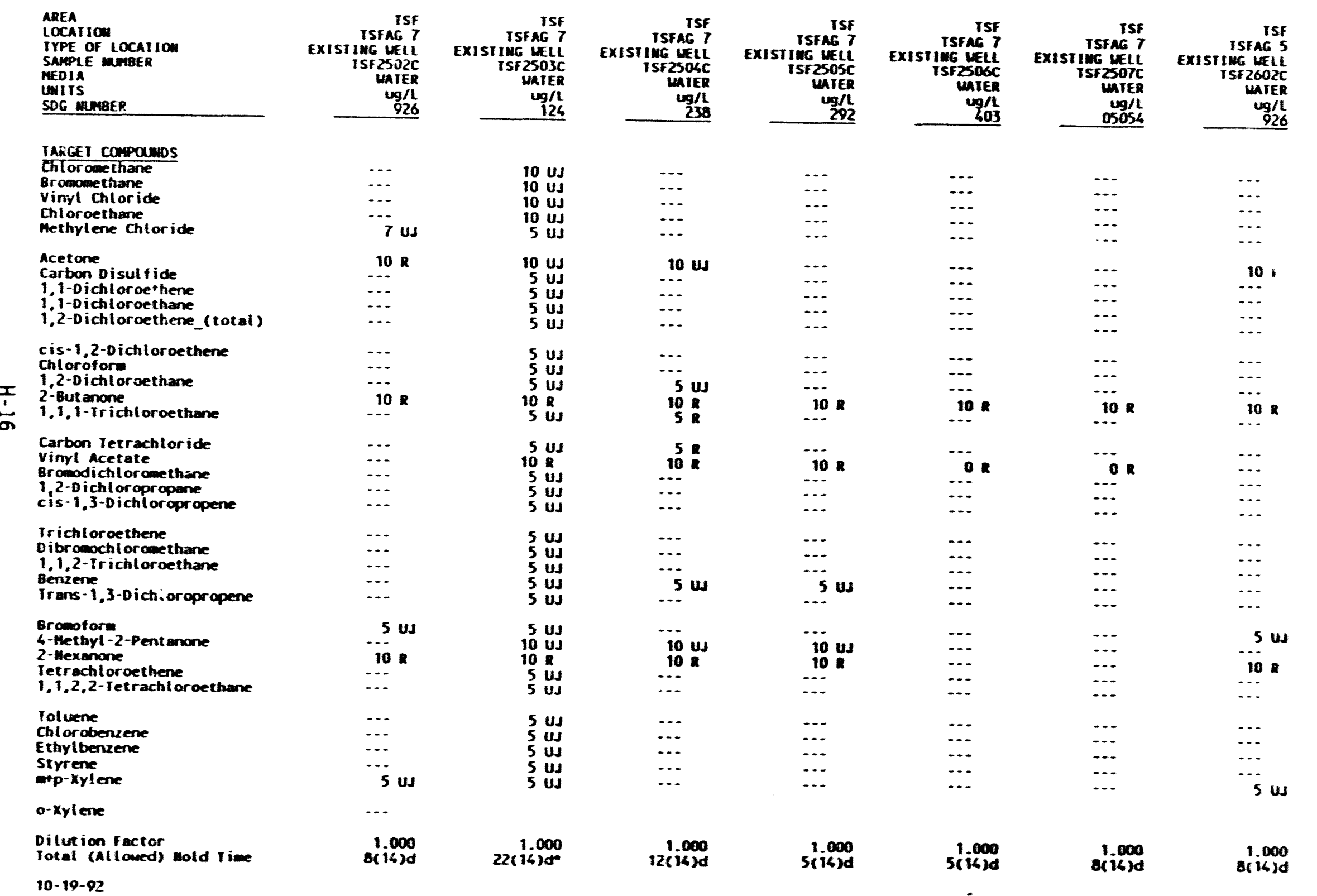


ISF-07 Perched Water Wells sen Data Document - October 1992

Table H-6. (continued).

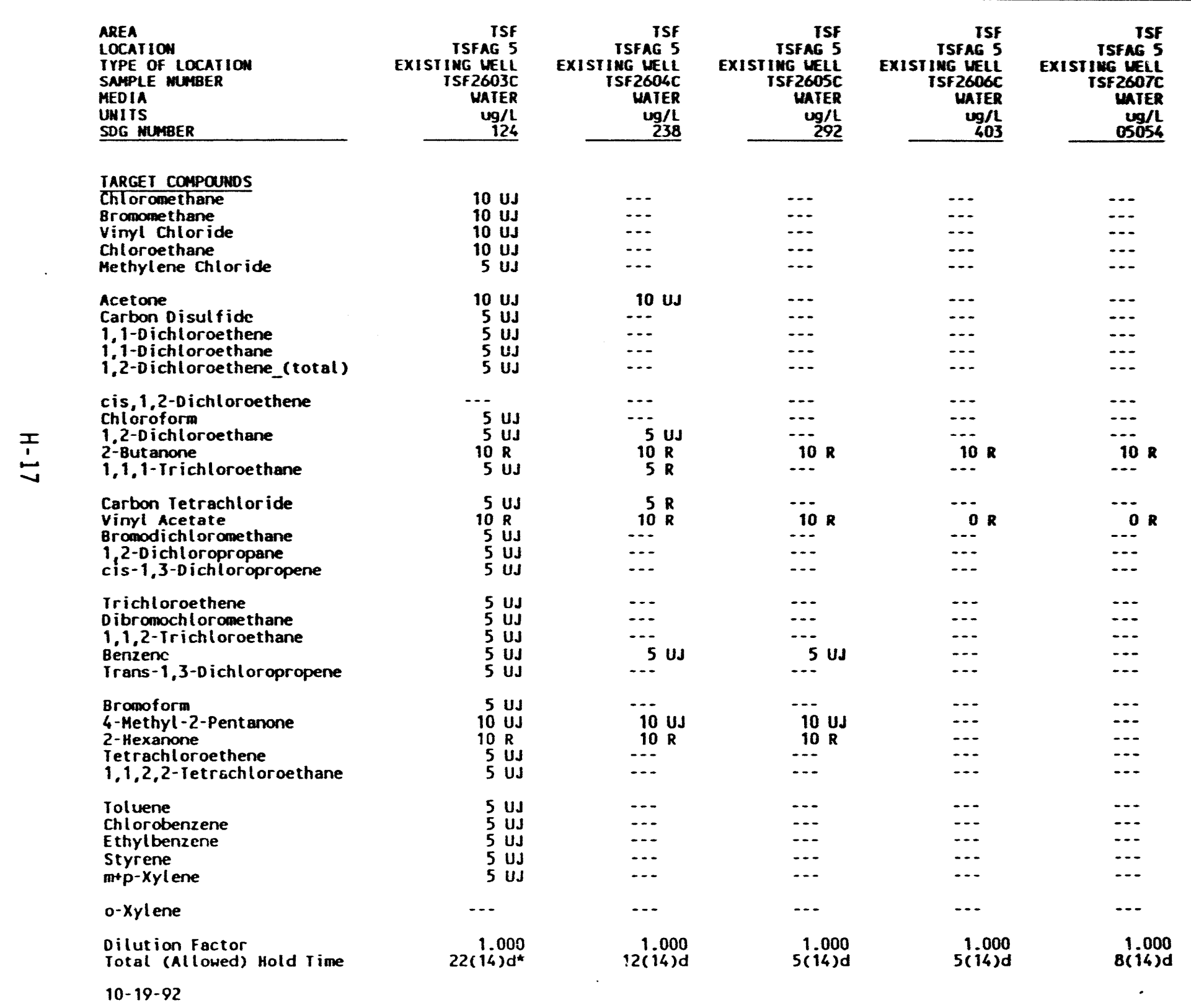


TSF-07 Perched Water Wells S\&A Data Document - October 1992

Table H-7. TSF-07 perched water wells-volatile organic replicate data.

\begin{tabular}{|c|c|c|}
\hline $\begin{array}{l}\text { AREA } \\
\text { LOCATION } \\
\text { TYPE OF LOCATION } \\
\text { SAMPLE NUMBER } \\
\text { MEDIA } \\
\text { UNITS } \\
\text { SOG NUMBER }\end{array}$ & $\begin{array}{r}\text { TSF } \\
\text { ISFAG } 7 \\
\text { REPLICATE } \\
\text { TSF2701C } \\
\text { HATER } \\
\text { Ug/L } \\
403 \\
\end{array}$ & $\begin{array}{r}\text { TSF } \\
\text { TSFAG } \\
\text { REPLICATE } \\
\text { TSF2BOIC } \\
\text { WAER } \\
\text { Ug/L } \\
403 \\
\end{array}$ \\
\hline $\begin{array}{l}\text { JARGEI COMPOUNDS } \\
\text { 2-Butanone } \\
\text { vinyl Acetate }\end{array}$ & $\begin{array}{rl}10 & R \\
0 & R\end{array}$ & 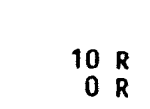 \\
\hline $\begin{array}{l}\text { Dilution factor } \\
\text { Total (Allowed) Hold Iime }\end{array}$ & $\begin{array}{l}1.000 \\
5(14) d\end{array}$ & $\begin{array}{l}1.000 \\
5(14) d\end{array}$ \\
\hline
\end{tabular}


Table H-8. TSF-07 perched water wells-volatile organic rinsate data.

\begin{tabular}{|c|c|}
\hline $\begin{array}{l}\text { AREA } \\
\text { LOCAIION } \\
\text { IYPE OF LOCAIION } \\
\text { SAMPLE NUMBER } \\
\text { MEDIA } \\
\text { UNIIS } \\
\text { SDG NUMBER } \\
\end{array}$ & $\begin{array}{r}\text { TSF } \\
\text { OC } \\
\text { RINSAIE } \\
\text { ISF2901C } \\
\text { WATER } \\
\text { Ug/L } \\
403 \\
\end{array}$ \\
\hline $\begin{array}{l}\text { IARGET COMPOUNDS } \\
\text { 2-Butanone } \\
\text { Vinyl Acetate } \\
\text { Toluene }\end{array}$ & $\begin{array}{rr}10 & R \\
0 & R \\
0.4 & J\end{array}$ \\
\hline $\begin{array}{l}\text { Dilution Factor } \\
\text { Total (Allowed) Hold Time }\end{array}$ & $\begin{aligned} 1.000 \\
5(14) d\end{aligned}$ \\
\hline
\end{tabular}


Table H-9. TSF-07 perched water wells-volatile organic trip blank data.

\begin{tabular}{|c|c|c|c|c|c|c|}
\hline $\begin{array}{l}\text { AREA } \\
\text { LOCATION } \\
\text { TYPE OF LOCATION } \\
\text { SAMPLE NUMBER } \\
\text { MEDIA } \\
\text { UNITS } \\
\text { SOG NUMBER } \\
\end{array}$ & $\begin{array}{r}\text { TSF } \\
\text { OC } \\
\text { TRIP BLANK } \\
\text { ISF3002C } \\
\text { HAER } \\
\text { Ug/L } \\
926 \\
\end{array}$ & $\begin{array}{r}\text { TSF } \\
\text { OC } \\
\text { TRIP BLANK } \\
\text { TSF3003C } \\
\text { WAIER } \\
\text { ug/L } \\
124 \\
\end{array}$ & $\begin{array}{r}\text { TSF } \\
\text { OC } \\
\text { IRIP BLANK } \\
\text { TSFO04C } \\
\text { WAIER } \\
\text { Ug/L } \\
238 \\
\end{array}$ & $\begin{array}{r}\text { TSF } \\
\text { OC } \\
\text { TRIP gLANK } \\
\text { TSF 3006C } \\
\text { WATER } \\
\text { Ug/L } \\
292 \\
\end{array}$ & $\begin{array}{r}\text { TSF } \\
\text { aC } \\
\text { TRIP BLANK } \\
\text { ISF3007C } \\
\text { WATER } \\
\text { Ug/L } \\
403 \\
\end{array}$ & $\begin{array}{r}\text { TSF } \\
\text { OC } \\
\text { TRIP BLANK } \\
\text { TSF300BC } \\
\text { WAITRR } \\
\text { Ug/L } \\
05054 \\
\end{array}$ \\
\hline $\begin{array}{l}\text { IARGET CoMPounDS } \\
\text { Chloromethane } \\
\text { Bromomethane } \\
\text { Vinyl Chloride } \\
\text { Chloroethane } \\
\text { Methylene Chloride }\end{array}$ & $\begin{array}{l}\cdots \\
\cdots \\
\cdots \\
\cdots\end{array}$ & $\begin{array}{l}10 \text { uJ } \\
10 \\
10 \mathrm{uJ} \\
10 \mathrm{uJ} \\
10 \mathrm{uJ} \\
5 \mathrm{uJ}\end{array}$ & $\begin{array}{l}\cdots \\
\cdots \\
\cdots \\
\cdots \\
\cdots\end{array}$ & $\begin{array}{l}\cdots \\
\cdots \\
\cdots \\
\cdots\end{array}$ & $\begin{array}{l}\cdots \\
\cdots \\
\cdots \\
\cdots\end{array}$ & $\begin{array}{l}\cdots \\
\cdots \\
\cdots \\
\cdots\end{array}$ \\
\hline $\begin{array}{l}\text { Acetone } \\
\text { Carbon Disulfide } \\
1,1-0 \text { ichloroethene } \\
1,1-0 \text { ichloroethane } \\
1,2-0 \text { ichloroethene_(total) }\end{array}$ & $\begin{array}{l}10 R \\
-1 . \\
-: \\
-\cdots\end{array}$ & $\begin{array}{ll}4 & J \\
5 & \text { UJ } \\
5 & \text { UJ } \\
5 & \text { UJ } \\
5 & \text { UJ }\end{array}$ & $\begin{array}{l}\cdots \\
\cdots \\
\cdots \\
\cdots \\
\cdots\end{array}$ & $\begin{array}{l}\cdots \\
\cdots \\
\cdots \\
\cdots\end{array}$ & $\begin{array}{l}\cdots \\
\cdots \\
\cdots \\
\cdots \\
\cdots\end{array}$ & $\begin{array}{l}\cdots \\
\cdots \\
\cdots \\
\cdots\end{array}$ \\
\hline $\begin{array}{l}\text { cis-1,2-Dichloroethene } \\
\text { chloroform } \\
1,2-0 \text { ichloroethane } \\
2-\text { Butanone } \\
1,1,1-\text { Irichloroethane }\end{array}$ & $\begin{array}{l}\cdots \\
\cdots \\
\cdots \\
10\end{array}$ & $\begin{array}{ll}5 & \text { uJ } \\
6 & \mathrm{~J} \\
5 & \mathrm{UJ} \\
3 & \mathrm{~J} \\
5 & \mathrm{UJ}\end{array}$ & $\begin{array}{rl} \\
5 \\
10 & R J \\
5 & R\end{array}$ & $\begin{array}{rl}\ldots & 4 \\
\ldots & d \\
10 & R\end{array}$ & $\begin{array}{c}\cdots \\
\cdots \\
10 R\end{array}$ & $\begin{array}{l}\cdots \\
11 \\
\cdots 10 R \\
\ldots\end{array}$ \\
\hline $\begin{array}{l}\text { Carbon Tetrachloride } \\
\text { vinyl Acetate } \\
\text { Bromodichloromethane } \\
1,2-D i c h l \text { oropropane } \\
\text { cis-1,3-Dichloropropene }\end{array}$ & $\begin{array}{l}\cdots \\
\cdots \\
\cdots \\
\cdots \\
-\cdots\end{array}$ & $\begin{array}{rl}5 & \text { UJ } \\
10 & R \\
5 & U J \\
5 & U J \\
5 & U J\end{array}$ & 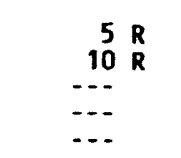 & $\begin{array}{l}\cdots \\
10 R \\
-1 . \\
\cdots \\
\cdots\end{array}$ & \begin{tabular}{c}
0 \\
0 \\
\hdashline- \\
$\cdots$
\end{tabular} & $\begin{array}{c}\cdots \\
0 \\
\cdots \\
\cdots \\
\cdots\end{array}$ \\
\hline $\begin{array}{l}\text { Trichloroethene } \\
\text { Dibromochl orome thane } \\
1,1,2-T r i \text { chloroethane } \\
\text { Benzene } \\
\text { Trans-1,3-Dichloropropene }\end{array}$ & $\begin{array}{l}\cdots \\
\cdots \\
\cdots \\
\cdots\end{array}$ & $\begin{array}{ll}5 & \text { UJ } \\
5 & \text { UJ } \\
5 & \text { UJ } \\
5 & \text { UJ } \\
5 & \text { UJ }\end{array}$ & \begin{tabular}{l}
$\cdots$ \\
$\cdots-$ \\
\hdashline 5 \\
5 \\
5 UJ
\end{tabular} & 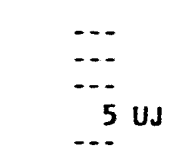 & $\begin{array}{l}\cdots \\
\cdots \\
\cdots \\
\cdots\end{array}$ & $\begin{array}{l}\cdots \\
\cdots \\
\cdots \\
\cdots \\
\cdots\end{array}$ \\
\hline $\begin{array}{l}\text { Bromoform } \\
\text { 4-Methyl-2-Pentanone } \\
\text { 2-Hexanone } \\
\text { Tetrachloroethene } \\
\text { 1,1,2,2-Tetrachloroethane }\end{array}$ & $\begin{array}{ll}5 \text { UJ } \\
-10 \\
10\end{array}$ & $\begin{array}{rl}5 & \text { UJ } \\
10 & \text { UJ } \\
10 & R \\
5 & \text { UJ } \\
5 & \text { UJ }\end{array}$ & $\begin{array}{l}10 \mathrm{UJ} \\
10 \mathrm{R} \\
\cdots \\
\cdots\end{array}$ & $\begin{array}{l}10 \text { UJ } \\
10 \text { UR } \\
\cdots\end{array}$ & $\begin{array}{l}\cdots \\
\cdots \\
\cdots \\
\cdots \\
\cdots\end{array}$ & $\begin{array}{l}\cdots \\
\cdots \\
\cdots \\
\cdots \\
\cdots\end{array}$ \\
\hline $\begin{array}{l}\text { Toluene } \\
\text { Chlorobenzene } \\
\text { Ethylbenzene } \\
\text { Styrene } \\
m+p-x y l \text { enes }\end{array}$ & $\begin{array}{l}\cdots \\
\cdots \\
\cdots \\
\cdots\end{array}$ & 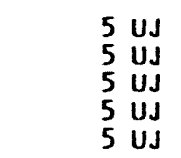 & $\begin{array}{l}\cdots \\
\cdots \\
\cdots \\
\cdots\end{array}$ & $\begin{array}{l}\cdots \\
\cdots \\
\cdots \\
\cdots\end{array}$ & $\begin{array}{l}\cdots \\
\cdots \\
\cdots \\
\cdots\end{array}$ & $\begin{array}{l}\cdots \\
\cdots \\
\cdots \\
\cdots\end{array}$ \\
\hline 0 -xylene & -.. & 5 UJ & $\ldots$ & -.. & ... & ... \\
\hline $\begin{array}{l}\text { Dilution Factor } \\
\text { Total (Allowed) Hold Time }\end{array}$ & $\begin{array}{l}1.000 \\
8(14) d\end{array}$ & $22(14) d^{1.000}$ & $\begin{array}{r}1.000 \\
12(14) d\end{array}$ & $\begin{array}{r}1.000 \\
5(14) d\end{array}$ & $\begin{array}{l}1.000 \\
s^{\prime}(14) \mathrm{d}\end{array}$ & $\begin{array}{l}1.000 \\
8(14) d\end{array}$ \\
\hline
\end{tabular}


ISF-07 Perched Hater Hells S\&A Data Document - October 1990

Table H-10. TSF-07 perched water wells-volatile Appendix IX organic data.

\begin{tabular}{lrr} 
AREA & TSF & ISF \\
LOCATION & ISFAG 7 & ISFAG 5 \\
TYPE OF LOCATION & EXISTING WELL & EXISTING WELL \\
SAMPLE NUMBER & TSF250IC & TSF2601C \\
MEDIA & WATER & WATER \\
UNIS & Ug/L & Ug/L \\
SOG NUMABER & TSF2501C & TSF250IC \\
\hline
\end{tabular}

IARGET COMPOUNDS

Dichlorodifluoromethane

lodome thane

Acrylonitrile

Acrylonitrile
Irichlorofluoromethane

Propionitrite

Allyl chloride

Diethyl ether

Methacrylonitrile

D ibromome thane

$\begin{array}{ll}\text { I } & \text { isobutyl alcohol } \\ 1 & 1,2-0 \text { ibromoethane } \\ \cong & 1,1,1,2-\text { Tetrachloloroethane }\end{array}$

1,3-Dichlorobenzene

1,2,3-Trichloropropane

Ethyl methacrylate

1,4-Dichlorobenzene

1,2-Dichlorobenzene

1,2-D ibromo-3-chloropropane

\section{Acetonitrile}

Acrylamide

1,4-Dioxane

Methyl methacrylate

Dilution Factor

Total (Allowed) Hold Iime

$\begin{array}{ll}5 R & \\ 5 R & 5 R \\ 5 R & 5 R \\ 5 R & 5 R \\ 5 R & 5 R \\ 5 R & 5 R \\ 5 R & 5 R \\ 5 R & 5 R \\ 5 R & 5 R \\ 5 R & 5 R \\ 5 R & 5 R\end{array}$

10-19-92

1.000


Table H-11. TSF-07 perched water wells-volatile Appendix IX organic trip blank data.

AREA

LOCAIION

TYPE OF LOCATION

SAMPLE NUMBER

MEDIA

UNITS

SDG NUMBER

ISF
OC
IRIP BLANK
TSF3001C
HATER
Ug/L
ISF2501C

TARGET COHPOUNDS

Methylene Chloride

Chloroform

Dichl orodifluorome thane

lodome thane

Acrolein

Acrylonitrile

Irichlor of luor one thane

Propionitrile

Allyl chloride

Diethyl ether

I Methacrylonitril

I sobutyl alcohol

1.2-0 ibromoethane

trans-1,4-Dichloro-2-butene

1,3-Dichlorobenzene

1,2,3-Trichloropropane

Ethyl methacrylate

1,4-Dichlorobenzene

ISF
OC

ANK

HATER

SF2501C

1,2-Dichlorobenzene

1,2-0 ibromo-3-chloropropane

Acetonitrile

Acetonitrile

1,4-0ioxane

Methyl methacrylate

$5 \mathrm{~J}$
$\mathrm{~S}$

$\begin{array}{ll}5 & R \\ 5 & R \\ 5 & R\end{array}$

$5 R$
5

Dilution Factor

rotal (Allowed) Hold Time

1.000

10-19-92 


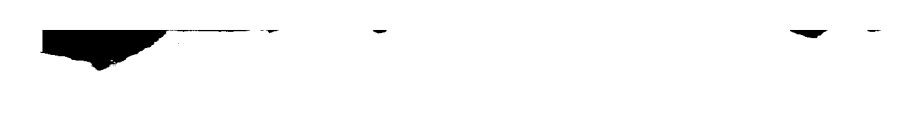

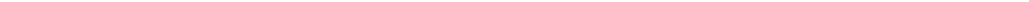


. 